UNIVERSIDADE DE SÃO PAULO

ESCOLA DE ENGENHARIA DE SÃO CARLOS

ESTER FECHE GUIMARÃES

\title{
MODELO INCLUSIVO PARA A \\ UNIVERSALIZAÇÃO DO SANEAMENTO BÁSICO EM ÁREAS DE VULNERABILIDADE SOCIAL
}

v.2 


\section{ESTER FECHE GUIMARÃES}

\section{MODELO INCLUSIVO PARA A UNIVERSALIZAÇÃO DO SANEAMENTO BÁSICO EM ÁREAS DE VULNERABILIDADE SOCIAL}

Tese apresentada à Escola de Engenharia de São Carlos da Universidade de São Paulo para obtenção do título de Doutor em Ciências da Engenharia Ambiental

Área de Concentração: Ciências da Engenharia Ambiental

Orientador: Prof. Dr. Tadeu F. Malheiros Co-orientador: Prof. Rui Cunha Marques

São Paulo 
AUTORIZO A REPRODUÇÃO TOTAL OU PARCIAL DESTA PESQUISA, POR QUALQUER MEIO CONVENCIONAL OU ELETRÔNICO PARA FINS DE ESTUDO E PESQUISA, DESDE QUE CITADA A FONTE.

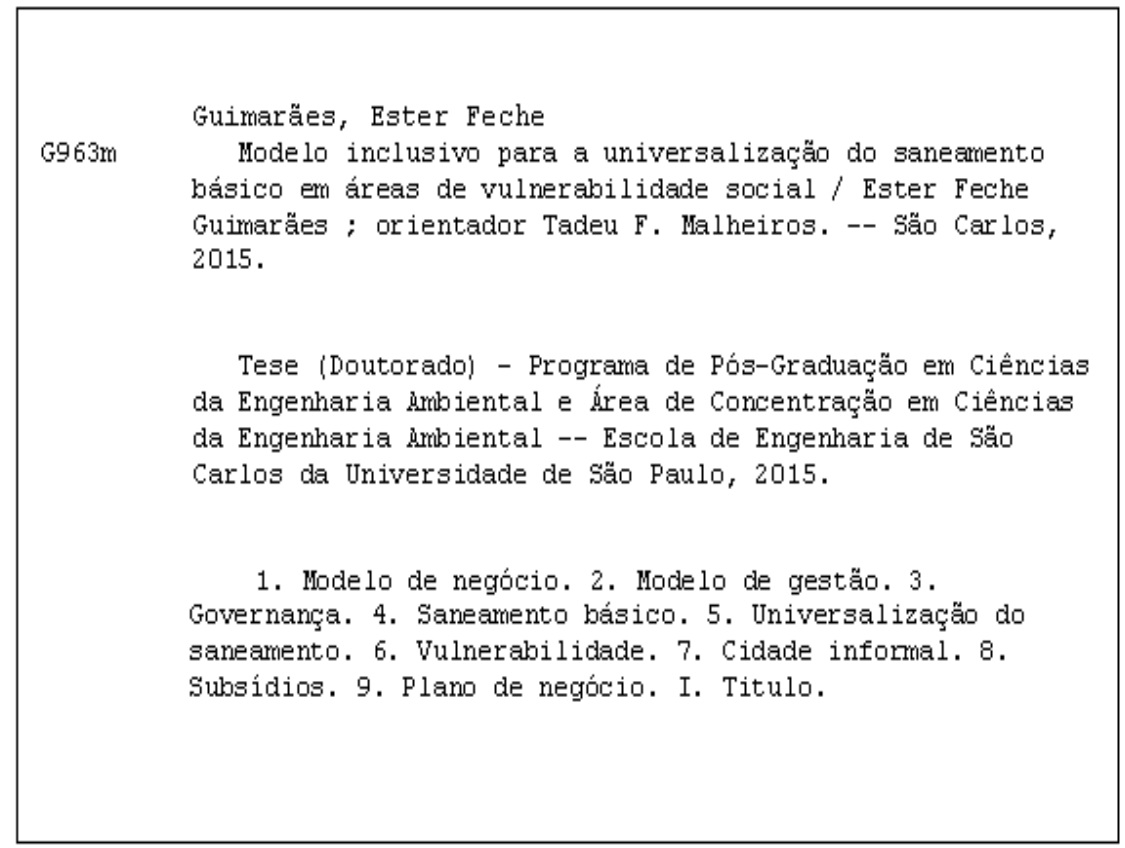




\section{FOLHA DE JULGAMENTO}

\section{Candidata: Engenheiro ESTER FECHE GUIMARĀES DE ARRUDA}

Titulo da tese: "Modelo inclusivo para a universalização do saneamento básico em áreas de vulnerablidade social".

Data da delesa: $24 / 08 / 2015$

\section{Comissão Julgadora:}

Prot. Associado Tadeu Fabrício Malheiros (Orientador) (Escola de Engenharia de Sâo Carios/EESC)

Prof. Dr. Rui Domingos Ribeiro da Cunha Marques

(Universidade de Lisboa/Portugal)

Prof. Titular José Sidnei Colombo Martinl (Escola Politécnica/EP-USP)

Dra. Sonia Maria Viggiani Coutinho (Pós-Doutorado/FAPESP)

Prof. Dr. Francisco Anuatiti Neto (Faculdade de Economia, Administração e Contabilidade de Ribeirão Preto/FEARPUSP)

Coordenador do Programa de Pós-Graduaçāo em Ciências da Engenharia Ambiental:

Prot. Associado Frederico Fablo Mauad

Presidente da Comissão de Pós-Graduação:

Prof. Associado Paulo César Lima Segantine

\section{Resultado:}

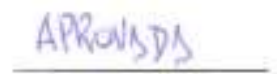

Deroutar

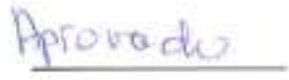

\section{APRDUADA}

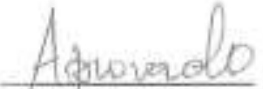


A meus filhos, Letícia e Rubens, com amor e respeito, pela paciência e generosidade em partilhar os longos períodos do nosso dia-a-dia, férias e momentos, que eram de vocês por direito, com o estudo e produção destas páginas, bem como por me incentivarem a não desistir. 
Agradecimentos à:

Deus que fortaleceu-me à escrever esta tese com objetivo de contribuir no propósito de melhoria da dignidade humana;

Mamãe e Papai, que me ensinaram amar o conhecimento e a justiça apoiados na Bíblia;

Tobias Jerozolimski, que autorizou com a presidencia da Sabesp o curso de doutorado na USP, bem como o tema escolhido;

Eridane Furlan, amiga sempre presente, por contribuir em discussões institucionais e jurídicas, e apoiar-me sempre;

Hugo de Oliveira (BID), pelas contribuições na construção do modelo econômico-financeiro e incentivar-me a inovação;

Fernando Gomes Garcia, por transcrever as premissas da tese na construção de simulador e pela tabulação dos questionários;

Companhia de Saneamento Básico do Estado de São Paulo, Diretor Luís Paulo de Almeida Neto, Superintendente da Baixada Santista eng. João Cesar Queiroz Prado, Diretor Metropolitano Paulo Massato Yoshimoto e respectivas equipes dos agentes comunitários, planejamento, engenharia da operação e controladorias.

Secretarias do Estado de São Paulo de Recursos Hídircos, Assistência Social, Habitação, Justiça e Cidadnia e EMPLASA. 
Agencias Reguladoras de Serviços de Saneamento e energia do Estado de São Paulo - ARSESP, e do Distrito Federal - ADASA.

Eng. Luís Zantut Diretor de Convênios e Parcerias da Prefeitura Municipal de Planejamento e Gestão do Guarujá e Sarita Patela.

Fernando Alvarez da SIGLASUL e Juliana Almeida Dutra da DEEP Consultorias.

ABES-Nacional, ABES-SP e AESabesp que abriram as portas às oficinas, entrevistas, e workshops.

John Briscoe+ (HU), Arlindo Philippi Jr. (USP-CAPES), Ricardo Toledo Silva (FAU-USP), Helena Allegre (LNEC), Paulina Beato (FMI), Jacques Marcovicth (FEA-USP), Stelio Marras (IEB/USP) e Laura Macruz (FSP/USP) por me auxiliarem na visão crítica, soluções possíveis e compartilhar suas ideias e pensamentos.

Co-orientador Prof. Dr. Rui Cunha Marques por ser acessível e ter disponibilidade em atender-me sempre que solicitado, bem como por contribuições técnicas de grande valia em todos as etapas da pesquisa, pelo apoio e incentivo.

Prof. Dr. Tadeu Malheiros orientador, pela liberdade dada na escolha do tema e na condução da pesquisa, bem como por suas valiosas contribuições no enfoque dos fundamentos da sustentabilidade, ampliando minha percepção no tema e propiciando um aprofundamento nas pesquisas. 


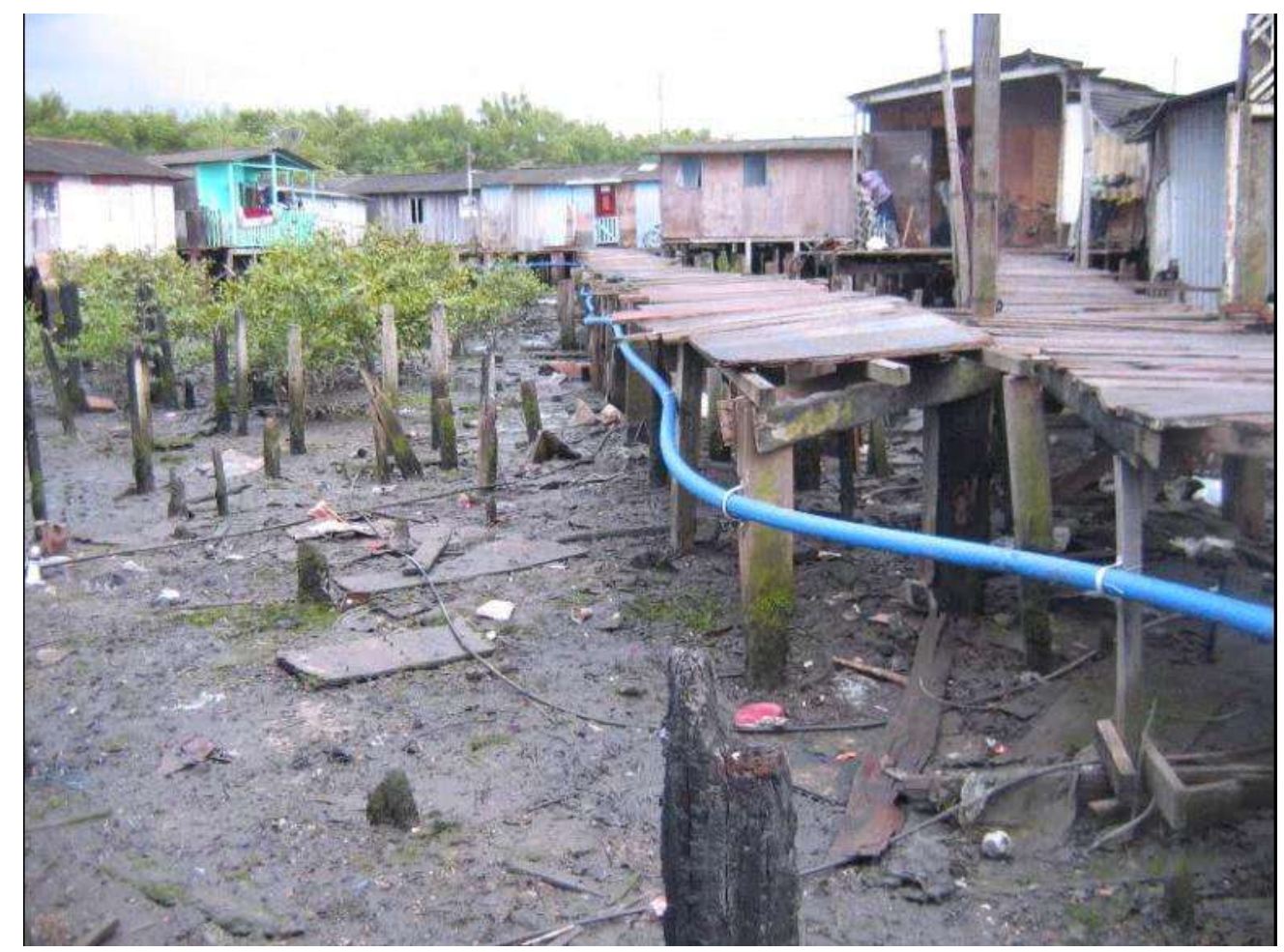

Qbniversalização Inclusiva

Significa prestar serviços públicos essenciais à vida de um subcidadầ, sub-incluido nas Pofiticas Púbficas, näo contado nas metas setoriais, mediante um processo participativo, conduzido pela concessionária em parceria com Poder Goncedente e demaís atores da sociedade, para prover água e esgotamento sanitárió, ainda que en áreas de exclusäo social por meio de arranjos sociotécnicos em construçöes singulares, inclusivas e cuidadoras do Direito Humano.

Gonceito Gonstruido Testa $\mathscr{T}_{\text {ese }}$ 


\section{RESUMO}

GUIMARAES, E.F. Modelo inclusivo para a universalização do saneamento básico em áreas de vulnerabilidade social. 2015. 486 f. Tese (Doutorado) - Escola de Engenharia de São Carlos, Universidade de São Paulo. São Paulo. 2015.

O marco regulatório do setor de saneamento no Brasil inseriu, em 2007, um novo regramento para operação dos serviços de abastecimento de água, coleta e tratamento de esgotos. As Agências Reguladoras instituídas pela legislação criam mecanismos econômico-financeiros visando induzir eficiência, eficácia e permitir apropriação social de ganhos de produtividade na prestação dos serviços públicos e na execução de atividades públicas de saneamento básico. No entanto, os modelos de negócio não atendem de forma satisfatória e homogênea todos os cidadãos, resultando-lhes em notórias disparidades no acesso aos serviços, em especial, nas áreas de vulnerabilidade social. Os impactos negativos dos assentamentos precários nas metrópoles refletem-se em custos aos sistemas ecológicos e humanos no ambiente urbano de países em desenvolvimento, como o Brasil. Em relação à universalização do acesso aos serviços de abastecimento de água e esgotamento sanitário em ambiente regulado e seus reflexos nos usuários, identificam-se mecanismos de exclusão provenientes do ordenamento jurídico. Direitos fundamentais aos serviços essenciais subordinam-se ao direito de propriedade e direito ambiental. $\mathrm{O}$ modelo de negócio para alcançar e manter a universalização do saneamento básico deve ser inovador para integrar demandas do cidadão em situação de exclusão social, por meio de governança que os considere, sem infringir legislações. Requer atuação articulada e integrada dos gestores do saneamento e setores correlatos com suas contribuições ao desenvolvimento urbano, que combine objetivos do atendimento com equacionamento dos problemas socioambientais, de forma a contribuir na tomada de decisão. A área de estudo foi a Região Metropolitana da Baixada Santista no Estado de São Paulo operada pela Companhia de Saneamento Básico - SABESP. Adotou-se procedimentos metodológicos multivariados contendo revisão bibliográfica, levantamento de melhores práticas sobre os arranjos institucionais; sistematização de dados públicos e privados; questionários aplicados a atores do setor e líderes das comunidades, entrevistas com atores estratégicos e gestores da concessionária, vistorias de domicílios representativos da área de estudo, oficinas de diagnóstico e construção participativa de um modelo inovador para universalização do saneamento. Adotou-se a Teoria Ator-rede para diagnóstico e mapeamento de controvérsias sociotécnicas e gaps de governança das áreas com populações vulneráveis. Os resultados inovadores foram: conceitos e indicadores de Universalização Inclusiva, Governança Inclusiva e Vulnerabilidade da concessão, modelo de estudo de viabilidade econômico-financeiro para a Cidade Informal por receita incremental com definição dos conceitos de volume excedente e receita acessória, modelo de equacionamento jurídico e de gestão. Têm-se como resultados: mapa de controvérsias da universalização; e Plano de Negócio Inclusivo - PNI, software de projeções e simulações de planejamento para a Cidade Informal e Modelo Inclusivo de Instituccional.

Palavras Chave: modelo de negócio, modelo de gestão, governança, saneamento básico, universalização do saneamento, vulnerabilidade, planejamento, indicador, favelas, Subsídios e Plano de negócio. 


\begin{abstract}
GUIMARAES, E.F. Modelo inclusivo para a universalização do saneamento básico em áreas de vulnerabilidade social. 2015. $486 \mathrm{f}$. Tese (Doutorado) - Escola de Engenharia de São Carlos, Universidade de São Paulo. São Paulo. 2015.
\end{abstract}

In 2007, the regulatory framework for the sanitation sector in Brazil entered in 2007, new rules for the operation of water supply services, collection and sewage treatment. Regulatory Agencies established by legislation create economic and financial mechanisms to set efficiency, effectiveness and allow social appropriation of productivity gains in the provision of public services and implementation of public activities sanitation. It becomes key opportunity against the current context, because the business models do not meet satisfactorily and homogeneously all citizens, leading them into notorious disparities in access to services, especially in the areas of vulnerability. The negative impacts of human activities misaligned the concept of quality of life and basic human rights are reflected in costs to ecological systems and humans, that is a reality still quite evident in the urban environment in developing countries like Brazil. Regarding for universal access to water supply and sanitation, adequate provision and its consequences to users, they identify mechanisms of exclusion from the legal system. Fundamental rights to essential services subordinate to the right to property and environmental law. The business model for achieving and maintaining universal sanitation must be innovative to integrate citizen demands for universal in regulated environment, through governance without infringing legislation. It requires coordinated and integrated action of sanitation managers and related sectors with their contributions to urban development; that combines service objectives with solving the socio-environmental problems in order to contribute to decision making. Make up the methodological procedures, the formulation of questions results of literature review and survey of best practices on the institutional arrangements which are necessary for the universalization of sanitation in vulnerable areas; systematization of public and private data; questionnaires with sector actors, interviews with key actors-network sector; questionnaires to managers of the dealership's case study, community leaders, and surveys of households representatives the 9 cities of the Baixada Santista and conducting participatory workshops for an innovative model for universal sanitation. It adopted the Actor-Network Theory for mapping socio-technical controversies and gaps in governance of the areas that need to be met by public services of water supply and sanitation to vulnerable populations. The model features components that provide security and addressing legal, economic, and financial management. The results are: of the universal controversy map; concepts and comprehensive indicators; review of the management model; business strategy; Creation of Inclusive Business Plan Template for Informal City and Sanitation Inclusive Model for 9 municipalities of the Baixada Santista in São Paulo operated by Basic Sanitation Company - SABESP. It builds-at the end of the activities, inclusive universal concepts and inclusive governance.

Keywords: business model, management model, governance, sanitation universal access, vulnerability, planning, indicators, favelas, business plan. 


\section{Lista de Figuras}

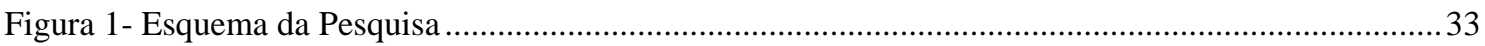

Figura 2 - Metodologia do Indicador de Atendimento de Saneamento ..................................................53

Figura 3 - Estratégias de Abordagem do Programa SELIGA ............................................................8 83

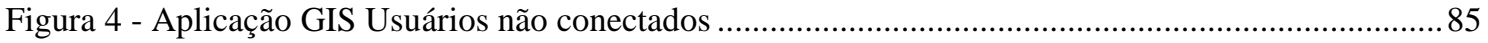

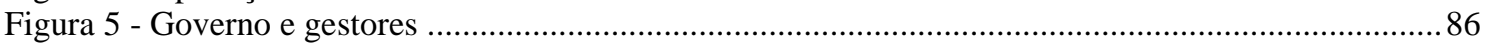

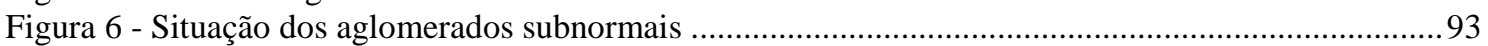

Figura 7 - Oficina de Controvérsias Sociotécnicas........................................................................ 100

Figura 8 - Oficina de Mapeamento das Controvérsias .................................................................. 103

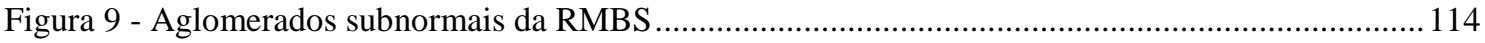

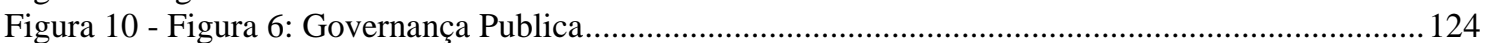

Figura 11 - Objetivos e Resultados de governança privada.........................................................125

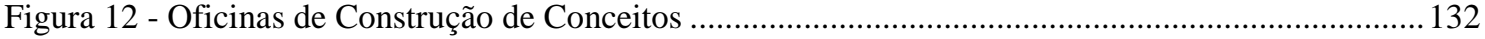

Figura 13 - Parâmetros da Governança inclusiva ............................................................................. 139

Figura 14 - Parâmetros dos Outcomes do Saneamento........................................................................ 141

Figura 15 - Blocos de consumo por categoria tarifária.................................................................... 196

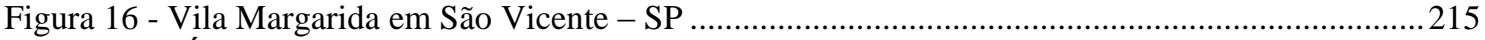

Figura 17 - Área do Dique da Vila Gilda. ...............................................................................221

Figura 18 - Fotos de arranjos técnicos nas palafitas de São Vicente ...................................................2231

Figura 19 - Fotos da Primeira reunião de lideranças em Guarujá.........................................................232

Figura 20 - Construção do Plano de Negócio Inclusivo ..................................................................235

Figura 21 - Plano Adutor Metropolitana o da RMBS .........................................................................241

Figura 22 - Lógica Geral de Cálculo para o Volume Medido de Água Residencial ...............................245

Figura 23 - Lógica Geral de Cálculo para o Volume Coletado de Esgoto Residencial ...........................251

Figura 24 - Lógica Geral de Cálculo para o Volume Coletado de Esgoto Não Residencial ....................254

Figura 25 - Lógica geral da projeção de volume coletado de esgoto.......................................................254

Figura 26 - Abrangência do programa Bolsa Família.............................................................................2279

Figura 27 - Domicílios Cadastradas no CADUNICO x Renda ...........................................................281

Figura 28: Manifestações da Comunidade da Rocinha e Vidigal ........................................................294

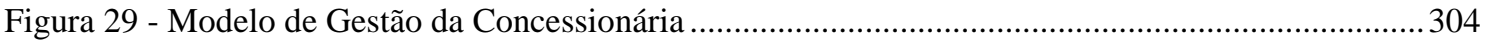

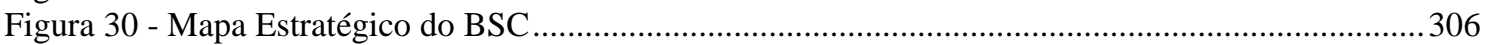

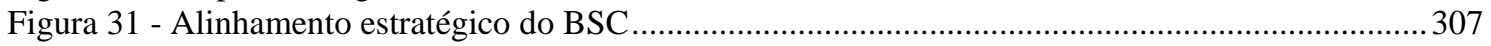

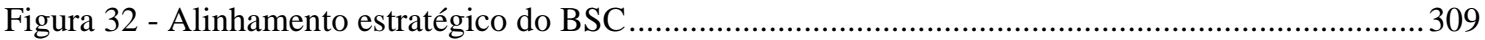

Figura 33 - Modelo de Gestão Inclusiva do Saneamento - Cartografia das Controvérsias da Gestão .....314

Figura 34 - Análise SWOT - Alcance do Objetivo da Universalização Inclusiva...................................316

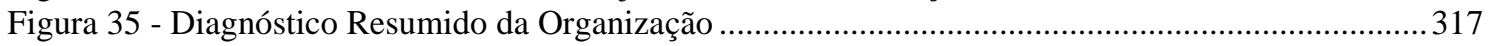

Figura 36 - Diagnóstico quanto atuação do Agente Comunitário........................................................320

Figura 37 - Planejamento Situacional da RMSP adaptado pela RMBS ............................................322

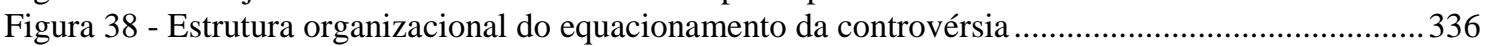

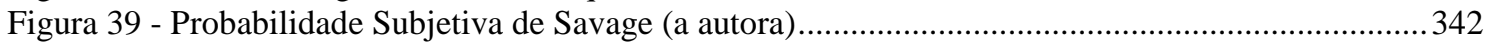

Figura 40 - Probabilidade Subjetiva de Savage (a autora) ..............................................................3.

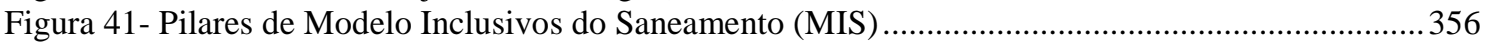

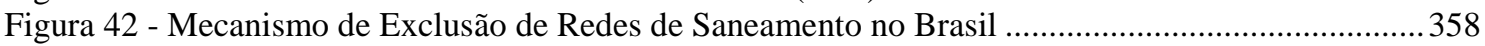

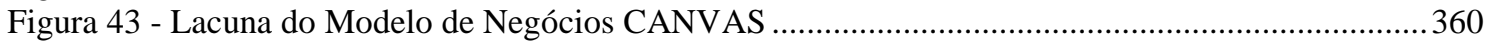

Figura 44 - Modelo de Negócios Inclusivos do Saneamento (MIS) ..............................................362

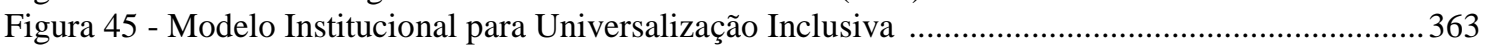




\section{Lista de Tabelas}

Tabela 1- Localidades Atendidas pela COPANOR de 2008 a 2013 ......................................................73

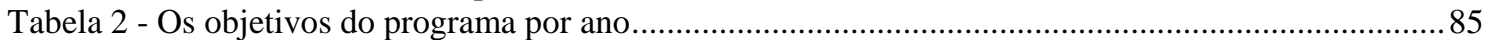

Tabela 3 - Fontes de Incertezas da Universalização do Saneamento pela Teoria Ator Rede .....................99

Tabela 4 - Domicílios da Cidade Informal da RMBS ........................................................................ 108

Tabela 5 - Resumo das Incertezas para Universalização da Cidade Informal ......................................111

Tabela 6 - Inovação dos Conceitos de Universalização .................................................................... 134

Tabela 7 - Tabela de Entrevistas e Questionários Aplicados........................................................... 148

Tabela 8 - Tipos de Questionários Aplicados .......................................................................... 148

Tabela 9 - Painel de Reguladores ............................................................................................... 151

Tabela 10 - Definição da Amostra de Entrevistas às Lideranças Comunitárias .....................................173

Tabela 11 - Definição da Amostra de Vistorias Realizadas Aglomerados Urbanos ............................... 179

Tabela 12 - Inovações sugeridas para o modelo de gestão pelos respondentes ........................................ 184

Tabela 13 - Inovações sugeridas para o Modelo de Negócio .................................................................. 184

Tabela 14 - Comparação de Base de Beneficiários da Assistência Social............................................. 195

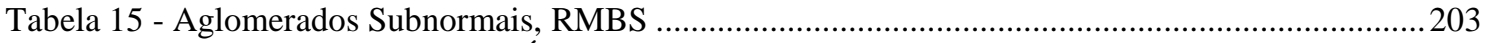

Tabela 16 - Taxa de Crescimento da Área Formal RMBS .................................................................204

Tabela 17 - Dados dos Assentamentos Precários atualizados pelos Municípios ..................................206

Tabela 18 - Vias de Circulação da RMBS ......................................................................................211

Tabela 19 - Consumo de água estimado em áreas irregulares .........................................................215

Tabela 20 - Consumo estimado em Áreas Irregulares de Vicente de Carvalho.....................................216

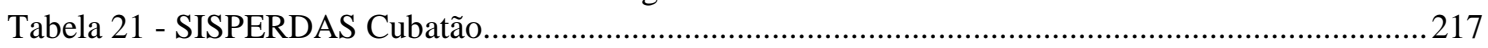

Tabela 22 - Famílias com Tarifa Social em Cubatão..........................................................................218

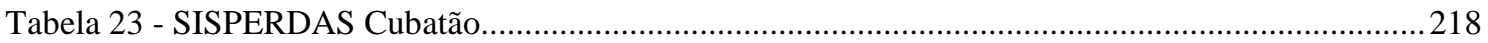

Tabela 24 - SISPERDAS setores de abastecimento de Cubatão .........................................................219

Tabela 25 - Quantidade de domicílios no Dique da Vila Gilda ...........................................................221

Tabela 26 - Resultados do EVEF da Intervenção em Santos.............................................................223

Tabela 27 - Resultados da Intervenção sociotécnica em Santa Cruz dos Navegantes ............................225

Tabela 28 - Resultados da Vistorias em Santa Cruz dos Navegantes .................................................226

Tabela 29 - Perdas Monitoradas em Santa Cruz dos Navegantes .........................................................227

Tabela 30 - Resultados da Comunidade Prainha $(11 / 2014)$............................................................228

Tabela 31 - Resultados das Vistorias em Prainha e Marezinha ...........................................................229

Tabela 32 - Perdas em Santa Cruz dos Navegantes.........................................................................230

Tabela 33 - Tabela dos Projeção de Ganhos para uma Intervenção sociotécnica em toda RMBS ...........234

Tabela 34 - Dados gerais atendimento SABESP - interior e litoral ..................................................240

Tabela 35 - Resultados das Taxas de Crescimento dos Domicílios informais .....................................246

Tabela 36 - Resultados das Projeções de Domicílios Informais e Economias/Ligações ..........................246

Tabela 37 - Resultado das projeções dos IUI de água residencial $(\%)$.................................................247

Tabela 38 - Resultados das projeções de água............................................................................248

Tabela 39 - Resultados das Projeções de volumes medidos e não medidos de água Total ......................249

Tabela 40 - Resultado das Projeções do Índice de Perdas Totais $(\%)$....................................................250

Tabela 41 - Resultado das projeções de esgoto coletado.................................................................253

Tabela 42 - Resultados das Projeções do Volume Tratado de Esgoto ...................................................255

Tabela 43 - Resultados das Projeções de Investimentos...............................................................257

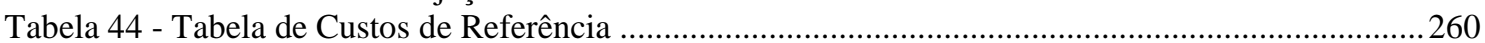

Tabela 45 - Resultados das Projeções de Custos ...................................................................................261

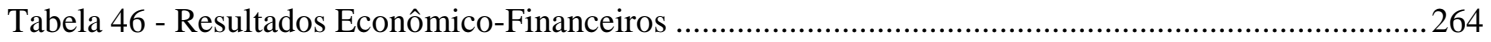

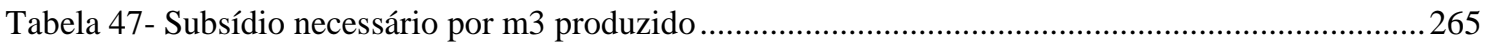

Tabela 48- Fluxo de Caixa por Receita Incremental ......................................................................266

Tabela 49 - Cálculo do IGI dos municípios..................................................................................267

Tabela 50 - Receita acessória pela distribuição do volume de perdas sociais recuperado.......................270

Tabela 51 - Classificação dos subsídios e suas principais características.............................................273

Tabela 52 - Subsídios à demanda: vantagens e desvantagens dos subsídios diretos e cruzados .............274

Tabela 53 - Externalidades inerentes ao acesso à rede de saneamento básico......................................2275

Tabela 54 - Subsídios da América Latina...................................................................................275

Tabela 55 - Critérios e requisitos para enquadramento na Tarifa Residencial Social ...........................2279

Tabela 56 - Acesso, qualidade e quantidade de água necessários para salubridade humana...................281 
Tabela 57 - Consumo mensal de água capaz de assegurar a salubridade individual segundo o número de

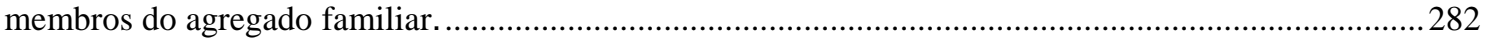

Tabela 58 - Recomendação dos níveis básicos de água necessários para a subsistência humana ............283

Tabela 59 - Experiências internacionais de subsídios tarifários ........................................................284

Tabela 60 - Características do Novo Modelo de Negócio Inclusivo do Saneamento ...............................369

Tabela 61 - Tabela de Vistorias dos Domicílios nos Pilotos Prainha e Marezinha ...............................425

Tabela 62 - Tabela de Vistorias dos Domicílios nos Pilotos Santa Cruz dos Navegantes......................426

\section{Lista de Quadros}

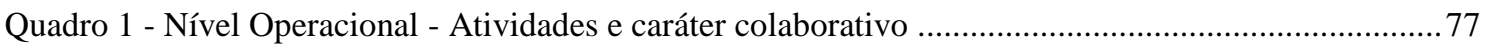

Quadro 2 - Nível da Formulação de Políticas - Atividades e caráter colaborativo...................................78

Quadro 3 - Nível Institucional - Atividades e caráter colaborativo .................................................78

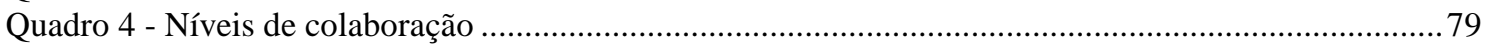

Quadro 5 - Comparação do modelo MNAC com o estado do Programa Córrego Limpo em 2012 ..............80

Quadro 6 - Relatos e preocupações identificadas dos participantes ....................................................... 101

Quadro 7 - Ontologia da Universalização do Saneamento .............................................................. 121

Quadro 8 - Categorização Analítica na Investigação........................................................................... 130

Quadro 9 - Diagnóstico dos Conceitos de Universalização ..................................................................... 133

Quadro 10 - Indicador de Universalização Inclusiva - IUI ............................................................... 138

Quadro 11 - Índice de Governança Inclusiva e seus estágios (IGI) .................................................. 140

Quadro 12 - Índice de Outcomes do Saneamento.............................................................................. 142

Quadro 13 - Indicador de Vulnerabilidade Empresarial (IVE) ............................................................ 143

Quadro 14 - Painel Desafios dos reguladores para atingir a universalização ........................................ 149

Quadro 15 - Ordenamento das Estratégias do Saneamento ...............................................................182

Quadro 16 - Inovação do modelo de gestão e negócio .................................................................... 182

Quadro 17 - Ações para o Planejamento Situacional Sociotécnicas......................................................2233

Quadro 18- Calculo da vulnerabilidade empresarial ......................................................................268

Quadro 19 - Diagnóstico da Inovação do BSC ................................................................................309

Quadro 20 - Resumo do Diagnóstico para Inovação da Estratégia Empresarial ......................................311

Quadro 21 - Diagnóstico de Nadler pela Unidade de Estudo ..................................................................318

Quadro 22 - Diagnóstico de Nadler para Inovação da Organização pela Unidade de Estudo ..................319

Quadro 23 - Ações no Complexo Conceiçãozinha, Marezinha e Prainha .............................................323

Quadro 24 - Programação de ações pelos grupos em município exemplo ...............................................325

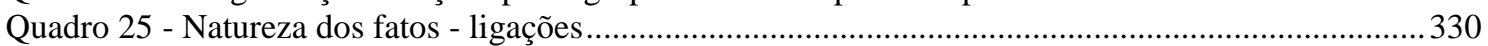

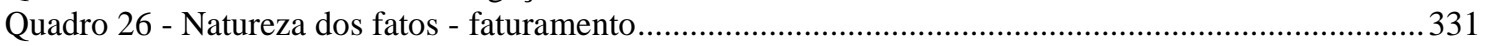

Quadro 27 - Natureza das ciências sociais - governança .................................................................332

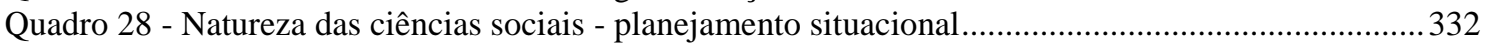

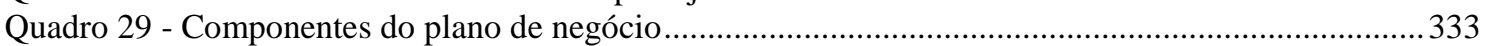

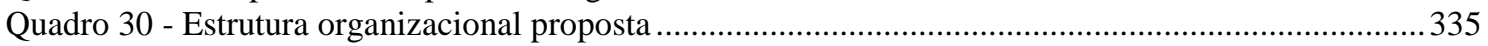

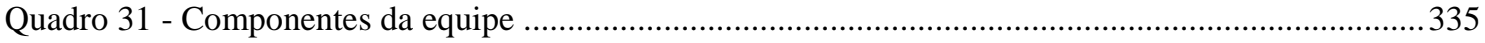

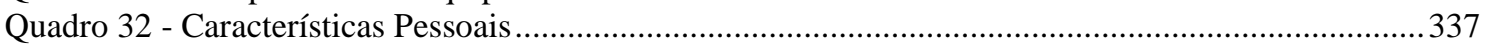

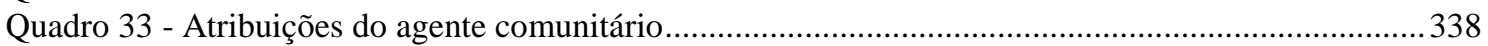

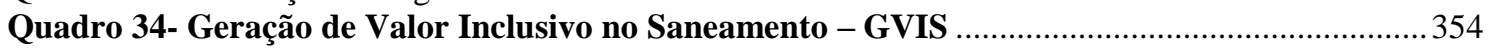

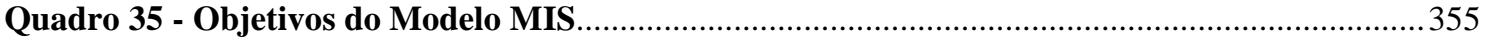

\section{Lista de Fórmulas}

Fórmula 1 - Função Construída da Correlação de Ligações Clandestinas.............................................210

Fórmula 2 - Indicador de Universalização Inclusiva ......................................................................24

Fórmula 3 - Índice de Perdas na Medição ...........................................................................................250

Fórmula 4 - Indicador de Universalização Inclusiva de Esgoto ...........................................................251

Fórmula 5 - Fórmula de Projeção de Volume Coletado de Esgoto .....................................................255

Fórmula 6 - Fórmula de projeção de volume coletado de esgoto .......................................................255 


\section{Lista de Gráficos}

Gráfico 1 - Pesquisa de fatores da universalização do saneamento no Brasil ...........................................97

Gráfico 2 - Desafios para implantação do Marco Regulatório .............................................................. 152

Gráfico 3 - Distribuição da amostra segundo a Natureza dos Grupos:................................................ 153

Gráfico 4 - Grupos atuantes na Universalização ............................................................................ 153

Gráfico 5 - Diagnóstico da Universalização do Saneamento............................................................... 154

Gráfico 6 - Existência de Instrumentos Articulados de Gestão ........................................................... 155

Gráfico 7 - Concessionárias e Universalização de Áreas Vulneráveis ..................................................155

Gráfico 8 - Reguladores e Universalização de Áreas Vulneráveis ........................................................ 156

Gráfico 9 - Planejamento e Universalização de Áreas Vulneráveis ........................................................156

Gráfico 10 - Prestação dos Serviços de Saneamento em Áreas Vulneráveis........................................... 157

Gráfico 11 - Estrutura Tarifária de Áreas Vulneráveis.................................................................... 157

Gráfico 12 - Subsídios Tarifários para Áreas Vulneráveis ................................................................. 158

Gráfico 13 - Margens Financeiras de Áreas Vulneráveis .................................................................. 158

Gráfico 14 - Custos para Operar Áreas Vulneráveis .......................................................................... 159

Gráfico 15 - Capacidade de Pagamento de Vulneráveis.....................................................................159

Gráfico 16 - Custos para Operar Áreas Vulneráveis ............................................................................ 160

Gráfico 17 - Custos dos Ativos das Áreas Vulneráveis ....................................................................... 160

Gráfico 18 - Taxas de Remuneração em Áreas Vulneráveis .............................................................. 161

Gráfico 19 - Inovação Regulatória Áreas Vulneráveis ...................................................................... 161

Gráfico 20 - Contribuição dos Grupos para Inovação da Universalização ........................................... 162

Gráfico 21 - Consciência Ambiental do Usuário de Baixa Renda....................................................... 162

Gráfico 22 - Qual grupo deve ser inovado.................................................................................. 163

Gráfico 23 - Governança e Participação Social ................................................................................. 163

Gráfico 24 - Diagnóstico da Universalização por Gestores da Área de Pesquisa................................... 167

Gráfico 25 - Distribuição das economias de água e esgoto nas categorias tarifárias residenciais ............. 171

Gráfico 26 - Distribuição do consumo medido de água e esgoto nas categorias tarifárias residenciais ... 171

Gráfico 27 - Concorrência no orçamento familiar com tarifa de água ................................................175

Gráfico 28 - Programas sociais do Governo Federal .................................................................. 175

Gráfico 29 - Respostas das Lideranças Comunitárias da RMSP ........................................................ 176

Gráfico 30 - Respostas das Lideranças Comunitárias da RMBS ...................................................... 177

Gráfico 31 - Priorização da Estratégia do Negócio de Saneamento ..................................................... 183

Gráfico 32 - Usuários da Concessionária nos setores de IPVS - SEADE .......................................... 196

Gráfico 33 - Descontos tarifários da categoria Residencial Social ....................................................... 197

Gráfico 34 - Gráfico de Dispersão de potencial abastecimento irregular ..............................................211

Gráfico 35- Projeções de Volumes de Água pelo Simulador ..........................................................259

Gráfico 36- Projeções de Perdas..........................................................................................................259

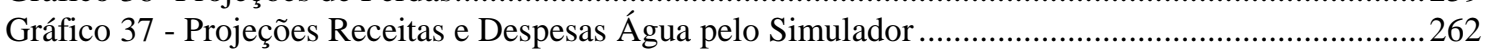

Gráfico 38 - Projeções Receitas e Despesas Esgoto pelo Simulador....................................................263

Gráfico 39 - Evolução de volumes excedentes e receitas acessórias ..................................................2270

Gráfico 40 - Despesa orçamentária por classes de rendimento ..........................................................287

Gráfico 41 - Despesa orçamentária por classes de rendimento ...........................................................28 287

\section{Lista de Mapas}

Mapa 1 - Mapa da Controvérsia pela Natureza dos Grupos e Ações

Mapa 2 - Mapa da Controvérsia da Universalização do Saneamento Teoria ANT .................................420

Mapa 3 - Mapeamento de Áreas Vulneráveis e Irregulares na RMSP ..............................................421

Mapa 4 - municípios do Estado de São Paulo .................................................................................422

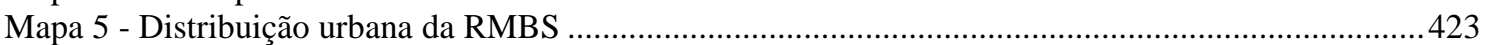

Mapa 6 - Aglomerados subnormais no município de Guarujá .....................................................424 


\section{Siglas e Abreviaturas}

ANEP: Associação Nacional de Empresas de Pesquisa;

ARSESP: Agência Reguladora de Saneamento e Energia do Estado de São Paulo;

BSC: Balance Score Card;

CADUNICO: Cadastro Único para Programas Sociais;

CBO: Comumunity-Based Organizations;

CEPAL: Comissão Econômica para América Latina e Caribe;

COHAB: Companhia Habitacional do Município de Santos;

GAP - Galerias de Águas Pluvial;

IBGE: Instituto Brasileiro de Geografia e Estatística;

IPEA: Instituto de Pesquisa Econômica e Aplicada;

IGI: Índice de Governança Inclusiva;

IUI: Indicador de Universalização Inclusiva;

IPVS: Índice Paulista de Vulnerabilidade Social;

MIS: Modelo Inclusivo do Saneamento;

MPE: Ministério Público Estadual;

NGO: Non-Governamental Organizations;

OCDE: Organização para Cooperação e Desenvolvimento Econômico;

OMS: Organização Mundial de Saúde;

ONU: Organização das Nações Unidas;

PHLIS - Plano Local de Habitação de Interesse Social;

PMSB: Plano Municipal de Saneamento Básico;

PNUD: Programa das Nações Unidas para o Desenvolvimento;

PPP: Parcerias Público-Privadas;

RMBS: Região Metropolitana da Baixada Santista;

RMSP: Região Metropolitana de São Paulo;

RTP: Revisão Tarifária Periódica; 
SABESP: Companhia de Saneamento do Estado de São Paulo;

SAAES: Sistemas de abastecimento de água e esgotamento sanitário;

SASESP: Secretaria de Assistência Social do Estado;

SBR: Setores de Baixa Renda;

SBSC: Sustainability Balance Score Card;

SEDAE: Sistema Estadual de Análise de Dados do estado de São Paulo;

SIG: Sistemas de Informação Geográfica;

UN: Unidade de Negócio;

VP: Volume produzido, em $\mathrm{m}^{3} / \mathrm{ano}$;

VCM: Volume de consumos medidos, em $\mathrm{m}^{3} / \mathrm{ano}$;

VO: Volume Operacional ou de Uso Especial, em $\mathrm{m}^{3} / \mathrm{ano}$. 


\section{Sumário}

RESUMO

1. INTRODUÇÃO

2. BALANÇO DAS REFERÊNCIAS COMO INVENTÁRIO PRÉVIO ..............37

2.1. Análise da Complexidade do Modelo .................................................. 37

2.1.1. Complexidade Jurídica dos serviços em áreas vulneráveis .................. 43

2.1.2. Complexidade Econômico-Financeira da Concessão ............................ 48

2.1.3. Complexidade dos Conceitos e Indicadores ........................................ 51

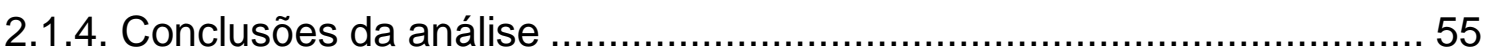

2.2. RESGATE CRÍTICO DA PRODUÇÃO TEÓRICA EXISTENTE............... 588

2.3. TAXONOMIA DE MODELOS EM ORGANIZAÇÕES SEMELHANTES..... 68

3. RESULTADOS E DISCUSSÕES DO POLO EPISTEMOLÓGICO ............. 89

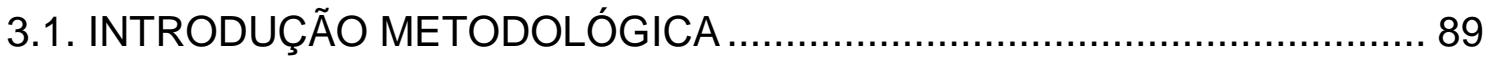

3.2. MAPEAMENTO DE CONTROVERSIAS TEORIA ATOR-REDE...............90

3.3. RESULTADOS DAS OFICINAS E QUESTIONÁRIOS ............................966

4. POLO TEÓRICO - NOVOS CONCEITOS E INDICADORES ................ 1199

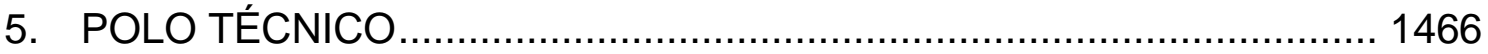

5.2. INVESTIGAÇÃO QUALITATIVA E QUANTITATIVA ....................... 1477

5.3. INVESTIGAÇÃO REGULADORES E CONCESSIONÁRIAS ............ 149

5.4. INVESTIGAÇÃO QUANTITAVA ATORES-REDE DO SETOR ........ 1522

5.5. INVESTIGAÇÃO QUALITATIVA GESTORES ............................ 1644

5.6. AVALIAÇÃO DA ESTRATÉGIA DE MAPEAMENTO DE ÁREAS VULNERÁVEIS E CHECAGEM DE BANCO DE BENEFICIÁRIOS ............. 1688

5.7. INVESTIGAÇÃO QUALITATIVA - LÍDERES COMUNITÁRIOS ..... 1711

5.8. RESULTADOS DA INVESTIGAÇÃO DE DOMICÍLIOS DAS

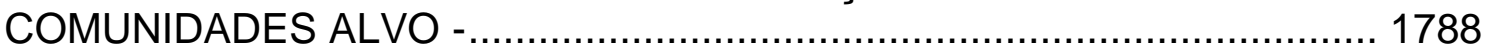

5.9. INVESTIGAÇÃO DA INCLUSÃO NA CADEIA DE VALOR............. 1800

5.10. INVESTIGAÇÃO QUALITATIVA QUANTO AO MODELO DE GESTÃO E MODELO DE NEGÓCIO - ATORES-ESTRATÉGICOS …....................... 1811

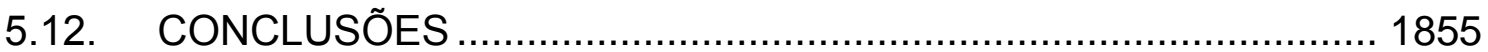

6. RESULTADOS DO POLO DE AVALIAÇÃO ….................................. 1877

6.2. AVALIAÇÃO DA REGULAÇÃO DO SANEAMENTO NO BRASIL .. 1877

6.3. AVALIAÇÃO DA GESTÃO DO SANEAMENTO NO BRASIL (ATORESREDE) 192

6.4. AVALIAÇÃO DAS BASES DE DADOS ......................................... 194

6.5. AVALIAÇÃO DAS LIDERERANÇAS COMUNITÁRIAS DE RMSP E RMBS 200

6.6. AVALIAÇÃO DAS INTERVENÇÕES NOS AGLOMERADOS......... 2033 
6.7. CONCLUSÕES DAS AÇÕES SOCIOTÉCNICAS232Erro! Indicador não definido.

7. CONSTRUÇÃO_DO_PLANO_DE_NEGÓCIO_INCLUSIVO............. 235

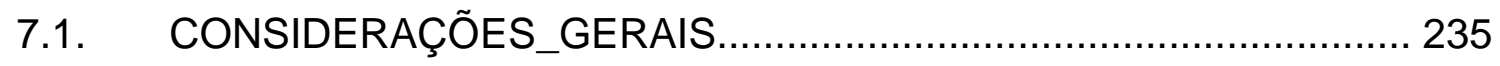

7.2. PLANO DE NEGÓCIO INCLUSIVO PNI-RMBS _.................... 237

7.3. PLANO DE INVESTIMENTO E EXPANSÃO DA CAPACIDADE DE OFERTA PARA A CIDADE INFORMAL ………….............................. 256

7.4. PROJEÇÃO DE CUSTOS......................................................... 260

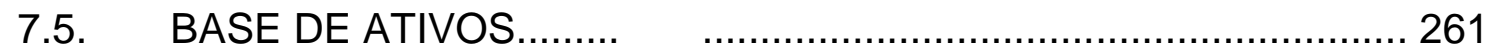

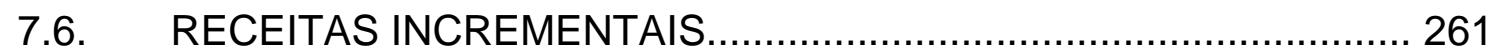

7.7. RESULTADOS ECONÔMICO-FINANCEIRO CONVENCIONAL...... 262

7.8. CÁLCULO_DO_ÍNDICE_DE_GOVERNANÇA_INCLUSIVA.............. 266

7.9. CÁLCULO_DA VULNERABILIDADE EMPRESARIAL ............. 267

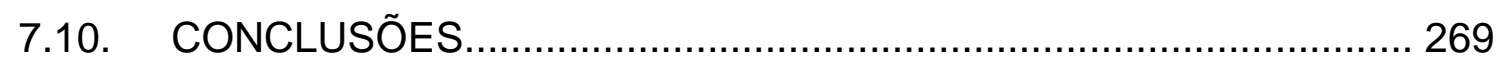

8. EQUACIONAMENTO ECONÔMICO-FINANCEIRO_....................... 272

9. EQUACIONAMENTO JURÍDICO POR MEDIAÇÃO..................... . 291

10. RESULTADOS DA AVALIAÇÃO DA ESTRATÉGIA EMPRESARIAL303

10.1. MODELO DE GESTÃO EMPRESARIAL …................................... 303

10.2. INOVAÇÃO DA ESTRATÉGIA EMPRESARIAL .............................. 309

10.3. CONCLUSÃO DA ESTRATÉGIA EMPRESARIAL............................. 310

11. AVALIAÇÃO DO MODELO DE GESTÃO PARA SBR ....................312

1.2. DIAGNÓSTICO_DA_GESTÃO_PARA SBR .............................. 313

11.3. DIAGNÓSTICO DA ORGANIZAÇÃO DO ATENDIMENTO SBR .......315

11.4. PLANEJAMENTO PARTICIPATIVO E CONTROLE SOCIAL 320

11.5. PROCEDIMENTOS ORGANIZACIONAIS E TEORIA ATOR-REDE 324

11.6. AVALIAÇÃO DA ESTRUTURA ORGANIZACIONAL........................334

11.7. CONCLUSÃO DO MODELO DE GESTÃO PARA SBR . .340

12. MODELO DE NEGÓCIO INCLUSIVO DO SANEAMENTO (MIS) 344

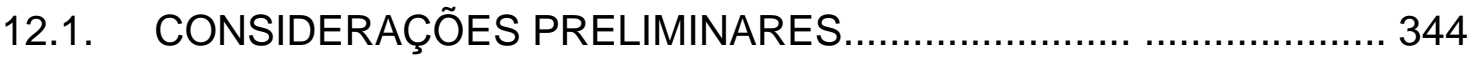

12.2. MODELOS DE NEGÓCIO INTERNACIONAIS COMPARÁVEIS. .... 347

12.3. NOVO REFERENCIAL TEÓRICO PARA MODELO INCLUSIVO 349

12.4. CONSTRUÇÃO MODELO INCLUSIVO DO SANEAMENTO 357

12.5. CONCLUSÃO .......................................................................... 365

13. CONCLUSÕES E RECOMENDAÇÕES DA TESE........................... 367

14. REFERÊNCIAS BIBLIOGRÁFICAS TESE ............................. 380

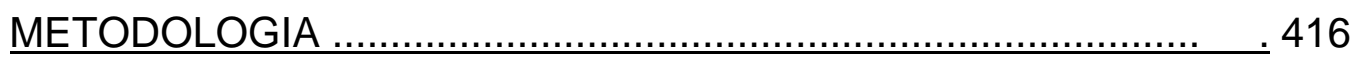


$\begin{array}{lllll}\text { ANEXO } & 1 & \text { AGENDA } & \text { DE } & \text { ENTREVISTAS, }\end{array}$ OBSERVAÇÃO........... 427

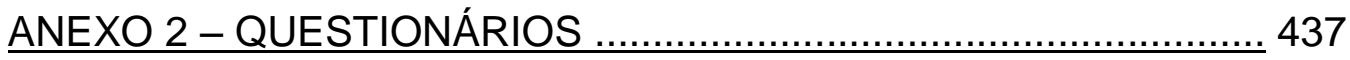

ANEXO 3 SIMULADOR PLANO DE NEGÓCIO INCLUSIVO RMBS .442

15. ANEXO DE FOTOS E LEVANTAMENTOS SABESP ............................ 474

16. PRODUÇÃO ACADÊMICA PUBLICADA E APROVADA .......................485 


\section{INTRODUÇÃO}

A realidade existente no Brasil é marcada pela heterogeneidade de renda, pelo mercado imobiliário e uso e ocupação do solo excludentes, que ampliam periferias, criando exclusão social e os chamados aglomerados subnormais.

O Instituto Brasileiro de Geografia e Estatística - IBGE (2010) considera como aglomerado subnormal o conjunto de, no mínimo, 51 unidades habitacionais (barracos, casas, etc.) carentes, em sua maioria de serviços públicos essenciais, ocupando ou tendo ocupado, até período recente, terreno de propriedade alheia (pública ou particular) e estando dispostas, em geral, de forma desordenada e densa. A identificação dos aglomerados subnormais deve ser feita com base nos seguintes critérios: a) Ocupação ilegal da terra, ou seja, construção em terrenos de propriedade alheia (pública ou particular) no momento atual ou em período recente (obtenção do título de propriedade do terreno há 10 anos ou menos); e b) Possuírem pelo menos uma das seguintes características: urbanização fora dos padrões vigentes - refletido por vias de circulação estreitas e de alinhamento irregular, lotes de tamanhos e formas desiguais e construções não regularizadas por órgãos públicos; ou precariedade de serviços públicos essenciais. Os aglomerados subnormais podem se enquadrar, observados os critérios de padrões de urbanização e/ou de precariedade de serviços públicos essenciais, na seguintes categorias: invasão, loteamento irregular ou clandestino, e áreas invadidas e loteamentos irregulares e clandestinos regularizados em período recente.

O crescimento populacional ocorrido de maneira concentrada em áreas urbanas no Brasil, que era inferior a $45 \%$ na década de 1950 , passou a $70 \%$, no final da década de 1960 , a $76 \%$, no final década de 1980 , alcançando, em 2013, quase $85 \%$ (IBGE, 2013), gerando transformações das estruturas das cidades brasileiras, acentuando conflitos referentes ao uso e ocupação do solo, num contexto que acaba sobrecarregando de forma negativa a população mais vulnerável.

Estes fatores evidenciam uma sociedade cada vez mais desigual, especialmente no acesso a infraestrutura de serviços básicos. A segregação 
pode ser entendida como o processo forçado de determinada população aglomerar-se em dada área, ocorrendo tanto por mecanismos do mercado de valorização ou desvalorização imobiliária, como por práticas efetivas de discriminação (TORRES, 2004; SABATINI, 2011).

Tal cenário está presente em grande parte das cidades brasileiras, mesmo tendo a Constituição Federal de 1988 (BRASIL, 1988, art.23) estabelecido competência às três esferas do poder público para proteção ao meio ambiente, para promoção de programas de saneamento básico e combate à poluição em qualquer de suas formas. Também, o artigo 196 confere direito de todos à saúde e o dever do Estado em instituir, mediante políticas sociais e econômicas, ações que visem redução do risco de doença e de outros agravos, bem como acesso universal e igualitário às ações e serviços para promoção, proteção e recuperação da saúde. Assim como, o artigo 225 confere direito do cidadão ao meio ambiente ecologicamente equilibrado, com dever do poder público e da coletividade de defendê-lo e preservá-lo para presentes e futuras gerações.

O marco regulatório do saneamento básico, Lei Federal 11.445/07,preconiza os objetivos da universalização dos serviços de saneamento no Brasil. A perspectiva sistêmica é observada conceitualmente e explicitada no atendimento universal da população alvo das ações de saneamento universalidade; na equivalência da qualidade sanitária de serviços, independente das condições socioeconômicas do usuário e da realidade urbanística onde vive - equidade; no atendimento dos serviços de saneamento com uma visão que entenda o saneamento como um conjunto de ações, envolvendo pelo menos o abastecimento de água, o esgotamento sanitário, a limpeza pública, a drenagem pluvial e o controle de vetores - integralidade; e como requisito indispensável para tornar visível e legitimada a diversidade de interesses, bem como para a apropriação dos equipamentos de saneamento pela população - participação e controle social (BRASIL, 2007). Em atendimento ao Marco, em 2007 foi aprovada a Lei Estadual 1.025/07, que criou a Agência Reguladora de Serviços de Saneamento e Energia no Estado de São Paulo - ARSESP. 
Ainda no Estado de São Paulo, a Política Estadual de Mudanças Climáticas PEMC, Lei Estadual ํo 13.798/09, objetiva disciplinar as adaptações necessárias aos impactos derivados das mudanças climáticas, destaca, como mecanismos importantes para a promoção do saneamento, o mapeamento e avaliação de vulnerabilidades e áreas de risco e necessidades de prevenção; a avaliação ambiental estratégica, com disciplinamento do uso do solo e planejamento regional; o planejamento emergencial contra catástrofes. No que tange às vulnerabilidades, o PEMC considera riscos sobre assentamentos e infraestrutura, destacando-se a alteração no regime hídrico, afetando o suprimento de água e seus múltiplos impactos nas infraestruturas urbanas, e ampliação de medidas de prevenção e resposta aos eventos extremos com desenvolvimento de ações integradas nos planos diretores e de bacias hidrográficas, considerando os prováveis impactos em cada região e realocação de famílias residentes em áreas de risco, entre outras (SÃO PAULO, 2009; EMPLASA, 2013).

Conforme a Organização Mundial da Saúde - OMS, saneamento do meio pode ser definido como "o controle de todos os fatores do meio físico do homem que exercem ou podem exercer efeito deletério sobre seu bem-estar físico, mental e social" (Philippi Jr 2004). As principais atividades que compõem o saneamento do meio incluem sistema de abastecimento de água; sistema de coleta e tratamento de águas residuárias; sistema de limpeza urbana; controle de artrópodes e roedores de importância em saúde pública (moscas, mosquitos, baratas, ratos, e outros); controle da poluição das águas, do ar e do solo; saneamento de alimentos; saneamento nos meios de transporte; saneamento de locais de reunião e recreação; saneamento de locais de trabalho; saneamento de escolas; saneamento de hospitais; saneamento de habitações; saneamento no planejamento territorial; Os serviços de abastecimento de água e esgotamento sanitário representam, portanto, pilares importantes no funcionamento de toda infraestrutura urbana, com reflexos na saúde e na qualidade de vida, sendo a ausência de acesso indicativa de vulnerabilidade da população.

No contexto da provisão dos serviços de abastecimento de água e esgotamento sanitário, as lacunas no Brasil ainda revelam um desafio na 
gestão para o desenvolvimento sustentável. Embora estudos (PNSB-IBGE, 2008; WHO, 2013) revelem que a taxa de cobertura de serviços de abastecimento de água em áreas urbanas do país se aproximam de 100\% (IBGE, 2010), principalmente nas regiões sul e sudeste do país, os levantamentos de campo demostraram que ainda há assentamentos nestas regiões que contam somente com acesso irregular de água ${ }^{1}$.

Estudos do Instituto Trata Brasil destacam também que o acesso a serviços de esgotamento sanitário é crescente, mas insuficiente, especialmente em áreas de assentamentos irregulares. A pobreza, a falta de informação, combinadas com baixos índices de acesso a serviços de saneamento básico, representam fator importante como responsável pela ainda significativa taxa de mortalidade infantil no Brasil (Trata Brasil, 2010).

As políticas públicas sustentadas na constituição de 1988 e no marco regulatório do saneamento (Lei 11.445 de 2007) são pontos de apoio e guias para mudanças no sentido de promover a universalização dos serviços de saneamento sob o enfoque do atendimento aos direitos humanos. Dentre outros aspectos, a Lei estabelece redefinições institucionais significativas, dando-se destaque à inserção da regulação nos novos contratos com o poder concedente e companhias de saneamento. Anteriormente ao marco regulatório do saneamento as operadoras eram reguladas pelos mecanismos de financiamento, pelas legislações da qualidade das águas, por legislações ambientais, por mecanismos de licitação, e, no caso de algumas de companhias de saneamento dos Estados de São Paulo - SABESP, Minas Gerais - COPASA e Paraná - SANEPAR, também pela Bolsa de Valores de São Paulo e de Nova York.

Após o marco regulatório de 2007, esforços setoriais vêm sendo feitos para criação de agências reguladoras dos serviços de abastecimento de água e esgotamento sanitário, para apoiar tecnicamente as municipalidades e acelerar os serviços de saneamento básico às metas nacionais de universalização. As agências reguladoras instituídas em atendimento a essa legislação criaram

\footnotetext{
${ }^{1}$ O Polo de Avaliação no Capítulo 6 apresenta este tema
} 
mecanismos de incentivo à eficiência técnica e eficácia social e efetividade da prestação dos serviços, para permitir a apropriação social de ganhos de produtividade na prestação dos serviços públicos e na execução de atividades públicas de saneamento básico.

Nesse sentido, os atuais modelos de negócio dos serviços de abastecimento de água e esgotamento sanitário serão progressivamente pressionados, em ambiente regulado, para atender de forma satisfatória e homogênea aos cidadãos, reduzindo as notórias disparidades no acesso aos serviços, em especial, nas áreas de vulnerabilidade.

Tanto processos de integração quanto processos de desintegração de usuários de redes, de inclusão e exclusão do acesso a serviços são evidências das disparidades e constitutivos das redes de infraestrutura, conectando e excluindo cidadãos de serviços públicos. Processos de desintegração e exclusão ocorrem por decisões de gestão frente a impeditivos de integração. Dois são identificáveis: os judiciais provenientes de impedimentos à concessionária atender áreas de invasão e os econômico-financeiros provenientes das exigências regulatórias de equilíbrio da concessão.

Os processos de integração, para serem viabilizados implicam em estratégias de circulação e de integração, havendo fluxo entre as partes e permitindo uma análise que contribua para superação da visão atomista e abra a possibilidade de percepção de atores/agentes em suas interações. Para isto, é imprescindível a reorientação dos valores e dos recursos em função da melhoria do nível de vida dos cidadãos (DUPUY, 1984).

É neste sentido que estão sendo empenhados esforços em políticas de universalização dos serviços, que consiste em estender a toda população, independentemente de contribuição financeira de cada indivíduo, o usufruto dos serviços apropriados às suas necessidades e à sua integralidade (MALHEIROS et al., 2006).

As respostas a este desafio da universalização não são triviais, uma vez que envolvem a articulação de atores governamentais e não governamentais para elaboração e implementação de políticas, planos, programas e projetos. Este 
processo de planejamento e gestão integrada demanda informação que permita identificação e mapeamento das populações privadas de seus direitos, ou empurradas para os bolsões ainda carentes de infraestrutura essencial, como saneamento, educação e habitação, entre outros.

O que torna esta situação bastante complexa é que não se trata somente de indisponibilidade de dados, mas saber-se quais e como os mecanismos e ferramentas devem ser apropriados pelos diferentes atores destes territórios para transformarem políticas em ações concretas e resilientes, que respondam exatamente ao complexo contexto em que estes territórios urbanos se encontram. Ou seja, elevado déficit de infraestrutura e consequente demanda de elevados investimentos, habitações em condições precárias, situações críticas quanto à regularização fundiária, entre outros aspectos, que exigem esforços multi-institucionais. Desta forma, as instituições responsáveis deverão desenvolver capacidades específicas para estes cenários, que exigem inovação em gestão nesta temática, em específico para desenvolver ferramentas que auxiliem a gestão destes serviços e indicadores capazes de mensurarem e retratarem a realidade vivenciada.

As diversas pressões que sofre uma concessionária de serviços públicos essenciais, num contexto de políticas públicas setoriais, cujas dimensões sociais não contemplam mecanismos de equacionamento de temas como capacidade de pagamento de parcela de seus usuários, bem como de dimensões judiciais de punição pelo atendimento às áreas irregulares, torna um desafio o desenvolvimento de um modelo que garanta eficazmente a operação com eficiência técnica e eficácia social de uma concessão urbana.

Portanto, o problema central foco desta pesquisa está no desenvolvimento de um modelo de negócio, que permita alavancar a universalização dos serviços de abastecimento de água e esgotamento sanitário e integre, em ambiente regulado, as urgentes demandas da sociedade pelo acesso universal, por meio da atuação articulada e integrada dos gestores do saneamento e setores correlatos com suas contribuições ao desenvolvimento urbano, que combine objetivos empresariais do atendimento as lacunas sociais, de forma a contribuir no formato de tomada de decisão e gerar valor para os usuários. 


\subsection{Pergunta de pesquisa}

A partir da hipótese de que um modelo inovador dos serviços de abastecimento de água e de esgotamento sanitário em áreas de vulnerabilidade social permitirá que a concessionária consiga responder estrategicamente aos desafios que vêm sendo trazidos pela própria universalização, de forma a operar em regime de eficiência técnica, eficácia social, proteção ambiental e governança, de maneira a inserir princípios do desenvolvimento sustentável na organização, emergem as questões:

Quais seriam os ajustes no atual modelo de saneamento para a universalização do saneamento em áreas de populações vulneráveis? Como incorporar na gestão da empresa mecanismos de governança para a sustentabilidade? Como universalizar serviços públicos para obtenção de benefícios socioambientais?

\subsection{Objetivo}

Objetivo principal é propor inovação no modelo para a universalização dos serviços de abastecimento de água e esgotamento sanitário em áreas de populações vulneráveis.

Objetivos específicos:

a. Reunir, analisar e inovar conceitos, modelos; identificar experiências de avaliação da universalização em áreas de vulnerabilidade e propor procedimentos com melhores práticas;

b. Identificar contribuições de programas de universalização do saneamento básico em áreas vulneráveis;

c. Elaborar modelo que integre informações multidisciplinares acerca da universalização do saneamento já alcançadas com uma proposta inovadora que equacione impeditivos nas dimensões organizacionais.

\subsection{Considerações sobre a escolha da tese}

Modelo Inclusivo é a lógica de como uma organização cria, distribui e captura valor de forma a considerar os cidadãos em situação de exclusão social, inserindo-os na cadeia de valor. Significa criar um novo paradigma para 
atender todo e qualquer cidadão na área de concessão garantindo a dignidade humana (para a universalização) com serviços essenciais de abastecimento de água e esgotamento sanitário (do saneamento básico) em locais habitados por subcidadãos em condições de pobreza, que não têm condições por si, de superarem as limitações impostas pela vida urbana (em áreas de vulnerabilidade social cujos cidadãos não sejam moradores de rua). Está fortemente atrelado à gestão, representando vantagens competitivas e aperfeiçoamento de processos. Sua construção, conceituação, mapeamento e monitoramento contribuem para que a estrutura empresarial, composta da alta administração e gestores compreendam, inovem, divulguem e registrem a racionalidade do negócio. Como resultados, o modelo define limites de criação de valor, processos e governança, no sentido de contribuir aos processos colaborativos, agrega valor aos serviços, promove a gestão de ativos intangíveis, melhora o desempenho empresarial por antever problemas futuros (OSTERWALDER \& PIGNEUR, 2011; BERGERON, 2003, KLANG et. al. 2010, BHATT, 2001, BOSE, 2004, SOSNA et. al. 2010).

Assim, faz-se necessário uma análise de contexto socioambiental para compreensão do modelo de gestão e de negócio dos serviços públicos de abastecimento de abastecimento de água e esgotamento sanitário em áreas de vulnerabilidade social.

O Atlas do Saneamento (IBGE, 2011, 2013) apresenta dados alarmantes da gestão do saneamento, por exemplo: intermitência do abastecimento em regiões de secas, ausência de serviços e cobrança, e taxas de mortalidade infantil correlacionada à ausência de serviços de saneamento, que demonstram o status atual da prestação dos serviços no Brasil. As regiões metropolitanas possuem cidades com diferentes qualidades de instrumentos de gestão, planejamento e legislação municipal no que tange política de saneamento e urbanização de assentamentos precários.

Os equacionamentos dos setores de infraestrutura para a universalização dos serviços em diversos países passam por mecanismos capazes de superar a crescente urbanização da pobreza, baixa qualidade ou ausência de serviços básicos, entendimento pela população que tem direito aos serviços e os acessa de forma lícita ou ilícita, ausência de mecanismos de financiamentos e política de subsídios para acesso da população de baixa renda e altos custos 
ambientais (DURANA ET. AL. 2010).

No Brasil ocorrem os mesmos fatos de origem, que são agravados pela ausência de uma estratégia nacional de universalização para aglomerados subnormais e de mecanismos nacionais de subsídios a populações de baixa renda (JULIANO ET. AL, 2014).

Alguns fatores estruturantes da sociedade brasileira, como o uso e ocupação do solo, o preço da terra e a periferização fazem com que cada vez mais existam pessoas em áreas irregulares, impactando a universalização dos serviços de saneamento.

A despeito da inserção nas diretivas do marco regulatório para universalização com participação e controle social, deslocando a centralidade dos serviços para o usuário, com dispositivos legais para um mercado regulado, as empresas seguem em práticas monopolistas buscando alternativas para equacionar esses desafios com recursos provenientes dos serviços prestados e dos acionistas. O planejamento pelo poder concedente e as providências para urbanização de aglomerados subnormais impressindíveis à universalização demandam esforços legais e técnicos além de recursos nem sempre disponíveis aos municípios. Por outro lado, o regulador tem priorizado definição de tarifas, orientação para a universalização (incentiva demanda) e fiscalização dos serviços técnicos. Deparam-se frequentemente com a intervenção pública sobre o preço, a gestão de um preço político frente ao preço de mercado (efeito sobre a oferta), inviabilidade econômico-financeira dos serviços dos municípios pobres, e desmantelamento do mecanismo de subsídios, o estabelecimento de limitações legais e regulatórias ao financiamento e organização da demanda, e a dificuldade em se adaptar a inovação.

Nesse sentido, deve-se considerar que a inovação tem uma dimensão de resultado e outra de processo que advém da capacidade de requisitos organizacionais e deliberação proposital para esse fim (SANTOS, BASSO, KIMURA, 2012; CROSSAN \& APAYDIN, 2010; PAVITT, 1982; NYBACK \& JENSSEN, 2012; PRESTER \& BOZAC, 2012). Fatores como metodologia, atendimento de mercado específico, matérias primas e concorrência vão levar à inovação, além de recursos disponíveis, processos internos e prioridades empresariais, sendo um dos motivadores principais à tomada de decisão, ambiente de inovação e elos internos que os unem entre si e com o meio 
externo, incluindo a estrutura de governança. Como consenso, os modelos devem conter estratégia clara, estrutura formal, recursos garantidos, fatores humanos e culturais considerados, e revisão de processos (SCHUMPETER, 1984; CHRISTENSEN, 2000; VAN DE VEM ET. AL., 2000).

Estes aspectos têm impacto importante na inovação dos serviços de saneamento. É necessário definição de uma inovação na governança empresarial, que cubra situações marginais, e lacunas da politica pública, que permita focalizar esforços e recursos para proteger a população mais vulnerável e possibilitar que essa tenha acesso universal aos serviços que presta uma concessionária.

Um dos principais impactos da inovação de gestão e do modelo de negócio decorrentes da economia atual é a ampliação do leque de configurações de novos negócios de uma organização, que aumentou a complexidade das decisões e dificultou a tomada de decisão pelos gestores (PATELI \& GIAGLIS, 2004). Estes impactos também afetam o saneamento.

As ineficiências técnicas que escapam a um sistema de informações não auditadas para o benchmarking ${ }^{2}$ entre empresas, a descontinuidade política de programas e projetos, e a desarticulação entre ministérios, secretarias e agentes reguladores desafiam a universalização.

A pergunta que emerge é quem será o provedor de um novo modelo? No aspecto da gestão, deverá promover o funcionamento dos serviços com celeridade, redução de gargalos decisórios, fortalecimento de parcerias entre poder público e concessionárias, e transparência com a sociedade. Faz-se necessário instrumentos aderentes à realidade urbana, de forma a inovar o modelo de negócio em regime de eficiência, eficácia e efetividade para a universalização, que seja capaz de perceber as mudanças na estrutura de mercado e sociedade, antecipando-se a elas de forma a compreender o propósito moral da transformação e trazer conceitos e conteúdos para a organização como valores empresariais.

Nesse sentido, parafraseando Porter \& Kramer (2011), o projeto de pesquisa busca a proposição de um Modelo inovador dos serviços públicos de

\footnotetext{
${ }^{2}$ Benchmarking é uma ferramenta caracterizada pela capacidade de aferir eficiência e eficácia da prestação dos serviços por meio de indicadores de produtividade das empresas, que são comparadas por reguladores (Guimarãaes et. al, 2014)
} 
saneamento, de forma a gerar benefícios sociais numa escala de iniciativas de geração de valor socioambiental e econômico com lições de inclusão. A universalização do saneamento básico deve incluir em sua estratégia contribuições na transformação da condição de vida do usuário de áreas de vulnerabilidade frente à importância da relação do mesmo com água e esgoto, por meio de mudanças da gestão da organização, governança e estratégias econômico-financeiras.

O tema é central para a engenharia ambiental, sendo que as discussões da sustentabilidade e as ciências ambientais contribuem à identificação dos determinantes sociais, legais e econômicos da universalização do saneamento.

\subsection{Limitações da construção da tese}

Esta tese não aborda modelos de negócio genéricos dos Sistemas de abastecimento de água e esgotamento sanitário - SAAES das empresas públicas ou privadas, modelos de concessão dos serviços em municípios dentro ou fora das regiões metropolitanas, operação de departamentos de águas e esgoto municipais ou qualquer outra modelagem que considere os usuários regulares das áreas consideradas atendíveis pelos novos contratos de programa. Igualmente não trata das modelagens de negócios para plantas de produção e tratamento de água e de plantas de tratamento e disposição final de esgotamento sanitário.

As delimitações da tese são dadas pelos limites geográficos e empresariais do cidadão habitante de áreas irregulares, de vulnerabilidade socioambiental, em condição de exclusão da operacionalização, implantação dos serviços essenciais, que devem ser prestados em atendimento aos direitos constitucionais, das políticas públicas do setor de saneamento, que habitam nos chamados assentamentos precários.

A metodologia de identificação e mobilização de lideranças comunitárias também não é objeto desta tese, por essa razão não será abordada, apenas citada.

\subsection{Abordagem metodológica}

Martins \& Theóphilo (2009) afirmam que a geração do conhecimento se 
processa em quatro polos: metodológico, epistemológico, teórico e técnico, que devem ser avaliados e que promoverão a construção do modelo desta pesquisa (Figura 1).

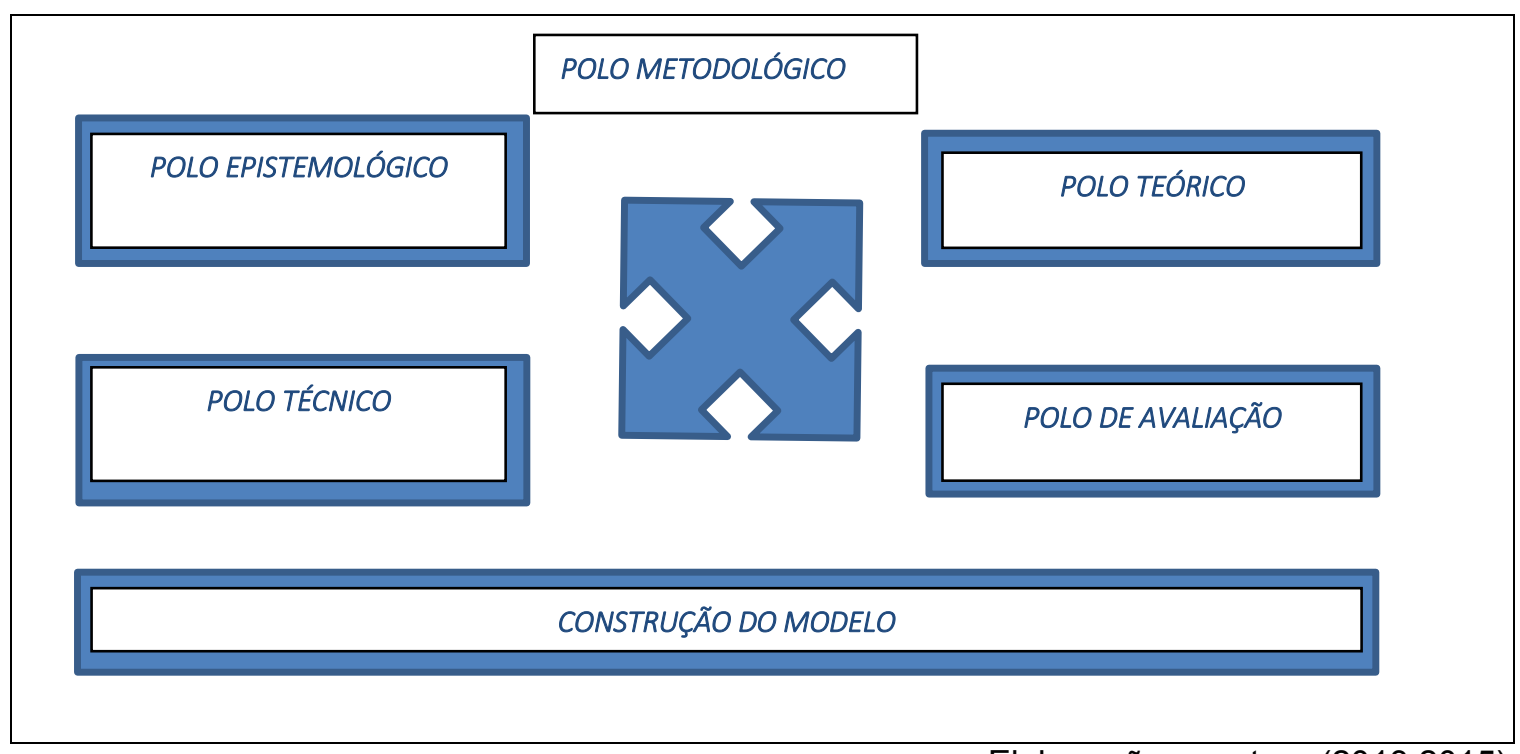

Elaboração: a autora $(2013,2015)$

Figura 1- Esquema da Pesquisa

Polo metodológico - apresenta os caminhos do método científico adotado para se atingir resultados e objetivos propostos e enquadra-se em qualitativo de pesquisa e recursos metodológicos multivariados de coleta de dados. É composto de: revisão de literatura; pesquisa documental; checagem por questionários dos dados secundários da operadora, Secretaria de Assistência Social e Fundação SEADE; levantamento de dados primários; entrevistas em profundidade; discussão de grupo (BAUER E GASKELL, 2002; DENZIN, 1970A; DENZIN, 1970B; DENZIN, 2000; KVALE, 1996; QUIVY E VAN CAMPENHOUDT, 1993; TRIVIÑOS, 1995, LATOUR, 2012).

Para produção e coleta dos dados foram aplicados questionários (Anexo 2) a 136 (cento e trinta e seis) atores do setor de saneamento, 11 entrevistas presenciais ou por Skype com atores-rede estratégicos do setor de saneamento; 28 (vinte e oito) entrevistas com gestores da concessionária, 68 (sessenta e oito) entrevistas com líderes comunitários, representando 6.800 famílias moradoras de aglomerados subnormais, e 2.515 (dois mil, quinhentos e quinze vistorias de domicílios representativos dos 9 municípios da RMBS com $96 \%$ de confiança e margem de erro de 1\%. Para construção do 
cartografia das controvérsias, definição de conceitos, indicadores, modelo e validação de resultados foram realizadas 20 (vinte) oficinas de construção participativa de um modelo inovador de negócio, que atenda aos desafios das controvérsias sociotécnicas do saneamento. A abordagem metodológica escolhida foi a crítico-dialética, que admite a inter-relação qualitativa e quantitativa entre uma visão dinâmica de fenômenos enfocando três dimensões: tramas de relações contraditórias de leis de construção conflitantes e transformação dos fatos, método de investigação da realidade (rompimento com o modo de pensar dominante e instaurar um método dialético) e uma práxis que revela mais do que o conflito de interesses, mas o foco transformador do fenômeno estudado. Segundo a metodologia, é fundamental não interpretar ou ocultar e somente relatar, não privilegiar ações concretas em detrimento das abstratas, num papel legislativo que abandona o relativismo (Latour, 2012).

Polo Epistemológico - é o orientador crítico dos demais polos. Esta prática científica definida por Bruyne et al. (1991) considera a complexidade das problemáticas das ciências sociais aplicadas e permite reavaliações e rearranjos, considerando que a pesquisa não é uma sequência de procedimentos e necessita de interpretações em cada polo com voltas constantes aos polos referenciais. É de abordagem complexa com cinco princípios fundamentais: 1.) Análise de uma problemática, devendo conter um inventário prévio do pesquisador que delineará e direcionará a pesquisa, demandando conhecimento profundo do pesquisador na problemática; 2.) Resgate crítico do referencial teórico, a fim de revisitar rupturas e superações julgadas necessárias); 3.) Taxonomia dos Modelos dos Setores de Baixa Renda - SBR; 4.) Mapeamento das Controvérsias, que organiza os múltiplos determinantes e demonstra a complexidade, os avanços obtidos em relação a controvérsia em situações específicas e implicações para a ação concreta, segundo a Teoria Ator-Rede de Latour (2012). Essa etapa foi realizada em cinco oficinas: duas de práticas de superação, uma de indicadores, e duas de construção do Mapa da Controvérsia.

Polo Teórico - trata-se de etapa de construção dos marcos conceituais. Foi desenhado com a proposta de procedimento de Quivy e Campenhoudt (1992), com as etapas de ruptura identificadas em oficinas, construção e verificação. 
Ocorreu mediante a proposição e construção dos marcos por três oficinas homogêneas clusterizadas por tipo de contribuição a validação/construção de conceitos e uma oficina complementar para os respectivos indicadores. A primeira foi composta por representantes da academia, operadores, reguladores e município para validar os critérios de análise identificados na literatura concorrentemente ao estudo de caso; a segunda, composta por técnicos, operadores, reguladores e gestores municipais das áreas piloto, e a terceira, composta por representantes dos grupos anteriores, usuários e sociedade civil organizada.

Polo Técnico - metodologia de pesquisa-ação, tendo por objeto de análise aglomerados subnormais (IBGE, 2011), com população em condição de habitação em áreas favelizadas, em situação de vulnerabilidade socioambiental determinadas a partir de um diagnóstico preliminar priorizado pela urgência de universalização, sujeitos a riscos de danos à saúde e meio ambiente, ampliados pelo número de cidadãos afetados por essa situação. Foi definido em conjunto com a concessionária como piloto no estado de São Paulo em área urbana metropolitana, regulada pela Agência Reguladora de Saneamento e Energia do Estado de São Paulo - ARSESP. Este polo contempla a aplicação de questionários a atores-rede (Anexo 2 - questionário 1) e usuários das áreas objeto de estudo (Anexo 2 - questionário 2) cujo objetivo foi de subsidiar oficinas para a construção do modelo de negócio e gestão. Os questionários aplicados em entrevistas qualitativas intra-organização (Anexo 2 - questionário 3), foram antecipadamente testados em atores de referência, e permitiram ajuste dos formulários qualitativos para determinar os elementos de linguagem e temas predominantes, cujo objetivo foi de subsidiar a construção do modelo de gestão.

Adotou-se o Código de ética ANEP-ICC/ESOMAR, fornecido pela Associação Nacional de Empresas de Pesquisa ANEP. Todos os entrevistados autorizaram que suas respostas fossem contabilizadas nesta pesquisa. Ainda assim, como garantia ao anonimato dos respondentes intra-organização, somente foram apresentadas consolidações e posicionamentos de forma coletiva e nunca individual. As entrevistas qualitativas, realizadas com especialistas dos setores de água e energia e catedráticos de universidades foram autorizadas por escrito ou verbalmente nas entrevistas que foram gravadas. Nenhuma 
gravação será divulgada ou disponibilizada a terceiros, conforme código de ética da ANEP. As datas das entrevistas, questionários, levantamentos de campo, oficinas e reuniões na condição de observadora constam da agenda (Anexo 1), e totalizadas no Quadro 01.

Polo de Avaliação - contemplou análise e interpretação dos resultados das atividades de campo com a geração de uma base empírica geo-referenciada da concessão em base disponível com dados socioeconômicos da Fundação Seade e dos usuários do sistema comercial da concessionária. Também consolidou os resultados dos questionários, e fundamentou a construção do modelo, procedimentos, funções e planejamento.

Construção do Modelo - deu-se por abordagem da dimensão social da vulnerabilidade, com suporte da teoria da administração para grandes organizações sociais, teoria-ator-rede para ciências naturais e ciências sociais e arcabouço jurídico. As concepções teórico-metodológicas apoiaram as oficinas para subsidiar o desenvolvimento do modelo em bases participativas. Foram 13 (treze) oficinas de contribuição ao desenvolvimento do modelo:

$>$ Três oficinas de mapeamento das praticas de governança para universalização utilizadas;

$>$ Duas oficinas de diagnóstico e identificação dos fatores-chave das práticas de gestão;

> Identificação e mobilização dos atores-rede;

> Três oficinas para inovação do modelo de gestão, governança e fatores que contemplassem a atenção às áreas em condição de vulnerabilidade social, com a finalidade de identificar os desafios da malha urbana frente à complexidade social;

> Cinco oficinas para subsidiar o desenvolvimento de um plano de negócio com indicadores de resultados e de governança da atuação nas áreas de vulnerabilidade utilizando intervenções micropolíticas na comunidade do modelo de gestão;

A construção do modelo institucional, o equacionamento econômico-financeiro e equacionamento jurídico foram desenvolvidos e apresentados aos atores do setor. Nesse sentido, o modelo inovador teve como objetivo equacionar os desafios dos serviços de saneamento básico aos SBR, de forma atingir a universalização. 


\section{BALANÇO DAS REFERÊNCIAS COMO INVENTÁRIO PRÉVIO}

\subsection{Análise da Complexidade do Modelo}

Preliminarmente, como inventário necessário (Latour, 2012), destaca-se que a história das concessionárias mistura-se à da política pública do setor de saneamento básico no Brasil, que não sofreu vácuos jurídicos legais e institucionais nas últimas décadas.

As referências institucionais brasileiras para a universalização do saneamento básico no Brasil originam-se no Código das Águas de 1934 (BRASIL, 1934) sustentando um modelo regulatório inovador na época, que ainda influencia as políticas públicas do País. Esse primeiro marco regulatório, definiu as águas como bem público, e um modelo estatizante do Estado Novo, conferindo necessárias ressalvas em seu texto quanto ao uso da água (irrigação, saúde e energia).

Na década 1970, o Plano Nacional de Saneamento - PLANASA definiu o modelo sobre o qual o saneamento foi fundamentado, cuja preocupação inicial era a universalização do acesso aos serviços de abastecimento de água potável a todas as camadas sociais por meio de regulamentação tarifária coerente com o poder aquisitivo da população (BRASIL, 1978B, BRASIL 1978A, art.10) e equilíbrio econômico-financeiro dos prestadores. O subsídio econômico financeiro foi o mecanismo instituído para a modicidade tarifária. Ainda, criou as Companhias Estaduais de Saneamento Básico - CEBs para executar essa política pública, com parcela de responsabilidade do poder público visando promover a saúde e o saneamento básico como fatores indispensáveis ao desenvolvimento social e econômico da população e do país.

O equilíbrio tarifário das CEBs foi previsto em lei para ocorrer por meio de subsídios cruzados, a fim de compatibilizar aspectos econômicos com objetivos sociais do momento em duas linhas. Subsídios entre categorias de usuários e regiões para a demanda, e subsídios à oferta mediante recursos do Banco Nacional da Habitação - BNH, criado em 1964 com a missão de implantar uma política de desenvolvimento urbano. Segundo Gómez-Lobo (2003), o subsídio constituem importante instrumento de política econômica, que subsídios 
consiste na entrega de recursos a um grupo de agentes econômicos (produtores ou consumidores), de um determinado setor, de forma a alterar o equilíbrio de mercado, que seria alcançado em condições normais, cuja finalidade é melhorar o bem-estar da sociedade.

O objetivo principal do PLANASA era de ampliar a cobertura dos serviços de saneamento básico. As metas do plano eram atender $80 \%$ da população urbana com serviços de água e 50\% com serviços de esgoto, até 1980 . O perfil da gestão do setor na ditadura militar de 1978 a 1988 caracterizou-se por centralização decisória, prestação dos serviços subordinada à auto sustentação tarifária, predominância das ações nas regiões mais desenvolvidas (Sul e Sudeste), aplicação dos subsídios cruzados e obrigatoriedade de concessão dos serviços locais às companhias criadas pelos estados brasileiros como requisito para que os municípios acessassem os recursos da União. Os recursos do Sistema Financeiro do Saneamento - SFS, foram disponibilizados após os municípios assinarem contratos de concessão com as Companhias Estaduais de Saneamento Básico - CESBs. Estes renunciaram suas prerrogativas de poder concedente, notadamente em matéria de política tarifária e de novos investimentos. (BRASIL, 2010). Dois instrumentos de financiamento apoiavam o plano: o programa de financiamento do Banco Nacional da Habitação - BNH, o Programa de Fianciamento para o Saneamento - FINASA e os Fundos de Água e Esgoto Estaduais - FAEs. O modelo do PLANASA enfocou a construção e ampliação dos sistemas, com menor ênfase na operação, o que levou a uma posterior degradação dos sistemas e índice elevado de perdas. No que tange os financiamentos para investimentos, de 1968 a 1971 quase 100\% dos investimentos realizados foram em redes de abastecimento de água e 30\% foram investidos em coleta e afastamento de esgoto. De 1968 a 1984, o BNH respondeu por 65\% dos recursos financiados, contra apenas 35\% dos fundos estaduais. Entre os municípios que não aderiram, apesar das dificuldades de financiamento, até 1996 mais de $60 \%$ atingiram coberturas de serviços de água superiores a $90 \%$. Entretanto, somente $57 \%$ dispunham de rede coletora de esgoto, sendo que $43 \%$ alcançaram cobertura superior a $90 \%$ da população, segundo diagnóstico realizado pela Associação Nacional dos Serviços Municipais de Saneamento ASSEMAE / Fundo Nacional da Saúde - FNS (1996). No início da década de 
80, o Planasa atingiu a meta de $80 \%$ de cobertura de água. Em 1985, entretanto, o BNH foi extinto, sendo substituído pela Caixa Econômica Federal, que reduziu a oferta de recursos. (SILVA, 2005).

A Política Nacional do Saneamento daquele período propiciou regras claras para as CEBs, sustentada no modelo de subsídios, de equilíbrio econômico financeiro da concessão, vinculando-o ao acesso de financiamentos instituídos para universalização. Este foi o mecanismo regulatório daquele período.

No âmbito do Estado de São Paulo, os serviços de água e esgoto em grande parte dos municípios do Estado de São Paulo eram administrados diretamente pelos municípios, quer através de departamentos municipais de saneamento básico, quer através de autarquias municipais. ${ }^{3}$

Em 1954, como resposta ao expressivo crescimento da população na Região Metropolitana de São Paulo, o Governo do Estado de São Paulo criou o Departamento de Águas e Esgotos, autarquia do Governo do Estado. O Departamento de Águas e Esgotos prestava serviços de água e esgotos para vários municípios da Região Metropolitana de São Paulo. Em 1968 ocorreu uma reestruturação importante das entidades concessionárias de serviços de água e esgoto no Estado de São Paulo, com a criação da COMASP, cujo objetivo era fornecer água potável por atacado para consumo público nos municípios da Região Metropolitana de São Paulo. Todos os ativos relacionados à produção de água potável na Região Metropolitana de São Paulo anteriormente pertencente ao Departamento de Águas e Esgotos foram transferidos a COMASP. Em 1970, foi constituída pelo Governo do Estado de São Paulo, a SAEC - Superintendência de Água e Esgotos da Capital para distribuir água e coletar esgoto na Cidade de São Paulo. Todos os ativos anteriormente pertencentes ao Departamento de Águas e Esgotos vinculados a estas atividades foram transferidos à SAEC. Também em 1970, o Governo do Estado de São Paulo constituiu a Companhia Metropolitana de Saneamento de São Paulo, ou SANESP, para prestar serviços de tratamento de esgoto na Região Metropolitana de São Paulo. Todos os ativos anteriormente pertencentes ao Departamento de Águas e Esgotos vinculados a estas

\footnotetext{
${ }^{3}$ Autarquias são órgãos públicos relativamente autônomos com existência jurídica, ativos e receitas próprias, constituídas por lei para assumir a administração de serviços públicos para os quais considera-se que serão melhor administrados por uma estrutura administrativa e financeira descentralizada.
} 
atividades foram transferidos à SANESP. O Departamento de Água e Esgotos foi posteriormente extinto.

Em 29 de junho de 1973, com o objetivo de implementar as diretrizes do Governo Federal estabelecidas no Plano Nacional de Saneamento - PLANASA, a COMASP, a SAEC e a SANESP se fundiram para formar a Companhia de Saneamento Básico do Estado de São Paulo - SABESP. O Plano Nacional de Saneamento foi um programa patrocinado pelo Governo Federal que financiou investimentos e auxiliou no desenvolvimento de empresas de serviços de água e esgoto controladas pelo Estado. Desde a constituição da companhia, outras sociedades de economia mista relacionada à produção e distribuição de água, coleta e tratamento de esgoto no Estado de São Paulo foram incorporadas a SABESP.

No entanto, o modelo PLANASA não logrou garantir o retorno dos pesados e intensos investimentos realizados pelas CEBs ainda pendentes de equacionamento econômico-financeiro. Isto porque, o modelo não foi capaz de solucionar a intensa interferência política que permeou e permeia a atuação das companhias estaduais, agregada à escassez de recursos municipais de toda natureza, potencializando a inadimplência prejudicando o equilíbrio econômico-financeiro da prestação dos serviços.

Nas décadas de 1970 e 1980 os programas, projetos e gestão das CEBs refletiram a busca da universalização nas práticas organizacionais apoiadas em política pública nacional, sendo que implantou uma teoria do bem-estar social e foi agente da política distributiva do Estado de São Paulo. Por essa razão, passou a ser objeto de pressão e manipulação política pelo poder concedente e afastou-se do modelo de tarifas que representava custos dos serviços e promoveu o desequilíbrio econômico-financeiro das concessões.

Em 1994 a Companhia de Saneamento Básico do Estado de São Paulo tornouse uma empresa de capital aberto objetivando captar recursos para investimentos. Operava 363 municípios, em 2013, no estado de São Paulo com uma estrutura de governança proveniente do Novo Mercado da Bolsa de Valores, Mercadorias e Futuros de São Paulo (BM\&FBovespa), American Depositary Receipts (ADR) e Bolsa de Valores de Nova York (NYSE), onde suas ações são negociadas. (SABESP, 2013). Em dezembro de 2014 realizou aproximadamente $\mathrm{R} \$ 2$ bilhões/ano de investimentos. 
A Constituição Federal de 1988 estabeleceu inter-relações do saneamento no artigo 23, incisos VI, VII e IX, atribuindo competências comuns a união, estados, distrito federal e municípios de proteger o meio ambiente, promover programas de construção de moradias e a melhoria das condições habitacionais e de saneamento básico, além de combater a poluição em qualquer de suas formas. No artigo 225 assegurou a todos o direito ao meio ambiente ecologicamente equilibrado, bem de uso comum do povo e essencial à sadia qualidade de vida, impondo ao poder público e à coletividade o dever de defendê-lo e preservá-lo para as presentes e futuras gerações. E no artigo 200 estabeleceu competências do sistema único de saúde de participação na Política de Saneamento (BRASIL, 1988). Quanto aos recursos hídricos, no artigo 20 conferiu à União a propriedade de rios, lagos e quaisquer correntes de água, superficiais ou subterrâneas, em território de exclusivo domínio federal ou que banhe mais de um estado, sirvam de limite com outros países ou se estendam a território estrangeiro ou dele provenham. E nos artigos 23, 24 e 26, inciso I da Constituição incluem entre os bens dos estados as águas superficiais ou subterrâneas fluentes, emergentes e em depósito, ressalvadas neste caso as decorrentes de obras da União.

A Lei n. 9.433, de 08/01/97, regulamenta o artigo 21, inciso XIX, da Constituição Federal, estabelecendo a competência da União para instituir a Política Nacional de Recursos Hídricos e o Sistema Nacional de Gerenciamento dos Recursos Hídricos, visando assegurar a necessária disponibilidade de água à atual e às futuras gerações (BRASIL, 1997). Em 1991, a Lei n. 7.663/91 instituiu a Política Estadual de Recursos Hídricos e o Sistema Integrado de Gerenciamento dos Recursos Hídricos (SIGRH) e adota as bacias hidrográficas como Unidades de Gerenciamento de Recursos Hídricos. A partir dessa legislação, após dois anos de estudos aprofundados e discussões públicas, foi elaborada e promulgada em 28/11/1997, a Lei no 9.866/97, que dispõe sobre as diretrizes e normas para a proteção e recuperação das bacias hidrográficas que compreendem os mananciais de interesse regional da cidade de São Paulo (SÃO PAULO, 1991). Esta legislação busca atender à necessidade de implementar ações de proteção em todo o Estado e preconiza a adoção da bacia hidrográfica como unidade de planejamento e gestão para os mananciais. Ao prever a criação das Áreas de 
Proteção e Recuperação dos Mananciais - APRMs permite a descentralização das ações que considerem as especificidades regionais para uma gestão mais eficiente e adequada. Outro instrumento inovador dessa lei foi à criação das Áreas de Intervenção, local de planejamento e execução das ações de recuperação de áreas degradadas, bem como de ações indutoras de usos e atividades compatíveis com a recuperação dos mananciais. As Áreas de Intervenção foram classificadas em áreas de: (i) Restrição à Ocupação; (ii) Ocupação Dirigida; (iii) Recuperação Ambiental.

$\mathrm{Na}$ Lei 9866/97 assinala-se que a cada APRM corresponderá uma Lei Específica, onde se estabelecem as Áreas de Intervenção e as respectivas diretrizes e normas ambientais e urbanísticas de interesse regional para a proteção e recuperação dos mananciais. Prevê-se também que a elaboração das leis específicas deve ser precedida de um Plano de Desenvolvimento e Proteção Ambiental - PDPA, o qual propõe as políticas públicas e os programas ambientais para cada APRM (SÃO PAULO, 1997).

A Lei estadual 12.233, promulgada em 16/01/2006 e regulamentada com 0 Decreto 51.686, de 22/03/2007, tornou-se a primeira Lei Específica ao criar a APRM do Guarapiranga e dispor em seu escopo o controle da ocupação por meio da gestão integrada, e o controle da quantidade e qualidade das águas. A lei prevê, entre outras disposições: metas de qualidade ambiental baseadas na qualidade da água, fornecendo parâmetros para o uso e ocupação do solo na bacia para a melhoria da qualidade das águas; definição de áreas, instrumentos e ações para a recuperação ambiental e de interesse social; descentralização dos procedimentos para licenciamento, fiscalização e monitoramento; utilização de instrumentos de compensação ambiental, tais como: criação de Reserva Particular do Patrimônio Nacional - RPPN; doação de terras para preservação ambiental; vinculação de áreas verdes existentes na bacia a empreendimentos ou obras para atendimento dos parâmetros urbanísticos; intervenções para recuperação ambiental e despoluição; previsão de recursos financeiros para viabilizar a aquisição de áreas e ações de recuperação ambiental; definição de condições para a adequação dos sistemas de resíduos sólidos; definição de diretrizes para os serviços públicos - SAAES (SÃO PAULO, 2006, 2007). 
Pesquisadores e setores de governo apontam que durante o período de 1991 a 2000 as áreas dos reservatórios das bacias da região metropolitana sofreram um crescimento da ocupação em $40 \%$, superando o crescimento médio dos respectivos municípios.

Mais recentemente, com a Política Nacional do Saneamento - Lei Federal 11.445/07 foi instituído o marco regulatório do saneamento com objetivos da universalização dos serviços de saneamento no Brasil. Os princípios constitucionais da universalidade, equidade, integralidade, participação e controle social, titularidade municipal e gestão pública são os princípios constituintes das políticas públicas de saneamento (BRASIL, 1988; BRASIL, 2006, 2007) retomando investimentos com aportes de recursos do Orçamento Geral da União, Fundo de Garantia por Tempo de Serviço - FGTS e FAT e a abertura do diálogo de diversos segmentos da sociedade com a criação do Conselho Nacional das Cidades e da Conferência das Cidades.

A nova legislação não foi omissa quanto à necessidade do mecanismo de subsídios necessário à universalização dos serviços, visando contribuir para o equacionamento da escassez de recursos municipais e assegurar a sustentabilidade das CEBs, porém remete o equacionamento ao bom desempenho tarifário do setor.

\subsubsection{Complexidade Jurídica da prestação dos serviços em áreas vulneráveis}

A Observação Geral nํ 15 do Comitê das Nações Unidas para os Direitos Econômicos, Sociais e Culturais, de 2002, introduziu de maneira clara os fundamentos jurídicos do direito à água. Parte-se da constatação de que o exercício do direito à água é sistematicamente negado, tanto nos países em desenvolvimento quanto em países desenvolvidos, e destaca-se que persistem contaminação e esgotamento de reservas de água, sendo que sua repartição desigual exacerba a pobreza. (ONU, 2003, p.2).

Acordos internacionais como o Protocolo de Kyoto, Objetivos do Milênio, Objetivos do Desenvolvimento Sustentável, Observações Gerais do Comitê das Nações Unidas para os Direitos Econômicos, Sociais e Culturais representam 
grandes esforços à propositura de mudanças das políticas públicas dos países. Entretanto, pesquisadores (DUPUY, 2003; BRISCOE Apud GUIMARÃES, 2013) alertam para a insuficiência dessas medidas.

Os SAAES representam pilares importantes no enfrentamento da crise urbana, sendo que a ausência de acesso indica um dos primeiros sinais da vulnerabilidade de uma população.

No contexto da provisão desses serviços, as lacunas no Brasil ainda revelam um desafio na gestão para o desenvolvimento sustentável. Embora estudos (IBGE, 2008, 2011; IPEA, 2013) indiquem que a taxa de cobertura de serviços de abastecimento de água em áreas urbanas do país se aproximem de $100 \%$, principalmente nas regiões sul e sudeste, pesquisas de campo mostram que assentamentos precários nessas regiões dispõem somente de acesso clandestino (RASERA, 2014; CALDERÓN, 2014, GUIMARÃES et. al., 2014). Destacam também que o acesso às redes públicas de esgotamento sanitário vem crescendo, mas ainda é insuficiente, especialmente em áreas de aglomerados subnormais. (EMPLASA, 2010, 2013; MINISTÉRIO DAS CIDADES, 2008). São diversos os dados disponíveis acerca da cobertura de abastecimento e esgotamento sanitário em áreas legais, porém faltam indicadores para medir disparidades da situação do usuário nas questões da universalização (JULIANO et al., 2012a).

As empresas de saneamento ${ }^{4}$, fundamentadas juridicamente na Constituição operam formalmente em áreas legais, e consentem que populações vulneráveis acessem água para suas necessidades. Contabilizadas em perdas sociais, essas águas representam de 8 a 12\% da produção, no caso do Estado de São Paulo (SABESP, 2014).

A despeito da pressão por parte de diversos atores para provisão de serviços de infraestrutura de saneamento básico, a resposta completa a toda esta problemática é complexa e demorada, pois implica em regularização e

\footnotetext{
${ }^{4}$ o termo saneamento aqui, visando melhor fluidez no texto, foi utilizado com o significado de serviços de abastecimento de água e esgotamento sanitário. Cabe destacar que a Política Estadual de Saneamento do Estado de São Paulo - Lei 7750 / 1992, define Saneamento ou Saneamento Ambiental, como o conjunto de ações, serviços e obras que têm por objetivo alcançar níveis crescentes de salubridade ambiental, por meio do abastecimento de água potável, coleta e disposição sanitária de resíduos líquidos, sólidos e gasosos, promoção da disciplina sanitária do uso e ocupação do solo, drenagem urbana, controle de vetores de doenças transmissiveis e demais serviços e obras especializados.
} 
titularidade da terra. Ao mesmo tempo, a pressão de cidadãos associada à urgência em termos de saúde pública, leva as operadoras de serviços de saneamento a encaminhar ações, mesmo que provisórias, para atender essas populações. Neste contexto, em vários casos sofreram ações judiciais por atenderem aos usuários em áreas de invasão, situação de diversos aglomerados subnormais do país, uma vez que estavam impedidos de oficialmente levar serviços de infraestrutura a áreas ilegais. Diversas ocorrências nas áreas de proteção de mananciais até a criação de uma legislação específica, levam as empresas a articulação formal com outros atores chave, como Ministério Público e prefeituras municipais, para que projetos sejam implementados e populações em áreas irregulares possam ser atendidas formalmente.

Processos de articulação para regularização das áreas são demorados, em diversos casos, descontinuados, com dificuldade de atender às dinâmicas de crescimento de áreas irregulares (RASERA, 2014; CALDERÓN, 2014). Davis (2006) afirma que existe um subcidadão, excluído do exercício de seus direitos, mas incluído nas suas obrigações.

O ordenamento jurídico do direito de acesso aos serviços básicos de infraestrutura de abastecimento de água e esgotamento sanitário está subordinado ao direito de propriedade e direito ambiental no Brasil. Nesse sentido, entes como Ministério Público acionam judicialmente as concessionárias e os profissionais que assentam redes de água e esgoto em áreas irregulares ou com restrições ambientais. Por essa razão, até que essas áreas sejam regularizadas, são consideradas como não atendíveis e não são incluídas nos indicadores e metas de universalização. As metas de atendimento e os indicadores do SNIS dizem respeito às áreas de concessão, cujas metas contemplam exclusivamente áreas atendíveis, ou seja, regulares. Portanto, esses habitantes são excluídos das metas da política pública, do poder concedente, e consequentemente, pelas prestadoras dos serviços públicos.

Em levantamento junto às municipalidades e concessionárias, quanto à existência de planejamento para urbanização de assentamentos precários e mecanismos de inclusão em favelas das áreas metropolitanas do Estado de 
São Paulo, exceto as favelas com programas sociais já estruturados e apoiados por grandes programas de financiamento, são raros os planos elaborados pelas municipalidades. Há uma baixa porcentagem de moradores incluídos no CadUnico para serem elegíveis dos programas de assistência social. A ausência de políticas habitacionais eficazes, a alta taxa de crescimento dessas áreas, a ineficiência do planejamento urbano e a demora dos programas de urbanização não favorecem a legalização das áreas e prejudicam a universalização dos serviços públicos de infraestrutura nessas áreas.

Segundo o Censo 2010 do IBGE, 3.224.529 domicílios, ocupados por 11.425.644 pessoas, estão localizadas em 6.329 aglomerados subnormais essas áreas estão à margem das regras do planejamento urbano de 323 municípios, sendo que $77 \%$ dos domicílios estão em Regiões Metropolitanas com mais de 2 milhões de pessoas; $59,4 \%$ da população de aglomerados subnormais estão em cinco RMs: São Paulo (18,9\%), Rio de Janeiro (14,9\%), Belém (9,9\%), Salvador (8,2\%) e Recife (7,5\%). Outros 13,7\% acumulam-se em outras quatro RMs: Belo Horizonte (4,3\%), Fortaleza (3,8\%), Grande São Luís $(2,8 \%)$ e Manaus (2,8\%). Essas nove RMs abrigam $73,1 \%$ da população de áreas informais identificadas na pesquisa; os locais mais procurados para o estabelecimento dos aglomerados subnormais é margens de córregos, rios ou lagos/ lagoas, em 12\% dos domicílios do País. (IBGE, 2010).

Faz-se necessário este enfoque para o entendimento de que o ordenamento jurídico do direito ao acesso aos serviços de abastecimento de água e esgotamento sanitário não se sobrepõe ao direito de propriedade. Nessa racionalidade, a concessionária operará áreas irregulares somente se autorizada pela justiça.

As empresas públicas, para atendimento de questões semelhantes, têm adotado técnicas originárias da teoria neoclássica da administração, fortemente influenciadas pelo modelo Weberiano burocrático, não no sentido das disfuncionalidades, mas do ponto de vista do melhor regramento (BRESSERPEREIRA \& SPINK, 1998). Justifica-se a adoção de tal modelo, considerando a necessidade da administração das empresas de engenharia, em grande parte de economia mista ou estatal estarem subordinadas a leis específicas, cujo 
rigor atinge o profissional individual e coletivamente.

Nesse contexto, as Companhias Estaduais de Saneamento Básico - CEBs vêm se empenhando em buscar eficiência produtiva e eficácia social na gestão valendo-se das melhores práticas da administração pública, sendo possível identificar diversos exemplos de boas práticas e casos de sucesso no atendimento de comunidades em situação de vulnerabilidade social. Observase, assim, no contexto da universalização de áreas consideradas irregulares, presentes na "cidade informal", que as soluções demandam grupos de trabalho composto por profissionais de diferentes saberes, permitindo melhor enfrentamento organizacional dos grandes desafios para atendimento a populações vulneráveis e em condição de exclusão.

Embora necessária à classificação e sumarização do conhecimento, inquestionavelmente as diferentes abordagens administrativas não são capazes, de forma isolada e descontextualizada, de proporcionarem com precisão os instrumentos e ferramentas adequados para decisões da administração e suas variáveis internas e externas (KOONTZ, 1980).

Barbosa (2010) descreveu que a forma de gestão para universalização do saneamento em áreas de pobreza no Brasil é composta de arranjos institucionais para atender a universalização em áreas irregulares, cuja necessidade de articulações com a Defensoria do Estado e Promotoria Pública antecipadamente possibilitaria um arranjo jurídico de regularização das áreas e posteriormente, parcelamento de dívidas e aplicação de tarifas sociais. Além destas questões, a serem tratadas de formas diferentes de acordo com o gestor, as tarifas sociais definidas por critérios estabelecidos há trinta anos nem sempre guardam relação com a real necessidade do cidadão, em função das diversas mudanças socioeconômicas da última década.

A escola de Saúde Pública de Harvard, partindo da noção de risco, definiu vulnerabilidade como um termo que vem da advocacia internacional sobre direitos do homem, que inicialmente era a garantia do direito à cidade de um grupo que pudesse estar sendo prejudicado (CZERESNIA \& FREITAS, 2003). Então, como resolver o dilema da gestão, em especial no contexto de países da América Latina, onde as realidades dos ambientes urbanos ocorrem na chamada cidade informal? 
Nesse sentido, o entendimento de que direito de propriedade e direito ambiental sobrepõem o direito humano fundamental do acesso a serviços essenciais compõem um dos principais obstáculos a serem transpostos pelo modelo para universalização do saneamento, requerendo inovação de mecanismos capazes de suprir demandas das populações em contextos vulneráveis, dentro do regime democrático.

O enfrentamento do desafio da Universalização dos serviços de abastecimento de água e esgotamento sanitário requer esforços de atualização em política, gestão e respectivos instrumentos e ferramentas que alavanquem ações integradas, fortaleçam diálogos entre partes interessadas. Devem ser principalmente, suficientes para superar os desafios do ordenamento jurídico em assentamentos precários das áreas urbanas.

\subsubsection{Complexidade Econômico-Financeira da Concessão}

A gestão empresarial dos serviços de abastecimento de água e esgotamento sanitário em áreas de vulnerabilidade social, no que tange a eficácia social, é fortemente impactada por modelos de subsídios definidos pela política pública. Ao executor da política pública, o agente regulador, compete garantir a modicidade tarifária para cobrir: custos eficientes dos serviços de médio e longo prazo, investimentos prudentes, remuneração de ativos e dos acionistas, serviço da dívida, para atingimento de metas dos contratos e de eficiência da operadora, de acordo com as melhores práticas de governança.

Essas questões ainda carecem de maiores esforços partindo de uma necessária revisão da Política Nacional de Saneamento no Brasil e de instrumentos institucionais mais eficazes uma vez que o equilíbrio econômicofinanceiro se dará por meio de tarifas cobradas aos usuários pelos serviços prestados. O usuário de baixa renda será subsidiado pelo modelo de subsídio cruzado, conforme definido no PLANSAB, porém, essa metodologia deixou de ser aplicável, pois se rompeu o modelo de subsídios cruzados entre municípios pelo Marco Regulatório; e também entre grandes e pequenos usuários de baixa renda motivados pela migração para uso de poços (BRASIL, 2007, 2010; JULIANO et al., 2012b). Dois argumentos apoiam esta afirmação. 
O primeiro diz respeito aos contratos entre operadora e município, chamados de Contratos de Programa. Em função do poder concedente ser o município fora das Regiões Metropolitanas, os contratos firmados após 2007 partem da premissa que o equilíbrio econômico-financeiro deve ser obtido isoladamente ao longo do período contratual. Ou seja, por meio de tarifas cobradas, cuja arrecadação é das contas faturadas aos usuários dos serviços públicos prestados dentro da área urbana do município que contratou a concessionária. Essa metodologia rompeu o subsídio cruzado entre municípios. O segundo diz respeito à evasão dos grandes usuários que, motivados pelos racionamentos e aumentos tarifários dos últimos dez anos, incorporaram fontes alternativas de abastecimento de água, que apontam a concessionária como a fornecedora menos viável pelos altos preços cobrados (JULIANO et al., 2012).

A partir de estimativas feitas por Cardoso et al. (2008), prevê-se que o número de poços perfurados anualmente no Brasil, para cálculo a partir de 1988, seja de 10.800 unidades, o que, se mantida essa projeção, representará uma média anual de 54.600 poços perfurados no Brasil até 2020 .

Os valores provenientes do uso da fonte alternativa de cada uma dessas outorgas que deixam de ser arrecadados demonstram a evasão do subsidiador, e representam falta do aporte previsto no estudo de viabilidade da concessão que seria necessário à produção, redes e ligações de água e saneamento para usuários que fazem parte das metas contratuais de universalização dos serviços de saneamento básico no Estado de São Paulo, e que necessitam de equacionamento dos subsídios. (JULIANO et al., 2012).

Esse comportamento dos grandes usuários, agravado pela crise hídrica, rompe o mecanismo de subsídios cruzados entre as categorias (social, residencial, comercial e industrial) e usuários (pequenos e grandes). Nesse sentido, difícil prever como a gestão empresarial e as políticas públicas responderão aos desafios da universalização dos serviços de saneamento frente ao desmonte desse mecanismo.

Os assentamentos irregulares somente passam a ser considerado em objetivos e metas para provisão de serviços públicos de abastecimento de água e esgotamento sanitário - SAAES, após a regularização das áreas. Nesse 
sentido, o acréscimo de demanda por subsídios que serão necessários às famílias de baixa renda da cidade ilegal não vem sendo computado e nem incluído, subdimensionando os cálculos dos investimentos necessários à universalização a partir de bancos de dados oficiais.

É possível concluir que os clientes não residenciais são, prioritariamente, os que subsidiam os usuários residenciais. A faixa de consumo de 21 a $50 \mathrm{~m} 3$ é aproximadamente quatro vezes a tarifa média do primeiro bloco na Região Metropolitana de São Paulo - RMSP (SABESP, 2014). Especial atenção deve ser dada aos usuários não residenciais, dada a importância dos mesmos para o financiamento dos subsídios e na sustentabilidade dos contratos no longo prazo.

Atualmente, os usuários residenciais estão distribuídos em três categorias (social, favela e normal) de cunho social, buscando subsidiar as classes de baixa renda através de tarifas inferiores às praticadas para usuários da categoria Residencial Normal. Os critérios de enquadramento na tarifa residencial social são: 1.) Se tratando de residência unifamiliar: tenha renda familiar de até 3 salários mínimos, seja morador de habitação subnormal com área útil construída de $60 \mathrm{~m}^{2}$ e consumidor monofásico de energia elétrica com consumo de até $170 \mathrm{kWh} / \mathrm{mês}$; ou esteja desempregado (SABESP, 2014), sendo que o último salário seja de no máximo 3 (três) salários mínimos, neste caso o tempo máximo será de 12 meses, não podendo ser renovado; 2) Se tratando de habitação coletiva: morar em habitações consideradas sociais, tipo cortiços e as verticalizadas, tais como unidade social verticalizada resultante do processo de urbanização de favelas (um salário mínimo correspondia à aproximadamente U\$230 em 2015).

Essas regras são definidas, presumindo-se caráter e situação transitória dos vulneráveis, no entanto a transitoriedade permanece por mais de 30 anos nos assentamentos precários. Os usuários residenciais das categorias social e favela, em termos do volume medido, representam $3,4 \%$ do consumo residencial total.

Segundo dados do IBGE (2011), cerca de $20 \%$ dos domicílios particulares permanentes urbanos do estado de São Paulo são considerados de baixarenda, sendo caracterizados por possuírem renda mensal per capita de, até, 
1/2 salário mínimo. Ainda, de acordo com o estudo de tarifas realizado pela SABESP (2003), a tarifa social da SABESP deveria ser outorgada aos usuários residenciais de regiões censitárias cujo Índice Paulista de Vulnerabilidade Social - IPVS seja 5 ou 6 (alta ou muito alta vulnerabilidade social, respectivamente), perfazendo, aproximadamente, $22 \%$ dos domicílios da área de concessão da empresa. Esses fatos corroboram para a suspeita da baixa cobertura da tarifa social residencial na área de concessão da empresa, por conta dos municípios pobres, além das situações favelizadas nas áreas urbanas. No entanto, oobservou-se o aumento da renda declarada pelas famílias nos aglomerados subnormais alterando a demanda por tarifa social.

Nesse sentido, a sobreposição da dimensão financeira sobre o social e ambiental é de fundamental importância para o saneamento quando inserido no contexto de sustentabilidade, em especial porque as três dimensões alinhadas configuram os grandes desafios do setor de saneamento e seu modelo regulado.

\subsubsection{Complexidade dos Conceitos e Indicadores}

De acordo com Silva (2005), o marco referencial de desempenho dos serviços desenvolvidos a partir do modelo do PLANASA foram os indicadores de desempenho do Catálogo Brasileiro de Engenharia Sanitária e Ambiental CABES publicado anualmente pela Associação Brasileira de Engenharia Sanitária e Ambiental - ABES, e que sistematizavam os relatórios de desempenho técnico-operacional dos serviços prestados pelas companhias estaduais de saneamento básico. De 1977 até 1995 o CABES constituía a única fonte sistemática de dados padronizados de desempenho do setor.

A estrutura típica de informações do CABES, com base no CABES do período de 1993 a 96, e mais tarde substituídos pelos relatórios do Sistema Nacional de Informações de Saneamento - SNIS, envolve informações relacionadas à cobertura dos serviços e em dados e indicadores relacionados ao desempenho operacional (SILVA, 2005).

Embora os relatórios mais recentes do SNIS incluam elementos de qualidade na prestação dos serviços - como intermitência, qualidade da água e atendimento a reclamações - que denotam preocupação com a eficácia da 
prestação, ainda assim, não constituem diagnósticos voltados à eficácia social (SILVA, 2005, p. 05).

Estão disponíveis dados oficiais do Sistema Nacional de Informações sobre Saneamento - SNIS, da Rede Interagencial de Informações para a Saúde RIPSA e do Instituto Brasileiro de geografia e Estatística - IBGE acerca da cobertura de abastecimento e esgotamento sanitário em áreas legais. Algumas dessas bases são provenientes da consolidação de questionários preenchidos pelos gestores, dificultando a identificação das disparidades de gestão e da situação do usuário nas questões da universalização nas áreas urbanas de pobreza. Ressalta-se que os indicadores do Sistema Nacional de Informações sobre Saneamento - SNIS (MC, 2009) têm por objetivo somente oferecer informações de caráter operacional, gerencial, financeiro e de qualidade dos serviços, a partir de informações colhidas, de forma voluntária dos prestadores de serviços e municípios convidados a participar da amostra (MALHEIROS et al., 2006).

Tem-se também o sistema de indicadores da Rede Interagencial de Informações para a Saúde - RIPSA, criada em 1996, por Portaria do Ministério da Saúde em acordo de cooperação com a Organização Pan-Americana de Saúde - OPAS, com a finalidade de fornecer dados básicos acerca das condições de saúde e tendência que possam vir a subsidiar políticas públicas, tendo por base o sistema de dados do Datasus (MALHEIROS et al., 2006).

A matriz de indicadores da RIPSA (2009) além de abranger indicadores de cobertura do sistema de saúde, apresenta indicadores de cobertura de abastecimento de água, esgotamento sanitário e coleta de lixo no meio urbano e rural de Estados, Regiões, Regiões Metropolitanas e Capitais.

Segundo a Pesquisa Nacional de Amostras de Domicílios - PNAD, em 2012 havia uma demanda habitacional para 5,24 milhão de domicílios no Brasil, desses, 740 mil famílias tinham renda inferior a três salários mínimos (IBGE/PNAD, 2013). No último censo, houve um incremento de mais de $10 \%$ na demanda por domicílios no estado de São Paulo, proveniente de moradias classificadas como subnormais. Em diversos municípios No último censo, houve um incremento de mais de $10 \%$ na demanda por domicílios no estado de São Paulo, moradias classificadas por subnormais. Um aumento de $6 \%$ nos últimos 10 anos das dinâmicas migratórias do país ocorreram de populações 
de pequenos municípios para as regiões metropolitanas onde os indivíduos vão rumo a favelização (IPEA, 2013).

Nesse sentido, identifica-se diversos desafios da universalização do saneamento básico no Brasil: serviços básicos nas áreas de vulnerabilidade social de baixa qualidade ou inexistentes; comportamento da população acessando as redes de forma ilícita; externalidades sobre a saúde pública e o meio ambiente não equacionadas; diferentes práticas de gestão e governança; comprometimento dos indicadores regulatórios; e elevada barreira de entrada, referente à baixa renda da população (GUIMARAES et al., 2014).

Ao analisar-se o Indicador de Atendimento de água ou esgoto dos domicílios urbanos são consideradas apenas áreas legais, ou seja, assentamentos irregulares são desconsiderados do cômputo, conforme (Figura 2).

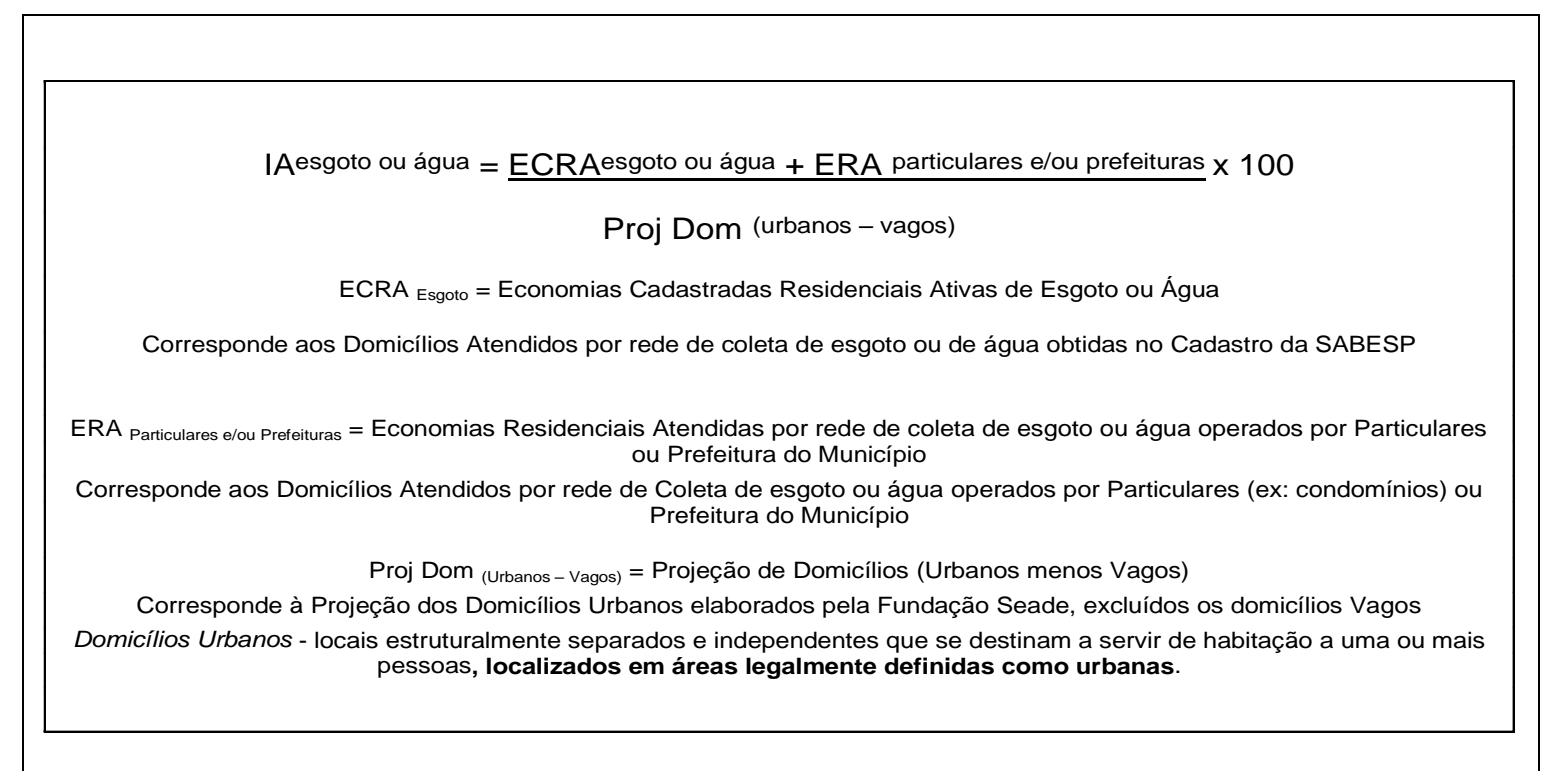

Fonte: ARSESP (2012)

Figura 2 - Metodologia do Indicador de Atendimento de Saneamento

Há também indicadores de acesso ao saneamento através das informações do IBGE com interface com o setor do saneamento, como a Pesquisa Nacional em Saneamento Básico, mas todos estes sistemas carecem de informações mais substantivas.

$\mathrm{Na}$ prática da gestão, como exemplo de como uma unidade de serviço da SABESP - Companhia de Saneamento Básico do Estado de São Paulo entende e opera a universalização, respeitando o ordenamento jurídico anteriormente analisado. Foram consideradas apenas os domicílios atendíveis inseridos no processo de regularização de áreas de mananciais de 5 (cinco) 
áreas, sendo realizadas 11 mil ligações de água, com atendimento a 38.500 habitantes, e 2.200 ligações de esgoto, com atendimento de 7.700 habitantes em áreas de proteção aos mananciais. Ficando pendentes ainda, 118 mil imóveis irregulares a serem atendidos que implicam em aumento de cobertura e redução de perdas comerciais provenientes ligações clandestinas, que a concessionária estava impedida judicialmente de atender (SABESP, 2011, ARSESP, 2014).

Há que se considerar as diversas formas da medição da universalização e projeções futuras. Na política pública, as metas de universalização estão apoiadas em projeções de crescimento populacionais num horizonte de 20 anos no PLANSAB - Plano Nacional de Saneamento sob dados censitários de 2.000 , atualizados por pesquisas pontuais. Nos contratos entre concessionária e município, o horizonte é de 30 anos, por exemplo, no Contrato Metropolitano de São Paulo sob os dados censitários de 2010. As projeções da universalização são realizadas pelas médias históricas de perfil dos domicílios, projetadas em tendências futuras. Os contratos de concessão têm um horizonte de tempo suficiente para englobar tanto as escalas de tempo humanas quanto ecológicas, portanto respondendo tanto as necessidades dos tomadores de decisão de curto prazo quanto às necessidades das futuras gerações. $O$ escopo de estudos de viabilidade é de 30 anos na maioria, porém o intervalo de avaliação não é suficiente para englobar os impactos locais recentes da urbanização acentuada nos últimos anos, quanto os distantes, sobre as pessoas e ecossistemas.

A regulação dos serviços de saneamento em São Paulo adotou mecanismo de benchmarking para promover a eficácia da operadora, por comparação de indicadores entre concessionárias semelhantes durante a primeira revisão tarifária. Estabeleceu um fator de eficiência do atendimento dos serviços aos usuários e acompanhamento das metas contratuais e refletidas no plano de negócio para operação em regime de eficiência. A concessionária tem buscado instrumentos para contribuir na eficácia na universalização para melhoria da governança sobre as áreas de concessão. Assim, diante de um contexto de monopólio estabeleceu-se um regime de concorrência para a concessionária com indicadores regulatórios, estando sujeita a fiscalizações, sanções e penalidades quanto ao descumprimento dos critérios de avaliação definidos 
pelo regulador e pelo contrato. Os indicadores são monitorados periodicamente pelo regulador, permitindo a comparabilidade e acompanhamento da evolução histórica de forma comparada entre empresas.

Os resultados dos serviços de abastecimento de água e esgotamento sanitário sobre a saúde de populações pobres e meio ambiente, chamados externalidades, é objeto de estudo por diversos autores.

Segundo McMichael (2004). A pobreza não somente torna mais vulnerável, como também perpetua um círculo vicioso. As aglomerações são fontes de pobreza, desigualdade e riscos para a saúde do meio ambiente. É necessário que as desigualdades, riscos à saúde urbana e meio ambiente sejam considerados nas políticas e procedimentos, pois conturbações convertem-se em grandes regiões metropolitanas por conta da expansão urbana, e os indicadores e índices ambientais podem evidenciar tendências distintas (SOBRAL\&FREITAS, 2010; ANTHONY \& MCHAEL, 2000; ALIER, 2009).

Os indicadores, quanto à externalidades do setor sobre a saúde, devem prestar-se aos objetivos e finalidades de detectar situações de risco relacionadas a problemas ambientais e de saúde, monitorar tendências no ambiente e de riscos à saúde, comparar condições ambientais e de saúde em diferentes áreas, permitindo a identificação de áreas prioritárias, avaliar o impacto de políticas e intervenções sobre as condições de saúde e ambiente contemplando a avaliação ambiental (ANDREAZZI et. al. 2007; SOARES et. al. 2002).

\subsubsection{Conclusões da análise}

A complexidade do acesso ao serviço público de abastecimento de água em áreas vulneráveis por populações pobres passa pelas três questões abordadas. O ser humano estando em área regulares ou irregulares, tendo ou não recursos financeiros, contado por indicadores ou excluídos deles, depende da água para sua sobrevivência e acessará clandestinamente ou legalmente com o conhecimento da concessionária. Essa é a controvérsia da universalização.

Pode-se identificar que a água está disponível nos bairros irregulares por 
ligações clandestinas. O furto de água traz consequências como a baixa qualidade dos serviços a outros consumidores, riscos de contaminação, perdas técnicas, e inadimplências acumuladas. Condições que afetam o benchmarking regulatório. Além disso, essas áreas possuem diferentes custos de conexão em função dos difíceis acessos físicos aos usuários, ausência de arruamento, e todo aparato social necessário ao atendimento por não estarem urbanizadas. A disponibilidade de rede de esgoto somente alcançou as metas de atendimento, quando promoveu mobilizações com apoio das ciências sociais para sensibilização da população, além do mecanismo de subsídio às famílias de baixa renda para conexões intra-domiciliares.

Faz-se necessária a definição de conceitos e indicadores que cubram situações marginais e permitam focalizar esforços e recursos para proteger a população mais vulnerável e possibilitar a essa o acesso aos serviços que presta uma concessionária. Também é necessário fornecer: ferramental para racionalização dos recursos destinados a esta finalidade, e sinais potentes e transparentes em relação aos benefícios que estão sendo concedidos, bem como custos e fontes de recursos que estão sendo utilizados para financiamento desses serviços.

As ligações de água clandestinas foram regularizadas somente mediante atuação junto a Promotoria do Estado e Ministério Publico para obtenção de autorização judicial à atuação em áreas favelizadas. A universalização depende da aderência ao ordenamento jurídico da ocupação do solo urbano, meio ambiente e recursos hídricos.

Nesse sentido, em obediência à legislação, as ações para a universalização, no entendimento jurídico das concessionárias, devem ser antecedidas pela legalização e urbanização da área. Essa prática justifica que as metas definidas contemplem apenas áreas regulares. Assim, os diálogos entre empresas e reguladores devem ser sustentados por um modelo de gestão que forneça credibilidade e transparência no processo de prestação de contas ao usuário e poder concedente quanto aos processos de acompanhamento de metas demonstrando as atribuições de cada ente para a promoção da universalização do saneamento.

A regulação foi um dos marcos de mudança no setor de saneamento nos últimos vinte anos. As externalidades positivas do setor, assim como as 
exclusões sociais, chamadas falhas de mercado, inerentes aos serviços de infraestrutura justificam a regulação. De modo geral, ela é necessária na presença de falhas de mercado, associada à externalidades que representam apenas custos ou benefícios de uma atividade que não são devidamente internalizados pelas empresas. No caso do saneamento há diversas externalidades ligadas a situações de custos não equacionadas: condição de vulnerabilidade social e ausência de definição dos subsídios e meio ambiente como política pública distributiva de renda.

No que tange ao planejamento de regularização das áreas favelizadas, reorganizam-se as priorizações em função dos Planos Urbanização de Núcleos previstos nos Programas das Secretarias de Habitação - SEHAB. Há uma realimentação do processo de planejamento subsidiado por acompanhamento sistemático das metas operacionais, no entanto a avaliação não promove mudanças estruturantes de processos em muitos casos, pela complexidade das articulações interinstituições. Como agravante, as secretarias dos municípios são conduzidas por indicação política, sofrendo descontinuidade de programas de regularização a cada processo eleitoral.

Tendo em vista a estratégia de urbanização e a operação do saneamento na base da organização, o contexto socioempresarial apresenta diversos arranjos de características decisivas promovidas pelo ator social que pleiteia e reivindica por líderes comunitários, caracterizando caráter mais social de classe frente ao desenvolvimento econômico, o poder público como executor da política de urbanização, o risco sanitário como coletivo e individual inserido na politica de saneamento e a racionalidade do direito fundamental para a universalização.

Os conceitos evoluem enquanto o saneamento social busca inserir nas práticas para universalização a participação e controle social, existentes nas diretivas constitucionais, até promover práticas sem conseguir efetivamente serem equacionadoras de todas as questões, mas fortalecendo o tecido socioempresarial.

O desafio de revisão das práticas é de propor um novo modelo que ultrapasse os limites da prestação dos serviços em áreas de vulnerabilidade, fato que exacerba as limitações no acesso à água e saneamento e promova processos para mitigações e ações de adequações para universalização em regime de eficiência técnica, eficácia social e efetividade. 


\subsection{RESGATE CRÍTICO DA PRODUÇÃO TEÓRICA EXISTENTE}

Para Juliano (2012), o desenvolvimento de um modelo de gestão do saneamento deve ocorrer num espaço autorizado pela organização, que reconheça a produção micropolítica com autonomia e busque soluções mais próximas ao cotidiano. Trabalhadores e usuários propõem uma nova forma de operar o saneamento, num projeto sanitário singular, como tentativa de aproximação da gestão ao usuário com um modelo que permita a implantação de espaço de discussão do dia-a-dia para revisão do trabalho, de forma a garantir a integralidade, equidade e universalidade.

Além deste enfoque integrador, são necessários esforços articulados no entendimento das relações ambiente - sociedade, que entremeiem o setor, bem como dos aspectos de integração inexistente de políticas públicas e da gestão, de forma a incorporar estrategicamente um olhar sobre as desigualdades desconsideradas num modelo hegemônico e que devem ser consideradas no novo modelo para desenvolvimento sustentável com foco na redução da desigualdade e no desenvolvimento do território (DAWBOR ET. AL, 2011; SEN, 1999-11; JULIANO et al., 2012).

Esta análise permite diversos arranjos institucionais, pois a universalização demanda um acesso suficiente e pleno a todas as capacidades instaladas, sendo possível análise por meio de um raciocínio topológico do fluxo de redes diante dos desafios das metrópoles para regulação de custos crescentes e deseconomias de escalas em consequência do crescimento desordenado. A avaliação de conectividade constitui - para fins de controle social dos serviços e, em última instância, da governabilidade - uma das mais desafiadoras questões da pesquisa urbana atual. Os antigos conceitos subjacentes de universalidade / cobertura aplicados à infraestrutura nas avaliações de pobreza urbana são hoje claramente insuficientes para representar a complexidade do contexto. Se esses conceitos seguirem utilizados da mesma forma, as avaliações refletirão a imprecisão dessas representações (SILVA, 2002; SILVA (2012) ${ }^{5}$.

\footnotetext{
${ }^{5}$ Prof. Ricardo Toledo Silva Disciplina AUT-818 Tecnologia e Gestão da Infra-estrutura Regional e Urbana. Notas de aula 29/03/2012 FAU-USP
} 
Marques (2011) afirma que os países abordam de forma distinta a universalidade dos serviços. Grande maioria aborda o tema em suas leis, sendo variado o modo que é instituído. Na Itália, França e nos Países Baixos a universalização é compulsória aos prestadores, mas para os demais, em sua maioria, a unidade gestora tem liberdade para a consecução da universalização.

Para esta análise, os fundamentos da teoria geral da administração devem ser considerados.

\subsubsection{As organizações no contexto da Administração}

Mintzberg (1994, 2007, 2010,) afirma que gestão deve ser substituída por administração, pois, além de não contemplar toda a administração, tem comportado definições e conceitos errados, que são inseridos de forma incorreta na engenharia.

Nesse sentido, o referencial teórico é da teoria da administração. Não compete a esta tese aprofundar a discussão dos acadêmicos da administração sobre o conceito de gestão, por essa razão, os capítulos de gestão se apoiam nos exclusivamente nos autores de referência.

Segundo Bresser-Pereira \& Spink (1998), no início do século XX, Max Weber sociólogo alemão publicou uma bibliografia a respeito das grandes organizações da sua época. Deu-lhes o nome de burocracia e passou a considerar o século $\mathrm{XX}$ como o século das burocracias, pois considerava que essas eram as organizações características de uma nova época. Basicamente, a finalidade era organizar detalhadamente e dirigir rigidamente as atividades das empresas com maior eficiência possível, caracterizada como um sistema social formal, impessoal e dirigida por administradores profissionais. Não se trata aqui do termo burocracia como as disfuncionalidades da burocracia Weberiana, mas das características reais e dos pilares da teoria, sendo eles:

$>$ O formalismo - cuja autoridade deriva de um sistema de normas com as características: a autoridade deriva de normas racionais-legais (baseada no Direito); as ações baseiam-se nas normas, que preveem as ocorrências e enquadrando-as dentro de um comportamento definido; o caráter hierárquico de forma piramidal; níveis de autoridade vertical, e horizontal 
(departamentalização) com funções e cargos.

> A Impessoalidade - o poder de cada indivíduo não deriva de sua personalidade, mas da norma que cria o cargo, o regulamenta e define suas atribuições.

> A administração profissional de conhecimento técnico especializado, aliado ao sistema de normas, diretrizes e rotinas. Suas características fundamentais são: existência do administrador profissional como especialista; o desempenho do cargo de administrador como fonte de renda; o administrador burocrático não possui os meios de administração e produção - ou seja, ele administra em nome de terceiros (diferenciação entre o empreendedor e o administrador); o administrador burocrático tem $\mathrm{o}$ "espírito de fidelidade ao cargo"; o administrador identifica-se com a empresa, e não com o chefe; o administrador profissional recebe remuneração em forma de dinheiro, substituindo honrarias, títulos; é nomeado através de um superior hierárquico, a partir de uma qualificação apresentada; o mandato do administrador é por tempo indeterminado, embora não constitua qualquer vínculo vitalício com o cargo; como corolário destas questões, o administrador burocrático segue uma carreira, tendo direito, ao final, à aposentadoria.

Sob o contexto organizacional, as organizações são levadas a incorporar as práticas e procedimentos definidos pelos conceitos que predominam no ambiente organizacional e que estejam institucionalizados na sociedade (MEYER \& ROWAN, 1977). A abordagem institucional tem sido capaz de fornecer explicações aos processos que envolvem as relações sociais, por importar-se com o que estão consolidados na sociedade em termos de valores, ações, padrões que são construídos e legitimados a partir das relações entre os diversos agentes organizacionais. Dessa forma, o institucionalismo tem sido caracterizado como o processo pelo qual procedimentos adquirem valor $\mathrm{e}$ estabilidade, conferindo comportamento mais estável e previsível, o que está economicamente associado à redução de custos derivados das incertezas nas relações interpessoais. Kast \& Rosemweig mantiveram a formulação processual das funções executivas e a integração na teoria dos sistemas, semelhantemente, a abordagem do processo à gerência de planejamento, organização, direção, comunicação e controle (HUNTINGTON, 1968; BERGER 
\& BERGER, 2002; ESCRIVÃO, 1995, WREN, 1979; LUTHANS, 1976; KATZ\&KAHN, 1987).

\subsubsection{O planejamento e a organização}

O planejamento estratégico surgiu na década de 50 com objetivo de contemplar dimensões técnico-econômicas entre oferta e demanda. É composto de método de análise das oportunidades ambientais, dos pontos fortes e fracos das empresas e de estratégias para alcança-las, contemplando análise de índices financeiros, administração por objetivos, orçamentos de capital, planejamento do lucro, e análise de programas. Dos anos 60 a 80 o planejamento estratégico enfatizou uma abordagem top-down para 0 estabelecimento de objetivos e planos, cujas etapas incluem definição de objeto do plano, identificação dos objetivos e das estratégias atuais, análise ambiental, análise dos recursos, identificação de oportunidades e ameaças, determinação do grau de mudança necessário, decisão da estratégia a ser adotada, implantação da estratégia, mensuração e controle (ANSOFF, DECLERCK E HAYES, 1990; BATEMAN \& SNELL, 1998; STONER E FREEMAN, 1992).

Enquanto o planejamento estratégico afeta a empresa em longo prazo, pois compreende decisões sobre produtos e serviços que deseja oferecer ao mercado, o planejamento tático analisa alternativas na missão, recursos, define diretrizes para áreas do negócio, oportunidades de mercado, organização para a execução do plano e instalações físicas, identifica os procedimentos nos níveis inferiores da organização e o planejamento operacional é o planejamento que elabora e controla cronogramas (MONTANA E CHARNOV, 1998; BATEMAN E SNELL, 1998).

Segundo Montana e Charnov (1998), como ferramenta do planejamento estratégico, o Balanced Scorecard (BSC), cujo conceito e ferramenta foram construidos por Kaplan \& Norton (1993, 1996a, 1996b), como o que traduz a missão e a estratégia das empresas num conjunto abrangente de medidas de desempenho que serve de base para um sistema medição e gestão estratégica, apoiado em 5 princípios: traduzir a estratégia em termos 
operacionais; alinhar a organização à estratégia; transformar a estratégia em tarefa de todos; converter a estratégia em processo contínuo; e mobilizar a mudança por meio da liderança executiva.

Naquela década, os fracassos experimentados pelo planejamento na América Latina com o fundamento básico do planejamento normativo - no qual quem planejava estava fora da - ou sobre a - realidade planejada e não coexistia na realidade com outros atores que também planejavam, conduziam a uma prática economicista e tecnocrática isolada do processo de governo e da razão política.

Ao substituir este pressuposto por seu correspondente estratégico - o ator que planeja está dentro da realidade e ali coexiste com outros atores que também planejam. O método de planejamento estratégico situacional aplicável aos casos de governos democráticos, nos quais existem diversos atores sociais, em situações de poder compartilhado, foi utilizado nos movimentos sociais para interferir na agenda política do Chile. Estabeleceu-se uma estratégia de trabalho em situação de poder compartilhado, pois um dos recursos que restringiam as capacidades de ação eram as restrições de poder (Matus, 1978, 1992,1993).

Entende-se que a construção desse planejamento é constitutivo de resultados eficazes para o saneamento, pois faz-se pautada na realidade da relação sanitarista-usuário, onde surgem o querer do usuário, os impedimentos jurídicos, que levam a leniência do poder concedente e as impossibilidades da operadora. Este tipo de planejamento também pode ser uma ferramenta para a construção de uma gestão compartilhada. Isto posto, os indicadores de sustentabilidade ocupam papel central nesse processo, pois podem ser usados como ferramenta de mobilização das partes interessadas, na análise e avaliação da universalização do saneamento e das ações necessárias para a sua efetividade (JULIANO et. al., 2012b).

\subsubsection{Estruturas e comportamento das organizações}

Segundo Stoner (1985), o comportamento social interno das organizações, no que tange a correlação entre a aplicação das teorias administrativas com os 
resultados por elas alcançados, indicaram que a tecnologia de produção afeta o desenho da empresa. Na produção mecanizada, a organização estrutura-se segundo os princípios da abordagem clássica, utilizando o modelo burocrático; quanto maior a previsibilidade dos resultados, maior a quantidade de níveis hierárquicos. As áreas predominantes na empresa variam conforme a tecnologia existente: pesquisa e desenvolvimento para tecnologia unitária; produção para mecanizada; marketing e vendas para automatizada.

As organizações, sobre o aspecto social externo, podem ser mecanicistas, com estrutura burocrática, divisão do trabalho, cargos com atribuições claras e definidas, centralização das decisões na cúpula, hierarquia rígida, comando único, regras e procedimentos formais; ou organizações orgânicas, com estruturas e hierarquias flexíveis, pequena divisão do trabalho, cargos dinâmicos sendo redefinidos pela interação com os demais trabalhadores, descentralização das decisões, predomínio da informação lateral, comunicações informais. Nesse sentido, a forma orgânica é mais apropriada para condições ambientais de mudança e inovação. (WERNECK, 2005).

Um dos mais relevantes autores que trataram sobre o comportamento social, em especial sobre a construção de sistemas cooperativos entre indivíduo nas organizações, foi Chester I. Barnard (WREN, 2007). Barnard considerava crucial, para que a organização alcançasse com eficácia os seus objetivos, que todos os seus integrantes cooperassem e aceitassem os objetivos do trabalho (ESCRIVÃO FILHO \& MENDES, 2010; MIGLIATO \& PERUSSI FILHO, 2010). Para a cooperação ocorrer, no entanto, deveria haver na organização um sistema eficaz de comunicação, que todos deveriam conhecer e acessar, sendo que o indivíduo utiliza a organização informal como um mecanismo de comunicação. Essa organização informal é representada por um grupo de pessoas e suas interações que, não necessariamente, promovem o objetivo da organização formal (TORGERSEN \& CRAIG, 1982). Assim, para indivíduos contribuírem com os esforços formais, para alcançar os objetivos da organização, deveriam ter satisfeitos os motivos pessoais (WREN, 2007). Considerando isso, para Barnard o papel do executivo (administrador) consistiria em conceber e gerenciar o sistema de comunicações, objetivando uma melhoria da comunicação com os grupos informais, e, em incentivar os integrantes a cooperarem na realização dos objetivos da organização e na 
elaboração de objetivos coesos, facilmente comunicáveis a todos os integrantes da organização (MIGLIATO; PERUSSI FILHO, 2010).

Por outro lado, Herbert A. Simon, autor bastante influenciado pelo trabalho sobre sistema social cooperativo, de Chester I. Barnard (ESCRIVÃO FILHO; GUERRINI, 2010), postulou que o processo decisório na organização deveria envolver grupos, resultando em decisões "compostas" (WREN, 2007). Para Simon, isso era necessário, pois um indivíduo sozinho não teria suficiente capacidade para a tomada de decisões racionais, já que fatores ambientais e restrições mentais limitavam-no na tentativa de alcançar de soluções ótimas (KALANTARI, 2010). O estruturalismo aplicado ao estudo das organizações visava analisar e explicar o funcionamento das organizações de maneira mais integrativa, considerando o relacionamento entre as perspectivas oriundas das teorias de administração científica, clássica e das relações humanas. Para os estruturalistas, essas teorias abordavam a realidade organizacional e humana de forma parcial e fragmentada, ao invés de considerar a organização como um "sistema deliberadamente construído e em constante relação de intercâmbio com o ambiente", constituído de partes interdependentes, que se relacionavam e constituíam um todo integrado a um sistema social (MOTTA \& VASCONCELOS, 2005).

Os estruturalistas acreditavam que as relações entre as partes, para a constituição do todo organizacional, deveriam ser enfocadas, sobretudo, as relações entre a organização formal e informal, considerando que essas constituíam partes de um todo intra-organizacional, estando sujeitas a situações de conflito, inevitáveis, inerentes, e, muitas vezes, necessárias ao desenvolvimento das partes (MOTTA \& VASCONCELOS, 2005). Nesse sentido, os estruturalistas colocavam em sua análise a aplicação de incentivos mistos, recompensas psicossociais e materiais/financeiras, e suas influências mútuas, para alcançar a colaboração dos indivíduos com a organização, considerando a ação humana condicionada por fatores mais complexos (MOTTA \& VASCONCELOS, 2005).

\subsubsection{Escolas do pensamento da administração}

Mintzberg et al. (2000, p.13-14) destacaram dez escolas de pensamento, 
acerca do processo de formulação estratégica, são elas: design, planejamento, posicionamento, empreendedora, cognitiva, aprendizado, do poder, cultural, ambiental e de configuração. Destacam-se a escola empreendedora, que trata o processo em termos da criação da visão pelo grande líder, e a escola ambiental retira a iniciativa do processo de dentro da organização, que passa a reagir às forças que o ambiente lhe impõe. Os processos de geração de estratégia podem conter elementos das diversas escolas.

\subsubsection{Estratégias das Organizações}

A palavra estratégia, embora antiga, está em grande modismo. Para Mintzberg et al. (2000, p. 17) o termo é definido de uma forma, mas frequentemente usado de outra. Os autores propõem a compreensão de estratégia sob os seguintes aspectos: plano, padrão, posição e perspectiva. A estratégia definida como um "plano" representa a perspectiva de "olhar para frente", é a estratégia pretendida; enquanto a definida como "padrão" representa o olhar sobre o comportamento passado, é a estratégia realizada. No decorrer da implementação da estratégia pode haver algumas adaptações, aquelas intenções que foram plenamente realizadas são conhecidas como estratégias deliberadas, enquanto as não realizadas são chamadas de estratégias irrealizadas. Há um outro caso denominado de estratégia emergente, no qual um padrão realizado não era expressamente pretendido. (MINTZBERG et al., 2000, p.18).

\subsubsection{Escolas das Organizações Sociais}

A escola empreendedora da administração do movimento contemporâneo, especificamente do grupo do empreendedorismo social e negócios ambientais sustentáveis, introduz o referencial teórico-conceitual no contexto do desenvolvimento socioambiental sustentável. Analisam as características dos negócios socioambientais sustentáveis seus potenciais e limitações identificando os desafios de gestão de empreendimentos com finalidades sociais e ambientais e a possibilidade de aplicações de conhecimentos, métodos e técnicas consagrados na administração das organizações. Desta maneira, pode-se analisar os principais processos de gestão de serviços 
regulados para desenhar a inovação necessária que promova a universalização dos serviços em áreas de vulnerabilidade, contemplando liderança, comunicação, estratégia, mensuração de resultados e impacto social, ambiental e econômico, agentes e interfaces com reguladores.

Nesse sentido, deve-se compreender a influência nas organizações do pensamento moderno, contemporâneo e adentrando no pós-modernismo, com organizações não mais pós-burocráticas, mas hiper-burocráticas, cujo paradigma dominante é da perspectiva funcionalista frente às competências explicadas nos saberes como conhecimento, habilidades e atitudes, que representam paradigmas sociais nas análises das organizações. (BURREL \& MORGAN, 1979).

\subsubsection{Modelo de negócios e a teoria da administração}

Na década de 1970 surgiu, pela primeira vez, o modelo de negócios, mas somente na década de 1990 passam a ser propostos e construídos na academia, ainda com deficiências de conceituação. Até o momento não há consenso sobre uma única definição. Incialmente, o modelo de negócio era exclusivo de empresas de tecnologia da informação com objetivos empresariais de criar, distribuir e capturar valor. Gradativamente expandiu-se para outras organizações, sendo que, o desenho conceitual explicita o conhecimento intrínseco do negócio (GHAZIANE\&VENTRESCA, 2005; OSTERWALDER et. al., 2005; ZOTTt\&AMIT, 2009; SOSNA et. Al, 2010; TEECE, 2010; KEEN\&QURESHI,2006; ZOTT ET. AL, 2010).

As grandes organizações sociais são classificadas em doi tipos: organizações comerciais, em suporte à sua missão e que não visam lucro; e de empreendedores sociais, chamados change makers, com objetivo de desenvolver novos serviços, novas combinações com objetivo de obtenção de lucro. As dimensões associadas a estes dois grupos de grandes organizações incluem atividade contínua de produção de bens ou serviços; nível de risco significante (gestores assumem total ou parcialmente o risco, depende de assegurar sua sustentação); quantidade de trabalhadores mínimos (não apenas voluntários); objetivo específico de benefício; transparência de seus indicadores sociais e governança participativa em negócios sociais em 
conselhos deliberativos. (BORZAGA \& GALERA, 2009).

Um modelo de negócio dessa escola deve ser capaz de baixar custos de atendimento e operação dos serviços; reduzir barreira de entrada (financeira); elaborar estratégias inovadoras de sensibilização; criar canais de crédito e subsídios; promover a participação e desenvolvimento do regulador para coibir a intervenção pública sobre o preço (preço político $X$ preço de mercado); dentre outros. Para os autores, a variação de escala e objetivos empresariais é diretiva para o sucesso, sendo explicados em diferenças apoiadas em relação ao modelo do negócio como: percepção dos obstáculos; visão; abertura de mercado de baixa renda e maturação do mesmo; criação de serviços e produtos complementares cujas ações se revertem em benefícios sociais; projetos pilotos antes das implantações em grande escala; rentabilidade; valores da empresa; subsídios; valor percebido sobre um serviço público e concessão de crédito para aumento de consumo com produtos complementares; redução da ineficiência e visão de P\&D sobre os setores de baixa renda (DURANA et al., 2010).

Os principais autores acadêmicos concordam que a estratégia empresarial, o modelo de gestão e o plano de negócio são fundamentais na definição de limites da empresa, criação de valor, organização de estrutura interna e governança para a composição e continuidade de um modelo de negócio (DELMAR\&SHANE, 2003; HONIG \& KARLSON, 2004; ROSA, 2009; FRASER \& GREENE, 2010, SEDDON \& LEWIS, 20003, PORTER, 2001; CASADEUS_MASANELL \& RICART, 2010; ZOTT \& AMITT,2008, MAGRETTA, 2002, GADIESH \& GILBERT, 2001).

Sobre esses referencias teóricos e conceituais acordados foi apoiada esta tese. Nesse sentido, faz-se necessário o desenvolvimento de mecanismos que promovam a gestão integrada aos atuais modelos socioeconômicos do saneamento, considerando suas externalidades e a interdisciplinaridade do assunto, bem como o fortalecimento da resiliência das comunidades nas áreas de vulnerabilidade que sofrem com os fenômenos devido ao crescimento desordenado e não sustentável dos assentamentos precários, a deficiência dos modelos de negócio, considerando estratégias, que incluam atividades produtivas em áreas vulneráveis dentro do tema da resiliência urbana, portanto, um modelo de negócio inclusivo. 


\subsubsection{Conclusão do Resgate Crítico da Produção Teórica}

O desafio de revisão bibliográfica do modelo de negócio aplicado às práticas do dos SAAES é identificar similares que considerem externalidades e falhas de mercado, cuja sustentabilidade em áreas de vulnerabilidade é prerrogativa, fornecendo evidências das limitações intrínsecas ao modelo e promovendo ajustes e mitigação das barreiras.

O modelo de negócio deve considerar obrigações em matéria de dignidade humana, mecanismos jurídicos, técnicos, econômicos e sociais para garantir um modelo de gestão inclusivo que atenda objetivos empresariais e do contratante (poder concedente) em regime de eficiência.

Destaca-se que os serviços de abastecimento de água e esgotamento sanitário - SAEs têm certas características que justificam a aplicação de políticas públicas sociais. Tanto o acesso dos usuários a esses serviços como aspectos relacionados ao meio ambiente derivados de sua disposição, marcam o forte caráter socioambiental do setor e enorme impacto que tem sobre 0 desenvolvimento humano na sociedade.

A teoria da administração tem demonstrado eficácia nos modelos para as organizações sociais quando o modelo de negócio, estratégia, planejamento empresarial são coerentes com a práticas de gestão, obtendo resultados que têm promovido geração, distribuição e captação de valor para suas empresas, sem uma politica social que os apoie. No aspecto da organização faz-se necessário reconhecer que não há modelo único, pois se opera com diferentes escolas da administração e híbridos que alcançam seus objetivos empresariais, uma vez que a escola do empreendedorismo atua em áreas vulneráveis com atos apoiadas nos princípios dos gestores pelo procedimental ou por valores pessoais em atender humanos vulneráveis.

\subsection{TAXONOMIA DE MODELOS EM ORGANIZAÇÕES SEMELHANTES}

Esse item tem por objetivo analisar as conexões e controvérsias, que constituem a problemática em diversos modelos de organizações de serviços públicos atendendo populações vulneráveis.

Segundo Durana et al. (2010) em cinco estudos de caso para desenvolver 
modelo de negócios para atender à população de baixa renda as grandes empresas de serviços de energia e gás na Venezuela, Argentina, Colômbia e Peru consideraram que a universalização para o SBR deve observar diversos aspectos, tais como: a crescente urbanização da pobreza; o acesso ilícito de serviços básicos; os custos elevados de operação; e a indefinição de uma estratégia empresarial.

As pesquisas feitas na Índia analisaram modelos de negócios sustentáveis para prestar serviços às populações pobres por meio de soluções de mercado, ou seja, negócios da economia formal que ajudaram a melhorar as condições de vida das pessoas que estão na base da pirâmide econômica. As 300 iniciativas de mercado estudadas revelaram modelos de negócio populares que trabalhavam, ou procuravam trabalhar em escala. As soluções de mercado como uma abordagem promissora de combate à pobreza apresentaram como pontos em comum dos negócios que conseguiram escala: organização de ponta a ponta, pois se criou não apenas um produto, mas um ecossistema abrangendo toda a cadeia de valor; manutenção do foco em um número reduzido de produtos ou serviços, para criar especialização e reduzir custos; equacionamento das fontes de financiamento subsidiado com acesso a financiamento com juros abaixo de mercado, para reduzir o custo de capital do empreendimento; e não esperar milagres no curto prazo. Muitos empreendimentos chegaram a levar de 10 a 15 anos para alcançar a escala desejada. As importantes lições aprendidas é que se deve tratar populações de baixa renda como clientes potenciais, como fornecedores ou produtores, inserindo-os na cadeia de suprimentos (MONITOR GROUP, 2009).

Nesse sentido, frente à crescente urbanização em habitações precárias, identificou-se a baixa qualidade ou ausência de serviços básicos, o comportamento da população, que entende que tem direito aos serviços e os acessa de forma lícita ou ilícita, as externalidades sobre a saúde e o meio ambiente, o modelo de gestão e governança, o comprometimento dos indicadores e uma elevada barreira de entrada.

Experiências de alguns países da África com similaridades características do desenvolvimento urbano no Brasil, como Senegal e África do Sul demonstram que um novo paradigma está sendo construído apoiado na colaboração e nas parcerias entre SAAES, municipalidades, Comumunity-Based Organizations - 
CBOs, Non-Governamental Organizations - NGOs e Parcerias PúblicoPrivadas - PPPs. Essa inovação tem conseguido alavancar esforços para universalização dos serviços para as comunidades de baixa renda (BROCKLEHURST AND JANSSENS, 2004, CROSS AND MOREL, 2005). O mesmo paradigma teve resultado no incremento do acesso aos serviços de água e esgoto para mais de 30.000 habitações em áreas de vulnerabilidade social e reduziu a frequência e gravidade das doenças de veiculação hídrica em crianças da Argentina. (ALMANSI ET AL., 2003, GALIANI ET AL., 2006). Convencionalmente, os clientes de baixa renda são vistos com baixa capacidade de pagamento para serviços melhores e mais adequados (ASIA, 1999). Ao mesmo tempo, clientes de baixa renda têm frequentemente demonstrado substancial disposição a pagar mais comumente para os serviços de água e esgotamento sanitário (BROCKLEHURST AND EVANS, 2001). De qualquer forma, era esperado que aumentasse a disposição a pagar, sinalizando as operadoras para expandir seus serviços para áreas vulneráveis. Isso foi relevante pelo fato dos clientes em situação de pobreza dominarem uma economia de países low-income uma vez que pesquisas indicam que essa participação contribue para recuperação dos custos em regime de eficiência, eficácia com sustentabilidade em alguns modelos de negócio.

Empresas sociais de água oferecem emprego a nível local e reinvestem o lucro na conservação e manutenção dos sistemas, gerando valor na cadeia produtiva. Empresas apoiam ONGs como Oxfam, WaterAid e Unilever Sunlight, que criaram centros de água no coração de comunidades urbanas, onde a água é bombeada de poços, tratada e vendida a baixo custo, ao lado de alimentos e produtos domésticos. Empresas sociais na África, Índia e Sul da Ásia são flexíveis, tem salários e custos menores e os rendimentos retornam para as comunidades, possuem estruturas de pagamento adequadas, mantendo ativos, reduzindo intermitência, informando exatamente quando o serviço será executado ou interrompido. Os serviços eram inicialmente gratuitos para usuários e pagos pelas empresas de serviços públicos, que por sua vez, recebiam os dados do usuário. Com o rápido crescimento e aumento do número de usuários propiciou um modelo com fins lucrativos, em oposição ao modelo de concessão sem fins lucrativos, cuja escala do desafio exigia. $O$ investimento em empresas sociais ajuda a garantir a sustentabilidade dos 
serviços, pois mantem as instalações e garantem a comunicação com os clientes. O atendimento por quiosques de água em Uganda, Quênia e Camboja com sistema de cartão pré-pago semelhante a um telefone prevê mais de 20 centros até 2016. Identificou-se que a construção bottom-up tem maior reconhecimento da comunidade, o que pode levar a alavancagem de políticas governamentais e nacionais, com objetivo final da empresa de universalização da água. O modelo de negócio em torno das empresas de serviços públicos forneceu ferramentas para a concessionária obter maior distribuição equitativa: uma rede inteligente, obtendo e fornecendo informações e auxiliando numa operação mais eficiente dos serviços públicos. O empreendedorismo social pode funcionar de forma eficiente, produzir excedentes das receitas sobre custos, remunerar investimentos e expandir o negócio (WHO, 2014,2015).

Identificam-se como referências, um exemplo de modelo de negócio do Brasil na Companhia de Saneamento Básico do Estado de Minas Gerais COPASA e dois modelos de gestão na Companhia de Saneamento Básico do Estado de São Paulo - SABESP.

\subsubsection{COPANOR - Estudo de Caso da Companhia de Saneamento Básico do Estado de Minas Gerais - COPASA.}

A Copasa Serviços de Saneamento Integrado do Norte e Nordeste de Minas Gerais - COPANOR S.A. é uma empresa da Companhia de Saneamento Básico do Estado de Minas Gerais - COPASA. A COPASA possui capital aberto, com investimentos da ordem de $\mathrm{R} \$ 980$ milhões/ano. Operava 626 municípios no estado de Minas Gerais com concessão de água e 283 com concessão de esgoto. Tem uma estrutura de governança proveniente do Novo Mercado da Bolsa de Valores, Mercadorias e Futuros de São Paulo (BM\&FBovespa), no qual suas ações são negociadas. Com objetivo de implantar SAAES em todas as localidades com população entre 200 e 5.000 habitantes no Norte e Nordeste de Minas, a COPANOR foi criada pela Lei Estadual de Minas Gerais 16.698/07, como subsidiária da COPASA. Objetiva a melhoria da qualidade de vida da população em sua área de abrangência, 
redução dos índices de mortalidade infantil causadas por doenças infecciosas e parasitárias, redução das desigualdades regionais e despoluição de rios e córregos. A Copanor é responsavel pela gestão dos serviços no Vale do Jequitinhonha, mantendo nível de qualidade equivalente ao dos serviços prestados pela Copasa-MG, em regime de subconcessão, observando as diretrizes do Plano de Saneamento Básico de sua região de atuação, estabelecido nos termos da Lei Federal no - 11.445, de 5 de janeiro de 2007 (COPASA, 2013).

Os principais objetivos informados incluem planejar, e prestar serviços de abastecimento de água e de esgotamento sanitário do Norte de Minas e das Bacias Hidrográficas dos Rios Jequitinhonha, Mucuri, São Mateus, Buranhém, Itanhém e Jucuruçu. Esta região já era operada pela COPASA, sendo uma das áreas de menor renda e maior vulnerabilidade socioambiental do Brasil. A criação da subsidiária COPANOR tem a missão de "oferecer serviços de abastecimento de água e esgotamento sanitário com tarifas reduzidas compatíveis com a realidade socioeconômica da população, em sua área de abrangência" (pg.) Para isso, os investimentos na implantação dos SAAES da Copanor foram subsidiados pelo Governo do Estado de Minas Gerais e coube à companhia a operação desses sistemas. Além do objetivo de consolidar Minas como um modelo em saneamento, a COPANOR, com uma política de tarifas reduzidas, propõem-se a ser uma empresa sustentável e contribuir para diminuição das desigualdades regionais e promover a inclusão social. (COPASA, 2013).

Para isso a COPANOR contou com recursos não onerosos do Estado para construir reservatórios, estações de tratamento de água e esgotos e redes de distribuição de água e esgoto, módulos sanitários nas sedes municipais e em localidades com população entre 200 e 5.000 habitantes de 463 localidades que apresentavam o mais baixo Índice de Desenvolvimento Humano (IDH) na região Nordeste do Estado de Minas Gerais. O modelo de gestão escolhido teve por objetivos conferir maior eficiência à operação local; reduzir custos; e gerar receitas suficientes para cobrir despesas operacionais, portanto, sem objetivos de lucro. Em 2012, estava atendendo 155 localidades beneficiando mais de 209 mil pessoas com serviços que garantiam, inclusive, módulos sanitários nas residências. Para provisionar os investimentos necessários, foi 
criado o Fundo Estadual de Saúde (FES) que contou com aporte do Governo Estadual de Minas Gerais de $R \$ 545$ milhões, dos quais $R \$ 264$ milhões foram aplicados em obras até 2011. A previsão de o montante restante ser investido até 2015 foi afetada pela crise hídrica. Segundo a matriz, o modelo tecnológico e organizacional adotado pela subsidiária, que permite o aumento da eficiência e a redução de custos operacionais na prestação de serviços de saneamento para as comunidades com baixo Índice de Desenvolvimento Humano (IDH), está ultrapassando as fronteiras de Minas. Porém, os funcionários da COPANOR denunciaram as condições de trabalho em redes sociais, pedindo apoio à população para que a empresa cumprisse suas funções operacionais. Pediam revisão quanto a grande disparidade salarial entre matriz e subsidiária e reclamavam do excesso de atribuições. Citavam como exemplo o operador de sistema, chamado de "o que faz de tudo", que exerce as funções de leiturista, serviços de manutenção e ligação em redes de distribuição de água e coleta de esgoto, operador da Estação de Tratamento de Água - ETA, operador da Estação de Tratamento de Esgoto - ETE, às vezes realizando até serviços de eletromecânica para qual não possui conhecimento técnico, atendente comercial, motorista condutor de produtos químicos perigosos, pois a empresa não possui profissionais suficientes nestas áreas (COPASA, 2011, 2013; SEGOV, 2012; JUSBRASIL, 2012, EXAME, 2015, Trata Brasil, 2015).

O número de comunidades atendidas no primeiro quadriênio de operação oscilou. Em dezembro de 2013, havia um total de 198 localidades atendidas com sistemas de abastecimento de água implantados, 61 localidades com sistemas de esgotamento sanitário, 886 famílias foram contempladas com a implantação de módulos sanitários com banheiro, tanque, chuveiro e pia em suas residências (Tabela 01).

Tabela 1- Localidades Atendidas pela COPANOR de 2008 a 2013

\begin{tabular}{lccccc}
\hline LOCALIDADES ATENDIDAS & $\mathbf{2 0 0 8}$ & $\mathbf{2 0 0 9}$ & $\mathbf{2 0 1 0}$ & $\mathbf{2 0 1 1}$ & Atual \\
\hline Total de Localidades - SAA & 22 & $\mathbf{3 0}$ & $\mathbf{8 5}$ & 26 & 163 \\
\hline Total de Localidades - SES & 10 & 4 & 3 & 1 & 18 \\
\hline População Beneficiada - SAA & 41.214 & 59.876 & 72.662 & 41.551 & 215.303 \\
\hline População Beneficiada - SES & 12.004 & 7.333 & 5.085 & 968 & 25.390 \\
\hline & & & \multicolumn{3}{c}{ Fonte: COPANOR (2013) }
\end{tabular}


Por levantamentos e entrevistas, o modelo da COPANOR adotou a prestação dos serviços integralmente por funcionários concursados da concessionária. Não houve a inserção do cidadão da comunidade na cadeia produtiva de valor, - que poderia reduzir as sobrecargas dos trabalhadores contratados e aumentar os produtos com geração de valor compartilhado. Percebe-se também, que seria necessária melhor instrumentalização nas funções da gestão administrativa e econômico-financeira da subsidiária, sendo que o fato de não objetivar lucro modificou a política empresarial de participação nos resultados dos funcionários alocados na subsidiária, promovendo tensões internas.

No segundo semestre de 2012, a administração da COPASA retomou as funções administrativas e financeiras por considerar que o modelo não estava respondendo aos desafios propostos, e que o retorno promoveria ganhos de escala ${ }^{6}$. O modelo empresarial, inovador para o setor, contou com subsídio do Estado para garantir viabilidade econômico-financeira e prover tarifas sociais para todos os usuários cadastrados no Cadastro Único e Bolsa Família Programas Sociais do Governo Federal, no entanto, as estruturas de gestão da COPANOR voltaram a ficar vinculadas à COPASA, cujos custos são maiores que os previstos no modelo inicial, para garantir que se atinja os objetivos empresariais.

Os investimentos feitos pelo governo do estado por meio da Copanor, com recursos do Tesouro Estadual, em obras de saneamento, equipamentos, materiais e serviços beneficiaram 88 municípios já estavam com a lei autorizativa para contratos de programa para a transferência dos serviços da prefeitura municipal para a Copanor. Esse já é considerado um modelo de referência onde 0 Estado provê o equacionamento de subsídios ao investimento e custos dos serviços, ensejando ainda a medição das externalidades positivas. Considera-se a COPASA como uma Corporate Entrepreneurship, conforme Borzaga e Galera.

\subsubsection{Estudos de Caso de São Paulo}

\footnotetext{
${ }^{6}$ em entrevista realizada pelos autores deste capítulo, 2012
} 


\subsubsection{Córrego Limpo - Estudo de Caso da Companhia de Saneamento Básico do Estado de São Paulo - SABESP}

A Prefeitura do Município de São Paulo e a SABESP criaram um programa para promover a coleta e afastamento dos esgotos coletados nas áreas de baixa renda do Estado de São Paulo em complementação ao Projeto de despoluição do Rio Tietê - batizado como Programa Córrego Limpo (PMSP, 2009). Segundo o plano municipal de saneamento do município de São Paulo, as ações a cargo da SABESP foram: eliminação das ligações clandestinas ou inadequadas; manutenção das redes; elaboração de projetos; licenciamento e execução de ligações; coletores e estações elevatórias; monitoramento da qualidade da água; e informação ambiental à população local. As ações do Município são: limpeza de margens e leitos de córrego; manutenção da rede pluvial; contenção de margens; remoção de população das áreas ribeirinhas por onde deve passar a infraestrutura de rede; urbanização de favelas; Implementação de parques lineares sempre que possível; e notificação de proprietários para que regularizem suas conexões. É importante observar que, dentre as maiores dificuldades deste programa está à necessidade de remoção e realocação de população de baixa renda da beira de córregos, em função da existência de ocupações precárias nas áreas de fundo de vale, onde devam ser implantados os coletores tronco. Os recursos para as ações de responsabilidade do município são provenientes dos aportes trimestrais da concessionária de $7,5 \%$ da receita bruta arrecadada no município em um Fundo Municipal de Saneamento e Infraestrutura, criado por lei n. 14.934/2009, quando da contratualização dos serviços entre município e Concessionária. $O$ contrato remete à agência reguladora por ocasião da revisão tarifária as definições quanto à consideração desse encargo (ARSESP, 2012). Até o ano de 2012 foram despoluídos pela concessionária 52 córregos e 1,7 milhão de pessoas beneficiadas (SABESP, 2011). O modelo de gestão adotado neste caso da SABESP, foi chamado de "Construção de Governança", em articulação e organização com a comunidade. O conceito de governança, segundo Donahue (2004, pg. 3), da Kennedy School of Government, de Harvard é: 
A essência da governança colaborativa é um novo nível de engajamento político/social entre vários setores da sociedade, que constitui uma maneira mais efetiva de enfrentar muitos dos problemas das sociedades modernas, muito além do que vários setores foram capazes de conquistar sozinhos.

No município de São Paulo há um elevado número de comunidades de baixa renda envolvidas em micro bacias distintas, cujo caráter descentralizado amplia a dificuldade dos agentes públicos se fazerem presentes em todos os córregos. Também, as diversas dimensões que a proteção destes fundos de vale requer, faz com que seja quase impossível ao poder público agir sozinho. A solução proposta no projeto foi montar uma estratégia de implantação de governança colaborativa em cada bacia hidrográfica contando com a comunidade local. A colaboração funciona como um tipo de rede de relacionamento. Na proteção dos córregos é indispensável à colaboração de todos os envolvidos direta e indiretamente. Neste caso, o objetivo foi identificar e/ou construir uma rede com várias organizações que formassem alianças temporárias ou permanentes em torno de um propósito específico: proteger os córregos e tornar duradouros os ganhos do Programa Córrego Limpo ${ }^{7}$.

$\mathrm{Na}$ definição das estratégias da governança colaborativa, o projeto piloto empregou o Modelo dos Níveis de Ação Colaborativa - MNAC, elaborado por Imperial (2005), da Universidade da Carolina do Norte, e já utilizado na análise do trabalho em seis bacias hidrográficas norte-americanas. Por meio do MNAC, buscou-se identificar padrões presentes em cada nível nas seis bacias norteamericanas analisadas. Operacionalmente, foram identificadas três atividades comuns a todas as bacias: melhoria das condições ambientais; instrução do público e dos tomadores de decisão; monitoramento e fiscalização (Quadro 1). Como o nível operacional é o último na cadeia da Governança Colaborativa, não traz muitos desafios estratégicos. Há a preponderância do poder público, e a cooperação da sociedade civil ocorre de forma marginal. Na experiência norte-americana, o nível operacional envolveu não só a questão das obras e infraestrutura, mas também a sensibilização da população para a questão da

\footnotetext{
${ }^{7}$ As informações aqui descritas da Governança Colaborativa, adotada no Programa Córrego Limpo, foram autorizadas pela Diretoria de Operação Metropolitana da SABESP.
} 
proteção dos recursos naturais, por meio de melhorias nas atividades de educação, além do monitoramento e fiscalização.

\begin{tabular}{|c|c|c|}
\hline Atividade & ções & jaráter colaborativo \\
\hline $\begin{array}{l}\text { Melhoria } \\
\text { das } \\
\text { condições } \\
\text { ambientais. }\end{array}$ & $\begin{array}{l}\text { Coleta de } \\
\text { implantação de melhores } \\
\text { práticas, coleta de lixo e } \\
\text { entulho. }\end{array}$ & $\begin{array}{l}\text { Parceria entre órgãos públicos dos níveis } \\
\text { federal, regional e local e entre órgãos do } \\
\text { mesmo nível. Envolve compartilhamento de } \\
\text { recursos, desde recursos financeiros e } \\
\text { técnicos até capacidade de planejamento e } \\
\text { gestão. }\end{array}$ \\
\hline $\begin{array}{l}\text { Educação } \\
\text { do público } \\
\text { e dos } \\
\text { tomadores } \\
\text { de decisão. }\end{array}$ & $\begin{array}{l}\text { Palestras, } \\
\text { preparação de matérias de } \\
\text { divulgação como guias e } \\
\text { cartilhas, treinamento e } \\
\text { assistência técnica voltados } \\
\text { para públicos específicos } \\
\text { como professores e } \\
\text { tomadores de decisão. }\end{array}$ & $\begin{array}{l}\text { Parceria com outros órgãos públicos, } \\
\text { escolas, ONGs. O setor público geralmente } \\
\text { entra com recursos financeiros e expertise } \\
\text { técnica, as ONGs também entram com } \\
\text { expertise técnica e com a organização do } \\
\text { treinamento; as escolas e outras associações } \\
\text { garantem o público. }\end{array}$ \\
\hline $\begin{array}{l}\text { Monitorame } \\
\text { nto/fiscaliza } \\
\text { ção. }\end{array}$ & Coleta & $\begin{array}{l}\text { Parceria com escolas e universidades locais } \\
\text { para a coleta de dados por meio } \\
\text { do voluntariado. }\end{array}$ \\
\hline
\end{tabular}

Fonte: SABESP (2011)

Quadro 1 - Nível Operacional - Atividades e caráter colaborativo

O nível da formulação de políticas é aquele que apresenta maior intensidade no caráter colaborativo. Envolve atividades de compartilhamento de conhecimentos e recursos, além de desenvolvimento de políticas compartilhadas, regulações e normas sociais (Quadro 2). Nesse nível constróise a rede de colaboração propriamente dita, embora ela deva ser reconhecida também no nível institucional. Os grupos de trabalho ou forças-tarefa podem incorporar novos atores à rede, e isso acaba gerando novas ideias, de forma a resolver problemas, construir relacionamentos e desenvolver confiança. As redes também criam canais valiosos de troca de informações.

\begin{tabular}{|c|l|l|}
\hline Atividade & Ações & Caráter colaborativo \\
\hline \multirow{5}{*}{$\begin{array}{c}\text { Compartilhamento } \\
\text { de }\end{array}$} & $\begin{array}{l}\text { Redução da assimetria de informações } \\
\text { por meio do desenvolvimento de bases } \\
\text { de dados comuns (com uso de Sistemas } \\
\text { de Informação Geográfica - SIG), }\end{array}$ & $\begin{array}{l}\text { Reúne todos as partes } \\
\text { interessadas, isto é, todos } \\
\text { aqueles que afetam ou são } \\
\text { afetados pela questão } \\
\text { ambecimentos } \\
\text { compartilhamento de recursos técnicos, } \\
\text { inventário de recursos integrados das bacias. São } \\
\text { (relatórios anuais, relatório de de } \\
\text { formados grupos de trabalho, } \\
\text { monitoramento, etc.) } \\
\text { forças tarefa e comitês } \\
\text { consultivos. }\end{array}$ \\
\hline Compartilhamento & Contratação de pessoal por um parceiro & Envolve principalmente \\
\hline
\end{tabular}




\begin{tabular}{|c|c|c|}
\hline $\begin{array}{l}\text { de } \\
\text { Recursos }\end{array}$ & $\begin{array}{l}\text { para prestação de serviços para outro, } \\
\text { uma organização recruta voluntários } \\
\text { para trabalhar para outra, colaboração } \\
\text { entre quadros } \\
\text { compartilhamento técnicos, } \\
\text { financeiros. }\end{array}$ & $\begin{array}{l}\text { ONGs, visando maior } \\
\text { eficiência e menor custo aos } \\
\text { projetos e tendo em vista as } \\
\text { limitações do setor público. }\end{array}$ \\
\hline $\begin{array}{l}\text { Desenvolvimento } \\
\text { de Políticas } \\
\text { compartilhadas } \\
\text { regulações e } \\
\text { normas sociais }\end{array}$ & $\begin{array}{l}\text { Desenvolvimento de documentos de } \\
\text { políticas compartilhadas, definição } \\
\text { conjunta de prioridades e } \\
\text { estabelecimento de "normas sociais" } \\
\text { (códigos compartilhados por todos) }\end{array}$ & $\begin{array}{l}\text { Envolve todos as partes } \\
\text { interessadas. }\end{array}$ \\
\hline
\end{tabular}

Fonte: (SABESP, 2012)

Quadro 2 - Nível da Formulação de Políticas - Atividades e caráter colaborativo

No nível institucional são desenvolvidas atividades como a formalização das políticas compartilhadas, assim como o desenvolvimento de organizações colaborativas (Quadro 3). Nesse nível, Imperial (2005) identificou fatores dos quais depende toda a estratégia de cooperação. Uma característica é que a colaboração deve se dar em um jogo em que todos ganham. Embora possam surgir conflitos, é essencial que haja objetivo comum e um mínimo de valores compartilhados, quando se juntam atores com visões conflitantes e objetivos excludentes, a colaboração não acontece. Outra necessidade é ter foco, pois iniciativas sem objetivos claros tendem a levar os participantes ao desinteresse. Também considera útil criar regras para reger o esforço colaborativo, para evitar perder muito tempo discutindo processos e procedimentos.

\begin{tabular}{|l|l|l|}
\hline Atividade & Ações & Caráter colaborativo \\
\hline $\begin{array}{l}\text { Formalização das } \\
\text { políticas } \\
\text { compartilhadas, } \\
\text { regras, normas, } \\
\text { práticas, processos e } \\
\text { procedimentos }\end{array}$ & $\begin{array}{l}\text { Elaboração de instrumentos regulatórios } \\
\text { como termos de cooperação, resoluções, } \\
\text { alterações de legislação, Leis e Decretos. }\end{array}$ & $\begin{array}{l}\text { Participação de todos } \\
\text { as partes } \\
\text { interessadas. }\end{array}$ \\
\hline $\begin{array}{l}\text { Desenvolvimento de } \\
\text { Organizações } \\
\text { Colaborativas }\end{array}$ & $\begin{array}{l}\text { Criação de organizações de segunda } \\
\text { ordem, isto é organizações que não só } \\
\text { respondem às mudanças no seu ambiente } \\
\text { de atuação como também revisam seus } \\
\text { próprios valores e crenças estabelecendo } \\
\text { um quadro de referência comum. }\end{array}$ & $\begin{array}{l}\text { Participação de todos } \\
\text { as partes } \\
\text { interessadas. }\end{array}$ \\
\hline
\end{tabular}

Quadro 3 - Nível Institucional - Atividades e caráter colaborativo 
A Unidade de Negócio - UN, no Norte da RMSP reúne-se mensalmente com lideranças comunitárias desde 1996 em locais fixos (SABESP ou centros de convivência comunitária) com objetivo de promover responsabilidade ambiental, melhor responder demandas das comunidades e fazer prestação de contas. Nesse sentido, entendem a colaboração entre empresa e sociedade, como tendo níveis (Quadro 4): operacional, formulação de políticas e Institucional. Há uma relação de antecedência entre os níveis, indicando que as ações colaborativas dependem de um suporte na formulação de políticas e são restringidas e promovidas pelas normas empresariais.

\begin{tabular}{|l|l|}
\hline Nível & Descrição \\
\hline Operacional & $\begin{array}{l}\text { Tem impacto direto no mundo real. Trata-se de intervenções como } \\
\text { implantação de infraestrutura ou então de processos educativos e } \\
\text { de monitoramento e avaliação. Envolvem, na maior parte das vezes, } \\
\text { serviços governamentais. }\end{array}$ \\
\hline Formulação de política & $\begin{array}{l}\text { Não tem impacto direto no mundo real. Tem caráter orientador, } \\
\text { incrementando a comunicação entre os atores, coordenando ações } \\
\text { e integrando políticas de maneira a alavancar os objetivos coletivos } \\
\text { (governança). }\end{array}$ \\
\hline Institucional & $\begin{array}{l}\text { Atividades que influenciam, restringem, incrementam ou promovem } \\
\text { ações no nível operacional e de formulação de política. }\end{array}$ \\
\hline
\end{tabular}

Fonte: (SABESP, 2012)

Quadro 4 - Níveis de colaboração

Aplicando os princípios do MNAC ao Programa Córrego Limpo da forma como estava em 2012, chega-se à síntese do Quadro 5. Nele, os espaços em branco mostram as oportunidades de aprimoramento da colaboração. Importante notar que dizem respeito à ampliação da cooperação entre órgãos públicos, mas também ao envolvimento de novos atores, sobretudo locais. A partir desse modelo, foram identificadas oportunidades para colaboração entre os envolvidos no Programa Córrego Limpo: comunidades vizinhas aos cursos d'água e órgãos públicos, como a Secretaria de Estado de Saneamento e Energia, a SABESP e as Secretarias Municipais de Coordenação das Subprefeituras, de Infraestrutura Urbana e Obras, de Habitação e do Verde e Meio Ambiente, sendo que as unidades regionais tiveram autonomia para organizar-se em atendimento as diretrizes estratégicas empresariais.

\begin{tabular}{|l|l|l|l|l|l|l|}
\hline Nível de colaboração & $\begin{array}{l}\text { Existe } \\
\text { colabo }\end{array}$ & $\begin{array}{l}\text { Órgãos } \\
\text { públicos }\end{array}$ & $\begin{array}{l}\text { Órgãos } \\
\text { públicos }\end{array}$ & ONGs & $\begin{array}{l}\text { Socieda } \\
\text { de Civil }\end{array}$ \\
\hline
\end{tabular}




\begin{tabular}{|c|c|c|c|c|}
\hline & & ração & $\begin{array}{l}\text { no } \\
\text { mesmo } \\
\text { nível }\end{array}$ & $\begin{array}{l}\text { de outro } \\
\text { nível }\end{array}$ \\
\hline \multirow[t]{3}{*}{$\begin{array}{l}\text { Opera } \\
\text { cional }\end{array}$} & $\begin{array}{l}\text { Melhoria das condições } \\
\text { ambientais }\end{array}$ & Sim & $\mathrm{X}$ & $\mathrm{X}$ \\
\hline & $\begin{array}{l}\text { Educação de público e } \\
\text { tomadores de decisão }\end{array}$ & Sim & $\mathrm{X}$ & $\mathrm{X}$ \\
\hline & Monitoramento e fiscalização & Sim & $\mathrm{X}$ & \\
\hline \multirow{3}{*}{$\begin{array}{l}\text { Formu } \\
\text { lação } \\
\text { de } \\
\text { Polític } \\
\text { as }\end{array}$} & $\begin{array}{l}\text { Compartilhamento de } \\
\text { conhecimentos }\end{array}$ & Não & & \\
\hline & Compartilhamento de recursos & Não & & \\
\hline & $\begin{array}{l}\text { Desenvolvimento de políticas } \\
\text { compartilhadas, regulações e } \\
\text { normas }\end{array}$ & Não & & \\
\hline \multirow{2}{*}{$\begin{array}{l}\text { Institu } \\
\text { cional }\end{array}$} & Formalização de políticas & Sim & $\mathrm{X}$ & $\mathrm{X}$ \\
\hline & Desenvolvimento & Não & & \\
\hline
\end{tabular}

Quadro 5 - Comparação do modelo MNAC com o estado do Programa Córrego Limpo em 2012

Fonte: SABESP (2012)

A partir da tipologia de bacias e da análise de redes sociais, o projeto piloto sugere algumas estratégias para estabelecimento de uma boa governança Colaborativa, como, antes do início de obras, comunicar o que se pretende com a intervenção. Também, segundo a metodologia, é necessário ouvir o público para conhecer sua percepção sobre a iniciativa; estimular e incorporar propostas locais de melhoria dos córregos que sejam complementares às do poder público; relacionar o córrego à vida das pessoas, por meio de material informativo sobre sua história; criar canal direto com gestores do programa para denúncias sobre deposição de lixo e entulho no córrego; disponibilizar página na World Wide Web na qual conhecimentos técnicos e da população possam ser compartilhados; criar relatórios de avaliação e monitoramento que informem a comunidade e a mantenha envolvida; firmar termo de cooperação envolvendo os participantes de cada bacia e definindo as regras para 0 processo colaborativo; e criar fóruns em cada uma das bacias participantes do programa, conforme relatórios de circulação restrita da SABESP.

Para os Fóruns foram feitas as seguintes recomendações: composição por representantes da SABESP e dos demais setores envolvidos; definição de objetivos e prioridades dos projetos de preservação dos córregos; disseminação das informações sobre o Programa; Apoio às iniciativas educacionais do nível operacional; auxilio aos processos de monitoramento e fiscalização no nível local; considerar diagnóstico das redes sociais existentes; 
onde houver redes consolidadas negociar com as lideranças locais; onde não houver, o poder público deverá tomar a iniciativa de instalação, convidando para participar os atores locais e, onde necessário, atores externos, como ONGs.

Do ponto de vista do impacto social, identificam-se maiores os efeitos sobre o tecido social da comunidade um modelo de governança colaborativa. Porém, observa-se ainda diversas controvérsias entre visões de enfoque sociotécnico quanto às atribuições do Estado. No que tange a provisão constitucional do direito aos serviços de saneamento básico ${ }^{8}$ há sempre a busca de um Estado provedor para superação de impedimentos trazidos pelo direito de propriedade, desafios legais para estabelecer parcerias e prover recursos contínuos para ampliar a base de famílias atendidas numa política social.

Nesse sentido, os benefícios das atividades do setor são tão impactantes que são claramente identificáveis e desejáveis as intervenções frente aos resultados socioambientais de despoluição dos córregos. Além do acesso aos serviços, surgiram novos comércios provenientes do acesso à água, promovendo aumento de renda, valorização imobiliária, consciência ambiental, construção de um sentimento de valorização do local, fortalecimento dos vínculos das redes sociais, e ligação de grupos dispersos entre cidadãos e organizações.

Permanecem desafios da mensuração de externalidades socioambientais nessas áreas. Considera-se a SABESP como uma change makers, conforme Borzaga e Galera.

\subsubsection{Seliga na Rede - Estudo de Caso da Companhia de Saneamento de SP}

O Programa Pró-Conexão - Se liga na rede foi uma parceria entre o Governo do Estado de São Paulo e a SABESP, firmada por meio da Lei Estadual no 1.687 sancionada em 2 de janeiro de 2012, que proporcionou a ligação

8 A Política Federal de Saneamento Básico do Brasil, Lei 11.445/2.007, define saneamento básico como o conjunto de serviços, infra-estruturas e instalações operacionais de abastecimento de água potável; esgotamento sanitário; limpeza urbana e manejo de resíduos sólidos; e drenagem e manejo das águas pluviais urbanas. 
intradomiciliar gratuita para clientes de baixa renda, com o objetivo de estimular a conexão à rede coletora de esgotos, visando à universalização dos serviços, despoluição dos corpos d'água e melhoria do meio ambiente em áreas regulares (SÃO PAULO, 2012) O programa é resultado de estudo realizado pela Diretoria Metropolitana que identificou que, do total de suas ligações, $20 \%$ não eram atendidos com esgoto, o que correspondia a 788 mil ligações apenas nessa diretoria. Depurando-se esse número, destacou-se o fato de que $13 \%$ dessas ligações dependiam apenas da execução do ramal intradomiciliar para se conectar a rede da SABESP. O custo é de U \$900/ unidade. Para uma família de classe média ou superior, esse valor não se constitui num impeditivo à realização da obra, já em relação a uma família de baixa renda, esse custo representa praticamente todo o rendimento da família em um mês.

O grande desafio da empresa tem sido a de incentivar a conexão de usuários em áreas de baixa renda do sistema de saneamento. O salário mínimo nessa região do Brasil era de U \$ 300 (SABESP, 2012). Neste sentido, uma parceria entre o Governo do Estado de São Paulo e SABESP Companhia foi criada por lei, que fornece a conexão domiciliar gratuitamente para clientes de baixa renda, com o objetivo de estimular a conexão com o sistema de saneamento, visando serviços universais, reparação de massas de água e melhoria do ambiente (SÃO PAULO, 2012).

A concessionária tem respondido aos desafios das áreas pobres e vulneráveis metropolitanas com a inovação do modelo de gestão de projetos-piloto e pelo uso do benchmarking para assuntos específicos. Por exemplo, a SABESP desenvolveu um exercício de avaliação comparativa com os sistemas de formação de Tóquio, Yokohama, Nagoya e Saitama com base em uma informação de base sobre o Programa de Perdas de Água.

Acordo de cooperação SABESP com o Estado previu escolha das áreas em parceria entre o Estado e a concessionária, gratuidade para o usuário por meio do pagamento de custos em $80 \%$ pelo Estado e $20 \%$ pela concessionária, pontos de vista técnicos de usuários da comunidade para apresentar um termo de adesão ao programa, e agendamento obrigatório e execução da obra no 
prazo de 8 a 12 dias (SABESP, 2012), o piloto foi realizado na UN Sul da RMSP.

De acordo com os documentos fornecidos pela SABESP, tomaram duas linhas para identificar as famílias que se beneficiaram do programa: análise do sistema de informações dos usuários de informação geo-referenciada e aplicados questionários de mapeamento de usuários socioeconômicos elegíveis e abordagem aos moradores (Figura 3).

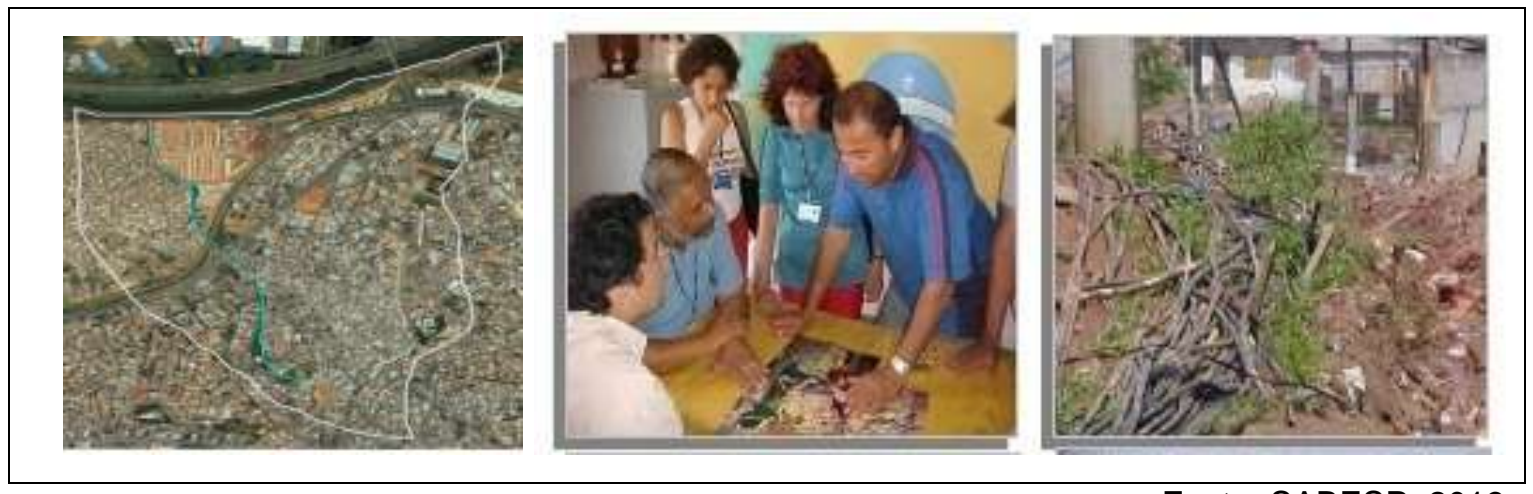

Fonte: SABESP, 2013

Figura 3 - Estratégias de Abordagem do Programa SELIGA

A amostra probabilística pesquisa quantitativa com um nível de confiança de 95,5\% foi realizada com os objetivos de mapear o perfil socioeconômico do público-alvo; identificar as razões pelas quais o cliente não estava conectado ao sistema de saneamento da SABESP, e identificar as percepções sobre o bairro onde o cliente vivia, bem como aspectos que poderiam ser usados como uma chamada para comunicar a conexão com o programa Rede.

Adotaram-se os seguintes critérios para eleger os beneficiários: famílias de baixa renda com rendimentos até 3 salários mínimos; residentes em áreas de alta vulnerabilidade social - grupos 5 e 6 do Índice Paulista de Vulnerabilidade. A meta do programa é realizar 191,7 mil ligações ao longo de 8 anos, beneficiando cerca de 800 mil pessoas. Estão estimados investimentos em torno de $\mathrm{R} \$ 350$ milhões para atingir a meta na SABESP. Desse valor, $80 \%$ serão financiados pelo Governo do Estado de São Paulo e os demais 20\% pela SABESP. A fim de subsidiar a estruturação do Programa, foi realizada uma pesquisa quantitativa amostral probabilística com nível de confiança de 95,5\% com os seguintes objetivos: mapear o perfil socioeconômico do público-alvo; 
identificar os motivos pelos quais o cliente não está conectado à rede de esgoto da SABESP; identificar as percepções sobre saneamento do bairro em que o cliente mora, bem como aspectos que possam ser usados como apelo na comunicação do Programa SELIGA na Rede. Os principais resultados das pesquisas demonstram que $54 \%$ dos entrevistados apresentavam um nível de instrução máximo de ensino fundamental incompleto; $86 \%$ da amostra se enquadra no critério de renda, recebendo até 3 salários mínimos por mês; $89 \%$ fato das pessoas se mostrarem dispostas a apoiar o programa; os entrevistados mostraram-se sensíveis aos problemas causados pela falta de rede de esgoto, sobretudo quanto ao mau cheiro, proliferação de insetos, mosquitos e ratos, além de sujeira na rua. Agrega-se a isso o fato de $74 \%$ terem interesse em receber maiores informações sobre o tratamento de esgoto; os entrevistados demonstraram ainda baixo conhecimento sobre 0 procedimento para realizar a ligação de esgoto, razão pela qual $40 \%$ não se conectarem. Outros $23 \%$ não o fizeram em virtude do custo da instalação ou tarifa. Para finalizar, na amostra, a maior parte do esgoto é lançada predominantemente no córrego (51\%); apenas $14 \%$ estão conectados à rede de esgoto da SABESP e o restante utiliza fossa ou outros meios.

A atuação da SABESP seguiu os seguintes procedimentos: a) Identificação dos imóveis com condições técnicas que permitam a conexão à rede coletora de esgoto dentro das áreas de alta vulnerabilidade, denominadas "Ligações Factíveis" ao Programa "Se Liga na Rede" (Figura 4). Essa etapa foi realizada por meio de sistema geo-referenciada onde são selecionados os imóveis que possuem apenas ligações de água, nos setores com alta vulnerabilidade classificados pelo Índice Paulista de Vulnerabilidade Social - IPVS com níveis 5 e 6 dentro da área de tratamento; b) Em seguida, uma equipe formada por pessoas da própria comunidade, especialmente treinadas e uniformizadas para a tarefa, visitam as famílias identificadas para explicar o que é o Programa e formalizar sua adesão por meio da assinatura de um termo; c) O serviço é então programado e executado pela Unidade que informa à equipe de adesão sobre a conclusão da obra para que o cliente seja visitado novamente, verificando assim sua satisfação em relação aos serviços prestados. 

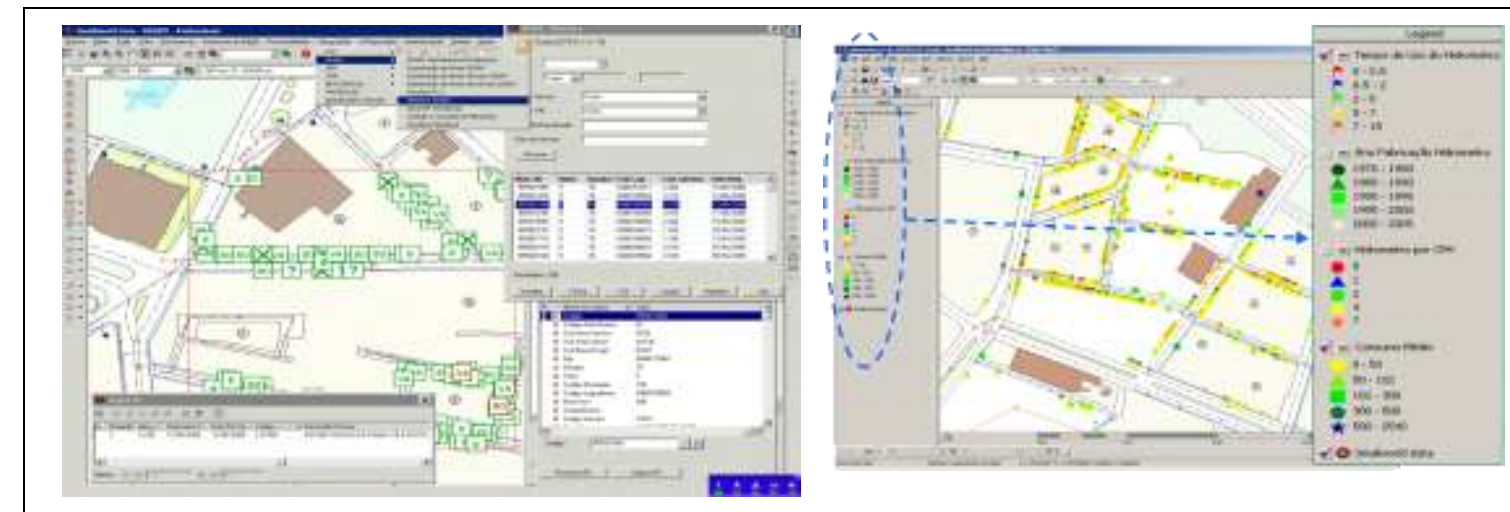

Fonte: SABESP, 2013

Figura 4 - Aplicação GIS Usuários não conectados

A população-alvo do programa são apresentados na Tabela 2.

Tabela 2 - Os objetivos do programa por ano

\begin{tabular}{ccccccccc}
\hline Região / Ano & Ano 1 & Ano 2 & Ano 3 & Ano 4 & Ano 5 & Ano 6 & Ano 7 & Ano 8 \\
\hline RMSP & 8.292 & 8.573 & 9.358 & 9.964 & 11.331 & 11.299 & 11.583 & 6.448 \\
\hline RMBS & 7.000 & 5.000 & 3.000 & 3.000 & 5.000 & 5.000 & 1.000 & 1.000 \\
\hline Campinas & 2.200 & 2.200 & 600 & 600 & - & - & - & - \\
\hline Interior & 7.617 & 8.051 & 8.760 & 9.499 & 9.985 & 10.771 & 11.847 & 12.773 \\
\hline Total & 25.109 & 23.824 & 21.718 & 23.063 & 26.316 & 27.070 & 24.430 & 20.221 \\
\hline
\end{tabular}

O objetivo do programa é a realização de 191.700 conexões (clientes), com resultados diretos para cerca de 800.000 pessoas 8 anos. Os investimentos são estimados em cerca de US \$350 milhões para alcançar este objetivo. Desse montante, $80 \%$ serão financiados pelo Governo do Estado de São Paulo e os restantes $20 \%$ pela empresa (SABESP, 2012). O distrito de Grajaú foi o objeto deste estudo piloto, com 1.390 potenciais usuários mapeados, dos quais $38 \%$ já foram implementadas. Assim, de acordo com o site da empresa, cerca de 14,4 milhões de litros de esgoto deixaram de ser lançado em um mês nos rios e córregos com a implementação desta fase. 


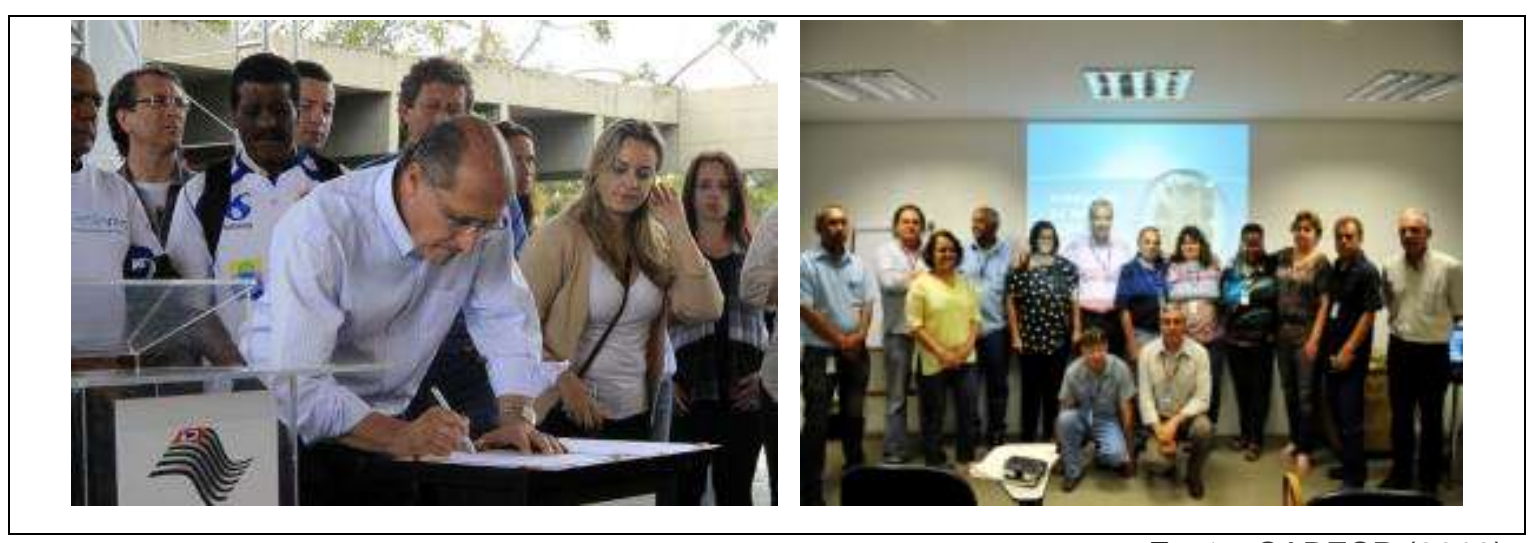

Fonte: SABESP (2013)

Figura 5 - Governo e gestores

Os acordos entre o Governo e operadora (figura 5) permitiram identificar áreas de vulnerabilidade dos usuários de baixa renda e da disponibilidade de redes para a ligação dos aglomerados subnormais, a definição de objetivos para a população desta faixa etária, a criação de uma barreira de investimento programa de financiamento de entrada para os serviços de baixa renda e de conformidade com os objetivos de negócio. A Figura 5 mostra os gestores governamentais dos Estados que assinaram o memorando entre as partes quanto ao projeto. Em todo o estado, 192.000 famílias foram conectados à rede: 76800 na Região Metropolitana de São Paulo; 30.000 da Baixada Santista ; 5600 de Campinas; e 79.300 em outros municípios. Na etapa subsequente, 40 cidades foram adicionadas, com mais 13500 ligações para beneficiar 40.000 pessoas, num investimento total de US $\$ 24,4$ milhões, dos quais $80 \%$ são do Governo do Estado e os $20 \%$ restantes serão feitas SABESP.A iniciativa vai beneficiar diretamente 800 mil pessoas e, indiretamente, cerca de 40 milhões de pessoas com a despoluição de córregos, rios, reservatórios e mares. O investimento total ao longo de oito anos é de 349.500 mil dólares americanos.

O programa tem a participação da comunidade. Em cada bairro, as casas são visitadas por um agente de beneficiário - um residente contratado pela SABESP para apresentar a iniciativa e explicar os benefícios da ligação de esgoto. Com a assinatura da adesão, a propriedade é fotografada, o trabalho programado e executado. No final, a casa é entregue à família em condição igual ou melhor. 
O acordo de cooperação previu a escolha das áreas pelo Estado e concessionária, com gratuidade para o usuário. O pagamento de custos foram realizados em $80 \%$ pelo Estado e $20 \%$ pela concessionária. Foi definido que os usuários da comunidade deveriam assinar um termo de adesão ao programa, e a concessionária fazer agendamento prévio à execução da obra no prazo de 8 a 12 dias (SABESP, 2012).

Uma equipe de mulheres da comunidade, especialmente treinadas para a tarefa para visitar as famílias identificadas apresentava o programa e formalizava a adesão da família, através da assinatura de um termo. Como resultado da inserção das mulheres na cadeia de valor, observou-se como o projeto gerou, capturou e distribuiu valor. $35 \%$ delas passaram a pagar 0 estudo dos filhos, $47 \%$ investiram em melhorias para as suas casas, 35\% acharam que melhoraram a qualidade de vida da família $22 \%$ voltaram a estudar, $4 \%$ investiram em carro.

O serviço foi então agendado e realizado pela unidade e o cliente foi visitado novamente, verificando assim a satisfação com os serviços prestados.

Esta etapa foi formalizada com a assinatura do recibo de serviços pelo cliente. Por fim, foi encaminhado ao Governo do Estado de São Paulo: demonstração de resultados, demonstração do programa de adesão; termo de adesão; conexão do imóvel; autorização do cliente; arquivo fotográfico antes e depois; e evidência de custos para execução dos serviços. Os resultados do programa indicaram 19.817 acessos realizados e $95 \%$ das pessoas de baixa renda entrevistadas ficaram satisfeitas com o trabalho realizado 9.

Os resultados contribuíram para a participação da comunidade, com o poder concedente apoiando parte dos custos, e a gestão da concessionária. Em planejamento de negócios, foram estabelecidos objetivos específicos para a população-alvo do programa. Nesse sentido, a universalização do saneamento transformou as condições de vida dos cidadãos moradores de áreas de vulnerabilidade.

\footnotetext{
${ }^{9}$ DEEP - Desenvolviemto e Envolvimento Estratégico de Pessoas e Cliente.
} 


\subsection{Conclusões}

Nos programas e projetos estudados apresentam-se diferentes arranjos institucionais para alcançar a universalização dos serviços públicos de saneamento básico por quiosques ou redes públicas às áreas de vulnerabilidade social, sem uma ontologia reconhecível de um modelo de negócio com objetivos claros do valor pretendido para as concessionárias e steakholders, quanto a quatro componentes principais de criar, capturar, configurar e entregar valor para o cidadão:

> Configuração de Valor: estratégia competitiva, gestão e governança;

> Captura de Valor: receitas e aspectos econômico-financeiros;

> Criação de valor: relacionamento com cidadãos excluídos, oferta, e identificação de externalidades;

> Cadeia de Valor: arquitetura de valor, gestão de processos para inclusão, inovação.

Há que se considerar que os equacionamentos do setor passam pela análise da urbanização; da baixa qualidade ou ausência de serviços básicos; dos riscos associados à forma em que a população mais carente que busca provisão destes serviços; da insuficiência de mecanismos de financiamentos e políticas de subsídios para ampliar acesso da população de baixa renda; da inadequada contabilização dos altos custos ambientais, associados ainda a indefinições de uma estratégia nacional para universalização dos serviços de saneamento básico em áreas de vulnerabilidade social urbanas e das exigências regulatórias.

Estes aspectos têm impacto importante nos processos de universalização dos serviços de saneamento, nos usuários, no entorno político e institucional destas regiões onde as áreas de vulnerabilidade social estão mais presentes, como as regiões metropolitanas, e diversas outras cidades de grande porte no Brasil.

O impacto tem grande relevância na gestão das operadoras de SAAES, pois tem reflexo na capacidade de cumprimento de contratos de concessão firmados com municípios, na implementação de programas de responsabilidade social e de sustentabilidade, e em seu equilíbrio econômicofinanceiro. Assim, na perspectiva das empresas operadoras, faz-se necessária definição de inovação na governança empresarial, que cubra situações 
marginais e permita focalizar esforços e recursos para proteger a população mais vulnerável e possibilitar o acesso universal aos serviços prestados. Também faz-se necessário estabelecer estratégia clara, modelo de negócio singular para o contexto, gestão articulada com comunidade, gestores e poder concedente, equacionamentos jurídicos, programas e recursos financeiros contínuos para universalização de áreas vulneráveis.

Esta inovação, de certa forma, será construída num contexto de lacunas das políticas de urbanização para equacionamento dos desafios da universalização frente ao modelo do saneamento. Inicialmente, por conta dos impedimentos legais, seguidos do equacionamento dos subsídios necessários à baixa renda para ao equilíbrio econômico-financeiro de um contrato por meio de tarifas. Há que se considerar as fragilidades do atual sistema de indicadores do SNIS Sistema Nacional de Informações em Saneamento, nos aspectos conceituais e metodológicos relacionados ao tema da vulnerabilidade social, que não favorece a formulação de planos, programas e projetos para assentamentos precários, e assim, não favorecem a articulação entre instituições que conduzem habitação, saneamento, desenvolvimento social, planejamento urbano e saúde. A inovação da gestão deverá promover o funcionamento da empresa com celeridade, redução de gargalos decisórios, fortalecimento de parcerias com poder público e fornecedores, e transparência com a sociedade civil. Para a universalização do saneamento, faz-se necessário uma maior aproximação de instrumentos e ferramental com a realidade fática, de forma a inovar num modelo de negócio em regime de eficiência técnica, eficácia social e efetividade sendo capaz de perceber as mudanças na estrutura de mercado e sociedade, antecipando-se a elas, de forma a compreender o propósito moral da transformação e trazer conceitos e conteúdo para a organização como valores empresariais em um modelo inclusivo do saneamento.

\section{RESULTADOS E DISCUSSÕES DO POLO EPISTEMOLÓGICO}

\subsection{INTRODUÇÃO METODOLÓGICA}

O polo epistemológico, como vigilância da pesquisa, considera dimensões da problemática, causalidade, validação e cientificidade (significância dos achados). Após o inventário prévio e revisão crítica da produção teórica 
existente, a fim de revisitar rupturas e superações julgadas necessárias, partiuse para a estratégia de mobilizar os atores externos à organização, gestores internos, representantes dos cidadãos, e potenciais usuários dos sistemas de abastecimento de água e esgotamento sanitário das áreas de vulnerabilidade para realizar o mapeamento da rede de controvérsias sociotécnicas para a universalização. Para tal os atores-rede (internos e externos à organização) escolhidos tinham experiências técnicas de gestão, atuando como decisores e influenciadores dos programas de universalização dos serviços de saneamento e urbanização das áreas de vulnerabilidade social.

Assim, esta etapa promoveu a construção do Mapa das Controvérsias sociotécnicas por meio de cinco oficinas. Elas capturaram o sentido da universalização nos diferentes momentos da administração, desde a etapa inicial com baixos índices de atendimento até estágio de serviços garantidos pelos princípios da continuidade, regularidade e atualidade da prestação dos serviços a todo usuário.

Foi necessário abrir as chamadas caixas pretas por Latour, sem uma guerra entre as ciências naturais e sociais, ou de denúncias, mas para desenhar a rede de inquietação das controvérsias. Este mapeamento explicitou os paradigmas atuais, frente às perguntas legítimas e respostas ininteligíveis que proporcionam uma assimetria entre objeto e método, ocultando-se as possibilidades de inovações no saneamento segundo a teoria ator-rede de Bruno Latour.

\subsection{MAPEAMENTO DE CONTROVERSIAS TEORIA ATOR-REDE}

A provisão de serviços essenciais, que afetam populações socialmente excluídas e meio ambiente, é parte dos desafios da engenharia ambiental. Num território de atuação em áreas urbanas e peri-urbanas das metrópoles, nas quais agentes públicos, privados e cidadãos atuam sobre ecossistemas frente às necessidades básicas, as controvérsias das soluções sociotécnicas acentuam-se nos países em desenvolvimento econômico acelerado. Os impactos provenientes dos eventos extremos do clima são potencializados pela forma de ocupação do território e crescimento desordenado das cidades, desconsiderando as limitações dos recursos naturais e vulnerabilidades 
socioambientais. Desta forma indaga-se como os diferentes atores dos processos decisórios respondem diante de riscos e danos, e tornam populações e ecossistemas resilientes ou adaptados. E, em qual paradigma 0 poder público, as empresas e a academia estão apoiados para provisão de soluções em resposta aos desafios trazidos pela urbanização. $O$ atual modelo de saneamento e seus dispositivos foram analisados e organizados previamente para contribuir com as oficinas da Teoria-Ator-Rede por meio da construção da cartografia de controvérsias da gestão do saneamento em áreas de vulnerabilidade social, aqui chamada de Mapa de Controvérsias, e pela identificação das incertezas da universalização em áreas favelizadas. Nesse sentido, caracterizar concatenações e mediadores para exemplificação de uma instrumentalização necessária a dirimir incertezas estabelecidas em relação à ação, abrindo assim, a caixa das controvérsias que permeiam a engenharia ambiental.

As controvérsias desenvolvidas sobre a rede dos atores atuantes no saneamento permitem diagnosticar que, atribuir ao setor uma definição de rede sociotécnica, é esconder as diversas opiniões éticas sobre decisões sociais. Ou seja, é a racionalidade de justificativas científicas para que universalizem ou não os serviços de saneamento em áreas de habitações subnormais em condição de exclusão social como áreas favelizadas, irregulares e de risco.

Os modelos de gestão adotados, a governança e a regulação tarifária são parte das melhores práticas do setor, porém os mecanismos são incapazes de revelar por indicadores ou certificados as controvérsias da provisão da água e saneamento em áreas de vulnerabilidade.

Para obtenção de um diagnóstico, as controvérsias sociotécnicas foram mapedas a partir da pesquisa de universalização do saneamento em áreas urbanas de vulnerabilidade no Brasil, apresentada no Gráfico 1 e detalhada no Capítulo 5.4. Tais controvérsias dizem respeito ao enovelamento, conforme Latour, de humanos e não-humanos na provisão de água e esgotamento sanitário aos cidadãos em condição de pobreza em áreas irregulares. Para Latour as incertezas se dão conforme a natureza dos grupos (humanos), dos objetos (não humanos), das ações, das ciências naturais e das ciências sociais. E a articulação entre agentes heterogêneos fará revelar que, de alguma maneira, sempre envolvemos, na produção do conhecimento, os 
chamados dados da natureza e os dados da sociedade (Latour, 2012).

A provisão de água e saneamento às populações em situação de vulnerabilidade é parte dos desafios da universalização do saneamento. A universalização do saneamento é a provisão de água e esgoto a todas as habitações em toda a área urbana de uma concessão dos serviços prestados por uma empresa a uma municipalidade. Nesse território de concessão em áreas urbanas e peri-urbanas de grandes cidades, agentes públicos, privados e cidadãos; demandantes, provedores dos serviços ou representantes do Estado atuam sobre as redes sociotécnicas de água e esgoto frente à necessidade básica essencial à vida. As controvérsias da universalização acentuam-se nos países em desenvolvimento econômico acelerado.

Usuários que se assentaram em áreas urbanas e peri-urbanas, cujas propriedades são de outros cidadãos, construíram habitações subnormais, demandaram água do poder público e dos prestadores de serviços de água. Identificaram-se controvérsias do modelo até hoje adotado para atendimento de água a esses cidadãos. Eles foram contados entre aqueles que necessitam de provisão de água e saneamento no planejamento urbano das municipalidades? Qual mecanismo de inclusão e exclusão das redes sociotécnicas de infraestrutura tem ditado os atos desse modelo? Em qual paradigma poder público, empresas, sociedade e cidadão individual estão apoiados na provisão de água e saneamento a todo o cidadão?

Nesse sentido, os desafios científicos trazidos pela universalização esbarram em conflitos de ordenamento jurídico - direito de propriedade e ambiental versus direitos fundamentais. Sendo que, equacionados, não definem um modelo universal. Semlhantemente, as controvérsias tarifárias sinalizam a incapacidade de valoração das externalidades do setor sobre a vida humana, saúde pública e meio ambiente, bem como se adota a pobreza como uma falha de mercado. É a razão pela qual, a controvérsia em torno da universalização do saneamento se incorpora a discussão da sustentabilidade. Sendo assim, o atual modelo e seus dispositivos foram analisados para contribuir à pesquisa sobre universalização dos serviços de saneamento em áreas de vulnerabilidade socioambiental do Brasil sob a lente da Teoria-Ator-Rede - ANT (LATOUR, 2012).

Primeira importante identificação de porta-voz para definição de grupos é o 
contexto sociológico, chamada natureza dos grupos.

A natureza dos grupos é caracterizada por formas controversas de atribuir identidade aos atores. No contexto urbano, existe um subcidadão excluído do exercício de seus direitos fundamentais, acessando clandestinamente as redes de água de maneira consensual da concessionária.

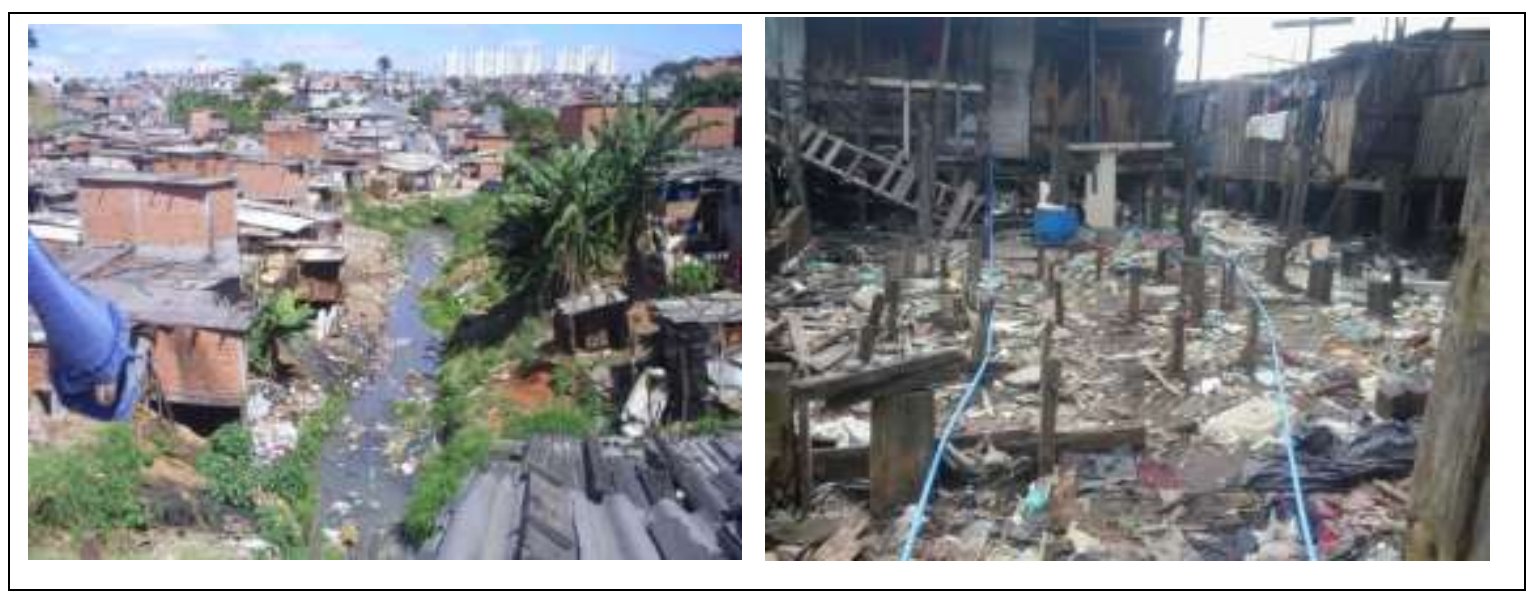

Fonte: SABESP $(2012,2014)$

Figura 6 - Situação dos aglomerados subnormais

Em um país da dimensão do Brasil, com taxas de urbanização e pobreza muito altas, são quase um corolário os assentamentos irregulares nas periferias e, em muitos casos, mescladas à cidade legal (Figura 6). Segundo a Central de Movimentos Populares (CMP-SP) há demanda por 1,2 milhão de moradias em cidades paulistas, equivalente a mais de $10 \%$ do total de domicílios do estado em atendimento às moradias classificadas por subnormais no censo 2010.

Desafios para as organizações podem ser identificados dentre os fatores justificados pela gestão de ocupação dos movimentos de 1997 a 2007 conduzida pelo Movimento dos Trabalhadores sem Teto em diversos municípios do estado de São Paulo como São Bernardo, Campinas, Guarulhos, Osasco, Taboão da Serra e Itapecerica da Serra. Segundo Miagusko (2012), a ocupação não é organizada, e acaba por introduzir conflitos de diferentes naturezas em suas demandas, sendo que o poder público empurra suas atribuições entre diferentes esferas de competências. Em geral, organizações governamentais e não governamentais não estão plenamente estruturadas para atenção às demandas provenientes de grupos humanos em contextos adhoc. Por essas razões, o modelo de gestão para a universalização do saneamento básico deve contemplar as demandas do cidadão numa nova 
postura participativa de forma a contribuir no formato de tomada de decisão e, do poder público, enquanto ente responsável pelo bem-estar social. Sem um planejamento urbano, o acentuado desenvolvimento econômico agrava as situações de moradores de aglomerados subnormais.

Outro importante porta-voz para definição de grupos é o contexto técnicosocial, chamado natureza das ações.

A natureza das ações é caracterizada por identificar em cada curso como os agentes deslocam e imiscuem objetivos originais, passando da certeza para a incerteza em relação à ação.

Para Juliano et. al. (2012), as políticas públicas sustentadas na constituição de 1988 e no marco regulatório do saneamento com os direitos preconizados são pontos de apoio e guias para mudanças que demandam pesquisas para transformação e profundo reorganizar do setor de saneamento para redefinição deste espaço onde se exerce o controle e gestão da infraestrutura de saneamento, onde os indivíduos estarão conectados, entendidos como grupo humano, como população.

A verticalização das cidades com menor dispersão e o uso mais eficiente de cada metro quadrado de área prioriza decisões individualistas e mais lucrativas nos centros urbanos, ou seja, a despeito da universalização de água poder ser requerida legalmente, segundo a teoria das redes urbanas, o planejamento clássico das cidades contrasta decisões de atendimentos a determinados grupos de interesses em áreas baseadas em zoneamento e uso e ocupação do solo. Esta é a prática de implementação territorial de redes de infraestrutura. (Dupuy G., 1992). Para Latour (1993) a rede de infraestrutura é forte condicionadora do espaço urbano, e se relacionam por meio de um conjunto de conexões que possibilitam o desenvolvimento desse espaço urbano.

Estas questões são tratadas de formas diferentes de acordo com os gestores. Por exemplo, as tarifas sociais definidas por critérios estabelecidos há trinta anos não guardam qualquer relação com a real necessidade do cidadão, em função das diversas mudanças de tipos de moradias, renda e hábitos de consumo de energia da população.

Outro importante porta-voz para definição de grupos, segundo Latour é a estatística social. A natureza dos objetos é caracterizada por apresentar as atividades dos objetos, onde o tipo de agências que participam das interações 
permanece em aberto.

Trazendo ao contexto do saneamento, o Atlas de Saneamento Básico no Brasil do IBGE (2011) apresenta dados sobre o censo 2010 alarmantes de intermitência de abastecimento de água em regiões de secas, ausência de serviços de esgoto e as maiores taxas de mortalidade infantil correlacionada à ausência de coleta de esgoto, que demonstram o status atual da prestação dos serviços no Brasil. Afirma que, nas regiões metropolitanas os municípios têm uma identidade política e nível de desenvolvimento e urbanização semelhantes, mas ao ver os dados identificam-se cidades com baixíssima governança. A despeito da inserção nas diretivas legais do marco regulatório para universalização, participação e controle social, orientando a transição do modelo monopolista para um mercado regulado, as empresas seguem buscando alternativas para equacionar os desafios da urbanização. A indefinição de um modelo que cubra situações marginais e permita focalizar esforços e recursos para atender a população mais vulnerável e possibilitar a essa o acesso universal aos serviços que presta uma empresa de saneamento, permite a continuidade de práticas ineficazes.

No Brasil, as ações para que o usuário se conecte as redes de infraestrutura de esgoto nas metrópoles são objeto da discussão para garantir a universalização e as dificuldades das operadoras dos serviços são reconhecidas como críticas, em especial nas questões dos usuários se conectarem a estas.

O outro importante porta-voz para definição de grupos, segundo Latour é o jornalismo social, que apresenta a natureza dos fatos.

A natureza dos fatos é caracterizada por apresentar os vínculos das ciências naturais com a sociedade que são fontes de controvérsias.

Juliano et. al (2012), em levantamentos documentais do setor de saneamento sobre os não-conectados de esgoto, afirma que se pressupõe que o morador de uma área de vulnerabilidade social deva mudar seu modo de vida em função da recém-implantada rede de esgoto, pois caso não se conecte, será enquadrado na legislação de crimes ambientais pela municipalidade. Num exemplo real, em área de vulnerabilidade social uma usuária é acionada por uma prefeitura por crimes ambientais. Ora, que sentido faz condenar uma dona de casa, idosa e moradora de um domicílio há 30 anos em áreas sem redes de coleta de esgoto à lei de crimes ambientais por não conectar-se a nova rede, 
obrigando-a sob as penas da lei a tornar-se usuária?

Assim, a disputa de saberes, ameniza a gravidade das questões de atendimento e universalização e aborda com naturalidade a institucionalização dos termos de exclusão propostos na universalização (Juliano, 2012).

Finalmente, o outro importante porta-voz para definição de grupos, segundo Latour é o estudo das Ciências Sociais, que é caracterizado pela escrita do relato dos riscos.

Latour (1999) afirma ser necessário fazer as ciências naturais e sociais entrarem em democracia, não aceitando que elas tenham o poder de definir como o mundo deve funcionar, deve-se antes promover uma imersão nas controvérsias, construir associações entre as naturezas cujo conteúdo e resultado são incertos e identificar e mapear uma cartografia para inovação.

\subsection{RESULTADOS DAS OFICINAS E QUESTIONÁRIOS}

As controvérsias da Universalização foram mapeadas, adotando-se a metodologia da Teoria Ator-Rede. Identificou-se os 5 grupos de incertezas como vigilância da pesquisa, considerando as dimensões da problemática, causalidade, validação e cientificidade (significância dos achados) da TeoriaAtor-Rede: 1.) natureza dos grupos (as formas controversas de atribuir identidade aos atores); 2.) natureza das ações (em cada curso de ação, agentes deslocam e imiscuem objetivos originais gerando nó ou ligadura); 3.) natureza dos objetos (considerados tipos de agenciamentos que promovem interações e permanece em aberto); 4.) natureza dos fatos (como são construídos os vínculos das ciências naturais com a sociedade de forma controversa); e 5.) natureza dos estudos realizados (os vínculos das ciências sociais e como são escritos os relatos de risco). Cabe nesse contexto conceituar: 1.) ator, não é fonte de ato, ele é alvo móvel de um conjunto de entidades que vão a sua direção; 2.) rede não é meio entre conexões, mas base das incertezas, hesitações, deslocamentos e perplexidades (LATOUR,2012).

A estratégia da pesquisa envolveu mobilizar os cidadãos, potenciais usuários dos sistemas de abastecimento de água e esgotamento sanitário das áreas irregulares para realizar o mapeamento da rede de controvérsias sociotécnicas para a universalização em abordagem antropológica. Fez-se necessário 
também, como primeira etapa de mobilização, identificar os atores-rede (internos e externos à organização) para reconhecer as experiências técnicas de gestão, dos decisores e influenciadores dos programas de urbanização e universalização das áreas de vulnerabilidade social.

Latour (2012) afirma que deve-se não tentar resolver as controvérsias. Deve-se rastrear conexões entre as controvérsias dos: grupos sociais, agrupamentos, sem grupos (por não pertencer a padrões de vínculos jurídicos) e elementos. Tomando o cuidado de não definir de antemão que grupo ou agrupamento poderia fornecer o contexto de todos os mapas. Assim, o ponto de partida deve ser a primeira fonte de incerteza: as controvérsias acerca dos agrupamentos que alguém pertence. Estando atento a infra linguagem que permite $o$ deslocamento de um quadro de referência a outro. Deve-se também identificar os mediadores (o que entra neles nunca é o que sai) e os intermediários (transportam significado sem transformar o conteúdo).

Inicialmente, para a identificação das fontes de incertezas da universalização do saneamento no Brasil foram aplicados questionários (Anexo 2 questionário 1) a 117 respondentes: atores do setor de saneamento e representantes da sociedade civil organizada, conhecedores e ativistas do setor, constituintes da amostra (Gráfico 1), sendo que todas as fontes de incertezas apontadas foram acatadas e compuseram a Tabela de Incertezas da Universalização (Tabela 3).

Gráfico 1 - Pesquisa de fatores da universalização do saneamento no Brasil

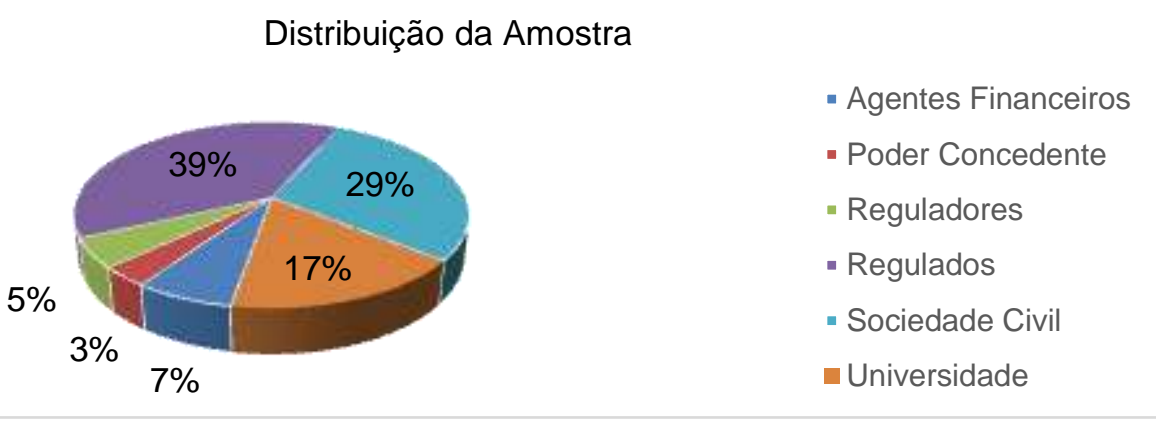

Elaboração: a autora (2013)

Os questionários respondidos foram tabulados para subsidiar as oficinas de construção do Mapa de Controvérsias na escolha de representantes dos grupos identificados para o mapeamento de controvérsias, e no subsídio a identificação das incertezas presentes nas áreas de vulnerabilidade objeto de estudo (grupos, ações, objetos, ciências naturais e sociais). 
Em segunda etapa, foi objeto a identificação das controvérsias sociotécnicas por meio de cinco oficinas (Figura 2) com representantes da sociedade civil, da concessionária da região metropolitana objeto de estudo, poder público, Reguladora, e academia. Inicialmente, foram analisadas e selecionadas incertezas e controvérsias (Tabela 3). Identificaram ações, grupos, objetos, fatos e riscos que caracterizam as incertezas da universalização das áreas de exclusão dos nove municípios metropolitanos objeto de estudo.

Foi feita apresentação do registro da oficina de relatos e levantamento das incertezas para o mapeamento sociotécnico na Teoria-Ator-Rede, sem uma guerra de ciências ou denúncias, mas com o desenho da rede de inquietação das controvérsias. Este explicita que paradigmas atuais, frente às perguntas legítimas e respostas ininteligíveis proporcionam uma assimetria entre objeto e método, ocultando-se as possibilidades de inovações no saneamento (LATOUR, 2012).

Nesse sentido, identificou-se no rastreamento das conexões entre as controvérsias dos: grupos sociais (usuários, não usuários, invasores, proprietários, concessionária, secretarias e outros), agrupamentos (associações de bairros, ONGs, associações de profissionais), sem grupos (por não pertencer a padrões de vínculos jurídicos, cidadãos na clandestinidade social) e elementos (água legal, água ilegal, esgoto, lixo). 0 ponto de partida, que fornece a primeira fonte de incerteza: as controvérsias acerca dos agrupamentos que alguém pertence, identificou-se os moradores em áreas legais $e$ áreas irregulares. A infra linguagem que permite $o$ deslocamento de um quadro de referência a outro, identificou-se cidadãos em áreas "congeladas" em transição para a regularização fundiária ou aguardando remoção para unidades habitacionais de programas de urbanização (mediadores) e os apoios sociais de cadastramentos de famílias (intermediários, que transportam significado sem transformar o conteúdo). 
Tabela 3 - Fontes de Incertezas da Universalização do Saneamento pela Teoria Ator Rede

\begin{tabular}{|c|c|c|c|c|c|}
\hline $\begin{array}{l}\text { NATU } \\
\text { REZA }\end{array}$ & GRUPOS & AÇÕES & OBJETOS & $\begin{array}{l}\text { IENCIAS } \\
\text { ATURAIS }\end{array}$ & CIENCIAS SOCIAIS \\
\hline $\begin{array}{l}\text { U } \\
\text { NI } \\
\text { VER } \\
\text { AS } \\
\text { LI } \\
\text { ZA } \\
\text { ÇÃO } \\
\text { ÉM } \\
\text { ÁREA } \\
\text { S } \\
\text { VULN } \\
\text { ERÁV } \\
\text { IES }\end{array}$ & $\begin{array}{l}\text { - Proprietários, Associação de moradores de } \\
\text { bairros, Setor Imobiliário, PROCON / IDEC } \\
\text { - Sem grupo /Subcidadãos } \\
\text { - Invasores e posseiros, MST / Gestão da } \\
\text { Ocupação } \\
\text { - Usuários de água, Não usuários de água, } \\
\text { Usuários de serviços de esgoto, Não usuários } \\
\text { de serviços de esgoto } \\
\text { - Empresas de saneamento, Governo e } \\
\text { Organizações Públicas, Agência Reguladora, } \\
\text { Conselhos Gestores, Secretaria da Fazenda } \\
\text { Estadual, CETESB, Organização Mundial de } \\
\text { Saúde, Secretaria de Estado da Saúde, } \\
\text { Vigilância sanitária, Secretaria de Estado de } \\
\text { Saneamento e Energia, Secretarias Municipais } \\
\text { de Coordenação das Subprefeituras, } \\
\text { Secretarias de Infraestrutura Urbana e Obras, } \\
\text { Secretaria de Habitação e do Verde e Meio } \\
\text { Ambiente. } \\
\text { - Central de Movimentos Populares, Pastoral } \\
\text { da Terra Pra } \\
\text { - Defensoria do Estado, Promotoria Publica, } \\
\text { Ministério das Cidades, Ministério da Saúde, } \\
\text { Ministério do Meio ambiente } \\
\text { - Sindicatos de trabalhadores, Partidos } \\
\text { políticos, Comitês de Bacias, ONGs, } \\
\text { Universidades e Associações Técnicas } \\
\text { - Agentes financeiros } \\
\text { - Empregados do prestador, } \\
\text { - Fornecedores externos de produtos, } \\
\text { Prestadores de outros serviços, Empreiteiros. } \\
\text { - Associações ambientalistas, Conselhos } \\
\text { Permanentes - Futuras Gerações } \\
\text { - População Vulnerável } \\
\text { - Mídia. }\end{array}$ & 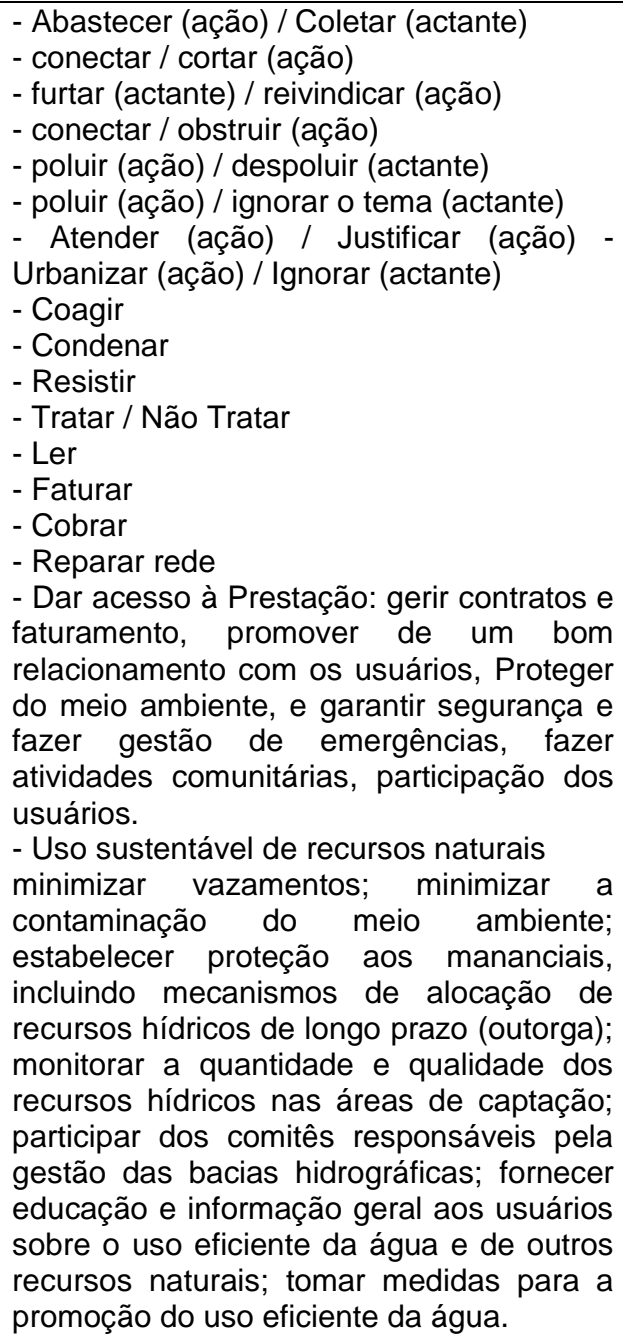 & $\begin{array}{l}\text { - Água } \\
\text { - Esgoto } \\
\text { - Disponibilidade } \\
\text { de água } \\
\text { - Quantidade de } \\
\text { água disponível } \\
\text { - Acesso } \\
\text { - Lixo } \\
\text { - Renda } \\
\text { - Propriedade } \\
\text { - Gato } \\
\text { - Hidrômetro de } \\
\text { - Galeria de } \\
\text { Aguas Pluviais } \\
\text { - rio } \\
\text { - Meio Ambiente } \\
\text { - Ligação } \\
\text { laboratórios. } \\
\text { desastres } \\
\text { naturais } \\
\text { Impacto } \\
\text { ambiental } \\
\text { Dano } \\
\text { Quantidade de } \\
\text { água } \\
\text { Qualidade da } \\
\text { água } \\
\text { Propriedades } \\
\text { organolépticas } \\
\text { (sabor, cor e } \\
\text { odor) } \\
\text { Cobertura } \\
\text { Fatura } \\
\text {-Custo- } \\
\text { InvestimentoDívi } \\
\text { da,Ativos,Indica } \\
\text { dores. }\end{array}$ & $\begin{array}{l}\text { (Intermediários) } \\
\text { - Redes de esgoto } \\
\text { - Redes de água } \\
\text { (Concatenadores } \\
\text { e Mediadores) } \\
\text { - Estações de } \\
\text { Tratamento de } \\
\text { Esgoto } \\
\text { - Uso sustentável } \\
\text { dos recursos } \\
\text { naturais legal } \\
\text { - marco legal com } \\
\text { contratos dos } \\
\text { usuários; } \\
\text { direitos } \\
\text { usuários; } \\
\text { responsabilidades } \\
\text { dos usuários; } \\
\text { condições de } \\
\text { aplicação de tarifa } \\
\text { social; } \\
\text { contratos de } \\
\text { concessões; } \\
\text { questões } \\
\text { operacionais: } \\
\text { Cronograma para } \\
\text { expansão dos } \\
\text { serviços; } \\
\text { procedimentos de } \\
\text { emergência; } \\
\text { - questões } \\
\text { financeiras: } \\
\text { custos; tarifas; } \\
\text { desempenho dos } \\
\text { serviços. }\end{array}$ & $\begin{array}{l}\text { 1. Sustentabilidade } \\
\text { - Política Pública } \\
\text { - Danos ambientais } \\
\text { - Mortalidade Infantil } \\
\text { - Doenças de veiculação } \\
\text { hídrica } \\
\text { - Equidade } \\
\text { - Disponibilidade } \\
\text { - Sustentabilidade } \\
\text { - Risco } \\
\text { - Vulnerabilidade } \\
\text { - Resiliência } \\
\text { - Adaptação } \\
\text { - Barreira de Entrada } \\
\text { - Assimetria } \\
\text { Informações } \\
\text { - Política de Subsídios } \\
\text { - Acessibilidade Econômica } \\
\text { - Condições } \\
\text { Aplicabilidade } \\
\text { - Política Inclusiva } \\
\text { - Interdisciplinaridade } \\
\text { - Perspectivas Teóricas } \\
\text { Socio-Espaciais } \\
\text { 2. Governança } \\
\text {-Planejamento Urbano } \\
\text { Fundiário } \\
\text { - Planejamento Municipal/ } \\
\text { Estadual/Federal } \\
\text { Saneamento } \\
\text { - Coações Técnicas } \\
\text { - Coações Econômicas } \\
\text { - Coações Políticas } \\
\text { - Coações Sociais } \\
\text { - Saberes } \\
\text { - Princípio da Precaução }\end{array}$ \\
\hline
\end{tabular}

Elaboração: A autora (2013) 
A escrita das narrativas, relatos e identificação das incertezas ocorreu em três etapas: mobilização de usuários e atores internos e externos à organização que promovem ou impedem a universalização, rastreamento de conexões entre as controvérsias, e identificação de incertezas do processo e da complexidade do sistema. Sem atritos entre ciências naturais e sociais fez-se o reconhecimento de modelos técnicos e arranjos sociais.

\subsubsection{Narrativas e relatos nas oficinas}

Diversas narrativas e relatos explicitam o contexto de risco para sociedade e para o meio ambiente não controlado. Alguns argumentos justificam que a natureza da questão não é epistêmica, mas enraizada na objetividade do relato que se liga ao fenômeno.

Para Dupuy (2002), o risco é um monstro que merece um tratamento cujo princípio da precaução é incapaz de conferir o devido tratamento. A complexidade de um ecossistema tem extraordinária estabilidade e notável resiliência, porém somente até o ponto da ruptura ou do colapso. Sendo que, o desaparecimento da resiliência é o alarme de que já é tarde demais, mas até que se esteja próximo dos limites, permite-se transitar nos ecossistemas com total impunidade.

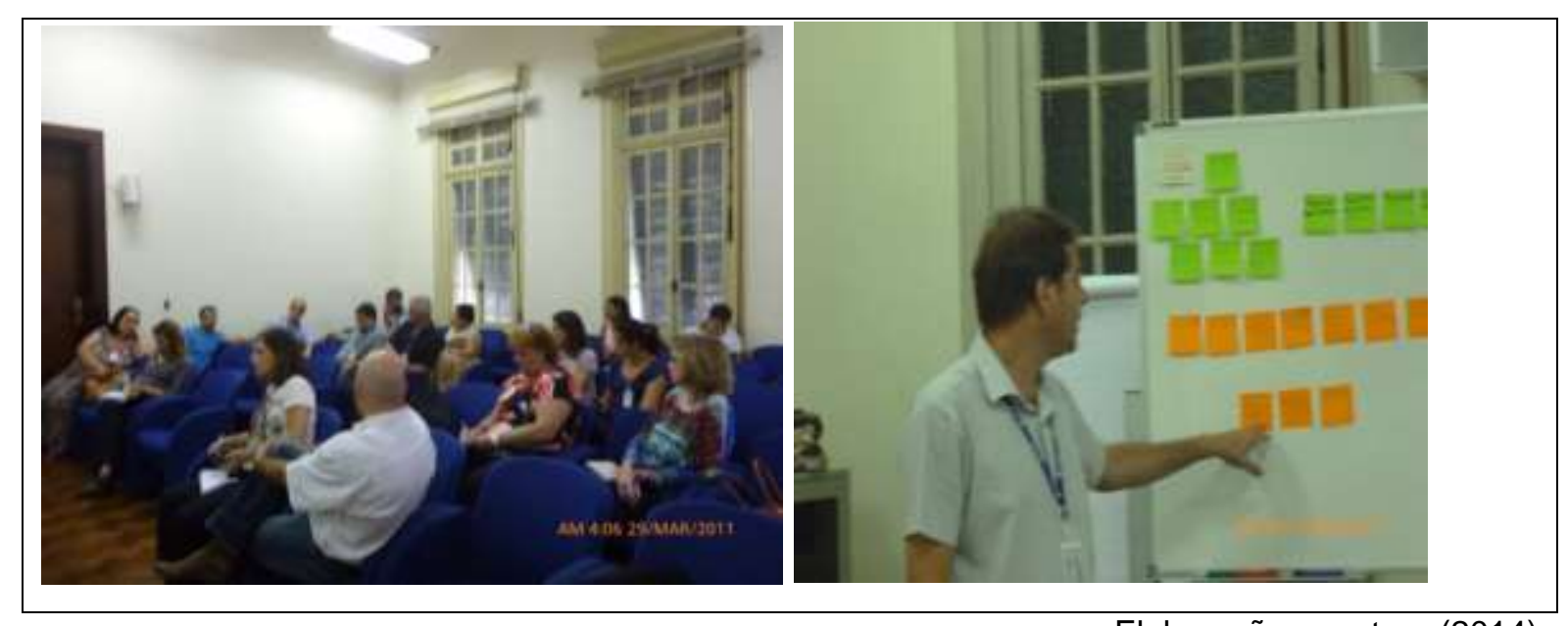

Figura 7 - Oficina de Controvérsias Sociotécnicas

Nesse sentido, toda entrevista, narrativa ou comentário enriquece a análise, por mais trivial que possa parecer. As narrativas da oficina (Figura 7) trouxeram à superfície controvérsias do objeto da análise (Quadro 6). 
Quadro 6 - Relatos e preocupações identificadas dos participantes

- Como está o mapeamento das áreas irregulares no país? Quais as iniciativas, programas que já existem para resolver o problema da universalização do saneamento nestas áreas?

- Quem vai pagar a conta? A informalidade se dá onde o Estado é ausente! Nenhuma das partes envolvidas Poderá se abster de participar da solução.

- Os projetos que são iniciados precisam ser bem planejados de forma que tenham continuidade. A universalização precisa ser firmada em um esforço conjunto. (poder público em todas as esferas, concessionárias de serviços, comunidade e ciência/universidades)

- Necessário conscientizar as populações para usar de forma adequada os recursos naturais. Demanda mudança na cultura do país de querer levar vantagem em tudo. $O$ saneamento deve estar apoiado em promover a saúde para todos.

- Considerando: 1.) A necessidade de reduzir e eliminar os impasses de áreas protegidas, a criminalidade, o desemprego e o emprego informal; 2.) A falta de verba para investimentos das prefeituras; 3.) A lei das PPPs; O excesso de dinheiro disponível com o Governo Federal e BNDES; 4.) Que não há prestação de serviço público gratuita. Proposta: Criar novos Bairros com toda infraestrutura necessária, com todos os equipamentos institucionais, com acessibilidade, para a remoção de famílias e a reordenação das áreas invadidas, seja ambiental ou de segurança. Chave: PPP Habitacional, Concessão Administrativa, PPP patrocinada.

- Aumentará a credibilidade do governo se enxergar que ele é parte no sistema

- Escalas dos problemas e foco - Ação x Planejamento Estratégico

- Os chamados vulneráveis não se sentem vulneráveis e não querem ser "taxados" de vulneráveis - querem ser identificados como comunidades tradicionais

- A universalização precisa ser firmada em um esforço conjunto. (poder público em todas as esferas, concessionárias de serviços, comunidade e ciência/universidades)

- Necessário revisitar conceitos, considerar saberes das comunidades, rever metas e indicadores que encobrem as exclusões.

- Inexiste planejamento nas municipalidades para loteamentos populares. Há somente ações corretivas

- Os técnicos vivem em áreas de conflitos sociais, com risco de morte para os trabalhadores e áreas dominadas pelo Quarto Poder.

- Necessário conscientizar as populações para usar de forma adequada os recursos naturais. O saneamento deve estar apoiado em promover a saúde para todos.

Elaboração: a autora (2014)

\subsubsection{Classificação das controvérsias quanto a natureza dos grupos:}

A natureza dos grupos diz respeito às limitações técnicas, variações ontológicas dos atores, partindo de subcidadãos e chegando a usuário, indicando os alinhamentos. Foram Identificados:

- Grupos controversos aos quais alguém pertence: moradores, proprietário da área, população, políticos do poder executivo e legislativo, segurança pública, governo municipal, companhia ambiental, órgãos públicos.

- Porta-Vozes de agrupamentos nas organizações formais e informais actantes - solucionadores: ministério público, operadora de serviços, lideranças comunitárias, moradores, proprietário da área, $\mathrm{p}$ população, município (movimento social e moradores), segurança pública, governo 
municipal, companhia ambiental, associações comunitárias, órgãos Públicos.

O rastrear das conexões da natureza das incertezas, iniciou-se com a Natureza dos grupos. Assim, como exemplo, o poder público (grupo) promove contexto de legalização (ação) para água (objeto), como forma de ter o uso sustentável dos recursos naturais (fato) com sustentabilidade (termo conferido pela influência dos estudos das ciências sociais no fato das ciências naturais). As fontes de incertezas da universalização do saneamento em áreas de exclusão social para uma amostra de 9 municípios metropolitanos no Brasil foram identificadas (Tabela 3 e Tabela 5).

\subsubsection{Classificação das controvérsias quanto a natureza das ações:}

A segunda fonte de incerteza é a ação, que deve ser encarada como um nó ou ligadura, um conjunto de funções, que podem muitas vezes ocorrer mediante uma força social capaz de impor uma obrigatoriedade dos atores fazerem coisas que não estão dispostos a fazer.

Assim, exemplificando, as ligaduras: o contexto legal é capaz de impor obrigatoriedades aos atores, onde a ação é fazer conexões e receber 0 abastecimento de forma regular, a ação fracassada é dada pelo impedimento de conectar, como consequência surge o poluir. Para esse nó ou ligadura, a força social pode ser capaz de impor modificações das ações nessas áreas. $O$ actante, aquele que resolve o problema podem ser o poder concedente e o judiciário. Assim:

- A ação é responsável pelo feito caracterizado por um verbo. Ex.: abastecer, urbanizar.

Os atores identificaram ações como: remover população, coletar esgoto, fazer reinvindicações, construir sistemas, suspender o abastecimento por débitos, economizar, vazamento (ocorrência de perdas), participar, planejar (participativo), lançar esgoto in natura, conectar redes, construir redes de água.

- O actante é a forma para equacionar uma ação incerta que não ocorre.

Os atores identificaram: construir credibilidade, dar continuidade, integrar socialmente, conhecer realidade social, integrar políticas públicas, realizar termos de ajustamento de conduta, educar, ações do MP, sensibilizar e educar pessoas. 
Nessa etapa, foi construído o mapa da controvérsia - MAPA 1 contemplando a natureza dos grupos e dos fatos, que trazem incertezas e tem atos controversos para que a eficácia da universalização se efetive (Figura 8).

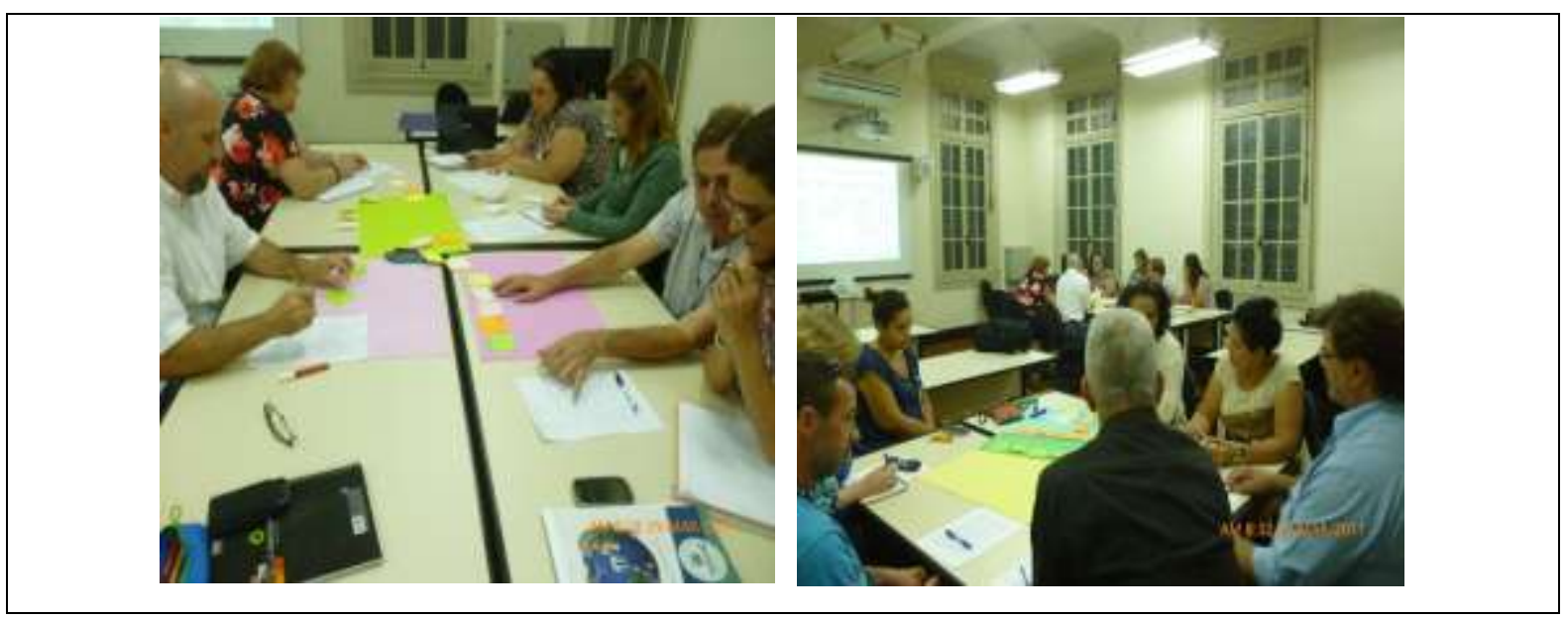

Elaboração: a autora (2014)

Figura 8 - Oficina de Mapeamento das Controvérsias

\subsubsection{Classificação das controvérsias quanto natureza dos objetos:}

Caracteriza-se nessa etapa as atividades dos objetos nas quais os atos que participam do mapeamento da controvérsia permanecem em aberto sem equaciona-la, e os objetos que participam do mapa no curso das soluções ajudam a rastrear as conexões sociais:

- Água, gato (ligação clandestina), esgoto, ligação em galeria de águas pluviais.

- Separação em ligações de água regular, ligações clandestinas.

- Acordos judiciais

\subsubsection{Classificação das controvérsias quanto natureza das ciências naturais}

Segundo, Latour (2012) cumpre seguir os próprios atores para empregar um slogan da ANT (Actor-Network-Theory), compreender suas inovações, o que a existência coletiva tornou-se suas mãos e quais definições melhor explicariam as novas associações estabelecidas para atender ao novo arranjo.

Como outro importante porta-voz para definição de grupos, segundo Latour, no contexto técnico-social, Dupuy (1992) afirma que a resposta do ordenamento para 
o crescimento da cidade em rede de infraestrutura contrasta com a realidade do crescimento urbano. Elas seguem o plano de desenvolvimento padrão, com base em decisões de zoneamento, que determinam usos da terra em uma base permanente. Tal plano é embasado no conceito de desenvolvimento espacial, porém o que foge a esse modelo é a mobilidade e mudança. O quadro planejador busca a certeza, mas é muitas vezes surpreendido. O uso da rede infraestrutura nem sempre corresponde à certeza e muitas vezes tem poucas implicações para o desenvolvimento. O zoneamento é a atividade básica do planejamento moderno, assim como tem sido nos Estados Unidos desde 1920. Porém, o planejamento espacial e formal cresceu nos séculos XIX e XX excluindo alternativas em rede infraestrutura e adotando um caráter "transacional", sugerindo o elemento de troca que mantém a estabilidade da mesma e seu funcionamento, pois ela remove o elemento de conflito e contradição por um planejamento generoso da infraestrutura.

Segundo os atores, as controvérsias da universalização surgem nos locais onde moradores de propriedades invadidas, demandam seu direito fundamental de acesso à água. Identificou-se usuários que se assentaram em propriedades de outras pessoas dentro de áreas urbanas e peri-urbanas e construíram habitações nos chamados aglomerados subnormais, demandando água do poder público e das empresas de saneamento. Aqueles que foram atendidos pelas organizações, o ator-dono da propriedade acionou a justiça e Ministério Público para impedir a concessionária de fornecer água apoiado no direito de propriedade, e ganharam a ação. Aqueles que não foram atendidos, acessaram os serviços de forma ilícita, com o conhecimento das empresas. A correlação da mortalidade infantil com ausência de saneamento e a poluição ambiental proveniente dos lançamentos de esgoto dessas habitações que levaram a impactos de elevado custo ambiental e social. Em algumas municipalidades, quando a rede é autorizada, o poder público obrigou moradores das áreas de vulnerabilidade se conectarem as redes de coleta de esgoto construídas, e, aqueles moradores que não se conectaram, foram enquadrados na Lei de Crimes Ambientais. Diversas mobilizações entre atores promoveram arranjos jurídicos que levaram a soluções pontuais.

A pesquisa das características fundamentais das redes de infraestrutura e suas implicações socioespaciais, bem como os procedimentos de planejamento urbano fundiário e dos equipamentos coletivos essencialmente setoriais, apresentam um 
quadro pouco propicio a reflexão transversal da mesma e de sua territorialidade, que implicaram em estratégias de circulação e de redes como jamais aconteceu em nenhum outro período. Assim, a primeira propriedade das redes de infraestrutura é a conexidade - qualidade de conexão, que tem ou em que há conexão, liga o usuário aos serviços básicos de água e esgotamento sanitário (DUPUY, 1984).

Os nós das redes são lugares das conexões, lugares de poder e de referência. É pela conexidade que a rede solidariza os elementos. Mas, ao mesmo tempo de ter o potencial de solidarizar, de conectar, também tem de excluir. Os organismos de gestão da rede, quer se trate de gestão técnica, econômica ou jurídica, não são neutros, eles colocam em jogo relações sociais entre os elementos solidarizados, e aqueles que permanecem marginalizados. Em outras palavras, nunca se lida com uma rede de infraestrutura máxima, definida pela totalidade de relações mais diretas, mas com a rede resultante da manifestação das coações técnicas, econômicas, politicas e sociais (DIAS,1994).

Nesse sentido, a hierarquização das redes de infraestrutura no espaço físico urbano, assim como a produção da vida urbana, os modos de viver e o trabalho na contemporaneidade são centrais para se pensar o saneamento. No contexto analisado é fundamental a compreensão de que mecanismos de planejamento setorial estão sustentando o modelo do saneamento em diversas esferas passando ao largo de questões apresentadas.

Segundo Silva (2008), uma etapa importante é avaliar a eficácia pública dos serviços, como pré-requisito da eficácia reguladora, e como estão avançando de acordo com as especificidades regionais e locais de cada caso e é nessa linha que se apresentaram os estudos exploratórios acima. Para ele, há diversidade de informações, e ferramentas de análise, bem como a concepção imprecisa do papel da participação social na ação reguladora. Nesse sentido, há risco de mascarar inconsistências e supervalorizar dimensões não essenciais dos serviços. Nessa perspectiva, seria precipitada uma formalização normativa antes que as relações de nexo causal entre o desempenho medido pelo lado da eficiência dos serviços sejam claramente cotejadas com sua eficácia.

Esta análise permite diversos arranjos institucionais, pois a universalização demanda um acesso suficiente e pleno a todas as capacidades instaladas, sendo possível análise por meio de um raciocínio topológico do fluxo de redes de 
infraestrutura diante dos desafios das metrópoles para regulação de custos crescentes e deseconomias de escalas em consequência do crescimento desordenado. A avaliação de conectividade constitui, para fins de controle social dos serviços e, em última instância, da governabilidade urbana, uma das mais desafiadoras questões da pesquisa urbana atual. Os antigos conceitos subjacentes de universalidade e cobertura de esgoto aplicados à infraestrutura nas avaliações de pobreza urbana são hoje claramente insuficientes para representar a complexidade da forma e da governabilidade urbana. Esses conceitos refletem imprecisão dessas representações (SILVA, 2002).

No contexto analisado é fundamental a compreensão de que mecanismos de planejamento setorial estão sustentando um modelo, em diversas esferas, passando ao largo das questões apresentadas, como questões das escolhas públicas frente às limitações provenientes dos modelos que confrontam soluções do Estado de Direito, e liberdade de mercado (PRZEWORSKI, 1994).

Nesse sentido, a descontinuidade dos programas governamentais e alternância alteram as prioridades estratégicas do modelo de gestão, levam a interrupções de projetos apoiados em crises macro e microeconômicas que afetam a continuidade das atividades.

Consideraram-se os fatos da universalização: ponto de partida dos vínculos das ciências naturais, os objeto das relações de poder. Estes podem ser intermediários, concatenadores e mediadores:

- Intermediários (apenas transportam objetos sem promover transformação) - Instalação de redes de água e esgoto, água (potabilidade);

- Concatenadores (transformam objetos) - parcerias;

- Mediadores (fazem a mediação entre atores e objetos) - Contratos, procedimentos - Políticas Públicas Integradas, reurbanização das áreas, acolhimento, mudança, adesão, planejamento participativo.

Identificou-se inicialmente os Intermediários (redes p/ usuários), Concatenadores (ETA's e ETE's), e Mediadores (gatos e gambiarras, redes para subcidadãos).

\subsubsection{Classificação das controvérsias quanto natureza das ciências Sociais}

A inserção da ciência social nos estudos das redes urbanas de infraestrutura focalizaram indústrias de tecnologias de redes considerando a 
interdisciplinaridade e perspectivas teóricas. A análise da correlação entre "provisão do" e "acesso às" redes urbanas e, sobretudo o funcionamento do atendimento em áreas urbanas, cuja diversidade de contextos revela a centralidade da infraestrutura na construção da cidade moderna centrada na produção e expansão capitalista, como uma constitutiva das relações sociais de desigualdades e como um espaço de transformação ambiental apresentada na história das mesmas e da infraestrutura. (TARR AND DUPUY, 1988).

Processos de integração e exclusão compõem mecanismos de atendimento em redes de infraestrutura. Os processos de integração implicam em estratégias para superação da visão hegemônica e possibilita a percepção de atores/agentes em suas interações, mediante a reorientação dos valores e dos recursos para a promoção do bem-estar social (DUPUY, 1984).

Segundo Latour, a cosmologia justificativa da controvérsia sociotécnica, termo de ciência social que sustenta no contexto a perpetuação das incertezas, deve ser identificada.

No contexto da controvérsia da universalização do saneamento, os domicílios de assentamentos precários cujas populações encontram-se em condição de exclusão social passam a fazer parte dos planos de saneamento municipais e do planejamento empresarial somente após a regularização fundiária e urbanização desses aglomerados urbanos.

Para Latour, a controvérsia está apoiada numa cosmologia justificativa. Identificou-se a cidade informal, onde estão escondidos, tanto os dados controversos da universalização, quanto à institucionalização das exclusões. Para a cidade informal não há metas de universalização. A cidade informal é a cosmologia justificativa da exclusão dos cidadãos a serviços de redes.

Nesse sentido a construção da transparência se dará pela definição de metas para a cidade informal, criação de fóruns de planejamento participativos, organização da oferta - quem financia a regularização e universalização, organização da demanda - inclusão de um cidadão no acesso à água e políticas públicas de construção e inclusão e exclusão.

A dimensão do contexto de exclusão socioambiental vivido pelos vulneráveis, consequentemente ausentes do plano de saneamento do município e concessionárias (Tabela 4) identifica 101.274 domicílios na cidade informal com cerca de 400 mil cidadãos no censo de 2010 (IBGE, 2010). 
Tabela 4 - Domicílios da Cidade Informal da RMBS

Domicílios Subnormais na Região da Baixada Santista

\begin{tabular}{c|c|c|c|c|c}
\hline município & $\begin{array}{c}\text { População } \\
\text { (Censo 2010) }\end{array}$ & $\begin{array}{c}\text { Áreas de risco } \\
\text { ocupadas por } \\
\text { moradias }\end{array}$ & $\begin{array}{c}\text { Domicílios em } \\
\text { áreas de risco }\end{array}$ & $\begin{array}{c}\text { Aglomerados } \\
\text { Subnormais }\end{array}$ & $\begin{array}{c}\text { Domicílios em } \\
\text { Aglomerados } \\
\text { Subnormais }\end{array}$ \\
\hline Bertioga & 47.572 & 0 & 0 & 5 & 3.300 \\
\hline Cubatão & 118.797 & 25 & 2.142 & 12 & 2.000 \\
\hline Guarujá & 290.607 & 15 & 4.361 & 49 & 35.107 \\
\hline Itanhaém & 87.053 & 0 & & 0 & 0 \\
\hline Mongaguá & 46.310 & 6 & 370 & 5 & 200 \\
\hline Peruíbe & 59.793 & 17 & 964 & 17 & 964 \\
\hline Praia Grande & 260.769 & 5 & 420 & 4 & 1.800 \\
\hline Santos & 419.757 & 22 & 5.547 & 8 & 9.455 \\
\hline São Vicente & 332.424 & 29 & 7.529 & 38 & 27.115 \\
\hline Total & 1.663 .082 & 119 & 21.333 & 138 & 79.941 \\
\hline
\end{tabular}

Fonte: Secretaria de Estado da Habitação do Estado de São Paulo (2013)

No que tange aos serviços públicos de saneamento, os diálogos entre cidadãos, empresas, poder público e reguladores devem estar sustentados por um modelo de governança e gestão que forneça credibilidade e transparência no processo de prestação de contas ao usuário e poder concedente quanto aos processos de acompanhamento de metas e negociação de tarifas das áreas regulares.

É fundamental para avaliação das condições de operação saber que as agências reguladoras brasileiras de saneamento têm regulado as questões econômicas por meio das revisões tarifárias e a eficiência e eficácia da prestação dos serviços em modelo de custos eficientes, sustentando a modicidade tarifária nas obrigações contratuais. Isso ocorre porque o foco da regulação atual está em garantir a remuneração dos custos dos serviços e dos planos de investimentos para atingimento das metas contratuais com custos eficientes e investimentos prudentes. Os reguladores entendem que aplica-se a áreas legais exclusivamente.

A política pública é clara quanto a universalização, porém não apresenta mecanismos de equacionamentos, deixando diversas lacunas como: fontes permanentes de financiamento para investimentos em áreas vulneráveis, fonte de recursos para os custos dos serviços em áreas de vulnerabilidade social, tanto no marco regulatório, quanto nos demais instrumentos como o PLANSAB - Plano 
Nacional de Saneamento Básico, que deve acentuar os diferentes resultados das operadoras.

Assim sendo, o modelo do saneamento demonstra uma lacuna ocasionada por controvérsias, no que diz respeito à situação dos cidadãos em áreas de vulnerabilidade. De forma que, tais áreas não são consideradas nas metas e nos indicadores de universalização no Brasil demonstrando fragilidade de um dos principais mecanismos de gestão e regulação - os indicadores do Sistema Nacional de Saneamento - SNIS, sendo que esses cidadãos não são contados como tal afetando inexoravelmente a eficácia social de um serviço público em uma área de concessão urbana.

Segundo Cave (2009), a apreciação do âmbito e os benefícios de uma reforma no longo prazo são os ganhos dos usuários e melhorias ambientais movidas principalmente pela inovação, que poderiam ser o resultado da regulação ou do estímulo a prestadoras em competirem individualmente, ou em parceria, para o negócio atingir objetivos do poder concedente e empresariais.

Os pontos elencados são foco dos desafios de revisão de políticas públicas, procedimentos empresariais e regulatórios, de forma a contemplar o subcidadãos, o direito fundamental, mediante um novo modelo de saneamento e da criação de mecanismos eficientes para desenvolvimento sustentável.

O ponto de partida dos vínculos das Ciências Sociais é a escrita da vida social, indivíduo e grupo, dados pelas justificativas da engenharia, direito, saúde, que segundo os atores são: adaptação, política inclusiva, resiliência, danos ambientais, manipulação dos moradores, doenças, alagamento, desmoronamento de encostas. Identificaram-se as tratativas paliativas como programa de urbanização e governança, participação social, controle social, ordenamento jurídico - regularização fundiária, princípio da precaução, sustentabilidade, política pública, vulnerabilidade, resiliência.

\subsection{ABRINDO AS CAIXAS PRETAS DE LATOUR PARA ÁREA DE ESTUDO}

Para Latour, faz-se necessário articular proposições, abrir as caixas pretas, testar, alistar contraprovas para verificar se os atores permanecem na mesma situação. Concluiu-se que a eficiência e a efetividade não se verificaram nas análises, pois a universalização excluiu as áreas favelizadas, irregulares e de risco, separando 
em áreas atendíveis e não atendíveis. Semelhantemente, os mecanismos de governança se submetem a naturalidade aos mecanismos de exclusão.

A universalização dos serviços de saneamento em áreas de vulnerabilidade social está sempre atrelada a programas de urbanização de assentamentos precários, provenientes de relações inter-setoriais. As diversas ações necessárias partem prioritariamente da regularização fundiária sustentada no direito constitucional de propriedade, que impede a atuação dos prestadores sobre áreas invadidas. Desta forma, as diversas ações que promovem o atendimento a essas áreas demandam esforços multisetoriais e com entendimentos controversos sobre o tema incluindo a judicialização dos trabalhos e participação da sociedade.

Certificações como a Norma ISO 24.510 traduzida no Brasil e publicada pela Associação Brasileira de Normas Técnicas (ABNT, 2012) recomenda que o prestador de serviços, o titular dos serviços e/ou as autoridades competentes incentivem e promovam a participação social em diferentes modelos de gestão para resolução de controvérsias.

Para elaboração do mapa de controvérsias, adotou-se a cidade informal da região metropolitana da Baixada Santista, no estado de São Paulo, Brasil, contendo 09 municípios metropolitanos com mais de 1,2 milhão habitantes e aproximadamente 400 mil em áreas favelizadas.

Segundo o Banco Interamericano para Desenvolvimento - BID (2012) a participação comunitária promove benefícios como: criação de responsabilidade política, racionalização das controvérsias, transparência ao processo de tomada de decisão e incremento da credibilidade institucional.

Nesse sentido, os atores identificaram que a gestão para provisão de um serviço público essencial à vida fomenta diversos arranjos sociais e técnicos para atendimento ao subcidadão urbano, que é excluído de serviços essenciais. Identificou-se arranjos como Paritá (projeto da concessionária para autorização da prestação de serviços em áreas irregulares).

A elaboração da cartografia das controvérsias iniciou-se pela elaboração do mapa das controvérsias (Mapa 1), contendo natureza dos grupos e das ações. Já no Mapa 2 foi acrescentado as demais naturezas das incertezas, revelando mediadores ainda que ocultos nas estruturas formais e informais, que permitem desenhar equacionamentos às controvérsias. Nessa etapa foram estabelecidas as conexões entre as incertezas da universalização como: água e vulneráveis 
com a governança, sustentabilidade, risco, resiliência, adaptação, participação social e regulação. Analisou-se em que medida os conceitos conseguem representar a singularidade da universalização em áreas de vulnerabilidade. A tabela 5, contendo o resumo das incertezas da área de estudo, foi construída com objetivo de contemplar de forma tabular, as incertezas que caracterizam a complexidade da universalização do saneamento em áreas urbanas de exclusão social reagregando o social.

Tabela 5 - Resumo das Incertezas para Universalização da Cidade Informal

\begin{tabular}{|c|c|c|c|c|c|}
\hline $\begin{array}{c}\text { Incer } \\
- \\
\text { tezas }\end{array}$ & $\begin{array}{c}\text { Natureza dos } \\
\text { grupos }\end{array}$ & Natureza das ações & $\begin{array}{c}\text { Nature } \\
\text { za dos } \\
\text { objeto } \\
\text { s }\end{array}$ & $\begin{array}{l}\text { Natureza dos } \\
\text { fatos }\end{array}$ & $\begin{array}{l}\text { Natureza } \\
\text { ciências } \\
\text { sociais }\end{array}$ \\
\hline $\begin{array}{l}\text { U } \\
\text { NI } \\
\text { VER } \\
\text { AS } \\
\text { LI } \\
\text { ZA } \\
\text { ÇÃO }\end{array}$ & $\begin{array}{l}\text { MP, } \\
\text { Operadora, } \\
\text { Lideranças, } \\
\text { Moradores, } \\
\text { Movimentos } \\
\text { Sociais de } \\
\text { Moradores, } \\
\text { SSP, } \\
\text { município, } \\
\text { CETESB, } \\
\text { Associações } \\
\text { Comunitárias, } \\
\text { Órgãos } \\
\text { Públicos }\end{array}$ & $\begin{array}{l}\text { Remover população, sensibilizar, } \\
\text { construir credibilidade, conectar, } \\
\text { coletar esgoto, continuidade, } \\
\text { integrar socialmente, participar, } \\
\text { conhecer realidade social, educar, } \\
\text { reivindicar, integrar política pública, } \\
\text { construir cisternas, suspender o } \\
\text { abastecimento por débitos, realizar } \\
\text { TACs, economizar, vazamento e } \\
\text { perdas, planejar (participativo), } \\
\text { lançar esgoto in natura, construir } \\
\text { redes de água, ações do MP, } \\
\text { empoderamento. }\end{array}$ & $\begin{array}{l}\text { Separ } \\
\text { ação } \\
\text { de } \\
\text { água } \\
\text { regula } \\
\text { r, e } \\
\text { ligaçõ } \\
\text { es } \\
\text { clande } \\
\text { stinas }\end{array}$ & $\begin{array}{l}\text { Políticas } \\
\text { Públicas } \\
\text { Integradas, } \\
\text { Instalação de } \\
\text { redes de água e } \\
\text { esgoto, } \\
\text { reurbanização } \\
\text { das áreas, } \\
\text { acolhimento, } \\
\text { água (potabilidade), } \\
\text { mudança, } \\
\text { adesão, } \\
\text { incerteza, } \\
\text { parcerias }\end{array}$ & $\begin{array}{l}\text { Manipulaç } \\
\text { ão dos } \\
\text { atores, } \\
\text { doenças, } \\
\text { danos } \\
\text { ambientais } \\
\text { alagament } \\
\text { o, } \\
\text { desmorona } \\
\text { mento de } \\
\text { encostas }\end{array}$ \\
\hline
\end{tabular}

Elaboração: A autora (2014)

Como referencia para abrir as chamadas caixas pretas das controvérsias, conforme Lagrange (2011) escreve sobre os estudos de Dupuy, deve-se apoiar no método de dialética aberta aplicada ao direito internacional e da sociedade. Sua pesquisa permitiu-Ihe destacar com precisão, em sua abordagem global sobre direito e sociedade, que nunca deve-se ignorar o significado de regras e instituições para os atores, de valores subjacentes, e que a oposição dinâmica relacional e institucional das tendências internacionais trazem considerações de justiça, regras técnicas ou antagonismos políticos que contribuem à construção de um novo paradigma. 


\subsection{MAPA DA CONTROVÉRSIA DA UNIVERSALIZAÇÃO NAS ÁREAS DE VULNERABILIDADE}

A construção participativa do mapa de controvérsias identificadas segundo a natureza dos grupos, das ações, dos objetos, dos fatos e dos estudos das ciências sociais foi apoiada em publicações de pesquisadores da metodologia de controvérsias ator-rede como Tomaso Venturini e Bruno Latour (VENTURINI \& LATOUR, 2009, VENTURINI,2012).

Adotou-se o software em plataforma livre wordpress para construção de um blog em atendimento ao IEB - Instituto de Estudos Brasileiro e do Departamento de Antropologia da Universidade de São Paulo teses das ciências naturais que adotaram a teoria ator-rede como orientador metodológico.

Desenhou-se o fluxo de dois cidadãos, um usuário e outro clandestino, que fazem parte da natureza dos grupos. Seguindo o fluxo, o clandestino (à direita) ignorou a propriedade de outro cidadão, fez uma conexão clandestina, a empresa deu uma solução sociotécnica e foi coagida judicialmente ao não atendimento. $O$ usuário em um programa de urbanização foi atendido pela concessionária por rede de água e foi conectado também à rede de esgoto (Mapa 1). No mapa completo da controvérsia foram identificadas as principais controvérsias cientificas: 1.) universalização e sustentabilidade, pensando risco, vulnerabilidade, resiliência e adaptação; e 2.) descontinuidade e ausência de planejamento e programas pensando as controvérsias da gestão na decisão, custo e economia verde.

\subsection{DISCUSSÃO APLICADA DO MAPEAMENTO DE CONTROVÉRSIAS}

Segundo Gibson (2006 b), as bases de avaliação da sustentabilidade têm sido introduzidas de varias formas e em muitos setores ao redor do mundo com dificuldade, pois seus requisitos e alternativas sempre dependem fortemente das circunstâncias particulares envolvidas. Assim, após algumas décadas de discussões e de experimentação, há um amplo consenso sobre os requisitos essenciais gerais para o progresso rumo à sustentabilidade. A integridade do sistema socioecológico significa construir relações sociedade-ambiente para estabelecer e manter a integridade dos sistemas socioambientais em longo prazo, e proteção das funções ecológicas que são insubstituíveis e das quais dependem a vida humana e a qualidade ambiental. 
Neste sentido, James J. Kay (1999) afirma que para manter a integridade do sistema é preciso mitigar mudanças contextuais que promovem estados indesejáveis e monitorar o ecossistema. Para tanto, é preciso entender melhor as complexas implicações sistêmicas de nosso modo de vida e reduzir as ameaças humanas para a integridade dos sistemas e a viabilidade de suporte da vida (GIBSON, 2006 b).

Há perguntas a serem respondidas. As atividades do saneamento garantem a integridade dos sistemas? Afetam a resiliência dos ecossistemas? Permitem a continuação das atividades das comunidades tradicionais nas localidades de atuação? Outras atividades locais combinam efeitos dos projetos do setor sobre os ecossistemas e as atividades tradicionais? As contínuas mudanças climáticas podem afetar as atividades e efeitos sobre a ecologia e comunidades de regiões? As perspectivas seriam diferentes sem algum projeto ou atividade do setor?

Para Sem (1999), o desenvolvimento pode ser visto como um processo de expansão das liberdades substantivas, mas ausência destas relaciona-se diretamente com: pobreza (privação dos indivíduos de saciar a sede e ter saneamento básico), carência de serviços e assistência pessoal (ausência de programas epidemiológicos, de saneamento e educação). A negação de liberdades é fruto de restrições impostas à participação da vida social, política e econômica da comunidade.

Sendo assim, para que se integre esse princípio às práticas de busca da sustentabilidade é necessário garantir a provisão do acesso aos serviços básicos essenciais e o envolvimento daqueles cujas necessidades estão em pauta (GIBSON, 2006c).

SAMPAIO (2003) aponta que "cada geração tem a responsabilidade de preservar os recursos naturais e a herança humana pelo menos no patamar que recebeu de seus antepassados". Nesse sentido, a equidade intergeracional está interligada ao princípio do desenvolvimento sustentável.

Em 1983, na Assembleia das Nações Unidas, por meio do Relatório Brundtland, a essência deste princípio à época era "o atendimento das necessidades e crescimento da sociedade presentes sem o comprometimento dos recursos necessários as gerações futuras" (PASOLD, 2007 apud DANI, et al., 2010, p ). Recentemente, o critério passou a considerar o desenvolvimento sustentável como forma de assegurar a igualdade entre as gerações futuras e garantir o 
acesso aos recursos naturais (Programa das Nações Unidas para o Desenvolvimento, 2011).

Segundo Fiorillo (2002), deve-se buscar a coexistência harmônica entre a economia e o meio ambiente para que se permita o desenvolvimento de forma sustentável, planejada e onde os recursos hoje existentes não se esgotem ou tornem-se inócuos, visto que o meio ambiente não pode sucumbir sob o pretexto de desenvolvimento porque os recursos ambientais não são inesgotáveis.

Para Gibson (2001), exercer a cidadania socioecológica é crucial para que haja governança democrática e para que se consiga preservar os ganhos da sustentabilidade. Nesse sentido, as bases da educação e emponderamento sugerem uma consequente necessidade de fortalecer individual e coletivamente 0 conhecimento sobre a promoção da cidadania e responsabilidade ecológica, e assim, construir capacidade civil para um envolvimento efetivo e integrado nas tomadas de decisão. Portanto, este princípio está diretamente relacionado ao direito de participação nas tomadas de decisão, como a regulação, direito do consumidor, estabelecimento e direito a serviços essenciais com tarifas subsidiadas, bem como tudo que diz respeito à participação coletiva dos diversos setores da sociedade. As áreas peri-urbanas têm acentuada ocupação desordenada em várzeas, morros, alagados e pela invasão de áreas vulneráveis e de proteção ambiental, gerando desmatamento, supressão de matas ciliares, erosão, ocupações irregulares em áreas de risco, poluição ambiental, além da alteração do curso e canalizações de rios com áreas degradadas e áreas contaminadas (Figura 9). Essas dependem de ações específicas, pois são objeto da especulação imobiliária pela valoração econômica.

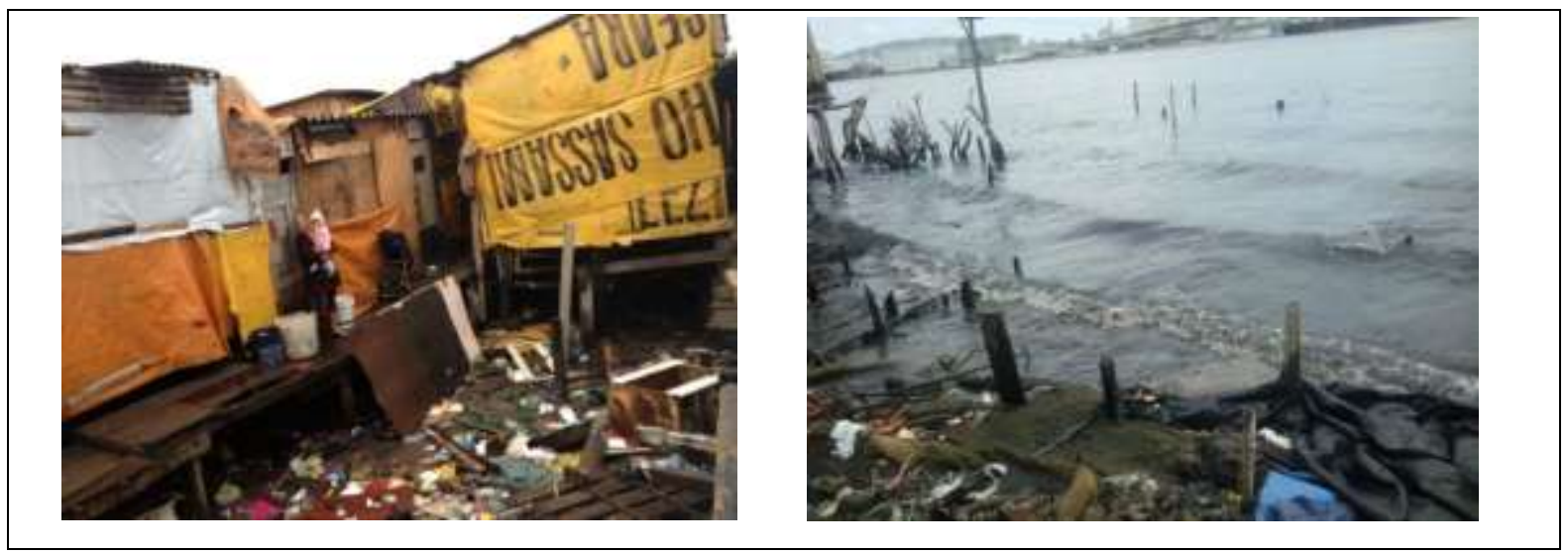

Fonte: a autora e SABESP $(2012,2014)$

Figura 9 - Aglomerados subnormais da RMBS 
Para Gunther (2006) cabe as políticas públicas estabelecer, de um lado, os mecanismos de responsabilização, instrumentos de ação e controle para recuperação e uso das áreas ambientais e contaminadas e medidas de acompanhamento da saúde dos moradores, e por outro, contemplar a revitalização do espaço e a reinserção urbana, na ótica da sustentabilidade ambiental e em resposta aos desafios do enfrentamento da degradação ambiental nas cidades.

A economia ecológica debate a dinâmica das cidades, e em especial das metrópoles e megalópoles, insustentáveis por natureza pela densidade populacional, que criam para si uma sustentabilidade artificial ao ignorar grande parte de seu custo ambiental real que será equacionado pelo saneamento ambiental. Os custos dos esgotos gerados são transferidos para longe no espaço e no tempo, e quem paga por eles são outros, ou então são as gerações futuras. De qualquer forma a economia está no cerne das preocupações ambientalistas (MARTÍNEZ ALIER, 2007).

Deve-se considerar que a vulnerabilidade e resiliência dos ecossistemas estão frequentemente em pauta juntamente com a adaptação, pois têm pontos de convergência como estresses, choques do sistema, sua resposta e a capacidade adaptativa. A resiliência seria a capacidade do sistema de receber uma ação externa e suportar a mudança sem alteração de seu estado, ou a capacidade de retornar a seu estado original. Em relação ao mapeamento, a pesquisa valida os dados para oferecer medidas mais robustas para análise de políticas e intervenção. Entra aí a questão temporal, de estar vulnerável em função do tempo. Sobre a percepção, o autor coloca que as pessoas sabem que a situação não está em conformidade, porém, não sabem identificar o que está errado. Para os tomadores de decisão, o autor coloca que eles sempre expressam surpresa frente a eventos extremos, apesar de muitas vezes haver certa previsão de ocorrência. Relaciona vulnerabilidade com sustentabilidade, com destaque para o principio da precaução como central nos processos de decisão. Uma das implicações da ausência de governança é que, geralmente, as populações mais vulneráveis são excluídas do processo de discussão, acesso ao poder e recursos. As vulnerabilidades, para 0 autor, devem ser identificadas no sistema socioecológico, reconhecendo os mecanismos causadores e estabelecendo a marginalização como sua causa, reconhecendo a pluralidade dos sistemas de 
governança para gerenciar os risco e promover a resiliência.

Hogan \& Mandarola (2012) trazem uma perspectiva dos estudos de população urbana, meio ambiente e riscos. A população urbana é mais da metade da população mundial e os estudos de risco e vulnerabilidade têm sido um dos temas interdisciplinares cada vez mais relevantes para análise urbana, devido à urgência de estudos que busquem compreender a ocorrência de eventos extremos. Afirmam que os estudos de vulnerabilidade tiveram como foco inicial a pobreza e desigualdade social. Em uma segunda etapa, o conceito incorpora estudos de perigos ambientais.

Posteriormente, devido às mudanças do clima, o conceito concentra-se sobre processos de população, incluindo mobilidade social e conceitos de resiliência e adaptação. Sendo que, a resiliência é o que é suportável para população e ambiente, e a adaptação é a estrutura que uma população cria para se proteger, independentemente da participação do Estado. Portanto, estudos de população e meio ambiente no aspecto de vulnerabilidade devem levar em consideração o que pensa esta comunidade, e qual a sua percepção de risco. Nesse sentido, falta investigação sociológica e etnográfica para aspectos da dinâmica social e vulnerabilidade da ausência da universalização dos SAAES em áreas de exclusão social. O debate sobre adaptação como o fortalecimento da resiliência passa por maior integração de políticas públicas e ações da sociedade civil para promoção de soluções (CEDEPLAR et. al. 2008).

Para Mandarola \& Hogan (2006) há uma contribuição da geografia e da demografia para a vulnerabilidade, nos eixos da pobreza e da dimensão ambiental. A geografia sistematiza as diferentes abordagens de vulnerabilidade, a probabilidade da exposição, e as suas consequências (e combinação destas): a vulnerabilidade como condição pré-existente (perigo); a resposta equilibrada à questão da vulnerabilidade (de resistência/ construção social); as potencialidades do local como propenso a um perigo. Portanto, mensura o risco psicofísico e a acompanha a resposta social. Assim, conceitua a vulnerabilidade como a propensão de sofrer o agravo frente à falta dos sistemas de contenção. Não é possível dar conta do estudo da vulnerabilidade em um único campo. A vulnerabilidade não é dada, mas construída pelo ambiente.

Nesse sentido, as populações em áreas urbanizadas têm possibilidades de resiliência e adaptação frente ao risco, restringidas pelo meio, tornando-se mais 
vulneráveis que uma população de semelhante situação de pobreza nos meios rurais.

As restrições de sobrevivência provida pelo meio ecológico em que se insere determinada população acentuam-se no meio urbano e aumentam a vulnerabilidade de determinado grupo.

O fato de não ter acesso ao mínimo legal de água para subsistência e espaço para qualquer tipo de cultivo ou criação caracterizam restrições urbanas para sobrevivência básica, os indivíduos buscam alternativas em córregos e suas várzeas, ficando sujeitos às enchentes.

Além disso, a proximidade aos próprios esgotos gerados e resíduos do consumo de produtos industrializados em substituição aos cultivados trazem outros agentes que se alimentam dessa cadeia alimentar como ratos e doenças. Caracterizam-se também nessas questões as distâncias dos centros, onde o cidadão estará excluído das diversas redes como transporte para deslocamento a centros de trabalho, educação e saúde, diminuindo suas possibilidades de escolhas.

Dupuy \& Offner (2005) afirmam que para compreender o desenvolvimento de um recurso e dar conteúdo à ideia de equidade socioespacial, a universalização é a fase final do desenvolvimento de um serviço como uma figura "teológica" do recurso.

\subsection{CONCLUSÕES}

A universalização não se justifica pela precisão, tipologia, oposição e aproximação que obrigue à execução. Os materiais aptos a estabelecer os fundamentos de uma sólida socioeconomia dos recursos estão postos em índices topológicos, modelos jurídico-institucionais e dispositivos tarifários. Resta combiná-los para estabelecer uma tipologia de regimes sociotécnico dos modos de universalização dos recursos sobre interações dos mesmos e dinâmicas espaciais.

Nesse sentido, faz-se necessária a inovação do modelo contemplando mecanismos que promovam uma governança efetiva, gestão participativa e a integração de atores considerando as controvérsias, externalidades negativas e positivas, falhas de mercado, interdisciplinaridade, perspectivas teórico-espaciais e coações que perpassam o tema para eficácia da universalização. 
Parafraseando Dupuy J. (2003) ao falar sobre riscos de acidentes com as termoelétricas e princípio da precaução. Há que se escolher o que conta mais, se a exigência ética de igualdade com princípios de universalização, ou o modo de vida e desenvolvimento. A parte privilegiada do planeta se isola em muros, que acirram o ressentimento, ou inventa outro modo de reportar-se ao mundo, à natureza, às coisas e seres, com possibilidade de proporcionar a universalização a todos.

A moderna missão do modelo de universalização é evidenciar as ações e omissões intoleráveis ao alcance de um modo de vida sustentável para as presentes e futuras gerações, e que, muitas vezes, não estão evidentes ao cidadão, além de mandatoriamente propor soluções inovadoras.

A defesa da racionalidade apoiada na teoria da decisão, certamente contribui para o estabelecimento de prioridades, porém a análise das controvérsias pela engenharia ambiental também é um revelador das necessidades urgentes do ponto de vista da resiliência e adaptação. Aceitar uma determinada ideia apoiada na universalização implica escolher certas intervenções efetivas sobre as decisões que mudam paradigmas. Implica, ao mesmo tempo, numa redefinição do espaço em que se exerce o controle e a gestão dos serviços públicos, pelos quais os indivíduos serão atendidos, entendidos como grupo humano, como população em ambiente sustentável. Urge elaborar estudos, definir conceitos, indicadores e ações organizadas para iniciativas e esforços de transformação em produção efetiva, de maneira a promover profunda reorganização institucional por meio de um novo modelo, com um agente transformador para a transformação da controvérsia de subcidadãos para chegarem a usuários.

A promoção de adequações necessárias à prevenção dos danos equilibrará a balança e neutralizará controvérsias da decisão para auxiliar as concessionárias, consultorias e poder público a deslocar a centralidade do modelo de decisão para outros paradigmas da sustentabilidade, metodologias da economia verde, e consideração do risco certo e do risco presumido. Finalmente, deve-se contribuir na tarefa de dar sentido à sociedade organizada e ao cidadão individual daquilo que não é evidente - o modo de vida num modelo sustentável. 


\section{POLO TEÓRICO - NOVOS CONCEITOS E INDICADORES}

\subsection{CONSIDERAÇÕES GERAIS}

Segundo Martins \& Theóphilo (2009), as teorias são instrumentos que orientam a observação empírica e a modelização de um quadro heurístico para a pesquisa, habilitando o pesquisador a perceber os problemas e suas possíveis explicações. Esta etapa da pesquisa foi composta inicialmente de revisão de literatura e pesquisa documental (BAUER E GASKELL, 2002; DENZIN, 1970A).

A revisão bibliográfica permitiu orientar as hipóteses e construir os conceitos para desenvolver uma investigação, com objetivo de identificar interpretações legais, sociais, ambientais, governamentais e empresariais sobre a governança para universalização em áreas vulneráveis, contemplando conceitos físicos e econômicos comparáveis, no eixo temporal e variáveis ambientais, que levaram em consideração a influência de externalidades, integralidade, resiliência, subsídios em seus diferentes mecanismos de planejamento setorial, manifestações locais, ordenamento jurídico, modelos de administração de uma organização e ferramental de apoio à gestão para o saneamento.

Complementarmente, um levantamento documental foi realizado na Companhia de Saneamento Básico do Estado de São Paulo e Unidades de Negócio, quanto aos arranjos necessários à universalização dos serviços em áreas vulneráveis, e construção de uma base empírica numa sistematização de dados públicos e confrontamento interno para equacionamento dos subsídios. Incluiu-se no levantamento da operadora: seu planejamento estratégico, planejamento tático da unidade de negócio, política comercial e procedimento para atendimento às áreas de vulnerabilidade, contrato de concessão e relatórios de gestão regulatória, programas de urbanização, relatório de sustentabilidade, relatório para investidores, plano de negócio e outros instrumentos identificados ao longo dos levantamentos.

Dados secundários e informações que compuseram o diagnóstico foram levantados junto aos gestores. Adotou-se usar dados públicos e divulgados nos seminários das associações dos engenheiros da SABESP, Associação Brasileira de Engenharia Sanitária e Ambiental e nas publicações da Agência Reguladora do Estado de São Paulo - ARSESP para a primeira revisão tarifária do Estado de 
São Paulo, e pelo poder concedente junto aos Contratos de Programa.

Obteve-se previa autorização da concessionária para estudo dos dados primários levantados pela pesquisadora.

A etapa de construção de marcos teórico resume fatos observados, promove a evolução da observação, estabelece o embasamento para a previsão e a explicação da universalização em áreas de vulnerabilidade. Esta etapa foi exploratória, mediante oficinas, para apresentar conceitos norteadores e discussões acerca do saneamento, bem como os casos em avaliação da universalização do saneamento que subsidiaram a concepção do modelo de governança. Deve ser entendida como mutante no eixo do tempo para subsidiar a concepção do modelo e respectivos fatores-rede.

O desenvolvimento econômico do final do século passado até o presente promoveu um crescimento desordenado nas áreas urbana, no Brasil. 0 atendimento com saneamento às populações em situação de vulnerabilidade social, assentadas muitas vezes em áreas irregulares demanda análise. Em que medida esses cidadãos são considerados e a gestão dos serviços de saneamento está preparada para atendê-los? Os desafios da urbanização requerem inovação de mecanismos capazes de suprir demandas por serviços essenciais às populações em contextos vulneráveis. Para a medição e visualização desse cenário é necessária inovação de conceitos, indicadores e ferramentas de governança capazes de capturar as condições de exclusão do ser humano. A inovação foi feita atuando-se na interface teórica e prática para construção participativa de requisitos de governança que foram testados em 8 municípios metropolitanos do Brasil. Foram identificadas as dimensões essenciais para a construção da governança que considere singularidades dos mecanismos de exclusão, e de indicadores voltados a atender o direito humano de acesso ao serviço de saneamento pelas populações vulneráveis. Por meio de 11 oficinas com atores do setor de diferentes atribuições, bem como usuários e sociedade civil organizada, após o mapeamento de controvérsias, construiu-se dois conceitos com respectivos indicadores: Universalização Inclusiva e Governança Inclusiva, e para testá-los desenvolveu-se um Modelo de Plano de Negócio Inclusivo para áreas de vulnerabilidade social. 


\subsection{INOVAÇÃO DOS CONCEITOS}

Diante da realidade do uso e ocupação do solo existente no Brasil, marcada pela heterogeneidade de renda, de condições sociais entre bairros e distritos, pelo aumento do favelamento nas grandes metrópoles, evidencia-se uma sociedade cada vez mais segregada (TORRES, 2004). Somando-se a esta segregação habitacional, há o crescimento populacional ocorrido de maneira concentrada em áreas urbanas. Este e outros fatores geram transformações nas estruturas das cidades acentuando conflitos referentes ao uso e ocupação do solo. Tais conflitos requerem agilidade para suprir demandas por serviços de infraestrutura, incluindo-se, fornecimento dos serviços de abastecimento de água e esgotamento sanitário (SAA\&ES).

Neste sentido, a universalização dos serviços consiste em estender a toda população, independentemente de contribuição financeira de cada indivíduo, o usufruto dos serviços apropriados às suas necessidades e à sua integralidade (MALHEIROS ET AL., 2006). E, conforme colocado por Heller (2009), a população menos atendida com os serviços, previsivelmente, é a de baixa renda, que vive em situação de maior vulnerabilidade social, ambiental e econômica (Ribas, 2007).

A universalização é definida por critérios que compõem as dimensões: institucional, operacional, recursos hídricos, gestão, social, financeira, abrangência. Apesar da incerteza observada no indicador, às séries históricas, dentro de conceitos de cobertura e atendimento, ligações ativas e inativas, perdas físicas e comerciais permitem a visualização da evolução dos serviços de abastecimento de água e esgotamento sanitário.

Identifica-se no conceito de universalização uma ontologia, que apresenta um progresso temporal com um conjunto de conceitos dentro de um domínio e seus relacionamentos (Quadro 7):

Quadro 7 - Ontologia da Universalização do Saneamento

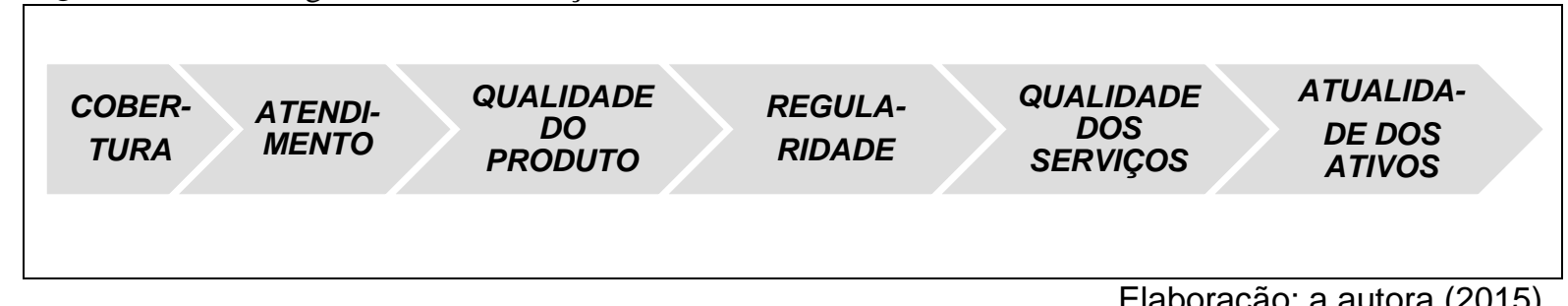


Assim, a universalização dos serviços públicos de saneamento básico é um conceito dinâmico, de caráter evolutivo ao longo do tempo, cujas demandas de melhorias contínuas exigem saltos de acordo com os objetivos alcançados. No Brasil, considera-se no primeiro momento, a disponibilidade de redes de distribuição de água, porém em países da África considera-se disponibilidade por quiosques e cisternas - cobertura. A despeito dos formatos adotados em função dos recursos disponíveis, o benchmarking de eficiência deve considerar modelos comparáveis. Em um segundo momento, a conexão direta às casas dos usuários - atendimento; em terceiro, a qualidade da água - qualidade dos produtos; em quarto, o fornecimento sem interrupções e tempo de retorno das reclamações qualidade dos serviços; em quinto, substituição sistemática dos ativos antes da depreciação e sucateamento - atualidade. Em todos os momentos, espera-se atendimento comercial acessível e tarifas módicas. Estes aspectos têm impacto importante na universalização dos serviços de saneamento, nos usuários e no entorno político e institucional de uma região (BRASIL, 2007, 2012, 2013, ARSESP, 2013, SABESP, 2013).

Deve-se destacar que o conceito de universalização do saneamento nas práticas do setor é restrito ao acesso aos serviços de abastecimento de água e esgotamento sanitário em áreas regulares.

Os serviços de abastecimento de água e esgotamento sanitário já possuem indicadores desenvolvidos e empregados historicamente para medição dos serviços. Identificam-se sistemas de indicadores que apoiam contratos de concessão e reguladores, como o Sistema Nacional de Informação do Saneamento (SNSA, 2010), e Pesquisa Nacional de Saneamento Básico - PNSB, com base de informações do Instituto Brasileiro de Geografia e Estatística - IBGE. Muito embora seja feita a utilização rotineira de indicadores pelas reguladoras, operadoras e poder público para mensurar o desempenho dos serviços, esta mensuração tem sido utilizada na eficiência técnica e eficácia social para áreas juridicamente regularizadas. Deste modo, nota-se que há lacunas, quando estes indicadores destinam-se a medir e monitorar a universalização dos serviços nas áreas de vulnerabilidade, áreas de invasão e moradores em situação de rua. Percebe-se que indicadores para os serviços de abastecimento de água e esgotamento sanitário voltados às populações vulneráveis não foram definidos e nem testados. 
O objetivo deste polo metodológico é abordar as novas preocupações trazidas pelos direitos fundamentais preconizados na Constituição Cidadã (Brasil, 1988) aos serviços essenciais, auxiliando no esclarecimento e identificação das complexidades de interesses e relações e propor equacionamentos. Segundo Juliano et. al.(2012) o saneamento é uma ferramenta de equidade no atendimento a um direito humano fundamental, porém seguem indefinidos os lugares do ser humano e do usuário nesse modelo. Nesse sentido, buscou-se construir, conceitos do saneamento quanto ao modo de operar vinculados aos mecanismos, não apenas de implantação das políticas públicas, e saberes técnicos, mas também dos que provém das relações sanitarista-usuário, para a população em vulnerabilidade social. Cada uma delas expressa processos produtivos, cujo modelo singular de construção será dos saberes que surgirão dessa relação, evidenciando a relevância da participação e controle social. Onde o usuário tem condições de, ao ser empodeirado, promover soluções, que seria a construção de modelos de operar de forma participativa.

Diante do grande número de pessoas vivendo em aglomerados subnormais no Brasil, surge à necessidade de um mecanismo que forneça informações sobre atingimento de metas, entendendo o potencial de uma adequada governança pública (Figura 10) e privada (Figura 117). Urge aos reguladores, municipalidades, operadores e sociedade, apropriarem-se de ferramentas que promovam maior credibilidade, transparência e aceitabilidade da gestão dos serviços essenciais às populações em situação de vulnerabilidade social. Ao mesmo tempo, novos conceitos e indicadores possibilitariam avaliar e pressionar políticas públicas e ações mais efetivas no planejamento, regulação, controle e participação social. 


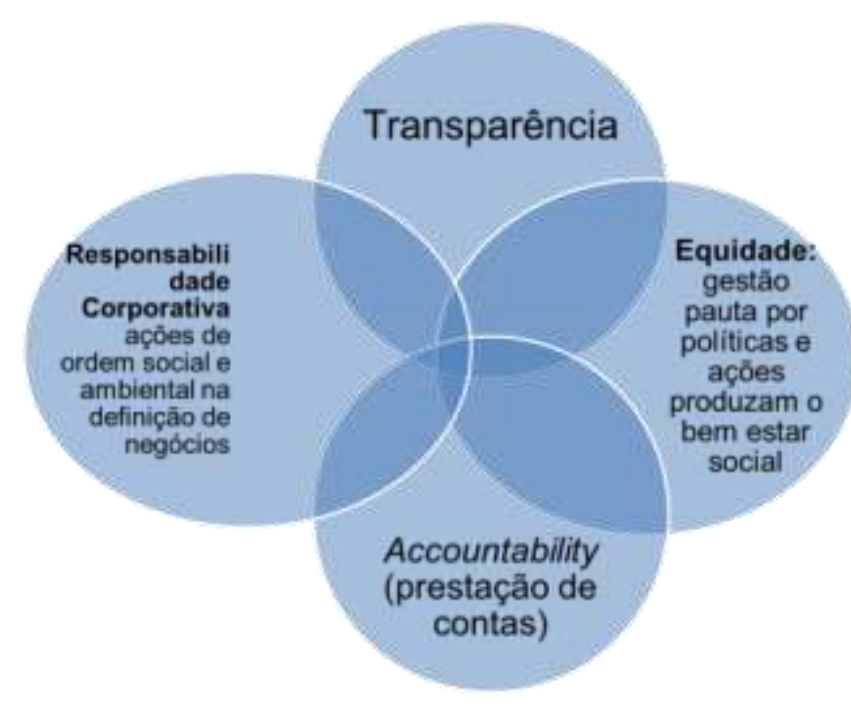

Elaboração: autora baseada em Slomski (2005)

Figura 10 - Figura 6: Governança Publica

Cidadania socio-ecológica e governança democrática constroem nossa capacidade de aplicar os princípios de sustentabilidade através de um pacote de práticas de tomadas de decisão melhor esclarecidas e melhor integradas no âmbito administrativo, de mercado e individual (Gibson, 2001).

A questão dos procedimentos e práticas governamentais na execução de suas metas adquire relevância, incluindo aspectos como o formato institucional do processo decisório, a articulação público-privada na formulação de políticas ou ainda a abertura maior ou menor para a participação dos setores interessados ou de distintas esferas de poder (WORLD BANK, 1992).

Ferramentas devem promover o mecanismo de controle e participação social e beneficiar tanto operadoras na escala do seu desempenho interno, voltados ao atendimento às populações vulneráveis, como a instrumentalização de políticas públicas, por meio do regulador, incentivando e disseminando as boas práticas dos serviços voltadas às populações vulneráveis.

Para vencer este desafio, entre as diversas ações a serem implementadas, é fundamental a estruturação de um plano de negócio, apoiado em conceitos, indicadores, custos reais e receitas provenientes de tarifas sociais, que permitam explicitar e abranger as singularidades dessa situação e auxilie no processo de planejamento dos serviços.

Deste modo, neste polo indaga-se: quais são os mecanismos passíveis de avaliar 
a prestação de serviços de abastecimento de água e esgotamento sanitário às populações vulneráveis?

A governança considera atos gestão que os legitima no alcance de seus objetivos (Figura 11). A governança, na qual o Estado pode utilizar as ferramentas que são aplicáveis no setor privado, inclui as práticas de governança corporativa, e chega à capacidade dos governos de planejar, formular e implementar politicas e cumprir funções. Os princípios que servem como base para as boas práticas da governança são transparência, equidade, accountability (prestação de contas) e responsabilidade corporativa. Assim, a governança surgiu para criar mecanismos de controle e monitoramento dos negócios, não somente pelos gestores, mas também pelos acionistas, possibilitando identificar e solucionar conflitos de agência (OCDE (2013), BIRD (1992), IBGC (2004), Malacrida \& Yamamoto (2006)).

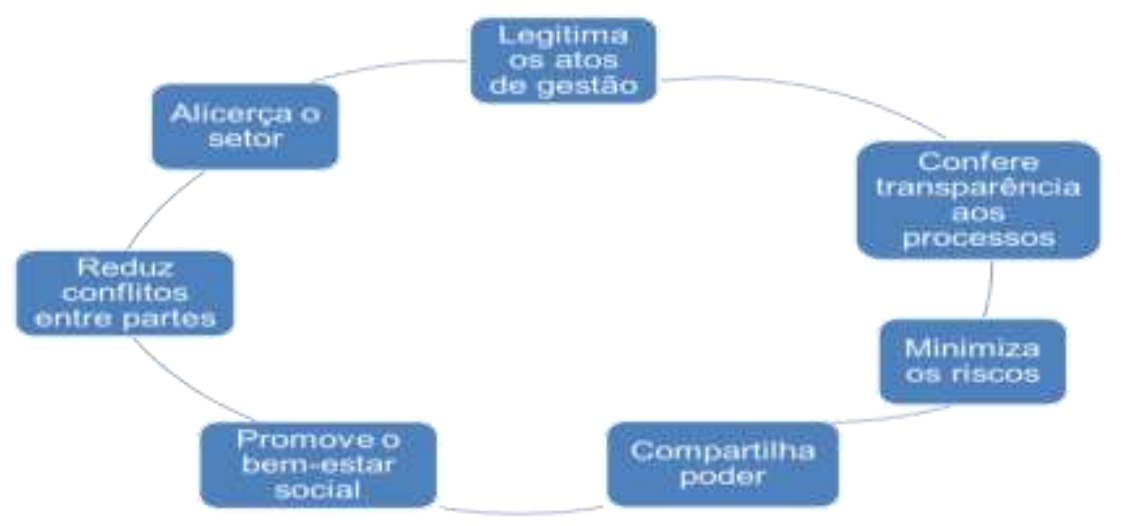

Fonte: Elaboração da autora. Base: OCDE (2013)

Figura 11 - Objetivos e Resultados de governança privada

Os indicadores de saneamento, no contexto regulatório, servem de base para avaliar a evolução temporal da eficiência da empresa regulada. Assim, demandase conceituação, definições e esclarecimentos quanto à realidade do uso de indicadores adotados para medida de universalização em áreas de vulnerabilidade social. O benchmarking é ferramenta caracterizada pela capacidade de aferir eficiência e eficácia da prestação dos serviços por meio de indicadores de produtividade das empresas, que são comparadas. Assim, objetiva-se trazer à discussão a aplicação de conceitos de empresa referência ou benchmarking que possam atender às peculiaridades da prestação dos serviços em áreas urbanas vulneráveis. 
Apesar de diversos estudos acerca da avaliação de desempenho e benchmarking do setor de saneamento na Europa, destacando como o setor de saneamento utiliza os indicadores de benchmarking para melhorar desempenho no setor (ADMIRAAL\&VAN HELDEN, 2003; BERG\&MARQUES, 2011; CRISTIA, 2006; ESCODA, 2005; GARCIA M., 2010; MARQUES et. al., 2010, 2011), e estudos ligados à provisão de saneamento para populações mais pobres (NDLOVU, 2011), e sobre indicadores de saneamento e saúde no Brasil (ANDREAZZI et. al., 2007; CALIJURI et al., 2009), entre outros, são raros os estudos no Brasil focados em benchmarking e indicadores para os serviços de universalização do saneamento.

O marco regulatório do saneamento inseriu regramento no setor para operação dos serviços. As agências reguladoras, criadas em atendimento a esse dispositivo, devem garantir, mediante mecanismos regulatórios, a eficiência de uma determinada atividade, por meio da comparação entre valores dos fatores de produção e a eficácia, que contabilize o grau de concretização de uma atividade e não a forma como esteja sendo desenvolvida, que constitui objeto da eficiência (MARQUES et. al. 2011).

Frente à nova era de inserção do saneamento em um ambiente competitivo, mediante a comparação entre as diferentes empresas, traz-se ao debate a gestão e a adoção de modelos de benchmarking como mecanismos de incentivo à eficiência e eficácia na regulação da prestação de serviços de saneamento. Além disso, o modelo existente não conseguiu atender de forma homogênea todas as áreas do país, restando ainda muita disparidade, especialmente em áreas de vulnerabilidade social, em que a irregularidade das moradias e a pouca capacidade financeira para pagamento das tarifas são barreiras para a prestação dos serviços de forma adequada. Pretende-se, assim, refletir em que medida as diferentes visões sobre gestão dos serviços de saneamento são percebidas e consideradas quando da definição de indicadores para sua regulação. 


\subsection{CONSIDERAÇÕES QUANTO AO MODELO ATUAL DE BENCHMARKING}

Os bancos de dados produzidos pelo Sistema Nacional de Informações sobre Saneamento (SNIS), Rede Interagencial de Informações para a Saúde (RIPSA), Instituto Brasileiro de Geografia e Estatística - IBGE em áreas legais e irregulares têm a dificuldade de não checar o prestador de serviços na área irregular ou se o uso é clandestino. As instituições de planejamento e urbanismo das esferas municipais, estaduais e federais são importantes fontes de geração de dados para a Secretaria de Planejamento do Estado de São Paulo e EMPLASA. As bases provenientes do Ministério das Cidades são consolidações de questionários preenchidos pelos próprios gestores. Há que se considerar que, informações dos serviços de saneamento baseadas em modelos de benchmarking ou comparação às melhores práticas auditadas pelas agências podem vir a suprir essa lacuna.

Diversos autores (CRISTIA, 2006; RIVERA, 2004; SPENDOLINI, 1994; VIDAL, 2006,) definem benchmarking como um processo contínuo e sistemático de avaliação de produtos, serviços e processos realizado por comparação de melhores práticas entre organizações, com a finalidade de se obter melhorias organizacionais. Os objetivos dessa ferramenta contribuem para 0 desenvolvimento do plano estratégico da empresa, com estabelecimento de metas de melhoria organizacional e de processos pela identificação das melhores práticas (VIDAL, 2006, p. 6-7).

Benchmarking é importante no setor da água , para documentar desempenhos, estabelecer linhas bases de medição de melhoria da produtividade e comparar operadores dos serviços. As classificações podem informar políticas das concessionárias e autoconhecimento da organização, possibilitando comparação de desempenho sobre os usos da água e entre diferentes países e estabelecendo pontes entre pesquisas acadêmicas, práticas comerciais dos operadores dos serviços e políticas públicas, que dialoguem com a realidade vivenciada pelos serviços de saneamento (BERG, 2007).

Os diversos estudos que abordam o benchmarking em relação à sua aplicação no setor público, especificamente em relação a aspectos de governança local (BOVAIRD\&LÖFFLER, 2002; BOWERMAN et al., 2002; DAVIS, 1998; 
DORSCH\&YASIN, 1998), indicam que os modelos de benchmarking existentes poderiam corresponder melhor às necessidades locais se, ao lado de focarem na alta desempenho do gerenciamento de serviços, também envolvessem a habilitação das comunidades locais para resolver suas necessidades atuais e futuras, devendo, portanto, ir além da prestação de serviços. Esse fator seria de grande relevância em se tratando de universalização do saneamento em áreas de vulnerabilidade social.

\subsection{CORRELAÇÃO SANEAMENTO E SAÚDE}

\subsubsection{Risco e externalidades da saúde}

Segundo Caponi (2003), a compreensão do conceito de saúde depende de parâmetros científicos e claramente estabelecidos num horizonte ilimitado de possibilidades de prevenção de enfermidades, e a possibilidade de intervir na prevenção de certos riscos que ameaçam a saúde das populações, por meio da bioestatística e da informática na ação sanitária para mapear os riscos mais frequentes nas diferentes populações e construir estratégias de prevenção das enfermidades e de promoção da saúde. A redução mortalidade infantil e das doenças de veiculação hídrica compõem importante análise por seus indicadores, da externalidade positiva do saneamento em assentamentos e em áreas irregulares, estabelecendo a condição sanitária local nos centros urbanos.

A Agência Nacional de Vigilância Sanitária / Ministério da Saúde - ANVISA/MS tem a responsabilidade pela normatização e fiscalização das condições humanas que contrariem diretrizes do Sistema Único de Saúde, por meio da vigilância sanitária, inclusive dos ambientes (art. 60 da Lei no 9.782/1999). O Plano Diretor de Vigilância Sanitária - PDVISA (BRASIL, 2007) contempla as diretrizes norteadoras necessárias à consolidação e fortalecimento do Sistema Nacional de Vigilância Sanitária (SNVS), com função de atuar na prevenção, eliminação ou minimização do risco sanitário nos diversos espaços, promovendo e protegendo a saúde da população, incluindo o uso da água. A regulação dos serviços de água e esgoto possui intersecção em quatro dimensões: proteção ao usuário; saúde e segurança; meio ambiente e objetivos sociais, considerando o risco iminente de doenças de veiculação hídrica (WORLD BANK, 2007). 
Os riscos afetam desigualmente a população, onde os pobres serão mais afetados que outros cidadãos em iguais condições, porém em melhores condições socioeconômicas, que teriam mais facilidades de se proteger ou minimizar os efeitos de situações de risco. As contaminações caracterizam o risco à saúde humana e aos ecossistemas, risco à segurança dos indivíduos e da propriedade, redução do valor imobiliário da propriedade e restrições ao desenvolvimento urbano.

Para Guilam (2009) a análise de risco epidemiológico está apresentada mediante a avaliação dos conceitos de riscos da engenharia, ciências sociais, economia. $O$ conceito de risco então é dado pela razão do número de pessoas afetadas por doença sobre o número de indivíduos efetivamente expostos, e, ainda, pela possibilidade de recorrência. Uma série de aspectos para se pensar: a incerteza da saúde como risco sanitário e de saúde - risco necessário de ser monitorado, administrado e prevenção de risco. Articula-se com uma racionalidade de saúde, politica econômica, social e jurídica.

a dimensão ambiental é de fundamental importância quando inserida no contexto de vulnerabilidade, em especial porque as dimensões social, ambiental e econômico alinhadas configuram os grandes desafios da sustentabilidade. A vulnerabilidade é multicausal e complexa, pois depende de uma rede de relações entre o meio físico, humano e a sociedade; em escala mais arrojada é interdisciplinar a partir de um perigo ou um conjunto de perigos, associados a uma localização e dinâmicas demográficas, grupos de áreas de risco para viver com percepção de risco (Marandola \& Hogan, 2006). No enfoque de mudanças climáticas, para Moser (1998) pobreza não é a mesma coisa que vulnerabilidade. Antes, há aspectos particulares da pobreza que tornam a população vulnerável. Para Adger (2006) a suscetibilidade e perigos, nos meios ambiental e social, impactam bem-estar do meio com a redução dos riscos. Surge a ideia de fortalecer uma comunidade para ela diminuir o grau de vulnerabilidade ou reduzir o risco no sistema socioecológico, reconhecendo os mecanismos causadores e estabelecendo a marginalização como causa da vulnerabilidade social, reconhecendo a pluralidade dos sistemas de governança para gerenciar os riscos e promover a resiliência, sendo relevantes para análise urbana de resiliência e adaptação (Marandola \& Hogan, 2006). Nesse sentido, as populações em áreas urbanizadas têm possibilidades de resiliência e adaptação frente ao risco, 
restringidas pelo meio, tornando-se mais vulneráveis que uma população de semelhante situação de pobreza nos meios rurais. As restrições de sobrevivência provida pelo meio ecológico em que se insere determinada população acentuamse no meio urbano e aumentam a vulnerabilidade de determinado grupo. $O$ fato de não ter acesso à água e espaço para qualquer tipo de cultivo ou criação caracterizam restrições urbanas para sobrevivência básica.

\subsubsection{Categorização Analítica}

$\mathrm{Na}$ teoria social voltada para o risco, o conceito de sociedade de risco foi desenvolvido pelo teórico alemão Ulrick Beck e Hannigan, considerando que as populações humanas, em todo o planeta estão expostas a situações de risco que se ampliaram na contemporaneidade e que os efeitos prolongados atingem de forma mais iníqua segmentos populacionais mais pauperizados da sociedade(Günther, 2006; Guilam, 1999; Araújo \& Gunther, 2009; Juliano et al., 2011). O Quadro 08 apresenta o resumo dos autores com a finalidade de aplicar a categorização à exposição ao risco que uma população sofre.

Quadro 8 - Categorização Analítica na Investigação

\section{PAPEIS SOCIAIS GENÉRICOS NA AVALIAÇÃO DE RISCO}

Portadores de risco - refere-se às vítimas que arcam com os custos diretos decorrentes do fato de trabalharem e viverem em ambientes perigosos.

Defensores dos portadores de risco - refere-se aos indivíduos e grupos sociais que adquirem visibilidade pública na busca dos direitos dos atingidos.

Geradores de risco - trata-se das empresas multinacionais químicas e farmacêuticas, as grandes empresas de serviços públicos, as indústrias.

Investigadores do risco - compreende os cientistas da comunidade acadêmica, os laboratórios governamentais e as agências a quem o poder público delega a competência para colher provas.

Árbitros do risco - são os tribunais, os mediadores, as agências reguladoras, os representantes parlamentares, os quais tentam determinar, de forma neutra, os níveis de tolerabilidade do risco,

Informadores do risco - refere-se aos meios de comunicação social, que assumem o papel de mensageiros ou repetidores da mensagem, tornando visíveis as ações sobre a situação de risco, ou divulgando assuntos do risco para a opinião pública e a agenda pública. 


\subsection{CONSTRUÇÃO DE CONCEITOS INCLUSIVOS DO SANEAMENTO}

As oficinas de conceitos, indicadores, visitas a campo e de planejamento permitiram a análise de controvérsias e recortes em que ocorrem os conceitos da política pública, contratos de concessão e convênios entre entes federados, normas regulatórias e procedimentos empresariais para universalização em áreas de vulnerabilidade. Foi identificado como as exclusões nos instrumentos normativos de áreas favelizadas ocorrem. Conforme Guimarães et al. 2014, considera-se superior o direito de propriedade ao direito humano fundamental de acesso aos serviços públicos. A racionalidade que apoia a decisão de apenas domicílios regulares serem conectados às redes públicas está nas ações judiciais que foram movidas contra os gestores que promoveram a ligação de água em domicílios de assentamento irregular em áreas urbanas por todo o Brasil.

Nas oficinas, os participantes foram distribuídos em dois grupos com objetivos diferentes: poder público e reguladores mapearam as lacunas da política pública que geravam impeditivos da atuação nas áreas de vulnerabilidade; concessionária, sociedade civil e academia mapearam as práticas de gestão que promoveram a universalização de áreas vulneráveis e as práticas judicias, por ações do Ministério Público, que impediram a concessionária atender essas áreas. O grupo de políticas públicas e o de práticas discutiram quem faz, o que, como, por que, para quê, com objetivo de identificar eficiência do processo e eficácia do resultado da universalização dos serviços públicos de abastecimento de água e de esgotamento sanitário por redes fixas em áreas de vulnerabilidade social. A discussão da política pública e das práticas de gestão do saneamento levou a concluir que a universalização deve ser inclusiva para alcançar a eficácia social do setor, e que a governança, como promotora da transparência, participação e eficiência, é falha, na medida em que não considera a cidadania como princípio e fundamento superior à legalidade de uma propriedade.

Nesse sentido, é mandatório garantir a pró-atividade de agentes públicos, poder concedente, legislativo para gestão da concessionária em atos de gestão menos alienados e mais inclusivos. Durante as oficinas as controvérsias sociotécnicas (Latour, 2012) foram mapeadas pelos atores envolvidos na temática. Os eventos realizados obtiveram uma frequência representativa por atividade, além da 
diversidade de instituições, regulador, concessionária, poder público e sociedade civil.

Os resultados das oficinas participativas de saberes e a sistematização das informações obtidas num simulador possibilitaram a estruturação de um plano de negócio para as áreas de exclusão, partindo-se de construção de conceitos e indicadores que capturam a condição da prestação dos serviços às populações excluídas, chamado Plano de Negócio Inclusivo - PNI. Três etapas de oficinas foram organizadas na Faculdade de Saúde Pública da Universidade de São Paulo com a participação de doutorandos, pós-doc, especialistas da concessionária, reguladores e do poder público (Figura 12).

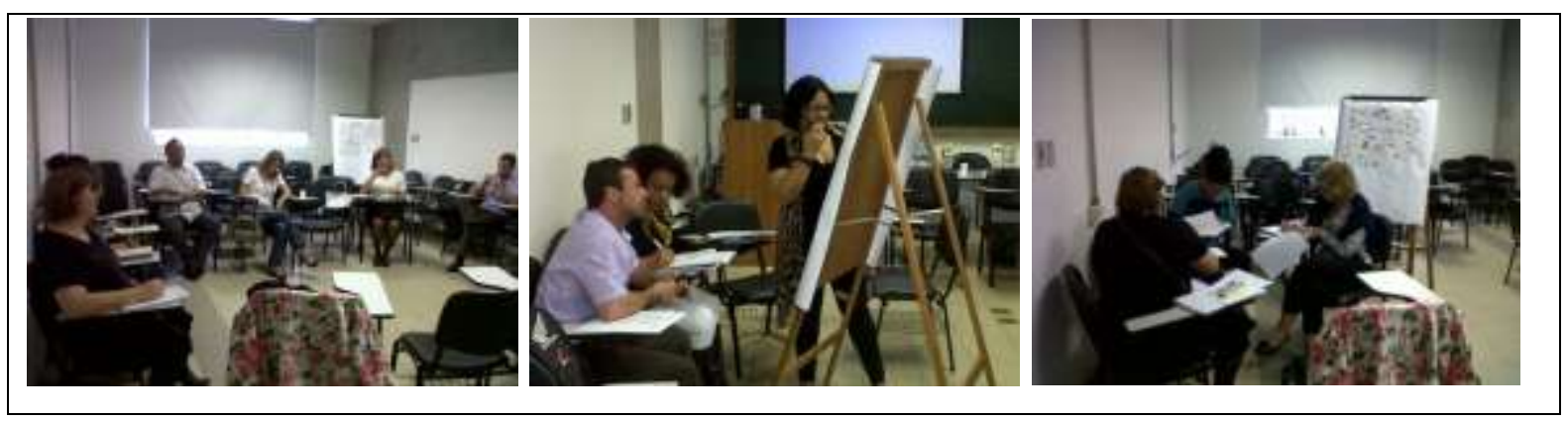

Fonte: autora (2014)

Figura 12 - Oficinas de Construção de Conceitos

\subsubsection{Oficina de Construção dos Conceitos Inovadores}

O diagnóstico e mapa de controvérsias construídos anteriormente, por meio de oficinas, serviram de apoio inicial para as discussões, organizadas em três (03) oficinas, para elaboração do diagnóstico e inovação do conceito (Quadro 09 e Tabela 06). As causas do problema listadas têm relação com a complexidade da universalização, porém não se objetivou nas oficinas correlações entre elas, evidências e conceitos. Ou seja, a construção do quadro com causas, evidências e conceitos não teve por objetivo organizar a controvérsia do mapa, mas evidencia-la para inovação dos conceitos.

Quadro 9 - Diagnóstico dos Conceitos de Universalização e Tabela 6 - Inovação dos Conceitos de Universalização. 
Quadro 9 - Diagnóstico dos Conceitos de Universalização

\begin{tabular}{|c|c|c|}
\hline \multicolumn{3}{|c|}{ PROBLEMÁTICA: Análise de lacunas da política pública } \\
\hline \multicolumn{3}{|c|}{ RELAÇÃO COM A POLÍTICA PÚBLICA PARA UNIVERSALIZAÇÃO POR REDE PÚBLICA } \\
\hline 1) CAUSAS & 2) EVIDÊNCIAS & $\begin{array}{l}\text { 3) CONCEITOS DO } \\
\text { MAPA }\end{array}$ \\
\hline $\begin{array}{l}\text { Conflito quanto ao } \\
\text { reconhecimento de } \\
\text { alternativas para a } \\
\text { prestação dos serviços } \\
\text { como atendimento e } \\
\text { Interesses dos diversos } \\
\text { atores } \\
\text { Conflito na cobrança do } \\
\text { serviço X capacidade de } \\
\text { pagamento } \\
\text { Uso e ocupação } \\
\text { desordenada do Solo }\end{array}$ & $\begin{array}{l}\text { Instalação de fossas não reconhecidas como } \\
\text { atendimento } \\
\text { Gestão do uso e ocupação do solo municipal } \\
\text { Planos Municipais fazem um recorte do Marco } \\
\text { Regulatório } \\
\text { Legislações setoriais X políticas ambientais e } \\
\text { outras "não interagem" } \\
\text { Contrato dos municípios de Recife e } \\
\begin{array}{l}\text { Petrópolis excluíram áreas favelizadas do } \\
\text { Contrato de Concessão - depois passaram a } \\
\text { atender por questões de pressão social }\end{array}\end{array}$ & $\begin{array}{l}\text { Planejamento Participativo } \\
\text { (com todos os atores } \\
\text { participantes envolvidos do } \\
\text { mapa de controvérsias) } \\
\text { Integração Social } \\
\text { Políticas Inclusivas } \\
\text { Programa de Urbanização } \\
\text { Integrado } \\
\text { Áreas definidas como } \\
\text { áreas urbanas }\end{array}$ \\
\hline \multicolumn{3}{|c|}{ Implicação Ética: Observância da Capacidade de Pagamento } \\
\hline
\end{tabular}

\section{PROBLEMÁTICA: Análise de lacunas das Práticas de Gestão}

RELAÇÃO COM A GESTÃO PARA UNIVERSALIZAÇÃO POR REDE PÚBLICA

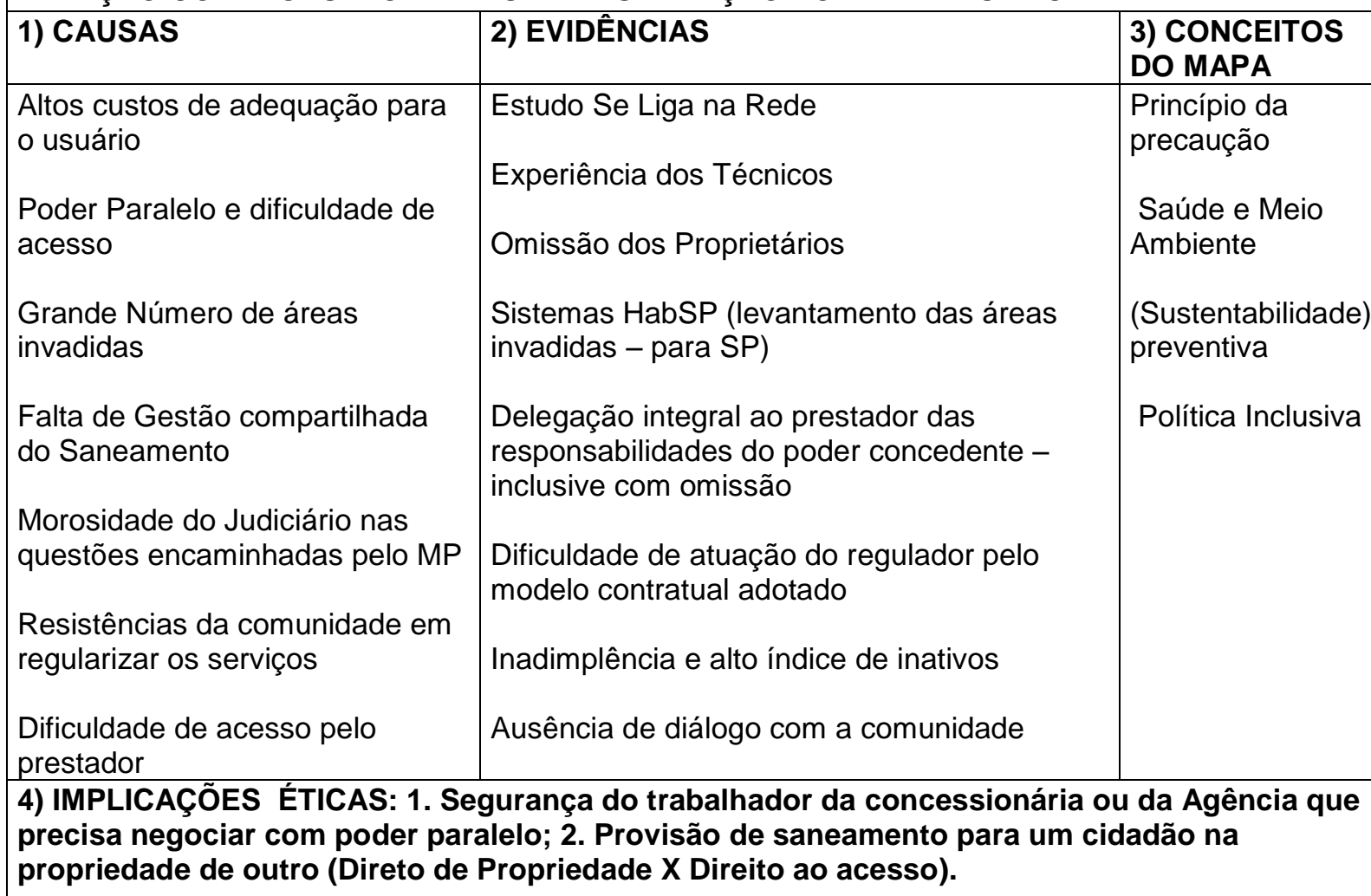

\section{5) BIBLIOGRAFIA: PNQS, Mídia, Publicações em Revistas Indexadas e Revistas das} Associações. 
Essa etapa permitiu diagnosticar-se dois principais problemas que impedem a efetividade do processo e resultado da ação:

O índice de atendimento dos domicílios urbanos com água apresenta alguma incerteza em virtude das situações de ilegalidade no que tange o uso e ocupação do solo;

Os processos e procedimentos de governança não capturam as áreas de assentamento precários, clandestinos e irregulares por estarem na ilegalidade e exclusão pelo fundamento jurídico de direito de propriedade. Em resposta às questões colocadas, diversos conceitos foram criados por meio de triangulação com banco de dados da concessionária e entrevistas a especialistas do setor em diferentes posições, identificando-se que somente dois respondiam às controvérsias do atendimento às populações em áreas de exclusão. Respostas frente às perguntas apresentadas aos grupos de políticas públicas e práticas empresariais foram tabuladas (Tabela 06)).

Tabela 6 - Inovação dos Conceitos de Universalização

\begin{tabular}{|c|c|c|c|c|c|c|c|}
\hline $\begin{array}{l}\text { Construção do } \\
\text { Conceito }\end{array}$ & Quem faz? & O que é? & O como & O Porquê & Para que & Métrica & Indicador \\
\hline $\begin{array}{c}\text { Conceito } \\
\text { Construído } \\
\text { para a } \\
\text { efetividade } \\
\text { do } \\
\text { resultado }\end{array}$ & $\begin{array}{c}\text { Concession } \\
\text { ária em } \\
\text { parceria } \\
\text { com os } \\
\text { demais } \\
\text { segmentos } \\
\text { da } \\
\text { sociedade e } \\
\text { com a } \\
\text { poder } \\
\text { concedente }\end{array}$ & $\begin{array}{c}\text { Atender } \\
100 \% \text { da } \\
\text { populaçã } \\
\text { o (regular } \\
\text { e } \\
\text { irregular) }\end{array}$ & $\begin{array}{c}\text { Por meio } \\
\text { de ações } \\
\text { integradas } \\
\text { e arranjos } \\
\text { sociotécnic } \\
\text { o }\end{array}$ & $\begin{array}{c}\text { população } \\
\text { residente } \\
\text { em áreas } \\
\text { irregulares } \\
\text { tem direito } \\
\text { ao acesso } \\
\text { ao } \\
\text { saneament } \\
\text { o }\end{array}$ & $\begin{array}{c}\text { Para } \\
\text { universaliz } \\
\text { ação } \\
\text { inclusiva }\end{array}$ & $\begin{array}{c}\text { Domicílios } \\
\text { atendidos } \\
\text { nas Áreas } \\
\text { irregulares } \\
\text { / Todos os } \\
\text { Domicílios } \\
\text { contados }\end{array}$ & $\begin{array}{c}\text { Indicador de } \\
\text { Universalizaç } \\
\text { ão Inclusiva } \\
\text { IUI } \\
\text {.Percentual } \\
\text { (0 a 100\%) }\end{array}$ \\
\hline $\begin{array}{c}\text { Conceito } \\
\text { Construído } \\
\text { para a } \\
\text { eficiência } \\
\text { do } \\
\text { processo }\end{array}$ & $\begin{array}{c}\text { Todos: } \\
\text { Prestador } \\
\text { Poder } \\
\text { Concedente } \\
\text { Regulador } \\
\begin{array}{c}\text { sociedade } \\
\text { civil }\end{array}\end{array}$ & $\begin{array}{c}\text { Garantir } \\
0 \\
\text { cumprim } \\
\text { ento de } \\
\text { atribuiçõe } \\
\text { s } \\
\text { dos } \\
\text { envolvido } \\
\text { s na } \\
\text { provisão } \\
\text { do } \\
\text { serviço } \\
\text { essencial }\end{array}$ & $\begin{array}{c}\text { Elaboração } \\
\text { de: } \\
\text { contratos, } \\
\text { leis, } \\
\text { normas e } \\
\text { procedime } \\
\text { ntos } \\
\text { detalhados } \\
\text { com } \\
\text { responsabi } \\
\text { lidades dos } \\
\text { atores } \\
\text { envolvidos }\end{array}$ & $\begin{array}{c}\text { Os } \\
\text { contratos } \\
\text { atuais não } \\
\text { incluem } \\
\text { essas } \\
\text { áreas e } \\
\text { atuação do } \\
\text { regulador } \\
\text { fica } \\
\text { limitada }\end{array}$ & $\begin{array}{c}\text { Para } \\
\text { garantir a } \\
\text { universaliz } \\
\text { ação dos } \\
\text { serviços } \\
\text { essenciais } \\
\text { de água e } \\
\text { esgoto em } \\
\text { áreas } \\
\text { excluídas }\end{array}$ & $\begin{array}{l}\text { Estabeleci } \\
\text { mento de } \\
\text { índice } \\
\text { representat } \\
\text { ivos } \\
\text { (número } \\
\text { absoluto) }\end{array}$ & $\begin{array}{c}\text { Índice de } \\
\text { Governança } \\
\text { Inclusiva } \\
\text { IGI } \\
\text { Número } \\
\text { absoluto } \\
\text { (0 a 1) }\end{array}$ \\
\hline
\end{tabular}


Cumpre previamente definir o conceito adotado de assentamentos precários. Segundo Cardoso (2009), a denominação assentamentos precários faz referência às situações das áreas ocupadas irregularmente, seja do ponto de vista legal, seja do ponto de vista urbanístico, e que apresentem deficiências de infraestrutura e de acessibilidade. Enquadrando o conceito de "precariedade" dentro da formulação das necessidades habitacionais proposta pela Fundação João Pinheiro, pode-se dizer que se trata de uma situação caracterizada fundamentalmente pela inadequação das moradias, em termos fundiários e de infraestrutura. Obviamente podem ocorrer situações de déficit ou de outras formas de inadequação dentro dos assentamentos. (Primeiro, 2010)

O conceito de assentamentos precários engloba diversas tipologias habitacionais, tendo como características comuns à precariedade das condições de moradia e sua origem histórica. Definidos como uma categoria abrangente de inúmeras situações de inadequação habitacional e de irregularidade seja urbanística - quanto ao parcelamento do solo e em relação à edificação, com o descumprimento da legislação de uso e ocupação do solo, seja ambiental — com a ocupação de áreas de risco e de proteção ambiental, seja fundiária - quanto à propriedade da terra - que constituem as formas predominantes de moradia das pessoas e famílias de baixa renda no Brasil (CARDOSO, 2009).

Considerando o contexto urbano, obteve-se como redação final para os conceitos inovadores para o saneamento construídos nas oficinas:

> Conceito Construído para a efetividade do resultado: chamou-se de Universalização Inclusiva, o resultado do processo realizado pela concessionária, em parceria com os demais segmentos da sociedade e com a poder concedente, para atender toda a população de áreas de exclusão social, por meio de ações integradas, junto à população residente em áreas irregulares para que tenha acesso ao mínimo saneamento básico. Para o conceito, construiu-se nas oficinas o Indicador de Universalização Inclusiva IUI, que será o número de ligações realizadas nessas áreas dividido pelo número total de habitações nelas existentes, objeto de Estudo em regime regulado. Indicador inédito para atuação nas áreas irregulares, assentamentos precários e aglomerados subnormais. 
> Conceito Construído para a eficiência do processo: chamou-se de Governança Inclusiva, que é o processo para garantir o cumprimento das funções do poder concedente, concessionária, regulador e entidades governamentais por meio de instrumentos institucionais com atribuições e competências claras e detalhadas de todos os atores para a universalização inclusiva dos serviços de saneamento, que promovam a participação social e permitam o controle social. Para o conceito, construiu-se nas oficinas o Indice de Governança Inclusiva - IGI. Indicador inédito para uma governança que acompanhe e promova a atuação nas áreas irregulares, assentamentos precários e aglomerados subnormais.

> Conceito Construído para a eficácia social: chamou-se Outcomes do Saneamento, que é a condição de perigo que vivem pessoas de baixa renda, com baixa resiliência, em áreas urbanas ou rurais, afetadas pelo direito de saneamento (cidade), que são expostas a riscos de saúde, ambientais, socioculturais e econômicas pela própria produção de vida da comunidade, sem acesso ao uso legal de saneamento, gerando esgotos e desmatamentos, trazendo vetores e doenças e promovendo maiores restrições de sobrevivência, agravando sua própria condição, demandando um sistema de governança para gerencia-la. Índice de Outcomes Sanitário mede os efeitos da universalização inclusiva, que é medido pela saúde - redução da mortalidade infantil, meio ambiente - erradicação de lançamento de esgotos, social - nível de educação, econômica - valorização imobiliária por meio de dados oficiais IBGE e SEADE para a subsídios à universalização inclusiva dos serviços de saneamento, que promovam a eficácia social. $O$ índice construído não foi testado, pois as bases não foram consideradas consistentes.

> Conceito Construído para a eficácia da gestão empresarial: Vulnerabilidade Empresarial no Saneamento. A vulnerabilidade empresarial, para o modelo do saneamento, pode ser definida pelo risco que sofre uma concessionária que opera centros urbanos, com áreas irregulares e de exclusão social não previstas nos planos municipais de saneamento pelo poder concedente e de negócio pelo organização, de desequilíbrio motivado por custos provenientes de perdas sociais ou súbitas regularizações e implantações de programas habitacionais que demandam redes e ligações para atendimento aos novos 
usuários. Elas estão alocadas em setor censitário possui baixa resiliência financeira de gestão, pois está aleijado de subsídios para investimentos e arrecadação. A gestão empresarial possui baixa adaptação às diversas formas ilegais que uma população adota para acessar serviços públicos de saneamento. A operação ocorre em áreas afetadas pelo dilema do direito de propriedade versus direito humano fundamental, expondo empresa a riscos legais, financeiros e operacionais, frente ao uso ilegal de água e produção de esgotos, adotando modelos de gestão que promovem maiores restrições da governança, agravam a vulnerabilidade socioempresarial, a condição de resiliência e adaptação, demandando um modelo empresarial inovador para gerencia-la. É medida pelo volume social de perdas ou \% de população em condição de exclusão.

\subsection{OFICINA DE INDICADORES INÉDITOS}

Indicador é uma ferramenta que permite a obtenção de informações sobre uma dada realidade. Deve ser simples de entender, possuir quantificação coerente e comunicar o estado do fenômeno observado. Um índice revela o estado de um sistema ou fenômeno, podendo ser construído para analisar dados através da junção de um jogo de elementos com relacionamentos estabelecidos (Khanna, 2000; Mitchell (1996); Prabhu et. Al (1999); Shields et al., 2002). Um indicador de desempenho é uma medida quantitativa de um aspecto particular do desempenho da concessionária ou do seu nível de serviço. É um instrumento de apoio à monitorização da eficiência e da eficácia da companhia, simplificando uma avaliação que de outro modo seria mais complexa e subjetiva.

A eficiência mede até que ponto os recursos disponíveis são utilizados de modo optimizado para a produção do serviço. A eficácia mede até que ponto os objetivos de gestão, definidos específica e realisticamente, foram cumpridos (ALEGRE et. al., 2000, p. 5-6):

Não são classificados como indicadores de desempenho eventuais indicadores de atividade que traduzem opções de gestão, mas não avaliem diretamente nem eficiência nem eficácia (por exemplo, a percentagem de atividade em regime de outsourcing), assim como também não são indicadores de desempenho aquelas medidas que, sendo relevantes em termos de análise, 
dependem predominantemente de fatores externos (por exemplo, a densidade de ramais por unidade de comprimento de conduta).

Um indicador de desempenho deve conter em si informação relevante, mas é inevitavelmente uma visão parcial da realidade da gestão na sua globalidade, não incorporando em geral toda a sua complexidade. Assim, o seu uso descontextualizado pode levar a interpretações erradas. É necessário analisar sempre os indicadores de desempenho no seu conjunto, com conhecimento de causa, e associados ao contexto em que se inserem.

A partir dos conceitos, adotou-se como princípios para definição dos indicadores o universo de comparação como relevo, status da urbanização, conceito, métrica, frequência, fórmula e sentido para resultados esperados. Identificou-se que dois indicadores são necessários e suficientes para a eficiência do processo e a efetividade do resultado, os quais foram construídos:

\subsubsection{Novo Indicador - Indicador de Universalização Inclusiva - IUI}

Esse indicador inédito medirá efetividade do resultado, onde a população em condição de exclusão, que foi conectada as redes para acessar com autorização legal ou judicial para atendimento aos serviços públicos essenciais de saneamento de uma concessionária. Nesse indicador são considerados exclusivamente os domicílios em áreas irregulares ou clandestinas invadidas (Quadro 10).

Quadro 10 - Indicador de Universalização Inclusiva - IUI

\begin{tabular}{|l|l|l|l|l|}
\hline Descrição dos Indicadores/Índices & \multicolumn{1}{|l|}{$\begin{array}{l}\text { Mét } \\
\text { rica }\end{array}$} & $\begin{array}{l}\text { Frequê } \\
\text { ncia }\end{array}$ & Fórmula & $\begin{array}{l}\text { Sen } \\
\text { tido }\end{array}$ \\
\hline $\begin{array}{l}\text { Objetiva medir os domicílios em aglomerados } \\
\text { subnormais conectados à rede pela concessionária, } \\
\text { em parceria com poder concedente e demais } \\
\text { segmentos da sociedade, para gradativamente } \\
\text { atender toda a população da cidade informal, por } \\
\text { meio de ações integradas, para que a população } \\
\text { residente em áreas de exclusão venha ter acesso } \\
\text { ao saneamento básico. }\end{array}$ & $\begin{array}{l}\text { Anu } \\
\text { al }\end{array}$ & $\begin{array}{l}\text { Domicílios } \\
\text { atendidos } \\
\text { Total } \\
\text { domicílios de } \\
\text { nos } \\
\text { aglomerados } \\
\text { subnormais } \\
\text { do município }\end{array}$ & & \\
\hline
\end{tabular}




\subsubsection{Novo Índice de Governança Inclusiva - IGI}

Esse indicador de eficiência do processo inédito deverá garantir a medição de todas as etapas para o cumprimento das atividades do poder concedente, concessionária, regulador e entidades governamentais, por meio de instrumentos institucionais com atribuições e competências claras e detalhadas, para a universalização inclusiva dos serviços de saneamento, que promovam a participação social e permitam o controle social (Figura 13), cujas seis dimensões da governança inclusiva, como etapas identificadas nas oficinas de práticas e políticas públicas para garantia da universalização inclusiva.

\section{Levantamento periódico das populações excluídas}

2. Planejamento Participativo periódico

3. Programas de Investimentos Contínuos

4. Alocação de Recursos Orçamentários

Referencia: a autora (2014)

Figura 13 - Parâmetros da Governança inclusiva

Os parâmetros identificados representam os estágios para atingimento de uma governança inclusiva. Assim, a governança que é cidadã deverá garantir a integração da gestão aos atuais modelos socioeconômicos, mensurar o compromisso da gestão com a comunidade, contemplar a interdisciplinaridade sociotécnica do assunto, fortalecer a resiliência das comunidades nas suas áreas de assentamento, estabelecer estratégias inclusivas de rede, gerar valor socioambiental, e transformar a condição de vida do usuário equacionando as deficiências das políticas públicas. Incialmente, ele sairá de níveis mínimos, considerando que a mobilização social terá um período para sua articulação e engajamento até atingimento de sua plenitude como o índice igual a 1, partindo de uma situação muito desfavorável em todos os estágios até chegar a muito favorável em todos eles. 
Quadro 11 - Índice de Governança Inclusiva e seus estágios (IGI)

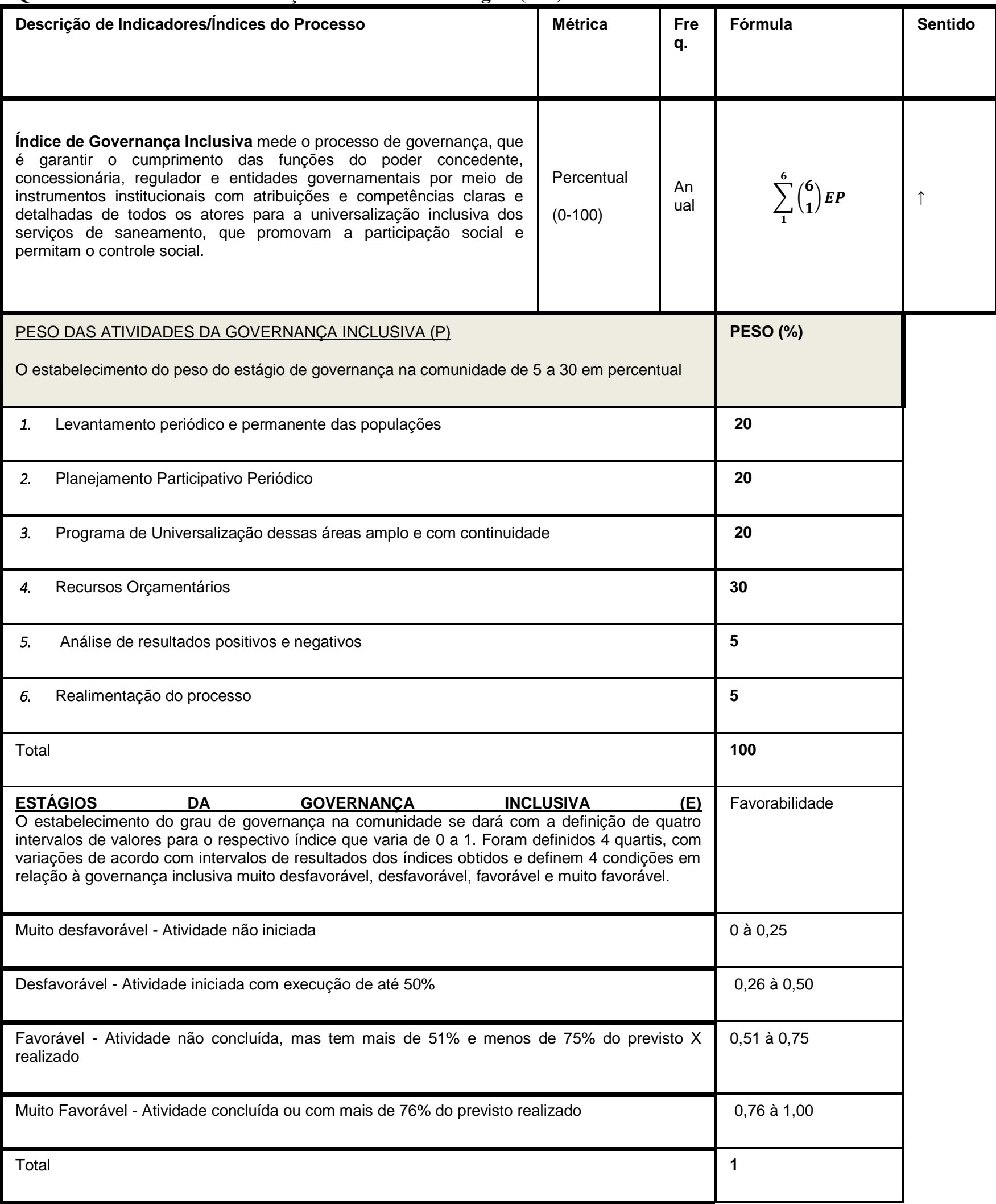

Elaboração: a autora (2014)

Em cada estágio da governança inclusiva avalia-se o desempenho do estágio

pela favorabilidade, e aplica-se o peso estabelecido pela importância do mesmo. 


\subsubsection{Novo Índice de Outcomes do saneamento (externalidades)}

Indicadores de externalidades do processo, no enfoque da sustentabilidade devem representar eficiência, suficiência, qualidade, equidade. Há pontos de alavancagem que podem mudar a estrutura dos sistemas para produzir mais do que queremos e menos do que é indesejável. Pontos de alavancagem frequentemente são contra intuitivos. Alguns são parâmetros imutáveis, outros são pontos de intervenção popular. Eles tornam-se pontos de alavancagem quando entram em intervalos, por exemplo, taxas de natalidade, controle dos ganhos em torno de loops de realimentação de reforço (Meadows, 1990,2003). As externalidades do saneamento identificadas no mapa de controvérsias e oficinas, provenientes dos atos de gestão para a universalização em áreas vulneráveis (Figura 14), afetam positivamente 0 ambiente e sociedade. Para 0 indicador proposto (Quadro 12) considerou-se a externalidade sobre a saúde, meio ambiente, absenteísmo escolar e mercado imobiliário. Este cálculo dependia da construção de uma base de dados que não contava dos objetivos da pesquisa, ficando indicativo para futuros estudos.

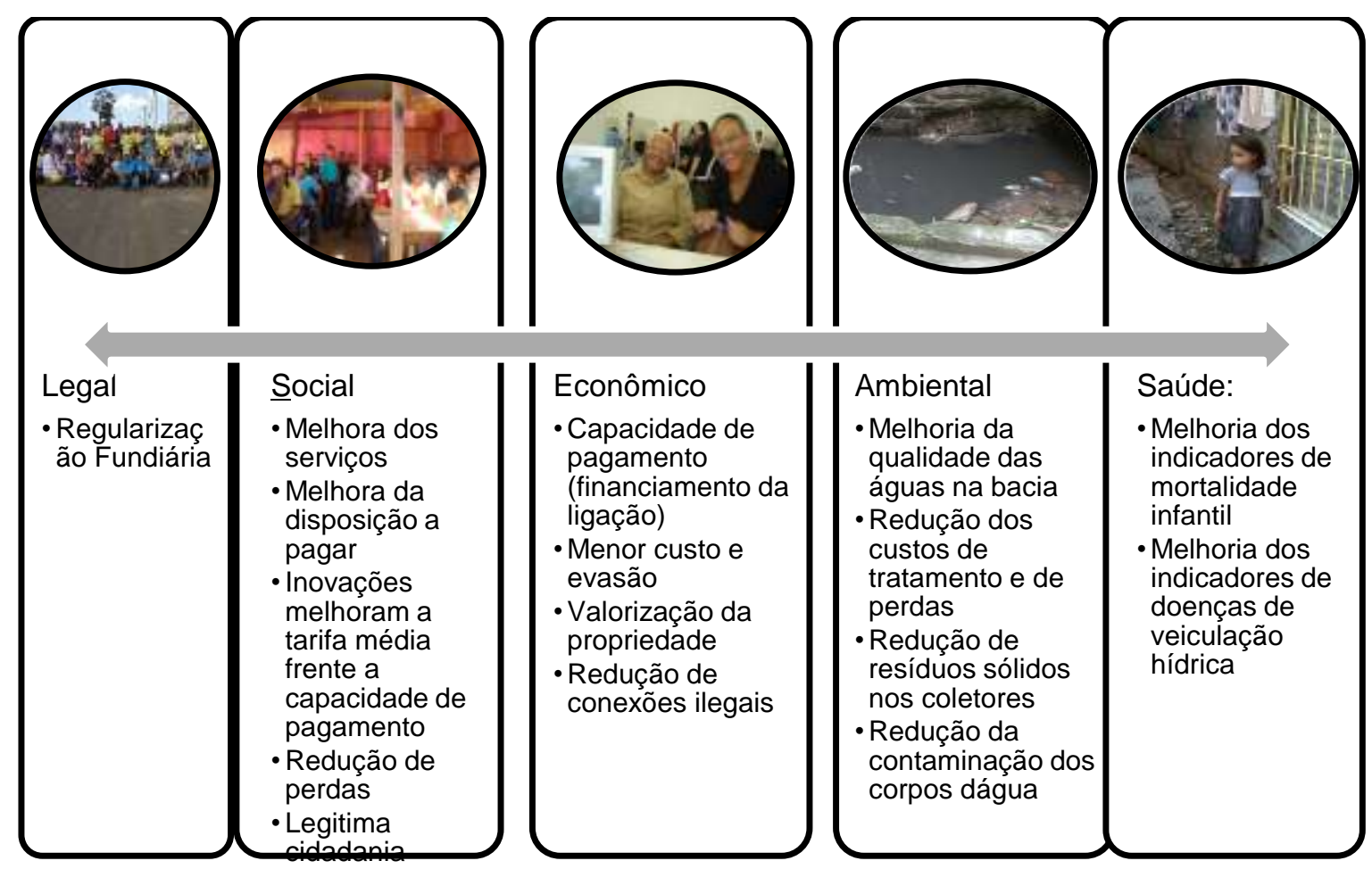

Fonte: a autora(2014)

Figura 14 - Parâmetros dos Outcomes do Saneamento 
Quadro 12 - Índice de Outcomes do Saneamento

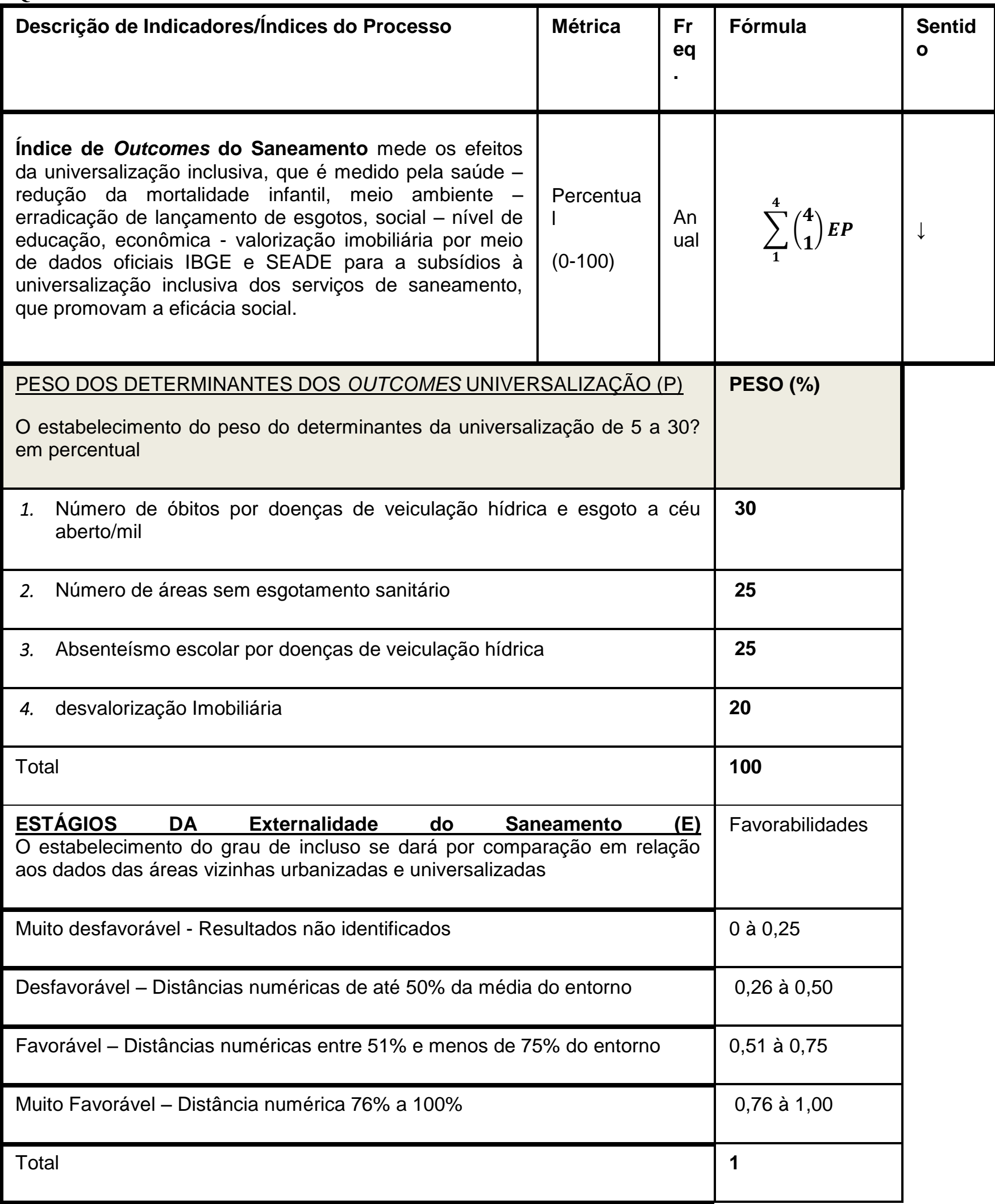

Fonte: a autora (2014) 


\subsubsection{Novo Indicador - Gestão de Dados de Vulnerabiliade Empresarial - IVE}

Desse levantamento, construiu-se um indicador inédito de Risco Regulatório. Esse indicador (Quadro 13) permite mensurar o percentual do abastecimento que atende usuários que necessitam da universalização inclusiva para acessar serviços essenciais, e que estando em áreas de vulnerabilidade socioambiental não estão incluídos em plano de saneamento e nem no planejamento empresarial, desequilibrando o estudo de viabilidade econômico-financeira da concessão.

Quadro 13 - Indicador de Vulnerabilidade Empresarial (IVE)

\begin{tabular}{|c|c|c|c|c|}
\hline Descrição do Indicador & Métrica & Frequência & $\begin{array}{c}\text { Fórmula } \\
\text { (x100) }\end{array}$ & Sentido \\
\hline $\begin{array}{l}\text { Indicador de Vulnerabilidade Empresarial } \\
\text { Objetiva medir o risco proveniente das } \\
\text { incertezas de atender domicílios em } \\
\text { aglomerados subnormais por impedimentos } \\
\text { legais, e mostrar gradativamente a redução dos } \\
\text { riscos sociotécnico de atuação num município. } \\
\text { (IVE): } \\
\text { IVE = Vsocial_x 100\% } \\
\text { Vtperdas } \\
\text { Sendo que: } \\
\text { Vsocial - Vazão Social - contribuições } \\
\text { voluntárias da Operadora } \\
\text { Vtperdas - Vazão Total de Perdas no setor } \\
\text { foco da medição }\end{array}$ & $\%$ & Mensal & $\begin{array}{c}V o x \\
100 \% \\
V t\end{array}$ & $\downarrow$ \\
\hline
\end{tabular}

(elaboração: a autora, 2015).

A aplicação desse indicador representa o percentual do volume de perdas que atende população do município, que não está em áreas atendíveis e não há subsídios para custos ou remuneração prevista nos planos de investimentos para sair dessa condição. É a avaliação qualitativa do risco regulatório da desregulamentação das áreas ocupadas, implicando em aumento de perdas. Esse indicador deverá ser monitorado anualmente, pois a elevação do mesmo 
corresponde ao comprometimento de metas de atendimento em regime de eficiência, definidas pelos reguladores, custo dos serviços, entendimento de ineficiência técnica no benchmarking de indicadores e fator $\mathrm{X}$, e deverá ser monitorado e considerado pelo regulador.

\subsection{DISCUSSÃO}

O fato das concessionárias e reguladores não incluírem nas suas práticas a gestão de dados públicos e empresariais consistentes para o atendimento das populações vulneráveis mostra que a concessionária e agência devem dar foco em sanar essa lacuna, no propósito de atender os objetivos da universalização inclusiva e da eficácia social. E, deste modo, emerge a inovação do regulador de serviços essenciais a minimizar as falhas do mercado.

O diagnóstico promovido pelas oficinas de saberes para conceitos e indicadores contribuiu à construção que contemplasse visões sociotécnicas, conforme os autores Guimarães et al. (2014), Latour (2012), Bossel (1999), Santos (2004); Irar (2005), Malheiros et al. (2006) e Reed (2008). Para avaliar uma situação tentando aproximá-la da realidade dos serviços, no tocante à qualidade e fornecimento às populações vulneráveis, é necessário observar as diversas relações existentes entre cidadãos e concessionária, e, para lidar com tantas informações e reconhecer quais realmente são mais relevantes, foi preciso o auxílio do PNI contendo indicadores, conceitos e metas, para poder-se visualizar a evolução do atendimento em serviços de abastecimento de água e esgotamento sanitário às populações vulneráveis, de forma que a gestão tenha mecanismos mais simples de avaliação.

O plano, indicadores e conceitos de inclusão propostos e validados têm as características necessárias para ter uma visão integrada do funcionamento dos serviços de saneamento nas áreas de exclusão; para expor as fragilidades da gestão e avaliar os fatores que orientam as ações para a universalização inclusiva; para elaborar um plano de ação comparticipação social; e para criar um plano de investimentos. A pressão exercida por diversas partes envolvidas, o impacto das ações de mudança e as respostas a partir de determinadas ações são objetos de uma governança inclusiva. O plano foi organizado utilizando-se 
novos paradigmas de diversas práticas de gestão, autores, listando diferentes problemas para considerar o direito aos serviços essenciais à sobrevivência humana a cidadãos que estão em condição de exclusão.

Nesse sentido, a construção de um modelo de dimensões essenciais, permite identificar os quesitos para um diagnóstico de gestão menos alienada e mais inclusiva para universalização dos serviços essenciais de saneamento em áreas de exclusão.

\subsection{CONCLUSÕES}

A universalização inclusiva somente é alcançada por um esforço conjunto de entes públicos, privados, sociedade civil e comunidade científica. Faz-se mandatório revisitar conceitos, considerar saberes das diversas comunidades, rever metas e indicadores que encobrem as exclusões. Os técnicos-sanitaristas vivem em áreas de conflitos sociais, em algumas, com risco de morte. $O$ saneamento deve estar apoiado em procedimentos e atos para promover $\mathrm{o}$ acesso aos serviços a todos, independentemente de sua condição social ou legal.

Nesse sentido, pontos relevantes foram equacionados. A assimetria de informações, mediante as ferramentas da governança inclusiva favorece a eliminação do mecanismo de exclusões das redes apoiada pelo Indicador de Universalização Inclusiva, pela inovação na forma de planejar e atender áreas vulneráveis reforçando a participação e controle social, independentemente de programas de urbanização apoiados por mecanismos judiciais de regularização. Deve-se, porém, considerar que essa metodologia promove a qualificação à participação de agentes públicos e cidadãos, contribuindo com seus saberes, e favorecendo o empoderamento de todos os atores. 


\section{POLO TÉCNICO}

\subsection{CONSIDERAÇÕES GERAIS}

Este polo guia os procedimentos de coleta de dados e transformação em informações em atendimento a pesquisa. Está ligado às estratégias, técnicas e escolhas práticas para encontro de fatos empíricos. Esta etapa envolveu mobilizar os atores-rede dos programas de urbanização e universalização das áreas de vulnerabilidade social e análise dos usuários subsidiados por tarifa social elegível ao benefício.

O Polo Técnico se deu inicialmente por análise dos Bancos de Dados da SABESP, Secretaria de Assistência Social, Fundação SEADE, seguida de entrevistas, aplicação de questionários (Anexo 2), mediação de painéis e vistorias de campo. Também fez parte deste polo oficinas de pesquisa-ação para refinamento dos parâmetros questionados (Anexo 1), seguidas de aplicação de questionários previamente planejados. O produto final das oficinas foi à elaboração de uma agenda prevendo planos de ações, metas, objetivos, responsabilidades, parcerias, prazos, recursos, monitoramento e avaliação. Nesta etapa foi feita a caracterização das evidências empíricas de campo e de levantamento técnico do setor, análise e sistematização de dados secundários para construção de base empírica de dados, aplicação de questionário aos atores-rede da universalização.

As entrevistas foram qualitativas e quantitativas, com atores-rede do processo de universalização internos à concessionária e externos do setor, segmentados.

O plano da pesquisa de campo incluiu identificação dos aglomerados subnormais, mapeamento em Sistema Geo-referenciado da concessionária, ou alternativamente na base IBGE de Aglomerados Subnormais, na ausência do sistema corporativo, a elaboração do questionário (Anexo 2 - questionário 2), pesquisa piloto. $O$ desenvolvimento da pesquisa em entrevistas e vistorias de campo ocorreu após o cálculo da amostra. Foram feitas a aplicação e edição de questionários; inserção em banco de Dados Access e transferência para o Excel para processamento dos dados das pesquisas, e estudos de correlação do número de domicílios subnormais com ligações clandestinas; análise dos dados e abertura das entrevistas com problemas situacionais. 


\subsection{INVESTIGAÇÃO QUALITATIVA E QUANTITATIVA}

Foram definidos em conjunto com a operadora, um piloto no estado de São Paulo em áreas urbanas com nove municípios e um município metropolitano regulado pela Agência Reguladora de Saneamento e Energia do Estado de São Paulo ARSESP. Atualmente, a concessionária opera todos os municípios da Região Metropolitana da Baixada Santista de São Paulo - RMBSP. O benchmarking adotado pela pesquisadora foi a Unidade de Negócio Norte na RMSP, que realiza um trabalho de relacionamento com as comunidades há 18 anos ininterruptamente com a mesma coordenadora.

A abordagem da dimensão social e técnica adotada propiciou maior abrangência às interpretações com o objetivo de desenvolver o modelo em bases participativas para universalização do saneamento em áreas vulneráveis, ocorrendo pelos seguintes procedimentos:

> Mapeamento das práticas de governança da RMSP, para alavancar a universalização, utilizadas nestas unidades como, por exemplo, práticas conjuntas com as secretarias da habitação, práticas de mutirão com a comunidade e soluções intra-organização.

- Metodologia de parcerias entre empresa e poder público - PARITA

- Encontros comunitários mensais e gestão social

- Ações em parceira com Ministério Público e carta em caráter precário.

> Identificação dos fatores-chave das práticas de gestão como, por exemplo: arranjos entre instituições, softwares e aplicativos de gestão e indicadores sociais participação social.

> Identificação e mobilização dos atores-rede: decisores e gestores da empresa, influenciadores, trabalhadores representantes junto às áreas, líderes comunitários, atores rede do poder público, reguladores, usuários, líderes comunitários e moradores das áreas de vulnerabilidade para análise do modelo e fatores chave das práticas sobre as atividades da operação nas áreas de vulnerabilidade e resultados para o cidadão das diferentes práticas;

O Polo Técnico também contemplou a aplicação de questionário a atores rede (Tabela 07 e Anexo 02) potenciais usuários das áreas de estudo. Teve por objetivo subsidiar as oficinas de gestão, mapeamento de controvérsias e 
identificação dos fatores-chave com os questionários da Tabela 8 , resumidos em 4 formulários (Anexo 2).

Foram entrevistadas a Fundação Seade e a Secretaria de Assistência Social do Estado de São Paulo - SASESP para obtenção de informações e dados que permitissem o estudo do banco de dados das populações vulneráreis categorizações e inclusões nos cadastros de assistência ao cidadão em situação vulnerável e concessionária.

Tabela 7 - Tabela de Entrevistas e Questionários Aplicados ${ }^{10}$

\begin{tabular}{l|c} 
7 - Tabela de Entrevistas e Questionários Aplicados & \\
\hline ATOR-REDE ANT & PESQUISADOS/ENTREVISTADOS \\
\hline Reguladores do Brasil & 14 \\
\hline Concessionárias & 10 \\
\hline Atores do setor no Brasil & 7 \\
\hline Diretoria RMSP - planejamento metropolitana & 17 \\
\hline Unidades de Negócio metropolitanas & 6 \\
\hline Planejamento da presidência & 17 \\
\hline Diretoria de sistemas regionais - RS & 2 \\
\hline Diretoria financeira & 3 \\
\hline Prestadores de serviços & 2 \\
\hline Advogados - escritórios & 3 \\
\hline Fundação Seade & 3 \\
\hline Universidade & 1 \\
\hline Empresa privada & 1 \\
\hline NWSC-Uganda & 2 \\
\hline UNESCO & 1 \\
\hline FMl & 1 \\
\hline Harvard / BIRD & 1 \\
\hline ONU & 22 \\
\hline Atores estratégicos - modelo & 68 \\
\hline Líderes comunitários & 219 \\
\hline Total de atores-rede & 2515 \\
\hline Total de domicílios vistoriados & Fonte: a autora (2015)
\end{tabular}

Tabela 8 - Tipos de Questionários Aplicados

\begin{tabular}{l|l}
\hline & FORMULÁRIO_QUANTIDADE \\
\hline 09052013 & QUESTIONÁRIOS_AGENTE_COMUNITÁRIO_SABESP_30 \\
16072013 & QUESTIONÁRIOS_GESTORES_PARTICIPANTES_IHE-USP_11 \\
20092013 & QUESTIONÁRIOS_ATORES_ABESGO_118 \\
13082013 & QUESTIONÁRIO_MN_LIIDERESCOMUNITÁRIOS_21 \\
09092014 & QUESTIONÁRIO-GESTORES_RS \\
11102014 & LIDERESCOMUNITÁRIOS \\
2015 & VILAMARGARIDA_12+9 \\
& QUESTIONARIO_MS_LIDERES_UGRSANTANA_24 \\
& QUESTIONÁRIO ABES_RS_19 \\
\hline
\end{tabular}




\subsection{INVESTIGAÇÃO QUALITATIVA - REGULADORES CONCESSIONÁRIAS}

Aplicação de questionários e workshops em forma de painel foram organizados pela pesquisadora no $27^{\circ}$ Congresso Nacional de Engenharia Sanitária e Ambiental de Goiás, em setembro de 2013, para avaliação dos temas que afetam a universalização no enfoque dos atores do setor. Do painel de dez reguladores, sendo 2 dos setores de energia e gás (Quadro 14), foi mediadora; e das empresas reguladas, observadora. Ambos foram instados a abordar as dificuldades da universalização em suas áreas de atuação e apresentar, em seus pontos de vista as inovações necessárias ao setor. Foram aplicados questionários (Anexo 2 - questionário 1) a 117 profissionais do setor. Aos reguladores foram encaminhadas questões prévias para apresentarem as dificuldades encontradas para desenvolver o marco regulatório; exercer autonomia administrativa, política e decisória; contratar mão de obra especializada e estudos regulatórios; e realizar programas de capacitação.

Quadro 14 - Painel Desafios dos reguladores para atingir a universalização

\begin{tabular}{|c|c|c|c|}
\hline Painel 1 & & \multicolumn{2}{|c|}{ REGULADORES - coordenadora a pesquisadora } \\
\hline Data: & & \multicolumn{2}{|c|}{$16 / 09 / 2013$} \\
\hline Hora: & & \multicolumn{2}{|c|}{16 às $18 \mathrm{~h} 30 \mathrm{minh}$} \\
\hline Promoção: & & \multicolumn{2}{|c|}{$\begin{array}{l}\text { BID e CÂMARA TÉCNICA DE REGULAÇÃO - Ester Feche } \\
\text { Guimarães }\end{array}$} \\
\hline Relatora & & \multicolumn{2}{|c|}{ Ester Feche Guimarães } \\
\hline Tema: & & \multicolumn{2}{|c|}{$\begin{array}{l}\text { Gestão Regulatória e desafios para desenvolvimento do marco } \\
\text { regulatório }\end{array}$} \\
\hline Observações: & & \multicolumn{2}{|c|}{$\begin{array}{l}\text { Cada regulador relatou as dificuldades que tem enfrentado } \\
\text { para desenvolver o marco regulatório sobre sua } \\
\text { responsabilidade. Quais foram os problemas que encontrou } \\
\text { para exercer sua independência e autonomia? Quais as } \\
\text { dificuldades para contratar ou selecionar mão de obra } \\
\text { especializada? Falta de disponibilidade de fundos para } \\
\text { contratar estudos técnicos ou realizar programas de } \\
\text { capacitação profissional? Dificuldades com as PGEs para } \\
\text { realizar licitações, etc. Este formato deve ser atendido por } \\
\text { todos. }\end{array}$} \\
\hline \multicolumn{4}{|c|}{ Participantes do Painel } \\
\hline \multirow[t]{2}{*}{1} & \multirow[t]{2}{*}{ Nordeste } & \multirow[t]{2}{*}{ AGERSA } & Raimundo Mattos Filgueiras \\
\hline & & & Experiência Bahia \\
\hline \multirow[t]{2}{*}{2} & \multirow[t]{2}{*}{ Sudeste } & \multirow[t]{2}{*}{ ARSESP } & José Luiz de Oliveira \\
\hline & & & Experiência São Paulo \\
\hline \multirow[t]{2}{*}{3} & \multirow[t]{2}{*}{ DF } & \multirow[t]{2}{*}{ ADASA } & Vinicius F. Benevides \\
\hline & & & Experiência Distrito Federal \\
\hline \multirow[t]{2}{*}{4} & \multirow[t]{2}{*}{ Nordeste } & \multirow[t]{2}{*}{ ARCE } & ALCEU GALVÃO \\
\hline & & & Experiência Ceará \\
\hline 5 & Sudeste & ARSEAE & RODRIGO POLIZZI \\
\hline
\end{tabular}




\begin{tabular}{|l|l|l|l|}
\hline & & & Experiência Minas Gerais \\
\hline 6 & Sul & AGERS & Edmundo F. Silva \\
\cline { 4 - 4 } & & Experiência Rio Grande do Sul \\
\hline 7 & Centro-oeste & AGR & Eduardo Henrique Cunha \\
\cline { 4 - 4 } & $\begin{array}{l}\text { Benchmarking } \\
\text { do Gás }\end{array}$ & \multirow{U}{*}{ USP } & Experiência Goiás \\
\hline 8 & $\begin{array}{l}\text { Benchmarking Zevi Kann } \\
\text { da Energia }\end{array}$ & USP & Experiência do Gás \\
\hline 9 & $\begin{array}{l}\text { Governo } \\
\text { Federal }\end{array}$ & PROREG & Experiência da Energia \\
\hline 10 & & Jadir Proença \\
\hline
\end{tabular}

Elaboração: A autora (2013)

Identificaram-se quatro pontos de convergência entre reguladores conforme Tabela 10: 1) Há ausência de diagnósticos que permitam homogeneidade de decisões dos reguladores; 2) Há desconhecimento pelos poderes concedentes da necessária autonomia do regulador para garantia de suas funções; 3) Há dificuldade dos reguladores em exercer a regulação econômica por desconhecimento em profundidade da economia da regulação e/ou indefinições na política de saneamento; e 4.) Há uma demanda de um sistema de indicadores auditado para efeito de parâmetros de eficiência (Gráfico 2).

As empresas de saneamento apresentaram os seguintes tópicos em comum quanto às dificuldades para universalização dos serviços em ambiente regulado: 1) O dilema de recursos da universalização frente à necessidade do cumprimento de deliberações para a eficiência e modernização dos serviços; 2) A quantidade de multas e fiscalizações; e 3) A indefinição da política tarifária para sustentabilidade. 


\section{Tabela 9 - Painel de Reguladores}

Gestão Regulatória e Desafios para Desenvolvimento do Marco Regulatório ${ }^{11}$

\begin{tabular}{|c|c|c|c|c|c|c|c|c|c|c|c|c|c|c|c|c|c|c|c|c|}
\hline Agência & 1 & 2 & 3 & 4 & 5 & 6 & 7 & 8 & 9 & 10 & 11 & 12 & 13 & 14 & 15 & 16 & 17 & 18 & 19 & 20 \\
\hline ADASA & $x$ & $x$ & & & & & & $x$ & & & & & & & & & & & & \\
\hline$A R C E$ & & & & & & & & & & & & & & & & & & & & \\
\hline AGERS & $x$ & $x$ & $x$ & & & $x$ & $x$ & $x$ & $x$ & $x$ & $x$ & $x$ & $x$ & $x$ & & & & & & \\
\hline AGERSA & $x$ & $x$ & & & & & & $x$ & $x$ & & $x$ & & & & & $x$ & & & & \\
\hline$A G R$ & $x$ & $x$ & & & & $x$ & & $x$ & $x$ & & $x$ & $x$ & & & $x$ & $x$ & & $x$ & $x$ & \\
\hline ARSAE & & $x$ & & $x$ & & & & & $x$ & & $x$ & & & & & & & & & $x$ \\
\hline ARSESP & $x$ & $x$ & & & $x$ & & $x$ & & & & & & & & & & $x$ & $x$ & & \\
\hline PROREG & $x$ & & & & $x$ & & $x$ & & & & $x$ & & & & & & $x$ & $x$ & $x$ & \\
\hline
\end{tabular}

Elaboração: a autora (2013)

${ }^{11}$ Legenda numeração Tabela 10: 1. Dificuldades para exercer autonomia administrativa; 2 . Dificuldades com orçamento para mao de obra especializada e políticas salariais; 3 . Indisponibilidade de fundos para política tarifária e mecanismo de subsídios; 4 . Baixo nível de recursos para realizar estudos; 5 . Dificuldade quanto a Morosidade para indicação de Diretores e Vinculo ao Executivo; 6. Dificuldades com as revisões tarifárias e preços de serviços; 7. Titularida de RMs e Falta de Condições para o Titular dos serviços; 8. Dificuldades normativas na prestação regionalizada; 9. Elaborar Planos de Saneamento; 10. Elaborar estudo comprovando a viabilidade; 11. Implantar instrumentos de controle e informação; 12. Definir política tarifária e de subsídios; 13. Aceite de mecanismos de subsídios entre municípios; 14. Criação de Leis municipais com taxas de serviços; 15. Dificuldade na funcionalidade do Conselho Estadual; 16 . Dificuldade com regramento de serviços não regulados; 17. Delimitações das funções regulatórias de Meio ambiente Recursos Hídricos Saúde MP Defesa do Consumidor da Concorrência; 18. Deficits para Transparência e Assimetria de Informaçõés; 19. Necessidade de Referencias Compatíveis; 20. Agência não é multisetorial 
Gráfico 2 - Desafios para implantação do Marco Regulatório ${ }^{12}$

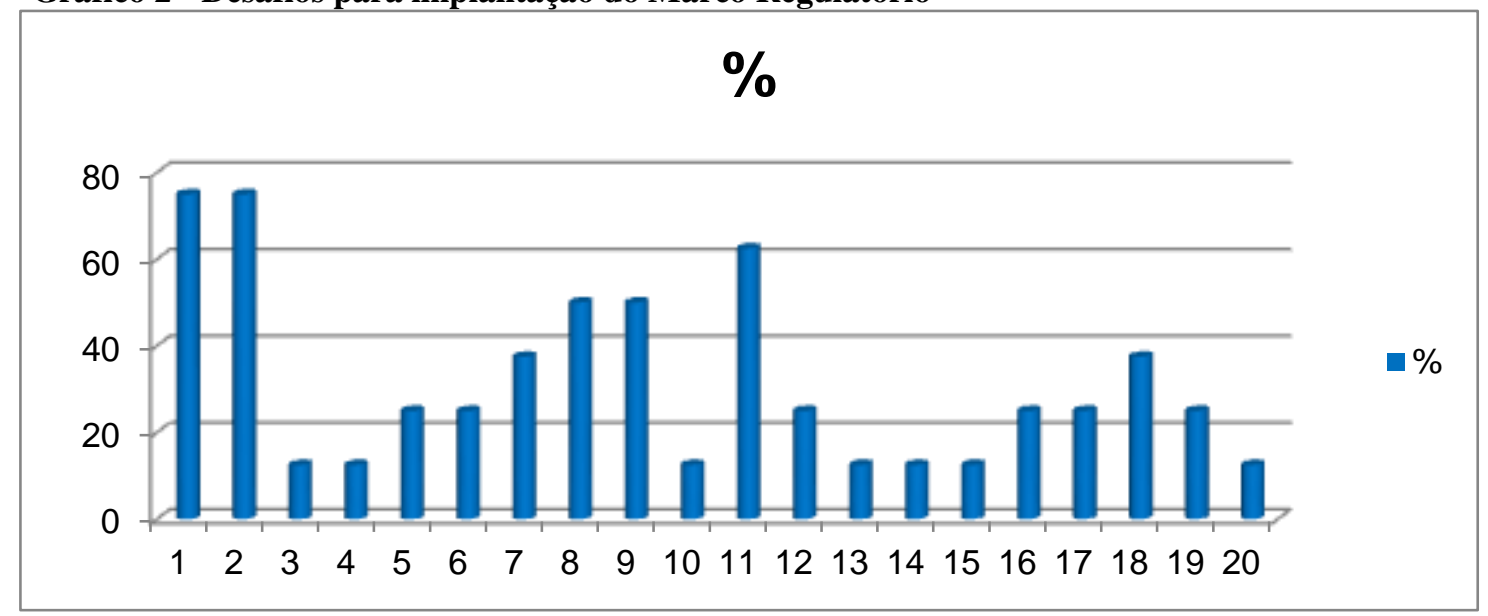

Elaboração: a autora (2013)

\subsection{INVESTIGAÇÃO QUANTITAVA ATORES-REDE DO SETOR}

Nesta etapa, o objetivo foi identificar os impeditivos à universalização no modelo de saneamento adotado à universalização nas áreas vulneráveis e identificação de experiência de sucesso e de fracasso, no enfoque da organização. Ocorreu no período de novembro a dezembro de 2013. Foram investigadas as dimensões: continuidade e permanência dos programas de universalização; qualidade dos serviços; questões econômico-financeiras; instrumentos institucionais da política pública; aspectos chave para promoção da universalização; atores-rede que promovem a universalização; como a concessionária promove 0 acesso aos serviços; barreiras de entrada e governança; análise das dimensões social, econômica, ambiental, patrimonial e da gestão empresarial, quanto ao atendimento às populações vulneráveis; quanto à interferência política e qualidade da administração.

\footnotetext{
12 Legenda numeração Gráfico 02: 1. Dificuldades para exercer autonomia administrativa; 2. Dificuldades com orçamento para mao de obra especializada e políticas salariais; 3. Indisponibilidade de fundos para política tarifária e mecanismo de subsídios; 4. Baixo nível de recursos para realizar estudos; 5 . Dificuldade quanto a Morosidade para indicação de Diretores e Vinculo ao Executivo; 6. Dificuldades com as revisões tarifárias e preços de serviços; 7. Titularida de RMs e Falta de Condições para o Titular dos serviços; 8. Dificuldades normativas na prestação regionalizada; 9. Elaborar Planos de Saneamento; 10. Elaborar estudo comprovando a viabilidade; 11. Implantar instrumentos de controle e informação; 12. Definir política tarifária e de subsídios; 13. Aceite de mecanismos de subsídios entre municípios; 14. Criação de Leis muncipais com taxas de serviços; 15 . Dificuldade na funcionalidade do Conselho Estadua; 16. Dificuldade com regramento de serviços não regulados; 17. Delimitações das funções regulatórias de Meio ambiente Recursos Hídricos Saúde MP Defesa do Consumidor da Concorrência; 18. Deficits para Transparência e Assimetria de Informações; 19. Necessidade de Referencias Compatíveis; 20. Agência não é multisetorial
} 
Inicialmente, os questionários foram testados em entrevistas prévias qualitativas com seis atores chave, conforme agenda e foi construído um formulário final para investigação quantitativa ${ }^{13}$. Os questionários qualitativos foram respondidos voluntariamente por 136 dos participantes do Congresso, que se identificaram como universidade, reguladores, regulados, poder concedente, agentes financeiros. Aqueles que não optaram por nenhuma das alternativas foram classificados como sociedade civil, conforme Gráfico 3.

Gráfico 3 - Distribuição da amostra segundo a Natureza dos Grupos:

Distribuição das Atividades dos Pesquisados

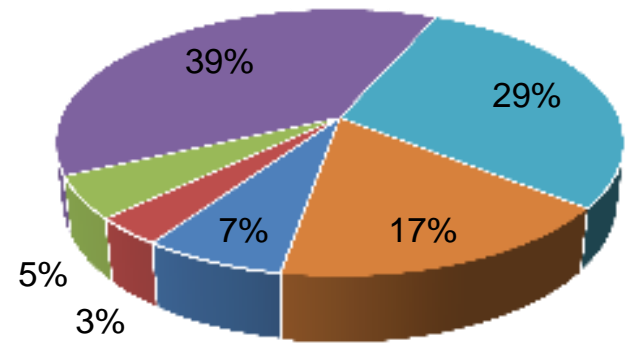

- Agentes Financeiros

- Poder Concedente

- Reguladores

- Regulados

- Sociedade Civil

- Universidade

Elaboração: a autora (2013)

Gráfico 4 - Grupos atuantes na Universalização

1) Quais atores mais atuam em arranjos para universalização em áreas vulneráveis?

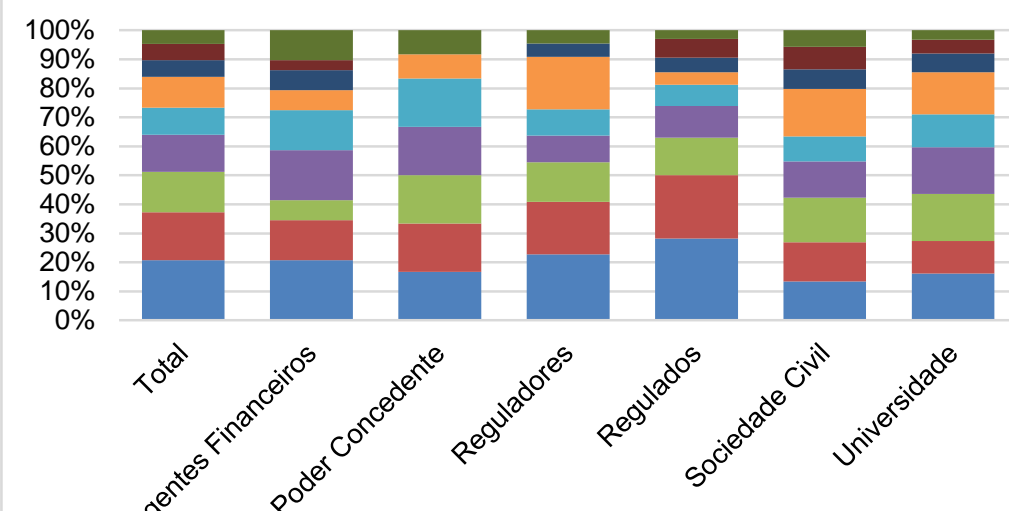

Elaboração: a autora(2013)
- Movimentos Sociais

- Organizações

Religiosas
Fundações

- outros por

Responsabil.Social

- Agentes

Financeiros

- Investidor

- O.N.G.S

negulador

- Comunidade e

Mutirões

- Ministério Público

- Poder Concedente

- Concessionaria

Em média, os respondentes entendem que a concessionária seguida dos movimentos sociais e Ministério Público são os atores mais atuantes nos ${ }^{13}$ Quastionários aplicados no Congresso Nacional da Associação Brasileira de Engenharia Sanitária e
Ambiental 
arranjos para universalização do saneamento em áreas de vulnerabilidade socioambiental (Gráfico 4). São apresentadas no Gráfico 5 as respostas consolidadas, os demais gráficos apresentam as respostas por natureza dos grupos.

Gráfico 5 - Diagnóstico da Universalização do Saneamento

2) O Poder Público tem instrumentos articulados de gestão dessas áreas?

5) Requer uma inovação do planejamento?

6) Da prestação dos serviços?

7) A estrutura tarifária tem robustez para financiar tarifas sociais?

8) Deve haver subsídios focados para os serviços para baixa renda?

9) Essas áreas têm margens financeiras?

10) Acarreta novos custos de produção e distribuição?

11) Acarreta novos custos de serviços e tecnologia?

12) Os clientes tem capacidade de pagamento?

15) Deve-se ter taxas de remuneração diferenciadas?

16) Demanda inovação regulatória?

20) A governança das instituições e a participação social dos usuários nessas áreas nos municípios onde atua...

$100 \% \quad 75 \% \quad 50 \% \quad 25 \% \quad 0 \% \quad 25 \% \quad 50 \% \quad 75 \% \quad 100 \%$

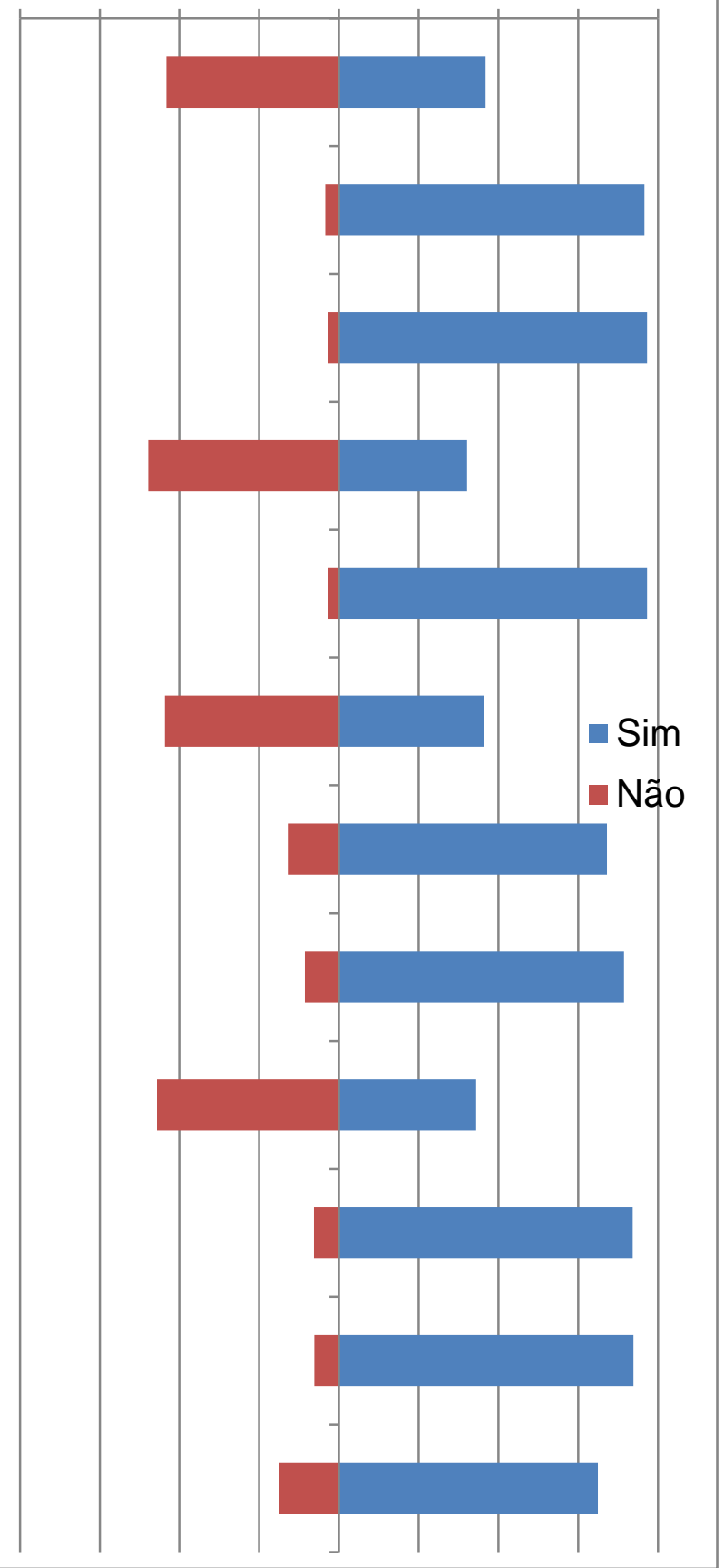

Elaboração: a autora (2013) 
Gráfico 6 - Existência de Instrumentos Articulados de Gestão

2) O Poder Público tem instrumentos articulados de gestão dessas áreas?

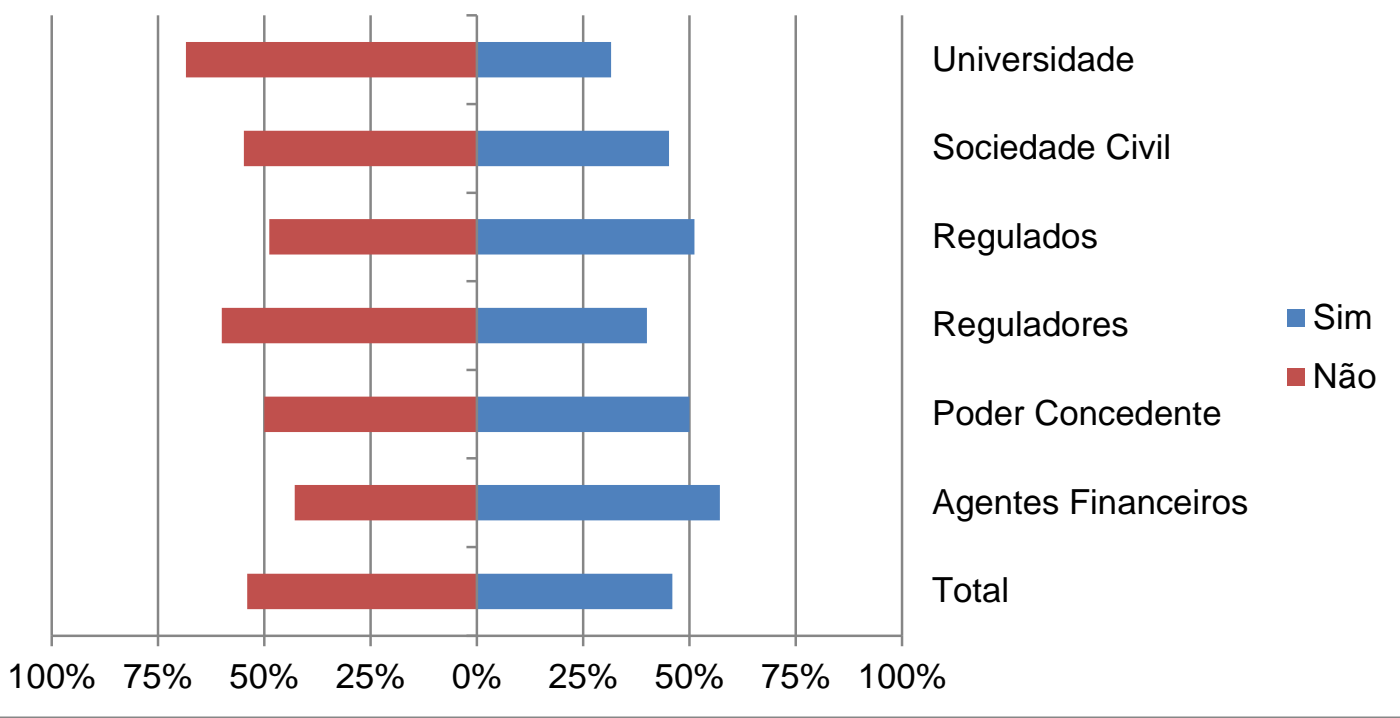

Elaboração: a autora (2013)

Unanimidade que não há instrumentos articulados para equacionamento dos impeditivos à universalização em áreas de exclusão social, conforme Gráfico 6.

Gráfico 7 - Concessionárias e Universalização de Áreas Vulneráveis

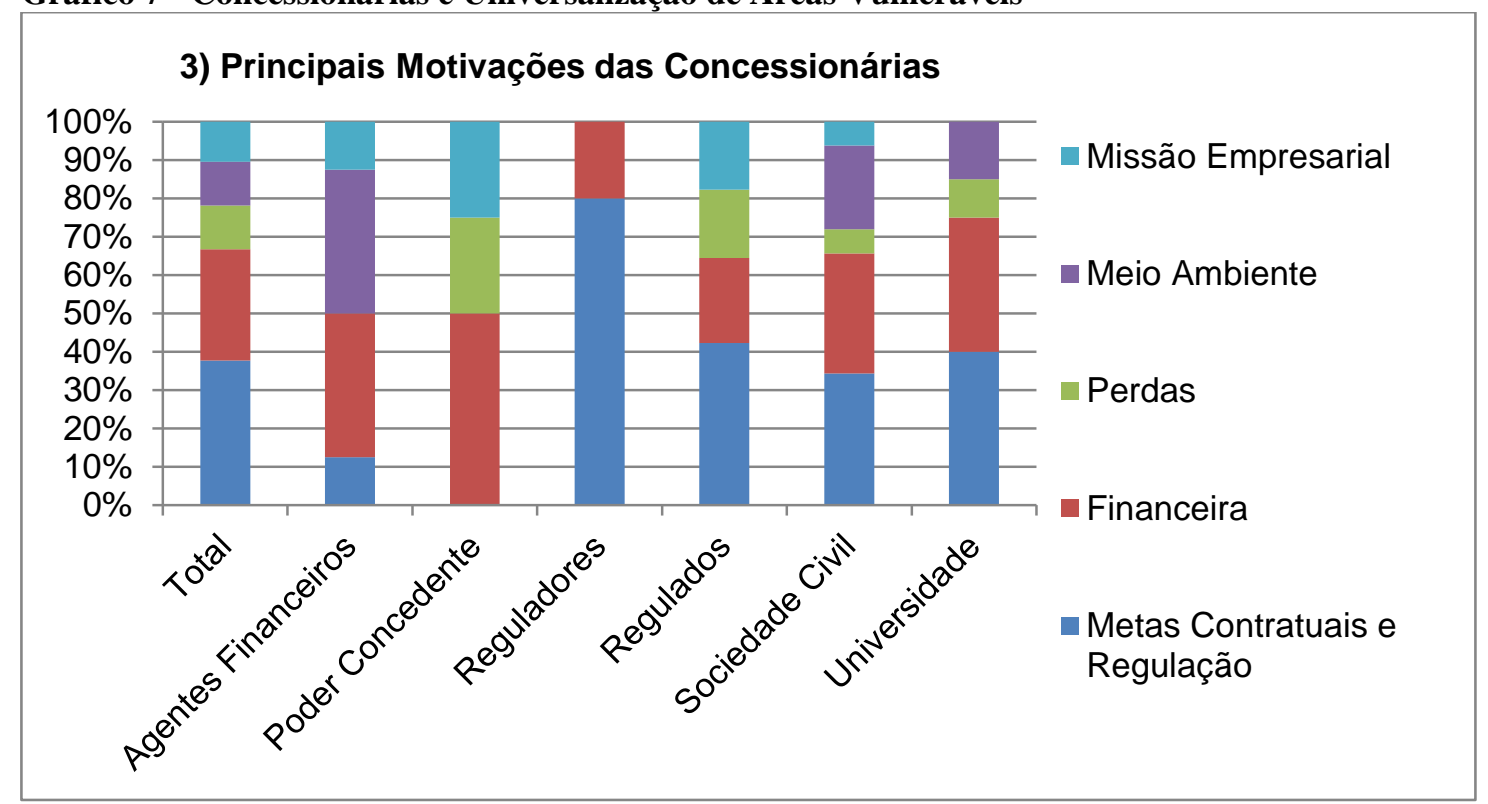

Elaboração: a autora (2013) 
Gráfico 8 - Reguladores e Universalização de Áreas Vulneráveis

4) Quais as principais motivação dos Reguladores?

Deliberaçõ

es

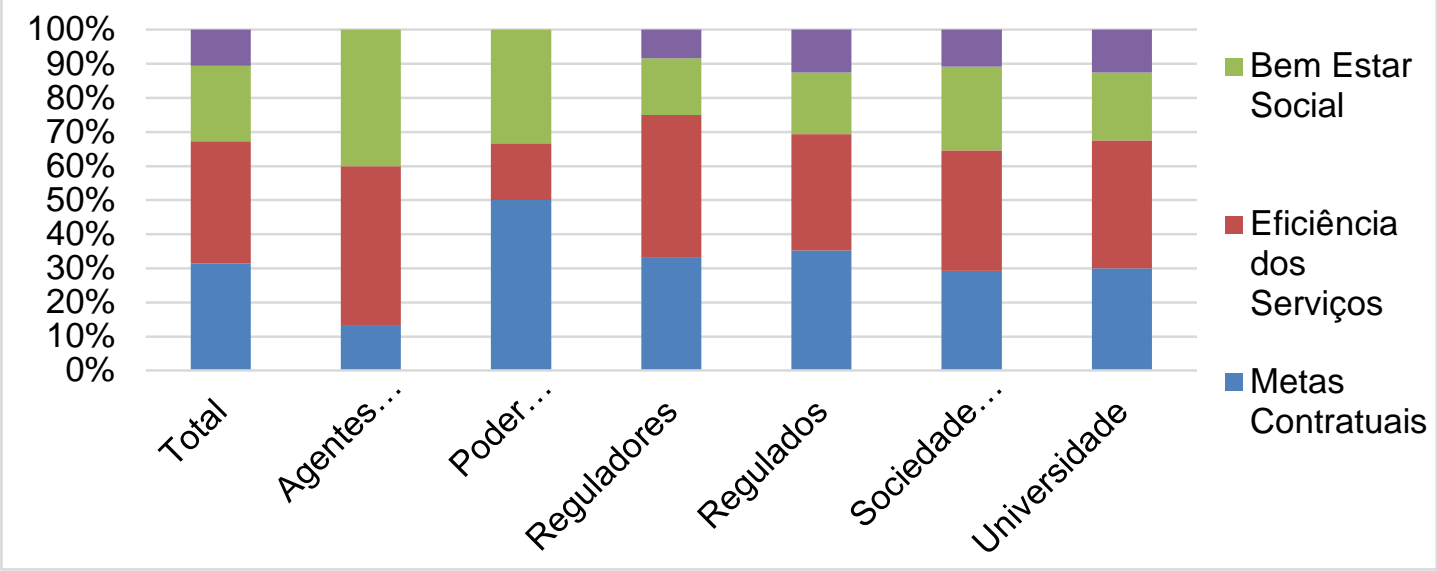

Elaboração: a autora (2013)

Nos Gráficos 7 e 8 identificou-se como principais mecanismos regulatórios: a eficiência dos serviços e as metas contratuais; e mecanismos empresariais: metas contratuais e questões financeiras. Observa-se que as metas contratuais são efetivos gatilhos. O poder concedente, a concessionária e o regulador responderam que as metas contratuais são as maiores motivações para a universalização numa concessão. Os agentes financeiros escolheram a eficiência dos serviços, assim percebe-se porque esse condicionante ainda não foi adotado nos mecanismos de financiamentos.

Gráfico 9 - Planejamento e Universalização de Áreas Vulneráveis

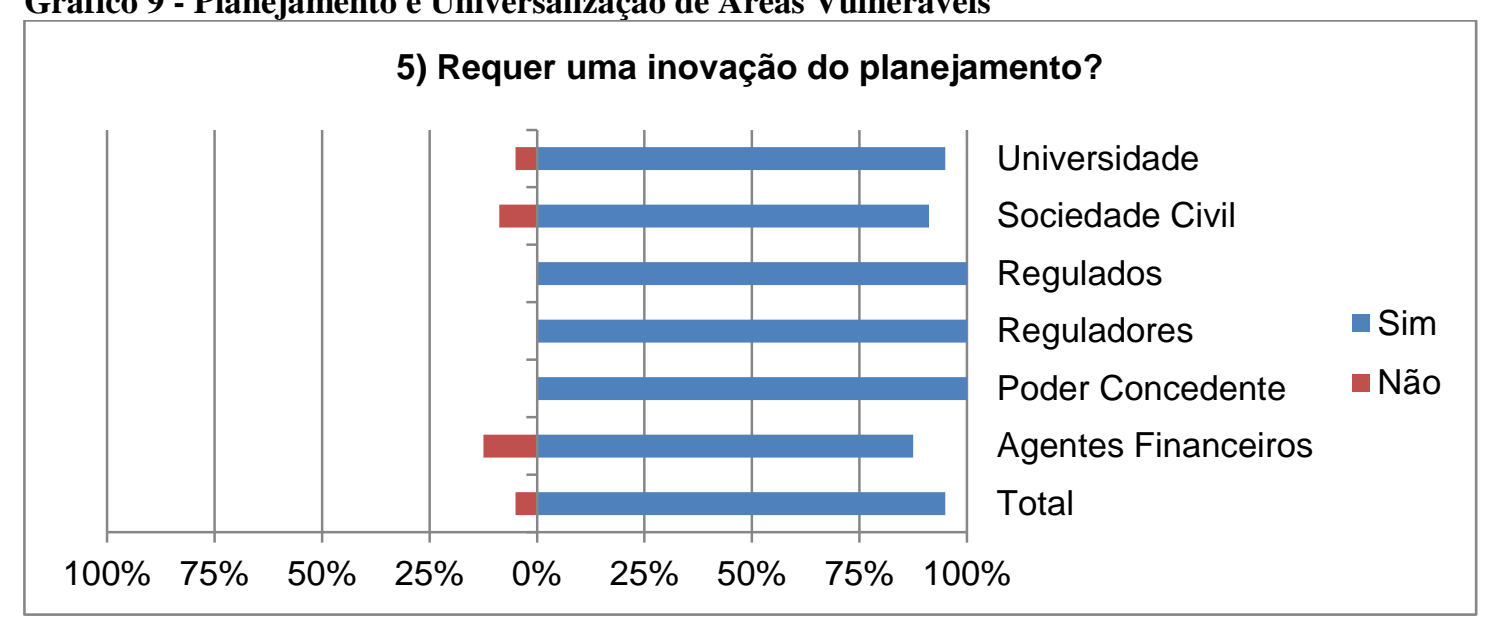

Elaboração: a autora (2013) 
Gráfico 10 - Prestação dos Serviços de Saneamento em Áreas Vulneráveis

6) Requer Inovação da prestação dos serviços?

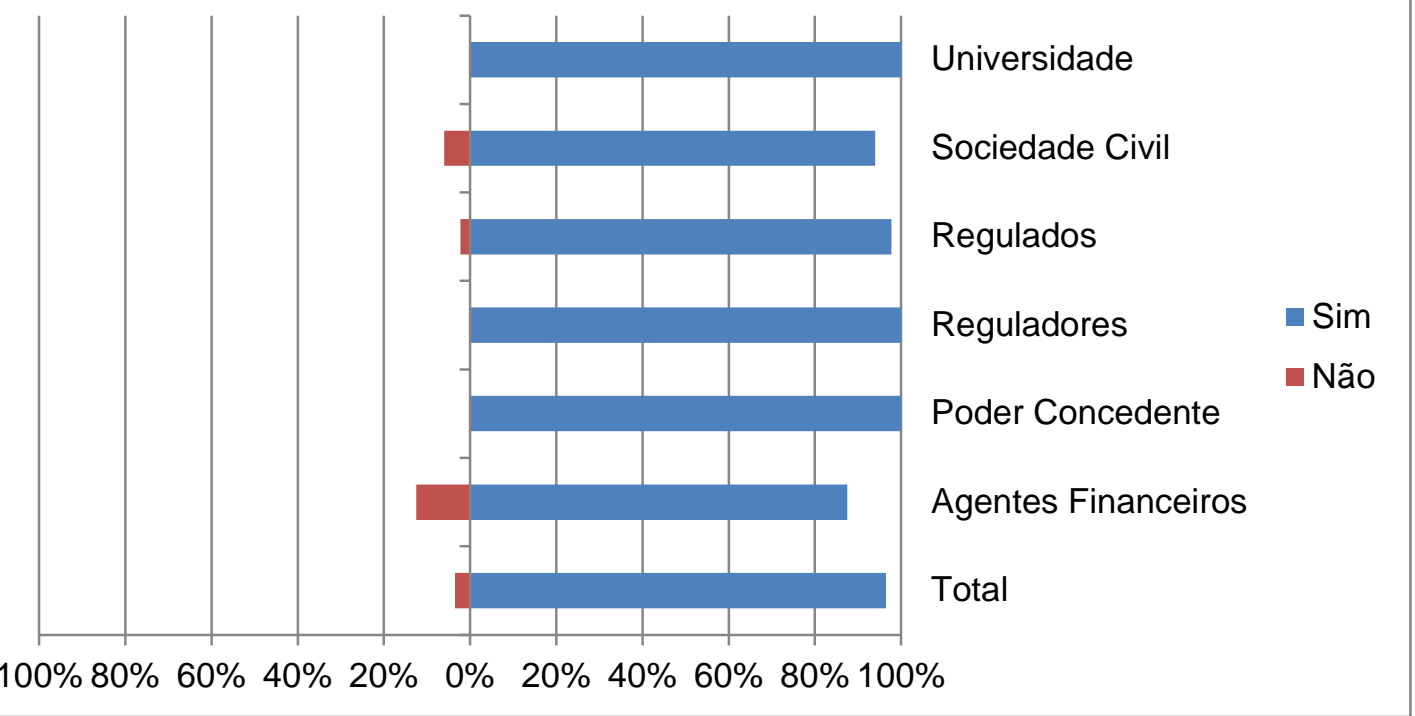

Elaboração: a autora (2013)

Conforme Gráficos 9 e 10 há unanimidade que é necessário inovação do planejamento e da prestação.

Gráfico 11 - Estrutura Tarifária de Áreas Vulneráveis

7) A estrutura tarifária tem robustez para financiar tarifas sociais?

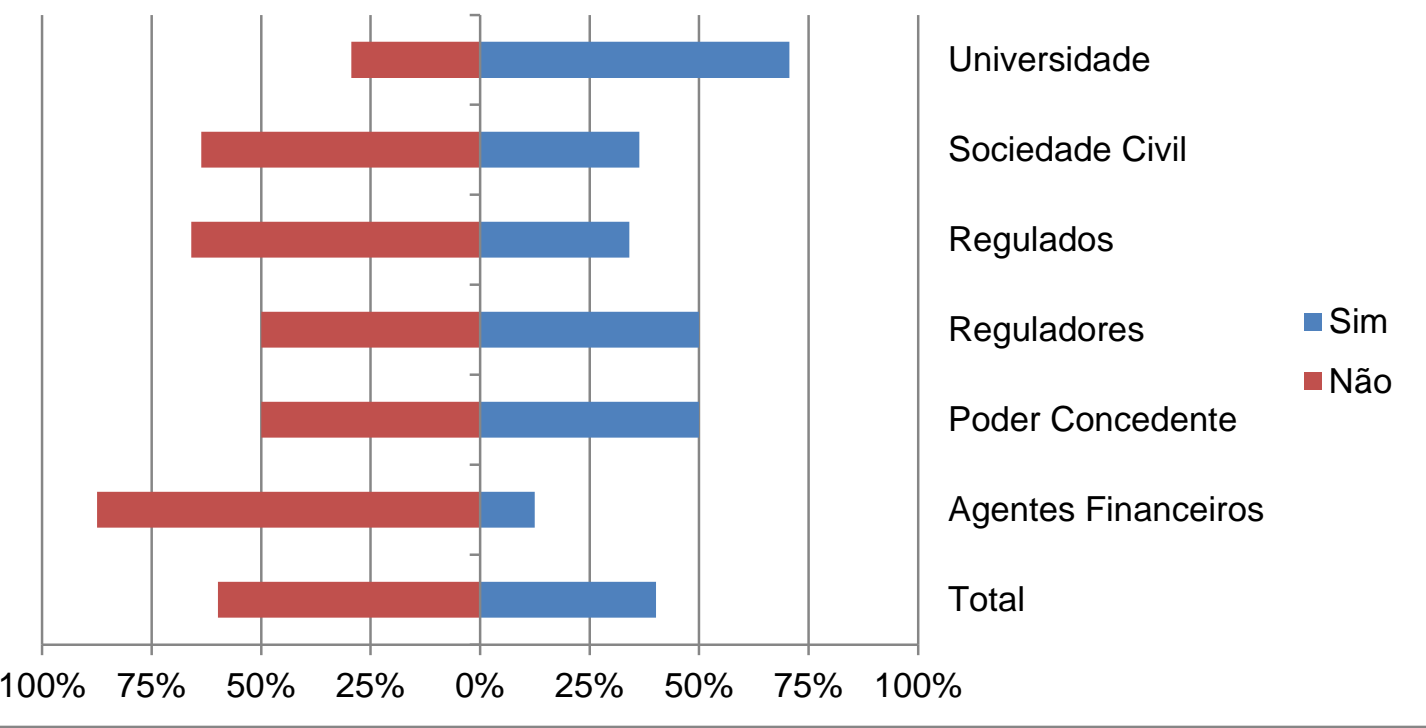

Elaboração: a autora (2013) 
Gráfico 12 - Subsídios Tarifários para Áreas Vulneráveis

8) Deve haver subsídios focados para os serviços para baixa renda?

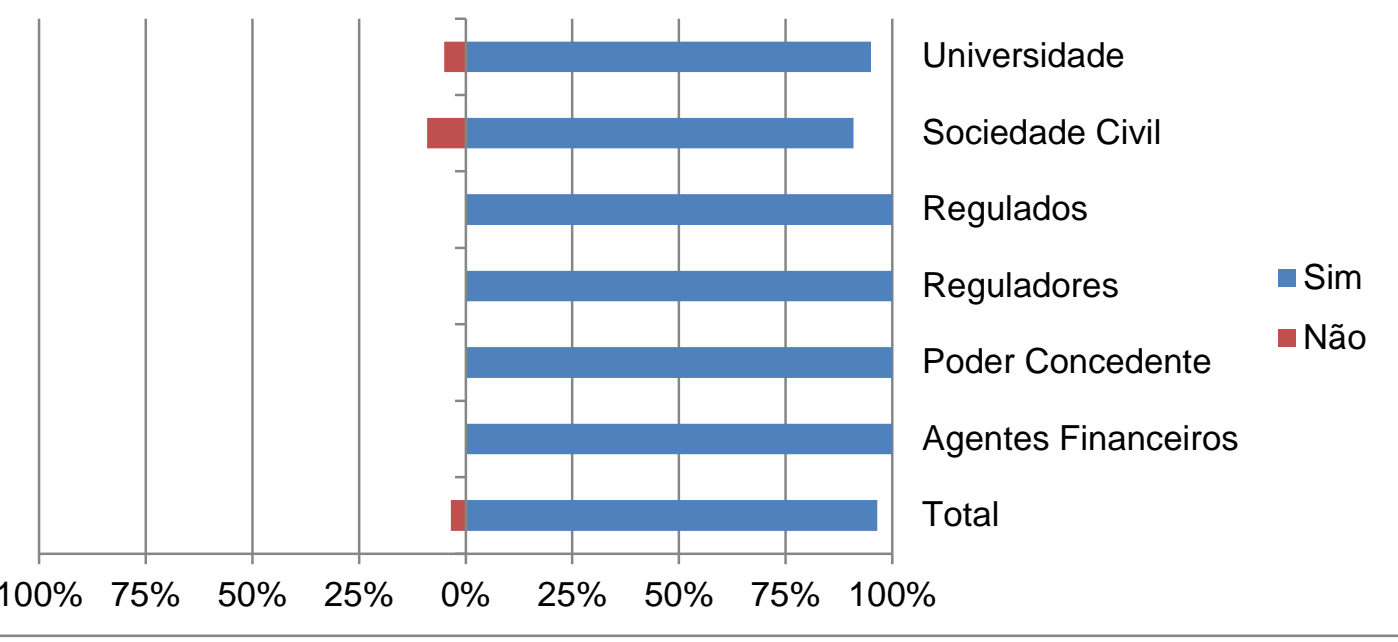

Elaboração: a autora (2013)

Os grupos questionados, exceto a universidade afirma não haver robustez tarifária para universalização, e todos acreditam ser necessário subsídios, conforme gráficos 11 e 12.

Gráfico 13 - Margens Financeiras de Áreas Vulneráveis

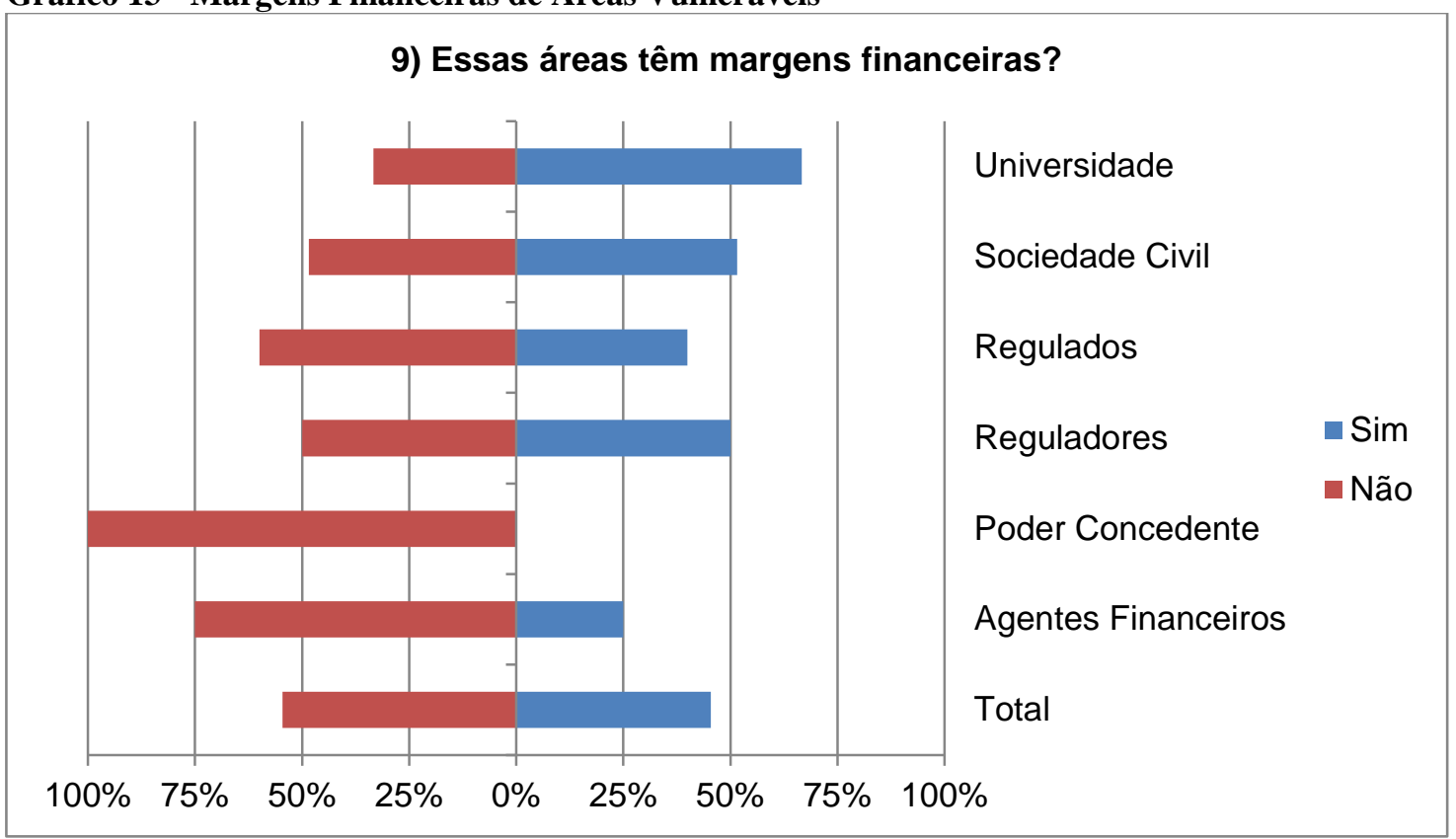

Elaboração: a autora (2013) 
Gráfico 14 - Custos para Operar Áreas Vulneráveis

10) Acarreta novos custos de produção e distribuição?

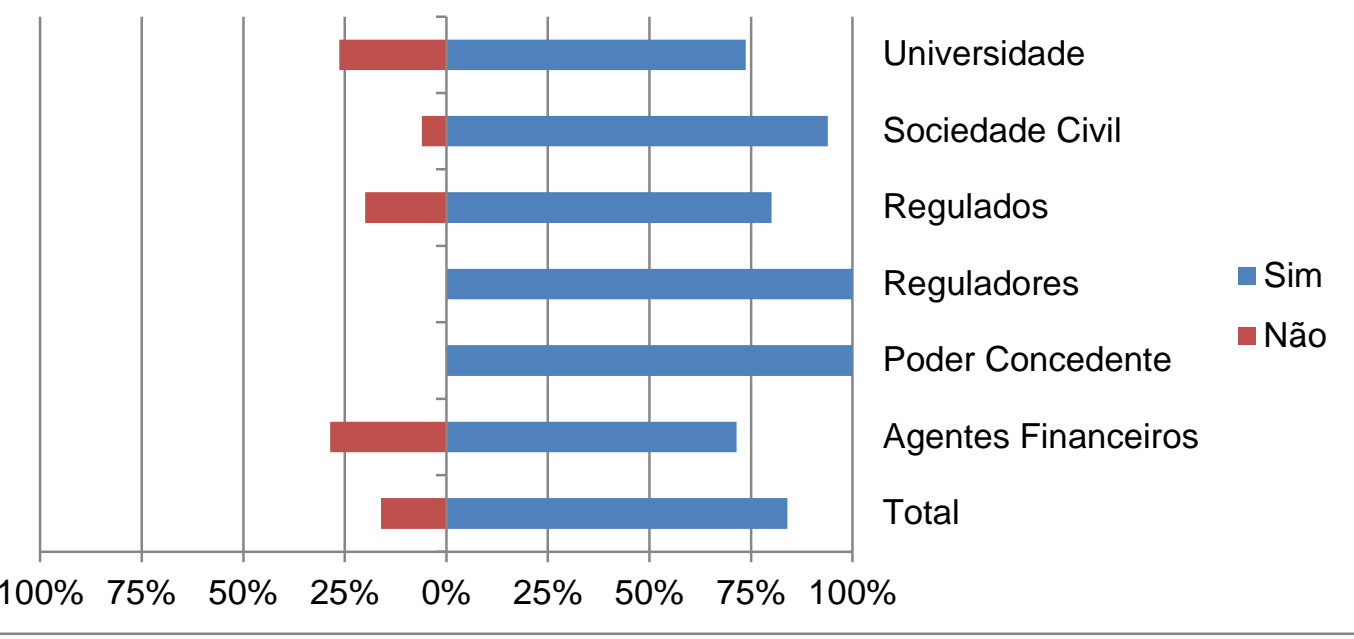

Elaboração: a autora (2013)

A Poder concedente afirmou que não há margens, porém os demais ficaram divididos quanto à capacidade de pagamento do usuário, conforme Gráfico 13.

Há unanimidade que acarreta novos custos atendimento adequado aos SBR, conforme Gráfico 14.

Gráfico 15 - Capacidade de Pagamento de Vulneráveis

12) Os clientes tem capacidade de pagamento?

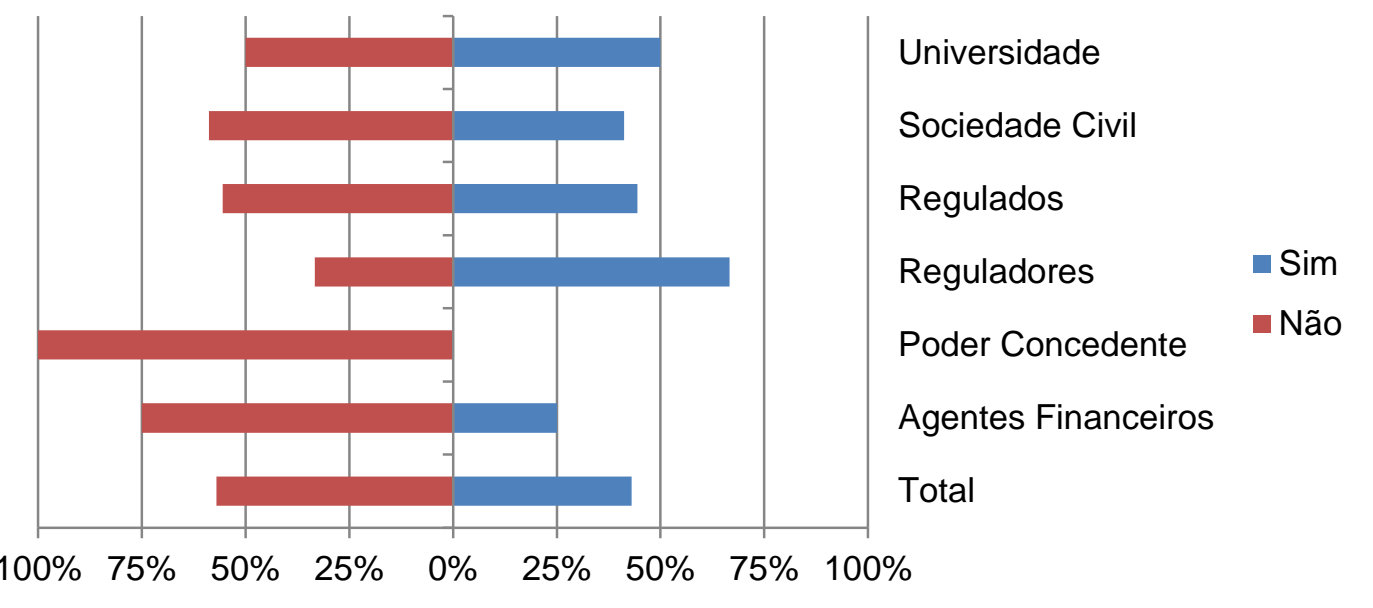

Elaboração: a autora (2013) 
Houve divisão de opiniões quanto à capacidade de pagamento conforme Gráfico 15 e unanimidade nos ganhos pela inclusão na cadeia de valor, conforme Gráfico 16.

\section{Gráfico 16 - Custos para Operar Áreas Vulneráveis}

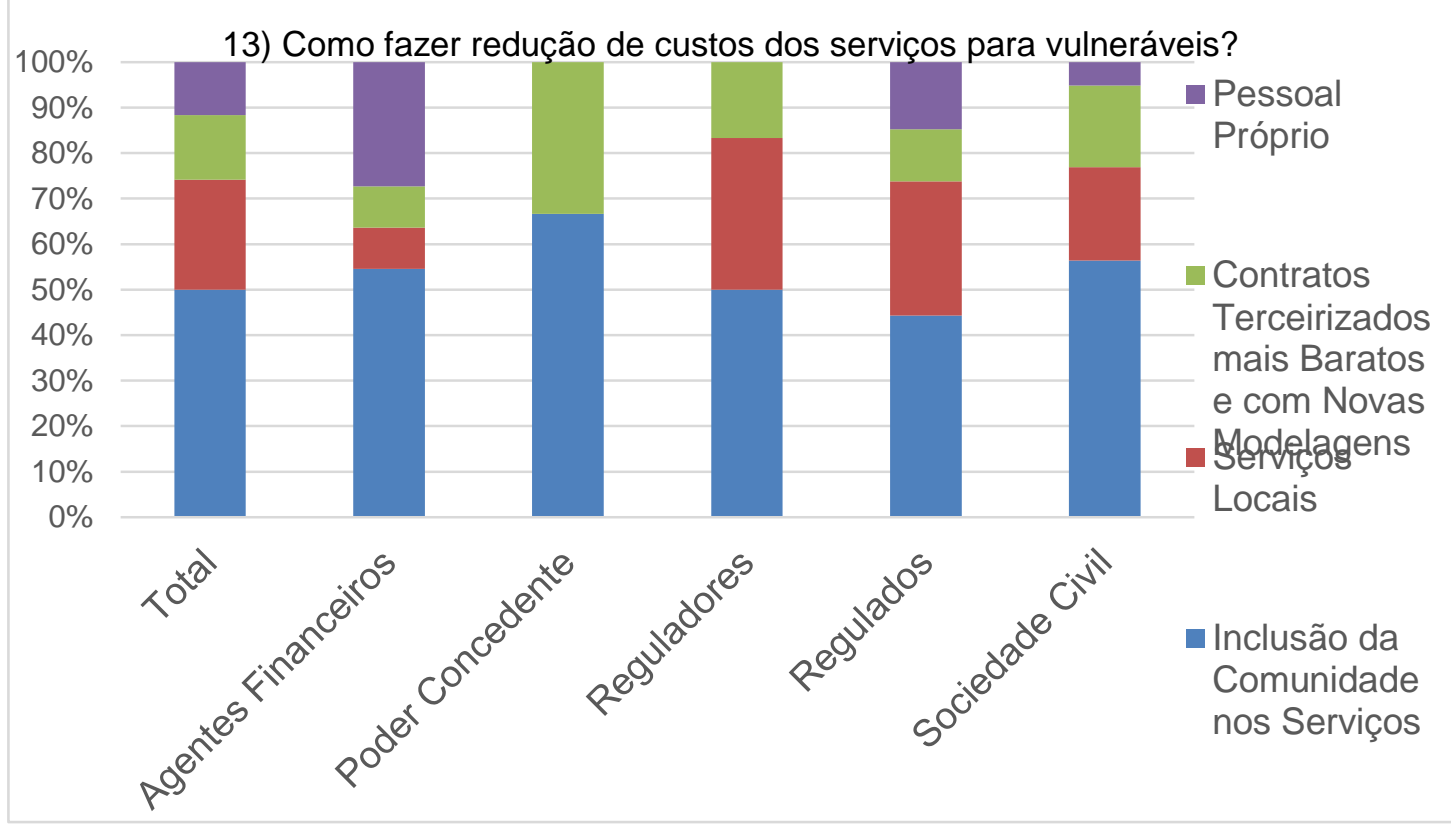

Elaboração: a autora (2013)

Gráfico 17 - Custos dos Ativos das Áreas Vulneráveis

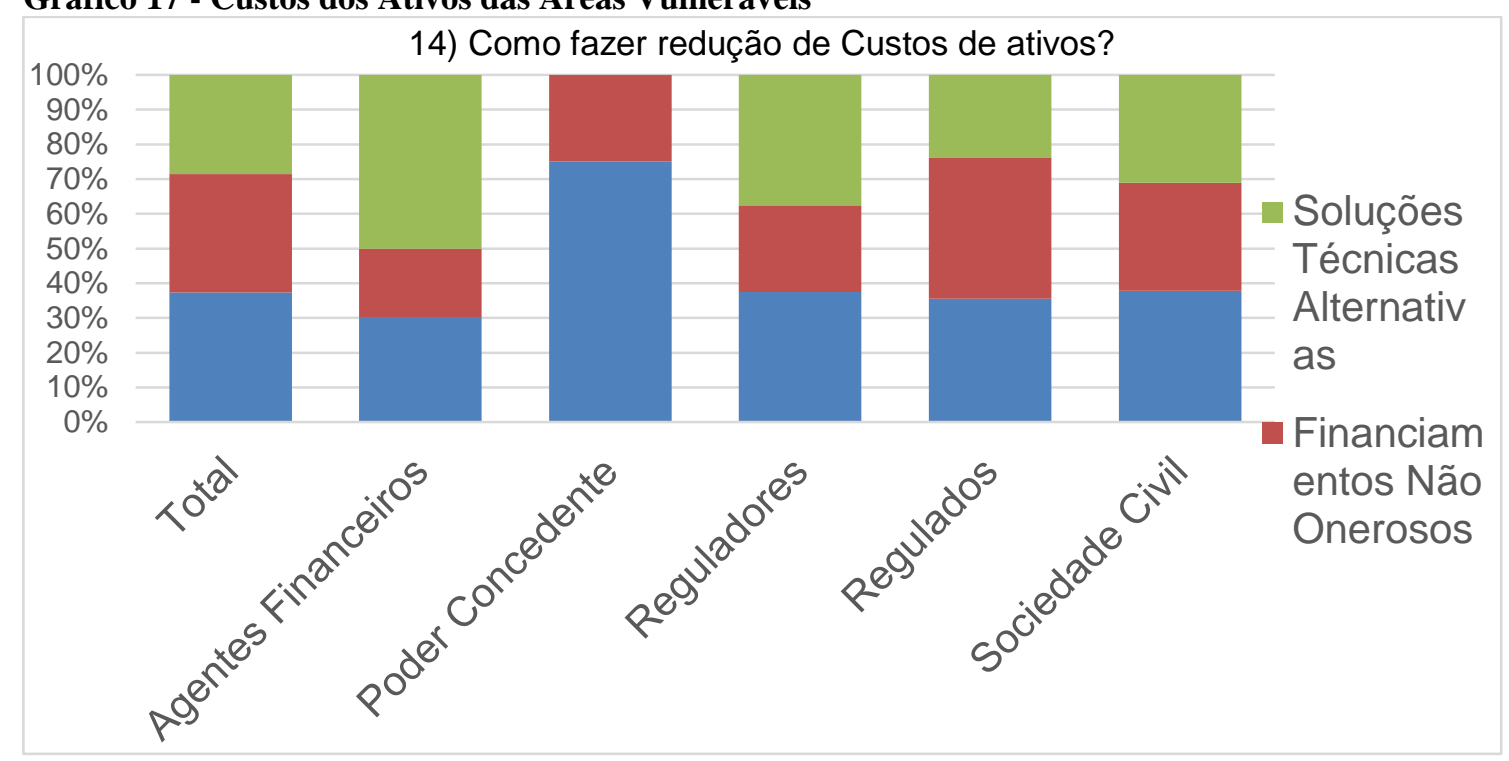

Elaboração: a autora (2013) 
No Gráfico 17, para a redução dos custos de investimentos, os respondentes optaram por financiamentos não onerosos, exceto só agentes financeiros que entendem que se podem reduzir os custos de investimentos com soluções tecnológicas.

Gráfico 18 - Taxas de Remuneração em Áreas Vulneráveis

15) Deve-se ter taxas de remuneração diferenciadas?

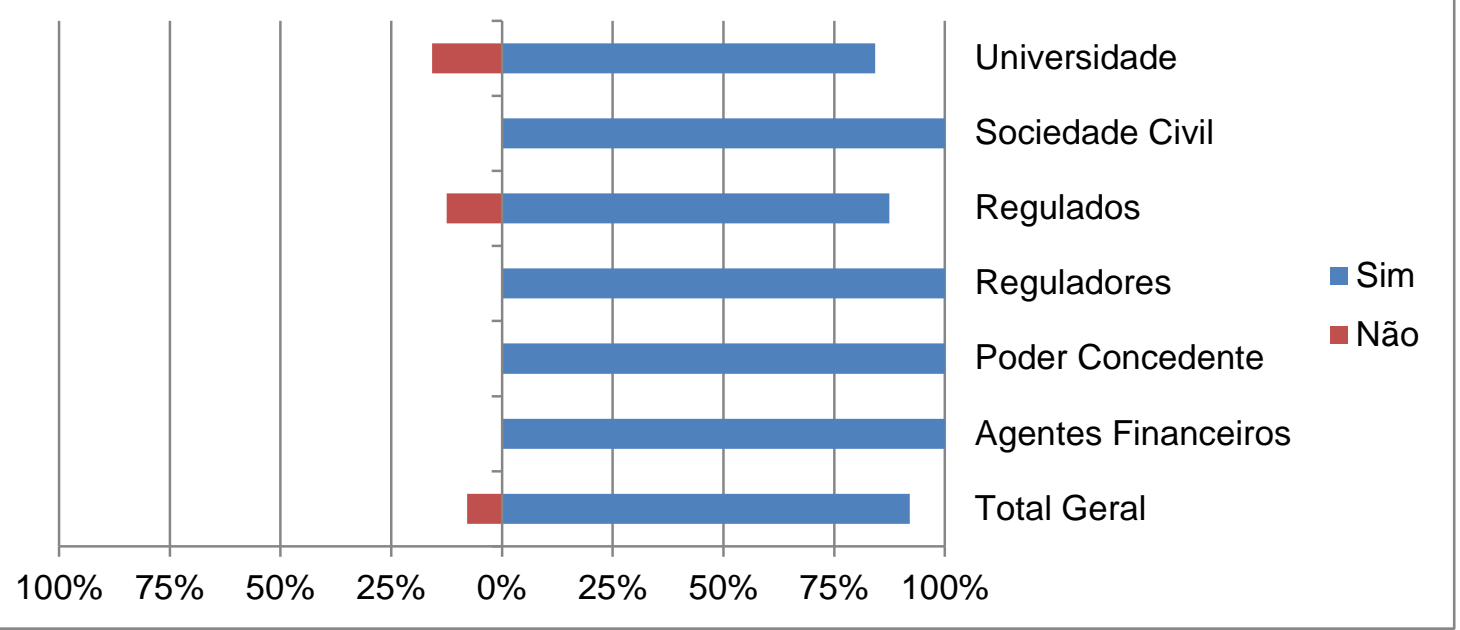

Elaboração: a autora (2013)

As respostas quanto à taxa de remuneração diferenciada foram unanimidade com todos os segmentos de entrevistados no Gráfico 18.

Gráfico 19 - Inovação Regulatória Áreas Vulneráveis

16) Demanda inovação regulatória?

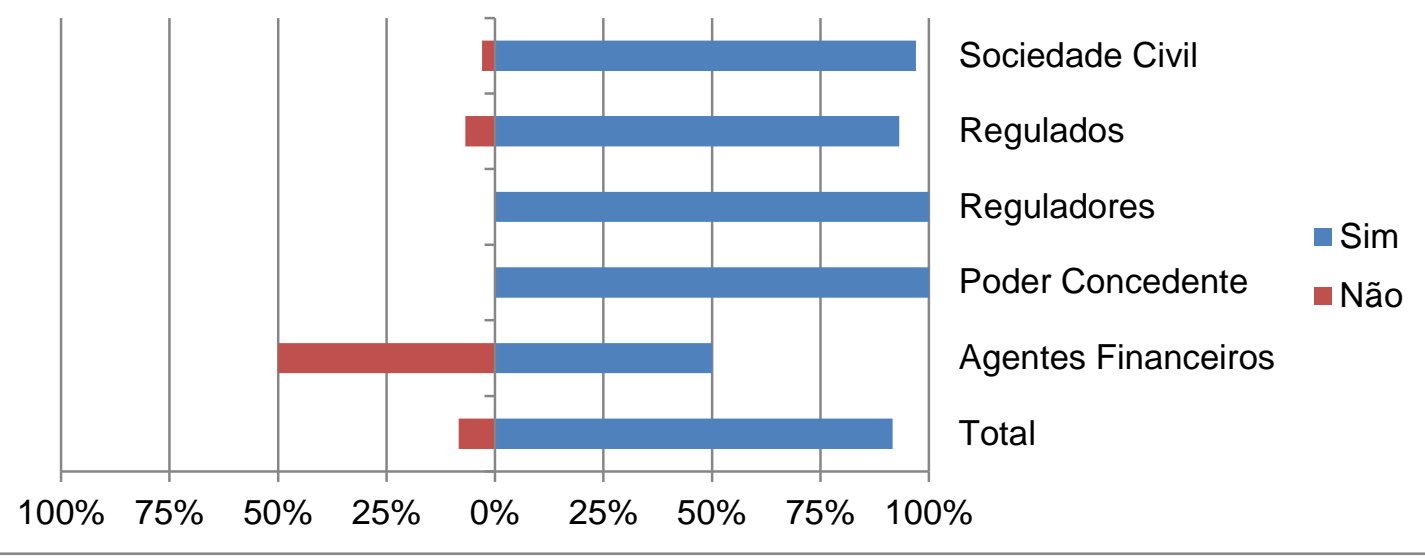

Elaboração: a autora (2013) 
No Gráfico 19 há unanimidade quanto à necessidade da inovação regulatória para o setor, divergindo apenas os agentes financeiros.

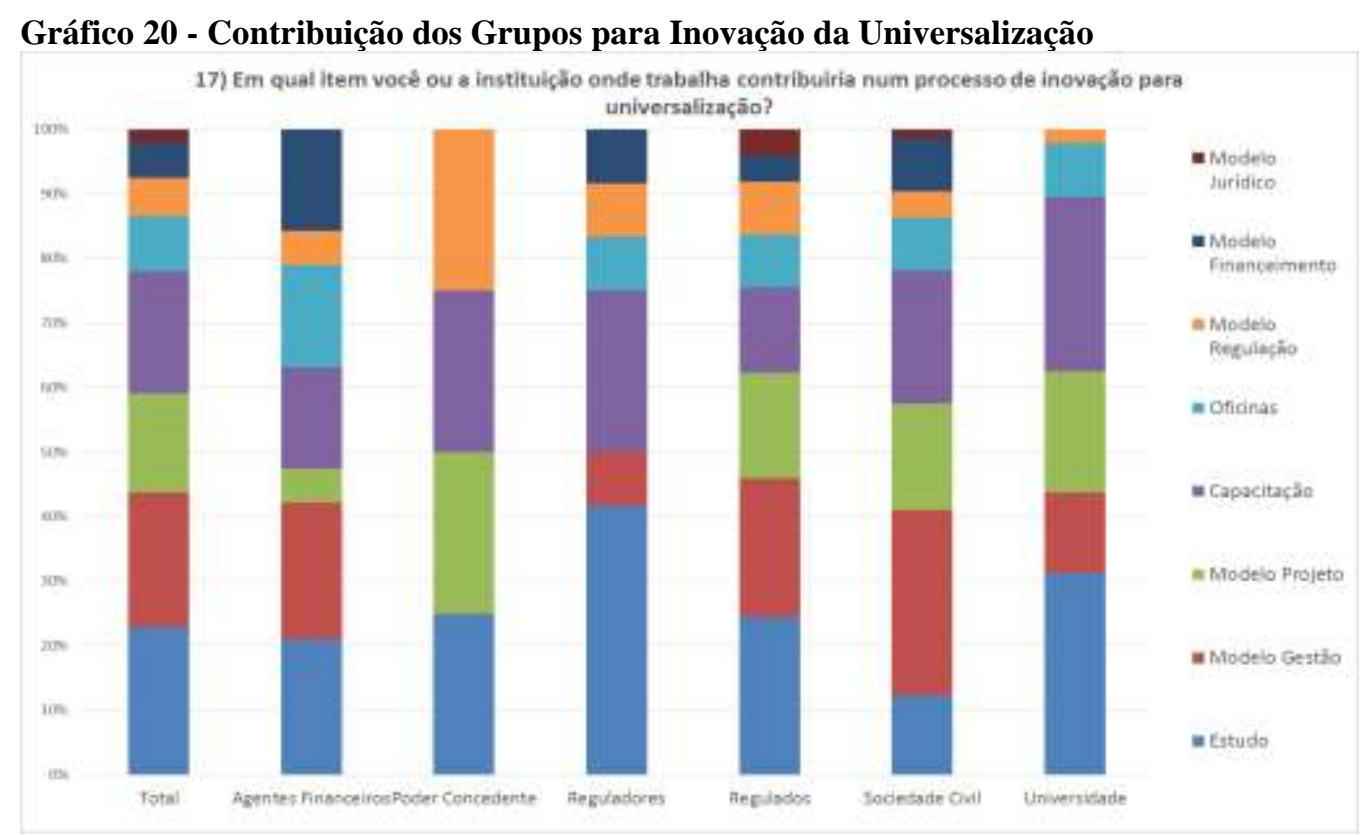

Elaboração: a autora (2013)

O Gráfico 20 demonstra a concentração de profissionais aptos à gestão e atividades correlatas, e poucos nos demais itens como: jurídico e financeiro.

\section{Gráfico 21 - Consciência Ambiental do Usuário de Baixa Renda}

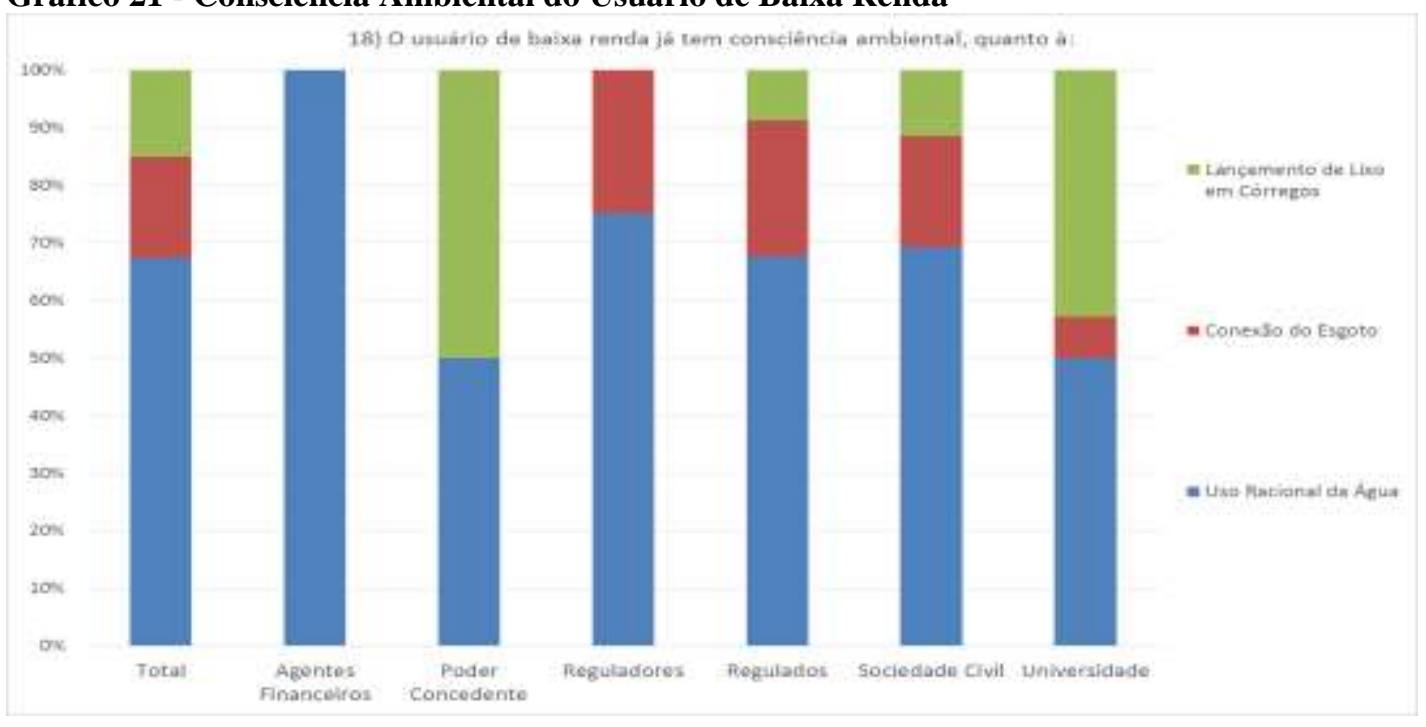

Elaboração: a autora (2013)

No Gráfico 21 há unanimidade que o usuário tem consciência ambiental. 
Gráfico 22 - Qual grupo deve ser inovado

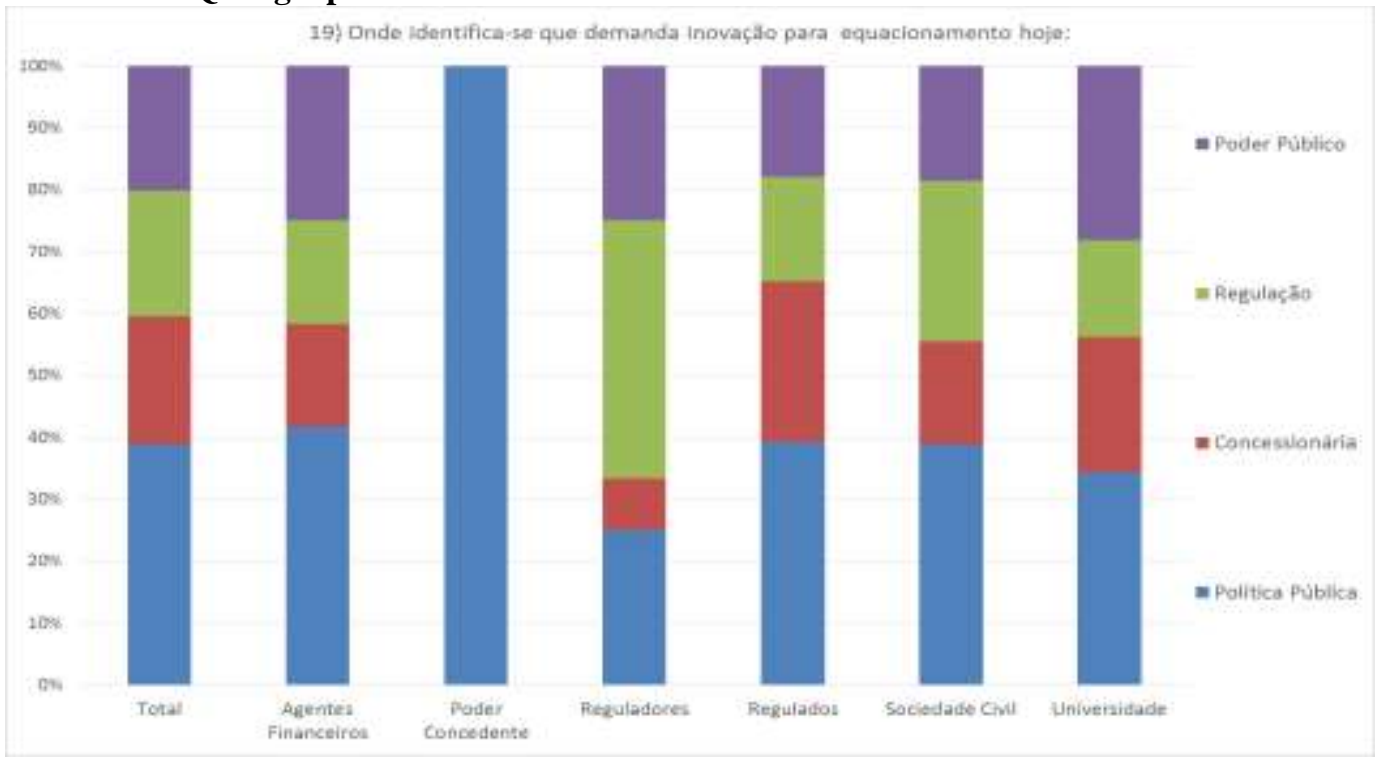

Elaboração: a autora (2013)

No Gráfico 22, como resposta unânime é a política pública que demanda inovação. Os reguladores acharam que a concessionária deve ser inovada, e a concessionária achou que era o regulador.

Gráfico 23 - Governança e Participação Social

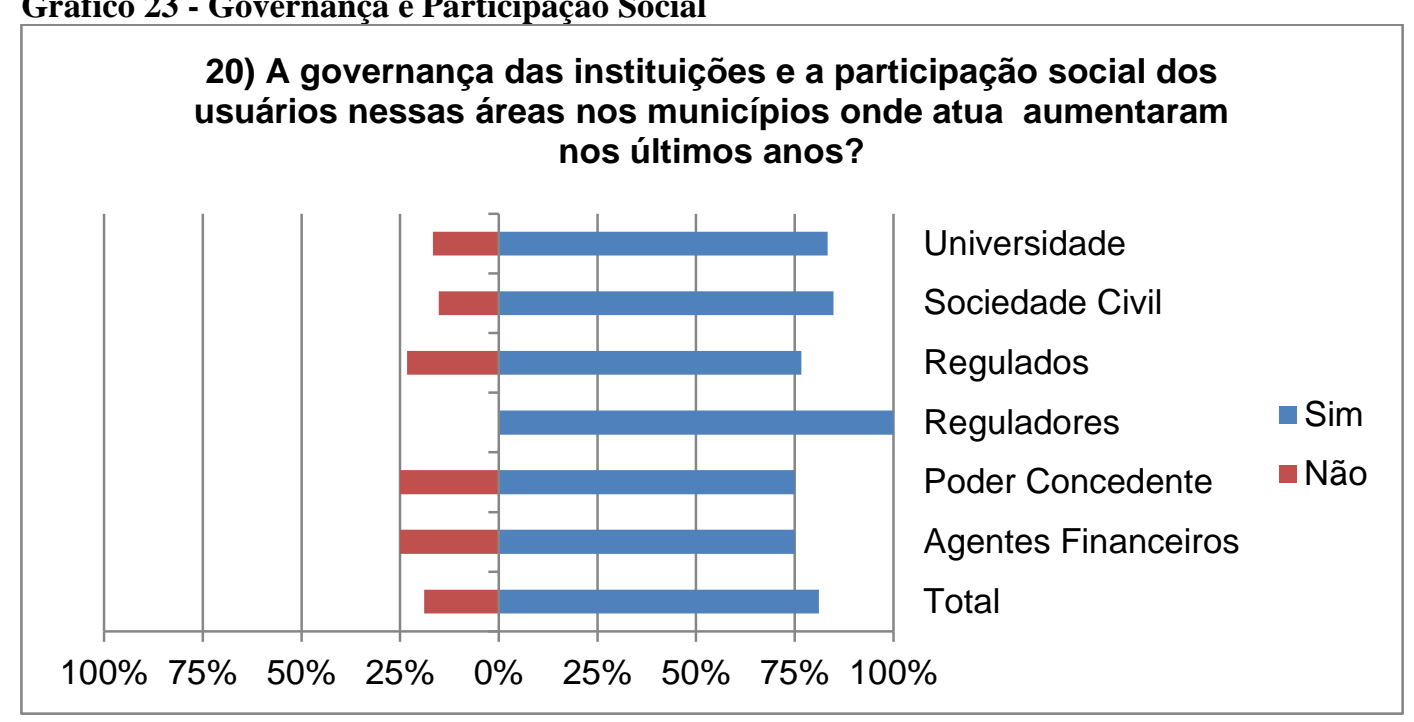

Elaboração: a autora (2013) 
No Gráfico 23 houve unanimidade dos entrevistados quanto à necessidade de inovação da governança. No gráfico 20 , como contribuição que cada grupo de atores poderia dar para a inovação do modelo, foi respondido: Agentes financeiros: estudos do modelo de gestão; poder concedente: estudos de modelo de projeto; Reguladores: estudos; Sociedade Civil: modelo de gestão; e Universidade: estudos.

As respostas serviram como referencial para as entrevistas qualitativas aplicadas nos atores em cargos da alta administração das instituições participantes do processo de universalização de áreas de vulnerabilidade.

\subsection{INVESTIGAÇÃO QUALITATIVA GESTORES INTRA-ORGANIZAÇÃO}

A investigação intra-organização foi realizada exclusivamente para as áreas objeto da pesquisa e áreas funcionais da concessionária, até nível de diretoria. Teve por objetivo, identificar, como a teoria da administração poderia contribuir à inovação do modelo de gestão, em quais bases conceituais e de práticas estava apoiado, e se era o mesmo adotado para a universalização de áreas vulneráveis. As variáveis de investigação escolhidas para o diagnóstico e descrição do modelo atual foi apoiado no Diagnóstico de Nadler: ambiente, organização, estratégia, tecnologia, estrutura organizacional e comportamento organizacional.

A primeira etapa foi de entrevistas qualitativas aplicadas aos gestores das áreas meio. A segunda etapa foi de aplicação de questionários a todos os agentes comunitários da RMSP (Anexo 2 - questionário 2) e a todos os gestores da RM da Baixada Santista, (Anexo 2 - questionário 3) atuando em interfaces de processo que promovem a universalização nas áreas vulneráveis - 13 (treze) gestores da RMBS e 15 (quinze) da RMSP.

Conforme metodologia adotada pela ANEP, os questionários qualitativos foram previamente testados em atores de referência em contexto ad-hoc, que permitiram ajuste dos formulários da pesquisa quantitativa, para determinar os 
elementos de linguagem e temas predominantes para alcançar os objetivos da construção do modelo.

\subsubsection{Perguntas aos gestores:}

O objetivo das perguntas apresentadas aos gestores foi relatar as práticas genéricas adotadas com respostas das áreas funcionais do tema. Como principais perguntas obteve-se:

1. Como funciona o Planejamento Estratégico, Tático e Operacional para o atendimento das áreas favelizadas e irregulares - antes da urbanização e até a urbanização?

No caso da RMSP, os escritórios regionais, chamados UGRs têm todas as áreas mapeadas no Sistema de Informações Geo-referenciadas - Signos. (quantidade de domicílios, titularidade, disponibilidade de redes, base da Fundação Seade de vulnerabilidade social, setores censitários, de abastecimento e esgotamento sanitário, arruamento, situação de fundo de vale e factibilidade de ligação de esgoto, entre outros dados geo-referenciados).

2. Como levantam dados para se planejarem no atendimento às áreas irregulares considerando o crescimento das populações nessas áreas. Como é o relacionamento com os municípios e outros órgãos do estado?

Cada caso tem uma tratativa. Alguns adotam a base do IBGE e atualizam com pessoal próprio, outros adotam as bases da prefeitura para o cadastro do Plano de Habitação de Integração Social.

3. Quais os programas (institucionais, de computador e procedimentos) que vocês adotam para monitorar perdas físicas e comerciais, atendimento aos clientes por rede ou outras possibilidades e divulgação e formas de promover a inclusão na tarifa social?

O volume de perdas nestas áreas é estimado, uma vez que não há setorização das favelas na maioria dos casos. É controlado e calculado pela área de perdas locais, depois são totalizados e informados manualmente à área de 
perdas central. Está em desenvolvimento/implantação um sistema integrado. As informações são estimadas, para esses casos, por não haver setorização das áreas favelizadas e irregulares na grande maioria das comunidades.

4. Como mobilizam funcionários e clientes? Podem fornecer relatórios e documentos recentes da UN e de resultados desse processo?

São mobilizados em seminários de planejamento e disponibilizaram dados e estudos das áreas objeto de estudo em curso.

5. Quais os problemas que vocês têm com essas comunidades como segurança, furto? Como superam essas questões? Fazem reuniões com as comunidades? Qual a frequência e número médio de participantes?

Cada área tem a sua particularidade, desta forma, as reuniões e envolvimento da própria comunidade é um componente variável. As áreas com maior criminalidade passaram por programas de conscientização para reduzir vandalismos. $E$ as áreas que possuem reuniões periódicas apresentam melhor relacionamento e conseguem parcerias com as comunidades.

Na segunda etapa foi aplicado questionário para obter o diagnóstico da área objeto de pesquisa. Os respondentes eram Agentes Comunitários e Gestores da área de serviços, engenharia e comercial da Região Metropolitana da Baixada Santista. 
Gráfico 24 - Diagnóstico da Universalização por Gestores da Área de Pesquisa

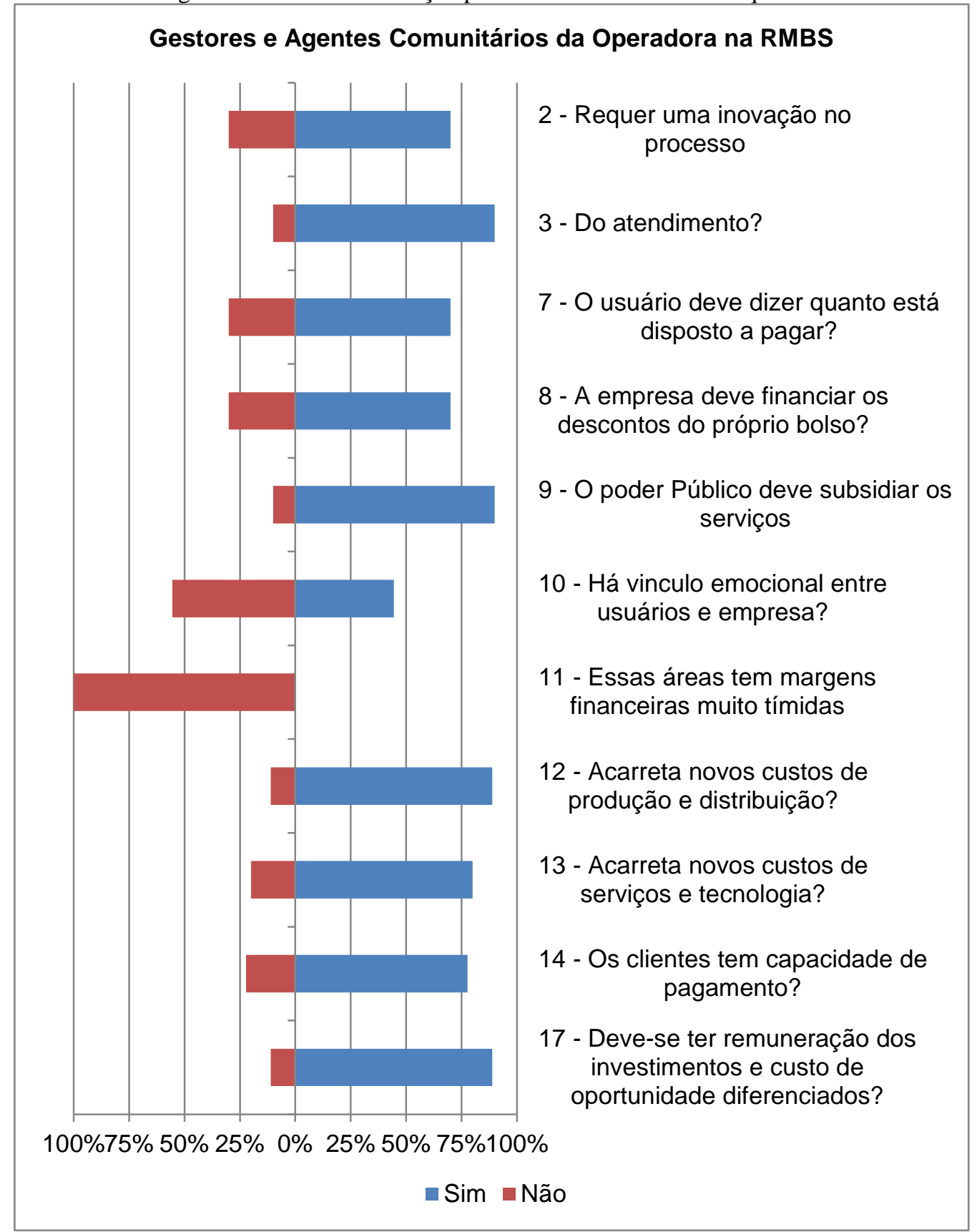

Elaboração: a autora(2014)

Como conclusão os gestores e agentes comunitários responderam que requer inovação da gestão (atendimento), não há margens (remuneração dos investimentos e custos de oportunidade diferenciados), demanda financiamento (poder público deve subsidiar serviços), aumenta custos (produção, distribuição e serviços) e não há capacidade de pagamento pelos usuários (Gráfico 24). 


\subsection{AVALIAÇÃO DA ESTRATÉGIA DE MAPEAMENTO DE ÁREAS VULNERÁVEIS E CHECAGEM DE BANCO DE BENEFICIÁRIOS}

Duas abordagens foram adotadas para avaliação: mapeamento das áreas irregulares do IBGE sobre os setores de vulnerabilidade da Fundação SEADE e mapeamento dos usuários com tarifa social da concessionária nos mesmos setores, cruzando com os domicílios cadastrados no Cadastro Único para Programas Sociais - CADUNICO cuja base de dados foi fornecida pela Secretaria Estadual de Assistência Social.

$\mathrm{Na}$ metodologia de triangulação múltipla partiu-se da identificação, mapeamento, limitação e seleção de áreas de exclusão do saneamento segundo o mapeamento da vulnerabilidade. Aplicou-se frente à necessidade de focalizar a vulnerabilidade, como conjunto de dimensões ligadas a condições de pobreza definidas pelo IPVS, privações de água tratada e esgotamento sanitário, uma vez que, nas áreas urbanas, é quase impossível distinguir os pobres afetados por condições de riscos ambientais e sanitários dos não pobres afetados pelas mesmas condições, em termos de resiliência e adaptação. Levaram-se em conta as dimensões de renda, educação e longevidade e componente geográfico à análise do IPVS acrescentado das dimensões de risco sanitário e ambiental com objetivo de identificar a resiliência e adaptação de uma comunidade. Esse indicador é capaz de classificar e localizar a vulnerabilidade socioambiental por setores censitários, dentro de um município, e combinar três dimensões, a socioeconômica, a demográfica e a sanitária, que classificam estes setores censitários em três grupos de vulnerabilidade socioambiental (IPVS 5, 6 e 7) (SEADE, 2012):

- Grupo 5 com vulnerabilidade alta, possuem as piores condições socioeconômicas, e na média os piores níveis de renda e escolaridade. Concentra famílias mais velhas, com menor presença de crianças pequenas e são atendidos por redes públicas de serviços de água e sem esgotamento sanitário;

- Grupo 6 com vulnerabilidade muito alta, apresentam as piores condições socioeconômicas urbanas, com grande concentração de famílias jovens, baixos 
níveis de renda e escolaridade e presença significativa de crianças pequenas e não são atendidos por redes públicas de serviços de água (acessam água ilegalmente) e não possuem esgotamento sanitário. Por ter esta combinação, é o grupo mais vulnerável em termos de resiliência e adaptação.

- Grupo 7, com vulnerabilidade muito alta, é o segundo grupo na dimensão socioeconômica rural, com grande concentração de famílias jovens, baixos níveis de renda e escolaridade e presença significativa de crianças pequenas e não são atendidos por redes públicas de serviços de água (acessam água legal ou ilegalmente) e não possuem esgotamento sanitário. Por ter esta combinação, é o grupo mais vulnerável em termos de resiliência e adaptação.

Em tese as políticas públicas de saneamento para combater a pobreza, assim como as estratégias empresariais para universalização dos serviços de saneamento, estavam focalizadas nos setores censitários pertencentes aos grupos de vulnerabilidade 5, 6 e 7, pois apresentavam os maiores níveis de vulnerabilidade em todos os aspectos com elevado risco, baixa resiliência e baixa adaptação. Cabe notar que é importante levar em consideração a diferença entre os setores classificados como pobres nos pequenos municípios e nas grandes áreas urbanas. Isso acontece porque os riscos sociais a que estão expostos são muito diferentes, e os efeitos negativos das condições de pobreza são mais intensas nos grandes centros urbanos. Os preços relativos são maiores e são necessários mais recursos nos meios urbanos para satisfazer as mesmas necessidades básicas, promovendo diferentes condições de vulnerabilidade, resiliência e adaptação (SABESP, 2014).

Com a finalidade de definir as economias a serem subsidiadas, foram analisadas somente as de população pertencente aos grupos de IPVS definidos para os critérios para a focalização (IPVS 5, 6 e 7).

O Mapa 3 apresenta nos municípios da RMSP, os setores censitários classificados de acordo com a porcentagem do total dos domicílios que pertencem aos grupos IPVS 5, 6 e 7, sem ligação de água e cercado de áreas abastecidas, totalizando 14079 áreas irregulares na RMSP (SABESP, 2014). 
Também foi feito a confrontação entre Bancos de Dados da Secretaria da Assistência Social dos Cadastrados no CADUNICO, usuários SABESP e Setores da Fundação Seade cujo Índice de Vulnerabilidade Social é 5 ou 6.

\subsubsection{População Vulnerável X Usuário Cadastrado na Tarifa Social}

A estrutura tarifária da SABESP apresenta tarifas discriminadas segundo categorias tarifárias, blocos de consumo e regionais tarifárias. São oito categorias tarifárias, quatro faixas (blocos) de consumo $^{14}$ e seis regiões tarifárias. A estrutura tarifária da empresa discrimina os usuários em oito categorias tarifárias: residencial, que se subdivide em três categorias de cunho social: social, favela e normal; comercial/entidade assistencial e normal; industrial; públicos sem contrato; públicos com contrato. A desagregação dos usuários residenciais nas três categorias de cunho social busca subsidiar as classes de baixa renda através de tarifas inferiores às praticadas para usuários da categoria residencial normal, enquadrando-se na Tarifa Residencial Social os usuários que atendam, pelo menos, um dos seguintes critérios: 1)Se tratando de residência unifamiliar: ter renda familiar de até três salários mínimos, ser morador de habitação subnormal com área útil construída de $60 \mathrm{~m}^{2}$ e ser consumidor monofásico de energia elétrica com consumo de até $170 \mathrm{kWh} / \mathrm{mês}$; ou estar desempregado, sendo que o último salário seja de no máximo 3 (três) salários mínimos, neste caso o tempo máximo será de 12 meses, não podendo ser renovado; 2) Se tratando de habitação coletiva: morar em habitações consideradas sociais, tipo cortiços e as verticalizadas, tais como Unidade Social Verticalizada resultante do processo de urbanização de favelas (ARSESP, 2013). O Gráfico 25 demonstra o percentual de economias segundo as categorias tarifárias residenciais. $O$ Gráfico 26 demonstra a participação do consumo medido segundo as categorias tarifárias residenciais.

\footnotetext{
${ }^{14}$ Exceto usuários das categorias residencial Social e Favela, que possuem 5 faixas de consumo.
} 
Gráfico 25 - Distribuição das economias de água e esgoto nas categorias tarifárias residenciais

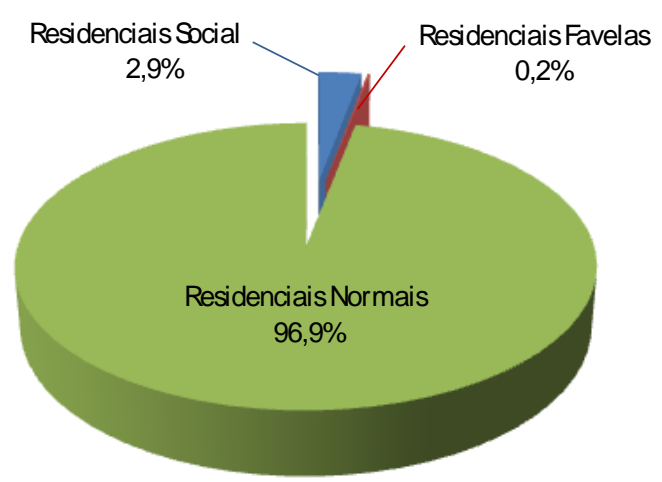

Fonte: SABESP (2012a).

Gráfico 26 - Distribuição do consumo medido de água e esgoto nas categorias tarifárias residenciais

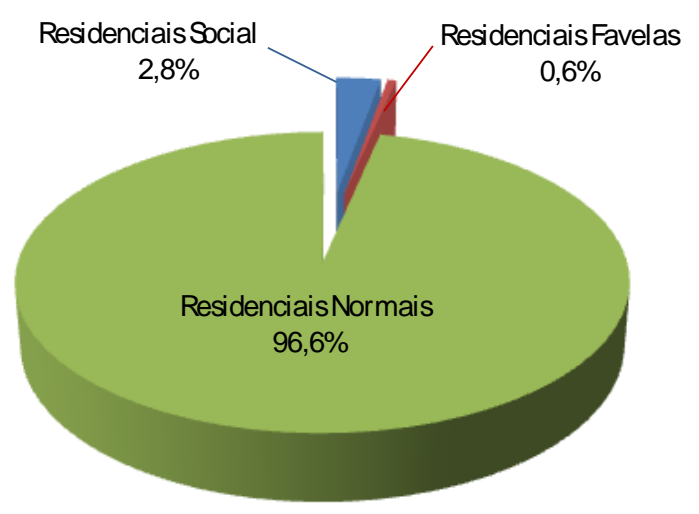

Fonte: SABESP (2012a).

Analisando os gráficos 25 e 26 observa-se que os usuários residenciais das categorias social e favela abrangem apenas $3,1 \%$ das economias residenciais totais. Em termos do volume medido, esses usuários representam $3,4 \%$ do consumo residencial total.

A comparação das bases de dados da Fundação Seade, Secretaria de Assistência Social e domicílios com tarifa social, é objeto do capítulo 8.

\subsection{INVESTIGAÇÃO QUALITATIVA - LÍDERES COMUNITÁRIOS}

Foi aplicado questionário (Anexo 2 - questionário 2) com objetivo de checar o cadastro de famílias assistidas pelos programas geridos pela SASESP e Fundação SEADE, validando e complementando com situação de acesso à 
água e esgotamento sanitário, com os principais dados para verificação do enquadramento na tarifa social.

Previamente à aplicação dos questionários foram feitas entrevistas em profundidade com seis líderes do processo de universalização em comunidades. Foram elaboradas questões objetivas com respostas simples e previstas, conforme identificadas junto com as lideranças e agentes comunitários da SABESP.

O desenho amostral foi aleatório, estratificado de acordo com a condição do líder comunitário da área de estudo da - UN e por aglomerado subnormal ${ }^{15}$ (Tabela 10.).

> A partir da definição das áreas de interesse no piloto foram levantadas as plantas de localidades fornecidas pelo SIG e aglomerados selecionados para as 2 Uns;

Foram convidados todos os lideres identificados pela agentes comunitários da concessionária;

> O entrevistado era obrigatoriamente morador (a) da área;

> Foram aplicados questionários para 68 líderes, que desejaram voluntariamente participar da pesquisa sobre suas áreas de representação nos encontros comunitários. Todos eram moradores das áreas que representavam as zonas amostrais com, aproximadamente, 6.800 residências subnormais em áreas favelizadas, cujo IPVS eram de nível 5 ou 6.

Foram definidas duas unidades amostrais nas RMs, Unidades de Negócio Norte e Baixada Santista, para aplicação dos questionários (Anexo 2 - questionário 2).

\footnotetext{
${ }^{15}$ Habitação precária construída em propriedade alheia (IBGE, 2011).
} 
Tabela 10 - Definição da Amostra de Entrevistas às Lideranças Comunitárias

\begin{tabular}{c|c|c|c|c|c}
\hline $\begin{array}{c}\text { Total de } \\
\text { domicílios } \\
\text { irregulares no } \\
\text { setor/UN }\end{array}$ & $\begin{array}{c}\text { Amostra dos } \\
\text { domicílios } \\
\text { representados } \\
\text { pelos } \\
\text { respondentes }\end{array}$ & $\begin{array}{c}\text { 2 Unidades } \\
\text { de } \\
\text { Negócios }\end{array}$ & $\begin{array}{c}\% \text { Calculo } \\
\text { da Amostra }\end{array}$ & $\begin{array}{c}\text { Margem } \\
\text { de Erro }\end{array}$ & $\begin{array}{c}\text { Nível de } \\
\text { Confiança }\end{array}$ \\
\hline $\begin{array}{c}14079-\text { RMSP } \\
\text { e }\end{array}$ & 68 & $\begin{array}{c}60 \text { RMSP e } \\
8 \text { RMBS }\end{array}$ & $40,97 \%$ & $1 \%$ & $96 \%$ \\
$\begin{array}{c}\text { Total = 16594 } \\
\text { Th15 - RMBS }\end{array}$ & & & & & \\
\hline
\end{tabular}

No universo de 14.079 domicílios, foram entrevistados 68 líderes, representando 6.800 domicílios em média, numa distribuição normalizada (média 0 e desvio padrão 1) foram englobados as situações que cobrem $96 \%$ dos casos com uma margem de erro de + ou $-1 \%$ da média.

Segundo a ABEP - Associação Brasileira de Empresas de Pesquisas, a amostra deve representar a população objeto de investigação, de forma a permitir o estudo das correlações entre ambas. No projeto, adotou-se técnica de amostra aleatória estratificada por conglomerados com estratégia de amostragem aleatória simples, que é aquela em que toda unidade da população estudada tem igual chance de ser incluída na amostra, e a probabilidade de uma unidade ser selecionada não é afetada pela seleção de outras unidades. Esta técnica de amostragem é utilizada quando a população é finita, reduzida e homogênea. Utilizaram-se quatro estágios de técnicas probabilísticas para vistorias e pesquisa com lideranças comunitárias: município, setor censitário do IBGE e classificação de IPVS do município, setor censitário, domicílio e/ou indivíduo, com coleta de dados por entrevistas pessoais e vistorias ao local. O erro amostral ou margem de erro é o intervalo de possíveis resultados, consideradas as características da amostra. Nível de confiança é a probabilidade de o valor do parâmetro em estudo pertencer ao intervalo centrado na estimativa estatística do parâmetro e limites determinados pelo erro amostral tolerado (OLIVEIRA e GRÁCIO, 2005, Barbetta, 1999).

Para o desenho dos questionários utilizados nesta investigação com os líderes comunitários foi utilizado um formulário e os seguintes procedimentos: 
> Realização de 01 grupo focal na casa de apoio social da concessionária de serviços à concessionária na Comunidade México 70 na RMBS. Estes se realizaram com a assistência de 6 chefes de família/lideres de comunidade;

> Realização de 02 entrevistas piloto na RMSP;

Aplicaram-se os questionários (Anexo 2 - questionário 2) em 05 encontros comunitários da RMSP e RMBS da agenda.

O Objetivo principal foi à verificação de como o líder comunitário avalia o tratamento conferido à sua comunidade, frente à inclusão em programas de universalização, acessibilidade a serviços comerciais, inclusão na tarifa social e hábitos de uso da água da comunidade, inserção no CADUNICO, Bolsa Família, e a percepção do impacto no orçamento familiar comparativamente ao preço de outros serviços públicos. A aplicação dos questionários foi realizada com auxilio dos agentes comunitários da concessionária, seguindo procedimentos padronizados da Universidade de São Paulo, supervisionado pela concessionária e orientador. As respostas codificadas e digitadas foram submetidas a um controle de consistência, antes de seu processamento.

Os dados foram processados com o software Access e Excel.

Foram definidos formulários após as entrevistas qualitativas com seis líderes comunitários da RMSP e RMBS. Os questionários da pesquisa quantitativa foi aplicada a 41 líderes comunitários da RMSP - MN (UN Norte), cujo programa social completou 18 anos ininterruptos em 2014.

Quanto a questões sobre trabalho, renda, tarifa e serviços e bens de consumo, que concorrem no orçamento familiar, observa-se que $67 \%$ não dos entrevistados, não achavam a tarifa alta comparada com serviços de telefonia celular, apesar de apenas 35\% estarem no mercado informal (Gráficos 27, 28 e 29). 
Gráfico 27 - Concorrência no orçamento familiar com tarifa de água

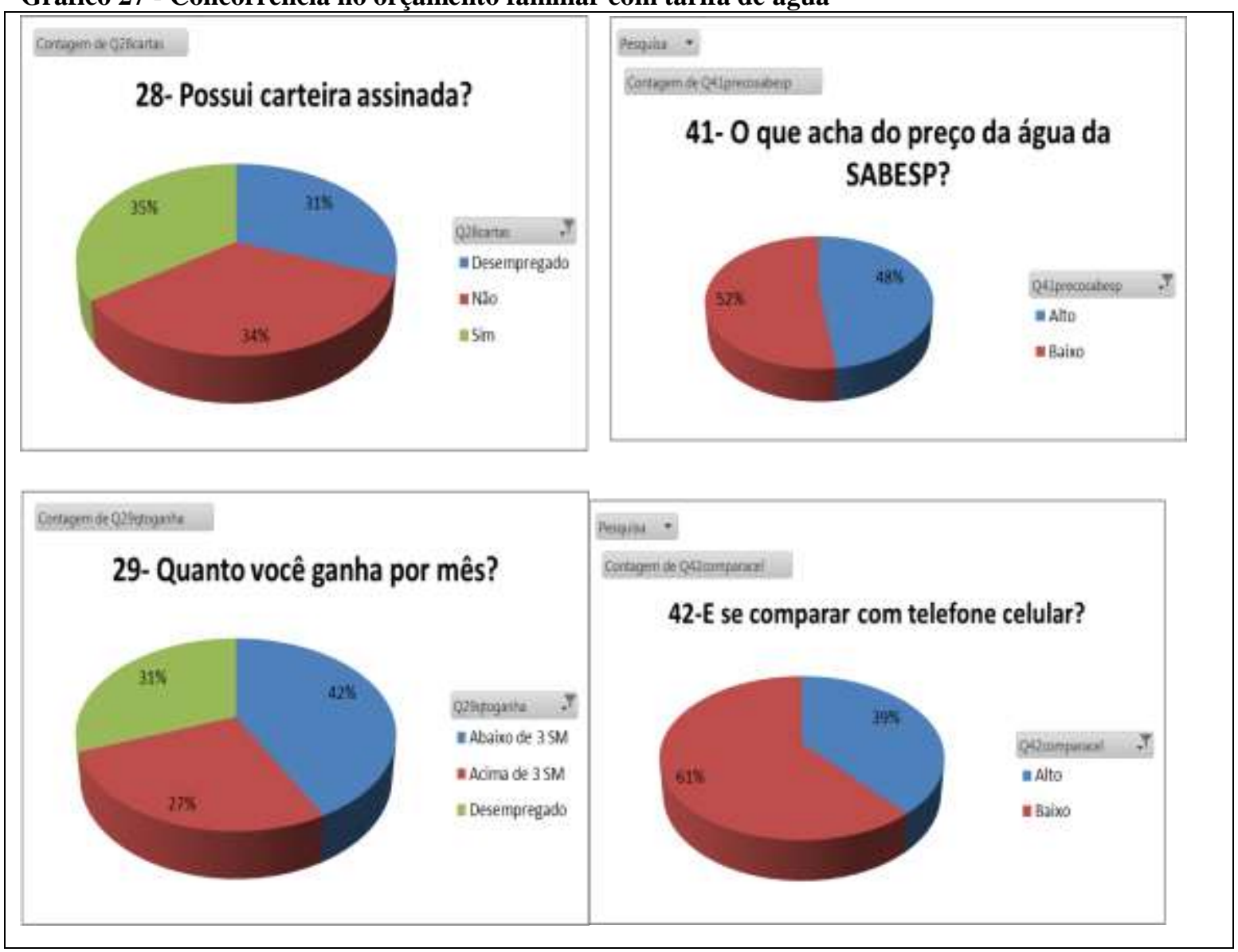

Fonte: a autora (2015)

Gráfico 28 - Programas sociais do Governo Federal

1 - Programas Sociais

- Cadúnico Bolsa Família - Outros

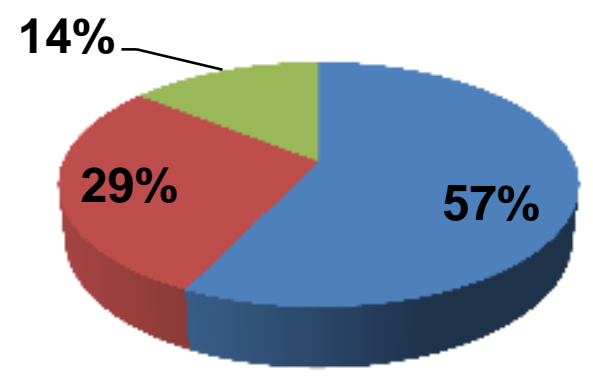

Fonte: a autora (2015)

As perguntas feitas aos líderes comunitários tinham por objetivo investigar se as condições de aplicabilidade das tarifas sociais eram aderentes à condição das populações no aspecto de estar ou não na economia formal, estar ou não em 
algum programa de assistência social e achar ou não as tarifas caras. Deve-se ressaltar que apenas 35\% dos entrevistados estavam na economia formal (Gráfico 27). Apesar de divididos quanto ao preço da água, ao comparar com a telefonia celular móvel e energia, achavam que o valor da fatura era baixo. Apenas $27 \%$ tinham uma renda superior a 3,5 salários mínimos, o restante recebia menos ou estavam desempregados.

Gráfico 29 - Respostas das Lideranças Comunitárias da RMSP

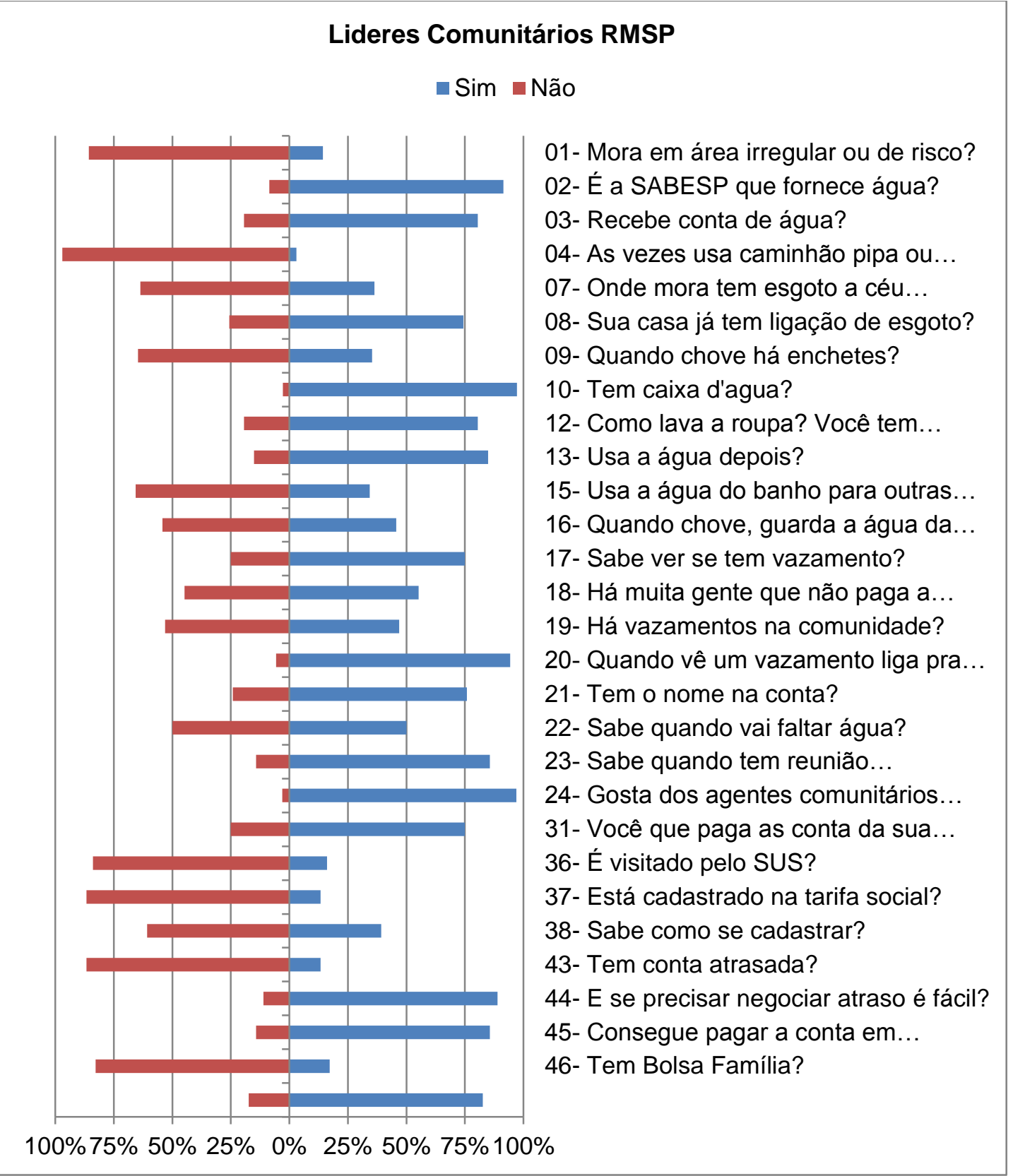

Fonte: a autora (2015) 
As respostas consolidadas dos 24 líderes comunitários da RMBS constam do Gráfico 30.

Gráfico 30 - Respostas das Lideranças Comunitárias da RMBS

\section{Lideres Comunitários RMBS}

$100 \% 75 \% 50 \% 25 \% \quad \% \quad 25 \% 50 \% 75 \% 100 \%$

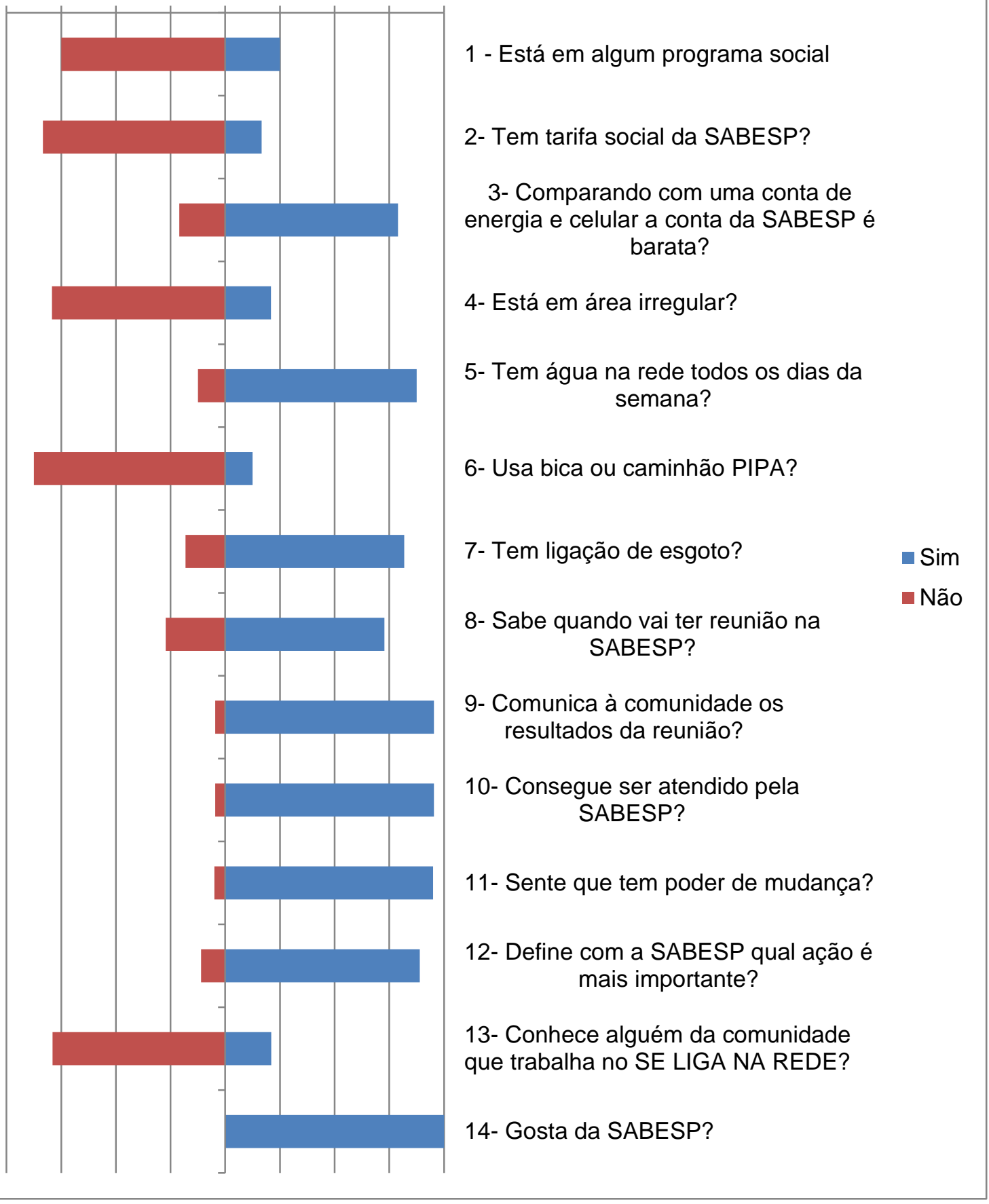

Fonte: a autora (2015) 
Cada líder comunitário representa em média cem domicílios do aglomerado urbano, segundo informações dos agentes comunitários da concessionária. As respostas subsidiaram a inovação da gestão, quanto às necessidades das comunidades para atendimento, frequência de reuniões, parâmetros para educação ambiental e divulgação de benefícios tarifários, e identificar o número de usuários dos serviços que estavam cadastrados nos programas sociais para área de estudo. Nos Gráficos 29 e 30, observou-se o bom relacionamento da concessionária com os usuários de baixa renda das duas áreas metropolitanas entrevistadas, baixo percentual de cidadãos entrevistados em áreas irregulares, podendo-se atribuir esse nível de respostas a um temor de confessar a invasão. Ainda assim, observou-se o baixo percentual de domicílios com tarifa social e demonstrou um desconhecimento do usuário quanto ao procedimento para se cadastrar e condições de aplicabilidade distanciadas da realidade. Mais de 50\% conseguiram negociar contas atrasadas facilmente, também se verificou que 0 percentual de pessoas cadastradas no Bolsa Família e CADUNICO não atingem $25 \%$ dos usuários entrevistados.

\subsection{RESULtAdOS DA INVESTIGAÇÃO DE DOMICÍlIOS DAS COMUNIDADES ALVO}

Foram definidas três unidades amostrais para piloto: Prainha, Marezinha e Santa Cruz dos Navegantes no município de Guarujá com aproximadamente 1500 unidades mescladas entre casas, comércios e indústrias. Os domicílios foram vistoriados com procedimentos empresariais padronizados de ligações clandestinas, vazamentos, não localizadas, ligações ativas e inativas pela unidade de negócio local.

\subsubsection{Amostra}

O tamanho amostral para a vistoria das conexões nos domicílios dos aglomerados urbanos no município de Guarujá é apresentado na Tabela 11.

Para análise estatística, calculou-se que foram vistoriados 7,5\% dos domicílios em aglomerados subnormais do município, significando que em uma distribuição 
normalizada (média 0 e desvio padrão 1) foram englobadas as situações que cobrem $96 \%$ dos casos com uma margem de erro de + ou - $2 \%$ da média.

Tabela 11 - Definição da Amostra de Vistorias Realizadas Aglomerados Urbanos

\begin{tabular}{|c|c|c|c|c|c|}
\hline $\begin{array}{c}\text { RMBS } \\
\text { Município Guarujá }\end{array}$ & Números & $\begin{array}{c}\text { Comunidades } \\
\text { Escolhidas }\end{array}$ & $\begin{array}{l}\text { Residências } \\
\text { Baixa renda }^{16}\end{array}$ & $\begin{array}{l}\text { Amostra dos } \\
\text { Domicílios }\end{array}$ & $7,5 \%$ \\
\hline $\begin{array}{l}\text { Pop. em Aglomerados } \\
\text { (habitantes) }\end{array}$ & 33.263 & Prainha & 1381 & Vistoriados & \\
\hline \% do Município & $38 \%$ & Marezinha & 544 & Erro Amostral & $2 \%$ \\
\hline $\begin{array}{c}\text { Número de } \\
\text { Assentamentos }\end{array}$ & 56 & Santa Cruz & 590 & Confiança & $96 \%$ \\
\hline $\begin{array}{c}\text { Número de } \\
\text { Hab./domicilio }\end{array}$ & 3,66 & Total & 2.515 & Heterogeneidade & $50 \%$ \\
\hline
\end{tabular}

Elaboração: a autora (2015)

\subsubsection{Vistorias de Domicílios e Aglomerados em Campo}

As vistorias foram realizada pela equipe operacional da unidade de negócio, com acompanhamento e análise dos resultados pela pesquisadora. As intervenções realizadas foram: identificação de ligações clandestinas, verificação de inativas, levantamento de vazamentos de campo, identificação de débitos pendentes, religações, supressões, parcelamento de débitos, enquadramento em tarifa social e pedidos de ligação de água em 2515 domicílios (Tabela 11). Nesse sentido, devem-se apresentar algumas definições da concessionária:

Ligações inativas: a supressão da ligação devido à existência de débitos;

> Ligações clandestinas: abastecimento direto da rede de forma irregular, causando perdas aparentes do volume de água consumido pelos domicílios;

Vistoria: procedimentos padronizados na concessionária de visita aos domicílios para verificação de existência de ligações clandestinas, vazamentos, ligações não localizadas, ligações ativas e inativas.

\footnotetext{
${ }^{16}$ Condomínios só nas UNs em que estes tenham uma participação relevante, caso contrário, as entrevistas se concentrarão em residências (COHAB e CDHU).
} 
Também foram vistoriadas situações de vazamentos, e de ligações não localizadas para elaboração do cadastro técnico e comercial dos usuários moradores dos assentamentos precários definidos sobre o mapa do município (Mapa 4 e Mapa 6).

As avaliações e análises dos resultados, conforme metodologia, as conclusões constam do Polo de Avaliação.

\subsection{INVESTIGAÇÃO DA INCLUSÃO NA CADEIA DE VALOR}

Para investigação da inclusão na cadeia de valor pela concessionária, nos termos das grandes organizações sociais, foram identificados programas empresariais com esta prática. A empresa ${ }^{17}$ contratada pela concessionária para atuar no arcabouço social junto às comunidades no Programa Se Liga na Rede formou equipes, compostas de mulheres das comunidades, que atuaram nos projetos de relacionamento comunitário, sendo que algumas eram líderes comunitárias. As equipes participaram de treinamentos e atuaram em programas em todas as regiões da cidade de São Paulo, e litoral para oferta de diversos serviços, cuja carência está sendo detectada, de acordo com cada região, em levantamentos realizados pela empresa contratada. As funcionárias entrevistadas que trabalhavam nos contratos do Se Liga conseguiram que: $35 \%$ passaram a pagar estudo dos filhos; $47 \%$ investiram em melhorias de suas casas; $35 \%$ acham que melhoraram a qualidade de vida da família; $22 \%$ voltaram a estudar; e 4\% investiram na troca do carro. Em relação aos seus desejos: $89 \%$ queriam voltar a estudar; $8 \%$ queriam comprar um carro; $8 \%$ queriam viajar; $23 \%$ queriam investir em melhorias para a casa; $21 \%$ queriam adquirir casa própria. As mulheres da nova classe $C$ não são apenas responsáveis pela maior parte da renda nos lares brasileiros: muito além dos estereótipos que comumente incidem sobre os trabalhadores da nova classe média, muitas dessas mulheres estão liderando uma verdadeira revolução social no País, ao investir em sonhos concretos, como a compra da casa própria, o ingresso na universidade ou em cursos de línguas, a educação dos filhos e

\footnotetext{
${ }^{17}$ DEEP - Desenvolviemto e Envolvimento Estratégico de Pessoas e Cliente.
} 
viagens ao exterior. Esta é conclusão de uma pesquisa realizada pela Deep Desenvolvimento e Envolvimento Estratégico de Pessoas e Clientes, que investe em mulheres da classe $\mathrm{C}$ como concessionárias de serviço em diversos projetos que vêm desenvolvendo, mostrando inclusão na cadeia de valor, geração e distribuição de valor.

Após treinamento das contratadas, a empresa tem por objetivo rentabilizar suas famílias, aperfeiçoar tempo das mulheres na gestão do lar e gerar renda às funcionárias. Com horários flexíveis e autonomia, são remuneradas por resultados, com excelentes resultados e metas atendidas, se caracterizando pelo sistema win-win ${ }^{18}$ (concessionária, contratada e comunidades) satisfazendo a todos os envolvidos nos projetos.

\subsection{INVESTIGAÇÃO QUALITATIVA QUANTO AO MODELO DE GESTÃO E MODELO DE NEGÓCIO - ATORES-ESTRATÉGICOS}

A aplicação do questionário nessa etapa ocorreu em painel sobre a crise hídrica $^{19}$, onde 0 contexto da escassez poderia ser um diferencial na reflexão quanto a perdas e desperdício. Foi distribuído um questionário (Anexo 2 questionário 4) com perguntas objetivas, que trouxeram a visão dos grandes atores e articuladores da política pública do Estado, cujo objetivo foi o de identificar as contribuições à inovação do modelo de saneamento para obter a universalização nas áreas irregulares em função da experiência de sucesso ou fracasso nas organizações em termos da oferta e da demanda.

Essa etapa teve por objetivo obter dos atores chave do saneamento no Estado de São Paulo e Governo Federal contribuições fundamentadas conceitualmente para inovação do modelo de negócio e de gestão da concessionária. Estes responderam (Anexo 2 - questionário 4) sobre o que consideravam prioritário para gestão e negócio de saneamento (Gráfico 31). Também relataram quais as

\footnotetext{
18 Win-win, termo da Escola da Administração Científica cujo paradigma de sucesso, cuja estratégia determina que todos os envolvidos devem ganhar e não apenas a empresa. Aplicado largamente no empreendedorismo das organizações sociais (Prahalad, 2008, p.73).

${ }^{19}$ Aplicados em Seminário sobre Crise Hídrica da Associação Brasileira de Engenharia Sanitária e Ambiental - SP
} 
inovações que foram sugeridas para o modelo de negócio e modelo de gestão (Quadros 15 e 16).

Quadro 15 - Ordenamento das Estratégias do Saneamento

Ordene estratégias por ordem de importância segundo sua visão:

( ) Estratégia de Conservação dos Recursos Hídricos e biodiversidade

\begin{tabular}{l} 
( ) Gestão de Perdas \\
\hline ( ) Gestão da Contaminação por lançamentos \\
\hline ( ) Gestão do uso e ocupação do solo \\
\hline ( ) Programa de Uso Racional da Água
\end{tabular}

Elaboração: a autora (2015)

\begin{tabular}{l} 
Quadro 16 - Inovação do modelo de gestão e negócio \\
$\begin{array}{l}1 . \quad \text { Em sua opinião, o que seria a inovação no modelo de gestão do } \\
\text { setor de saneamento atualmente em áreas de vulnerabilidade } \\
\text { socioambiental? }\end{array}$ \\
\hline $\begin{array}{l}\text { sm sua opinião, qual seria a inovação do modelo de negócio do } \\
\text { setor de saneamento atualmente em áreas de vulnerabilidade } \\
\text { socioambiental? }\end{array}$
\end{tabular}

Elaboração: a autora (2015) 


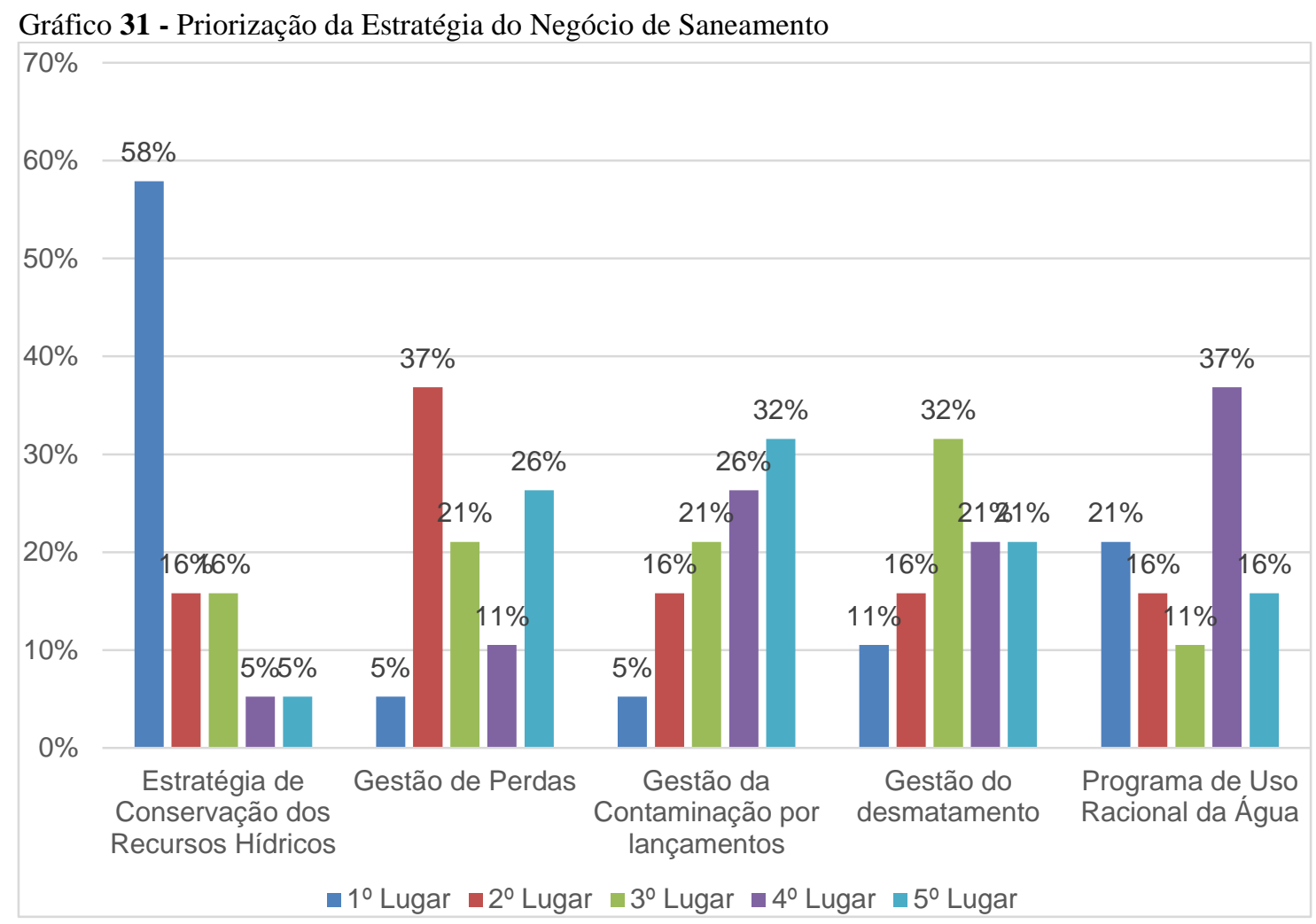

Elaboração: a autora (2015)

Entre as respostas nas quais o pensamento do entrevistado está com fundamentação teórica conceitual alinhada ao referencial teórico da pesquisa, foram escolhidas as respostas principais e solicitada autorização para constar nessa tese.

Dos 19 respondentes: 16\% não responderam o que seria uma inovação do modelo de gestão; $26 \%$ não responderam o que seria uma inovação do modelo de negócio; 0,5\% não sabia a diferença e se confundiram. As tabelas 12 e 13 mostram as sugestões dos pesquisados. A tabela 12 apresenta as sugestões dadas para a pergunta sobre inovação do modelo de gestão na primeira coluna. Na segunda coluna, a letra $(G)$ indica que a sugestão dada é para inovação da gestão, conforme perguntado; a letra $(\mathrm{N})$ indica que a sugestão dada é para inovação do modelo de negócio. Semelhantemente, a tabela 13 apresenta as sugestões dadas para a pergunta sobre inovação do modelo de negócio na primeira coluna. Na segunda coluna, a letra $(G)$ indica que a sugestão dada é 
para inovação da gestão; a letra $(\mathrm{N})$ indica que a sugestão dada é para inovação do modelo de negócio, conforme perguntado.

Tabela 12 - Inovações sugeridas para o modelo de gestão pelos respondentes

\begin{tabular}{|c|c|}
\hline Inovações para o Modelo de Gestão & $\begin{array}{l}\text { Conceito } \\
\text { de } \\
\text { Gestão/ } \\
\text { Negócio }\end{array}$ \\
\hline $\begin{array}{l}\text { Integrar todas as gestões locais e regionais, eliminando "feudos" de } \\
\text { secretárias/órgãos/entidades que atrasam a gestão do uso da água. Fomentar o interesse } \\
\text { privado (como ocorre em rodovias) e tirar dele (e de outros setores privados através de } \\
\text { benefícios) recursos financeiros pra serem reaplicados à gestão da água. }\end{array}$ & G \\
\hline $\begin{array}{l}\text { Possibilidade de atuação direta das companhias de saneamento na fiscalização do uso do } \\
\text { sistema (inclusive autuação) }\end{array}$ & G \\
\hline $\begin{array}{l}\text { Criação de uma base legal sólida para enfrentamento das crises sem interferências políticas } \\
\text { eleitorais. }\end{array}$ & $\mathrm{N}$ \\
\hline $\begin{array}{l}\text { Os modelos apresentados pela SABESP e Sanasa devem ser unificado e estudado p/ o estado } \\
\text { e como não dizer ao Brasil, pois a crise é nacional para com gastos regionalizado. }\end{array}$ & $\mathrm{N}$ \\
\hline $\begin{array}{l}\text { Realização de uma auditoria nacional, estadual e municipal da utilização dos recursos hídricos, } \\
\text { incluindo balanço de recursos e entrega de captação. } \\
\text { Envolvimento da sociedade na fiscalização do uso de recursos hídricos, com a implementação } \\
\text { de sistema de comunicação de denúncias pelo número de telefone } 0800 \text {. }\end{array}$ & $\mathrm{N}$ \\
\hline $\begin{array}{l}\text { Não só planejar e executar a obra, mas ensinar a população a usar a obra (marketing social e } \\
\text { educação ambiental). }\end{array}$ & G \\
\hline Compromisso político com o social não com interesses particulares; controle do estado. & G \\
\hline Os critérios de gerenciamento das válvulas e redutores de pressão. & $\mathrm{G}$ \\
\hline $\begin{array}{l}\text { Ao lado de ações técnicas e operacionais, promover a educação visando o bom uso e o } \\
\text { reaproveitamento deste recurso cada vez mais escasso. }\end{array}$ & G \\
\hline $\begin{array}{l}\text { A consideração do efeito das "mudanças climáticas" no planejamento hídrico e energético em } \\
\text { todo o território nacional e a consideração desde efeito na elaboração de nossas políticas } \\
\text { públicas. }\end{array}$ & G \\
\hline $\begin{array}{l}\text { Inserir na grade curricular das escolas públicas e particulares desde a educação infantil, } \\
\text { disciplina relacionada à conservação dos recurso hídricos e energia. }\end{array}$ & G \\
\hline Esclarecer as competências de cada instância e ator & G \\
\hline $\begin{array}{l}\text { Gestão profissional e não político-partidária. } \\
\text { Adoção de plano direto, mas faltam as ações necessárias (com horizonte de plano mais } \\
\text { abrangente). }\end{array}$ & G \\
\hline Dar mais atenção aos cuidados com as nascentes. & G \\
\hline Fortalecimento da empresa publica através do fortalecimento de seu quadro técnico. & G \\
\hline $\begin{array}{l}\text { A gestão que hoje é de certa forma integrada deveria ser mais ampla com relação a bacias e } \\
\text { estados vizinhos, possibilitando maior discussão entre os gestores nacionais. }\end{array}$ & G \\
\hline
\end{tabular}

Tabela 13 - Inovações sugeridas para o Modelo de Negócio

Inovações para o Modelo de Negócio

Assim como a Petrobrás gerencia, negocia, distribui, capta, explora Etc., o petróleo, a água deveria passar pelo mesmo processo de administração (claro, sem os mesmos "vícios" de corrupção pontados ultimamente). 


\begin{tabular}{l|c}
\hline $\begin{array}{l}\text { Valorização da capacidade ociosa dos sistemas produtores de água para enfrentamento da } \\
\text { crise de escassez hídrica, como agora vivida. }\end{array}$ & $\mathrm{G}$ \\
\hline $\begin{array}{l}\text { Instituição da compra obrigatória, por concessionárias de serviços públicos de água, de } \\
\text { volumes disponibilizados por pessoas físicas ou jurídicas, de direito privado. }\end{array}$ & $\mathrm{N}$ \\
\hline $\begin{array}{l}\text { Reservar investimento e profissionais. } \\
\text { A convocação social e educação ambiental (Integradas). }\end{array}$ & $\mathrm{G}$ \\
\hline Estatização dos saneamentos no país e energia elétrica. & $\mathrm{N}$ \\
\hline PPP’s & $\mathrm{N}$ \\
\hline Uma remodelação na cobrança do uso da água. & $\mathrm{G}$ \\
\hline Tratar os serviços de saneamento como essenciais; e não mercadoria. & $\mathrm{N}$ \\
\hline Hidrômetro individualizados. & $\mathrm{N}$ \\
\hline $\begin{array}{l}\text { Buscam incessante no combate as perdas através de novas tecnologias, combater a indústria } \\
\text { do vazamento que suga recursos de maneira incessante, desterceirizar o setor atendendo com } \\
\text { mão de obra própria fortalecendo a empresa pública. }\end{array}$ & $\mathrm{G}$ \\
\hline $\begin{array}{l}\text { Dado o resultado de pesquisa que apontam para o futuro não haverá disponibilidade hídrica } \\
\text { para todos as necessidades, poderia se pensar em após penalizar pessoas físicas e jurídicas } \\
\text { que consomem muito, redirecioná-las para as população/áreas com menor poder aquisitivo. } \\
\text { Para irmos contrário ao que ocorreu na África. }\end{array}$ & $\mathrm{N}$ \\
\hline
\end{tabular}

Elaboração: a autora(2015)

Os entrevistados eram profissionais de cargos estratégicos das concessionárias, do Estado, imprensa, agentes financiadores e escritório de advocacia, consultorias, universidade e sociedade civil.

Para inovação do Modelo de Negócio, os entrevistados foram unanimes em sugerir inovação na atuação no setor, por ordem de importância, para a conservação dos recursos hídricos e biodiversidade, seguida de gestão de perdas e programa de uso racional de água. Pode-se identificar como gatilho da inovação do modelo, segundo os especialistas do setor, a gestão da oferta escassez hídrica, seguida da gestão da demanda - perdas e Programa de Uso Racional de Água - PURA.

\subsection{CONCLUSÕES}

As aplicações dos questionários demandaram uma análise, conforme metodologia adotada, para inovação do modelo considerando as controvérsias sociotécnicas e a complexidade do contexto. Nesse sentido, elas foram objeto do Polo de avaliação.

Sinteticamente, as respostas dos reguladores evidenciaram as dificuldades dos reguladores em exercerem suas funções pelas deficiências estruturais, 
interferência do poder concedente sobre suas atividades, ausência de instrumentos da política pública para garantias do equilíbrio contratual nas revisões tarifárias.

Identificou-se, pelas respostas dos gestores que envidaram esforços para atender a população vulnerável em áreas regularizadas, com instrumentos de inclusão na cadeia de valor, porém o número de beneficiários incluídos na tarifa social demonstram as dificuldades de quanto às regras de enquadramento.

As respostas dos usuários demonstrara satisfação com a concessionária, mas desconhecimento para cadastramento na tarifa social e de programas para melhoria do bem-estar social, sendo que a fatura de água não foi considerada cara por ele.

As vistorias em campo demonstraram o alto número de ligações clandestinas nesses locais e a necessidade da participação de profissionais das ciencias sociais para contribuirem na atuação técnica junto às comunidades.

Observou-se que no aspecto do conhecimento para inovação, o setor tem dificuldades de reconhecer a diferença entre modelo de gestão e de negócio, e priorizar ações e estratégias frente às diferentes demandas e crise, e de propor inovações para modelo de negócio que supere as dificuldades setoriais. 


\section{RESULTADOS DO POLO DE AVALIAÇÃO}

\subsection{CONSIDERAÇÕES GERAIS}

O polo de avaliação compreende instrumental para as avaliações qualitativas e quantitativas e consequentemente subsidiar a construção do modelo. Os dados foram processados com o Microsoft Access, Microsoft Excel e Signus - sistema georeferenciado da operadora. Os seguintes resultados para cada cluster e para o total dos entrevistados foram realizados: tabulações simples para cada pergunta e tabulações cruzadas segundo variáveis sociodemográficas e outras de interesse identificadas: grupos de interesse econômico, técnico e jurídico. A interpretação dos resultados dos questionários respondidos (Anexo 2) e dados coletados foi realizada com emprego da triangulação múltipla com checagens (Adorno \& Castro, 1994; Denzin, 2000; Minayo e col., 2005; Patton, 2002) e incorporação de análise temática como procedimento interpretativo para aprofundamento de resultados obtidos por meio da estratégia da triangulação (Bardin, 1995; Minayo, 2004). Desenvolveu-se uma análise com base no modelo de dados de painel para o modelo de administração, considerando o efeito específico dos estados nas variáveis não observadas: políticas públicas e exigências regulatórias e contratuais metropolitanas permitindo comparar a universalização dos serviços de saneamento em relação às áreas de vulnerabilidade social.

\subsection{AVALIAÇÃO DA REGULAÇÃO DO SANEAMENTO NO BRASIL}

Segundo os Palestrantes, não se deve focar numa regulação perfeita, porque é impossível de atingi-la, antes devemos preparar sistemas de regulação onde as imperfeições estejam identificadas e controladas. As questões permitem-nos avançar nos modelos, pois alguns pontos são universais: se as tarifas não cobrem os custos, a probabilidade de cair na armadilha da ineficiência é elevada; a incorporação do setor privado facilita a regulação econômica; o incremento da cobertura do serviço através de apenas investimento privado não 
costuma ser viável; e os esquemas mistos público-privados funcionam muito melhor, mas o seu desenho não é trivial e os riscos devem ser compartilhados entre público e privado.

Os reguladores apresentaram suas dificuldades para desenvolver o marco regulatório em sua área de atuação. Os pontos elencados por todos incluem ausência de diagnósticos que permitam homogeneidade de decisões; desconhecimento pelos poderes concedentes da necessária autonomia do regulador; dificuldade em exercer a regulação econômica frente ao equacionamento dos subsídios necessários à sustentabilidade dos serviços; e necessidade de um sistema auditado de indicadores para efeito de parâmetros de eficiência. É unânime a necessidade de uma agenda positiva de discussões entre agências e concessionárias.

Entende-se que a gestão regulatória e os desafios para desenvolvimento do marco regulatório são interesse de discussão na agenda nacional, mas esta não ocorreu nos últimos dois anos, a despeito da disposição dos reguladores participantes: ADASA, ARCE, AGERS, AGERSA, AGR, ARSAE, ARSESP e PROREG. Foram constatados quatro pontos de convergência: 1) Há ausência de diagnósticos que permitam homogeneidade de decisões dos reguladores; 2) Há desconhecimento pelos poderes concedentes da necessária autonomia do regulador para garantia de suas funções; 3) Há dificuldade dos reguladores em exercer a regulação econômica por desconhecimento em profundidade da economia da regulação e/ou indefinições na política de saneamento; e 4.) Há uma demanda de um sistema de indicadores auditado para efeito de parâmetros de eficiência.

Os presidentes/diretores das concessionárias questionaram a multiplicação de multas no dilema da melhoria dos serviços frente às demandas para universalização, de critérios homogêneos para taxas de regulação e multas, de melhoria da transparência para uso dos recursos, audiências públicas e consultas públicas e que as agências estão interferindo na atividade privada.

As conclusões da compilação das respostas dos reguladores e das empresas reguladas para a promoção da universalização do saneamento no Brasil foram: 
Os levantamentos e os estudos revelam um divórcio entre práticas empresariais e regulatórias no sentido de apoiar decisões quanto a priorizações de programas de investimentos que promovam a universalização versus programas de melhorias dos serviços. Nesse sentido, há uma dualidade extremada entre a visão de bem-estar social do regulador e concessionárias. Há ausência de diagnósticos que permitam homogeneidade de decisões dos reguladores quanto à priorização de recursos necessários à universalização e investimentos para alavancar a excelência e eficiência dos serviços. Restando conflitos e recursos administrativos quanto a normas regulatórias;

As deliberações das revisões tarifárias, no que tangem a definição de custos eficientes e investimentos prudentes apresentam insuficiência de critérios, indicadores, assim como de valores de referência das regiões e dos prestadores de serviços, bem como ausência de manuais de referência para o setor. Pelo lado da concessionária há ausência de dados primários, heterogeneidade e mudanças de conceitos com ruptura das séries históricas;

Os reguladores adotam metodologias do setor elétrico, que não são capazes de capturar as externalidades do setor de saneamento, sendo que não provêm critérios para cobrir custos ambientais. Pelo lado das concessionárias, há incapacidade de apresentar os benefícios trazidos pelo setor e propostas apoiadas em planos e projetos de efetivos resultados para a prestação dos serviços;

O modelo de comando e controle adotado pelas agências, de maior rapidez e visibilidade, proliferou-se rapidamente por meio de cópias de normas e deliberações publicadas nos grandes centros urbanos, aumentando os custos dos serviços em pequenos municípios sem uma análise prévia de risco regulatório;

Identifica-se a inexistência de uma agenda positiva de médio e longo prazo para a discussão, ajustes de processos das concessionárias, análise de custos incorridos por normas e deliberações, impactos na arrecadação e faturamento das concessionárias e aumento de custos 
finais para usuário, impedindo o planejamento e organização do setor para atendimento às exigências regulatórias;

A publicidade preconizada pela constituição e marco regulatório dada às decisões de diretoria das agências, audiências e consultas públicas de contratos e normas demandam expressivas melhorias;

Os mecanismos de incentivos adotados nas revisões tarifárias estão apoiados em dados enviesados a favor da concessionária, pela deficiência de um sistema de indicadores regulatórios nacionais que permitam um benchmarking entre operadores com clusterizações de municípios e áreas de concessão semelhantes, cuja séries históricas sejam auditadas nacionalmente. Complementarmente, as concessionárias consideram de grande complexidade a implantação de uma contabilidade regulatória que promova um plano de custos em função das economias de escala e escopo;

Os modelos híbridos da regulação econômica adotados não conseguem conferir a necessária modicidade tarifária essencial ao equilíbrio contratual para os diferentes atores do setor, como usuários, prestadores, poder concedente, financiadores, bem como atrair investidores para 0 setor;

Ressalta-se que as estruturas tarifárias não permitem identificar claramente os custos e subsídios entre contratos (municípios) dentro e fora das regiões metropolitanas e municípios com sistemas integrados, sendo adotados diferentes critérios pelos reguladores: por volume, número de usuários, população ou valores de arrecadação;

As taxas de regulação e multas demandam critérios homogêneos e transparência junto ao poder concedente e sociedade civil, quanto ao uso pelo regulador e reversão efetiva em melhorias aos usuários dos serviços do município objeto de regulação;

A ausência da prestação de contas do uso desses recursos pode tornarse um elemento de risco para as agências junto ao poder concedente e sociedade civil, demandando maior efetividade de audiências públicas e consultas públicas e outros sistemas de publicidade às decisões. 
Observa-se isso em função de algumas atuações pontuais da AGU, TCU e TCE;

> Os reguladores como executores da Política Pública adotaram modelos regulatórios, que podem gerar insegurança jurídica para manutenção das regras contratuais pactuadas para concessões, Parcerias Publico Privadas - PPPs, Sociedades de Propósito Específico - SPEs, Locação de Ativos e outros arranjos institucionais que promovem novos investidores no setor;

> Destaca-se a ausência de um modelo de subsídios em substituição ao subsídio cruzado, impossível de ser continuado em função da autossuficiência necessária em cada contrato preconizada no PLANSAB. Deve-se ressaltar que o Movimento Municipalista favoreceu imensamente os grandes municípios e deixou os pequenos sem uma modelagem substituta ao modelo de subsídios cruzados entre municípios, adotado na Era PLANASA, em especial os que se encontram em situação de vulnerabilidade social;

> Os Ministérios da Cidade e da Saúde tem suas atribuições, objetivos estratégicos e metas, no que tange ao saneamento voltados para obras. Distantes de promover uma coordenação regulatória federal fazem orientações dissonantes do enfoque regulatório, apresentando erros conceituais e jurídicos, demandando capacitação dos gestores.

Há que se considerar a relação entre poder concedente, regulador indicado pelo poder executivo e concessionária num território objeto de regulação, a quem se subordinam e a efetiva autonomia decisória do regulador e conflitos de interesses, caracterizando um iminente risco sobre o equilíbrio econômicofinanceiro da concessão e de investidores no setor. 


\subsection{AVALIAÇÃo dA GESTÃo do SANEAMENTO NO BRASIL (ATORES- REDE)}

Os recursos necessários à sustentabilidade dos SAAES no que tange áreas de vulnerabilidade social, como pequenos municípios e áreas urbanas favelizadas demandam equacionamento dos subsídios necessários à universalização. Nesse sentido, o questionário (Anexo 2 - questionário 1) aplicado incluiu aos 147 profissionais do setor perguntas quanto à robustez das estruturas tarifárias, necessidade de subsídios diretos semelhantes à energia elétrica e se demanda inovação regulatória.

Os entrevistados se identificaram como universidade, reguladores, regulados, poder concedente, agentes financeiros.

Aqueles que não optaram por nenhuma das alternativas foram classificados como sociedade civil. As respostas dos especialistas de saneamento têm consenso em algumas dimensões que direcionaram a construção do modelo. A primeira delas é que a universalização dos serviços demanda inovação do planejamento e da forma de prestação dos serviços e de regulação. Outra resposta de consenso é sobre a necessidade de subsídios focados para os serviços às populações de baixa renda. Também há o consenso de que essas áreas acarretam maiores custos de produção, distribuição, serviços e tecnologias. Outro consenso é que se devem ter taxas de remuneração diferenciadas. Para os entrevistados, a governança e a participação social devem ser melhoradas.

Esses pontos foram considerados para a construção do modelo em oficinas e estudos.

Algumas questões dividiram a opinião dos respondentes (universidade, sociedade civil, reguladores, poder concedente e agentes financeiros) quanto à existência de instrumentos articulados do poder público para universalização, quanto à robustez das estruturas tarifárias para o equilíbrio tarifário, quanto à existência de margens e capacidade de pagamento dos possíveis usuários, demostrando desconhecimento e ausência de estudos e publicações sobre os temas. 
Estes pontos foram estudados e levantados junto a especialistas no tema.

Entendem que os personagens que contribuem para a universalização, incluem movimentos sociais, organizações religiosas, fundações, agentes financeiros, investidores, concessionária, poder concedente, ministério público. A distribuição equilibrada de escolhas demonstra a necessária articulação de todos os atores para a superação dos impeditivos à universalização em áreas urbanas favelizadas.

As duas principais motivações das concessionárias para a universalização dessas áreas envolvem: missão empresarial, meio ambiente, perdas, financeira e metas contratuais e regulatórias. Em primeiro lugar foi eleita à missão empresarial seguida do dano ambiental, e em segundo lugar o dano ambiental seguido da missão empresarial. Essa resposta demonstrou como a missão empresarial influencia os gestores nos seus atos de inclusão.

As principais motivações dos reguladores incluem eficiência dos serviços e as metas contratuais, ficando em terceiro lugar o bem-estar social, que levou a análise dos estudados mecanismos de exclusão e naturalidade como isto ocorre. A distribuição das respostas permitiu definir os participantes das oficinas em seus grupos e em que medida poderia contribuir para o modelo inovador.

Em situações nas quais as dúvidas ou ausência de referências eram de todos os entrevistados, observou-se que metodologia de oficinas não seria produtiva. Isto ocorreu para o equacionamento jurídico e econômico de subsídios e fundos. Para tal adotou-se estudos, revisão bibliográfica e entrevistas posteriores para apresentação de modelo.

No modelo de gestão identificou-se diversas práticas que foram analisadas frente às referências bibliográficas, como a inserção na cadeia de valor de moradores das favelas para serviços, mutirão para obras e financiamentos não onerosos. No entanto, esses equacionamentos não estão inseridos nos procedimentos e nas práticas empresariais como regra, mas como situações transitórias.

Demandados sobre como suas instituições poderiam contribuir para inovação, a grande concentração de respostas focou na gestão, seguida por estudos e capacitação, sugerindo programas de uso racional da água. Menos de $5 \%$ dos 
respondentes poderiam contribuir com inovação jurídica e modelos econômicofinanceiros.

Finalmente, $40 \%$ dos entrevistados identificavam a necessidade da revisão da política pública Usuários de baixa renda e prestação de serviços em aglomerados subnormais.

Os questionários (Anexo 2 - questionário 3) aplicados a todos os gestores das áreas de planejamento, engenharia dos serviços, comercial e controladoria da concessionária operando a Região Metropolitana objeto do estudo abordou os temas identificados no grupo de atores Brasil que podiam ser construídos e mapeados por oficinas.

Foram questionados se achavam necessárias à inovação de processo e atendimento na gestão. A maioria dos entrevistados respondeu, que sim. Essa questão tinha por objetivo identificar a conscientização e disponibilidade em participar de um modelo inovador.

No aspecto econômico-financeiro foram questionados se o usuário deveria dizer o quanto está disposto a pagar, $25 \%$ disseram que não, mas os restantes optaram afirmativamente; $25 \%$ dos gestores negaram que a concessionária deveria subsidiar do próprio bolso os descontos e o restante optou por sim. $90 \%$ dos questionados entendem que é o poder público que deveria financiar. E, finalmente, todos os questionados afirmam que as áreas de vulnerabilidade têm margens tímidas. Quanto aos custos, todos foram unânimes com a ideia que atender essas áreas vulneráveis não incorre em novos custos de produção, serviços e tecnologias. Esse foi um paradigma quebrado em termos das entrevistas aplicadas no Brasil, que foi checado no plano de negócio.

No que tange a tarifa e pagamento pelos cidadãos, majoritariamente os gestores responderam que os moradores das áreas daquela região possuem capacidade de pagamento.

\subsection{AVALIAÇÃO DAS BASES DE DADOS}

Os bancos de dados das populações cadastradas foram disponibilizados pela Concessionária (clientes com tarifa social), Secretaria de Assistência Social do governo do estado (cidadãos cadastrados no CadUnico), e Fundação SEADE 
(base geo-referenciada com setores classificados segundo o IPVS) disponibilizados após entrevistas e solicitação da pesquisadora foram compilados na concessionária sobre a base cartográfica e apresentados na Tabela 14. Nessa etapa foi feita a caracterização das evidências empíricas de campo e de levantamentos técnicos do setor, análise e sistematização de dados secundários para construção de base empírica de dados usados na parte de planejamento, plano de negócio e estudo de subsídios, e plano de ação para inclusão de domicílios na tarifa social. Também permitiu incluir no questionário (Anexo 2 - questionário 2) a checagem do cadastro de famílias assistidas pelos programas geridos pela SASEP, complementando com situação de acesso à água e esgotamento sanitário, com os principais dados para verificação do enquadramento na tarifa social. Deve-se ressaltar que para garantir a mesma referência temporal foi adotada a base de 2012 da concessionária.

Tabela 14 - Comparação de Base de Beneficiários da Assistência Social

\begin{tabular}{|c|c|c|c|c|c|c|c|}
\hline \multicolumn{4}{|c|}{ Cadastro Único } & \multirow{2}{*}{$\begin{array}{c}\begin{array}{c}\text { Renda } \\
\text { Cidadã } \\
(2)\end{array} \\
\text { Qtde. } \\
\text { famílias } \\
\text { renda per } \\
\text { capita até } \\
\text { 1/2 salário } \\
\text { mínimo } \\
\text { (mil) }\end{array}$} & \multicolumn{3}{|c|}{ Cadastro $\underset{(3)}{\operatorname{con} c e s s i o n a ́ r i a}$} \\
\hline $\begin{array}{c}\text { Qtde. } \\
\text { famílias } \\
\text { Cadastradas } \\
\text { (mil) }\end{array}$ & $\begin{array}{c}\text { Qtde. } \\
\text { famílias } \\
\text { renda per } \\
\text { capita até } \\
\text { 1/2 salário } \\
\text { mínimo } \\
\text { (mil) }\end{array}$ & $\begin{array}{l}\text { Qtde. } \\
\text { famílias } \\
\text { renda per } \\
\text { capita até } \\
\mathrm{R} \$ 140,00 \\
\text { (mil) }\end{array}$ & $\begin{array}{c}\text { Qtde. } \\
\text { famílias } \\
\text { recebem } \\
\text { benefício } \\
\text { do Bolsa } \\
\text { Família } \\
\text { (mil) }\end{array}$ & & $\begin{array}{c}\text { Qtde } \\
\text { economias } \\
\text { Tarifa } \\
\text { Social } \\
\text { (mil)I }\end{array}$ & $\begin{array}{c}\text { Qtde } \\
\text { economias } \\
\text { Tarifa } \\
\text { Favela } \\
\text { (mil) }\end{array}$ & $\begin{array}{c}\text { Qtde } \\
\text { economias } \\
\text { Social Favela } \\
\text { (mil) }\end{array}$ \\
\hline $1.135,8$ & $1.052,9$ & 802,3 & 506,5 & 609,5 & 160,4 & 18,7 & 179,1 \\
\hline
\end{tabular}

Fonte: (1) Ministério Desenvolvimento Social, ref. Abr./2012; (2) Secretaria Assistência Social. - ref. 2011 (todo Estado SP); (3) SABESP (2012).

Aplicando-se sobre os setores definidos pela Fundação Seade quanto ao IPVS à base cadastral da RMSP, $15 \%$ dos usuários concentraram-se em setores com IPVS 5 e 6 Gráfico 32, representando aproximadamente 500 mil ligações e 800 economias em situação de alta vulnerabilidade. 
Gráfico 32 - Usuários da Concessionária nos setores de IPVS - SEADE

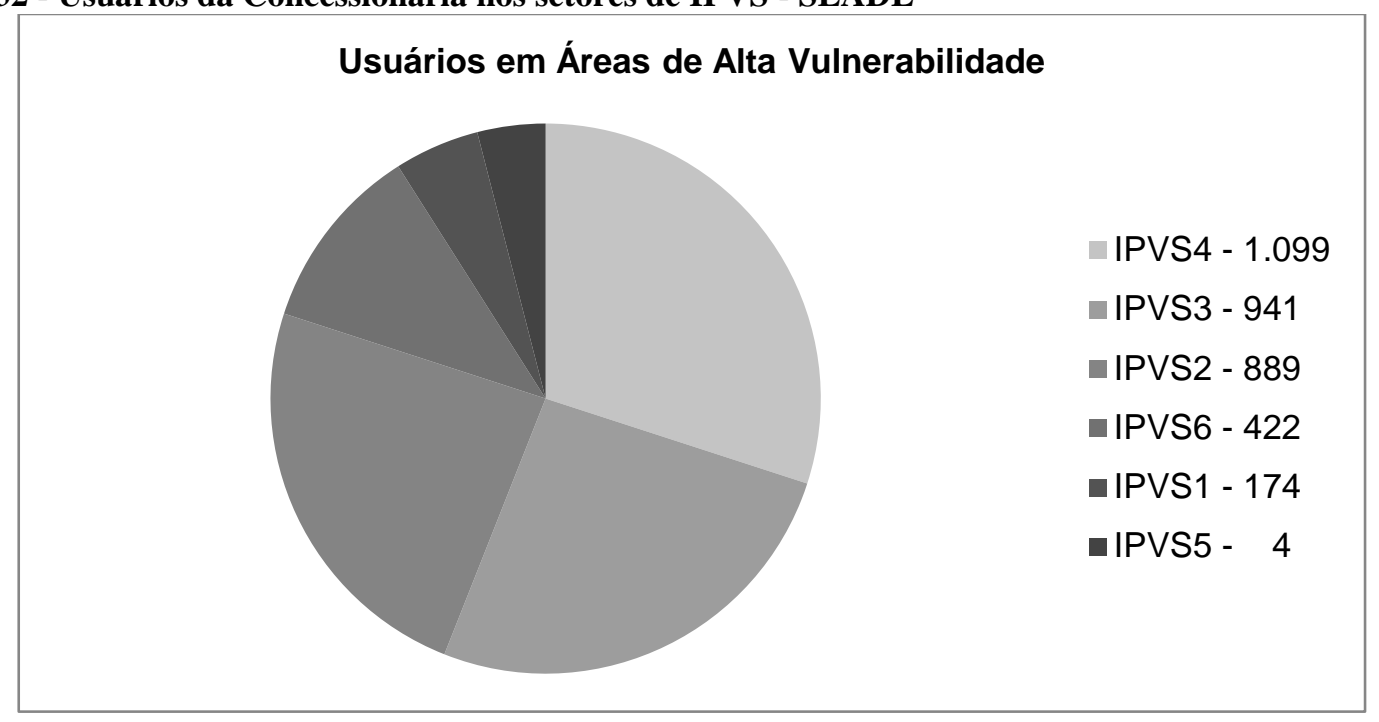

Fonte: SABESP 2013 (sobre a base da Fundação SEADE

A regra de enquadramento definida pela Agência Reguladora para beneficiários da tarifa social excluiu $90 \%$ dos usuários moradores dos setores censitários com IPVS 5 e 6 desse benefício; 89\% dos usuários em setores de IPVS 5 e 6 estão com ligações ativas.

Para identificação dos descontos concedidos às categorias subsidiadas comparam-se suas tarifas com as praticadas aos usuários equivalentes das categorias não subsidiados. Essa comparação deve ser feita em blocos (Figura 15), uma vez que a estrutura tarifária é do tipo por blocos crescentes. As distintas categorias tarifárias possuem os seguintes blocos.

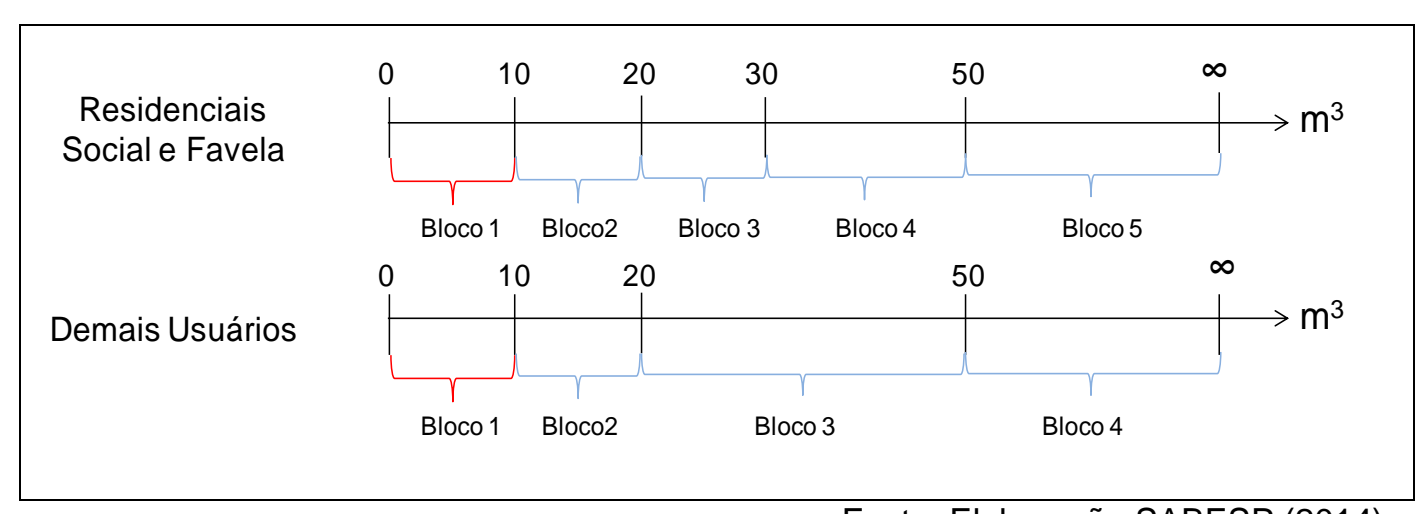

Fonte: Elaboração SABESP (2014).

Figura 15 - Blocos de consumo por categoria tarifária. 
Há duas peculiaridades das tarifas por blocos de consumo na SABESP: o primeiro bloco de consumo (até $10 \mathrm{~m} /$ mês) representa um consumo mínimo faturável; e os usuários da categoria tarifária residencial favela pagam somente até o limite de $22 \mathrm{~m}^{3}$, ou seja, a partir desse limite o consumo é gratuito. No caso da tarifa aplicável aos usuários residenciais sociais percebe-se que, independente do serviço prestado (água e/ou esgoto), os descontos são regressivos - de acordo com o incremento dos blocos de consumo - em relação à tarifa dos residenciais normais( Gráfico 33).

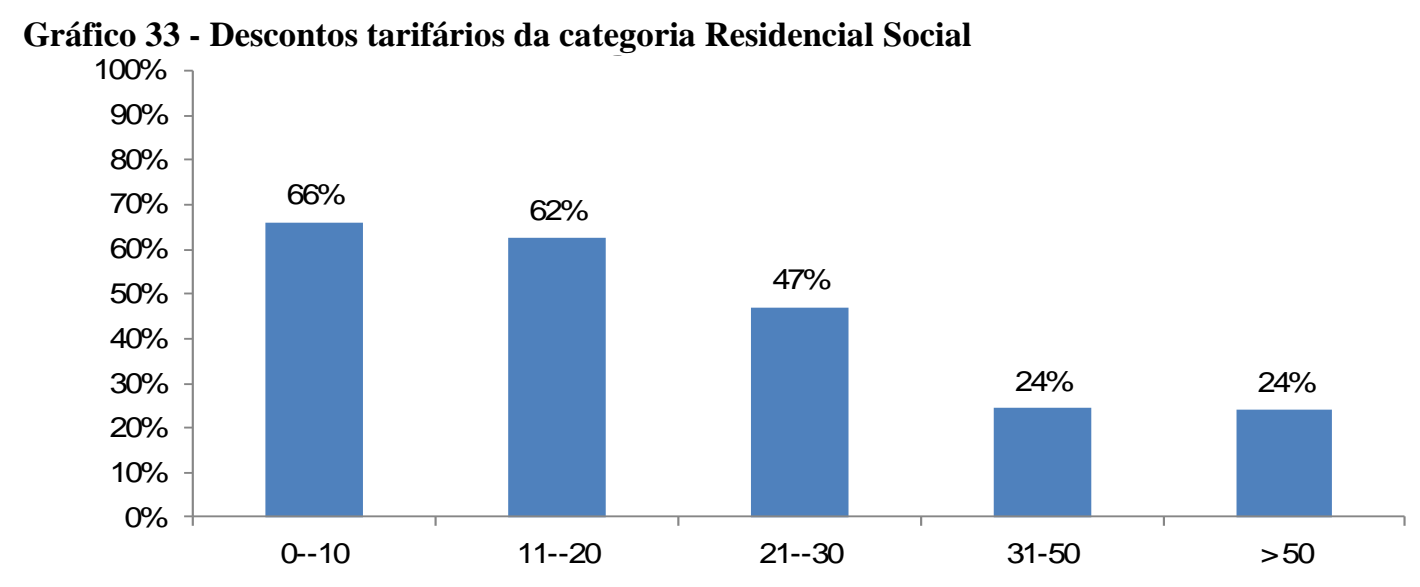

Fonte: SABESP, 2012.

No primeiro e segundo blocos de consumo os descontos alcançam patamares superiores a $60 \%$. No entanto, verifica-se que mesmo para consumos superiores a $20 \mathrm{~m}^{3} /$ mensais há ainda descontos tarifários consideráveis.

Conforme será visto no capítulo 8 , esses níveis de consumo são superiores às necessidades básicas que asseguram a salubridade familiar, não fazendo sentido, portanto, serem alvos de políticas de subsídios tarifários.

O subsídio tarifário é cruzado, sendo que os usuários não residências normais financiam a categoria residencial e à medida que se aumenta o consumo das categorias não subsidiadas aumenta-se o peso na compensação dos subsídios. Adicionalmente, entende-se que há um subsídio cruzado entre regionais tarifárias, onde o quociente das tarifas aplicáveis a um usuário não residencial - 
da categoria tarifária comercial normal, industrial e público sem contrato ${ }^{20}$ - em relação às tarifas aplicáveis a um usuário residencial da categoria tarifária residencial normal. As tarifas dos usuários não residenciais são, independentemente da faixa de consumo e regional tarifária, superiores às tarifas aplicáveis aos usuários da categoria residencial normal, no geral ${ }^{21}$, o custo de atendimento é semelhante, com independência do tipo de consumidor e região tarifária, o principal motivador dessa distinção tarifária são os subsídios cruzados. Os altos consumos independentemente da região financiam grande parte dos subsídios cruzados.

É possível concluir que os clientes não residenciais são, prioritariamente, os que subsidiam os usuários residenciais. No entanto, percebe-se que há subsídios tarifários mal alocados, onde usuários da categoria residencial normal são parcialmente subsidiados desnecessariamente pelos usuários não residenciais, mesmo que não façam jus a receber esse benefício tarifário e tenham capacidade de pagamento estando em bairros de classe média e média alta. A alta progressividade tarifária também deve ser revista, seja para usuários residenciais ou não residenciais. A tarifa relativa ao terceiro bloco (de 21 a 50 m3) é, aproximadamente, quatro vezes a tarifa média do primeiro bloco na RMSP, por exemplo. Especial atenção deve ser dada aos usuários não residenciais, dada a importância dos mesmos para o financiamento dos subsídios e na sustentabilidade da empresa no longo prazo. Em ultima instância a alta progressividade aplicada a esses usuários incentiva a busca por fontes alternativas e quebra do mecanismo de subsídios cruzados, levando a concessionária ao desequilíbrio econômico-financeiro (SABESP, 2013).

O critério de renda per capita não é suficiente para identificar as economias a serem subsidiadas, já que existem muitas outras características que indicam o nível de pobreza de um domicílio.

\footnotetext{
${ }^{20} \mathrm{Na}$ prática, as tarifas dos usuários Comerciais Normais, Industriais e Públicos sem Contrato são as mesmas dentro de uma mesma região tarifária.

${ }^{21}$ Grandes usuários industriais podem gerar efluentes não domésticos cujo tratamento é razoavelmente superior aos efluentes dos demais usuários. Contudo, para esses usuários há tarifas específicas - não reguladas - de acordo com a qualidade do efluente.
} 
Ainda que a linha de pobreza indique a quantidade de receita necessária para cobrir as necessidades básicas de alimentação, não aponta características de fluxo ou de stock sobre a pobreza. Por esse motivo, não é considerado um instrumento adequado para identificar a população que deve receber o subsídio. O IDH, disseminado pela ONU, teve origem na necessidade de medir o nível de desenvolvimento social e econômico das populações no mundo. Sendo um índice que obedece a critérios internacionais, é adequado para estudos, diagnósticos e comparações entre municípios, regiões, países e continentes.

Através do IDH observou-se que o componente de renda é o que mais afeta o IDH municipal, pois são o menos desenvolvido em comparação com os demais indicadores dessa medição de pobreza. Isto mostra uma alta concentração de renda, já que, apesar de ter níveis altos de riqueza (segundo os efeitos mostrados pelo IPRS), a renda per capita é baixa (de acordo com o apontado pelo IDH). A dimensão de educação segundo o IDH é a que apresenta mais desenvolvimento, embora, ao analisar os resultados pelo IPVS, perceba-se o déficit de educação existente (PNUD, 2006 a).

O IPVS é um indicador de condições populacionais, localizadas espacialmente, por setor censitário. Ele permite comparações intramunicipais, interbairros e inter-ruas de um mesmo bairro. É um indicador multifatorial, que considera ativos acumulados por moradores dos setores censitários (como nível de rendimento e nível de instrução do chefe de cada domicílio), assim como porcentagem do tamanho e composição da família, além da idade do chefe e dos dependentes.

O IPVS permite estabelecer indícios da possibilidade de determinado percentual de famílias do setor censitário permanecer no mesmo nível econômico, ou até de ampliar, no futuro, a situação de pobreza em que se encontra se políticas públicas concretas não forem estabelecidas para interferir nessa trajetória previsível (SEADE, 2012 a, 2012c).

O critério de nível de rendimento é um indicador de pobreza, pessoal ou domiciliar, através de uma única variável monetária. Já os níveis de IPVS são indicadores coletivos para um setor censitário, multifatoriais, que ponderam variáveis de diversos tipos: individuais, como nível educacional, faixa etária e rendimento do chefe; e coletivas, como idade dos filhos, porcentagem de 
domicílios com rendimento de até 3 salários mínimos, dividido pelo rendimento total do setor censitário, e porcentagem de responsáveis de domicílios analfabetos ou com ensino fundamental incompleto, sobre 0 total de responsáveis do setor censitário. Desse modo, a comparabilidade entre os dois resultados não é possível. Evidentemente, espera-se que haja uma semelhança entre os resultados, mas nada, além disso.

Analisando a questão por regiões atendidas, tem-se que a região que tem melhores níveis de condições socioeconômicas é a RMSP. O IPVS consegue desagregar a informação de vulnerabilidade de tal maneira que, embora a RMSP concentre a maior riqueza dos municípios atendidos pela SABESP, também concentra a maior quantidade de vulneráveis. A região do Litoral é onde há mais desigualdade nas condições socioeconômicas. Assim sendo, o IPVS é bastante adequado como um dos critérios a ser adotado no estabelecimento de políticas e programas públicos de atuação visando localização espacial de famílias, com bastante precisão. No caso dos subsídios para tarifas de água, o IPVS pode ser indicado como um critério a ser adotado em longo prazo, para a seleção de domicílios a serem subsidiados, pois permite identificar as economias que dificilmente mudariam sua trajetória de vulnerabilidade no decorrer do tempo, considerando características socioeconômicas e de ciclo de vida da família. Portanto, tomam-se os grupos mais vulneráveis, catalogados como IPVS 5 e 6 , onde se concentram as famílias mais vulneráveis e com menor possibilidade de alterar seu estado de vulnerabilidade, no longo prazo.

Adicionalmente o IPVS pode ser utilizado para priorização dos investimentos, pois, ao incluir o componente geográfico, possibilita a identificação das áreas mais vulneráveis e que requerem melhor atenção por parte da empresa.

\subsection{AVALIAÇÃO DAS LIDERERANÇAS COMUNITÁRIAS}

Os líderes comunitários que responderam a esse questionário (Anexo 2 questionário 2) participam de programas promovidos pela área de referência e benchmarking da RMSP, na Zona Norte. Essa foi à região mais afetada pela crise hídrica de 2014/2015 e foi escolhida como benchmarking, após oito visitas de levantamentos e participação em reuniões das lideranças comunitárias com a 
concessionária. Dessas reuniões saem encaminhamento de demandas que devem ser atendidas ou explicadas até a reunião do mês consecutivo. Participaram das reuniões, além dos líderes comunitários (lideranças das áreas favelizadas), agentes comunitários (funcionários da operadora, em geral assistentes sociais e sociólogos que fazem a interface entre empresa e comunidade 24 horas por dia, 7 dias por semana, atuando com atendimento telefônico por celular para toda e qualquer emergência que o líder comunitário identifique na comunidade), gerentes comercial, técnico; CONSEG - Conselho de Segurança do Estado, representante da Prefeitura, do Ministério da Justiça e Saúde. Nas reuniões das diversas comunidades de cada escritório regional todos os gerentes de departamento que têm atividades dentro das comunidades e superintendente participam fazendo apresentações das obras previstas e realizadas e anotam demandas dos lideres para responder na reunião do mês subsequente com as providencias tomadas.

Os líderes participantes, na sua maioria, moravam em áreas irregulares ou de risco, eram abastecidos pela operadora: e não usavam caminhão pipa (apesar da crise hídrica) e tinham caixa d'água, isto significa que a concessionária superou impeditivos à operação nessas áreas de forma satisfatória para os usuários.

Nos quatro encontros comunitários foram aplicados os questionários (Anexo 2 questionário 2). $25 \%$ dos respondentes veem esgoto a céu aberto na comunidade, não tinham ligação de esgoto e estavam em área de enchentes. $\mathrm{A}$ universalização não foi completada e ainda há impeditivos técnicos, econômicos ou jurídicos em determinadas áreas. Quanto aos hábitos de consumo, 75\% tinham tanquinho, armazenavam água de lavar roupa para outros usos, e sabiam identificar vazamentos; $50 \%$ guardavam água de chuva; $25 \%$ não reusavam água do banho, demonstrando resultado de trabalhos de educação ambiental para promover comportamentos com foco na sustentabilidade dos usuários da unidade de negócio. Quanto à comunidade, 50\% afirmaram que muita gente não paga a conta de água e se revoltam com isso, que há vazamentos pela comunidade e que são avisados pela concessionária quando vai faltar água; $100 \%$ avisam o agente comunitário quando há vazamento; $75 \%$ 
tem nome na conta, sabem quando haverá reunião com a SABESP, e são os pagadores das contas. Essas respostas mostram como a relação entre concessionária e os usuários é acompanhada de forte senso de cidadania das lideranças, agindo como guardiões dos serviços públicos.

Um percentual de $98 \%$ dos respondentes disseram gostar do agente comunitário, observando-se um fortíssimo espírito empreendedor e cuidador nos Agentes Comunitários (funcionários da SABESP). E um percentual de $75 \%$ dos respondentes que não sabem se estão cadastrados em tarifa social, ou como se cadastrar. Não tinham contas vencidas, afirmaram ser fácil negociar com a SABESP, e não tinham bolsa família. Essa questão leva a necessidade da avaliação da capacidade de pagamento de uma conta de água, ainda que por comunidades de baixa renda, frente ao valor da fatura.

Houve um percentual de $90 \%$ que não são visitados pelos agentes do SUS.

Deve-se ressaltar os pontos relevantes para análise e estratégia de comunicação junto às lideranças comunitárias:

$>$ No que tange às características socioeconômicas, todos os líderes entrevistados são moradores de setores censitários cujo IPVS é 5, 6 ou 7;

$>$ Os setores censitários foram mapeados na base cartográfica do sistema e estão representados no MAPA 5 com os respectivos aglomerados urbanos;

$>0$ perfil demográfico das comunidades representadas pelos respondentes, conforme dados do IBGE, é de assentamentos subnormais, ou seja, habitações que demandam infraestrutura mínima de serviços públicos essenciais;

$>$ O perfil psicográfico dos líderes demonstra sua capacidade nata de intermediação e representatividade de suas comunidades de forma verbal, porém na sua maioria se sentiram constrangidos em serem parcialmente alfabetizados ao responder os questionários, por essa razão os questionários foram modificados para forma de teste, sim ou não;

> Quanto ao perfil econômico, são empreendedores em diversas atividades junto à comunidade, desde orfanatos, cuidadores de crianças para mães trabalharem, representantes do conselho tutelar, hortas comunitárias, e 
outros arranjos empreendedores de SBR e não possuem qualquer tipo de comprovação de renda;

> Representavam em sua maioria mais de 100 famílias cada um deles.

> O questionário aplicado aos líderes comunitários da RS - UGR Santana foi reduzido e otimizado, pois seria aplicado a um grupo que teria reunião pela primeira vez com a concessionária nessa UN;

> As respostas subsidiaram a revisão do procedimento comercial, programa de educação ambiental, orientações sobre vazamentos aparente, e mutirão aos sábados para novas ligações, cadastramento na tarifa social, parcelamento de débitos, regularização de ligações clandestinas e inserção de nome nas contas, estratégia e estrutura;

> Há baixo número de cidadãos beneficiados pelos programas sociais federais como Bolsa Família e 57\% estão no CADUNICO, além de mais de $75 \%$ dos cidadãos que não são visitados pelos Agentes do Sistema Único de Saúde (Gráfico 28).

\subsection{AVALIAÇÃO DAS INTERVENÇÕES NOS AGLOMERADOS}

No Brasil, no censo 2010, há 15.868 setores censitários (5\%) caracterizados como aglomerados subnormais com 3.224 mil domicílios, 58,5\% localizados na região sudeste (IBGE, 2011).

Tabela 15 - Aglomerados Subnormais, RMBS (com exceção de Itanhaém e Mongaguá) - segundo Censo- 2010.

\begin{tabular}{|c|c|c|c|c|c|c|}
\hline Município & Pop. Geral & $\begin{array}{c}\text { Pop. em } \\
\text { assentamentos }\end{array}$ & Domicilios & $\begin{array}{c}\text { Média Hab. } \\
\text { Por domicílio }\end{array}$ & $\begin{array}{c}\text { \% da pop. em } \\
\text { assentamentos }\end{array}$ & Assentamentos \\
\hline Bertioga & 47.645 & 10.444 & 2.925 & 3,57 & $21,99 \%$ & 11 \\
\hline Cubatão & 118.720 & 49.134 & 14.841 & 3,31 & 41,52 & 16 \\
\hline Guarujá & 290.752 & 95.427 & 26.095 & 3,66 & 32,86 & 46 \\
\hline Praia Grande & 262.051 & 17.343 & 4.848 & 3,58 & 6,63 & 6 \\
\hline Santos & 419.400 & 38.159 & 10.767 & 3,57 & 9,13 & 24 \\
\hline São Vicente & 332.445 & 86.684 & 24.067 & 3,60 & 26,22 & 27 \\
\hline & 1.471 .013 & 297.191 & 83.543 & $(\mathrm{M}) 3,54$ & & 130 \\
\hline
\end{tabular}

IBGE(2010) 
Conforme IBGE na Tabela 15, a Região Metropolitana da Baixada SantistaRMBS é composta por 09 municípios: Santos, São Vicente, Guarujá, Praia Grande, Cubatão, Itanhaém, Peruíbe, Bertioga e Mongaguá, estima-se uma população de 1.7 milhões de habitantes, e um crescimento geométrico de apenas $1,02 \%$ a.a. entre 2000 e 2010, um pouco acima que a taxa registrada para o Estado de São Paulo para áreas regulares(IBGE, 2010).

Entre os anos 2000 e 2010 a RMBS ocorreu uma migração, partindo de Santos em direção à periferia da região metropolitana da Baixada Santistamotivada pela valorização imobiliária e o custo de vida. Os municípios de Bertioga e Praia Grande aumentaram significativamente os residentes fixos neste período. Os municípios de Santos, Cubatão, Guarujá, São Vicente e Praia Grande representam a maior concentração populacional da região, com suas áreas urbanas formando uma mancha quase contínua na parte mais central da RMBS. Santos, São Vicente e Praia Grande são os municípios mais verticalizados, sendo a disponibilidade de áreas de expansão urbana bastante restrita na porção insular dos dois primeiros.

Tabela 16 - Taxa de Crescimento da Área Formal RMBS

\begin{tabular}{|l|c|c|c|}
\hline $\begin{array}{c}\text { RMBS, Estado de São } \\
\text { Paulo e Brasil }\end{array}$ & $\begin{array}{c}\text { População } \\
2010\end{array}$ & $\begin{array}{c}\text { População } \\
2000\end{array}$ & $\begin{array}{c}\text { Crescimento } \\
\mathbf{2 0 0 0 - 2 0 1 0} \\
(\%)\end{array}$ \\
\hline Bertioga & 47.572 & 30.039 & 58,4 \\
Cubatäo & 118.797 & 108.309 & 9,7 \\
Guarujá & 290.607 & 264.812 & 9,7 \\
Itanhaém & 87.053 & 71.995 & 20,8 \\
Mongaguá & 46.310 & 35.098 & 31,9 \\
Peruíbe & 59.793 & 51.451 & 16,2 \\
Praia Grande & 260.769 & 193.582 & 34,7 \\
Santos & $\mathbf{4 1 9 . 7 5 7}$ & $\mathbf{4 1 7 . 9 8 3}$ & $\mathbf{0 , 4}$ \\
São Vicente & 332.424 & 303.551 & 9,5 \\
\hline RM Baixada Santista & $\mathbf{1 . 6 6 3 . 0 8 2}$ & $\mathbf{1 . 4 7 6 . 8 2 0}$ & $\mathbf{1 2 , 6}$ \\
\hline Estado de São Paulo & $\mathbf{4 1 . 2 6 2 . 1 9 9}$ & 36.969 .476 & $\mathbf{1 1 , 6}$ \\
\hline Brasil & 190.755 .799 & 169.590 .693 & $\mathbf{1 2 , 5}$ \\
\hline
\end{tabular}

Fonte: IBGE, Censos Demográficos 2000 e 2010.

Conforme IBGE o maior crescimento populacional deu-se nos municípios periféricos: Bertioga, Praia Grande e Litoral Sul - Itanhaém, Mongaguá e Peruíbe - e os municípios centrais: Cubatão, Guarujá e São Vicente, tiveram valores muito parecidos, de cerca de 12\% (Tabela 16). 
A região da Baixada possui uma grande concentração de população de baixa renda residente em assentamentos precários e áreas de proteção ambiental, cujos municípios de São Vicente, Vicente de Carvalho (Guarujá) e Cubatão se destacam nessa questão, com grande parte da população em áreas de risco (deslizamentos de encostas, inundações causada por enchentes, entre outros), ausência de infraestrutura e serviços de assistência e saúde adequados tornam essa população cada vez mais vulnerável.

Segundo a fundação Seade, o município de Guarujá e Cubatão apresentam a maior taxa da região de mortes por mil nascidos vivos - 18,71/ 1000 (IBGE, 2010; SEADE, 2012).

Os diagnósticos mais atualizados são os Planos Locais de Habitação de Interesse Social (PLHIS), que apresentam demanda habitacional dos municípios, definindo diretrizes, estratégias, linhas de ação e programas, além de estabelecerem metas e recursos para 0 atendimento de necessidades habitacionais identificadas. É um instrumento de articulação da política habitacional e de controle e monitoramento de seus resultados (EMPLASA, 2012).

O Sistema Nacional de Habitação de Interesse Social - SNHIS e o Fundo Nacional de Habitação de Interesse Social - FNHIS, criados pela Lei $\mathrm{n}$. 은 11.124/2005, subdivididos em Subsistemas de Habitação de Interesse Social, determina que o conteúdo básico para elaboração do PLHIS considere os seguintes aspectos: necessidades habitacionais - déficit e inadequação (devidamente mensurado e especializado), quadro normativo e institucional, levantamento de áreas de risco e áreas degradadas. Parte de seus dados são apresentados nas tabelas 12 e 13 para os núcleos de assentamentos precários no município de Guarujá (Prainha, Marezinha e Santa Cruz dos Navegantes).

O conceito de assentamento precário e/ou irregular que orientou a elaboração do mapeamento, e posteriormente do PLHIS por município, tomou como ponto de partida o conceito utilizado pelo Ministério das Cidades, advindas com a recente Política Nacional de Habitação (MINISTÉRIO DAS CIDADES, 2009).

Para uma melhor análise das questões habitacionais, adotou-se para análise e planejamento dados dos PLHIS dos municípios integrantes da Região 
Metropolitana da Baixada Santista, propostos pelo Ministério das Cidades em 2005 (Tabela 17) e atualizados pelas Prefeituras à Secretaria de Habitação do Estado.

Tabela 17 - Dados dos Assentamentos Precários atualizados pelos Municípios

\begin{tabular}{|c|c|c|c|c|c|c|}
\hline \multicolumn{7}{|c|}{ _ocal de Habitação de Interesse Social - PLHIS } \\
\hline Município & Pop geral & $\begin{array}{l}\text { Pop. em } \\
\text { assentamentos }\end{array}$ & Domicilios & $\begin{array}{l}\text { Média Hab. } \\
\text { Por domicílio }\end{array}$ & $\begin{array}{l}\% \text { da pop. em } \\
\text { assentamentos }\end{array}$ & Assentamentos \\
\hline (1)Bertioga & 47645 & 27.656 & 8.378 & 3,30 & $58 \%$ & 36 \\
\hline (2)Cubatão & 118.720 & 70.105 & 19.422 & 3,61 & $57 \%$ & 23 \\
\hline (3)Itanhaém & 87.057 & 28.680 & 5.177 & 5,54 & $6 \%$ & 83 \\
\hline (4)Guarujá & 290752 & 121.742 & 33.263 & 3,66 & $38 \%$ & 56 \\
\hline (5) Monganguá & 46293 & 2.117 & 570 & 3,71 & $22 \%$ & 11 \\
\hline (6)Praia Grande & 244.533 & 36.676 & 9.855 & 3,72 & $15 \%$ & 74 \\
\hline (7)Peruibe & 57.161 & 11.228 & 3.172 & 3,54 & $7 \%$ & 33 \\
\hline (8)Santos & 413.524 & 33.828 & 9.455 & 3,58 & $8 \%$ & 30 \\
\hline \multirow[t]{2}{*}{ (9) São Vicente } & 323.599 & 110.488 & 27.622 & 4,00 & $34 \%$ & 48 \\
\hline & 1.629 .284 & 442.520 & 116.914 & $(\mathrm{M}) 3,62$ & & 394 \\
\hline \multicolumn{7}{|c|}{$\begin{array}{l}\text { (1) Prefeitura de Bertioga- } 2010 \\
\text { (2) Fonte: PMC/ Multisetorial, Mc }\end{array}$} \\
\hline \multicolumn{7}{|c|}{$\begin{array}{l}\text { (3) PMH Itanhaém - Diagnóstico do Setor Habitacional- 2011- Para a regularização jurídica, foram identificadas } 82 \text { áreas - } \\
\text { sendo } 75 \text { áreas públicas e } 7 \text { áreas privadas. Das } 75 \text { áreas públicas, } 58 \text { estão inseridas no Programa Cdade Legal do Governo }\end{array}$} \\
\hline \multicolumn{7}{|c|}{ (4) Informações atualizadas em 2011-Prefeitura de Guarujá } \\
\hline \multicolumn{7}{|c|}{ (5) Informações da Secretaria de Estado de Habitação- 2010} \\
\hline \multicolumn{7}{|c|}{$\begin{array}{l}\text { (6) Prefeitura da Estância Bal neária de Praia Grande- } 2008 \\
\text { (7) População estimada 2008- Dados do PUHS2009 }\end{array}$} \\
\hline \multicolumn{7}{|c|}{ (8)Fonte: IBGECenso Demográfico, 2000 e CEM/ CBRAP, 2007.} \\
\hline
\end{tabular}

Elaboração: SABESP (2014)

Comparando as tabelas 15 e 16, ficou evidente pelos levantamentos municipais que o número de assentamentos e domicílios aumenta anualmente, retratando o difícil cenário de ocupações e favelização da Baixada Santista. Dados diferentes do mesmo município são encontrados nas secretarias de planejamento e Ministério das Cidades. Os planos elaborados pelas prefeituras registram o levantamento de dados em fontes secundárias, estudos e pesquisas acadêmicas, informações oficiais disponibilizadas pelas diferentes esferas de governo; e a elaboração e sistematização de informações de levantamentos e estimativas realizadas pelas PMs e consultorias. Os números apurados,são incertos quanto a realidade local, e demonstram divergência entre as fontes oficiais.

Com relação à questão habitacional, comparativamente, todos os municípios da RMBS apresentam índices maiores de déficit habitacional concentrado na faixa de renda até três salários mínimos.

A concessionária presta serviços de abastecimento de água e esgotamento sanitário na Baixada Santista: Santos, São Vicente, Cubatão, Praia Grande, 
Bertioga, Guarujá, Itanhaém, Mongaguá, Peruíbe. Na RMBS a proporção de pessoas residentes em aglomerados subnormais é de 17,9 \% em relação à população total e representa uma população residente em domicílios particulares ocupados em aglomerados subnormais de 297.191 habitantes (EMPLASA, 2010). Os movimentos pendulares são majoritariamente internos às RMs, sendo que o percentual de crescimento entre 2000 a 2010 foi de $57 \%$ na Região Metropolitana da Baixada Santista. (EMPLASA, 2012). O sistema de informações georeferenciadas em implantação na Baixada Santista adotou bases cartográficas orto-retificadas (Emplasa, 2007). A base contém o mapeamento das áreas de risco realizadas pelo Instituo de Pesquisa Tecnológico (2004 e 2007) para os municípios de Guarujá, Santos e São Vicente. A concessionária inseriu informações do cadastro de redes e dados dos usuários.

Constatou-se a complexidade do contexto e a demora em equacionar a questão habitacional em situações como no município de São Vicente com a Vila Margarida, antigo aglomerado México 70, conforme o texto:

Conforme os dados apresentados no relatório (SABESP, 2010, apud DAEE, 2010b, p.56)). verifica-se ainda que, na porção oeste da área continental do município estão previstas melhorias e ampliações no bairro do Humaitá, Samaritá, Quarentenário e Rio Negro. No tocante à região de Samaritá, a SABESP planeja a implantação de rede de coleta e ampliação da capacidade de tratamento do sistema de esgoto existente no bairro. Segundo a empresa (SABESP, 2012), o valor desta obra deve ultrapassar $\mathrm{R} \$ 6$ milhões, atendendo a 50 mil habitantes dos bairros da área continental do município. De qualquer modo, é importante considerar que um dos grandes vetores de crescimento da área central da Baixada Santista é a porção oeste da área continental de São Vicente, cuja cobertura do sistema de esgotos ainda é muito deficitária, mesmo considerando as intervenções realizadas nos últimos anos. Desta forma, é importante considerar a possibilidade de encurtamento dos prazos para implantação dos investimentos em saneamento nesta área, além de 
acelerar as intervenções urbanísticas previstas para os assentamentos situados nos diques, ao norte da área insular do município, ao redor do Jóquei, além da ampliação da cobertura da Vila Margarida, México 70 e Barreiros e demais áreas sem cobertura da área insular, efetivando a realização de ligações nas redes de esgotos nestas área.

Quando se analisa as metas empresariais e planos de negócios regulatórios publicados pela agência reguladora, parte-se da origem das informações utilizadas para definir os níveis de atendimento de áreas atendíveis (regulares) com sistemas de abastecimento de água e esgotamento sanitário dimensionados para tal. As incertezas provenientes das características jurídicas, sociais, econômicas e políticas dos municípios nos quais a concessionária atua são diretivas determinadas pela realidade em contraposição à legalidade do cadastro de domicílios urbanos e rurais do IBGE e municípios. Os índices de atendimento calculados subsidiam as metas do planejamento estratégico, tático e operacional. Tomando-se como exemplo o índice de atendimento de áreas de vulnerabilidade, atualmente, com quase a totalidade dos domicílios atendidos com água, faz-se necessário um refinamento para identificação da parcela não atendível, em área de assentamentos precários, áreas irregulares como parte da Vila Margarida, em São Vicente; Prainha e Marezinha no município de Guarujá e Vila dos Pescadores no município de Cubatão.

Como resultado da pesquisa junto a concessionária, quanto a coleta e organização dos dados de diferentes atores, visando, subsidiar o planejamento tático das unidades de negócio, e, ao mesmo tempo, alinhar com outros atores responsáveis por programas de urbanização e de desenvolvimento humano, por secretarias de planejamento, habitação, saneamento, meio ambiente, saúde, entre outros, identificou-se que apesar da incerteza observada no indicador, as séries históricas, dentro de conceitos de cobertura e atendimento, ligações ativas e inativas, perdas físicas e comerciais, permitem a visualização da evolução dos serviços de abastecimento de água e esgotamento sanitário e do grande passo dado pelas concessionárias nos diversos municípios operados nesses últimos anos. Anualmente a concessionária tem feito revisões dos dados 
oficiais para dar coerência ao seu planejamento e às suas unidades de negócio. Assim, recalcula os resultados provenientes das diferenças entre cadastros prórpio e de assistência social do estado, que apresenta situações díspares para o planejamento.

Os atuais modelos de benchmarking do setor de saneamento apresentam ainda significativas lacunas ocasionadas por disparidades da gestão, no que diz respeito à situação dos cidadãos em áreas de vulnerabilidade (SABESP, 2011). Tais áreas não são consideradas nas metas e nos indicadores de universalização no Brasil até que sejam regularizadas, demonstrando fragilidade de um dos principais mecanismos de gestão e regulação, os indicadores do Sistema Nacional de Saneamento SNIS.

Quanto ao modelo de gestão, o setor de saneamento é um monopólio natural (redes físicas dedicadas) sujeito a diversos tipos de regulação e pressões políticas. Tem por características a satisfação de necessidades básicas dos usuários, a universalização dos serviços e demanda atenção estratégica às populações de baixa renda adotando diversos caminhos para eficiência técnica e eficácia social. As empresas brasileiras de saneamento, muitas vezes foram acionadas juridicialmente quando atendiam em água aos usuários em áreas de invasão, situação de diversas favelas do país, uma vez que os sistemas de controle entendem que as empresas operadoras estão impedidas de levar serviços de infraestrutura a áreas ilegais.

Nesse sentido, a universalização depende da aderência ao ordenamento jurídico da ocupação do solo urbano, meio ambiente e recursos hídricos.As ações judiciais contra a provisão de água nessas áreas justificam que as metas definidas contemplem apenas áreas regulares, ou em processo de regularização, onde a infraestrutura de saneamento básico é parte integrante desta regularização (integração de ações). Os diálogos entre empresas e reguladores devem ser sustentados por um modelo de benchmarking que forneça credibilidade e transparência no processo de prestação de contas ao usuário e poder concedente quanto aos processos de acompanhamento de 
regulação técnica, econômica e social. É preciso que o planejamento seja claro, de forma a se inserir no processo estratégico das operadoras, fortalecendo durabilidade econômica, administrativa e de diálogos.

Nesse sentido, a tese traz como inovação a função que permitiu identificar por tabulação de todos os resultados das vistorias, num gráfico de dispersão, uma previsão de ligações clandestinas em aglomerados subnormais em uma área de concessão urbana e seus impactos para análise da vulnerabilidade empresarial ao operar tais espaços. O reflexo no modelo de organização das empresas, custos de operação, sendo, portanto, parte essencial da pesquisa. Por essa razão, todos os dados das 2515 vistorias realizadas nos 37 assentamentos precários foram tabulados no gráfico de dispersão (Gráfico 34) das comunidades vistoriadas (Anexo Tabelas 61 e 62) para identificar a correlação entre número de domicílios num micro setor de cada aglomerado subnormal e domicílios potenciais de abastecimento clandestino. Conforme gráfico genérico (Gráfico 34) obteve-se uma correlação conforme a Fórmula 1, onde y é o número de ligações clandestinas e $\mathrm{x}$ é o número de domicílios no assentamento precário.

Fórmula 1 - Função Construída da Correlação de Inativas com Domicílios de um Aglomerado Subnormal

$$
\begin{gathered}
y=0,1757 x+7,5423 \\
R^{2}=0,1613
\end{gathered}
$$

O desenvolvimento da fórmula teve por objetivo estimar ou antever o número de ligações clandestinas nas áreas de favelas e, em função disso, estimar intervenções necessárias, plano de custos e perdas sociais. Segundo o modelo, para cada 100 aglomerados haverá 25 ligações clandestinas representando $25 \%$ do total de domicílios do aglomerado subnormal. 
Gráfico 34 - Gráfico de Dispersão de potencial abastecimento irregular

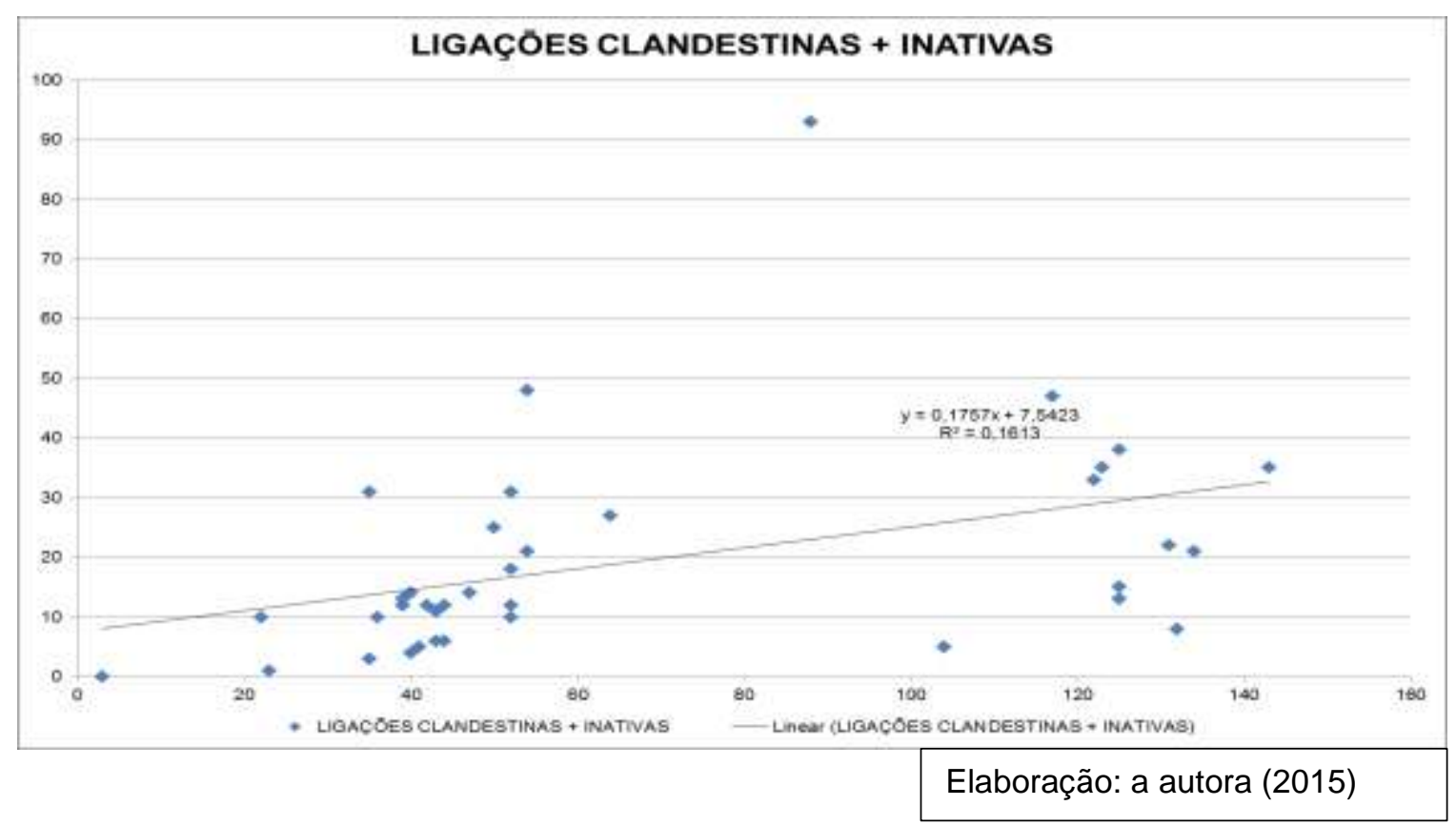

\subsubsection{Avaliação das sistemáticas de Intervenções}

Inicialmente, foram consideradas as dificuldades técnicas da universalização, por meio dos dados das vias de circulação interna dos aglomerados para se assentar redes e conectar ligações. Segundo o censo (IBGE, 2010) havia 3.200 mil domicílios em assentmentos precários no Brasil, sendo que $51,8 \%$ da área é formada por ruas, o restante eram becos, travessas, caminho, trilha, escadaria, sem via de acesso, passarela, pinguela e rampa, requerendo arranjos sociotécnico, que melhoram a eficiência técnica, apesar de diferentes dos projetos clássicos da engenharia civil e sanitária (Tabela 18).

Tabela 18 - Vias de Circulação da RMBS

\begin{tabular}{c|c|c}
$\begin{array}{c}\text { Tipo de Acesso } \\
\text { Beco/travessa }\end{array}$ & n. de domicílios (mil) & $\%$ \\
\hline Caminho/trilha & $3.224,9$ & 40 \\
\hline Escadaria & 65,1 & 2 \\
\hline Sem via de circulação interna & 136,8 & 0,9 \\
\hline Passarela/pinguela & 28,7 & 1 \\
\hline Rampa & 30,8 & 0,4 \\
\hline Rua & 12,4 & 51,8
\end{tabular}

Fonte: IBGE Censo Demográfico (2010) 
Os engenheiros chamam de gambiarras os arranjos técnicos que superam os impedimentos do modelo rede-centrado, que aguarda a urbanização para atender populações vulneráveis. Considerando o exposto, especial atenção foi dada às áreas de ocupação irregular e de restrição ambiental e as questões que deveriam ser enfrentadas, em grande maioria no âmbito municipal, de forma a garantir a expansão dos serviços.

A fragilidade da dimensão habitacional é intensificada nessas áreas, quando observados outros indicadores de condições de vida (Cerqueira \& Pupob, 2009). O abastecimento de água ocorre através de ligações clandestinas, numa sequência de mangueiras flexíveis de borracha emendadas de forma precária, constituindo uma tubulação de risco para o consumo, uma vez que tais mangueiras passam por dentro da maré, onde se misturam aos dejetos domésticos lançados, juntamente com o lixo, conforme Anexo de fotos. Muitas das habitações não dispõem de instalações hidros sanitárias (banheiros) adequadas que proporcionem higiene pessoal e doméstica.

O fator ambiental e operacional relevante observado nestes aglomerados foi o alto consumo e a elevada perda água por vazamentos e o consumo excessivo por domicílio. Estudos realizados em parceria com centros internacionais de pesquisa e desenvolvimento, como o Japan International Cooperation Agency JICA apontaram que o consumo de água nestas regiões chegam a ser até duas vezes maiores que nas áreas regularizadas.

Conforme identificado nas visitas de campo e mostrado nas figuras, todas as comunidades acessavam água da concessionária por meio de ligações clandestinas por mangueiras e bombas de sucção colocadas diretamente nas redes públicas para quando há baixa pressão na redes.

A primeira intervenção objeto de avaliação foi do município de Santos conforme Milhoratti et. al. (2014).

Programas habitacionais de Santos promoveram a regularização dos assentamentos e autorizaram a concessionária a assentar redes e regularizar as ligações clandestinas. No aspecto técnico-empresarial, todo produto que foi 
entregue e, por alguma razão, não foi faturado, não sendo contabilizado como receita, é considerado perda. Identificam-se dois tipos de perdas de água num sistema de abastecimento:

> A perda real, que corresponde ao volume de água produzido que não chega ao consumidor final em razão de vazamentos nas redes de distribuição e ligações domiciliares.

$>$ E a perda aparente, que corresponde ao volume de água produzido que não é contabilizado pela companhia de saneamento. Também se identificam erros na medição de hidrômetros, fraudes, ligações clandestinas e falhas no cadastro comercial.

Tanto as perdas reais como as perdas aparentes representam para 0 consumidor um componente importante nas tarifas por eles pagas, já que geralmente esses custos são incorporados à sua composição de preços.

Para um domínio efetivo do controle de perdas, foram estabelecidos setores de abastecimento estanques, com apenas um ponto de entrada de água e com medição do volume admitido nesse ponto. Foram realizadas a gestão das pressões no setor, reduzindo as elevadas pressões noturnas uma vez que elevam vazamentos. Assim, foram realizar medições efetivas dos volumes de água produzidos, o controle de vazões mínimas noturnas, a micromedição e o controle dos usos sociais.

As ações da área comercial que visam redução das perdas aparentes foram relacionadas à melhora no desempenho da micromedição, através de ações nas seguintes áreas: dimensionamento e substituição de hidrômetros; controle sobre fraudes e ligações clandestinas; melhoria no sistema comercial e qualificação da mão de obra dos profissionais de leitura, fiscalização e análise das informações. O controle da inadimplência foi fator determinante para o equilíbrio econômicofinanceiro, cuja cobrança foi feita por meio de ações administrativas, que incluiram o corte do fornecimento de água e a supressão da ligação. Na não regularização dos débitos, fez-se a cobrança amigável e, posteriormente, a cobrança judicial. São chamadas de ligações inativas aquelas que tiveram a supressão da ligação devido existência de débitos. Existem casos em que após 
a supressão os imóveis continuam ocupados e se abastecem clandestinamente causando perda aparente do volume de água por eles consumido. Assim, foram realizadas vistorias periódicas nas ligações inativas, visando identificação de abastecimento irregular. Em núcleos de baixa renda, nenhuma das modalidades de cobrança mostrou-se eficaz. Nesses locais, a persistência das ações de corte iludem o gestor que imagina ter esgotado as ações de cobrança administrativa, restando apenas o corte do fornecimento para fazer cessar o aumento dos débitos e pressionar o cliente a resolver o caso. Tal ação muitas vezes conduz os clientes à clandestinidade, interrompendo o faturamento sobre seu consumo, mas não reduzi os custos operacionais, já que os imóveis continuam se abastecendo.

Outra intervenção estudada foi Vila Margarida no município de São Vicente.Em muitos casos, a concessão de descontos ou facilidades de negociação, revisão na modalidade da tarifa cobrada ou outras providências podem resgatar 0 cliente, e vitando não só perda do faturamento, como também a melhoria no desempenho da apuração do consumo e, consequentemente, redução das perdas aparentes, como por exemplo, a Vila Margarida, no município de São Vicente (figura 16), cujas ações de fraudes e uso de bombas para sugar a rede geram vazamentos e impactam na eficiência técnica das áreas regulares no entorno, cujos consumos foram estimados para os aglomerados normais no estudo da JICA (Tabelas 19 e 20). 


\section{Vila Margarida}

\begin{tabular}{|c|c|c|c|}
\hline \multirow{2}{*}{ Setor } & \multicolumn{3}{|c|}{ Ligaç̃̃es } \\
\cline { 2 - 4 } & Ativas & Inativas & Ligações \\
\hline 08 & 886 & 86 & 972 \\
\hline 09 & 2.035 & 197 & 2.232 \\
\hline 10 & 1.412 & 167 & 1.579 \\
\hline 10 & 2.193 & 328 & 2.521 \\
\hline 11 & 28 & 75 & 103 \\
\hline 12 & 495 & 272 & 767 \\
\hline 13 & 1.043 & 783 & 1.826 \\
\hline 14 & 934 & 266 & 1.200 \\
\hline Total & $\mathbf{9 . 0 2 6}$ & $\mathbf{2 . 1 7 4}$ & $\mathbf{1 1 . 2 0 0}$ \\
\hline
\end{tabular}

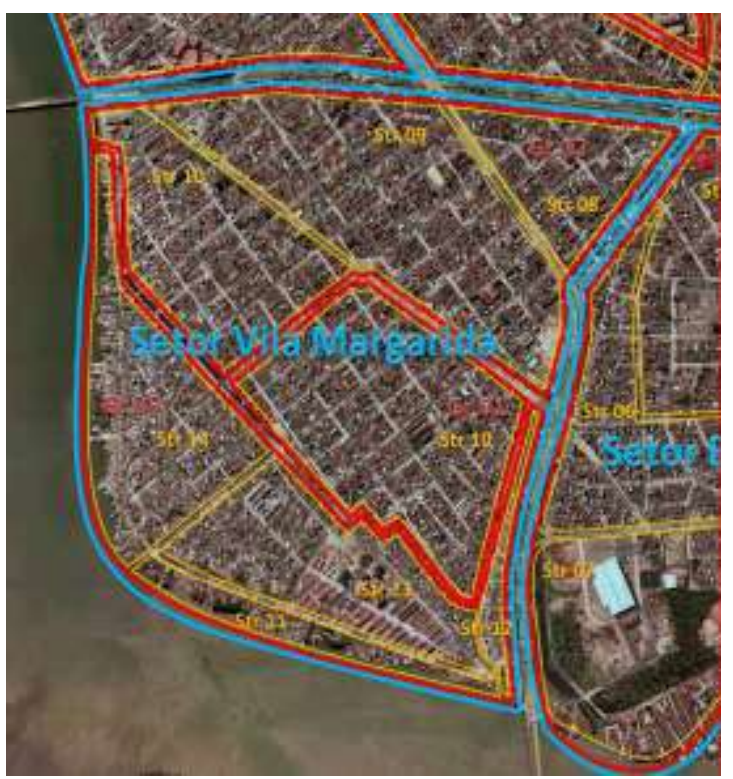

Fonte: SABESP (2014)

Figura 16 - Vila Margarida em São Vicente - SP

Tabela 19 - Consumo de água estimado em áreas irregulares

ÁREAS IRREGULARES EM GUARUJA

\begin{tabular}{l|l|l}
\hline BAIRROS & $\begin{array}{l}\text { MORADIAS } \\
\text { ESTIMADA }\end{array}$ & $\begin{array}{l}\text { CONSUMO } \\
\text { ESTIMADO } \\
\text { (m3/mês) }\end{array}$ \\
\hline $\begin{array}{l}\text { LIGAÇÕES IRREGULARES EM } \\
\text { GUARUJÁ }\end{array}$ & 18.321 & $557.508,03$ \\
\hline \multirow{2}{*}{$\begin{array}{l}\text { LIGAÇÕES REGULARES EM } \\
\text { GUARUJÁ }\end{array}$} & $\begin{array}{l}\text { LIGAÇÕES } \\
\text { REGULARES }\end{array}$ & $\begin{array}{l}\text { CONSUMO } \\
\text { MEDIDO } \\
\text { (m3/mês) }\end{array}$ \\
\cline { 2 - 3 } & 39.122 & $1.277 .954,00$ \\
\hline TOTAL EM GUARUJÁ & 57.443 & $\begin{array}{l}1.835 .462,03 \\
\text { Elaboração: SABESP(2015) }\end{array}$
\end{tabular}

Em São Vicente, estimou-se uma perda média de 30\%, com a ligações irregulares. 
Tabela 20 - Consumo estimado em Áreas Irregulares de Vicente de Carvalho

\begin{tabular}{|c|c|c|}
\hline \multicolumn{3}{|c|}{ ÁREA IRREGULARES EM VICENTE DE CARVALHO } \\
\hline BAIRROS & $\begin{array}{l}\text { MORADIAS } \\
\text { ESTIMADA }\end{array}$ & $\begin{array}{c}\text { CONSUMO ESTIMADO } \\
\text { (m3/mês) }\end{array}$ \\
\hline \multirow{3}{*}{$\begin{array}{l}\text { LIGAÇÕES } \\
\text { IRREGULARES }\end{array}$} & 7.438 & $226.338,34$ \\
\hline & $\begin{array}{c}\text { LIGAÇÕES } \\
\text { REGULARES }\end{array}$ & $\begin{array}{l}\text { CONSUMO MEDIDO } \\
\text { (m3/mês) }\end{array}$ \\
\hline & 25.489 & $502.721,00$ \\
\hline $\begin{array}{l}\text { TOTAL EM VICENTE } \\
\text { DE CARVALHO }\end{array}$ & 32.927 & $729.059,34$ \\
\hline TOTAL DO MUNICÍPIO & 90.370 & $2.564 .521,37$ \\
\hline
\end{tabular}

Em Vicente de Carvalho, estimou-se uma perda de $31 \%$, com as ligações irregulares.

Outra intervenção estudadae foram os aglomerados subnormais das Tabelas 21 e 22 estão na periferia de Guarujá e Vicente de Carvalho, causando sérios problemas quanto ao desabastecimento de áreas regulares, conforme ANEXO Planta 1 da concessionária. Frente aos números apresentados identificou-se necessidade em regularizar as ligações de água, bem como a intensificação nos reparos das redes existentes e/ou a substituição para a readequação e normalização da distribuição. Para avaliação dos levantamentos e inovação do modelo de gestão estruturou-se esta avaliação, conforme o histórico pesquisado e oficinas realizadas.

Assim, o município de Cubatão subsidiou análise dos resultados obtidos com as intervenções sociotécnicas que foram selecionados por dados de três áreas, cujos dados foram coletados de 2011 a 2014 (Rasera, 2014) e atuação técnica e comercial. A segunda, os dados são provenientes de estudo realizado no município de Santos (Milhoratti et. al., 2014), durante intervenções técnicas em 2012. A terceira com arranjos sociotécnicos no município de Guarujá (SABESP, 2013). 


\subsubsection{Intervenções técnicas e comerciais em áreas de Cubatão}

Esse município foi visitado pela pesquisadora pela primeira vez em 31/08/2011 com objetivo de estabelecer piloto da pesquisa. Foi objeto de estudo de Rasera (2015) e Calderon (2015), que testaram indicadores pré-existentes no setor de saneamento, mas não adotados para áreas irregulares na dimensão técnica e comercial. Somente estão refletidas, em 2014, ações provenientes da atuação sociotécnica, uma vez que a abordagem inicial era de caráter rede-centrado, apresenta-se no sistema corporativo comercial, o número de ligações nas Tabela 21, na Tabela 22 e Índices de perdas, em 2013 e 2014 na Tabela 23.

Tabela 21 - SISPERDAS Cubatão

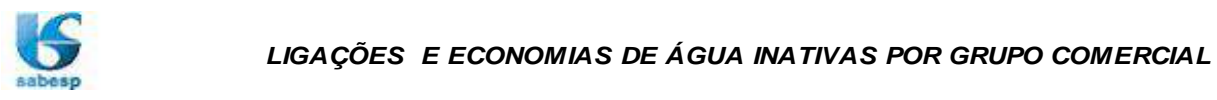

MUNICÍPIO: CUBATÃO

\begin{tabular}{|c|c|c|c|c|c|c|c|c|c|c|c|c|c|c|}
\hline & \multicolumn{2}{|c|}{ jan/13 } & \multicolumn{2}{|c|}{ fev/13 } & \multicolumn{2}{|c|}{$\mathrm{mar} / 13$} & \multicolumn{2}{|c|}{$a b r / 13$} & \multicolumn{2}{|c|}{$\mathrm{mai} / 13$} & \multicolumn{2}{|c|}{ jun/13 } & \multicolumn{2}{|c|}{ jul/13 } \\
\hline Grupo & Lig & Econ & Lig & Econ & Lig & Econ & Lig & Econ & Lig & Econ & Lig & Econ & Lig & Econ \\
\hline 01 & 4 & \begin{tabular}{|l|}
163 \\
\end{tabular} & 4 & 163 & 4 & 163 & 4 & 163 & 4 & 163 & 5 & 164 & 5 & 164 \\
\hline 02 & 167 & 212 & 165 & 210 & 167 & 212 & 171 & 216 & 175 & 220 & 174 & 219 & 180 & 220 \\
\hline 03 & 114 & 122 & 112 & 120 & 114 & 122 & 114 & 122 & \begin{tabular}{l|l}
115 \\
\end{tabular} & 123 & 115 & 123 & 115 & 123 \\
\hline 04 & 49 & 63 & 50 & 64 & 49 & 63 & 48 & 62 & 50 & 64 & 51 & 65 & 52 & 66 \\
\hline 06 & 61 & 64 & 61 & 64 & 61 & 64 & 61 & 65 & 61 & 64 & 61 & 64 & 61 & 63 \\
\hline 07 & 85 & 95 & 85 & 95 & 85 & 95 & 85 & 95 & 86 & 96 & 85 & 94 & 84 & 93 \\
\hline 09 & 68 & 74 & 67 & 72 & 68 & 74 & 69 & 75 & 74 & 81 & 75 & 82 & 76 & 83 \\
\hline 11 & 94 & 114 & 93 & 114 & 94 & 114 & 94 & 114 & 94 & 114 & 94 & 114 & 94 & 115 \\
\hline 12 & 205 & 219 & 202 & 216 & 205 & 219 & 204 & 218 & 211 & 225 & 214 & 228 & 215 & 229 \\
\hline 13 & 63 & 65 & 61 & 63 & 63 & 65 & 61 & 63 & 60 & 62 & 61 & 63 & 62 & 64 \\
\hline 14 & 124 & 136 & 122 & 134 & 124 & 136 & 128 & 146 & 126 & 144 & 126 & 144 & 127 & 146 \\
\hline 17 & 99 & 113 & 97 & 111 & 99 & 113 & 98 & 117 & 98 & 117 & 99 & 118 & 99 & 117 \\
\hline 18 & 223 & 229 & 227 & 233 & 223 & 229 & 214 & 220 & 195 & 200 & 168 & 172 & 141 & 144 \\
\hline 19 & 45 & 52 & 43 & 50 & 45 & 52 & 44 & 51 & 43 & 50 & 44 & 51 & 45 & 53 \\
\hline 20 & 53 & 55 & 53 & 55 & 53 & 55 & 53 & 57 & 53 & 57 & 53 & 57 & 52 & 57 \\
\hline 22 & 256 & 260 & 253 & 257 & 256 & 260 & 256 & 260 & 286 & 290 & 291 & 295 & 285 & 289 \\
\hline 25 & 110 & 726 & 110 & 726 & 110 & 726 & 111 & 727 & 111 & 727 & 112 & 729 & 110 & 727 \\
\hline 26 & 87 & 93 & 85 & 91 & 87 & 93 & 87 & 93 & 86 & 92 & 130 & 136 & 91 & 97 \\
\hline 31 & 48 & 51 & 49 & 52 & 48 & 51 & 48 & 52 & 50 & 54 & 48 & 51 & 47 & 50 \\
\hline Total & 1.955 & 2.906 & 1.939 & 2.890 & 1.955 & 2.906 & 1.950 & 2.916 & 1.978 & 2.943 & 2.006 & 2.969 & 1.941 & 2.900 \\
\hline
\end{tabular}

Fonte: Sistema SISPERDAS (2015)

Como principais resultados, por entrevistas e pelos dados do sistema corporativo, considerando o histórico do município, observou-se o controle sistemático do número dos ligações inativas e de domicílios beneficiados por tarifa social em $100 \%$ (Tabelas 22 e 23).

Nas ações técnicas de combate às perdas, tem-se uma pequena redução, porém há que se considerar que os aglomerados urbanos tiveram uma taxa de crescimento média do município de $9,7 \%$ e os aglomerados subnormais de $12,6 \%$. 
Esse percentual deve ser considerado na análise de resultados do programa de combate às perdas chamadas de sociais, pois o fato de manter o percentual pode representar uma efetiva redução de perdas totais. As ações que contribuíram a estes resultados estão neste capítulo.

Tabela 22 - Famílias com Tarifa Social em Cubatão

\begin{tabular}{|c|c|c|c|c|c|c|c|c|c|c|c|c|c|c|}
\hline & \multicolumn{2}{|c|}{$\mathrm{jan} / 13$} & \multicolumn{2}{|c|}{ fev/13 } & \multicolumn{2}{|c|}{$\mathrm{mar} / \mathbf{1 3}$} & \multicolumn{2}{|c|}{$a b r / 13$} & \multicolumn{2}{|c|}{$\mathrm{mai} / \mathbf{1 3}$} & \multicolumn{2}{|c|}{ jun/13 } & \multicolumn{2}{|c|}{ jul/13 } \\
\hline Grupo & Lig & Econ & Lig & Econ & Lig & Econ & Lig & Econ & Lig & Econ & Lig & Econ & Lig & Econ \\
\hline 01 & 497 & 1.056 & 496 & 1.055 & 599 & 1.397 & 604 & 1.402 & 621 & 1.419 & 741 & 1.539 & 752 & 1.550 \\
\hline 02 & 4 & 4 & 4 & 4 & 4 & 4 & 4 & ${ }^{4}$ & 4 & 4 & 4 & 4 & 4 & 4 \\
\hline 03 & 11 & 12 & 11 & 12 & 12 & 13 & 12 & 13 & 12 & 13 & 12 & 13 & 11 & 12 \\
\hline 04 & 3 & 3 & 3 & 3 & 4 & 4 & 5 & 5 & 5 & 5 & 5 & 5 & 5 & 5 \\
\hline 06 & 232 & 232 & 235 & 235 & 237 & 237 & 234 & 234 & 234 & 234 & 238 & 239 & 240 & 242 \\
\hline 07 & $\begin{array}{l}873 \\
\end{array}$ & 873 & 813 & 813 & 832 & 832 & 736 & 736 & 716 & 716 & 713 & 713 & 719 & 719 \\
\hline 09 & 3 & 3 & 3 & 3 & 3 & 3 & 3 & 3 & 4 & 4 & 5 & 5 & 5 & 5 \\
\hline 11 & 0 & 0 & 0 & 0 & 0 & 0 & 0 & 0 & 0 & 0 & 0 & 0 & 0 & 0 \\
\hline 12 & 3 & 3 & 3 & 3 & 3 & 3 & 3 & 3 & 3 & 3 & 2 & 2 & 2 & 2 \\
\hline 13 & 23 & 736 & 22 & 720 & 24 & 737 & 25 & 738 & 28 & 741 & 27 & 740 & 28 & 741 \\
\hline 14 & 5 & 5 & 4 & 4 & 5 & 5 & 4 & 4 & 4 & 4 & 4 & 4 & 5 & 5 \\
\hline 17 & 2 & 2 & 2 & 2 & 2 & 2 & 2 & 2 & 2 & 2 & 2 & 2 & 2 & 2 \\
\hline 18 & 646 & 655 & 685 & 694 & 723 & 732 & 740 & 749 & 782 & 791 & 865 & 874 & 938 & 947 \\
\hline 19 & 10 & 10 & 10 & 10 & 10 & 10 & 9 & 9 & 9 & 9 & 8 & 8 & 8 & 8 \\
\hline 20 & 9 & 11 & 9 & 11 & 9 & 11 & 9 & 11 & 9 & 9 & 9 & 9 & 9 & 11 \\
\hline 22 & 638 & 641 & 658 & 661 & 667 & 671 & 599 & 601 & 555 & 557 & 507 & 508 & 475 & 476 \\
\hline 25 & 465 & 551 & 464 & 552 & 469 & 557 & 482 & 570 & 479 & 567 & 478 & 566 & 481 & 569 \\
\hline 26 & 74 & 1.761 & 75 & 1.762 & 75 & 1.762 & 75 & 1.762 & 75 & \begin{tabular}{l|l|}
1.762 \\
\end{tabular} & 27 & 1.761 & 26 & 1.699 \\
\hline 31 & 11 & 12 & 11 & 12 & 11 & 12 & 11 & 12 & 11 & 12 & 11 & 12 & 11 & 12 \\
\hline Cotal & 3.509 & 6.570 & 3.508 & 6.556 & 3.689 & 6.992 & \begin{tabular}{|l|}
3.557 \\
\end{tabular} & 6.858 & 3.553 & \begin{tabular}{l|l|}
6.852 \\
\end{tabular} & 3.658 & 7.004 & 3.721 & 7.009 \\
\hline
\end{tabular}

Fonte: Sistema SISPERDAS (2015)

Tabela 23 - SISPERDAS Cubatão

\begin{tabular}{|c|c|c|c|c|c|c|c|c|c|}
\hline$\bigcup_{\text {sabosp }}$ & & Índic & $\begin{array}{l}\text { de Per } \\
\text { ce de }\end{array}$ & $\begin{array}{l}\text { de Água } \\
\text { das de F }\end{array}$ & $\begin{array}{l}\text { I/ramal } \\
\text { uramen }\end{array}$ & $\begin{array}{l}\text { lia)- IF } \\
-I P F\end{array}$ & & & \\
\hline Bairros & & dores & jan/13 & $\mathrm{fev} / 13$ & $\mathrm{mar} / 13$ & $a b r / 13$ & $\mathrm{mai} / 13$ & jun/13 & $\mathrm{jul} / 13$ \\
\hline Bolsão $7 / 8$ & IPDt & (1/ramal.dia) & 108 & 105 & 101 & 91 & 80 & 83 & 94 \\
\hline Bolsão $7 / 8$ & IPF & $(\%)$ & 8,1 & 7,4 & 6,7 & 5,2 & 3,7 & 3,8 & 5,2 \\
\hline Casqueiro & IPDt & (1/ramal.dia) & 136 & 68 & 81 & 97 & 107 & 122 & 200 \\
\hline Casqueiro & IPF & $(\%)$ & 3 & $-3,1$ & -2 & $-0,6$ & 0,5 & 2,2 & 8,6 \\
\hline Centro I & IPDt & (1/ramal.dia) & 406 & 418 & 447 & 457 & 443 & 432 & 417 \\
\hline Centro I & IPF & $(\%)$ & 32,5 & 33,4 & 35,1 & 35,7 & 34,9 & 34,2 & 33,3 \\
\hline Centro II & IPDt & (1/ramal.dia) & 670 & 672 & 621 & 632 & 632 & 631 & 635 \\
\hline Centro II & IPF & $(\%)$ & 44,1 & 44,2 & 42,1 & 42,6 & 42,6 & 42,5 & 42,7 \\
\hline Ilha de Caraguatá & IPDt & (1/ramal.dia) & 195 & 196 & 185 & 189 & 189 & 190 & 209 \\
\hline Ilha de Caraguatá & IPF & $(\%)$ & 20,7 & 20,8 & 19,6 & 19,9 & 19,8 & 19,9 & 22 \\
\hline Indústrias & IPDt & (1/ramal.dia) & 1.715 & 1.958 & 2.279 & 2.613 & 2.581 & 2.570 & 2.563 \\
\hline Indústrias & IPF & $(\%)$ & 15,6 & 17,5 & 20 & 22,3 & 22 & 21,8 & 22 \\
\hline Pinhal do Miranda & IPDt & (1/ramal.dia) & 237 & 281 & 281 & 277 & 270 & 269 & 262 \\
\hline Pinhal do Miranda & IPF & $(\%)$ & 15,1 & 18,7 & 18,7 & 18,3 & 17,6 & 17,3 & 16,5 \\
\hline Vila Natal & IPDt & (1/ramal.dia) & 262 & 261 & 261 & 260 & 263 & 264 & 262 \\
\hline Vila Natal & IPF & $(\%)$ & 11,8 & 11,8 & 11,8 & 11,9 & 12,2 & 12,4 & 12,5 \\
\hline Vila Pescadores & IPDt & (1/ramal.dia) & 123 & 123 & 121 & 101 & 102 & 104 & 105 \\
\hline Vila Pescadores & IPF & $(\%)$ & 3,9 & 3,9 & 3,8 & 1,7 & 1,8 & 2 & 2,1 \\
\hline TOTAL & IPDt & (1/ramal.dia) & 317 & 315 & 317 & 322 & 319 & 318 & 326 \\
\hline TOTAL & IPF & $(\%)$ & 19,4 & 19,3 & 19,5 & 19,9 & 19,6 & 19,6 & 20,3 \\
\hline
\end{tabular}


O município de Cubatão foi o primeiro que a concessionária implantou setorização em áreas de assentamentos precários com VRP's e macromedição nas áreas irregulares. Seus resultados tem rastreabilidade, pois foram efetivamente medidos conforme observa-se nos dados do sistema corporativo.

A Tabela 24 apresenta os resultados confrontados com a média anual. A discussão sobre a setorização de áreas de vulnerabilidade mostrou-se coerente com os resultados eficazes no combate a perdas, quando combinado ao combate de inativas, fraudes e vazamentos. Após os resultados desse setor, e discussões levadas à concessionária, foi ampliada a medição das áreas e setorização em outros municípios dessa e de outras regiões. Para análise, foram selecionados três setores, cujos dados geo-referenciados da base de ativos são:

Tabela 24 - SISPERDAS setores de abastecimento de Cubatão

MUNICÍPIO DE CUBATÃO

\begin{tabular}{c|c|c|c}
\hline Setor Abastecimento & Domicílios & IPM $^{22}(\%)$ & $\begin{array}{c}\text { IPF }^{23} \\
\text { (\% Outubro/13) }\end{array}$ \\
\hline Pinhal do Miranda & 4.831 & 16 & 11,2 \\
\hline Vila Natal & 3.033 & 17,7 & 12,7 \\
\hline Vila Pescadores & 957 & 10,7 & 2,3
\end{tabular}

Fonte: SABESP Setor Cubatão (2014)

Ps.: Dados Negativos significam problemas com o data-loger e foram desprezados na média

Para estudo econômico-financeiro, foi considerado o mês de referência de Janeiro de 2014. Em relação à estimativa de perdas de água, volume para assentamento precário foi considerado a média de Janeiro a Julho (VO), e tabela tarifária vigente. Calculou-se o valor recuperado:

Vila Esperança $\left(\mathrm{VO}=127.216 \mathrm{~m}^{3}\right) \quad=>$

$\mathrm{R} \$ 292.875,66$

Vila dos Pescadores $=\left(\mathrm{VO}=48.962 \mathrm{~m}^{3}\right)$

$=>$

$\mathrm{R} \$ 91.423,61$

Pinhal do Miranda $=\left(\mathrm{VO}=15.263 \mathrm{~m}^{3}\right)$

$=>$

$\mathrm{R} \$ 28.225,32$

OBS: Nos demais grupos não têm "VO" para assentamento precário

Tanto a Vila Esperança como a Vila dos Pescadores apresentaram valores médios das faturas como Tarifa Mínima, com elevação do usuários com Volume mínimo $\left(10 \mathrm{~m}^{3}\right)$ em Tarifa Mínima Residencial Social. O número de famílias inseridas na tarifa social foi ampliado em 100\%, no entanto, com relação a indicadores de perdas

\footnotetext{
22 IPM - Indice de Perdas Médio Anual

${ }^{23}$ IPF - Indice de Perdas Físico
} 
analisados nos índices porcentuais de perdas físicas, identificou-se uma singela redução média após estarem setorizados e macro medidos, com atuação sociotécnica conduzida pela área técnica de serviços da concessionária. As ações de recuperação e atuação junto a essas comunidades no setor de Cubatão, desde 2011, passam por elaboração de cadastro de rede, aumento da frequência de reuniões como secretaria da habitação e CDHU, identificação de ligações ativas e inativas para direcionar para novas redes e negociar dívidas, mapeamento de vielas sem rede e implantação de novas redes, assentamento de reforço de redes de diâmetro de $300 \mathrm{~mm}$ até Vila Esperança, gestão e atualização de cadastro de 4800 habitações com ligações ativas, instalação de macromedidores nas comunidades do município (Vila Esperança e Vila dos Pescadores) com medição de 326 1/ramal dia (30\%), implantação de programa de inativas - PIS e gestão de pressões para evitar falta de água. Um TAC - Termo de Ajustamento de Conduta fez congelamento e cadastramento das famílias.

Identificaram-se os seguintes resultados obtidos pela concessionária:

Como conclusão, houve aumento de $100 \%$ de famílias beneficiadas pela Tarifa Social; oscilações de número de ligações, e de índice de perdas pelo sistema aparentemente não relevantes ao longo desse período, entretanto, como a taxa de crescimento dos aglomerados subnormais de Cubatão é de $12,6 \%$, esse percentual deve ser considerado na análise de resultados, pois representa ações técnicas efetivas e impactam parâmetros de projeção. Recuperação de $\mathrm{R} \$ 60,00 /$ domicílio em Vila Esperança, $\mathrm{R} \$ 30,00 /$ domicilio em Vila dos Pescadores e $\mathrm{R} \$ 29,50 /$ domicilio em Pinhal do Miranda. Base janeiro de 2014.

\subsubsection{Avaliação das intervenções técnicas comerciais em áreas vulneráveis de Santos}

Segundo Milhoratti et. al. (2014), os estudos foram realizados pelos técnicos no Dique da Vila Gilda, um aglomerado subnormal com mais de 7.000 palafitas sobre 0 manguezal, sendo Área de Preservação Permanente - APP, as margem do Rio dos Bugres localizada na divisa de Santos com São Vicente, sendo identificadas 1796 ligações de água. Os demais domicílios eram abastecidos por ramais clandestinos assentados no mangue, sob as casas, cujas ligações inativas e clandestinas representam $3,3 \%$ do total de economias do município de Santos. O direito 
ambiental impediu a regularização da área, exceto onde há cadastro para remoção pela Companhia Habitacional do Município de Santos (COHAB Santista). O abastecimento de água era proveniente do Jardim Rádio Clube, no Setor Zona Noroeste, por redes de água da rua adjacente com becos e ruas com redes correm entre as habitações. Os ramais clandestinos estão abaixo da cota da maré e são aterrados com resíduos de construção e lixo pelos habitantes. Os ramais clandestinos tem grande número de vazamentos e a dificuldade de reparo permite a liberalidade da água vazando 24 horas por dia. A distribuição de ligações do Dique de Vila Gilda é dada na Tabela 25.

Tabela 25 - Quantidade de domicílios no Dique da Vila Gilda

\begin{tabular}{|lcll|}
\hline Dique da Vila Gilda & Domicílios & $\%$ no Dique & $\%$ no Município \\
\hline Ativas & 1796 & $25,7 \%$ & $1,0 \%$ \\
\hline Inativas & 1242 & $17,7 \%$ & $14,0 \%$ \\
\hline Sem Cadastramento & 3962 & $56,6 \%$ & \\
\hline
\end{tabular}

Para superar os impeditivos de operação frente à irregularidade a Unidade definiu duas principais ações sociotécnicas para a redução de perdas reais, por meio da realização de obras estruturantes; e recuperação de ligações inativas por meio de autação pela equipe comercial realizada dentro da comunidade dos aglomerados urbanos dos Bairro Jardim Rádio Clube e do Dique da Vila Gilda (Figura 17).

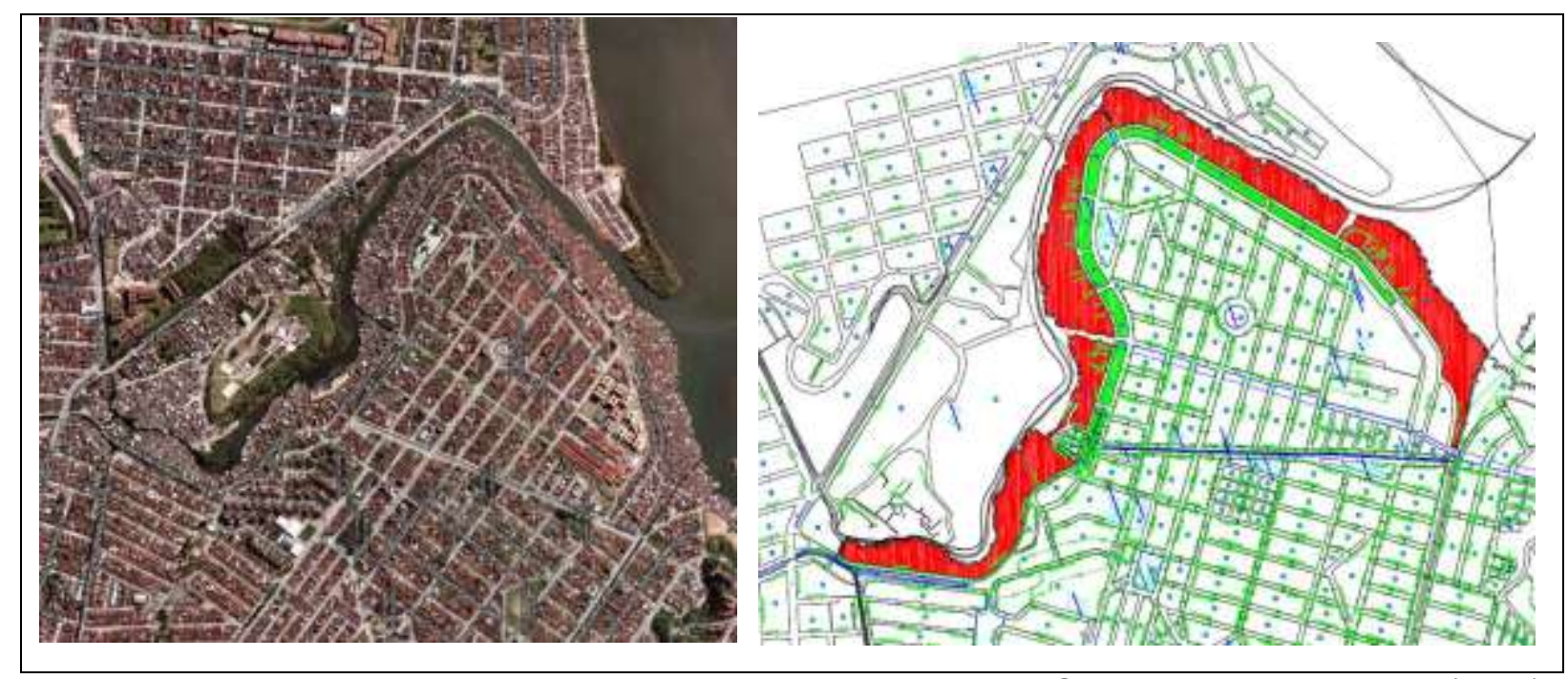

Fonte: IBGE Aglomerados Urbanos (2010)

Figura 17 - Área do Dique da Vila Gilda.

Em junho/2013 foram assentadas $1.500 \mathrm{~m}$ de rede primária de abastecimento nas quadras que estão entre a área regular e a irregular do Dique, gerando melhor 
abastecimento e redução de reclamações de falta d'água e de baixa pressão tanto na área do Dique como nas regiões regulares. Foram identificados locais críticos de abastecimento para renovação de redes para PEAD DN $50 \mathrm{~mm}$ e troca de ramais prediais das ligações ativas. Como ação comercial, num beco com 40 domicílios havia somente 11 cadastrados no sistema comercial da concessionária como regulares. Como ação operacional, como o abastecimento deficiente era causado por vazamentos invisíveis na rede de distribuição interna, que foram eliminados por remanejamento de redes e ramais. Com isso, as ligações clandestinas ficaram sem abastecimento e improvisaram novas ligações clandestinas para se abastecerem. Os técnicos concluíram que obtiveram êxito exclusivamente na garantia de estanqueidade da rede de distribuição, pois as tubulações novas são em PEAD eletrofundido e foram assentadas acima do nível da maré e estabeleceram: recuperar ligações inativas com regras flexíveis de parcelamento, implantação de tarifa social e redução dos débitos existentes, redução das pressões para redução de perdas nos ramais clandestinos.

A avaliação feita pelos atores é que a abordagem social pode melhorar os resultados futuros, onde a comunidade deve ser convidada a participar de reunião com representantes do CONSEG, município, concessionária e outros agentes como saúde e habitação como feito na unidade benchmarking. Deve-se fazer: identificação do nome dos proprietários, emplacamento das palafitas, para a localização do imóveis com ligações inativas no cadastro comercial, para identificação dos débitos; apresentação da proposta para negociação dos débitos existentes em condições flexíveis; prestação de esclarecimentos e fazer o recebimento da documentação para implantação da Tarifa Social, se este for o caso; explanação sobre os benefícios da adesão, as características de qualidade e regularidade do serviço e as peculiaridades decorrentes da ligação de água regularizada e vistorias comerciais para verificação e concessão dos benefícios pertinentes a cada um dos imóveis para resultados mais amplos e efetivos. Na frente de ação técnica, devem-se substituir redes e ramais internos aos becos. Como diferencial disponibilizou-se um ponto de água para os imóveis irregulares, evitando o uso da rede de ramais existente e garantindo a redução das perdas por vazamentos com esse tipo de abastecimento. Todo o volume fornecido para esses imóveis são contabilizados por meio de instalação de hidrômetro para medição do VUS (Volume Total de Usos Sociais NãoMedidos) em cada ponto executado. Tomando por base os custos e expectativa de 
retorno foi elaborado um estudo de viabilidade com os seguintes resultados (Tabela 26:)

Tabela 26 - Resultados do EVEF da Intervenção em Santos

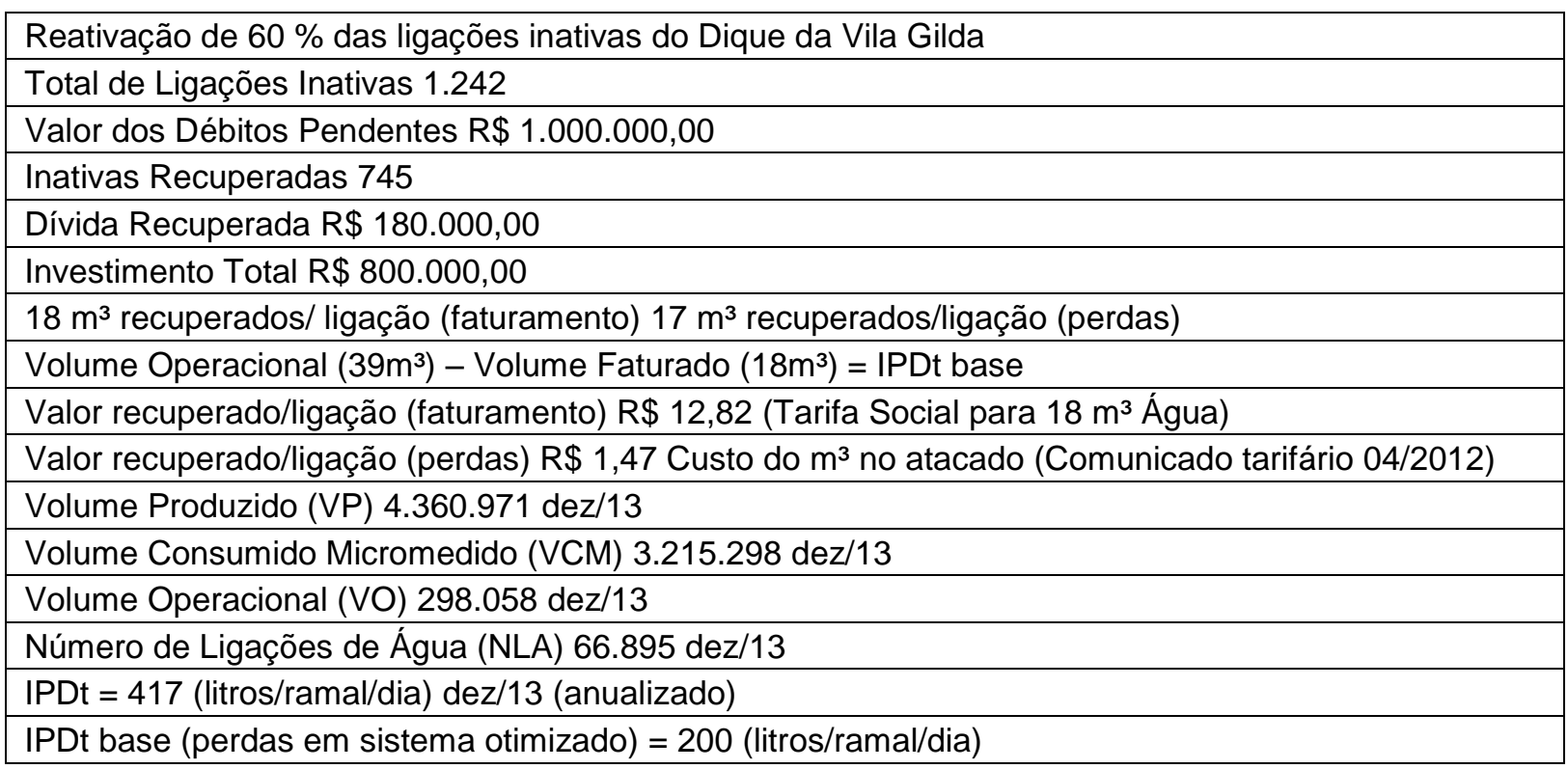

Como conlcusão, houve um aumento de 1,1\% no número de ligações de água ativas com aumento de volume medido de $0,4 \%$; redução de $2,6 \%$ no índice de perdas e de 17 m3/ligação/dia. Projetou-se uma redução de 16,9\% do volume de perdas (m3/mês) para 2014/2015 liberando 730 mil m3/ano para outras áreas; $60 \%$ de inativas recuperadas; $30 \%$ de dívida recuperada; um custo médio de $\mathrm{R} \$ 114,29 /$ domicílio. O efeito taxa de crescimento populacional em aglomerados urbanos de Santos foi considerado irrelevante 0,4\% segundo IBGE. Base dezembro de 2013.

O volume de perdas físicas economizado nas áreas de intervenção sociotécnicas e liberados para áreas urbanizadas à tarifa residencial normal chamou-se volume excedente. Ele representa um volume maior disponibilizado à demanda resultante de práticas de gestão sem incrementos do volume produzido.

Elaboração: a autora (2015)

\subsubsection{Avaliação das intervenções sociotécnicas em GUARUJÁ}

A Baixada Santista possui cerca de 390 assentamentos, sendo que aproximadamente metade se abastece de água de forma clandestina e não tem coleta e tratamento de esgotos, comprometendo a qualidade da água, não só dos moradores destas comunidades, mas também da comunidade vizinha. 
Para o Município do Guarujá adotou-se analisar os resultados do sistema corporativo de perdas, sistema comercial e sistema de concessões. O furto de água em assentamentos precário/subnormais é estimado nas Tabelas 22 e 23 e Imagens de Satélite. Fotos do local demonstram a dimensão e gravidade dos fatos (Anexo de fotos). Estimou-se $30 \mathrm{~m}^{3} /$ moradia/mês nas áreas irregulares, uma vez que antes do início das reuniões com as comunidades e intervenções sociotécnicas o volume médio oscilava entre 30 e $33 \mathrm{~m} /$ mês/domicílio nos aglomerados subnormais. Os gestores adotaram inicialmente 22, porém após a macromedição e setorização identificou-se que o valor se aproxima de $30 \mathrm{~m}^{3} / \mathrm{mês} /$ domicílio. Conforme o sistema de perdas identificou-se por volta de $30 \%$ (Tabela 22). Os dados calculados foram sobre uma população de aproximadamente 120 mil habitantes, representando $38 \%$ da população total do domicílio, segundo a Prefeitura, contemplam 56 assentamentos.

Os resultados obtidos no Município de Guarujá são parciais, uma vez que não há uma série histórica de um ano desde o início das pesquisas na inovação dos Arranjos Sociotécnicos e do Modelo de Gestão. No entanto, deve-se destacar que após o diagnóstico organizacional, construção do planejamento situacional, construção de procedimento sociotécnico e reuniões com líderes comunitários, foram definidos o planos de ação, relatados para as comunidades Prainha, Morrinho e Santa Cruz dos Navegantes de Guarujá.

\subsection{Vistoria a Santa Cruz dos Navegantes.}

Há 590 domicílios irregulares em Santa Cruz dos Navegantes (Tabela 62). Foram realizadas vistorias em todos os imóveis, verificadas a condição de abastecimento e a situação de inadimplência para negociação de débitos, em especial os que possuem débitos e parcelamentos acumulados e se abastecem de forma irregular. $O$ objetivo foi torná-los usuários com faturas em dia, diminuir perdas físicas e comerciais. Também foi acordado com as lideranças formais e informais da comunidade, que a concessionária passaria a suprimir as ligações irregulares sem que os funcionários sofressem ameaças. Para maior efetividade no combate as perdas, atuou-se nas 320 palafitas existentes na comunidade em áreas irregulares, que serão removidas futuramente, impedindo a concessionária de regularizar as ligações. Os barracos eram abastecidos por mangueiras que passavam por dentro da lama do mangue, colocando em risco a qualidade da água da área formal, se 
abastecendo por furto das redes. Muitas mangueiras apresentavam vazamentos e, como a pressão era baixa, os moradores instalavam bombinhas (Fotos 13), aumentando ainda mais o risco de contaminação, pois junto com água da SABESP também ia para as residências a água do mangue e os esgotos produzidos por eles mesmos nos imóveis, cujos dados constam da Tabela 27.

Tabela 27 - Resultados da Intervenção sociotécnica em Santa Cruz dos Navegantes

\begin{tabular}{|c|c|c|c|c|c|c|c|c|c|}
\hline \multirow{3}{*}{\multicolumn{2}{|c|}{$\begin{array}{c}\text { EXECUTADAS } \\
\text { AÇÃO } \\
\text { LIGAÇÕES (A) }\end{array}$}} & \multirow{2}{*}{\multicolumn{2}{|c|}{ FONTE }} & \multicolumn{6}{|c|}{ QTDADE } \\
\hline & & & & \multirow{2}{*}{$\begin{array}{l}\mathbf{N}^{\circ} \\
34 \\
\end{array}$} & \multirow{2}{*}{$\begin{array}{c}\text { AÇÃO } \\
\text { PLA }\end{array}$} & \multirow{2}{*}{ TOTAL } & \multirow{2}{*}{$\begin{array}{c}\mathbf{M}^{3}(\mathbf{1}) \\
327 \\
\end{array}$} & \multicolumn{2}{|c|}{$\mathbf{R} \$\left({ }^{2}\right)$} \\
\hline & & \multicolumn{2}{|c|}{ CIGFK } & & & & & $\mathbf{R} \$$ & 571,88 \\
\hline \multicolumn{2}{|c|}{ RELIGAÇÕES } & \multicolumn{2}{|c|}{ CIGFK } & 53 & Religação & 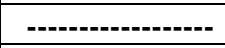 & & $\mathbf{R} \$$ & 891,46 \\
\hline \multicolumn{2}{|r|}{ DÉBITOS } & \begin{tabular}{|l|}
$\mathbf{A}$ \\
$\mathbf{I}$
\end{tabular} & SANEAR & 78 & $\begin{array}{c}\text { parcelamento ou } \\
\text { pagamento }\end{array}$ & 1133 contas & 510 & $\mathbf{R} \$$ & $\mathbf{5 7 . 8 7 1 , 6 1}$ \\
\hline \multicolumn{2}{|c|}{ SUPRESSÕES } & \multicolumn{2}{|c|}{ CIGFK } & 21 & Supressões & |---------------.- & ---------- & \multicolumn{2}{|c|}{---------------------. } \\
\hline \multicolumn{2}{|c|}{ TOTAL } & & & 186 & 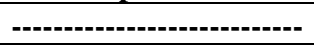 & 1133 contas & 837 & $\mathbf{R \$}$ & $59.334,95$ \\
\hline $\begin{aligned} \mathbf{A ~ R} \\
(\mathbf{P R}\end{aligned}$ & $\begin{array}{l}\text { ALIZAR } \\
\text { EVISÃO) }\end{array}$ & \multirow{2}{*}{\multicolumn{2}{|c|}{ FONTE }} & \multicolumn{6}{|c|}{ QTDADE } \\
\hline & ÇÃO & & & $\mathbf{N}^{\mathbf{0}}$ & AÇÃO & TOTAL & $M^{3}(\mathbf{1})$ & & $\$(2)$ \\
\hline $\begin{array}{r}\text { LIGAÇ्̃ } \\
\text { IM }\end{array}$ & $\begin{array}{l}\text { ES (A) (1.466- } \\
\text { ÓVEIS) }\end{array}$ & & $\mathrm{JS}$ & 243 & PLA & ----------------- & 2337,66 & $\mathbf{R} \$$ & $4.087,26$ \\
\hline $\begin{array}{r}\text { RELIG } \\
\text { IN } \\
\end{array}$ & $\begin{array}{l}\text { ÇÕES (342 - } \\
\text { TIVAS) }\end{array}$ & & JS & 282 & Religação & ------------------ & 2712,84 & $\mathbf{R} \$$ & $4.743,24$ \\
\hline & DF́RITOS & $\mathbf{A}$ & PIS & 350 & & & & & $\begin{array}{l}\mathrm{R} \$ \\
\mathbf{6 7 2 , 5 5}\end{array}$ \\
\hline & DEBTTOS & $\mathbf{I}$ & PIS & 251 & Parcelamento & $X X X$ contas & & & $\begin{array}{l}\mathrm{R} \$ \\
63,36\end{array}$ \\
\hline SUP & ZESSÕES & & & $\mathbf{0}$ & Supressões & & $\mathbf{0}$ & $\mathbf{R} \$$ & - \\
\hline & OTAL & & & 1126 & 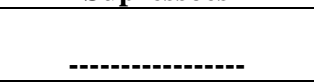 & & $\mathbf{5 0 5 0 , 5}$ & & $\begin{array}{r}\mathrm{R} \$ \\
338.466,41 \\
\end{array}$ \\
\hline $\begin{array}{l}\text { PEN } \\
\text { (EXI }\end{array}$ & $\begin{array}{l}\text { TÊNCIAS } \\
\text { CUÇÃO) }\end{array}$ & FO & NTE & & & QTDADE & & & \\
\hline & Çत̃̃̃ & & & $\mathbf{N}^{\mathbf{0}}$ & AÇ̃̃O & TOTAL & $\mathbf{M}^{3}(\mathbf{1})$ & & $\$\left({ }^{2}\right)$ \\
\hline LIGA & ÇÕES (A) & & SI & 4 & PLA & 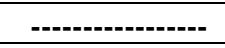 & 38 & $\mathbf{R} \$$ & 67,28 \\
\hline REL & GAÇÕES & & SI & 7 & Religação & ----------------. & 67 & $\mathbf{R} \$$ & 117,74 \\
\hline & DF́BITOS & $\mathbf{A}$ & PIS & $\mathbf{0}$ & & 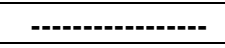 & $\mathbf{0}$ & $\mathbf{R} \$$ & - \\
\hline & DEBITOS & & PIS & 15 & Parcelamento & |--.--.--.--.--.- & 144 & $\mathbf{R} \$$ & 252,30 \\
\hline SUP & RESSÕES & & SI & 77 & Supressões & 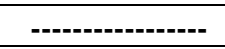 & & & \\
\hline UMA & CLIENTE) & SAN & EAR & 19 & Planilha & ----------------.- & 183 & $\mathbf{R} \$$ & 319,58 \\
\hline $\begin{array}{r}\text { Outros ( } \\
\text { CAV., S } \\
\text { L. }\end{array}$ & $\begin{array}{l}\text { E., REGUL. } \\
\text { UBST. L.A. e } \\
\text {., Etc.). }\end{array}$ & SAN & EAR & 16 & Planilha & ----------------- & 154 & $\mathbf{R} \$$ & 269,12 \\
\hline & OTAL & & & 138 & & & 587 & $\mathbf{R} \$$ & $1.026,02$ \\
\hline & & & )$=9,62 \mathrm{M}$ & ECOI & = GUARUJÁ = REF 08 & 14 (CIGFK) & & & \\
\hline & & $\left({ }^{2}\right)=$ & $\mathrm{R} \$ 16,82 / \mathrm{E}$ & ON T & . 0 = GUARUJÁ = REF & 08/14 (CIGFK) & & & \\
\hline & & & $\left({ }^{3}\right)=30$, & $3 \mathrm{~m}^{3} / \mathrm{n}$ & is $($ PRIMAHD) $=\mathbf{R} \$ 71$ & 42 TL. 0 & & & \\
\hline & & & & SITA & EM OUTUBRO/14 = 2 & & & & \\
\hline & cálculo p & & & & & & & & \\
\hline$M^{3}\left({ }^{3}\right)$ & Receita & $\operatorname{tas}(\mathbf{I}$ & $\left.\$ / \mathbf{m}^{3}\right)$ & & & & & & \\
\hline 7394 & & $\mathbf{R} \$$ & $\mathbf{1 7 . 3 5 5 , 0}$ & & & & & & \\
\hline 8581 & & $\mathbf{R} \$$ & $20.140,4$ & & & & & & \\
\hline & & $\mathbf{R} \$$ & $203.672,5$ & & & & & & \\
\hline & & & $425.963,3$ & & & & & & \\
\hline $\mathbf{0}$ & & & $\$$ & & & & & & \\
\hline 15976 & & & $667.131,4$ & & & & & & \\
\hline
\end{tabular}


A Tabela 27 mostra os resultados operacionais e comerciais (ação) da concessionária refletido nos sistemas corporativos representanto recuperações financeiras $(R \$)$ das ações desenvolvidas na comunidade Santa Cruz dos Navegantes, incluindo as ações executadas até 17/11/2014 onde ocorreram ações sociotécnicas.

Nas análises foram consideradas as receitas assessórias (incremental) resultantes da intervenção sociotécnica nas áreas de vulnerabilidade social. As águas que não se perderam foram consumidas e faturadas em outros setores em categorias de uso residencial, comercial ou industrial e tarifas normais. Trouxe assim duas dimensões da intervenção sociotécnica: o resultado ambiental evitando perdas e desperdícios, e o resultado financeiro da receita auferida com a perda evitada, do chamado volume excedente.

Tabela 28 - Resultados da Vistorias em Santa Cruz dos Navegantes

\begin{tabular}{|c|c|c|c|c|c|c|}
\hline \multicolumn{7}{|c|}{ Sta CRUZ - Vistorias realizadas - Total de imóveis 1466 } \\
\hline & $\begin{array}{c}\text { TOTAL DE } \\
\text { VISTORIAS }\end{array}$ & $\begin{array}{c}\text { LIGAÇÕES } \\
\text { CLANDESTINAS }\end{array}$ & $\begin{array}{c}\text { COM } \\
\text { VAZAMENTO }\end{array}$ & $\begin{array}{c}\text { NÃO } \\
\text { LOCALIZADOS }\end{array}$ & ATIVAS & INATIVAS \\
\hline TOTAL & 590 & 34 & 0 & 138 & 466 & 124 \\
\hline
\end{tabular}

\begin{tabular}{|c|c|c|c|c|c|c|}
\hline \multicolumn{4}{|c|}{ Ações Executadas } & \multicolumn{3}{|c|}{ A Realizar } \\
\hline Serviço & $n^{\circ}$ & $\mathbf{M}^{3}$ & $\mathbf{R} \$$ & Serviço & $n^{\circ}$ & $\mathbf{R} \$$ \\
\hline Novas ligações & 34 & 327 & $R \$ 571,00$ & Novas ligações & 243 & \\
\hline Religações & 53 & 510 & $R \$ 891,00$ & $\begin{array}{c}\text { Religações } \\
\text { ( inativas) }\end{array}$ & 282 & \\
\hline $\begin{array}{c}\text { Débitos } \\
\text { recuperados }\end{array}$ & $\begin{array}{l}73 \text { - total de } \\
1038 \text { contas }\end{array}$ & & $R \$ 54.637,00$ & $\begin{array}{l}\text { Débitos a } \\
\text { recuperar }\end{array}$ & 601 & $R \$ 629.635,91$ \\
\hline Supressões & 21 & & & Supressões & & \\
\hline
\end{tabular}

Elaboração: SABESP (20104)

Esse locais foram previamente setorizados e instalados macromedidores, por essa razão já refletem os dados registrados no Sistema Corporativo de Perdas SisPerdas (Tabela 29).

O setor apresentou uma redução de $33,5 \%$ no volume de perdas sociais e do volume por domicílio de 10 a 18 mil m3/mês.

Foram considerados dados mais conservadores, em função da grande oscilação do sistema de aquisição de dados de vazão - data logger, sendo que a redução de 
volume foi disponibilizada na rede do município garantindo maior disponibilidade hídrica e receitas acessórias.

O conceito adotado de receita acessória é para identificar o valor faturado dos volumes economizados no aglomerado subnormal. Eles já eram produzidos e entregues, mas que passam a não ser mais perdidos e passam a ser vendidos à tarifa residencial normal em outras áreas, porque não são mais desperdiçados nos aglomerados subnormais.

O estudo de viabilidade determina a receita incremental, ou seja a receita adicional em resultante pela escolha de alternativa da decisão de adotar a universalização inclusiva e atuar em perdas sociais em detrimento da decisão de ampliar a oferta hídrica.

Tabela 29 - Perdas Monitoradas em Santa Cruz dos Navegantes

Sisperdas - Sistema de Informações de Controle de Perdas - R

Relatório Anual por Setor de Abastecimento

RS - Município: Guarujá outubro/2014

\begin{tabular}{|c|c|c|c|c|c|c|c|}
\hline & VP & VCM & VO & VF & $\mathrm{VPER}_{\mathrm{T}}$ & Qmin & VPER $_{R}$ \\
\hline Mês/Ano & (m³/mês) & (m³/mês) & (m³/mês) & (m³/mês) & (m³/mês) & $\left(\mathrm{m}^{3} / \mathrm{h}\right)$ & (m³/mês) \\
\hline julho/14 & 49.953 & 14.390 & 18.958 & 16.436 & 16.605 & & - \\
\hline agosto/14 & 60.396 & 13.960 & 18.958 & 16.227 & 27.478 & & - \\
\hline setembro/14 & 42.878 & 14.329 & 18.958 & 16.599 & 9.591 & - & . \\
\hline outubro/14 & 33.201 & 14.465 & 18.958 & 16.850 & -222 & & - \\
\hline
\end{tabular}

ROP - Departamento de Controle de Perdas e Planejamento Operacional $\quad$ Emissão: 3/12/2014

Elaboração: SABESP (20104)

\subsection{Vistoria ao Complexo Prainha-Marezinha}

Esta comunidade é conhecida como uma das áreas mais violentas do Guarujá e apresenta cerca de 780 palafitas com ligação clandestina, em área proteção ambiental e de risco, o que impossibilita regularização. Os moradores abastecem-se por ramais clandestinos colocados por eles mesmos de diversos pontos da rede pública, provocando vazamentos permanentes, quedas de pressão e contaminação na rede, afetando o abastecimento das áreas formais. Muitos moradores utilizavam bombinhas para puxar a água da rede (Fotos 21, 22 e 23), retiravam os hidrômetros, fraudavam as ligações de água, elevando as perdas operacionais e financeiras do município. Algumas lideranças e associações organizadas manifestaram interesse em ajudar a concessionária no processo de regularização da área. Na área formal, 
foram realizadas diversas obras de ampliação e complementação das redes existentes e aumento do diâmetro das redes de distribuição, retirando os ramais que perfuravam de forma irregular as redes para abastecer os barracos, para regularizar a pressão e diminuir os vazamentos, além de possibilitar a macromedição, uma vez que foi instalada uma linha única de alimentação. As Tabelas 30, 31 e 32 mostram os resultados operacionais e comerciais dos levantamentos desenvolvidos na comunidade Prainha até 17/11/2014 pela operadora.

Tabela 30 - Resultados da Comunidade Prainha (11/2014)

\begin{tabular}{|c|c|c|c|c|c|c|c|c|}
\hline \multirow{2}{*}{\multicolumn{2}{|c|}{$\frac{\text { EXECUTADAS }}{\text { AÇÃO }}$}} & \multirow{2}{*}{ FONTE } & \multicolumn{6}{|c|}{ QTDADE } \\
\hline & & & \multirow{2}{*}{\begin{tabular}{|l|}
$N^{\circ}$ \\
93
\end{tabular}} & \multirow{2}{*}{$\begin{array}{c}\mathbf{A C ̧} \tilde{\mathbf{A} O} \\
\text { PLA }\end{array}$} & \multirow{2}{*}{$\begin{array}{c}\text { TOTAL } \\
-\end{array}$} & \multirow{2}{*}{\begin{tabular}{|c|}
$\mathbf{M}^{\mathbf{3}}(\mathbf{1})$ \\
1101 \\
\end{tabular}} & \multicolumn{2}{|c|}{$\mathbf{R} \$\left({ }^{2}\right)$} \\
\hline \multicolumn{2}{|c|}{ LIGAÇÕES (A) } & CIGFK & & & & & $\mathrm{R} \$$ & $2.001,36$ \\
\hline \multicolumn{2}{|c|}{ RELIGAÇÕES } & CIGFK & 21 & religação & --------------- & 249 & $\mathrm{R} \$$ & 451,92 \\
\hline \multirow{2}{*}{ DÉBITOS } & $\mathrm{A}$ & \multirow{2}{*}{ SANEAR } & \multirow{2}{*}{14} & \multirow{2}{*}{$\begin{array}{l}\text { parcelamento ou } \\
\text { pagamento }\end{array}$} & \multirow{2}{*}{249 contas } & & \multirow{2}{*}{$\mathrm{R} \$$} & \multirow{2}{*}{$8.910,61$} \\
\hline & $\mathrm{I}$ & & & & & & & \\
\hline \multicolumn{2}{|c|}{ SUPRESSÕES } & CIGFK & 28 & supressões & exclusões & & & \\
\hline \multicolumn{2}{|c|}{ TOTAL } & ------------ & 156 & ------------------- & |------------------ & 1350 & $\mathrm{R} \$$ & $11.363,89$ \\
\hline \multicolumn{2}{|c|}{$\begin{array}{l}\text { A REALIZAR } \\
\text { (PREVISÃO) }\end{array}$} & \multirow{2}{*}{ FONTE } & \multicolumn{6}{|c|}{ QTDADE } \\
\hline \multicolumn{2}{|c|}{ AÇÃO } & & $\mathbf{N}^{0}$ & AÇÃOO & TOTAL & $\mathbf{M}^{3}(\mathbf{1})$ & \multicolumn{2}{|c|}{$\mathbf{R} \$\left({ }^{2}\right)$} \\
\hline \multicolumn{2}{|c|}{$\begin{array}{l}\text { LIGAÇÕES (A) (1.627- } \\
\text { IMÓVEIS) }\end{array}$} & VUS & 763 & PLA & & 9034 & $\mathrm{R} \$$ & $16.419,76$ \\
\hline \multicolumn{2}{|c|}{$\begin{array}{l}\text { RELIGAÇÕES (212 - } \\
\text { INATIVAS) }\end{array}$} & VUS & 188 & religação & & 2226 & $\mathrm{R} \$$ & $4.045,76$ \\
\hline \multirow{2}{*}{ DÉBITOS } & $\mathrm{A}$ & PIS & & \multirow{2}{*}{ parcelamento } & \multirow{2}{*}{$\mathrm{XXX}$ contas } & & & \\
\hline & $\mathrm{I}$ & PIS & & & & & & \\
\hline \multicolumn{2}{|c|}{ SUPRESSÕES } & & 0 & supressões & |----------------- & 0 & $\mathrm{R} S$ & \\
\hline & & & 951 & |----------------- & |----------------- & 11260 & $\mathrm{R} \$$ & $20.465,52$ \\
\hline $\begin{array}{l}\text { PEN } \\
\text { (EXE }\end{array}$ & & FONTE & & & QTDAD & & & \\
\hline & & & $\mathbf{N}^{\mathbf{0}}$ & AÇÃO & TOTAL & $\mathbf{M}^{3}(\mathbf{1})$ & & \\
\hline LIGAÇÕE & & CSI & 1 & PLA & & 12 & $\mathrm{R} \$$ & 21,52 \\
\hline RELIGAÇ & & CSI & 3 & Religação & & 36 & $\mathrm{R} \$$ & 64,56 \\
\hline DÉRITOS & $\mathrm{A}$ & PIS & 0 & Parcelamento & & 0 & $\mathrm{R} S$ & \\
\hline DEDITUS & $\mathrm{I}$ & PIS & 7 & Farceramento & & 67 & $\mathrm{R} \$$ & 150,64 \\
\hline SUPRESS & & CSI & 1 & Supressões & & & & \\
\hline UMA (CL) & & SANEAR & 4 & Planilha & & 47 & $\mathrm{R} \$$ & 86,08 \\
\hline $\begin{array}{l}\text { OUTROS } \\
\text { (L.E., REQ } \\
\text { SUBST. L. }\end{array}$ & & SANEAR & 16 & Planilha & & 189 & $\mathrm{R} \$$ & 344,32 \\
\hline & & & 32 & & & 352 & $\mathrm{R} \$$ & 667,12 \\
\hline$(1)=11,84$ & $=\mathrm{VI}$ & ENTE DE C & $\mathrm{VALH}$ & $\mathrm{O}=\mathrm{REF} 08 / 14(\mathrm{CI}$ & $\mathrm{K})$ & & & \\
\hline$\left({ }^{2}\right)=\mathrm{R} \$ 21$ & L.0 & VICENTE I & CARV & $\mathrm{ALHO}=\mathrm{REF} 08 / 14$ & CIGFK) & & & \\
\hline$(3)=30,43$ & $\mathrm{MA}$ & D) $=\mathrm{R} \$ 71$ & TL. 0 & & & & & \\
\hline VISITAS I & -1 & $=237$ & & & & & & \\
\hline
\end{tabular}

\begin{tabular}{|c|c|}
\hline $\mathbf{M}^{3}\left({ }^{3}\right)$ & $\mathbf{R} \$\left(^{3}\right)$ \\
\hline 23218 & $54.493,46$ \\
\hline \multirow[t]{3}{*}{5721} & $13.426,96$ \\
\hline & $\mathrm{R} \$ \quad 203.672,55$ \\
\hline & $\mathrm{R} \$ \quad 425.963,36$ \\
\hline 0 & $\mathrm{R} \$$ \\
\hline 28939 & $\mathrm{R} \$ \quad 697.556,33$ \\
\hline
\end{tabular}


Tabela 31 - Resultados das Vistorias em Prainha e Marezinha

\begin{tabular}{|c|c|c|c|c|c|c|}
\hline \multicolumn{7}{|c|}{ Complexo Prainha/ Marezinha } \\
\hline & $\begin{array}{c}\text { TOTAL DE } \\
\text { VISTORIAS }\end{array}$ & $\begin{array}{c}\text { LIGAÇÕES } \\
\text { CLANDESTINAS }\end{array}$ & $\begin{array}{c}\text { COM } \\
\text { VAZAMENTO }\end{array}$ & $\begin{array}{c}\text { NÃO } \\
\text { LOCALIZADOS }\end{array}$ & ATIVAS & INATIVAS \\
\hline Prainha & 1381 & 33 & 17 & 48 & 1144 & 239 \\
\hline Marezinha & 1925 & 119 & 20 & 64 & 1483 & 444 \\
\hline TOTAL & 3306 & 152 & 37 & 112 & 2627 & 683 \\
\hline
\end{tabular}

\begin{tabular}{|c|c|c|c|c|c|c|}
\hline \multicolumn{4}{|c|}{ Ações Executadas } & \multicolumn{3}{c|}{ A Realizar } \\
\hline Serviço & $\mathbf{n}^{\circ}$ & $\mathbf{M}^{\mathbf{3}}$ & $\mathbf{R} \$$ & Serviço & $\mathbf{n}^{\circ}$ & $\mathrm{R}$ \\
\hline Novas ligações & 93 & 1101 & $\mathrm{R} \$ 2.001,36$ & Novas ligações & 763 & $\mathrm{R} \$ \quad 16.419,76$ \\
\hline Religações & 21 & 249 & $\mathrm{R} \$ 451,92$ & $\begin{array}{c}\text { Religações } \\
\text { (inativas) }\end{array}$ & 188 & $\mathrm{R} \$ \quad 4.045,76$ \\
\hline $\begin{array}{c}\text { Débitos } \\
\text { recuperados }\end{array}$ & 14 & 249 contas & $\mathrm{R} \$ 8.910,61$ & $\begin{array}{c}\text { Débitos a } \\
\text { recuperar }\end{array}$ & & \\
\hline Supressões & 28 & & & Supressões & & \\
\hline
\end{tabular}

Elaboração: SABESP (20104)

Nas entrevistas realizadas no local foi constatada a satisfação dos moradores com a concessionária. "Alguns traficantes que estavam de plantão na "biqueira" declararam estar satisfeitos com a atuação e parceria da concessionária com a comunidade e se dispuseram em colaborar e cuidar das novas redes instaladas para que ninguém danifique, " a comunidade está muito agradecida e a gente tem que dar valor para quem ajuda" afirmou um dos entrevistados.

Segundo os dados registrados no Sistema de Controle de Perdas - SisPerdas, o setor apresenta uma queda considerável no índice de perdas (Tabela 32).

O setor apresentou uma redução de $57,21 \%$ no volume de perdas ( $\mathrm{m} 3 / \mathrm{mês}$ ) medido no setor em três meses de intervenção sociotécnica, entre julho e outubro de 2014, cuja redução do volume considerado foi de $49 \mathrm{mil} \mathrm{m3/mês} \mathrm{que} \mathrm{gerarão} \mathrm{receitas}$ acessórias.

Os resultados melhores de Prainha e Marezinha sobre Santa Cruz dos Navegantes está ligado a não terem ocorrido problemas com o data logger. 
Tabela 32 - Perdas em Santa Cruz dos Navegantes

Sisperdas - Sistema de Informações de Controle de Perdas - R

\begin{tabular}{|c|c|c|c|c|c|c|c|c|}
\hline \multicolumn{8}{|c|}{ Relatório Anual por Setor de Abastecimento } & \\
\hline \multicolumn{8}{|c|}{ RS - Município: Vicente de Carvalho outubro/2014 } & \\
\hline \multicolumn{8}{|c|}{ Setor de Abastecimento: 0310018 - VC1 } & \multirow[b]{2}{*}{ VPER $_{A}$} \\
\hline \multirow[b]{2}{*}{ Mês/Ano } & VP & VCM & VO & VF & $\mathrm{VPER}_{\mathrm{T}}$ & Qmin & VPER $_{R}$ & \\
\hline & (m³/mês) & (m³/mês) & (m³/mês) & (m³/mês) & (m³/mês) & $\left(\mathrm{m}^{3} / \mathrm{h}\right)$ & (m³/mês) & (m³/mês) \\
\hline julho/14 & 304.569 & 93.924 & 123.333 & 111.457 & 87.312 & & 4 & - \\
\hline agosto/14 & 294.565 & 96.594 & 123.333 & 113.258 & 74.638 & & - & - \\
\hline set/14 & 292.384 & 96.103 & 123.333 & 113.221 & 72.948 & & - & - \\
\hline out/14 & 249.459 & 88.799 & 123.333 & 108.191 & 37.327 & & -1 & - \\
\hline \multicolumn{6}{|c|}{ ROP - Departamento de Controle de Perdas e Planejamento Operacional } & \multicolumn{2}{|c|}{ Emissão: 3/12/2014 } & \\
\hline
\end{tabular}

Elaboração: SABESP (20104)

No aspecto social, as ações implementadas e os benefícios trazidos para a comunidade, melhoraram a imagem e respeito pela concessionária (Anexo de fotos).

Em vistoria e entrevistas constatou-se que a população ficou mais satisfeita com a atuação e as parcerias empresa-comunidade, valorizando e reconhecendo os funcionários (Figura 18). Houve uma melhoria na relação com a comunidade.

A equipe técnica, liderada pela área de serviços de engenharia, demonstrou forte empenho na resolução e superação dos problemas encontrados no início das atividades.

Tanto a equipe técnica quanto a comercial desenvolveram procedimentos para atuação, considerando a realidade das comunidades informais do Guarujá para garantia da aproximação e atuação junto às lideranças comunitárias.

Os resultados da atuação de caráter social contribuíram para melhoria da relação da concessionária com a comunidade, eliminação de vazamentos aparentes nos caminhos com a fiscalização de desperdícios da comunidade pela própria comunidade, demostrando que a intervenção social promove resultados ambientais por meio da educação e conscientização da comunidade. 


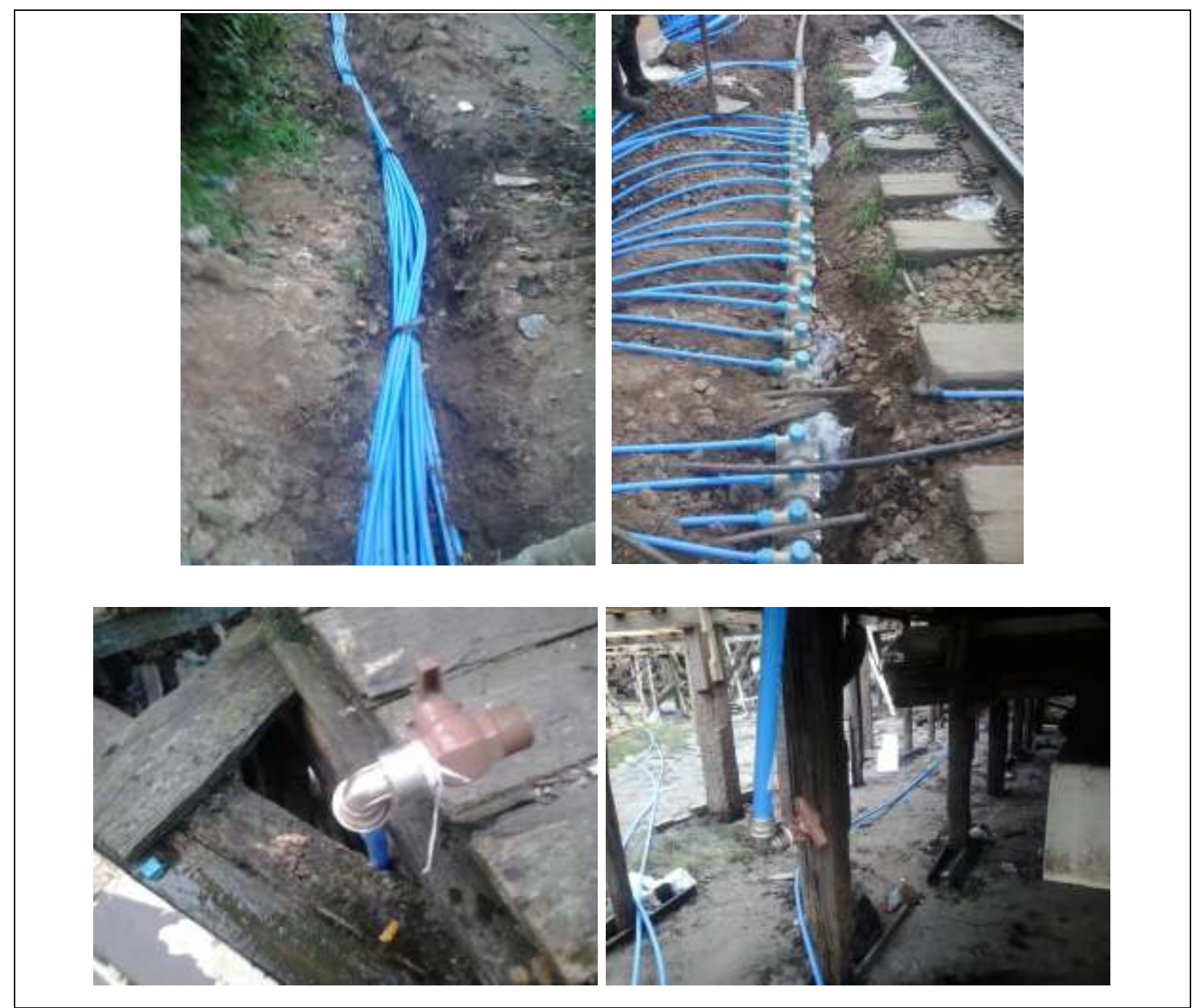

Figura 18 - Fotos de arranjos técnicos nas palafitas de São Vicente

Elaboração: SABESP (20104)

\subsection{Encontro com líderes comunitários de Guarujá}

O primeiro encontro com as lideranças comunitárias do Guarujá ocorreu em 18/12/2014, com presença de 23 lideranças, representando seus respectivos bairrosConseg e Conselho Tutelar, concessionária com corpo técnico e social de apoio aos comunitários. Foi apresentada palestra sobre uso racional da Água, com objetivo de mostrar a importância da comunidade colaborar reduzindo o consumo, consertando vazamentos internos. Foram dadas orientações aos moradores que moram nas áreas irregulares e apresentadas as ações que a concessionária vem realizando para melhorar o atendimento da comunidade do Guarujá, mostrando o Programa Sociotécnico em curso. As lideranças levantaram questionamentos quanto à implantação de novos projetos e a continuidade do programa; as obras pendentes 
e a melhoria da infraestrutura de saneamento em alguns bairros específicos; a questão da concessionária ir aos bairros ampliar o processo de conscientização; os líderes presentes ofereceram a sede de suas entidades para encontros comunitários e ações comerciais. A reunião teve um ótimo impacto, pois os lideres sentiram-se valorizados (Figura 19). Alguns dos questionamentos e dúvidas realizadas foram imediatamente respondidos e todos os líderes receberam ficha pra preenchimento de demandas e reivindicações e responderam questionário da pesquisadora (Anexo 2 - questionário 2) da pesquisadora.

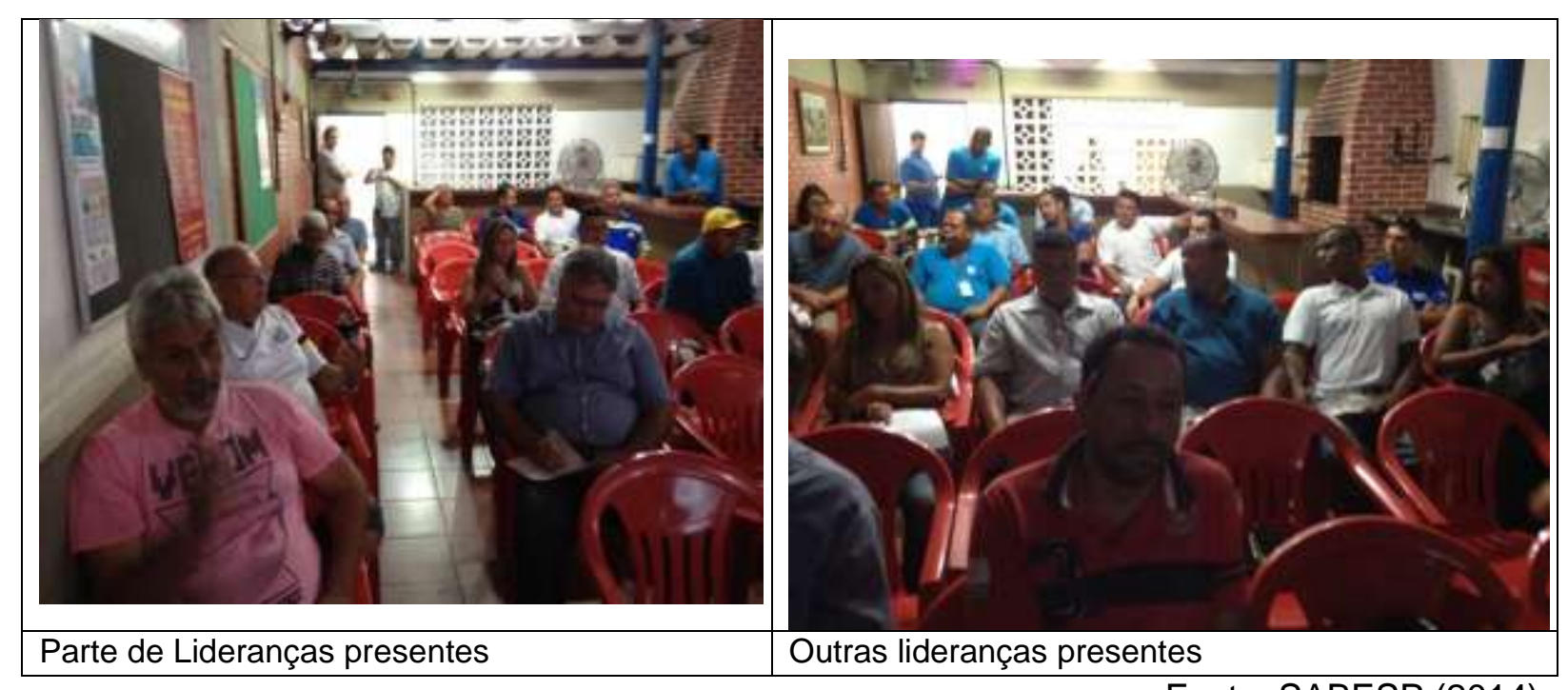

Fonte: SABESP (2014)

Figura 19 - Fotos da Primeira reunião de lideranças em Guarujá

\subsection{CONCLUSÕES}

Para Santos, a atuação nas áreas irregulares exige abordagem sociotécnica, procedimentos comerciais inclusivos para flexibilização nas negociações e inclusão na tarifa social, e parceria entre concessionária e comunidades. Partindo de um diagnóstico do bairro, contemplando as ações de saneamento já realizadas, as pendentes e as em andamento, aplicação de questionários, encaminhamento de ofício a prefeitura solicitando os dados oficiais referentes à comunidade, técnicos da prefeitura e concessionária devem se reunir para compatibilizar informações das áreas. Nesse cenário, o retorno do investimento se dará a partir de 2016, a uma taxa de $33 \%$ ao ano, com um faturamento extra de $R \$ 185.756,47$, em 5 anos, e foi estimado em $R \$ 180.000,00$ pela negociação dos débitos existentes, em $R \$$ 115.000,00/ano pelo incremento no faturamento gerado pelas ligações de água 
recuperadas e redução de $R \$ 223.000,00$ /ano nos custos de produção de água, decorrente da redução no volume perdido nos vazamentos.

Para Guarujá, o atuação sociotécnico foi realizado pela equipe operacional e pelos técnicos comunitários - Lima e Francisco, com retirada de todas as mangueiras de dentro do mangue, substituindo-as por novas mangueiras suspensas nas palafitas para impedir a contaminação, consertando vazamentos e, explicaram aos moradores a importância de economizar água e manter as ligações sem vazamentos. Os moradores se mostraram satisfeitos promovendo melhoria da imagem da concessionária. Algumas mulheres afirmaram que as crianças estão menos doentes e que os problemas de diarreia diminuíram. Notou-se também um sentimento de pertencimento após a geração da conta com o nome do usuário. Foram identificadas ações essenciais de inserção no Planejamento ( Quadro 17).

Quadro 17 - Ações para o Planejamento Situacional Sociotécnicas

\begin{tabular}{|l|}
\hline Obrigatoriedade de Setorização e macromedidores/VRPs nos aglomerados subnormais \\
\hline Regularização das ligações de água \\
\hline Negociação de Débitos \\
\hline Cadastramento em Tarifa Social \\
\hline Regularização das situações de esgotamento sanitário \\
\hline Predefinição de Critérios adotados para atuação na área \\
\hline Regularização das ligações deve ser iniciada nas áreas consolidadas e com cadastro \\
\hline Segunda etapa vistorias em palafitas com regularização em acordos com a comunidade. \\
\hline Problemas que devem ser previstos \\
\hline Vielas em área consolidada com ligações clandestinas \\
\hline Imóveis com ligações inativas, por conta débitos não acordados \\
\hline Necessidades específicas de assentamento de rede coletora de esgotos \\
\hline Imóveis com rede coletora usando galerias de água pluvial - GAP \\
\hline Imóveis cadastrados como se tivessem ligação de esgoto (TL1) e conectados a GAP \\
\hline Lideranças reclamando de problemas com a qualidade de serviços terceirizados \\
\hline Encaminhamentos Inovadores por demanda das lideranças \\
\hline $\begin{array}{l}\text { Atendimento da comunidade por meio de uma agência móvel e realização de palestras educativas, } \\
\text { jogos e gincanas com as crianças. }\end{array}$ \\
\hline Eventos em parceria com prefeitura por meio das Secretarias de Habitação e Meio Ambiente \\
\hline Uso do Jornal da Comunidade para divulgação das atividades da Concessionária \\
\hline Capacitação e Inclusão de moradores da comunidade nos serviços terceirizados \\
\hline
\end{tabular}

Elaboração: a autora (2015)

Como conclusão do capítulo, estima-se:

Redução entre 33,5 a 42,7\% no índice de perdas sociais, (assumiu-se 33,5\%)

Aumento de volume disponibilizado à rede de 40 a 57\% (assumiu-se 40\%)

$\mathrm{Y}$ (inativas $)=0,18 \mathrm{X}$ (domicílios em aglomerados $)+7,54$ 
Essa análise permite estimar uma maior disponibilidade hídrica no sistema de distribuição e uma receita acessória não prevista. Também segundo, a Fórmula 1, construída em função do Gráfico 34 de dispersão, permitiu-se analisar o número de inativas a serem recuperadas, conforme Fórmula 1, podendo-se, nesse sentido, passar a estimar-se o número de inativas nos aglomerados subnormais da Baixada Santista.

A Tabela 33 apresenta as projeções dos dados para os parâmetros (inativas, volume perdido, ganho de volume, índice de perdas e redução mínima do índice) previstos para todos os domicílios municípios da RMBS, por resultados obtidos nas parametrizações dos estudos das comunidades piloto e por funções de regressão, gráficos de dispersão, receita acessória e fluxo de caixa com receita incremental.

Tabela 33 - Tabela dos Projeção de Ganhos para uma Intervenção sociotécnica em toda RMBS

\begin{tabular}{|c|c|c|c|c|c|c|}
\hline & $\begin{array}{c}\text { Domicílios nos } \\
\text { Aglomerados } \\
\text { Subnormais }^{24}\end{array}$ & $\begin{array}{l}\text { Inativas } \\
\text { Previstas }^{25}\end{array}$ & $\begin{array}{l}\text { Volume } \\
\text { Disponibilizado } \\
(1000 \mathrm{~m} 3)^{26}\end{array}$ & $\begin{array}{l}\text { Ganho } \\
\text { Mínimo do } \\
\text { Volume } \\
\text { Perdido } \\
\text { (1000 m3) }\end{array}$ & $\begin{array}{l}\text { Índice de } \\
\text { Perdas }^{28}\end{array}$ & $\begin{array}{c}\text { Redução } \\
\text { Mínima do } \\
\text { Índice } \\
\text { Perdas } \\
\text { Prevista }^{29}\end{array}$ \\
\hline Bertioga & 8.378 & 1515,58 & 9.604 & 2.228 & 30,6 & 5,94558 \\
\hline Cubatão & 19.422 & 3503,5 & 14.802 & 3.374 & 30,8 & 5,88126 \\
\hline Itanhaém & 5.177 & 939,4 & 12.744 & 305 & 39,1 & 0,78591 \\
\hline Guarujá & 33.263 & 5994,88 & 47.599 & 7.235 & 38,8 & 4,93924 \\
\hline Mongaguá & 570 & 110,14 & 6.231 & 548 & 29,5 & 2,17415 \\
\hline $\begin{array}{l}\text { Praia } \\
\text { Grande }\end{array}$ & 9.855 & 1781,44 & 34.404 & 2.064 & 28,4 & 1,4271 \\
\hline Peruíbe & 3.172 & 578,5 & 8.364 & 234 & 31,1 & 0,729295 \\
\hline Santos & 9.455 & 1709,44 & 51.940 & 1.662 & 17,3 & 0,46364 \\
\hline $\begin{array}{l}\text { São } \\
\text { Vicente }\end{array}$ & 27.622 & 4979,5 & 48.780 & 6.634 & 49,8 & 5,67222 \\
\hline otal & 116.914 & 21052,06 & 234468 & 24.286 & & \\
\hline
\end{tabular}

\footnotetext{
${ }^{24}$ Fonte: Dados do PHLIS

${ }^{25}$ Aplicação da Fórmula 1 do Gráfico de Dispersão

${ }^{26}$ Fonte: Sistema Corporativo de Perdas - dez/2014

${ }^{27}$ Aplicação de (40\% sobre o volume disponibilizado VD do Sistema Corporativo de Perdas)*Percentual de domicilios subnormais no municípios, aprirori como se todos gastassem o mesmo volume - dez/2014.

${ }^{28}$ Sistema Corporativo de Perdas - dez/2014

${ }^{29}$ Aplicação de (33,5\% sobre o indice de perdas IGPM do Sistema Corporativo de Perdas)*Percentual de domicílios subnormais no municípios, aprirori como se todos gastassem o mesmo volume - dez/2014.
} 


\section{CONSTRUÇÃO DO PLANO DE NEGÓCIO INCLUSIVO - PNI 7.1. CONSIDERAÇÕES GERAIS}

O Plano de Negócio Inclusivo - PNI foi realizado com participação de gestores da unidade de negócio em cinco oficinas econômico-financeiras num período de dois meses. Os profissionais eram engenheiros, administradores e economistas que trabalhavam em atividades de planejamento, operação, atividades comerciais e controladoria. $O$ objetivo dessas oficinas era criar uma base de referência para o planejamento empresarial em regime regulado da cidade informal da RMBS. Nesse sentido, considerou-se exclusivamente os assentamentos precários e seus referenciais específicos para definição de metas, custos, investimentos e receitas até o ano de 2020. Para operacionalização desenvolveu-se um simulador para subsidiar o planejamento, cálculo de projeções e permitir o acompanhamento das ações planejadas (figura 20).

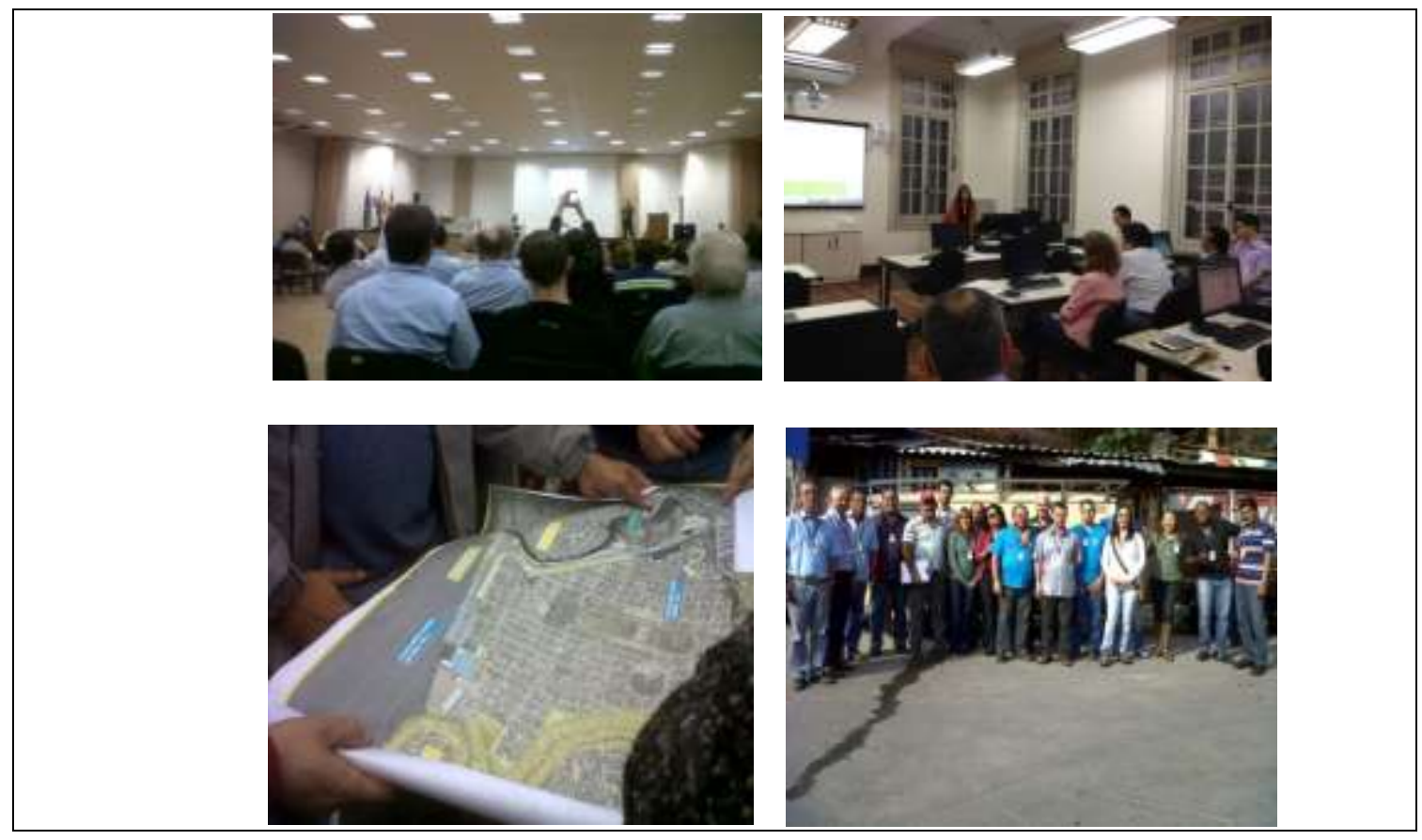

Elaboração: a autora (2014)

Figura 20 - Construção do plano de negócios inclusivo

Mediante este sistema, os gestores definiram metas de universalização inclusiva para cada aglomerado subnormal. O sistema, pelas parametrizações previamente definidas calculou investimentos necessários ao atendimento das mesmas, custos 
operacionais e receitas, bem como tributos provenientes das ações nos aglomerados subnormais.

Os gestores fizeram projeções com o simulador em equipamentos individuais com simulações resultantes e correção dos parâmetros em atividades locais, segundo a suas vivências e geraram o primeiro orçamento das áreas irregulares da concessionária (Figura 20).

Adotou-se parâmetros da contabilidade e dados comerciais e de perdas históricos da área, incluindo referências de preços dos serviços do departamento de planejamento e controladoria.

As informações resultantes em planilhas fazem a geração automática do plano de negócios e permite ajustes e inserção no planejamento BSC - Balance Score Card.

Estabeleceu-se elo entre o planejamento situacional e plano de negócios. Foram calculadas metas para os indicadores definidos no polo teórico e inseridos no mapa estratégico do BSC da UN: indicador de universalização inclusiva, governança inclusiva e vulnerabilidade empresarial.

O simulador desenvolvido para este plano inclusivo contém macros com fórmulas para projeções de volumes, receitas, custos, investimentos e resultados para a cidade informal. Foram adotados dados: de referência dos históricos dos usuários em áreas que foram recentemente regularizadas para volumes médios, receita e inadimplência; da concessionária provenientes do sistema da contabilidade, sistemas de contratação de serviços e obras em aglomerados subnormais; fornecidos pela Caixa Econômica Federal dos financiamentos concedidos aos municípios e concessionária; e taxas regulatórias praticadas. Como resultado obteve-se planilhas com os cálculos do plano, gráficos em correlação e fluxo de caixa. (ANEXO 3).

A inovação deste plano é a metodologia de análise de viabilidade e atratividade do negócio calculados considerando: 1.) os volumes economizados (volume excedente) nas áreas dos aglomerados subnormais, que 2.) geram resultados financeiros provenientes da entrega dos mesmos em áreas urbanizadas da concessão à tarifa média (Receita acessória) e 3.) mensuração da vulnerabilidade de uma concessão com assentamentos precários; sendo o instrumento técnico que documenta os compromissos entre Estado, concessionária e sociedade civil para universalização inclusiva por meio da participação social, permitindo o efetivo controle social. 


\subsection{PLANO DE NEGÓCIOS INCLUSIVOS - PNI-RMBS}

\subsubsection{Histórico do Plano}

Destaca-se que, para efeito da apresentação na tese, foi inserido apenas um resumo consolido dos nove Planos de Negócio da Cidade Informal de todos os municípios da RMBS. A concessionária o adotou para obtenção de recursos do FEHIDRO e atendimento de todos os aglomerados urbanos da Região Metropolitana da Baixada Santista no Comitê de Bacias.

Tendo em vista o tema, o alcance e a importância da concessionária, operando na Região Metropolitana da Baixada Santista em todos os municípios, o plano tem como foco de atuação a universalização inclusiva, a gestão do saneamento em áreas de vulnerabilidade socioambiental da Baixada Santista e a governança inclusiva, conceitos definidos nessa tese, para os municípios de Santos, São Vicente, Cubatão, Praia Grande, Bertioga, Itanhaém, Mongaguá, Peruíbe.

Analisou-se equacionamentos por tarifas com mecanismo de subsídios cruzados considerou-se a fórmula de remuneração dos investimentos, custos dos serviços e de capital e os resultados foram comparados com as necessidades de aportes para subsídios focados.

Nesse sentido, o plano de negócios da cidade informal considerou na sua parametrização as condições excepcionais, como doações, participação do poder público de forma não onerosa, mutirões da comunidade para assentamentos de rede e outras construções da universalização em arranjos sociotécnico participativos, garantindo ganhos das singularidades do modelo para a comunidade local. Estabeleceu-se como premissas não haver remuneração indevida, ou seja política distributiva de ganhos sociais dessas áreas com transferências às áreas nobres, e não admitir o rateio dos custos da administração central para essas áreas.

As bases de dados de domicílios, de redes e ligações e de mapas e informações geo-referenciadas adotadas como referência constam do capítulo 6.6 de avaliação dos aglomerados subnormais.

No plano, adotou-se dados populacionais da AGEM - Agencia Metropolitana da Baixada Santista, PHLIS - Plano Local de Habitação de Interesse Social, IBGE, Fundação Seade e Instituto Polis. Houve um refinamento realizado pelos gerentes 
da concessionária com levantamento dos agentes comunitários e prefeituras para minimizar efeitos da assimetria de informações, pois os dados objeto de planejamento referem-se às populações em habitações precárias, áreas irregulares e assentamentos urbanos. A dificuldade da manutenção de um banco de dados das famílias elegíveis para cadastro social é evidente, pois os municípios não estão instrumentalizados para tal.

Identificou-se um conjunto de estudos recentes dos impactos do Pré-sal elaborados por meio de um convênio entre a Petrobras e Instituto Polis, que foram publicados em 2013 (INSTITUTO POLIS, 2013). Abrangem a realidade de 13 municípios do litoral paulista (sul e norte) que deverá contribuir para a consolidação de um estudo regional, com objetivo principal de formular programas de desenvolvimento local e regional considerando as transformações que poderão ocorrer no litoral paulista em função de diversos projetos e obras de impacto com a exploração de petróleo e gás nas camadas do Pré-sal, a ampliação dos portos, duplicação de rodovias, entre outros.

No entanto, as informações técnicas sobre os reais panoramas de planejamento são frágeis e não há análise histórica sistematizada dos impactos socioambientais da implantação de polos petroquímicos como Camaçari e Campos de Goytcazes, sobre os municípios, no que tange a ocupação desordenada e aumento das exclusões sociais. Isto dificulta a elaboração de planos de urbanização, e consequentemente, os de saneamento pelos municípios.

Por essas razões foi necessário elaborar o plano de negócios dos SAAES da cidade Informal da Baixada Santista de maneira participativa com atores da concessionária, agência metropolitana, agência reguladora, municípios e sociedade civil.

O Plano de Negócios mensurou os recursos necessários para universalização dos serviços de abastecimento de água e esgotamento sanitário em ambiente regulado, considerando o direito humano das comunidades em situação de exclusão social em atendimanto a diretriz estratégica empresarial. 


\subsubsection{Objetivos do Plano}

O desenvolvimento de um plano de negócios para a Cidade Informal teve por objetivo quantificar os recursos necessários a tornar eficaz a universalização inclusiva e gerar informações que garantissem a governança inclusiva, adotando os conceitos, indicadores e ações do planejamento estratégico e situacional das oficinas, estabelecendo referencial metodológico para determinação de investimentos e custos necessários aos serviços nas áreas de aglomerados subnormais. Identificou-se a monetização do planejamento, metas e indicadores para a Universalização Inclusiva dos serviços públicos de saneamento básico em áreas favelizadas e assentamentos, podendo ser áreas regulares ou irregulares, que fazem parte da cidade informal da RMBS, por meio das seguintes componentes: projeção de demanda por serviço (água e esgoto) para as comunidades, categorias de usuários das comunidades, agrupados em residencial e não residencial, quantidade de usuários: ligações e economias das comunidades na Cidade Informal, níveis de consumo: volumes consumidos, coletados, faturados para as comunidades, projeção da oferta: perdas, necessidade de produção, capacidade dos sistemas, dimensionamento dos sistemas de coleta e tratamento de esgoto, indicadores que demonstram a condição da prestação dos serviços, custos de referência exclusivamente da cidade informal, investimentos para obras daquela natureza, despesas históricas, plano de expansão da oferta: demanda projetada baseada no custo contratual histórico, plano de desenvolvimento da empresa: eficiência produtiva, qualidade dos serviços, atendimento ao usuário, e estimativa de redução de perdas.

O horizonte de temporal considerado nas projeções foi de 2014 a 2020. Para as projeções foi considerado como ano referência 2013. As informações com nível de desagregação dos dados municipais compuseram o plano de investimentos.

A área de atuação da SABESP inclui todos os municípios da Baixada Santista, pela Diretoria de Sistemas Regionais, que é composta por 8 municípios(Tabela 34 e Figura 21): 
Tabela 34 - Dados gerais atendimento SABESP - interior e litoral

\section{Dados Gerais}

\begin{tabular}{l|l}
\hline População total atendida & 1.714 mil Habitantes \\
\hline Domićlios & $956 \mathrm{mil}$ \\
\hline Ligações de Água & $501 \mathrm{mil}$ \\
\hline Rede de Água & $6.221 \mathrm{~km}$ \\
\hline Volume Água População Fixa & $504.085 \mathrm{~m} 3 /$ dia \\
\hline Volume Água População Flutuante & $843.723 \mathrm{~m} 3 /$ dia \\
\hline Ligações de Esgoto & $295 \mathrm{mil}$ \\
\hline Rede de Esgoto & $2.972 \mathrm{~km}$ \\
\hline Volume Esgoto População Fixa & $403.268 \mathrm{~m} 3 /$ dia \\
\hline Volume Esgoto População Flutuante & $674.978 \mathrm{~m} 3 /$ dia \\
\hline
\end{tabular}

Cidade Informal

\begin{tabular}{l|l}
\hline População da Cidade Informal & 442.500 \\
\hline Número de Assentamentos & 394 \\
\hline Número de domicílios subnormais & 116.914 \\
\hline Média de habitantes por domicílio & 3,62
\end{tabular}

Referência: dados fornecidos pela da Superintendência RS 2013 SABESP 


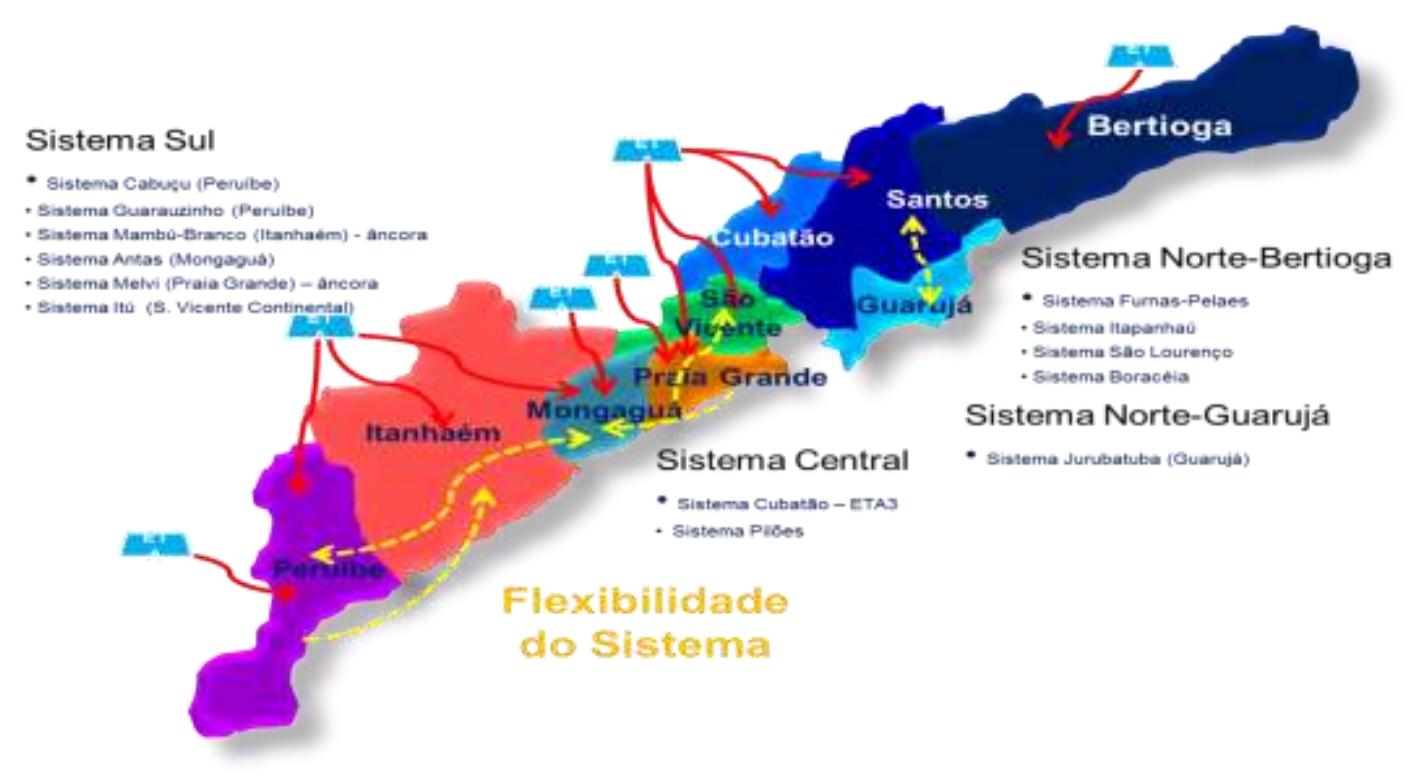

Fonte: SABESP (2013)

\subsubsection{Relação dos Sistemas Integrados}

$\mathrm{Na}$ etapa de produção de água dos municípios da Baixada Santista existem aqueles que além de produzirem água potável para o abastecimento dos usuários do município em que se situam, também atendem a um conjunto de municípios adjacentes. Esta configuração é denominada sistema integrado de produção de água e assim se caracteriza, pois os volumes de água, assim com as despesas e os ativos encontram-se majoritariamente atribuídos ao município produtor, sem que, na maioria dos casos, haja imputações aos demais municípios que formam parte do sistema.

A UN da Baixada Santista possui dois sistemas produtores integrados: sistema centro, que compreende o sistema central, Norte-Guarujá e Norte-Bertioga, que abastece os município de Cubatão, São Vicente, Santos, Praia Grande e Guarujá, e o Sistema Sul que abastece os municípios de Peruíbe, Itanhaém, Mongaguá, Praia Grande e São Vicente.

O tratamento de esgotos também ocorre de maneira semelhante ao abastecimento com Sistemas Integrados de Tratamento de Esgoto Sanitário. A Baixada Santista possui os sistemas integrados de tratamento de esgoto de Santos (EPC - Praia de 
José Menino) que trata os município de Santos e São Vicente, e o sistema de Praia Grande (EPC - Praia Boqueirão) que trata Praia Grande e São Vicente.

\subsubsection{Características da Área de Atuação da RMBS}

\subsubsection{1. Área Formal e Informal}

A análise e premissas de partida para o plano de negócios dos aglomerados subnormais que compõem a cidade informal da Região Metropolitana da Baixada Santista- RMBS foram objeto do capítulo 6.6. No entanto, os dados foram revistos e junto à Emplasa e secretárias de planejamento dos municípios e gerentes dos municípios de forma a obter dados mais precisos e atuais para a valoração dos investimentos.

\subsubsection{Restrições jurídicas e socioambientais}

As interfaces existentes entre os sistemas dos municípios também podem ser fatores limitantes para a expansão dos serviços, visto que devem ser buscadas soluções integradas e não conflitantes para os problemas comuns, o que exige um esforço conjunto das administrações dos municípios envolvidos, tornando o processo mais demorado.

Especial atenção deve ser dada às áreas de ocupação irregular e de restrição ambiental, que dependem de autorização judicial ou regularização de áreas particulares ou públicas invadidas.

A principal restrição à atuação da concessionária parte da justiça por meio de impedimentos impetrados e ações judiciais contra a empresa e aos funcionários por assentamento de redes em áreas privadas invadidas, ou pelo Ministério Publico contra assentamento de redes em APPs - Areas de Proteção Permanente, inclusive em áreas cujos assentamentos passam de 5 anos, sendo este 0 primeiro impedimento de entrada identificado nas oficinas e questionários.

Os ganhos de intervenções nessas áreas implicaram em resultados socioambientais locais e financeiros pelo volume disponibilizado, após a redução de perdas nessas áreas, para outras áreas frente à redução de perdas sociais.

\subsubsection{Gestão do mercado informal}

A atuação nas áreas descritas, para regularização das ligações de água nas áreas consolidadas ou em fase de regularização, bem como a intensificação nos reparos das redes existentes e/ou a substituição para a readequação e normalização da 
distribuição, bem como ação dos agentes comunitários foram realizadas pelas equipes de campo.

Os índices calculados subsidiaram as metas do planejamento estratégico, tático e operacional e da Gestão Inclusiva da Região Metropolitana da Baixada Santista. Tomando-se como exemplo o índice de atendimento de áreas de vulnerabilidade, atualmente, com quase a totalidade dos domicílios atendidos com água, fez-se um refinamento para identificação daquela parcela não atendida.

Nesse sentido o PNI insere a mudança de processo de forma que a empresa preparou-se para coletar e organizar dados, que serviram de base nos processos de negociação com os diferentes atores, visando subsidiar o planejamento estratégico da empresa de saneamento, e fomentar enfoque alinhado com os outros atores do desenvolvimento humano, como as secretarias de saneamento e recursos hídricos, habitação, meio ambiente, saúde, justiça, cidadania e Ministério Público.

Apesar da incerteza observada nos indicadores, às séries históricas, dentro de conceitos de cobertura e atendimento, ligações ativas e inativas, perdas físicas e comerciais permitiram a visualização da evolução dos serviços de abastecimento de água e esgotamento sanitário e do grande passo dado pela concessionária.

Anualmente a concessionária faz revisões dos dados oficiais para dar coerência ao seu planejamento e às suas unidades de negócio. Assim, recalcula os resultados provenientes das diferenças entre seu cadastro e da Fundação SEADE, que apresentam ajustes às situações díspares para o planejamento.

O índice de atendimento aos domicílios urbanos com água apresenta alguma incerteza em virtude das situações legais observadas. Por fim, enfatiza-se que o desenvolvimento de oficinas de conceitos para a proposta de um indicador foi capaz de capturar essas incertezas, e atender aos cidadãos em áreas de exclusão por meio do Indicador de Universalização Inclusiva - IUI.

Ainda assim, a adequabilidade frente à impossibilidade de fazer análise de eficiência comparando empresas de porte diferentes, de estrutura de capital diferentes, subsidiadas com não subsidiadas atendendo em áreas urbanas tem comprometido os indicadores de benchmarking e as decisões do regulador sobre os mecanismos 
de incentivos de uma revisão tarifária. O problema é foco de discussão de diversos autores, tais como Dupuy (1998), Veltz, (1999), Dias (1994) e Przeworski (1994).

Nesse sentido, há que se considerar as questões das escolhas públicas e empresariais frente às limitações provenientes dos modelos que confrontam soluções do Estado de Direito e liberdade de mercado. Para tanto se colocou esforços nesta tese, voltada à inovação organizacional e jurídica para enfrentamento do desafio do acesso universal dos serviços com equilíbrio da concessão.

\subsubsection{Projeção dos Volumes Medidos de Água na Cidade Informal}

As projeções do mercado foram realizadas a partir de estimativas de consumos médios nas áreas de assentamentos subnormais e do aumento esperado do número de economias/ligações. Para tanto, foram consideradas separadamente as categorias de usuários, residencial e não residencial, dados os diferentes comportamentos associados à natureza de cada atividade e dados do polo de avaliação.

\subsubsection{Projeção dos Volumes não Medidos de Água}

O acesso à água se dá por meios legais e ilegais (chamado gatos). As projeções do mercado foram realizadas a partir de estimativas de consumos e do aumento esperado do número de economias/ligações não medidas nos locais setorizados ou de volumes estimados para cada comunidade em função da média de consumo de comunidades semelhantes. Para tanto, foram consideradas separadamente as estimativas de volumes para demanda residencial e não residencial apoiados no polo de avaliação.

\subsubsection{Demanda de água residencial}

A evolução de mercado residencial nos aglomerados subnormais varejo foi calculada seguindo a mesma lógica com base nos consumos unitários (Figura 22). 


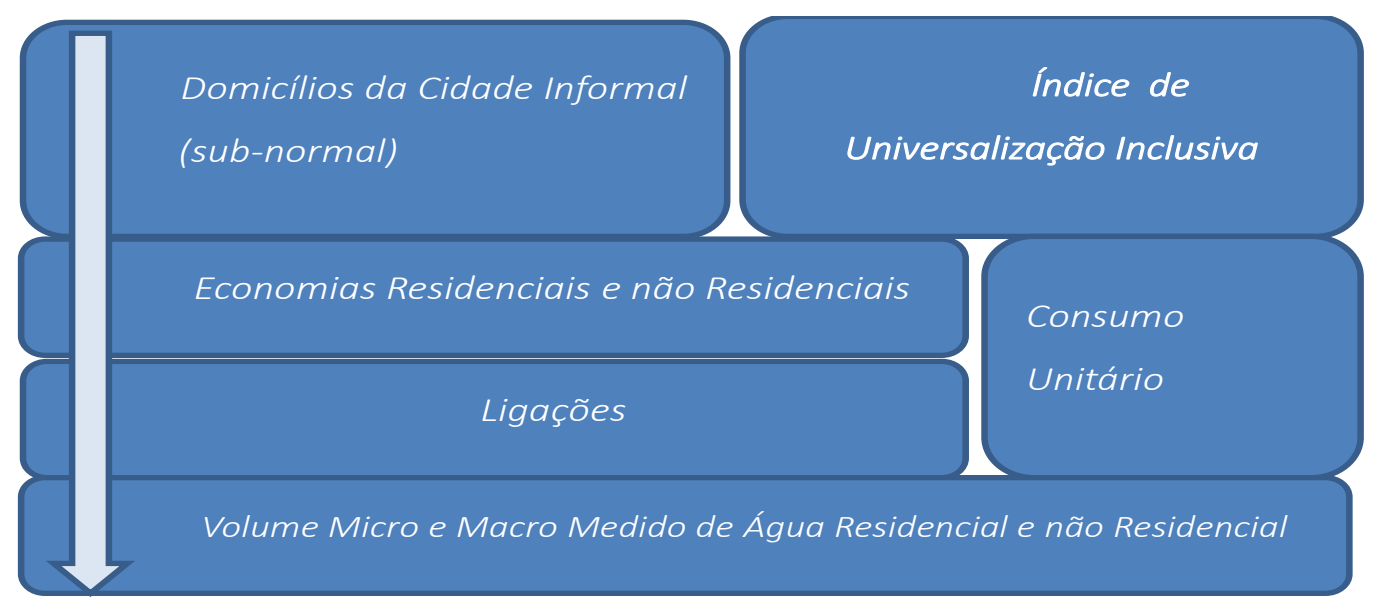

Figura 22 - Lógica Geral de Cálculo para o Volume Medido de Água Residencial

A seguir, são explicitadas como foram atualizadas a projeções de cada um dos itens acima.

\subsubsection{Domicílios da Cidade Informal}

Os dados de entrada para a evolução de mercado informal são baseados nas projeções do PHLIS 2010 da RMBS com atualizações feitas pelo município. Para esse PN, optou-se por utilizar a rubrica domicílios em áreas irregulares e aglomerados subnormais, segundo o PLHIS para tal evolução.

Como uma primeira tentativa, a análise e projeções para os domicílios adotados nesse PNI foram iguais ao PHLIS. Todavia, tal aproximação deve ser condizente com a realidade da unidade em função das características socioambientais da região. Assim, para calcular os domicílios irregulares dessa unidade ajustou-se os valores de domicílios em áreas irregulares a fim de atender as peculiaridades das áreas litorâneas. O Mapa 1 do PHLIS para a Baixada Santista demonstra uma grande área de necessária intervenção e planejamento, cujos custos do atendimento são crescentes, porém os serviços de saneamento são essências ao cidadão.

Os levantamentos permitiram identificar duas taxas médias de crescimento dos domicílios para referência das projeções dos anos de 2014 a 2020:

- Taxa de crescimento da cidade formal 2000 a 2010 em 2,2 \%, a.a. na RMBS, conforme referência da concessionária;

- Taxa de crescimento de assentamentos 2000 a 2010 Baixada Santista entre 0,4 e $58,4 \%$ nos diferentes municípios da RMBS (IBGE em 10 anos). 
Como resultado da oficina de planejamento com todos os gestores da Baixada Santista, optou-se para o primeiro ciclo de planejamento da universalização inclusiva na RS uma taxa geométrica de crescimento inicial anual de $2,45 \%$, superior à calculada para as áreas formais da mesma região. Adotou-se Taxa geométrica de crescimento anual (TGCA) - IBGE (Tabela 35), realizado no primeiro PNI.

Tabela 35 - Previsão das Taxas de Crescimento dos Aglomerados Subnormais, em (\%)

\begin{tabular}{c|c|c|c|c|c|c|c} 
Local & 2014 & 2015 & 2016 & 2017 & 2018 & 2019 & 2020 \\
\hline RS Formal & $2,2 \%$ & $2,1 \%$ & $2,1 \%$ & $2,0 \%$ & $2,0 \%$ & $1,9 \%$ & $1,9 \%$ \\
\hline RS Informal & 2,45 & 2,04 & 1,88 & 1,88 & 1,88 & 1,88 & 1,90
\end{tabular}

Elaboração: a autora (2014)

A partir das taxas de crescimento apresentadas acima (conforme fórmulas Anexo3 Memória do Simulador), projetou-se os valores absolutos dos domicílios objeto de atendimento pela concessionária. Os resultados das projeções são apresentados na Tabela 36:

Tabela 36 - Projeções de Domicílios Atendidos - Aglomerados Subnormais da RMBS

Ano Dom. Tot.

NTDA

NERA

\begin{tabular}{|r|r|rr|}
\hline 2014 & 110.028 & 5547 & 6108 \\
\hline 2015 & 113.648 & 21421 & 23626 \\
\hline 2016 & 115.967 & 42179 & 46748 \\
\hline 2017 & 118.143 & 65874 & 72941 \\
\hline 2018 & 120.300 & 89456 & 99080 \\
\hline 2019 & 122.623 & 10558 & 121423 \\
\hline 2020 & 124.926 & 11671 & 129461 \\
\hline
\end{tabular}

Elaboração: SABESP (2014)

Dom. Tot. é o total de domicílios em aglomerados subnormais da RMBS.

NTDA é o numero de ligações cadastradas em situação regular.

NERA é o numero de domicílios cadastrados em situação regular.

\subsubsection{Projeções anuais do Índice de Universalização Inclusiva de Água}

O Indicador de Universalização Inclusiva de Água (IUI) foi calculado por meio da razão entre o Número de Economias Residenciais de Água (NERA) e o Número Total de Domicílios Atendidos (NTDA) da Cidade Informal, conforme fórmula 2: 
Fórmula 2 - Indicador de Universalização Inclusiva

$$
\mid U I=\frac{N E R A * 100}{N T D A}
$$

Para recalcular o IUI de água do ano base foram utilizados os dados observados de Economias Residenciais de Água verificados em dezembro de 2013 no sistema comercial e os dados de domicílios do PHILS no mesmo período.

As projeções do índice de atendimento para o período 2013-2020 dos aglomerados subnormais foram calculadas com base no crescimento de economias residenciais de água e de domicílios da cidade informal esperados para os aglomerados subnormais, levando em conta as particularidades das regiões.

Para os aglomerados urbanos sem dados, as projeções do índice de atendimento podem ser feitas por interpolação linear entre o índice verificado no ano base e o ano onde é esperado o maior índice de atendimento ou a universalização. O ano de maior índice de atendimento será obtido das metas propostas nos PHLIS.

As projeções realizadas consideraram os estudos da AGEM/EMPLASA Planejamento Estratégico da Metrópole da Baixada Santista para garantia da coerência com as projeções do Governo do Estado de SP.

Os dados referentes às economias atendidas no ano base e às metas de atendimento foram obtidas primeiramente para aglomerados depois município. A partir dos dados referentes a cada município calculou-se o índice de atendimento resultante para a Baixada Santista (Tabela 37).

Tabela 37 - Resultado das projeções dos IUI de água residencial (\%)

\begin{tabular}{|c|l|l|l|l|l|l|l|}
\hline Ano & 2014 & 2015 & 2016 & 2017 & 2018 & 2019 & 2020 \\
\hline IUIagua (\%) & 5,0 & 18,8 & 36,4 & 55,8 & 74,3 & 89,3 & 93,5 \\
\hline
\end{tabular}

Elaboração: a autora (2014)

Adotou-se 93,5\% em 2020, pois os gerentes consideraram que as condições de planejamento para universalização inclusiva devem ser anualmente revistas para definir o incremento anual executável. 


\subsubsection{Demanda Residencial}

O consumo unitário residencial consiste no volume demandado por economia doméstica. Em virtude das diversas variáveis que influenciam o consumo domiciliar e da estabilidade dos dados observados, optou-se por adotar a partir da média de consumo dos domicílios nos aglomerados, em projeção linear decrescente até a média dos consumos das unidades residenciais normais. Estudos demonstram que a educação ambiental nas comunidades promove a redução do consumo médio por habitação e quebra de tendência justificando uma alteração nos consumos futuros. As ligações foram atualizadas mantendo a premissa de estabilidade da relação economia/ligação. A partir do número de economias e dos respectivos consumos unitários, foram atualizados os Volumes Medidos de Água Residencial. As projeções do volume medido total e o número de ligações foram calculados diretamente por meio de séries de tendência histórica. Assim, o consumo unitário foi calculado a posteriori a partir da razão entre volume projetado total dividido pelo número de ligações. Dessa maneira, estimam-se reduções ( tabelas 38 ).

Tabela 38 - Resultados das projeções de água

\begin{tabular}{|c|c|c|c|c|c|c|c|}
\hline Cidade Informal & 2014 & 2015 & 2016 & 2017 & 2018 & 2019 & 2020 \\
\hline $\begin{array}{l}\text { n. de ligações de } \\
\text { água }\end{array}$ & 5.547 & 21.421 & 42.179 & 65.874 & 89.456 & 109.558 & 116.771 \\
\hline $\begin{array}{l}\text { n. de economias de } \\
\text { água }\end{array}$ & 6.108 & 23.626 & 46.748 & 72.941 & 99.080 & 121.423 & 129.461 \\
\hline $\begin{array}{l}\text { volume medido } \\
\text { Residencial } \\
\text { (1000m3/economia) }\end{array}$ & 18,9 & 17,0 & 16,0 & 16,4 & 16,5 & 16,6 & 16,7 \\
\hline $\begin{array}{l}\text { volume medido não } \\
\text { residencial } \\
\text { (1000m3/ano) }\end{array}$ & 22,6 & 21,2 & 20,7 & 20,9 & 20,9 & 20,8 & 20,8 \\
\hline
\end{tabular}

\subsubsection{Demanda de Água Total}

O volume produzido de água representa o volume que é disponibilizado no sistema antes da distribuição e engloba o volume consumido mais perdas no sistema. 
O Volume de Uso Especial (VO) consiste no volume de água relacionado a usos sociais, operacionais, emergenciais e próprios. Para esse volume, os dados do ano de 2011 foram atualizados de acordo com os dados verificados enquanto as projeções partiram do pré-suposto de um crescimento proporcional do VO à soma dos volumes medidos residenciais e não residenciais.

A partir da atualização do volume de perdas e do volume medido de água, foram calculadas as projeções do Volume Produzido de água (volume distribuição + perdas no sistema para os Aglomerados subnormais)(Tabela 39):

Tabela 39 - Resultados das Projeções de volumes medidos e não medidos de água Total

\begin{tabular}{r|r|r|r|r}
\multicolumn{1}{r|}{ m3/ano } & $\begin{array}{c}\text { Volume Anual } \\
\text { Medido }\end{array}$ & $\begin{array}{c}\text { Volume Anual } \\
\text { Não Medido }\end{array}$ & $\begin{array}{c}\text { Volume } \\
\text { Operacional Total }\end{array}$ & $\begin{array}{c}\text { Volume } \\
\text { Produzido Total }\end{array}$ \\
\hline 2014 & 1.401 .773 & 36.439 .710 & 18.175 .408 & 87.004 .989 \\
\hline 2015 & 4.937 .736 & 32.141 .338 & 15.124 .570 & 80.187 .398 \\
\hline 2016 & 9.214 .320 & 25.820 .536 & 11.593 .467 & 70.030 .826 \\
\hline 2017 & 14.710 .053 & 18.402 .392 & 8.837 .656 & 60.921 .579 \\
\hline 2018 & 20.103 .757 & 11.042 .582 & 6.709 .625 & 53.045 .404 \\
\hline 2019 & 24.670 .619 & 4.820 .656 & 5.129 .452 & 47.091 .648 \\
\hline 2020 & 26.476 .792 & 2.969 .832 & 4.193 .219 & 44.882 .176
\end{tabular}

Elaboração: a autora (2014)

\subsubsection{Projeção do Índice de Perdas Totais - IPT}

O índice de perdas reflete o volume de água que foi produzido, mas não foi entregue ao cliente final. O cálculo do índice considerou os seguintes volumes:

- $\quad$ Ano Base: Cálculo do IPT através dos volumes OES e Volume produzido

- $\quad$ Projeções: redução gradual. Estimou-se ou os percentuais (\%) de perdas para as comunidades, chamadas perdas sociais, no entanto, como não foram setorizadas as áreas de operação nas favelas, os dados imiscuem-se com perdas na rede.

VP: Volume produzido, em $\mathrm{m}^{3} / \mathrm{ano}$

VCM: Volume de consumos medidos, em $\mathrm{m}^{3} / \mathrm{ano}$;

VO: Volume Operacional ou de Uso Especial, em $\mathrm{m}^{3} / \mathrm{ano}$; 
As metas do indicador IPM (Índice de Perdas na Medição) foram determinadas, através da fórmula 3:

Fórmula 3 - Índice de Perdas na Medição

$$
I P M=\frac{(V P-V C M-V O)}{V P}, \text { em } \%
$$

Os valores do ano base foram atualizados até dezembro de 2014 por meio dos dados verificados da empresa. (Tabela 40):

\begin{tabular}{c|c|c|c|c|c|c|c} 
Tabela 40 - Resultado das Projeções do Índice de Perdas Totais (\%) \\
Perdas & 2014 & 2015 & 2016 & 2017 & 2018 & 2019 & 2020 \\
\hline $\begin{array}{c}\text { Índice de Perdas sobre o } \\
\text { Volume Consumido }\end{array}$ & 35,6 & 35,5 & 35,1 & 34,4 & 33,5 & 32,4 & 31,7 \\
\hline $\begin{array}{c}\text { Volume Operacional / Volume } \\
\text { Disponível }\end{array}$ & 1,7 & 1,5 & 1,3 & 1,2 & 1,0 & 0,9 & 0,7 \\
\hline $\begin{array}{c}\text { Volume de Uso Social / } \\
\text { Volume Disponível }\end{array}$ & 19,2 & 17,5 & 15,7 & 13,9 & 12,1 & 10,4 & 8,6
\end{tabular}

Elaboração: a autora (2014)

\subsubsection{Projeção do Volume Coletado de Esgoto}

O volume de esgoto total é função das contribuições pontuais de esgotos proveniente das economias residenciais e não residenciais. O calculo do volume total de esgoto coletado é a somatória dos volumes de esgoto residencial e não residencial. As projeções dessas contribuições também foram estimadas por categoria de consumo e apresentam a lógica do Plano de Negócios da concessionária. A seguir, são explicitadas como foram atualizadas e calculadas as projeções de cada uma das contribuições da coleta.

\subsubsection{Contribuição de Esgoto Residencial e Indicador de \\ Universalização Inclusiva de Esgoto}

A evolução de mercado de esgoto residencial é feita de maneira análoga ao mercado de água. A unidade de projeção para as contribuições unitárias da categoria residencial incide sobre o número de economias atendidas de esgoto. Essa por sua vez, depende diretamente da evolução do número de Domicílios Da Cidade Informal ponderado pelo índice de atendimento de coleta. 
Ano Base: Numerador do IAA (Economias Residenciais de água (m3/mês)

- $\quad$ Projeção: linear até ano onde é esperado o maior índice de atendimento ou a universalização (contratos de programa ou 2020).

- $\quad 80 \%$ do consumo unitário de água.

A figura 23 mostra em linhas gerais a metodologia utilizada para estimar a evolução da contribuição residencial de esgoto:

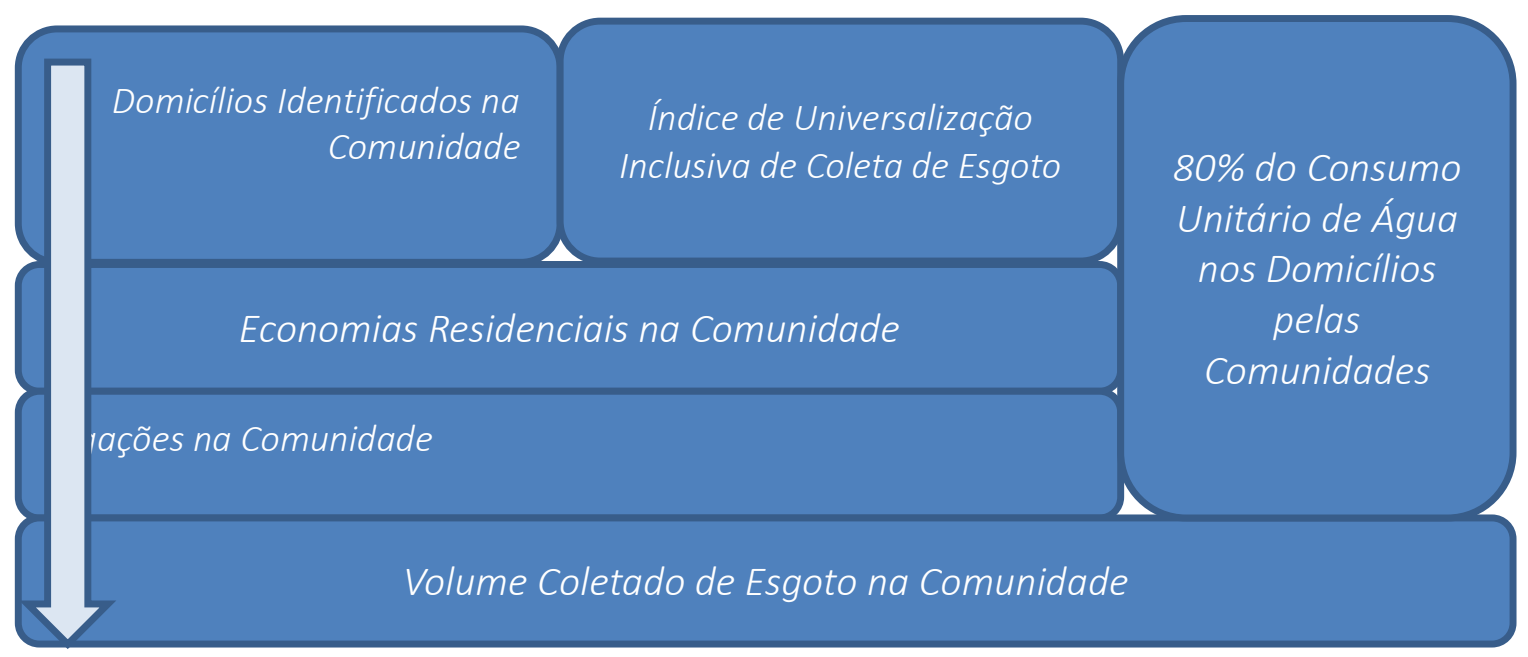

Elaboração: a autora (2014)

Figura 23 - Lógica Geral de Cálculo para o Volume Coletado de Esgoto Residencial

As projeções de domicílios da Cidade Informal e de consumos unitários de água foram abordadas nos itens anteriores. Observa-se pela figura acima que diferentemente do PN da Concessionária, não é mais utilizado o coeficiente de retorno para o cálculo do volume coletado, isto é, os volumes coletados de esgoto são projetados conforme os valores de esgoto obtidos comercialmente.

\subsubsection{Indicador de universalização de coleta inclusiva de esgoto}

O índice de coleta inclusiva de esgoto (ICIE) foi calculado a partir da Fórmula 4.

Fórmula 4 - Indicador de Universalização Inclusiva de Esgoto

Índice de Universalização Coleta

Inclusiva da de Esgoto =
Número de Ec. Res. de Esgoto Incluidas

Domicílios da Cidade Informal 
Para atualizar o índice de coleta do ano base foram utilizados os dados observados de Economias Residenciais de Esgoto verificados em Dezembro de 2011 e os dados de domicílios dos aglomerados subnormais.

As projeções do índice de atendimento para o período 2012-2020 levaram em conta as particularidades locais e o ICIE foi calculado com base no crescimento de Economias Residenciais de Esgoto e de Domicílios da Cidade Informal. Para as demais unidades, as projeções do índice de coleta, para o período 2012-2021, foram feitas através de interpolação linear entre o índice no ano base e 0 ano onde é esperado o maior índice de atendimento ou a universalização. Os dados referentes às economias no ano base $e$ ás metas de atendimento são obtidas primeiramente por município. A partir dos dados referentes aos domicílios da Cidade Informal de cada município e do índice de coleta calculou-se o índice resultante para cada um (Tabela 46).

\subsubsection{Contribuição unitária de esgoto residencial}

Projetadas as economias de esgoto, o volume total foi calculado a partir da soma das contribuições unitárias, isto é, do volume coletado por economia doméstica. A contribuição unitária de esgoto é diretamente proporcional ao consumo de água residencial. Como dito anteriormente, para o cálculo do volume coletado de esgoto não foi considerado nenhum Coeficiente de Retorno para ponderar os consumos de água.

\subsubsection{Resultados das projeções de demanda residencial de esgoto}

A partir da atualização do índice de atendimento em coleta de esgoto e das projeções de domicílios nos aglomerados subnormais, foram projetadas as economias de esgoto. Os resultados são apresentados na Tabela 41.

Em função das projeções de economias apresentadas acima e das contribuições unitárias de esgoto, foram atualizados os volumes coletados. Além do volume coletado, foram atualizadas também as ligações residenciais de esgoto. Diferentemente das ligações de água, para o serviço de esgoto não foi possível observar uma estabilidade temporal entre a relação economias/ligação. Esse 
comportamento ocorreu em função do aumento de universalização inclusiva de coleta de esgoto. Em função do aumento de cobertura de coleta de esgoto, as projeções de ligações foram calculadas através do número de economias levando em conta o grau de cobertura de esgoto existente. Para os municípios cujo atendimento encontra-se ainda em nível de precariedade, a relação economias/ligação foi projetada partindo da premissa de convergência desse valor para a relação observada no serviço de água. No ano base foi atualizada a relação verificada em 2014 e o ano de convergência foi considerado aquele em que se obtém a universalização do serviço de coleta de esgoto. Os anos intermediários foram calculados por interpolação linear (Tabela 41).

Tabela 41 - Resultado das projeções de esgoto coletado

\begin{tabular}{c|c|c|c|c|c}
\multirow{2}{*}{$\begin{array}{c}\text { Totalizações } \\
\text { Esgoto }\end{array}$} & $\begin{array}{c}\text { Domicílios } \\
\text { Cadastrados }\end{array}$ & $\begin{array}{c}\text { Economias } \\
\text { Cadastradas }\end{array}$ & $\begin{array}{c}\text { Volume } \\
\text { Coletado } \\
\text { Regular }\end{array}$ & $\begin{array}{c}\text { Volume } \\
\text { Coletado } \\
\text { Irregular }\end{array}$ & $\begin{array}{c}\text { Volume } \\
\text { Tratado }\end{array}$ \\
\hline 2014 & 41 & 41 & 12.284 & 160.522 & 0 \\
\hline 2015 & 2.016 & 2.222 & 368.570 & 162.681 & 331.605 \\
\hline 2016 & 12.483 & 13.852 & 2.146 .549 & 165.607 & 1.991 .014 \\
\hline 2017 & 31.827 & 35.349 & 5.519 .791 & 168.372 & 5.436 .707 \\
\hline 2018 & 60.489 & 67.205 & 10.561 .688 & 2.255 & 10.325 .534 \\
\hline 2019 & 95.119 & 105.761 & 16.646 .555 & 2.325 & 16.194 .066 \\
\hline 2020 & 111.596 & 124.170 & 19.623 .056 & $\begin{array}{c}1.582 \\
\text { Elaboração: a autora (2014) }\end{array}$
\end{tabular}

\subsubsection{Contribuição de esgoto não residencial}

As categorias não residenciais identificadas foram calculadas totalizadas e com metodologias análogas ao consumo de água. Os resultados diretos das projeções são o volume coletado total e o número de ligações. A contribuição unitária foi calculada indiretamente a partir da razão entre volume projetado total dividido pelo número de ligações de esgoto. $O$ ano base adotado foi 2014 e a taxa projeção foi de 2014 a 2020 foi a de crescimento dos aglomerados subnormais estimadas pelo PHLIS com ajustes da área de planejamento da unidade de negócio da concessionária.

A figura 24 mostra em linhas gerais a metodologia de projeção dos volumes medidos de esgoto não residencial. 


\section{Volumes Não Residenciais

Elaboração: a autora (2014)

Figura 24 - Lógica Geral de Cálculo para o Volume Coletado de Esgoto Não Residencial A seguir, são explicitadas como foram feitas as atualizações e projeções de cada um dos itens da figura acima.

\subsubsection{Projeção do volume tratado de esgoto da cidade informal}

O volume tratado de esgoto, gerado no mercado de varejo e no atacado, representa a parcela de volume coletado e infiltrado que é encaminhado às Estações de Tratamento. Para a projeção de volume tratado deve ser considerada apenas aquela parcela de volume coletado que é efetivamente encaminhada para as estações de tratamento. $\mathrm{O}$ ano base adotado foi 2014 e a taxa projeção foi de 2014 a 2020 desagregados por município, com Índice de tratamento calculado por interpolação (Figura 25, Formula 5).

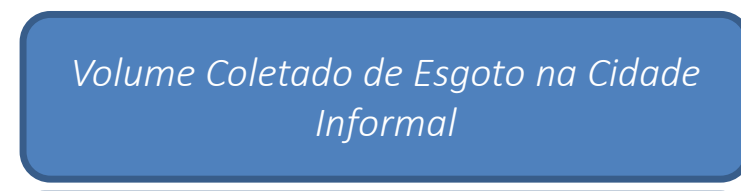

Indice de Tratamento de Esgoto da Cidade Informal
Volume Infiltrado de Esgoto na Cidade Informal

\section{Volume Tratado de Esgoto da Cidade Informal}

Elaboração: a autora (2014)

Figura 25 - Lógica geral da projeção de volume coletado de esgoto

O volume tratado de esgoto é calculado conforme Fórmula 5. 
Fórmula 5 - Fórmula de Projeção de Volume Coletado de Esgoto

Vol. Tratado de Esgoto $=$ Vol. Coletado de Esgoto na Cidade Informal ${ }^{*}$ Coef.Retorno ${ }^{*}$ ITIE da Cidade Informal

+ Vol. Infiltrado de Esgoto

A metodologia de cálculo de projeção do volume coletado foi explicitada nos itens anteriores. A seguir é explicitado como foi feita a projeção do índice de tratamento.

\subsubsection{4. Índice de tratamento de inclusivo de esgoto da cidade informal}

O índice de tratamento representa a razão entre o volume tratado de esgoto (sem considerar as infiltrações) e o volume coletado, onde o volume coletado é ponderado por um coeficiente de retorno. O fator denominado Coeficiente de Retorno pondera os valores de volume coletado de esgoto. O valor adotado para esse coeficiente foi mantido como $80 \%$, valor tradicionalmente utilizado para absorver o consumo de água residencial. Note-se que, diferentemente dos outros índices que são calculados através do número de economias, a cobertura de tratamento de esgoto é uma função de volumes:

Fórmula 6 - Fórmula de projeção de volume coletado de esgoto

Índice de Tratamento de Esgoto

Da Cidade Informal
Volume Tratado de Esgoto

Volume Coletado de Esgoto * Coeficiente de Retorno

Deve-se observar que o Volume Tratado de Esgoto não considerou o volume infiltrado na rede. Os valores dos índices de tratamento do ano base (dezembro de 2013) foram atualizados com os índices verificados da empresa. Para o interior, as projeções foram realizadas por meio de interpolação linear entre o índice verificado no ano base e o ano onde é esperado o maior índice de atendimento ou universalização. Os volumes tratados de esgoto foram atualizados no ano base de acordo com o Volume Coletado e o ITE verificado no ano. As projeções foram recalculadas até o ano de 2021 conforme a projeção desses valores(Tabela 42). 


\begin{tabular}{c|l|l|l|l|l|l|l}
$\begin{array}{c}\text { Cidade } \\
\text { Informal }\end{array}$ & 2014 & 2015 & 2016 & 2017 & 2018 & 2019 & 2020 \\
\hline Indicador (\%) & 68,8 & 85,0 & 84,9 & 88,7 & 89,3 & 89,9 & 90,4 \\
\hline Volume (m3) & 0 & 331.605 & 1.991 .014 & 5.436 .707 & 10.325 .534 & 16.194 .066 & 18.904 .370 \\
Elaboração: a autora (2014)
\end{tabular}

\subsection{PLANO DE INVESTIMENTO E EXPANSÃO DA CAPACIDADE DE OFERTA PARA A CIDADE INFORMAL}

O Plano de Investimento previsto pela concessionária considera o fluxo de desembolso esperado até o ano de 2020 com dados monetários apresentados em moeda de Dezembro de 2014. Estão apresentados também os principais quantitativos físicos para os sistemas de abastecimento de água e de esgotamento sanitário previstos no Programa de Investimentos, para o período 2014-2020 (Anexo 02).

O plano de Investimentos da Cidade Informal da Baixada Santista operada pela concessionária foi elaborado com base nas oficinas que revisitaram o BSC, planejamento estratégico empresarial e respectivas metas. Como premissas adotouse: apresentar as planilhas com as projeções físicas, explicando as premissas, e as dificuldades para se obtiver outros dados físicos, demonstrar a aderência entre o crescimento físico e a projeção de mercado informal, através de nota explicativa, elaborar uma nota explicativa com o detalhamento dos investimentos considerados por município. Nesse sentido, algumas reformulações foram acordadas apoiada numa outra ferramenta, o SBSC - Sustainability Balance Score Card, (Quadros 18 e 19).

Considerou-se também o Planejamento Situacional e Procediemntos do Capítulo 11.

\subsubsection{Programas Estruturantes das áreas favelizadas da RMBS}

Deve-se considerar que segundo dados da concessionária, dos cento dezesseis mil domicílios dos aglomerados subnormais, cinquenta mil serão beneficiados pelos programas em curso. O Programa de Aceleração do Crescimento tem recursos empenhados para obras de habitação e infraestrutura na Baixada Santista. Tem por finalidade a reurbanização de áreas de proteção permanente, manguezais, rios e canais, marcadas por um quadro acentuado de pobreza urbana, alta densidade populacional e degradação ambiental. Este Programa, sob coordenação das 
Secretarias Municipais de Planejamento, engloba intervenções para melhoria em favelas, loteamentos precários e conjuntos habitacionais contemplando desafetação e urbanização. Seu escopo de ações, com previsão de conclusão até 2015 inclui urbanização de favelas, expansão de infraestrutura urbana para comunidades de baixa renda, construção de conjuntos habitacionais, implantação e/ou melhorias de sistemas de esgotos sanitários e de abastecimento de água. Prevê investimentos totais da ordem de $R \$ 1,3$ bilhões, com recursos da União. A responsabilidade da SABESP refere-se à indicação dos locais a serem beneficiados com novas redes e fiscalização das implantações e melhorias de sistemas de água e esgotos. Nos levantamentos feitos os junto a órgãos financiadores, como a Caixa Econômica Federal, identificou-se divergência de informações quanto ao número de populações assentadas, domicílios e obras previstas dificultando o levantamento.

\subsubsection{Resultados do Plano de Investimentos}

É objetivo deste plano implantar um programa estruturante apoiado nos cálculos dos investimentos por município. Elaborou-se a projeção dos desembolsos até 2020, com valores constantes de dezembro de 2014 para atividades técnicas identificadas como essenciais para a universalização nessas áreas (Tabela 43).

\begin{tabular}{l|l|l|l|l|l|l|c}
\multicolumn{2}{c}{ Tabela 43 - Resultados das Projeções de Investimentos } \\
Investimentos & $\begin{array}{l}2015 \\
(\mathrm{R} \$ \mathrm{mil})\end{array}$ & $\begin{array}{l}2016 \\
(\mathrm{R} \$ \mathrm{mil})\end{array}$ & $\begin{array}{l}2017 \\
(\mathrm{R} \$ \mathrm{mil})\end{array}$ & $\begin{array}{l}2018 \\
(\mathrm{R} \$ \mathrm{mil})\end{array}$ & $\begin{array}{l}2019 \\
(\mathrm{R} \$ \mathrm{mil})\end{array}$ & $\begin{array}{l}2020 \\
(\mathrm{R} \$ \mathrm{mil})\end{array}$ & Totais (R\$mil) \\
\hline $\begin{array}{l}\text { Setorização ou } \\
\text { macromedição } \\
(\mathrm{R} \$)\end{array}$ & 11.749 & 8.729 & 6.854 & 6.814 & 5.369 & 5.349 & 45.689 \\
\hline $\begin{array}{l}\text { Troca de } \\
\text { Ramais }(\mathrm{R} \$)\end{array}$ & 5.721 & 6.312 & 6.616 & 6.675 & 6.716 & 5.696 & 38.382 \\
\hline Redes & 17.921 & 20.425 & 22.976 & 23.871 & 21.884 & 18.077 & 133.222 \\
\hline $\begin{array}{l}\text { Instalação das } \\
\text { Ligações }\end{array}$ & 4.025 & 8.306 & 12.314 & 15.843 & 17.107 & 7.192 & 65.910 \\
\hline \multicolumn{1}{c}{ TOTAL } & 39.416 & 43.772 & 48.760 & 53.203 & 51.076 & 36.314 & 283.203
\end{tabular}




\subsubsection{Gráficos de Volumes do Plano Inclusivo}

O simulador de projeções de volumes, receita e custos da Cidade Informal foi desenvolvido em nove versões em forma de planilhas e gráficos. Os valores apresentados são os resultados das oficinas de planejamento feita pelos gestores de cada município. Nesse simulador foram inseridas as informações divididas em 5 grupos: domicílios, volumes, perdas, redes (água e esgoto) e informações financeiras. Para o cálculo das projeções levaram-se em conta algumas premissas:

> As referências adotadas são de áreas de assentamentos precários;

$>$ O objetivo para o abastecimento de água é efetuar o cadastramento comercial, porque essas economias já possuem ligação física;

$>$ O objetivo da coleta de esgoto é efetuar a ligação física, comercial e intradomiciliar;

$>$ O objetivo dos kits de educação ambiental é promover ininterruptamente ações de comunicação junto a comunidade para promoção do uso racional da água;

Para a expansão desses resultados, adotou-se um programa de investimento com custos e indicadores das áreas objeto desse plano. Houve evolução das demandas por produção, universalização de água e índice de perdas. De forma geral, a universalização inclusiva esta refletindo um grau significativo de redução de perdas do município que são apresentados (Gráficos 35). Os fatores foram adotados em função da observação do desempenho nas áreas de estudo, conforme capítulo 11 .

O gráfico de perdas (Gráficos 36 ) representa as projeções do plano frente à ampliação da universalização inclusiva, e o índice projetado toma por base 0 observado pós intervenções sociotécnicas com setorização e medições de vazões do polo de avaliação.

Os gráficos (Gráficos 37 e 38) de receitas e despesas representam as variáveis e respectivas projeções realizadas no $\mathrm{PNI}$ e o volume excedente, que não será mais perdido (Tabelas 37 a 48). 
Gráfico 35- Projeções de Volumes de Água pelo Simulador

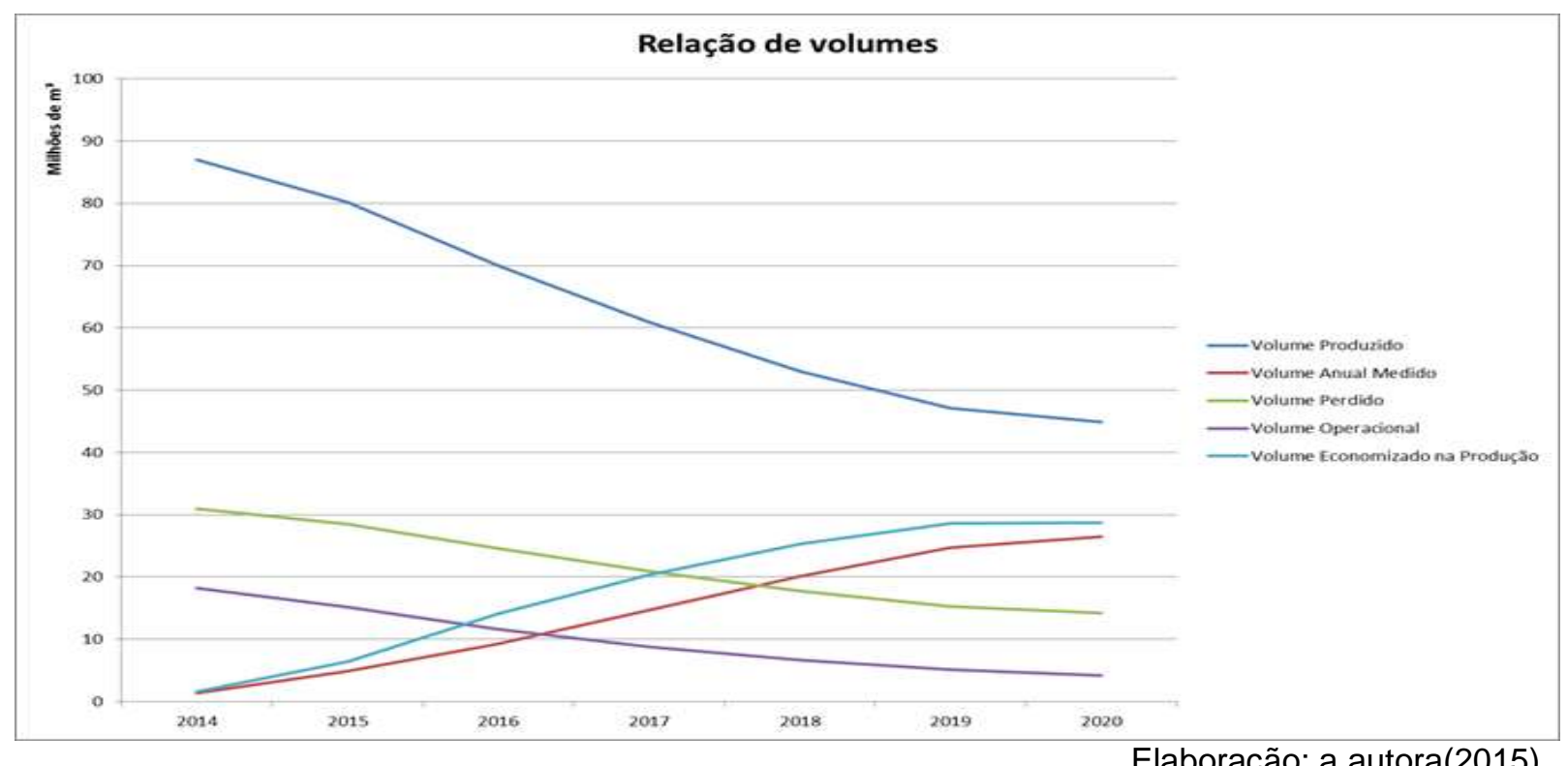

Conclui-se no gráfico 35, haverá uma economia de $40 \mathrm{mil} \mathrm{m3}$, provenientes de intervenções que impactarão $30 \%$ do volume total produzido e entregue na Cidade Informal da Baixada Santista até 2020. Este volume era perdido, e foi recuperado com o nome de volume excedente em função da intervenção sociotécnica para redução de perdas físicas no setor. Impacta na redução de volume de perdas físicas e operacionais dentro da comunidade e do volume gasto por economia, com uma redução do volume de produção para esta área. Também, haverá um aumento do volume medido nessas áreas (Anexo3).

Gráfico 36- Projeções de Perdas

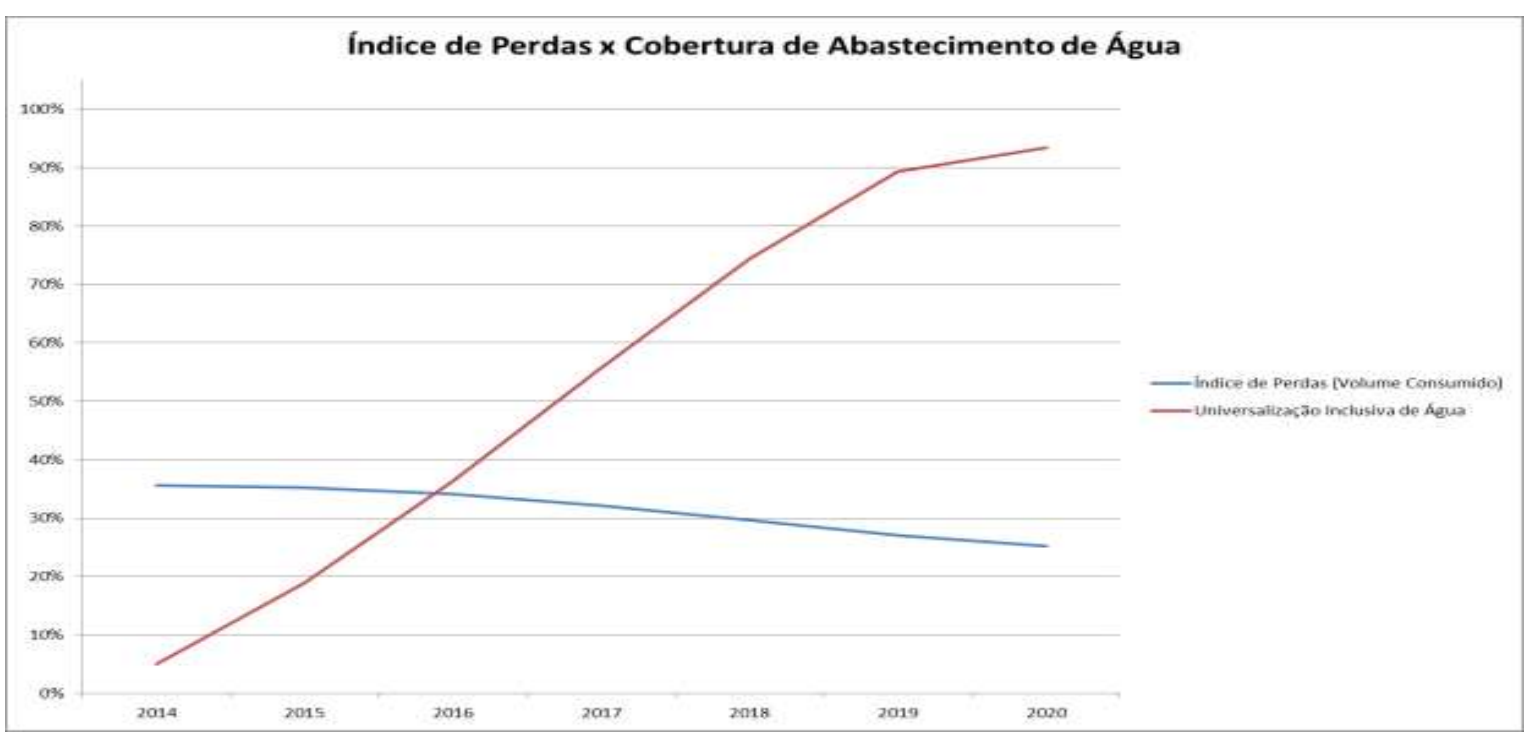

Elaboração: a autora(2015) 
Conclui-se no gráfico 37, que o aumento de ligações regularizadas nos aglomerados subnormais, apresentadas pelo indicador de universalização inclusiva tem uma correlação com a redução do Índice de Perdas da Baixada Santista.

Observando os resultados, deve-se destacar que o índice reduzirá apenas aproximadamente quatro por cento no período, pois a ausência de setorização e macromedição nesses aglomerados tem levado a cálculos de estimativa do Volume Social, gerando distorções e transferências de volumes entre parâmetros de cálculos (Anexo3). Sendo que a ausência de medição nos aglomerados subnormais demandando estimativas de Volume Social, pode gerar transferências de ineficiências técnicas para parâmetros dos aglomerados sociais.

Nas áreas de estudo com unidades terminais remotas das áreas do estudo de caso identificou-se uma redução real de água que foi fornecida aos setores de 30 até $50 \%$, conforme polo de avaliação técnica. No entanto, nas projeções deve-se considerar os ajustes metodológicos de medição e indicadores, que ocorrerão no período.

\subsection{PROJEÇÃO DE CUSTOS}

Os cálculos deste capítulo incluíram os seguintes custos diretos para exclusivamente a Cidade Informal de pessoal, materiais, materiais de tratamento, energia elétrica, serviços e despesas gerais, cujas referências foram fornecidas pela controladoria da concessionária e departamento de planejamento, dadas nas Tabelas 44 e 45.

Os custos fiscais Incluem: PIS/Cofins e Taxa de Regulação

Tabela 44 - Tabela de Custos de Referência

Custo Médio

\begin{tabular}{c|c}
\hline Distribuição de Água $\left(\mathrm{R} \$ / \mathrm{m}^{3}\right)$ & $\mathrm{R} \$ 1,16$ \\
\hline Coleta de Esgoto $\left(\mathrm{R} \$ / \mathrm{m}^{3}\right)$ & $\mathrm{R} \$ 1,60$
\end{tabular}

Elaboração: a autora (2014) 


\begin{tabular}{l|l|l|l|l}
\multicolumn{2}{l}{$\begin{array}{l}\text { Tabela } \\
\text { ANO }\end{array}$} & $\begin{array}{l}\text { Resultados das Projeções de Custos } \\
\text { Regulares Diretos c/ Lig. }\end{array}$ & Custos Diretos c/ Lig. Irregulares & Custos Fiscais \\
\hline 2014 & $(1.953 .327,29)$ & $(31.702 .547,28)$ & $(103.435,05)$ \\
\hline 2015 & $(6.013 .543,35)$ & $(27.962 .964,34)$ & $(345.621,01)$ \\
\hline 2016 & $(10.913 .916,45)$ & $(22.463 .866,08)$ & $(642.967,27)$ \\
\hline 2017 & $(17.237 .141,19)$ & $(16.010 .080,97)$ & $(1.036 .305,13)$ \\
\hline 2018 & $(23.450 .295,81)$ & $(9.607 .046,37)$ & $(1.421 .100,46)$ \\
\hline 2019 & $(28.712 .492,82)$ & $(4.193 .971,10)$ & $(1.742 .373,78)$ \\
\hline 2020 & $(30.793 .458,38)$ & $(2.583 .754,15)$ & $(1.875 .674,26)$ \\
\hline
\end{tabular}

\subsection{BASE DE ATIVOS}

A base de ativos adotou-se por princípio a setorização das áreas, na impossibilidade, estimou-se com base nas informações da AGEM sobre o PHLIS, a avaliação exclusivamente de ativos onerosos, desconsiderando os ativos provenientes de programas cujos recursos não implicam em onerosidade para a concessionária.

\subsection{RECEITAS INCREMENTAIS}

Para cálculo das receitas adotou-se a tarifa social aprovada pela Agência Reguladora, vigente em 2014 para cálculo das receitas (ARSESP, 2013). O processo de cálculo usado na Tabela 46 utilizou formulas, cujas explicações constam do Anexo 3.

Após a apresentação à controladoria da unidade de negócio da concessionária para o cálculo da receita projetada, adotou-se um redutor de 50\% proveniente da inadimplência recorrente nos aglomerados subnormais da região de estudo. 


\subsection{RESULTADO ECONÔMICO-FINANCEIRO}

Segundo a metodologia de avaliação de resultado econômico-financeiro adotado haverá um déficit, que no estudo de tarifas para serviços prestados às populações de baixa renda, corresponde ao subsídio necessário à ao equilíbrio à operação dos aglomerados subnormais até 2020 (Tabela 46 e Gráficos 37 e 38) . A somatória dos investimentos (setorização, troca de ramais, redes e ligações), custos de operação (energia elétrica, pessoal, materiais de tratamento e outros) e fiscais, comunicação e educação ambiental, subtraída das receitas é de ordem de oitenta milhões até o ultimo ano. Há que se considerar alguns pontos não considerados no estudo de viabilidade contratual e regulatório: 1) redução dos custos com irregulares de 31 milhões para 2,5 milhões até 2020; 2) redução do volume entregue em 43 milhões de m3 inserindo novos parâmetros para o desenvolvimento sustentável, uma vez que esse volume seria de perdas dentro das áreas em ligações clandestinas e vazamentos. Também passa a ser uma prioridade a análise de outras formas de financiamentos não reembolsáveis para investimentos e menores tarifas.

Considerou-se a condição dos volumes economizados pelo programa sociotécnico que será disponibilizado para outras áreas a tarifas não sociais, que comporão nesse caso, receitas acessórias para efeito de análise.

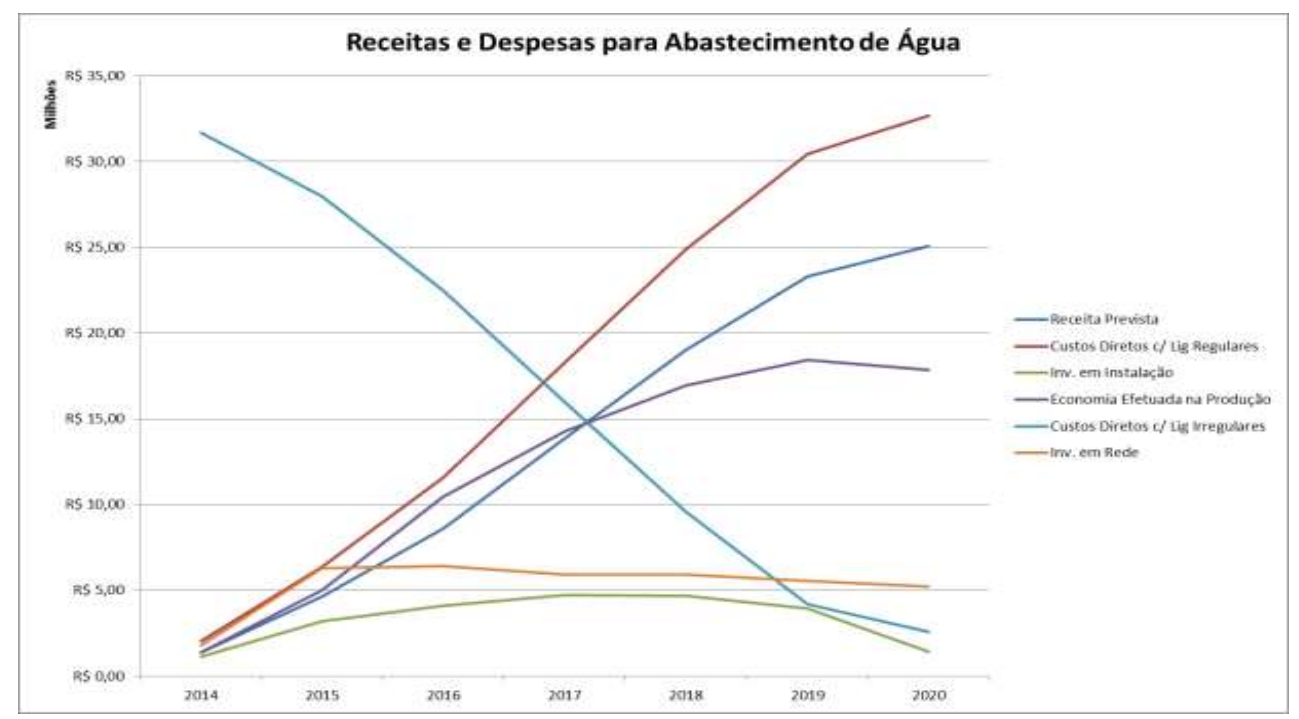

Elaboração: a autora (2014)

Gráfico 37 - Projeções Receitas e Despesas Água pelo Simulador 


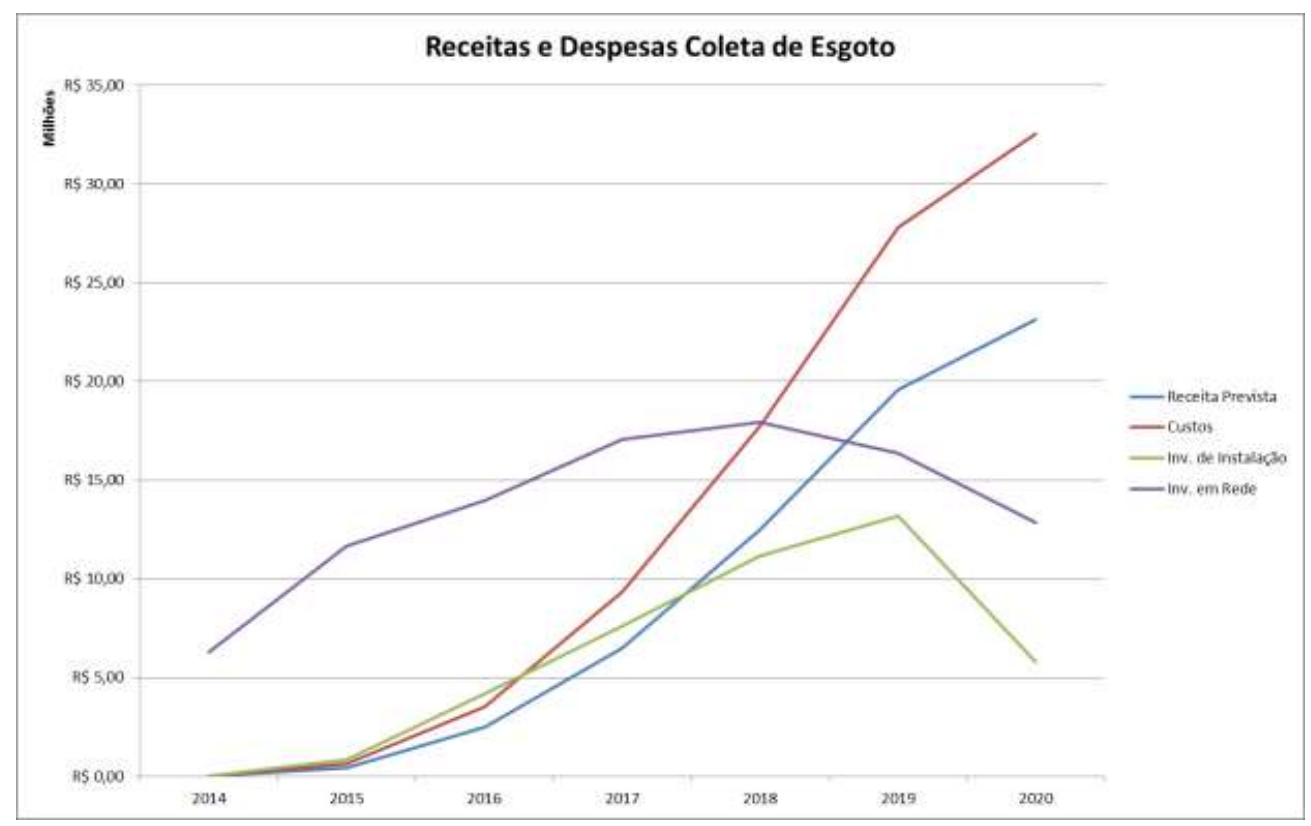

Gráfico 38 - Projeções Receitas e Despesas Esgoto pelo Simulador

Elaboração: a autora (2014) 
Tabela 466 - Resultados Econômico-Financeiros

\begin{tabular}{|c|c|c|c|c|c|c|c|}
\hline \multirow{2}{*}{$\begin{array}{l}\text { Resultados } \\
\text { Financeiros }\end{array}$} & \multicolumn{7}{|c|}{ Ano } \\
\hline & 2014 & 2015 & 2016 & 2017 & 2018 & 2019 & 2020 \\
\hline Receita Prevista & 1.762.197,36 & 6.369.393,89 & 13.996.437,19 & $25.637 .379,98$ & $39.644 .476,71$ & $54.045 .634,37$ & $60.773 .456,65$ \\
\hline \multicolumn{8}{|l|}{ Custos } \\
\hline $\begin{array}{l}\text { Fiscais (PIS/Cofins e } \\
\text { Taxa de Regulação) }\end{array}$ & $(104.605,60)$ & $(378.092,89)$ & $(830.840,97)$ & $(1.521 .857,70)$ & $(2.353 .331,43)$ & $(3.208 .196,97)$ & $(3.607 .566,49)$ \\
\hline $\begin{array}{l}\text { Diretos c/ Lig. } \\
\text { Regulares }\end{array}$ & $(1.960 .566,40)$ & $(6.595 .689,61)$ & $(14.266 .432,67)$ & $(26.091 .686,71)$ & $(40.239 .842,06)$ & $(55.035 .682,44)$ & $(61.616 .475,86)$ \\
\hline Kit Agente Comunitário & $(551.340,00)$ & - & - & - & - & - & - \\
\hline Total de Custos & $(2.616 .512,00)$ & $(6.973 .782,50)$ & $(15.097 .273,64)$ & $(27.613 .544,41)$ & $(42.593 .173,49)$ & $(58.243 .879,41)$ & $(65.224 .042,35)$ \\
\hline \multicolumn{8}{|l|}{ Investimentos } \\
\hline $\begin{array}{l}\text { Setorização ou } \\
\text { macromedição (R\$) }\end{array}$ & $(822.158,79)$ & $(11.749 .497,96)$ & $(8.729 .497,96)$ & $(6.854 .497,96)$ & $(6.814 .497,96)$ & $(5.369 .497,96)$ & $(5.349 .497,96)$ \\
\hline Troca de Ramais $(\mathrm{R} \$)$ & $(643.065,36)$ & $(5.721 .737,35)$ & $(6.312 .157,56)$ & $(6.616 .588,77)$ & $(6.675 .870,30)$ & $(6.716 .768,60)$ & $(5.696 .048,47)$ \\
\hline Redes & $(8.066 .438,00)$ & $(17.921 .034,00)$ & $(20.425 .882,50)$ & $(22.976 .308,50)$ & $(23.871 .254,50)$ & $(21.884 .004,50)$ & $(18.077 .981,50)$ \\
\hline Instalação das Ligações & $(1.120 .260,66)$ & $(4.025 .717,08)$ & $(8.306 .576,59)$ & $(12.314 .667,97)$ & $(15.843 .440,47)$ & $(17.107 .984,52)$ & $(7.192 .015,10)$ \\
\hline $\begin{array}{l}\text { Total de } \\
\text { Investimentos }\end{array}$ & $(10.651 .922,81)$ & $(39.417 .986,39)$ & $(43.774 .114,61)$ & $(48.762 .063,20)$ & $(53.205 .063,23)$ & $(51.078 .255,58)$ & $(36.315 .543,03)$ \\
\hline
\end{tabular}


Nesse sentido, o subsidio necessário ao equilíbrio econômico financeiro no período de análise foi calculado pela divisão do resultado (receita- investimentos totais custos totais - tributos) pelo volume total entregue à cidade informal (Tabela 47).

Tabela 47- Subsídio necessário por m3 produzido

\begin{tabular}{|c|c|}
\hline Ano & $\begin{array}{c}\text { Subsídio necessário } \\
(\mathrm{R} \$ / \mathrm{m} 3 \text { entregue nos } \\
\text { aglomerados subnormais })\end{array}$ \\
\hline $\mathbf{2 0 1 4}$ & 0,13 \\
\hline $\mathbf{2 0 1 5}$ & 0,31 \\
\hline $\mathbf{2 0 1 6}$ & 0,44 \\
\hline $\mathbf{2 0 1 7}$ & 0,70 \\
\hline $\mathbf{2 0 1 8}$ & 1,11 \\
\hline $\mathbf{2 0 1 9}$ & 1,58 \\
\hline $\mathbf{2 0 2 0}$ & 1,79 \\
\hline
\end{tabular}

Elaboração: a autora (2015)

Explica-se o aumento do subsídio necessário ao longo dos anos pela redução do volume entregue aos aglomerados subnormais e o aumento dos investimentos ao longo dos anos calculados. Alternativamente, a possibilidade de separação de subsídios à oferta (investimentos) dos subsídios à demanda (população de baixa renda) ao logo do período um Plano de Negócios deve conter basicamente os objetivos e metas, o planejamento físico para alcançar as metas, o mecanismo e os recursos necessários para sua execução, uma análise de sua sustentabilidade e seu equacionamento financeiro. O método adotado consistiu no cálculo do fluxo de caixa relacionado à área de habitações subnormais e irregulares. Foram comparadas as receitas resultantes da prestação do serviço com o OPEX, Tributos e CAPEX necessários para regularizar a situação da área. Os resultados indicam a necessidade de um acréscimo de até $R \$ 1,79$ na conta mínima de $10 \mathrm{~m} 3$. Ficando clara a necessidade de subsídios, cujo equacionamento é detalha nos capítulos seguintes.

Nesse sentido, uma análise incremental de comparação a receita dos consumidores da categoria social que estão sendo legalizados, acrescido da análise da receita 
incremental da agua que poderá ser vendida aos consumidores normais como alternativa. Esta receita somente deve ser comparada com o CAPEX e os Tributos. $O$ resultado positivo do fluxo demonstra que por essa metodologia que considera os volumes economizados e não perdidos, a intervenção é atrativa para um modelo de negócio, e caso o resultado fosse negativo haveria a necessidade de um subsidio para prestação do serviço, conforme Tabela 48.

Tabela 48- Fluxo de Caixa por Receita Incremental

\begin{tabular}{|c|c|c|c|}
\hline PARAMETROS & SITUACAO ATUAL & SITUACAO FUTURA & FONTE \\
\hline Volume Produzido para a Cidade Informal & 4800 & 2900 & PNI \\
\hline Volume Produzido para a Cidade Formal & 124944 & 126844 & $\mathrm{PNI}$ \\
\hline Volume Produzido Total & 129744 & 129744 & RT2012 \\
\hline ANC & $70,0 \%$ & $25,0 \%$ & PNI \\
\hline Volume Faturado Cidade Informal & 3360 & 725 & PNI \\
\hline Volume faturado Cidade Formal & 112989 & 133214 & RT2012 \\
\hline TMs/m3 (Cidade Informal) & $\mathrm{R} \$ 0,50$ & $\mathrm{R} \$ 0,50$ & PNI \\
\hline TMn/m3 (Cidade Formal) & $\mathrm{R} \$ 3,46$ & $\mathrm{R} \$ 3,46$ & RT2014 \\
\hline Opex/m3 & $\mathrm{R} \$ 1,16$ & $\mathrm{R} \$ 1,16$ & $\mathrm{PNI}$ \\
\hline Impostos & $8,0 \%$ & $8,0 \%$ & PNI \\
\hline FLUXO DE CAIXA & SITUACAO ATUAL & SITUACAO FUTURA & INCREMENTAL \\
\hline Receita Cidade Informal & $1.680,00$ & 362,50 & $-1.317,50$ \\
\hline Receita Cidade Formal & $432.306,24$ & $438.880,24$ & $6.574,00$ \\
\hline Receita Total & $433.986,24$ & $439.242,74$ & $5.256,50$ \\
\hline OPEX Cidade Informal & $5.568,00$ & $3.364,00$ & $-2.204,00$ \\
\hline OPEX Cidade Formal & $144.935,04$ & $147.139,04$ & $2.204,00$ \\
\hline CAPEX & $39.416,00$ & $36.314,00$ & $-3.102,00$ \\
\hline Impostos Cidade Informal & 134,40 & 29,00 & $-105,40$ \\
\hline Impostos Cidade Formal & $34.584,50$ & $35.110,42$ & 525,92 \\
\hline Fluxo Caixa Liquido & $(354.283,34)$ & $(364.425,32)$ & $10.141,98$ \\
\hline
\end{tabular}

Fonte: a autora(2015)

Como o resultado do fluxo de caixa foi positivo, não haverá contribuição do usuário ou do fundo perdido para equilíbrio, tornando atrativa a atuação em termos de modelo de negócio.

\subsection{CÁLCULO DO ÍNDICE DE GOVERNANÇA INCLUSIVA}

O objetivo do Índice de Governança Inclusiva (IGI) é realizar o monitoramento das ações necessárias à garantia da inclusão e gestão permanente para promover a Universalização Inclusiva de todas os aglomerados subnormais, que tiveram os cálculos dos resultados do primeiro ano de análise . 
Conforme Capítulo 4.5., exercer a governança Inclusiva é garantir o cumprimento das funções do poder concedente, concessionária, regulador e entidades governamentais por meio de instrumentos institucionais com atribuições e competências claras e detalhadas de todos os atores para a universalização inclusiva dos serviços de saneamento, que promovam a participação social e permitam o controle social. O cálculo de seu índice segue metodologia do Quadro 11, aplica-se por município, e foi calculado para o ano de 2014 (Tabela 49)

Tabela 49 - Cálculo do IGI dos municípios

\begin{tabular}{c|c|c|c|c|c|c|c}
\multirow{2}{*}{\begin{tabular}{c} 
Parâmetros/muni $\begin{array}{c}\text { Dimensão } \\
\text { cípio }\end{array}$ \\
\cline { 2 - 8 }
\end{tabular}} & $\begin{array}{c}\text { Levantamen } \\
\text { to }(1)\end{array}$ & $\begin{array}{c}\text { Planejamen } \\
\text { to (2) }\end{array}$ & $\begin{array}{c}\text { Program } \\
\text { a ST (3) }\end{array}$ & $\begin{array}{c}\text { Recurs } \\
\text { o (4) }\end{array}$ & $\begin{array}{c}\text { Anális } \\
\text { e (5) }\end{array}$ & $\begin{array}{c}\text { Realim } \\
\text { entaçã } \\
\text { o (6) }\end{array}$ & íGI \\
\hline Guarujá & 0,50 & 0,50 & 0,25 & 0 & 1 & 1 & $35 \%$ \\
\hline Cubatão & 0,50 & 0,50 & 0,25 & 0 & 1 & - & $30 \%$ \\
\hline Santos & 0,50 & 0,50 & 0,25 & 0 & - & - & $25 \%$ \\
\hline São Vicente & - & 0,50 & 0,25 & 0 & - & - & $15 \%$ \\
\hline Bertioga & - & 0,50 & 0,25 & 0 & - & - & $15 \%$ \\
\hline Praia Grande & - & 0,50 & 0,25 & 0 & & & $15 \%$ \\
\hline Peso & 20 & 20 & 20 & 30 & 5 & 5 &
\end{tabular}

Elaboração: a autora (2014)

As notas dadas aos municípios parte como exemplo do Guarujá - (1) levantamento periódico e permanente das populações: 20 (Peso) X 0,50 (Atividade não concluída) = 1; (2) Planejamento participativo periódico: 20 (Peso) X 0,5 (Atividade com execução até $50 \%$ ) = 10; (3) Programa de universalização dessas áreas amplo e com continuidade: 20 (Peso) X 0,25 (Programa em construção) = 5; (4) Recursos orçamentários: 30 (Peso) $\times 0$ (Não há recursos) =0; (5) Análise de resultados positivos e negativos: 5 (Peso) $X 1$ (Analise realizada) $=5$; (6) Realimentação do processo: 5 (Peso) X 1 (Muito favorável) $=5$; Totalizando no exemplo um Índice de Governança Inclusiva de $35 \%$, que deverá ter um esforço para chegar a 100\% nos anos seguintes do Planejamento.

Identificou-se uma ausência de dados consistentes do Serviço Único de Saúde SUS, além da ausência do Agente da Saúde na área, segundo informações dos moradores. Nesse sentido optou por não considerar esses dados para cálculo de outcome do saneamento.

\subsection{CÁLCULO DA VULNERABILIDADE EMPRESARIAL}

A gestão da vulnerabilidade empresarial associada ao risco regulatório é importante 
ferramenta de governança regulatória que permite monitoramento das mudanças provenientes da atuação judicial, municipal ou da ausência da mesma impactando positivamente ou negativamente nos resultados empresariais, que não poderão ser atribuídos pelo regulador à ineficiência técnica, mas deverão demonstrar o esforço da concessionária na redução desse efeito. Em aplicação ao contexto das premissas e cálculos anteriores, propõe-se um indicador que, aplicado, mensure 0 impacto da desregulamentação no estudo de viabilidade do contrato de concessão. Foi calculado para o primeiro município que teve uma intervenção sociotécnica nos moldes da teoria ator-rede (Quadro 18):

Quadro 18- Calculo da vulnerabilidade empresarial

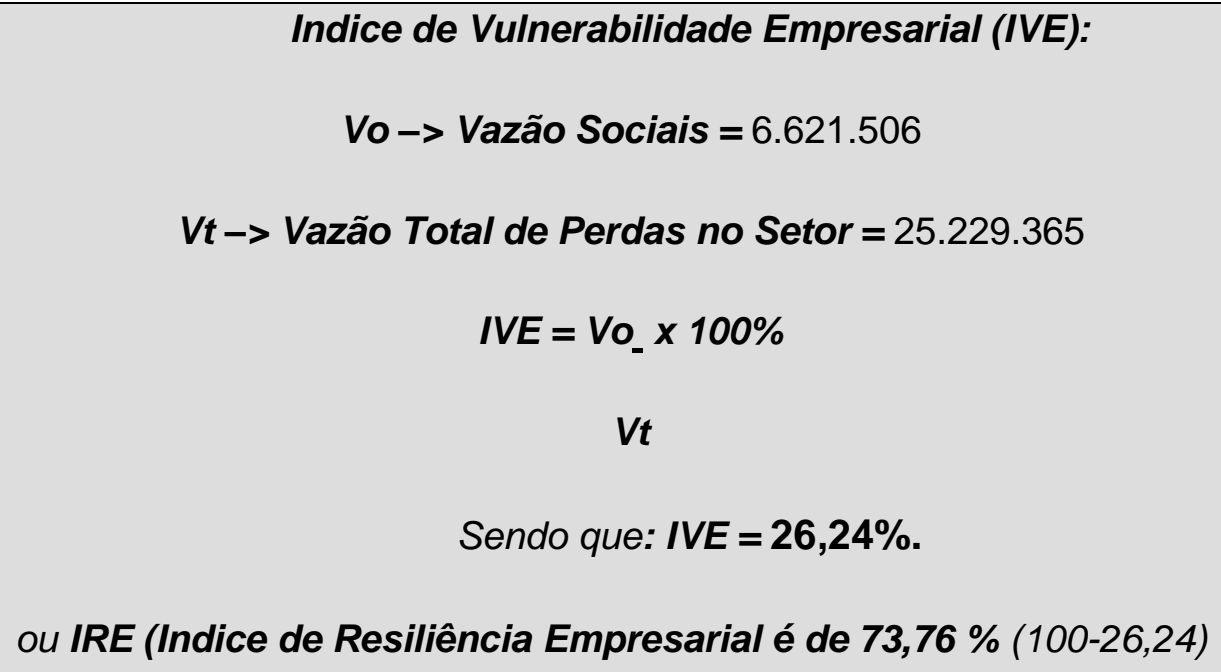

Elaboração: a autora (2014)

A aplicação de indicador representa o percentual de volume utilizado no município que não serão remunerados por tarifas, mas que tem um uso social. É a avaliação qualitativa de que o risco regulatório da ocupação desordenada sobre o contrato de concessão é de $26,24 \%$.

Como se aplicaria o índice de vulnerabilidade empresarial nas concessões adotouse um estudo de caso real do município metropolitano de Cuiabá de concessão privada.

\subsubsection{Cuiabá um caso real de conflitos por divergências de PMSB, contrato e plano de negócio.}

Diversas matérias foram publicadas referentes à construção de 12.000 Unidades 
concluídas do Programa Minha Casa Minha Vida em Cuiabá, que não foram atendidas em redes públicas de abastecimento de água e esgotamento sanitário. Segundo a concessionária é um investimento não previsto no Plano Municipal de Saneamento Básico - PMSB. Os empresários do ramo da construção civil receberam a cobrança de $R \$ 24$ milhões para a realização de serviços. Segundo o Ministério Público Estadual - MPE, o investimento é objeto do contrato de concessão, e seguindo o PMSB, é de obrigação da concessionária, incluindo captação da água, tratamento, bombeamento para um reservatório a ser construído e canalização para a distribuição. (Circuito Mato Grosso, 2015).

Segundo o relatório do MPE, há divergências entre o planejado pelo município no PMSB, o termo de referência e o plano de negócios apresentado pela CAB Cuiabá, durante o processo de licitação. (Diário de Cuiabá, 2015).

Foram estabelecidos termos para a universalização da água, no entanto, não foi estabelecido nenhum prazo. A concessionária vem desenvolvendo um trabalho para que ocorra essa universalização, mas sem prazo. O MPE pediu a condenação do poder público (prefeito), Concessionária (presidente) e Agência (presidente) pelo descumprimento da obrigação de promover a universalização do abastecimento de água em Cuiabá (G1(2015).

Nesse caso, o índice de vulnerabilidade empresarial poderia ser calculado como 12.000 domicílios construídos/ 159.000 domicílios totais segundo dados do censo (IBGE, 2010). O índice de vulnerabilidade é de 7,55\%. Resta compor algumas análises complementares para identificar em que percentual passa do tolerável e passa a ter um risco de desequilíbrio irreparável para a operadora ou para a qualidade dos serviços. Certo é que alguém arcará com os efeitos dessas questões.

\subsection{CONCLUSÕES}

O estudo de viabilidade econômico-financeiro convencional mostra-se insuficiente para capturar os resultados ambientais provenientes da gestão da intervenção sociotécnica, como no caso da Baixada Santista. Há que se considerar o aumento dos recursos hídricos disponibilizados nas redes distribuição dos setores vizinhos à área vulnerável - Volume Excedente no Gráfico 39 pelo histórico de volumes medidos de Santa Cruz dos Navegantes no município de Guarujá. Identificou-se pela macromedição de vazão no setor (em azul), que houve uma redução do volume entregue à área. Os volumes perdidos antes da intervenção sociotécnica passaram 
a ser disponibilizados à outras áreas vizinhas urbanizadas. A receita obtida por esses volumes entregues para outros setores, fora da área de intervenção, para usuários sem caracterização sociais, com tarifas normais garantiram o equilíbrio econômico-financeiro, chujo conceito adotado é a Receita Acessória. A representação gráfica do fluxo de caixa da Tabela 48 é apresentada no Gráfico 39.

Gráfico 39 - Evolução de volumes excedentes e receitas acessórias

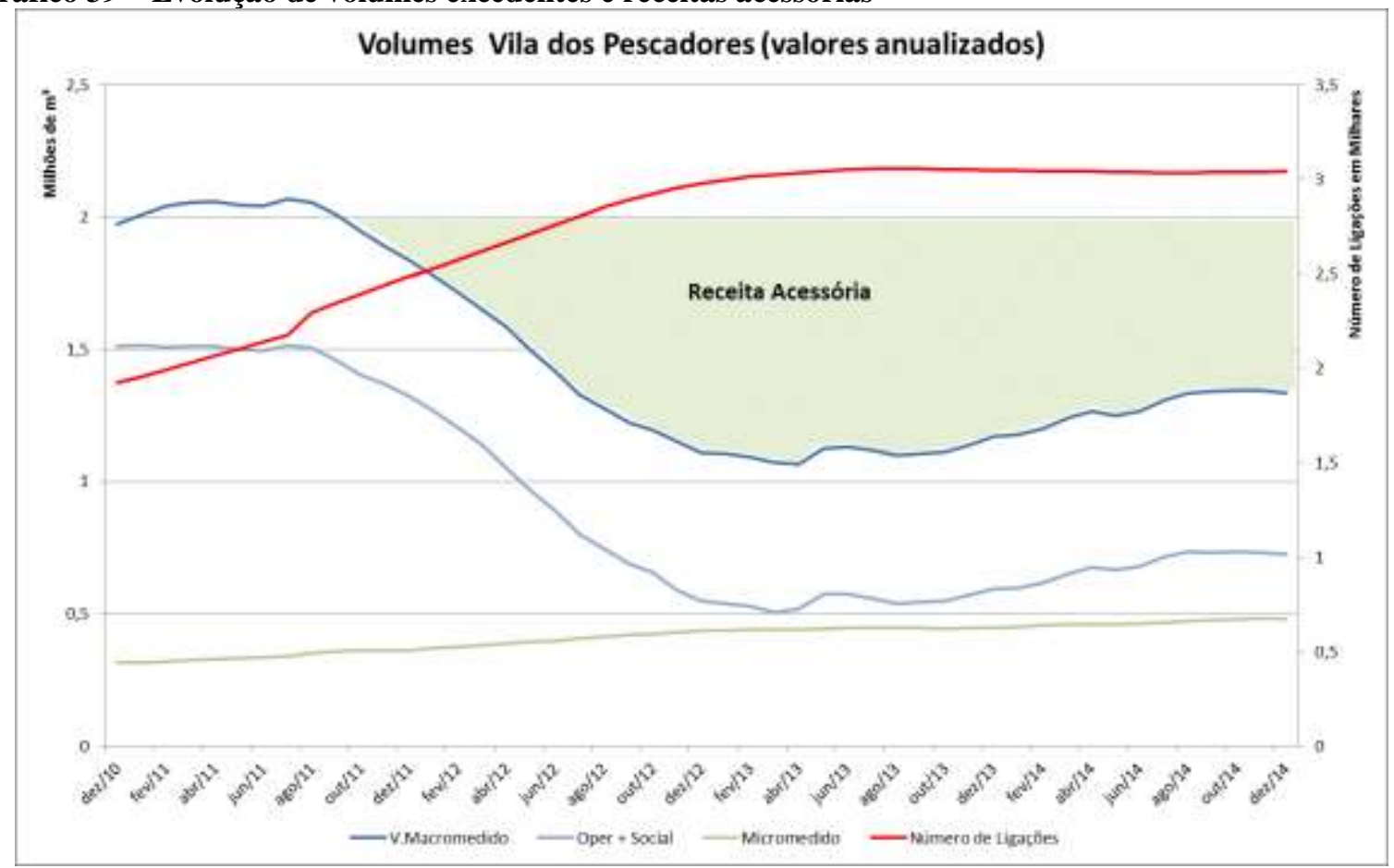

Fonte: a autora (2015)

Assim, o cálculo que contribuiu para inovação do estudo de viabilidade foi o da receita incremental (Tabela 50), cujo volume excedente anteriormente perdido passou a ser faturado à tarifa média do município, para efeito de demonstração dos ganhos da intervenção sobre as áreas irregulares.

Tabela 50 - Receita acessória pela distribuição do volume de perdas sociais recuperado

\begin{tabular}{c|c|c|c} 
Ano & $\begin{array}{c}\text { Volume Economizado } \\
(\mathbf{m} 3)\end{array}$ & $\begin{array}{c}\text { Tarifa Média } \\
(\mathbf{R} \mathbf{)}\end{array}$ & $\begin{array}{c}\text { Receita Acessória } \\
(\mathbf{R} \mathbf{)}\end{array}$ \\
\hline 2011 & 27.132 & 3,06 & 83.025 \\
\hline 2012 & 645.318 & 3,17 & 2.045 .659 \\
\hline 2013 & 873.204 & 3,16 & 2.759 .323 \\
\hline 2014 & 517.373 & 3,21 & 1.660 .768 \\
\hline Total & 2.063 .027 & & 6.548 .774
\end{tabular}

Nesse sentido, o volume estimado não perdido, e entregue para outro setor do 
mesmo ou até de outro município será de 2.000 mil de m3 no período de quatro anos. A receita acessória calculada correspondente de $R$ \$ 6 milhões no mesmo período. Esses dois parâmetros mostram os ganhos ambientais e econômicos da governança inclusiva.

Identificou-se que as incertezas provenientes dos fatos jurídicos, sociais, econômicos e políticos dos municípios nos quais a concessionária atua são determinantes da realidade que afetam a dignidade humana e impedem o mínimo para a subsistência. O plano de negócio que está apoiado na metodologia ator-rede (Latour, 2012) e no Mapa de Controvérsias (Mapa 2) construído para definição de metas de forma a facilitar o planejamento dos empreendimentos e ações envolvidas, permite estabelecer um programa permanente para a Baixada Santista subsidiando argumentações à captação dos recursos necessários à obtenção dos resultados .

Nesse sentido, a coordenação falha na elaboração dos PMSBs sem PNIs tendem a multiplicar ações judiciais sobre os conteúdos dos termos, prazos e valores de investimentos previstos nas PPPs e outros regimes de concessões. As considerações do atendimento às áreas vulneráveis, em questões de como são excluídos da regulação e a ausência do cálculo do risco contratual implicam numa maior vulnerabilidade empresarial e pode comprometer o acesso a universalização dos serviços de saneamento e estudos de viabilidade originais.

É mandatório monitorar a judicialização das áreas vulneráveis e empreendimentos de programas de urbanização que não se comunicam com as concessionárias. Percebe-se também como as taxas de crescimento dos aglomerados subnormais devem ser consideradas, pois impactam o plano de investimentos e podem efetivamente afetar o equilíbrio econômico-financeiro do contrato.

A inovação do PNI apresenta uma metodologia considerando projeções populacionais e taxas de crescimento dos aglomerados, parâmetros reais e funções preditivas dos efeitos das intervenções sociotécnicas junto às comunidades baseadas nos pilotos. Investimentos necessários foram calculados apoiados em valores de referência locais e critérios da base de ativos e financiamentos não onerosos. Os rateios da administração central não foram admitidos nessas áreas. As transferências dos ganhos por doações de redes e mutirão também foram isolados, para garantia de os ganhos socioeconômicos não fossem transferidos para áreas consolidadas. A fonte desses dados foi o sistema da contabilidade. 
O plano de negócios da cidade informal deve ser base para estudos de viabilidade para novos contratos de concessão de áreas urbanas e PPPs patrocinadas que podem ser afetadas pelo crescimento desordenado e morosidade dos programas de urbanização, adotando-se o equilíbrio por um fluxo de caixa com receita incremental considerando volumes excedentes e receitas acessórias.

Nesse sentido, quanto às questões regulatórias e empresariais, o Plano de Negócios Inclusivo permite, por um lado, estabelecer mecanismos de ação e controle da universalização das áreas vulneráveis e as medidas de acompanhamento da eficiência técnica e eficácia social dos serviços públicos aos cidadãos por meio da governança inclusiva. Por outro lado, o PNI permite monetizar a ação sociotécnica para a promoção de arranjos inovadores da prestação dos serviços transitórios de saneamento nesse espaço de inclusão urbana, na ótica da sustentabilidade e em resposta aos desafios do enfrentamento da degradação socioambiental nas metrópoles.

\section{EQUACIONAMENTO ECONÔMICO-FINANCEIRO ${ }^{30}$}

\subsection{Introdução}

Como a provisão dos serviços públicos a populações de baixa renda devem ser equacionadas, considerando a capacidade de pagamento dos usuários e o equacionamento necessário para superar as barreiras de entrada, identificou-se municípios dentro da área na tese que não teriam condições per si de viabilidade, dependendo de outras formas de subsídios.

Os subsídios podem ser entendidos como um instrumento de política pública que consiste na entrega de recursos a um grupo de agentes econômicos (produtores ou consumidores), de forma a alterar o equilíbrio de mercado que seria alcançado em condições normais, com a finalidade de melhorar o bem-estar da sociedade. Os bens públicos se caracterizam por serem de consumo coletivo, onde a demanda de um determinado agente não implica, necessariamente, na diminuição da oportunidade de consumo a outro. Já os bens meritórios se caracterizam por sua

\footnotetext{
${ }^{30}$ Parte deste capítulo é resumo do Estudo contratado pela SABESP e realizado pela Siglasul Consultoria. O uso pela pesquisadora está autorizado pela SABESP, que detem o direito contratual da autoria e pela Siglasul. Tratase de documento de circulação restrita, cujos relatórios constam da Bibliografia (SIGLASUL, 2012a, 2012b).
} 
importância social e por gerarem externalidades positivas, almejando-se a universalização do acesso a tais produtos/serviços. Enquadram-se bens públicos a água; e como meritórios, o esgotamento sanitário. Nesse sentido, no setor de saneamento, os subsídios são instrumentos necessários para promover o acesso universal a esse serviço essencial motivado pelo caráter meritório por ser um serviço básico, essencial à vida humana e diretamente relacionado ao meio ambiente, cujas externalidades positivas afetam a sociedade e ambiente.

\subsection{Fundamentos dos subsídios}

Podem ser classificados dependendo dos agentes econômicos envolvidos, da origem dos recursos para financiamento e do foco no serviço prestado (Tabela 51) (SABESP, 2005).

Tabela 51 - Classificação dos subsídios e suas principais características

\begin{tabular}{|c|c|c|}
\hline Estrutura & Mecanismo & Características \\
\hline \multirow{2}{*}{ Beneficiários } & $\begin{array}{c}\text { Indiretos } \\
\text { (conferido aos produtores) }\end{array}$ & $\begin{array}{l}\text { - Denota redução dos custos de produção; } \\
\text { - Equivale a um aumento da oferta do mercado; } \\
\text { - Causa incentiva restrito à redução dos custos; }\end{array}$ \\
\hline & $\begin{array}{c}\text { Diretos } \\
\text { (conferido aos consumidores) }\end{array}$ & $\begin{array}{l}\text { - Reduz os preços pagos pelos usuários; } \\
\text { - Equivale a um aumento da capacidade de } \\
\text { pagamento; }\end{array}$ \\
\hline \multirow[t]{2}{*}{$\begin{array}{ll}\text { Fonte } & \text { de } \\
\text { financiamento }\end{array}$} & $\begin{array}{c}\text { Tarifários } \\
\text { (inseridos na estrutura tarifária) }\end{array}$ & $\begin{array}{l}\text { - Podem gerar receitas além/aquém do } \\
\text { necessário para cobrir o custo; } \\
\text { - Podem gerar descontentamento nos usuários } \\
\text { financiadores do subsídio; } \\
\text { - Causam ineficiência no uso do recurso; }\end{array}$ \\
\hline & \begin{tabular}{|c|} 
Fiscais \\
(uso de recursos orçamentários)
\end{tabular} & $\begin{array}{l}\text { - Necessária alocação criteriosa dos recursos } \\
\text { orçamentários; } \\
\text { - Formulação deve estar focada nas limitações } \\
\text { do orçamento público; }\end{array}$ \\
\hline \multirow[b]{2}{*}{ Serviço } & $\begin{array}{c}\text { Acesso } \\
\text { (conexão à rede do prestador) }\end{array}$ & $\begin{array}{l}\text { - Elimina a barreira ao acesso ao serviço } \\
\text { prestado; } \\
\text { - Importante mecanismo de universalização dos } \\
\text { serviços; }\end{array}$ \\
\hline & $\begin{array}{c}\text { Consumo } \\
\text { (utilização do serviço prestado) }\end{array}$ & $\begin{array}{l}\text { - Reduzem o valor pago pelos usuários de } \\
\text { menor poder aquisitivo; } \\
\text { - Importante mecanismo para assegurar o } \\
\text { consumo mínimo necessário de determinado } \\
\text { serviço; } \\
\text { - Deve ser devidamente calculado para não } \\
\text { gerar ineficiência no uso do recurso; }\end{array}$ \\
\hline
\end{tabular}

Fonte: SABESP (2014).

Os subsídios à oferta, em geral, são fiscais e podem tomar a forma de transferências em espécie, isenções governamentais ou de alguma entidade externa e servem para 
reduzir o custo da provisão do serviço. Os subsídios à demanda funcionam como um redutor dos preços aos usuários. O tipo mais comum, e internacionalmente consagrado para o setor de saneamento (SABESP, 2006, 2012), é o subsídio cruzado (subsídio tarifário), cuja tarifa aplicada ao grupo de consumidores não subsidiados é maior que custo da provisão do serviço para esses consumidores. A receita excedente serve para cobrir o déficit gerado pelo grupo de consumidores subsidiados, ou seja, que pagam tarifas inferiores ao custo de provisão do serviço. A Tabela 52 apresenta uma matriz de vantagens e desvantagens dos subsídios diretos e cruzados.

Tabela 52 - Subsídios à demanda: vantagens e desvantagens dos subsídios diretos e cruzados

\begin{tabular}{l|l|l}
\multicolumn{1}{c|}{ Conceito analisado } & \multicolumn{1}{|c|}{ Subsídio direto } & \multicolumn{1}{|c}{ Subsídio cruzado } \\
\hline Eficiência Econômica & Maior. & Menor. \\
\hline Eficácia Social & Maior. & Menor. \\
\hline Custos administrativos & Maiores. & Menores. \\
\hline Sustentabilidade & $\begin{array}{l}\text { Dependente de orçamento } \\
\text { público. }\end{array}$ & $\begin{array}{l}\text { Dependente de: mecanismos } \\
\text { regulatórios contratuais já pactuados, } \\
\text { evasão de grandes consumidores e } \\
\text { definição de mecanismos de equilíbrio } \\
\text { entre municípios em áreas } \\
\text { metropolitanas. }\end{array}$ \\
\end{tabular}

Fonte: Elaboração a autora (2015).

Um estudo do BID (BID, 2007), elaborado com base nas pesquisas de lares dos países da América Latina, indicou que dos 50 milhões de habitantes que não tinham acesso à água potável, $70 \%$ correspondiam aos segmentos de baixa renda; também dos 125 milhões de habitantes sem serviço de coleta e tratamento de esgoto, 84\% correspondem aos segmentos mais baixos de renda. Portanto, está intimamente relacionado o baixo nível de renda domiciliar a ausência do serviço de saneamento, ainda que não seja possível determinar o percentual de serviços não prestados devido ao custo de conexão. O estudo salienta ainda que muitas vezes a rede de saneamento está próxima ao imóvel, que não se conecta devido seus habitantes não terem condições de financiar os gastos incorridos para conexão. Esse custo, em 
geral, não é subsidiado pelo Estado, mesmo sendo muito importante para determinar o sucesso da política de expansão do SAAES.

Dado o caráter meritório do setor de saneamento pelas suas externalidades positivas entende-se que seja necessário buscar a universalização do serviço garantindo, não só o acesso à população de baixa-renda como também o consumo dos mesmos em regime de eficiência. A Tabela 53 sintetiza algumas das principais externalidades causadas pelo acesso/falta de acesso à rede de saneamento.

Tabela 53 - Externalidades inerentes ao acesso à rede de saneamento básico

\begin{tabular}{|c|c|c|}
\hline $\begin{array}{c}\text { Foco das } \\
\text { Externalidades }\end{array}$ & $\begin{array}{l}\text { Disponibilidade dos serviços de } \\
\text { saneamento: externalidades } \\
\text { positivas }\end{array}$ & $\begin{array}{l}\text { Indisponibilidade dos serviços de } \\
\text { saneamento: externalidades } \\
\text { negativas }\end{array}$ \\
\hline $\begin{array}{l}\text { Direitos } \\
\text { humanos }\end{array}$ & $\begin{array}{l}\text { 1) Aumento da dignidade humana; } \\
\text { 2) Exercício dos direitos humanos; } \\
\text { 3) Inserção na sociedade; }\end{array}$ & - \\
\hline Saúde pública & $\begin{array}{l}\text { 1) Diminuição de disseminação de } \\
\text { doenças; } \\
\text { 2) Diminuição da mortalidade infantil; } \\
\text { 3) Diminuição do tempo de } \\
\text { morbidade; }\end{array}$ & $\begin{array}{l}\text { 1) Proliferação de doenças ligadas ao } \\
\text { uso indevido da água; } \\
\text { 2) Aumento da mortalidade infantil; } \\
\text { 3) Sobrecarga dos serviços de saúde }\end{array}$ \\
\hline Meio ambiente & $\begin{array}{l}\text { 1) Uso sustentável dos recursos } \\
\text { hídricos; } \\
\text { 2) Salubridade ambiental; }\end{array}$ & $\begin{array}{l}\text { 1) Poluição da água; } \\
\text { 2) Poluição ambiental com o uso de } \\
\text { fontes alternativas de esgotamento } \\
\text { sanitário; }\end{array}$ \\
\hline $\begin{array}{l}\text { Desenvolvimento } \\
\text { econômico }\end{array}$ & $\begin{array}{l}\text { 1) Valorização da propriedade; } \\
\text { 2) Viabilização de pequenos } \\
\text { negócios; } \\
\text { 3) Promoção de inclusão social; }\end{array}$ & $\begin{array}{l}\text { 1) Perpetuação da pobreza } \\
\text { 2) Aumento do custo de tratamento } \\
\text { da água e do esgoto; }\end{array}$ \\
\hline
\end{tabular}

Fonte: BID (2007)

A título de exemplificação do exposto, devem-se considerar os prestadores da América do Sul, Argentina e Colômbia, que implantaram subsídios ao acesso e à demanda, o Chile que implantou subsídio à demanda (Tabela 54).

Tabela 54 - Subsídios da América Latina

\begin{tabular}{l|l|} 
País & Subsídios ao acesso \\
\hline Argentina & Foram criadas duas medidas distintas \\
& - criação de um encargo aplicável aos \\
usuários existentes no sistema único \\
(SU) e financiamento em longo prazo \\
dos custos de conexão de novos \\
usuários (CIS) - o governo buscou \\
garantir o acesso universal aos \\
serviços de saneamento na área \\
metropolitana de Buenos Aires. Essas
\end{tabular} \mid

Subsídios ao consumo A estrutura tarifária da Aguas y Saneamientos Argentinos S.A. (AySA) é alicerçada em subsídios cruzados. Além disso, desde 2002 são previstos descontos tarifários focados nos usuários vulneráveis. Portanto, que existem simultaneamente dois tipos de subsídios à demanda: cruzados e diretos, sendo que o segundo surgiu, 


\begin{tabular}{|c|c|c|}
\hline & $\begin{array}{l}\text { medidas permitiram que, desde } 2006 \text {, } \\
\text { aproximadamente } 1 \text { milhão de } \\
\text { habitantes foram conectados às suas } \\
\text { redes. }\end{array}$ & $\begin{array}{l}\text { basicamente, da necessidade de } \\
\text { suplantar as deficiências da concepção } \\
\text { e aplicação do primeiro. }\end{array}$ \\
\hline Colômbia & $\begin{array}{l}\text { Há mais de vinte anos o setor de } \\
\text { saneamento colombiano conta com } \\
\text { um sistema de subsídios baseado na } \\
\text { estratificação socioeconômica dos } \\
\text { usuários residenciais. O governo } \\
\text { federal destina } 5,4 \% \text { de um fundo } \\
\text { específico, denominado Sistema } \\
\text { General de Participaciones (SGP), } \\
\text { para o setor de saneamento. }\end{array}$ & $\begin{array}{l}\text { A estrutura tarifária das empresas de } \\
\text { saneamento apresentam subsídios } \\
\text { cruzados, onde usuários não } \\
\text { residenciais e usuários residenciais } \\
\text { dos estratos mais altos subsidiam } \\
\text { aqueles usuários residenciais dos } \\
\text { estratos mais baixos. Na ausência de } \\
\text { recursos desses dois mecanismos, há } \\
\text { financiamento por outros fundos } \\
\text { federais e/ou municipais para o uso } \\
\text { contínuo dos serviços. }\end{array}$ \\
\hline Chile & & $\begin{array}{l}\text { O governo chileno adota subsídios à } \\
\text { demanda do tipo direto, focado em } \\
\text { famílias consideradas vulneráveis. } \\
\text { O subsídio é implementado através de } \\
\text { um desconto para os primeiros } 15 \mathrm{~m} 3 \\
\text { de consumo, com até } 4 \text { indivíduos. O } \\
\text { déficit orçamentário causado pelo } \\
\text { desconto tarifário é coberto por um } \\
\text { fundo federal instituído por Lei. O } \\
\text { governo instituiu o Sistema de } \\
\text { Protección Social Chile Solidario, onde } \\
\text { as famílias em condições de extrema } \\
\text { pobreza recebem financiamento de } \\
100 \% \text { de sua fatura caso o consumo } \\
\text { mensal não exceda } 15 \mathrm{~m} 3 \text { - Chile } \\
\text { Solidario. }\end{array}$ \\
\hline
\end{tabular}

Fonte: SABESP (2013)

O subsídio ao acesso geralmente conta com a participação do Estado, diretamente cobrindo déficits tarifários através de fundos específicos - ou indiretamente - por tarifas e preços de serviços, que permeiam a estrutura tarifária dos usuários já existentes em prol dos subsidiados.

\subsection{Referencial Teórico}

O tema da caracterização da pobreza no setor de saneamento ganha importância, na medida em que os programas de assistência social adotaram diferentes indicadores para medição e atendimento de populações vulneráveis em diferentes serviços públicos, esferas de governo, em caráter temporal transitório ou permanente, dependendo da condição de um cidadão superar as limitações sociais e se tornar apto e qualificado a dispensar um subsídio. O regulador desse serviço publico essencial realiza revisões tarifarias a cada quatro anos, devendo definir por meio de normas os critérios de aplicabilidade da tarifa social, como faixa de renda, condição de moradia, situação quanto ao mercado de trabalho, garantindo o equilíbrio contratual durante o período de concessão. 
Segundo a OCDE (CLOUDE, 2002) a definição de pobreza tem uma dimensão essencialmente de renda, apesar de levar em consideração dois outros elementos em sua análise: a desigualdade e a vulnerabilidade do indivíduo. Segundo a OCDE as diversas abordagens da pobreza têm em comum o estabelecimento de uma linha de corte abaixo da qual os indivíduos - famílias - são considerados como tendo, ou uma renda inadequada (linha de corte de baixa renda) ou um caráter intrínseco de pobreza (linha da pobreza), definida como pobreza relativa (FORSTERS, 1994; OCDE, 2000).

A Declaração da ONU, de junho de 1998, assinada pelos chefes de todas as agências da entidade, define a pobreza como, dentre outras, violação da dignidade humana, não ter o suficiente para alimentar a família, implicando em viver em ambientes marginais, sem acesso a água potável ou saneamento básico (GORDON. 2005).

Diversos pesquisadores caracterizam a pobreza com diversas dimensões que incluem renda, educação, desenvolvimento industrial, econômico e humano para a caracterização do acesso a bens de consumo, condições precárias de subsistência, de acesso ao mercado de trabalho, e de superação das limitações ambientais em um período de tempo (PNUD, 2006 a, 2006 b; PNUD, 2012; MELO e BANDEIRA, 2005, BIRD, 2012; IBGE, 2012, VASCONCELOS, 2011). As seguintes dimensões compõem os indicadores: 1) a vulnerabilidade, a falta de acesso ao conhecimento, o acesso ao trabalho, à escassez de recursos, o desenvolvimento infantil, e condições de moradia.

A concessionária adotou a Fundação SEADE, responsável pelo Sistema Estadual de Análise de Dados, para definição de pobreza e mapeamento de usuários com o IPVS, que por meio de uma ótica multidimensional, considera, além da renda, os aspectos de moradia, educação, saúde e inserção no mercado de trabalho, (SEADE, 2012d) permite identificar e localizar espacialmente as áreas que abrigam os segmentos populacionais mais vulneráveis à pobreza. Ele possibilita uma visão mais detalhada das condições de vida do município, de forma a permitir o desenho de ações locais focalizadas, especialmente por parte do poder público municipal. $O$ IPVS consiste na resultante da combinação entre as dimensões socioeconômica e 
demográfica: 1) A dimensão socioeconômica; 2) A dimensão demográfica está relacionada ao ciclo de vida familiar (SEADE, 2012a, 2012b, 2012c, 2012d).

Entre os órgãos pesquisados o aspecto multidimensional da pobreza, ainda que nem todos possuam indicadores mensuráveis para todas as dimensões consideradas. Fundamentalmente, a conceituação de pobreza gira em torno de aspectos relativos à renda, desigualdade social e acesso a educação.

\subsection{Base de Beneficiários CADUNICO e Tarifa Social Concessionária}

No contexto de individualização para identificar e mensurar os beneficiários que fizessem jus aos programas de distribuição de renda e combate à fome, o governo federal criou um sistema de cadastramento da população vulnerável socioeconomicamente, que foi denominado CADUNICO (BRASIL, 2004) para programas de transferência direta de renda, como o Bolsa Família (BRASIL, 2004, 2012), sendo sua aplicação compulsória para políticas de cunho social de nível federal e opcional nas outras esferas do governo.

A utilização de um banco de dados único pelas três esferas de governo - União, estados e municípios foi adotado também pelos setores de infraestrutura para as políticas tarifárias. A seleção dos beneficiários em cada programa ocorre segundo critérios e procedimentos estabelecidos pelos mesmos. Podem-se citar, como utilizadores do CADUNICO, os seguintes programas: Bolsa Família; Cisternas; Tarifa Social de Energia Elétrica; Minha Casa, Minha Vida. Conta com 11 milhões de famílias inscritas. A Figura 38 demonstra o comparativo da abrangência do programa Bolsa Família em 2004 e 2011, onde fica evidenciado o aumento da cobertura desse programa assistencial. 


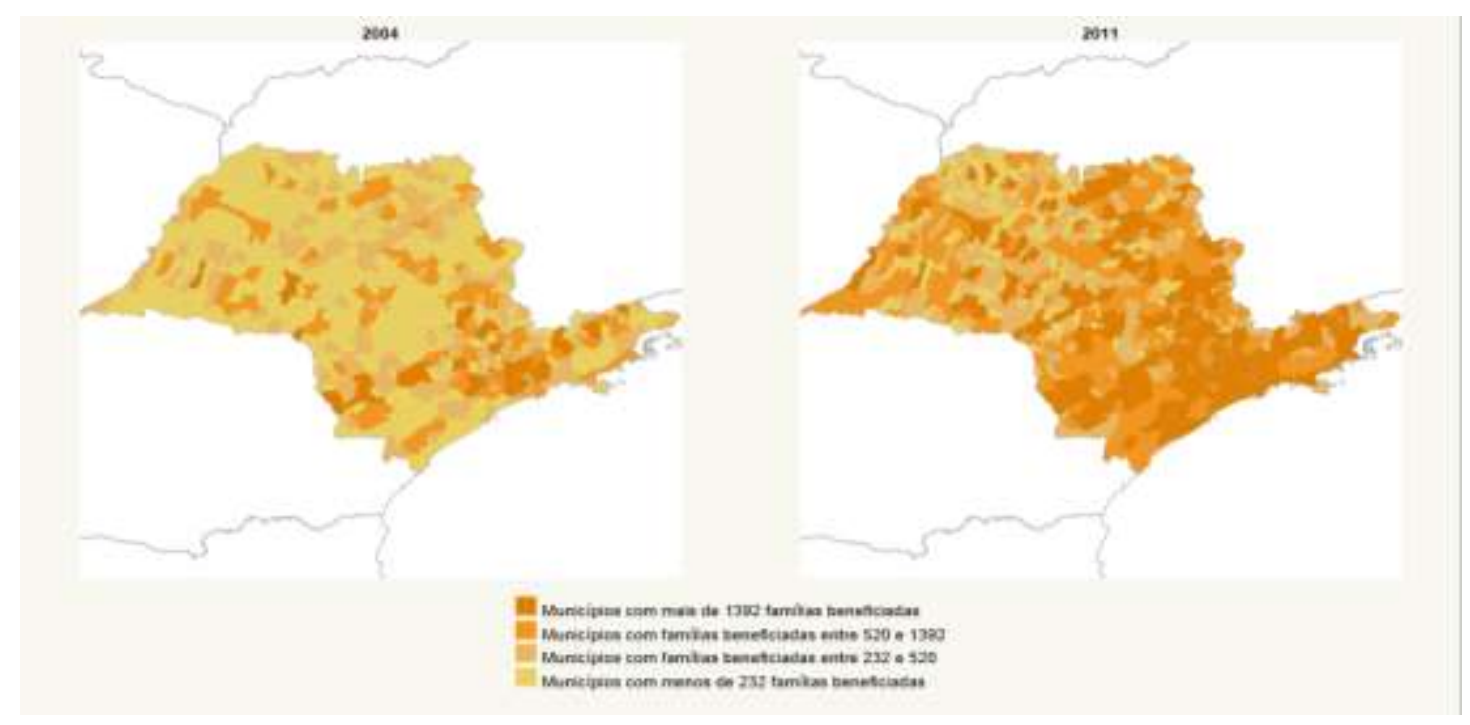

Fonte: MDS, Relatório de Informações do Bolsa Família e do Cadastro Único, 2012 Figura 26 - Abrangência do programa Bolsa Família no estado de São Paulo: Comparativo 2004, 2011 A seguir descreveremos, de forma sucinta, os critérios de elegibilidade para tarifas sociais nos setores de saneamento, energia elétrica, gás natural e telecomunicações.

\subsection{Regras de Aplicabilidade da Concessionária e Agência}

Há mais de uma década que a política tarifária dos serviços públicos de água e esgotos é competência exclusiva dos governos estaduais ou consórcios nas RMs ou municipais fora delas. Cada poder concedente orientou sua política de forma própria, o que gerou enorme diversidade de políticas tarifárias e metodologias para sua justificação nas concessionárias estaduais de saneamento no país (Tabela 55).

Tabela 55 - Critérios e requisitos para enquadramento na Tarifa Residencial Social entre as Companhias Estaduais de Saneamento Básico (CESB) do Brasil - 2012

\begin{tabular}{c|c|l} 
CESB & $\begin{array}{c}\text { Estado } \\
\text { S }\end{array}$ & \multicolumn{1}{c}{ Critérios e requisitos para enquadramento na Tarifa Residencial Social } \\
\hline SABESP & SP & $\begin{array}{l}\text { Deve ser atendido, no mínimo, um dos critérios: } \\
\text { 1) renda familiar de, até, 3 salários mínimos, sendo considerada habitação } \\
\text { subnormal com área construída de até } 60 \mathrm{~m}^{2} \text { e consumo de energia inferior a } \\
170 \mathrm{kWh} / \mathrm{mês} ; \\
\text { 2) estar desempregado, desde que o ultimo salário recebido seja de, no } \\
\text { máximo, 3 salários mínimos; } \\
\text { 3) estar enquadrado como habitação coletiva considerada social, cortiços ou } \\
\text { conjuntos habitacionais verticalizados; }\end{array}$
\end{tabular}

Elaboração: a autora (2015)

OBS: Critérios como estar adimplente, pertencer ao cadastro da empresa, dentre outros não foram assinalados, devido à preconização de que essas são práticas correntes nas distintas concessões. 
A utilização do cadastro único do governo federal - ou de programas que fazem uso do mesmo, como o Bolsa Família - em comunhão com critérios de renda familiar e características do domicílio são práticas, em geral, comuns do setor para seleção dos beneficiários das tarifas residenciais sociais. Também se verificou que existe, frequentemente, um limite máximo de consumo a ser subsidiado. No caso do saneamento, os requisitos são definidos pelas agências reguladoras, sendo de caráter voluntário as concessionárias a inserção dos vulneráveis de uma área de concessão no cadastro de beneficiários da tarifa social. Este tema não é efetivamente regulado pelas Agências conforme capítulo de avaliação, cujas entrevistas demonstram em diferentes escalas, que as populações não sabem como se cadastrar no CadUnico, Bolsa Família e tarifa social das concessionárias de uma região.

\subsubsection{Pobreza e acesso aos serviços de saneamento}

Conforme Capítulo 6.4 e 6.5, o público-alvo de aplicação dos subsídios explícitos está bem delineado, totalizando aproximadamente $18 \%$ dos domicílios presentes na área de concessão da concessionária. No entanto, faz-se necessário entender as reais necessidades desse público no que tange ao setor de saneamento, ou seja, dado o panorama atual da prestação do serviço, qual deve ser o foco do subsídio: ao acesso, ao consumo ou a ambos os serviços. Aproximadamente $19 \%$ dos domicílios de São Paulo possuem rendimentos de, no máximo, 1/2 salário mínimo por habitante, sendo este é um dos menores valores percentuais dentre os estados do Brasil, ainda que em valores absolutos represente cerca de 2,4 milhões de domicílios. De acordo com os dados do CADUNICO, das famílias cadastradas no estado de São Paulo, 62\% estão em municípios atendidos pela concessionária. Essa proporção se mantém quando consideradas famílias com renda per capita de até $1 / 2$ salário mínimo ${ }^{31}$ (Figura 27).

\footnotetext{
${ }^{31}$ É importante observar que, para essa análise inferiu-se como premissa que uma família (do Cadastro Único) equivale a um domicílio (do Censo) a título de comparação. Essa consideração pode sofrer distorções uma vez que pode haver domicílios de baixa renda com mais de uma família elou possíveis fraudes no sistema, além de que os dados refletem realidades de anos diferentes, i.e, o Censo data de 2010, o Cadastro Único, de 2011.
} 


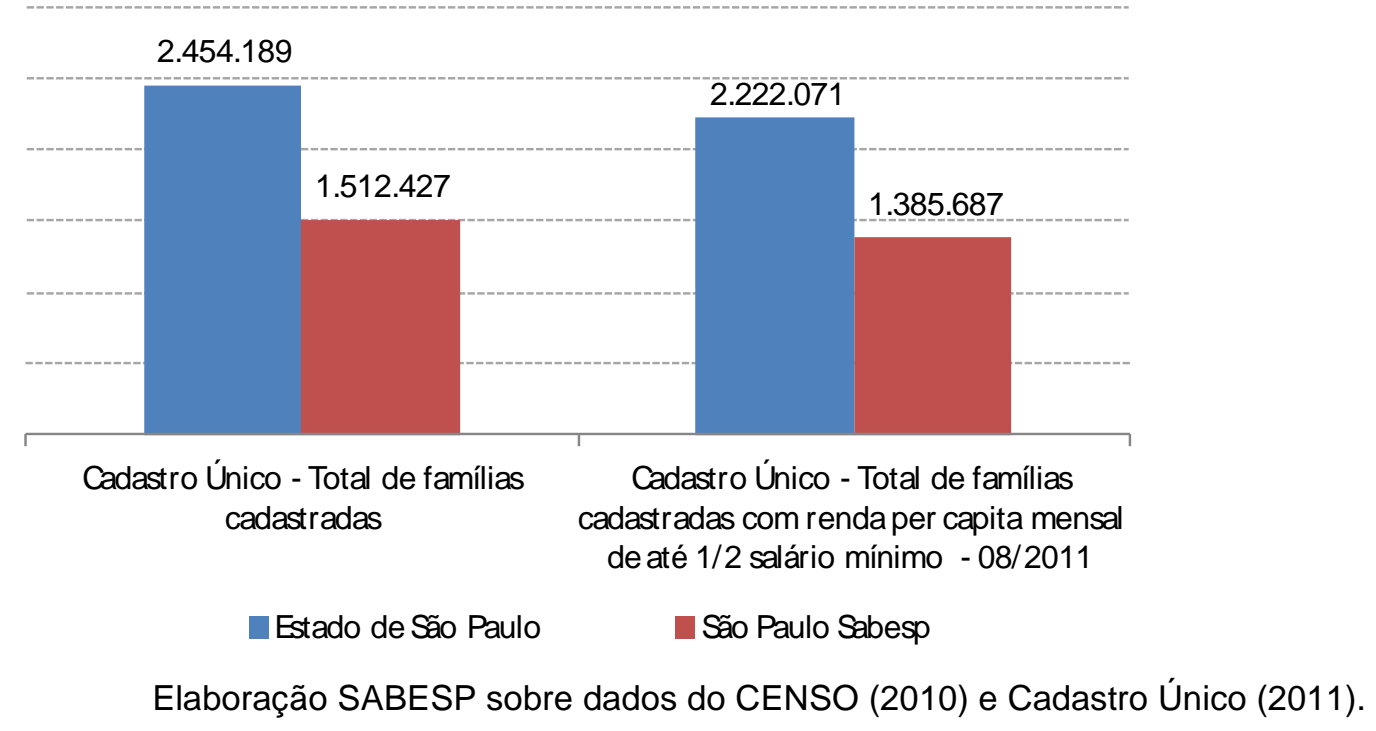

Figura 27 - Domicílios Cadastradas no CADUNICO x Renda

\subsubsection{Volume mínimo de água para subsistência humana}

Há que se considerar as recomendações das medidas e estimativas do volume de água necessário para a subsistência humana dos organismos internacionais, e das práticas e experiências nacionais e internacionais. Segundo a Organização Mundial da Saúde a dotação média que assegura um baixo risco à saúde é de 50 litros por pessoa/dia. No entanto, o nível ótimo de disponibilidade do recurso corresponde a uma dotação de 100 litros por pessoa/dia (Tabela 56).

Tabela 56 - Acesso, qualidade e quantidade de água necessários para salubridade humana

\begin{tabular}{|c|c|c|c|c|}
\hline $\begin{array}{l}\text { Nível de } \\
\text { serviço }\end{array}$ & Distância/tempo & Volume de água & $\begin{array}{c}\text { Risco para saúde e } \\
\text { higiene }\end{array}$ & $\begin{array}{l}\text { Prioridades de } \\
\text { intervenções externas }\end{array}$ \\
\hline $\begin{array}{c}\text { Sem } \\
\text { Acesso }\end{array}$ & $\begin{array}{l}\text { Mais de } 1 \mathrm{~km} \text { do } \\
\text { recurso; ou } \\
\text { Percurso de ida e } \\
\text { volta superior a } 30 \\
\text { minutos. }\end{array}$ & $\begin{array}{l}\text { Quantidade } \\
\text { média menor } \\
\text { que } 5 \text { litros por } \\
\text { pessoa/dia. }\end{array}$ & $\begin{array}{l}\text { Muito Alto. } \\
\text { Estão em risco as } \\
\text { práticas de higiene. } \\
\text { Consumo básico } \\
\text { pode ser } \\
\text { prejudicado. }\end{array}$ & $\begin{array}{l}\text { Muito alta. } \\
\text { Complementação do } \\
\text { nível básico de serviço. } \\
\text { Educação higiênica. }\end{array}$ \\
\hline $\begin{array}{l}\text { Acesso } \\
\text { básico }\end{array}$ & $\begin{array}{l}\text { Menos de } 1 \mathrm{~km} \text { do } \\
\text { recurso; ou } \\
\text { Percurso de ida e } \\
\text { volta inferior a } 30 \\
\text { minutos. }\end{array}$ & $\begin{array}{l}\text { Quantidade } \\
\text { média de cerca } \\
\text { de } 20 \text { litros por } \\
\text { pessoa/dia. }\end{array}$ & $\begin{array}{l}\text { Alto. } \\
\text { Estão em risco as } \\
\text { boas práticas de } \\
\text { higiene. }\end{array}$ & $\begin{array}{l}\text { Alto. } \\
\text { Melhoria do nível do } \\
\text { serviço. Educação para } \\
\text { higiênica. }\end{array}$ \\
\hline $\begin{array}{l}\text { Acesso } \\
\text { intermédio }\end{array}$ & $\begin{array}{l}\text { Água fornecida nas } \\
\text { proximidades da } \\
\text { habitação em pelo } \\
\text { menos um ponto. }\end{array}$ & $\begin{array}{l}\text { Quantidade } \\
\text { média de cerca } \\
\text { de } 50 \text { litros por } \\
\text { pessoa/dia. }\end{array}$ & $\begin{array}{l}\text { Baixo. } \\
\text { De modo geral, não } \\
\text { prejudica as boas } \\
\text { práticas de higiene. }\end{array}$ & $\begin{array}{l}\text { Baixa. } \\
\text { Incentivo ao acesso } \\
\text { ótimo. } \\
\text { Educação para } \\
\text { higiênica. }\end{array}$ \\
\hline
\end{tabular}




\begin{tabular}{|c|c|c|c|c|}
\hline $\begin{array}{l}\text { Nível de } \\
\text { serviço }\end{array}$ & Distância/ tempo & Volume de água & $\begin{array}{c}\text { Risco para saúde e } \\
\text { higiene }\end{array}$ & $\begin{array}{l}\text { Prioridades de } \\
\text { intervenções externas }\end{array}$ \\
\hline $\begin{array}{l}\text { Acesso } \\
\text { Ótimo }\end{array}$ & $\begin{array}{l}\text { Abastecimento } \\
\text { contínuo de água } \\
\text { através de } \\
\text { múltiplos pontos. }\end{array}$ & $\begin{array}{lll}\text { Mais de } & 100 \\
\text { litros } & & \text { por } \\
\text { pessoa/dia. } & \end{array}$ & $\begin{array}{l}\text { Muito Baixo. } \\
\text { De modo geral, não } \\
\text { prejudica as boas } \\
\text { práticas de higiene. }\end{array}$ & $\begin{array}{l}\text { Muito Baixa. } \\
\text { Incentivo ao uso } \\
\text { eficiente do recurso. }\end{array}$ \\
\hline
\end{tabular}

Fonte: ONU (2002).

Segundo recomendação da OMS, o consumo mensal de água capaz de assegurar a salubridade de todos os indivíduos de um agregado familiar varia consideravelmente segundo o número de membros do mesmo e o nível de disponibilidade do recurso. $\mathrm{A}$ Tabela 57 apresenta cenários com disponibilidades intermediária e ótima, respectivamente, para 50 e 100 litros/habitante/dia.

Tabela 57 - Consumo mensal de água capaz de assegurar a salubridade individual segundo o número de membros do agregado familiar.

\begin{tabular}{c|c|c}
$\begin{array}{c}\text { Quantidade de } \\
\text { membros do agregado } \\
\text { familiar }\end{array}$ & $\begin{array}{c}\text { Consumo mensal, em } \mathbf{m}^{\mathbf{3}} \text {, para } \\
\text { a demanda per capita de 50 } \\
\text { l/dia }\end{array}$ & $\begin{array}{c}\text { Consumo mensal, em } \mathbf{~ m}^{\mathbf{3}} \text {, para } \\
\text { a demanda per capita de 100 } \\
\text { l/dia }\end{array}$ \\
\hline 3 & 4,5 & 9 \\
\hline 4 & 6 & 12 \\
\hline 5 & 7,5 & 15 \\
\hline 6 & 9 & 18
\end{tabular}

Fonte: SABESP (2013)

A determinação dos consumos mínimos necessários para garantir a salubridade familiar depende, dentre outras questões, do número de indivíduos do domicílio, da disponibilidade do recurso, do clima, do acesso a demais serviços de infraestrutura. Para detalhar a necessidade mínima de água para o ser humano, GLEICK e IWRA (1996), do Pacific Institute for Studies in Development, Environment, and Security desenvolveram um estudo, baseado em estudos anteriores, para definir o mínimo de água que deve ser assegurado para a sobrevivência humana. O estudo busca identificar os consumos mínimos de água necessários para subsistência humana ${ }^{32}$, saneamento, banho e preparação de alimentos. Naturalmente, em função das

\footnotetext{
${ }^{32}$ No que tange a água para beber, o autor salienta que há variáveis, tal qual condição climática onde o indivíduo está inserido e suas características fisiológicas, que devem ser levadas em consideração para sua mensuração.
} 
diferenças culturais e climáticas dos países, dentre outras, esses "mínimos requeridos" variam consideravelmente, fazendo com que os autores adotem o conceito da amplitude de variação requerida do recurso. Por exemplo, eles estimaram que a necessidade básica de água para beber de um indivíduo típico de $70 \mathrm{~kg}$ seja em torno de 3 litros por dia - considerando-se um clima de temperatura mediana. Já em um clima tropical e subtropical a demanda, para esse mesmo individuo, gira em torno de 5 litros/dia/pessoa. Apesar da estimativa de uso de água variar de acordo com cultura, hábitos alimentares, condições climáticas, tecnologia de processamento de alimentos, dentre outros fatores, os autores apontam níveis mínimos requeridos para atingir a salubridade do indivíduo segundo o uso final (água para beber, higiene, saneamento e preparação de alimentos) (Tabela 58).

Tabela 58 - Recomendação dos níveis básicos de água necessários para a subsistência humana

\begin{tabular}{|c|c|c|c|}
\hline Finalidade & $\begin{array}{c}\text { Mínimo } \\
\text { Recomendado } \\
\text { (litros/pessoa/dia) }\end{array}$ & $\begin{array}{c}\text { Intervalo } \\
\text { (litros/pessoa/dia) }\end{array}$ & Mínimo para Utilidade \\
\hline Água Potável & 5 & 2 a 5 & $\begin{array}{l}\text { condições climáticas moderadas e com } \\
\text { níveis médios de atividades físicas. }\end{array}$ \\
\hline Saneamento & 20 & 0 a 75 (ou mais) & $\begin{array}{l}40 \text { l/p/d para ligações sanitárias diretas } \\
\text { em países industrializados. Demais } \mathrm{p} / \\
\text { banheiros ineficientes. }\end{array}$ \\
\hline Banho & 15 & 5 a $70^{c}$ & $\begin{array}{l}\text { Preferências sociais para os países } \\
\text { moderadamente industrializados. Regiões } \\
\text { ricas em água estes valores podem ser } \\
\text { excedidos. Os valores menores refletem o } \\
\text { uso mínimo para os países em } \\
\text { desenvolvimento. }\end{array}$ \\
\hline $\begin{array}{l}\text { Culinária } \quad \text { e } \\
\text { Cozinha }\end{array}$ & 10 & 10 a $50^{c}$ & \\
\hline $\begin{array}{l}\text { Total } \\
\text { Recomendado }\end{array}$ & 50 & - & \\
\hline
\end{tabular}

Fonte: GLEICK e IWRA (1996)

Para elaboração dessa tabela estão excluídos os montantes de água necessários para cultivar alimentos. Os autores recomendam, portanto, um consumo mínimo de subsistência de 50 litros/pessoa/dia, destinados a suprir as necessidades de água potável para beber, cozinhar, banho e saneamento básico. No entanto, cabe salientar que usos diversos da água - como lavagem de roupas, limpeza da habitação etc. - não são levados em consideração nesse estudo. 


\subsection{Benchmarking}

\subsubsection{Internacional}

Para ilustrar a prática internacional de concessão de subsídios tarifários - no que concerne principalmente ao volume total subsidiado, foram selecionadas três distintas experiências: a do Chile, a da Colômbia e a de Portugal. A Tabela 59 aponta, dentre outras informações, o tipo de subsídio concedido, o volume subsidiado e os critérios de aplicação das tarifas sociais.

Tabela 59 - Experiências internacionais analisadas para concessão de subsídios tarifários: Os casos Chileno, Colombiano e Português.

\begin{tabular}{|c|c|c|c|}
\hline Análise & Chile $^{1}$ & Colômbia ${ }^{2}$ & Portugal $^{3}$ \\
\hline Subsídio & $\begin{array}{l}\text { À demanda, do tipo } \\
\text { direto; }\end{array}$ & $\begin{array}{l}\text { À demanda, do tipo } \\
\text { cruzado, com tarifas } \\
\text { maiores para residências } \\
\text { de classe alta e usuários } \\
\text { não residenciais. }\end{array}$ & À demanda, do tipo direto; \\
\hline $\begin{array}{c}\text { Volume } \\
\text { subsidiado }\end{array}$ & Até $15 m^{3}$ mensais; & Até $20 \mathrm{~m}^{3}$ mensais; & Até $15 m^{3}$ mensais; \\
\hline Parcela da tarifa & Fixa e variável; & Fixa e variável; & Fixa e variável; \\
\hline $\begin{array}{l}\text { Critério de } \\
\text { subsídio }\end{array}$ & $\begin{array}{l}\text { O Estado financia: } \\
\text { - } 50 \% \text { da fatura dos } \\
\text { usuários de baixa renda } \\
\text { até o limite de } \\
15 \mathrm{~m}^{3} / \mathrm{mês} \text {; ou } \\
\text { - O total da fatura dos } \\
\text { usuários considerados } \\
\text { vulneráveis até o limite } \\
\text { de } 15 \mathrm{~m}^{3 /} \text { mês. }\end{array}$ & $\begin{array}{l}\text { Três primeiros estratos } \\
\text { socioeconômicos recebem } \\
\text { subsídio, quais sejam: } \\
\text { 1) Baixo-baixo; } \\
\text { 2) Baixo; } \\
\text { 3) Médio-baixo; }\end{array}$ & $\begin{array}{l}\text { Isenção das tarifas fixas e } \\
\text { variável do primeiro bloco } \\
\text { de consumo (até } 15 \mathrm{~m}^{3} \text { ). } \\
\text { Serviços de gestão de } \\
\text { resíduos: isenção da } \\
\text { respectiva tarifa fixa. }\end{array}$ \\
\hline Beneficiário & $\begin{array}{c}\text { Definido por condição } \\
\text { socioeconômica: Renda; }\end{array}$ & $\begin{array}{c}\text { Definido por condição } \\
\text { socioeconômica: Renda; }\end{array}$ & $\begin{array}{l}\text { Definido por condição } \\
\text { socioeconômica: Renda; }\end{array}$ \\
\hline
\end{tabular}

Fonte: SABESP (2013)

${ }^{1}$ Lei 18.778/89 - Superintendencia de Servicios Sanitarios (SISS);

${ }^{2}$ Resolução 04/94 da Comisión de Regulación de Agua Potable y Saneamiento Básico (CRA);

${ }^{3}$ Recomendação IRAR 01/2009 - Entidade Reguladora dos Serviços de água e Resíduos (ERSAR);

Apesar de não apresentar consenso, identifica-se que os subsídios aplicáveis às empresas analisadas são, no geral, conferidos à demanda, aplicáveis tanto à parcela fixa quanto a variável da estrutura tarifária até um volume médio de 15 a 20 $\mathrm{m}^{3} /$ mês. Os subsídios são conferidos, basicamente, levando em considerações dimensões socioeconômicas, em especial, a renda.

\subsubsection{Recomendação do volume de água a ser subsidiado}


Pode-se considerar que o volume de 100 litros/habitante/dia é o mínimo necessário para assegurar a salubridade do indivíduo. Ainda, de acordo com os dados do censo IBGE (2010), pode-se calcular que o número médio de habitantes por domicílio cuja renda mensal per capita seja de até 1/2 salários mínimos na área de concessão da SABESP é de 3,27 $\pm 0,27$ pessoas/domicílio. Adotando o volume de 100 litros/habitante/dia e considerando uma família média de baixa renda $(3,27$ habitantes/domicílio), estima-se que o consumo mensal suficiente para satisfazer a salubridade de seus indivíduos seja de aproximadamente $10 \mathrm{~m}^{3}$ mensais, conforme o calculo apresentado na equação (i):

Consumo mensal por domicilio $=30$ dias $\times 3,27$ habitantes $\times 100$ litros $=9.821$ litros $\cong 10 \mathrm{~m}^{3}$ (i)

No cenário internacional, há uma tendência de que o volume subsidiado seja entre $15 \mathrm{~m}^{3}$ e $20 \mathrm{~m}^{3} /$ domicílio/mês. No Brasil, observa-se que o volume subsidiado, no geral, encontra-se até $20 \mathrm{~m}^{3} /$ domicílio/mês, tendo uma grande concentração de empresas que empregam o limite subsidiado de $10 \mathrm{~m}^{3} /$ domicílio/mês. O estudo da concessionária de 2006 sugeriu um volume de $13 \mathrm{~m} 3 /$ domicilio/mês a ser subsidiado, já na primeira revisão tarifária foram sugerido $10 \mathrm{~m} /$ domicílio/mês, autorizando critérios adicionais como tamanho da família ou uso intensivo de água para fins médicos.

\subsubsection{Comprometimento de renda com serviços de saneamento segundo estudos e recomendações internacionais}

As tarifas dos serviços de abastecimento de água e esgotamento sanitário devem avaliar a capacidade e a disposição das famílias para pagar por esses serviços, em especial, aquelas de baixa renda ou em altas condições de vulnerabilidade social. No entanto, deve-se ter em mente que a noção de "capacidade de pagamento" é distinta do conceito de "disponibilidade de pagamento". A disponibilidade de pagamento refere-se ao valor que um consumidor está disposto a pagar por determinado produto/serviço. Ela depende das preferências do usuário e das quantidades/qualidades das alternativas tangíveis ao mesmo. Para medi-la utilizamse enfoques de preferência revelada (valoração por substitutos inferiores) e de preferência declarada (onde se obtém informações sobre o comportamento dos indivíduos frente a cenários hipotéticos). Ambos os enfoques devem ser tratados com extrema precaução, pois dependem de critérios claros e objetivos para sua 
mensuração. Já a capacidade de pagamento refere-se à capacidade financeira do agregado familiar em relação ao custo de uma cesta básica de produtos/serviços. Essa também é uma noção subjetiva e deve ser usada como critério indicativo. No setor de saneamento o enfoque da capacidade de pagamento familiar é o mais indicado. A água, apesar de ser um bem essencial, no geral, recebe inadequadas valorações. De forma semelhante o esgotamento sanitário, apesar de trazer externalidades positivas para sociedade como um todo, é subvalorizado pelos indivíduos mais carentes.

Para definir o grau de acessibilidade econômica (capacidade de pagamento) geralmente se estabelece que o gasto familiar não deva exceder uma determinada porcentagem de sua renda. Existem diferentes critérios para determinação desse percentual para o serviço de saneamento, sendo os principais indicados a seguir:

- O relatório de Programa das Nações Unidas para o Desenvolvimento Humano da PNUD (2006) menciona que, a fim de cumprir os objetivos do milênio, os governos deveriam garantir que nenhuma família gaste mais de $3 \%$ de sua renda para cobrir suas necessidades com abastecimento de água.

- Segundo a OMS (2004), o consumo de subsistência é aquele que cobre todas as necessidades alimentares e higiênicas. A OMS recomenda que sejam gastos, para o consumo de subsistência, até 3\% da renda mensal com abastecimento de água e $2 \%$ para esgotamento sanitário.

Com base no exposto verifica-se que o comprometimento de renda com serviços de saneamento - segundo estudos e recomendações internacionais, gira em torno de 3 a $5 \%$ do total da renda familiar.

\subsubsection{Pesquisa de Orçamentos Familiares (POF)}

A Pesquisa de Orçamento Familiar dispõe sobre as despesas efetuadas, os rendimentos e variação patrimonial das famílias - aspectos básicos para a análise dos orçamentos domésticos - além de alguns fatores relacionados à avaliação subjetiva das condições de vida. Entre 2008 e 2009,o gasto familiar no estado de São Paulo, por faixa de renda e tipo de serviço: energia elétrica; telefonia fixa; telefonia celular; pacote telefônico, TV e internet; gás doméstico e saneamento foram analisados para identificação da participação da conta de saneamento no orçamento familiar (Gráfico 40). 


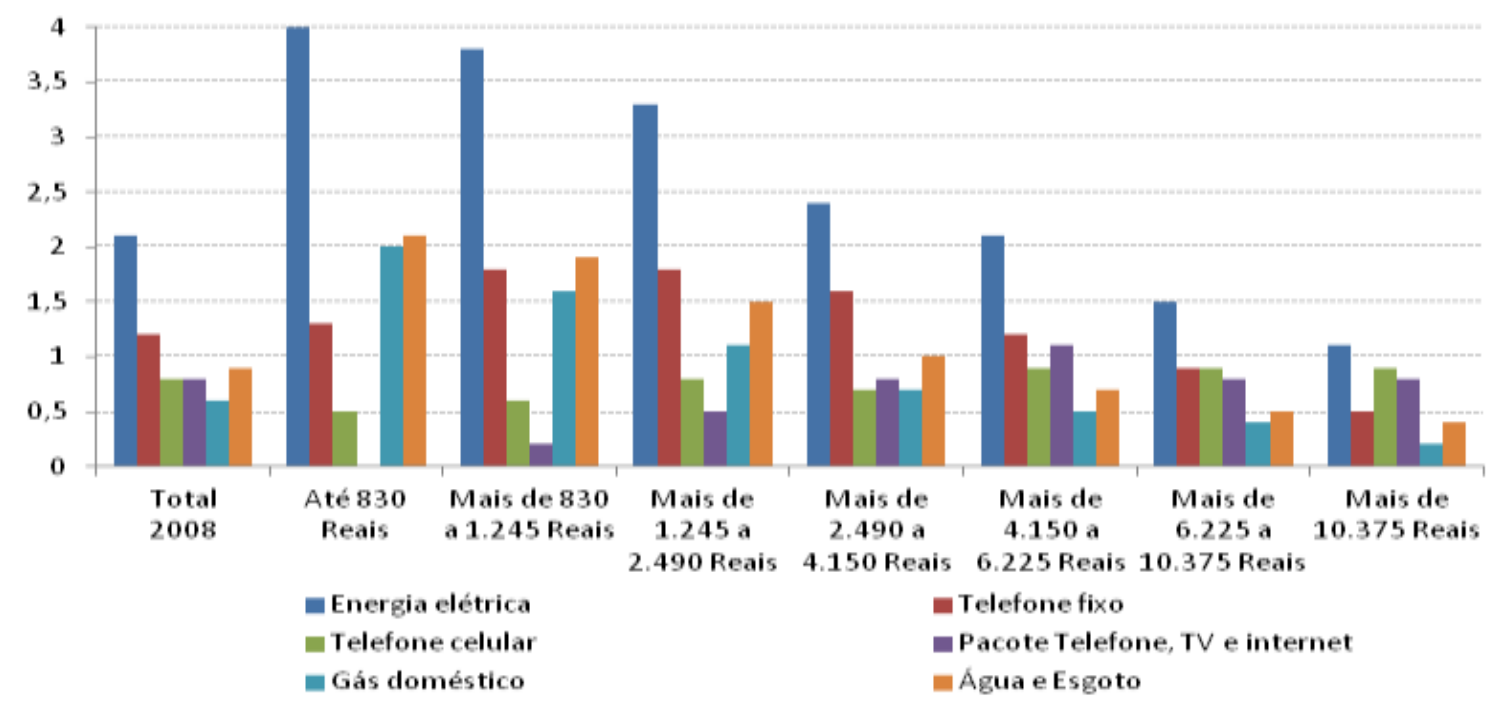

Fonte: POF, IBGE (2008/2009)

Gráfico 40 - Despesa orçamentária por classes de rendimento, segundo os tipos de despesas, no Estado de São Paulo (\%)

Nota-se que, no Estado de São Paulo, o comprometimento do orçamento familiar com os serviços de saneamento é de, no máximo, $2 \%$. O comprometimento do orçamento familiar para as despesas com serviços saneamento no estado de São Paulo e no Brasil foi levantado (Gráfico 41). No estado de São Paulo, em especial, as primeiras faixas de renda apresentam maior comprometimento de renda (aproximadamente $2 \%$ ) que no Brasil como um todo (aproximadamente 1,6\%).

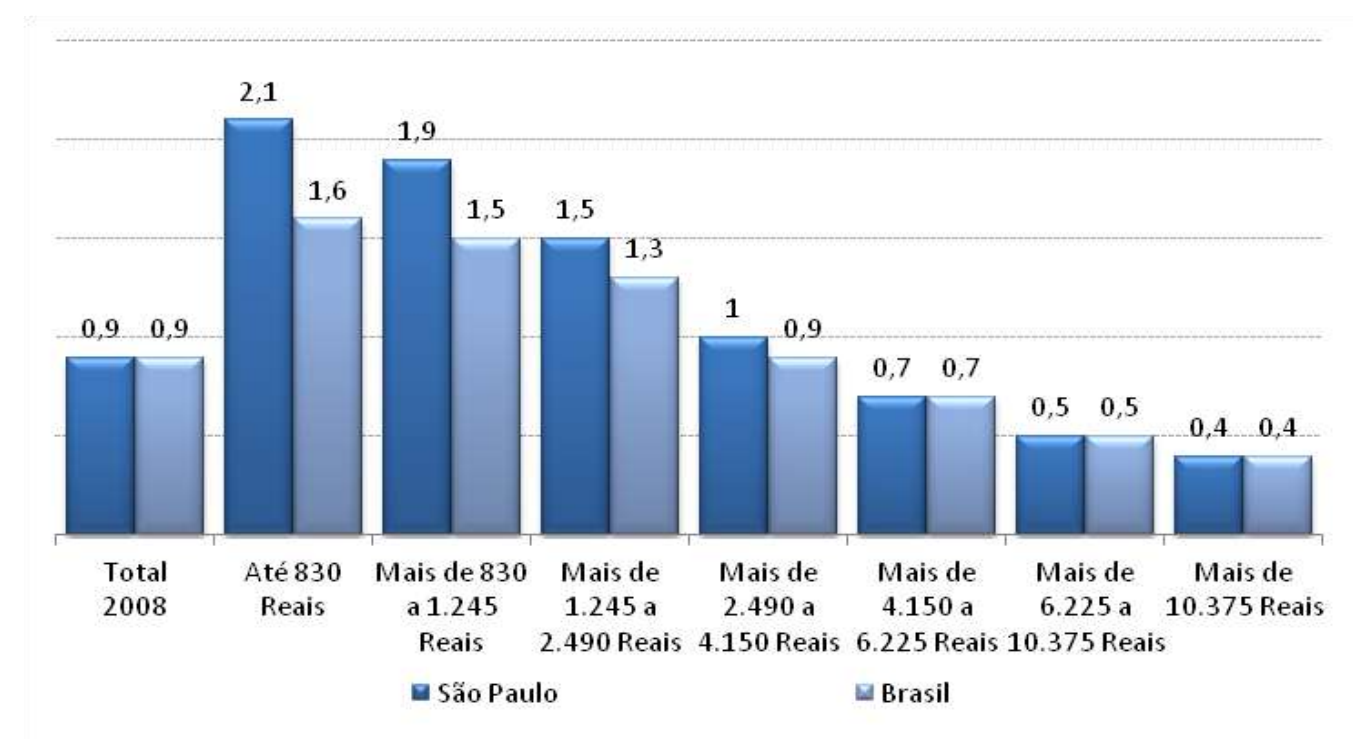

Fonte: POF, IBGE (2008/2009)

Gráfico 41 - Despesa orçamentária por classes de rendimento, em saneamento, no Estado de São Paulo e no Brasil (\%) 
Ressaltamos que a base de dados da POF abrange somente as regiões metropolitanas. Nesse caso, as análises podem ser distorcidas se consideradas para um estado como um todo. No caso do Estado de São Paulo, os dados demonstrados são referentes às regiões metropolitanas de São Paulo, Baixada Santista e Campinas. Em síntese, verifica-se que as tarifas atualmente praticadas no estado estão abaixo do patamar máximo de $5 \%$ sugerido pela OMS.

\subsection{Síntese da metodologia proposta para focalização dos subsídios}

A metodologia proposta para a focalização dos subsídios tem como etapa primordial a definição de pobreza, que envolve diversas dimensões além da renda, como vulnerabilidade social, desigualdade etc. Nesse contexto, foram levantadas as possíveis métricas e fontes para essa conceituação, e, como consequência, definição do público alvo da política de subsídios tarifários na área da concessionária.

A despeito do CADUNICO ser de baixa adesão, bem como o Bolsa Família, nos questionários aplicados nos líderes comunitários dos aglomerados urbanos (Gráfico 27 e 28), considerou-se como mais adequada a adoção desse critério, frente às dificuldades da criação e manutenção de um cadastro específico para serviços de saneamento, para a identificação dos potenciais beneficiários das tarifas sociais, desde que o pretendente possua renda familiar per capita de, até, 1/2 salário mínimo mensal. Definido o público alvo das tarifas subsidiadas pudemos quantificar os domicílios particulares permanentes que, segundo dados do censo de 2010, se enquadrariam dentro dos critérios de elegibilidade das tarifas sociais para a área de concessão da SABESP, perfazendo um total de 1,38 milhões de domicílios, aproximadamente. Por outro lado, definimos, de acordo com os preceitos da OMS e outros estudos, que o consumo de salubridade gira em torno de 100 litros/habitante/dia. Dessa maneira, através dos dados do Censo de 2010, obtivemos o número médio de habitantes por domicílio para a área de concessão, de tal sorte que estimamos um consumo subsidiado de $10 \mathrm{~m}^{3}$ mensais por economia. Segundo estudo da concessionária a partir do histograma de consumo do ano de 2011, admitindo-se que os domicílios subsidiados (1,38 milhões) encontravam-se igualmente distribuídos nas faixas de consumo das economias da categoria Residencial Social da empresa, foi considerado que o volume máximo subsidiado 
por economia não ultrapassasse $10 \mathrm{~m}^{3}$, concluiu-se que os consumos médios das residências a serem subsidiadas seriam de $11,75 \mathrm{Mm}^{3} /$ mês de água e 9,49 $\mathrm{Mm}^{3} /$ mês de esgoto.

Nesse sentido, os resultados trazidos pelos estudos da concessionária (SABESP, 2004,2005, 2012a) convergem para as mesmas conclusões.

\subsection{Conclusões e equacionamento}

Os subsídios tarifários nos setores de infraestrutura - em especial em saneamento, que é um bem meritório - envolvem uma gama de interesses e objetivos que suscitam questionamentos em diversos campos de estudo - como econômicos, políticos e sociais.

Segundo, MARQUES (2005), o valor social proveniente de uma política de subsídios do setor de saneamento é maior que o valor econômico. No entanto, o setor requer maiores estudos quanto às externalidades positivas do saneamento em comunidades vulneráveis.

Quanto aos critérios de elegibilidade da tarifa social, o CADUNICO captura requisitos além da renda, e que tem sido aperfeiçoado e atualizado com regularidade pelos municípios.

Há necessidade de se garantir o volume mínimo de subsistência subsidiado, 100 litros/habitante/dia, garantindo a educação para inibição do desperdício nas suas diversas formas.

Há que se analisar o comprometimento máximo de renda destinado aos serviços de saneamento, de tal sorte que a tarifa, mesmo sendo subsidiada, não ocasione uma privação das necessidades básicas desses indivíduos, não ultrapasse $5 \%$. Deve-se no entanto, reconhecer as diferentes rendas das comunidades em locais com maior ou menor grau de acesso ao mercado de trabalho.

Nesse sentido, o caráter múltiplo do assunto - subsídio tarifário - demanda definição de uma nova política pública para subsídios às populações vulneráveis, que o regulador, como executor da política pública, tenha instrumentos para a garantia do equilíbrio de um contrato por revisões tarifárias. Sugere-se equacionamento com a criação de um Fundo de Subsídios à Universalização Inclusiva, considerado no modelo inclusivo do saneamento. 
Em atendimento à essa lacuna, tramita no legislativo, importante projeto de lei federal para a revisão do Marco Regulatório do saneamento, PL95/2015, que propõe a utilização dos tributos recolhidos pelas concessionárias a título de PIS e PASEP para investimentos em áreas de vulnerabilidade social alinhado aos argumentos dessa pesquisa. Conforme (BRASIL, 2015):

\begin{abstract}
Altera a Lei $n^{\circ} 11.445$, de 5 de janeiro de 2007, que estabelece diretrizes nacionais para o saneamento básico, para criar o Regime Especial de Incentivos para o Desenvolvimento do Saneamento Básico - REISB, com o objetivo de estimular as pessoas jurídicas concessionárias de serviços públicos de saneamento básico a aumentarem seu volume de investimentos, por meio da concessão de créditos relativos à Contribuição para o Financiamento da Seguridade Social (COFINS) e à Contribuição para o Programa de Integração Social e de Formação do Patrimônio do Servidor Público (PIS/PASEP).

.... Para investimentos com recursos próprios ou onerosos realizados pela concessionária em:
\end{abstract}

I - intervenções em áreas ocupadas por população de baixa renda, visando à regularização urbanística e fundiária necessária para a implantação de sistemas de água e esgoto;

II - limpeza, despoluição e canalização de córregos;

III - implantação para preservação de áreas de mananciais e unidades de conservação necessárias à proteção das condições naturais e de produção de água;

IV - investimentos em esgotamento sanitário em áreas com predomínio de população de baixa renda;

$V$ - investimentos em projetos de redução nos níveis de perdas, reais e aparentes, nos sistemas de abastecimento de água.

O projeto cita as externalidades positivas geradas pelo acesso aos serviços de água e esgoto, e as particularidades econômicas do setor sanitário (monopólio natural e altos custos irrecuperáveis, entre outros) justificam a existência de um subsidio e apresentam o estudo do Instituto Trata Brasil (Trata Brasil, 2010). O equacionamento dos custos dos serviços, não contemplado. Outro ponto que deve ser considerado, é de que o crédito aproveitado, o Regulador deverá abater o valor da Base de Remuneração Regulatória dos investimentos previstos nos projetos aprovados, oque reverterá em uma menor tarifa social para o cidadão de baixa renda do município, setorizando os ganhos, para impedir a transferência de benefícios financeiros às áreas de menor vulnerabilidade. 


\section{EQUACIONAMENTO JURÍDICO POR MEDIAÇÃO}

\subsection{Introdução}

No Brasil, há 11 milhões de cidadãos (IBGE, 2010) vivendo em assentamentos precários, habitando em áreas irregulares ou com limitações ambientais, que acessam de forma clandestina serviços públicos de saneamento, energia, gás e lixo até que sejam beneficiados por programas de urbanização para baixa renda. Por recursos metodológicos multivariados o presente artigo busca aprofundar o diagnóstico da problemática social para promoção da Universalização Inclusiva do Saneamento. $O$ acesso aos serviços públicos deve ser enfrentado pelo Estado de modo a compatibilizar as restrições legais relativas ao uso e ocupação do solo urbano com a preservação do meio ambiente e ao direito de propriedade e atenção ao princípio constitucional da dignidade humana. Embora autoridades administrativas e judiciais atuem, pontualmente, no sentido de mitigar os efeitos adversos provocados pela falta desses serviços é imprescindível o reconhecimento da realidade fática e o estabelecimento de uma política pública específica, ainda que em regime transitório, para propiciar, de imediato, à consecução de direitos humanos fundamentais aos cidadãos assentados em áreas irregulares.

Os Princípios, Direitos Constitucionais e as diretrizes do Marco Regulatório do Setor de Saneamento Básico - Lei federal n 11.445, de 05 de janeiro de 2007 direcionam-se enfaticamente ao atendimento das demandas de populações em situação de vulnerabilidade socioambiental (BRASIL, 1988, 2007).

Entretanto, é evidente que a existência do contexto jurídico institucional protetivo não assegurou e assegura aos cidadãos pauperizados, domiciliados em áreas irregulares com total descaso do poder público, o acesso imediato, ainda que transitório, aos serviços de abastecimento de água e esgotamento sanitário. Portanto, é fundamental obter soluções juridicamente seguras, compatíveis e articuladas com as demais políticas públicas, de modo a sustentar os atos de gestão voltados à promoção da universalização inclusiva .

Identifica-se o direito de acesso aos serviços públicos de saneamento básico 
segundo os pilares do Estado Democrático de Direito ${ }^{33}$ inseridos na CF/88, dos quais se destacam: a cidadania e dignidade da pessoa humana (art. $1^{\circ}$, incisos II e III); a construção de uma sociedade justa e solidária; a erradicação da marginalização, redução da desigualdade social (art 3ㅜ, inciso I e III); o princípio da igualdade (art. $5^{\circ}$ ); os direitos sociais à saúde (art 6ㅇ); os princípios gerais da atividade econômica para uma existência digna (art. 170), o escopo do direito público e privado, o que requer o trato do saneamento como direito social nos Artigos 100, 198.3, 205, 204, 225 e 84 (BRASIL, 1988, TRATABRASIL, 2010).

Nesse contexto, investigou-se a eventual prevalência do direito ao meio ambiente equilibrado e direito à propriedade, relativamente, ao direito de acesso da presente geração de excluídos sociais aos serviços públicos de saneamento básico, de modo a conferir a esses cidadãos subsistência, com o mínimo de dignidade humana.

Sob o enfoque da engenharia sanitária, artigos da Constituição foram objeto de diversos autores sobre direitos instituídos (CASTRO e HELLER, 2009; TEMÓTEO, CRIOLLO, et al., 2010; HELLER, NASCIMENTO e PAIVA, 2002; NASCIMENTO e PAIVA, 2005; GALVÃO, 2006), dos entes federados e da sociedade civil num contrato de concessão, dos cidadãos no direito a saúde e ao meio ambiente ecologicamente equilibrado para presentes e futuras gerações, das diretivas do marco regulatório: universalidade, equidade, integralidade, participação e controle social, e empoderamento (BRASIL, 2007).

A questão converge para reflexões sobre justiça, erradicação da pobreza, marginalização, redução das desigualdades sociais como objetivos nacionais.

Para Sarlet (2007, 2008 e 2010) a proteção dos direitos sociais é constitutiva das garantias do progresso adquirido pela sociedade contra medidas restritivas de direitos humanos.

A relevância dos direitos humanos fundamentais e da função social da propriedade é afetada por restrições do direito ambiental e de propriedade privada, que funcionam como fundamentos impeditivos à provisão de serviços públicos de abastecimento de 
água e esgotamento sanitário às populações vulneráveis, moradores de favelas e áreas irregulares, assentados sob a omissão do poder público.

Nesse sentido, Canotilho (2006) afirma que o legislador não pode extinguir o direito social violando o núcleo constitucional protegido, considerando um retrocesso social.

O planejamento, a gestão e a execução de políticas públicas consistentes, articuladas e compatíveis entre si, construídas mediante amplo debate social assumem papel relevante no enfrentamento adequado da problemática proposta, com vista ao desenvolvimento de cenários, que efetivem a dignidade humana, em especial, para os cidadãos em situação vulnerável. A evolução de toda a coletividade, e não apenas de uma parcela desta, deve ser a finalidade principal do estabelecimento do Estado e do desenvolvimento de suas atividades, demandando uma governança inclusiva dos serviços de saneamento.

As restrições, que permeiam a universalização inclusiva, decorrentes dos princípios e normas ambientais, de uso e ocupação do solo urbano e de proteção à propriedade privada emolduram os principais desafios à imediata universalização dos serviços em áreas irregulares.

A universalização nas áreas irregulares se dá exclusivamente por arranjos institucionais condicionados às articulações de diversos atores sociais, a exemplo dos órgãos de controle e fiscalização ambientais, consumeristas, Defensoria Pública, Ministério Público (Barbosa, 2010).

Nesse sentido, o empreendedorismo e a articulação voluntária de agentes comunitários, pontualmente, superam barreiras à universalização dos serviços nessas áreas de exclusão social, todavia, sem conseguir a escala necessária às dimensões urbanas das metrópoles.

A reflexão acerca da vulnerabilidade social converge inexoravelmente para os princípios fundamentais consolidados na Declaração Universal dos Direitos Humanos, que enfatizam a dignidade humana e a igualdade de direitos como fundamentos de justiça e liberdade (ONU, 1948), sendo que a atenção ao regime democrático e aos direitos fundamentais é indispensável ao estabelecimento da democracia. 


\subsection{Resultados}

O diagnóstico obtido nas oficinas de especialistas do setor, acadêmicos e sociedade civil apresenta a análise dos conceitos normas e práticas de gestão para identificar causas, evidências, controvérsias e principais implicações éticas, conforme Quadro 9. Como impeditivo à universalização identificou-se: ilegalidade do cidadão, quando morador de áreas irregulares, ou enquanto não urbanizadas; morosidade do processo de regularização e urbanização, superando 30 anos, e justificado por questões ambientais; desatualização de dados dos assentamentos para planejamento; e ausência de instrumentos jurídicos institucionalizados para promover a universalização. O diagnóstico identificou como ocorre a exclusão de áreas favelizadas e irregulares da universalização. Se por um lado o judiciário se apoia no direito de outro cidadão sobre sua propriedade, ou da preservação de Áreas de Proteção Permanente. No aspecto de gestão, a racionalidade que apoia a decisão de apenas domicílios regulares serem conectados às redes públicas está nas ações judiciais contra os prestadores e gestores que promoveram a ligação das redes de água a domicílios de assentamento irregular em áreas urbanas por todo o Brasil.

\subsection{Discussão}

Frente ao crescimento desordenado nas áreas urbanas, com populações de baixa renda habitando em aglomerados subnormais em áreas invadidas, identificou-se que, por um lado, há ausência de serviços básicos ou baixa qualidade em um modelo excludente jurídico, de gestão e governança. Por outro lado, há um comportamento da população, que entende que tem direito aos serviços e os acessam de forma clandestina.

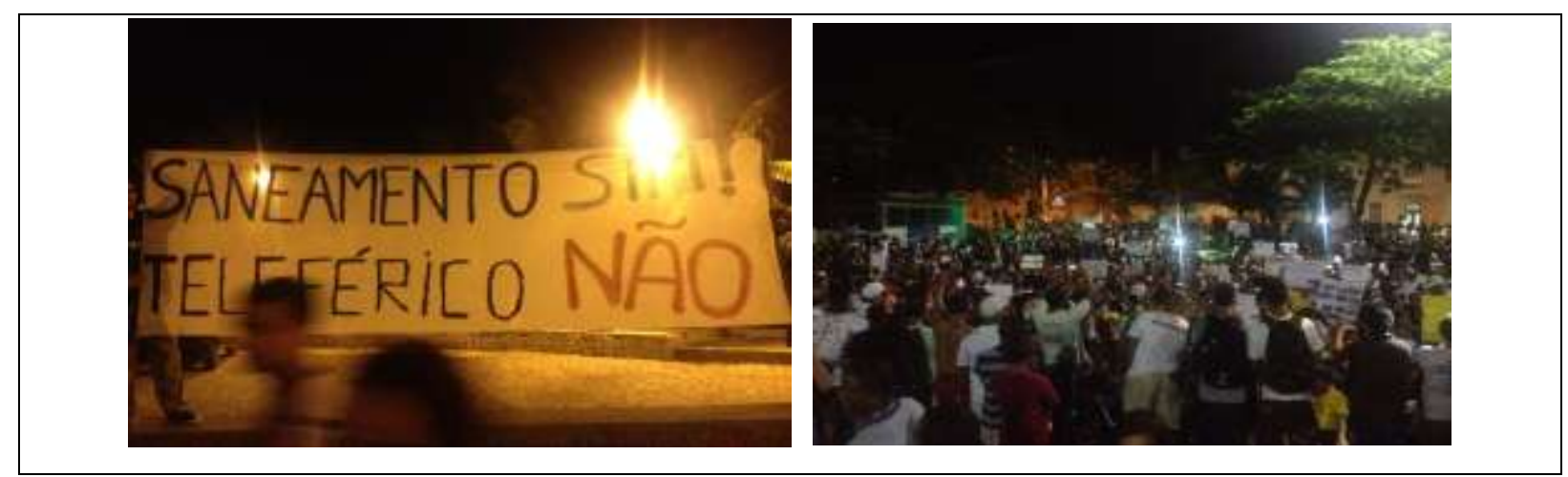

Autor das Fotos: Luís Bulcão/G1

Figura 28: Manifestações da Comunidade da Rocinha e Vidigal 
Em 2014, semelhantemente aos movimentos sociais do sec. XX, chamados batepanelas comandadas pela Pastoral da Terra nos anos 70 , manifestações públicas, conforme Fotos 1 em Movimentos sociais se multiplicaram como nos exemplo por: habitação e saneamento básico pelas comunidades Vidigal e Rocinha no estado do Rio de Janeiro no período pré-copa; por regularidade de abastecimento da água nas habitações pelo Movimento Sem-Teto em São Paulo no período pré-eleições; por abastecimento da cidade de Itu no estado de São Paulo; regularidade do abastecimento em Vitória do Espírito Santo; por baixa pressão na rede em determinados horários e vazamentos pela população de Belo Horizonte no estado de Minas Gerais (G1, 2013; SABESP, 2014; G1, 2014).

Os danos sobre a saúde e o meio ambiente são crescentes (TRATABRASIL, 2010), e comprometem os indicadores de desenvolvimento (GUIMARÃES et al., 2014).

Em resposta ao diagnóstico das oficinas, pesquisou-se junto a juristas as principais fundamentações para autorização e atendimento das populações em áreas vulneráveis, passando pela análise das políticas inclusivas: A Lei Federal 11.445, art. $3^{\circ}$, inciso III que define a universalização para todos os domicílios ocupados; Domicílio como lugar onde a pessoa natural estabelece-se com ânimo definitivo (Código Civil, art. 70). (BRASIL, 2007); A Lei Federal n 11.977/09, art. 47, inciso VII, que prevê a regularização fundiária em ocupações há mais de cinco anos dos imóveis situados em zonas especiais de Interesse Social - ZEIS ou áreas da União, dos Estados, do Distrito Federal e dos municípios declaradas de interesse para implantação de projetos de regularização fundiária de interesse social; e o Estatuto da Metrópole, Lei Federal no 13.089/15, que estabelece diretrizes para planejamento, gestão e execução das funções públicas sobre o plano de desenvolvimento urbano integrado e outros instrumentos e critérios para ações de governança interfederativa $^{34}$. (BRASIL, 2007, 2013, 2015). Assim é possível existe a possibilidade das áreas irregulares serem atendidas, após cinco anos, desde que tenha havido o estabelecimento de sua população no local com ânimo definitivo. No entanto, para Guimaraes et. al. (2015) as reinvindicações culminam nas

\footnotetext{
${ }^{34}$ Deve atender a Governança Inclusiva, que é o processo para garantir o cumprimento das funções do poder concedente, concessionária, regulador e entidades governamentais por meio de instrumentos institucionais com atribuições e competências claras e detalhadas de todos os atores para a universalização inclusiva dos serviços de saneamento, que promovam a participação social e permitam o controle social (GUIMARÃES et al., 2015).
} 
restrições socioambientais que uma prestação de serviços sofre, combinadas a maturidade cidadã de uma comunidade. $\mathrm{Na}$ contemporaneidade das atuais manifestações identificou-se diferentes estágios de gestão da reinvindicação. 0 conceito de universalização apresenta uma ontologia, conforme Quadro 7, com uma evolução temporal, sendo que os indicadores de saneamento são afetados pela lacuna ocasionada por disparidades jurídicas, no que diz respeito à situação da legalidade dos cidadãos em áreas de vulnerabilidade social. Os domicílios dessas áreas não são considerados nas metas setoriais e nos indicadores de universalização no Brasil até que as áreas sejam regularizadas, demonstrando fragilidade de um dos principais mecanismos de gestão e regulação, os indicadores do Sistema Nacional de Saneamento SNIS (Juliano et. Al 2014), e Planos de Saneamento, sendo necessário para essa medição à adoção do IUI ${ }^{35}$.

No Projeto Paritá, criado pela concessionária para contribuir a universalização de áreas irregulares da Zona Leste da RMSP, desenvolveu-se metodologia para elaboração de projeto e análise de impactos, para quando acionados, o atendimento a população tenha maior celeridade. Identificou-se a regularização, entre 2008 a 2011, de 37 áreas em aglomerados subnormais ${ }^{36}$, promovendo o fortalecimento do tecido socioambiental por alianças estratégicas (PARITÁ SABESP, 2011).

Considerando a controvérsia do contexto, os prestadores, fundamentados juridicamente na Constituição Federal, operam formalmente nas áreas legais e fazem concessões voluntárias de água nas áreas irregulares, para assegurar a vida e saúde dos cidadãos e evitar a as consequências da omissão no seu atendimento. Por essa razão, muitas vezes são acionados por prover água aos cidadãos em áreas de invasão (situação das diversas favelas do país, segundo o levantamento censitário de 2010, três milhões de domicílios ocupados por mais de onze milhões de pessoas).

Faz-se necessário este enfoque para o entendimento da racionalidade pretendida, que muitas vezes apoia as ações judiciais que intervém para o atendimento dessas populações. Os vácuos, defeitos, conflitos legislativos, as omissões do Poder

\footnotetext{
35 Objetiva medir os domicílios em aglomerados subnormais conectados à rede pela concessionária, em parceria com poder concedente e demais segmentos da sociedade, para gradativamente atender toda a população da Cidade Informal, por meio de ações integradas, para que a população residente em áreas de exclusão venha ter acesso ao saneamento básico GUIMARÃES et al. 2015).

${ }^{36}$ O aglomerado subnormal representa o conjunto constituído por 51 ou mais unidades habitacionais caracterizadas por ausência de título de propriedade e pelo menos uma das características abaixo: - irregularidade das vias de circulação e do tamanho e forma dos lotes e/ou carência de serviços públicos essenciais (como coleta de lixo, rede de esgoto, rede de água, energia elétrica e iluminação pública)" (IBGE, 2011a)
} 
Público, os maus feitos administrativos, as incompatibilidades e inconsistências insolúveis entre políticas públicas relevantes não justificam, sob hipótese alguma, o desprezo e o afastamento dos princípios universais que norteiam a Constituição da República Federativa do Brasil de 1988 (Brasil, 1988).

Evidencia-se a necessidade de hierarquização principiológica e de relativização das normas vigentes, com o objetivo de propiciar o atendimento do cidadão visando à efetivação da dignidade humana nas suas exigências mais elementares.

Segundo Piovesan (2000), a dignidade da pessoa humana, está apoiada na segurança jurídica, princípio Constitucional, condicionado a interpretação das suas normas sobre Direitos e Garantias Fundamentais do sistema jurídico brasileiro, com exigências de justiça e valores éticos, dando sentido à segurança jurídica e proteção de direitos sociais.

Segundo Canotilho (1993, 2001, 2006), ao Estado compete dar maior alcance aos direitos sociais, diminuir as desigualdades, não permitir retrocessos sociais para garantia de direitos fundamentais, e acerca da dignidade humana afirma a necessidade da preservação, em favor dos indivíduos, da integridade e da intangibilidade do mínimo existencial, que não fica ao "arbítrio estatal".

Barroso (2010) sustenta que o mínimo existencial constitui o núcleo essencial dos direitos fundamentais, cujo conteúdo corresponde às pré-condições para o exercício dos direitos individuais, conforme CF no Art.125 à saúde essencial, à assistência aos desamparados no art. 126, e ao acesso à justiça no art. 127, sendo que dispensa desenvolvimento prévio pelo legislador. Por integrar o núcleo essencial dos direitos fundamentais, o mínimo existencial tem eficácia direta e imediata, operando tal qual uma regra.

Complementarmente, os ditames da justiça social, com observância da função social da propriedade (BRASIL, 1988, art. 170, III) e o direito ao meio ambiente ecologicamente equilibrado, bem de uso comum do povo e essencial à sadia qualidade de vida, impõe ao Poder Público e à coletividade o dever de defendê-lo e preservá-lo também para presentes gerações (BRASIL, 1988, art. 225), tendo a política de desenvolvimento urbano por objetivo ordenar as funções sociais da cidade e garantir o bem-estar de seus habitantes (BRASIL, 1988, art. 182).

Deve-se considerar que a oferta de bem-estar ao cidadão inclui o direito de acesso 
aos serviços de saneamento básico, como condições mínimas de sobrevivência cujas atribuições devem ser exercidas de forma concorrente entre os entes federados e abrange o saneamento básico, (BRASIL, 1988, art. XII). Ainda, a Lei de Concessões n. 7.217/2010 traz a natureza da essencialidade dos serviços públicos de saneamento, bem como a Lei Federal $n^{\circ} 7.783 / 89$, que regulamenta greves, considera saneamento básico como serviços ininterruptos ou atividades essenciais à população.

O arcabouço jurídico do saneamento básico, acima citado determina a necessidade de diagnóstico e soluções para as populações vulneráveis e atendimento imediato e transitório para a presente geração vulnerável.

Segundo Soares (2008), a mediação de conflitos é um processo no qual um terceiro promove a comunicação entre os envolvidos, por meio do diálogo, cooperação, igualdade de condições, cidadania para construir relações e prevenir futuros conflitos, sendo adequada para conflitos em torno de recursos hídricos.

Pode-se considerar três principais escolas de mediação: a de negociação de Harvard, cujo principal impedimento é o pré-requisito de equilíbrio de poder dos mediados e equidistância do mediador; a transformativa, cuja teoria da transformação dos mediados pode trazer saídas do conflito, e a da circular narrativa, na qual o caos e a re-estruturação da relação, a qual promove mudança da conduta futura (Fisher at. al.,1981,1994; Suares, 2005; Bush \& Folger,1996, Kriktek, 1998; Moore, 1998).

Ainda, como efetivo avanço para a atuação em conflitos por mediação a Lei Federal 13.140/2015 regulamenta a mediação judicial e extra-judicial, aplicável a entidades públicas e privadas, para que as partes envolvidas encontrem soluções consensuais às controvérsias que solucionará as questões mapeadas (Brasil, 2015).

No entanto, para Soares ${ }^{37}$, a Lei trouxe entraves para a mediação ambiental e demanda parecer do Ministério Publico e homologação de um juiz previamente a arbitragem. Também, exige a análise dos limites da disputa diante dos limites

\footnotetext{
${ }^{37}$ Samira lasbeck de Oliviera Soares em entrevista aos autores em 12/11/2015
} 
possíveis e aplicáveis (Soares, 2008). Nesse sentido, a governança deve ser revisitada, num modelo mais inclusivo conforme, Guimarães et. al. 2015.

O arcabouço jurídico citado apresenta-se eficaz à autorização para a promoção da universalização dos serviços de saneamento básico em áreas de pobreza, em caráter transitório, do ponto de vista da dignidade humana.

A permanência de populações excluídas do acesso universal e igualitário aos serviços públicos e ações de saneamento básico revela a violação ao princípio da dignidade humana e isonomia, além de infração aos direitos fundamentais à saúde e qualidade de vida no presente, e em detrimento, inclusive, das futuras gerações.

No entanto, considerando a realidade fática, as populações vulneráveis sem acesso aos serviços de saneamento básico demandam tratamento de todos os gargalos jurídicos o que perpassa pela compatibilização e relativização das normas ambientais, de propriedade, pois o princípio da dignidade humana apresenta grande desafio e encontra-se no rol de denominados casos difíceis.

O acesso do cidadão aos serviços públicos essenciais nessas áreas, via de regra, ocorre de maneira clandestina e precária, não obstante os assentamentos humanos sejam de conhecimento notório e, porque não dizer, consentido pelo poder público, haja vista a sua omissão permanente em detectar e solucionar, tais deficiências por meio de políticas públicas e planos e ações governamentais.

Para atender a universalização em áreas irregulares, há necessidade de intervenções e articulações junto ao poder público propiciando arranjos jurídicos ainda que transitórios que permitam disponibilizar o acesso aos serviços até a regularização adequada dessas áreas ou outra solução que prestigie a dignidade humana.

A universalização dos serviços tem por característica a satisfação de necessidades básicas e vitais dos usuários, e demanda atenção estratégica às populações de baixa renda em direitos fundamentais, sendo necessária uma nova governança, mais inclusiva e menos alienada da realidade, que supere as justificativas de exclusões de rede, tendo em vista que essa insegurança e instabilidade, o sistema social moderno leva às situações de risco. Sendo o risco intrínseco a vida social moderna, decorrente do próprio desenvolvimento da sociedade, de maneira que o sistema jurídico será essencial ao desenvolvimento da mesma. 
Resta evidente que a noção de dignidade humana e a iniciativa arriscada de agentes comunitários, muitos deles atuando em substituição ao poder público em prol da vida, tem sido o alavancador do acesso ainda que precário e irregular em áreas de exclusão social, mitigando os efeitos devastadores da falta de água potável e de esgotamento sanitário sobre a saúde coletiva.

A materialização do equacionamento jurídico proposto está na Lei Estadual $\mathrm{N}$. 980/2015 do Poder Executivo do Estado de São Paulo, aprovado pela Assembleia Legislativa de São Paulo, em setembro de 2015 (SÃO PAULO, 2015) e sancionado em outubro de 2015, que dispõe sobre a área de proteção e recuperação dos Mananciais do Alto Tietê e Cabeceiras, suas áreas de intervenção respectivas normas ambientais e urbanísticas de interesse regional para a proteção e recuperação dos mananciais. Apresenta normas para, dentre outras ações, universalizar as Zonas Especiais de Interesse social - ZEIS da Bacia. Destaca-se o Art. 4 Paragrafo 1, que define área de intervenção visando à aplicação de instrumentos de planejamento e gestão para cumprimento de metas qualidade e quantidade de água. Também a ocupação que afeta os recursos hídricos, Assentamento Habitacional Precário de Interesse Social ocupado por população de baixa renda, caracterizado por ausência o precariedade de infraestrutura e irregularidade urbanística. Define Habitação de Interesse Social HIS, como aquela que depende de política pública para satisfazer sua necessidade habitacional. Determina a criação de um Sistema de Saneamento Ambiental: conjunto de infraestrutura para abastecimento de água e esgotamento sanitário. Que será atendido pelo Plano de Negócio Inclusivo (PNI).

Destaca-se ainda o Capítulo V (art. 9, 15, 31 e 48) definições para interevenções técnicas nas áreas de especial interesse para a preservação ambiental são admitidas instalações de sistemas de saneamento com intervenções de interesse social em áreas pré-existentes para melhoria das condições de habitabilidade, para a implantação e melhoria progressiva do sistema público de saneamento ambiental, ligações para sistemas de esgotamento sanitário, e criação de um programa de monitoramento da qualidade ambiental de responsabilidade do prestador.

Nos artigos 50, 51, 52 e 55 apresentam responsabilidades do poder concedente 0 licenciamento de infraestrutura urbana e de saneamento ambiental, quando houver impossibilidade de averbação por pendências de ocupação, uso-capião. 
O artigo 80 indica como origem dos aportes financeiros para cumprimento da lei no Fundo Estadual de Recursos Hídricos - FEHIDRO, prestadoras, Estado, Município e União, compensações e outros.

Finalmente, no Artigo 81 - constitui infração toda ação ou omissão que importe na inobservância dos preceitos da Lei 980/2015, com infrações, multas e outras sanções. No Capítulo de disposições transitórias, as funções do órgão técnico do Sistema de Gestão serão executadas pela Secretaria de Saneamento e Recursos Hídricos.

Nesse sentido, efetiva-se a política pública por um Programa Metropolitano de Universalização Inclusiva para o Saneamento Básico, adotando os instrumentos de governança metropolitana - governança inclusiva e câmaras de mediação ou mutirões de atuação junto ao poder público e Ministério Público.

\subsection{Conclusão}

A defesa da universalização do saneamento como direito social requer a inclusão do tema na discussão da dignidade humana, do mínimo de subsistência e do direito humano fundamental. Ainda, envolve a necessidade de consideração do ordenamento jurídico do direito de propriedade e direito ambiental e o que acarreta para as atuais gerações em situação de vulnerabilidade social, as decisões judiciais em defesa das futuras gerações, excluindo as atuais do acesso a serviços públicos de saneamento. Destacando, que não se defende neste artigo a regularização da invasão.

No entanto, é notório que as pessoas em áreas irregulares são populações invisíveis, não vocalizadas, cujos direitos fundamentais de acesso aos serviços de saneamento devem ser considerados na forma da constituição cidadã. Subsidiariedade do direito fundamental antecede a questão da regularidade.

Nesse sentido, cumpre que o Estado e o poder judiciário promovam ações de forma mais explicita para que esses cidadãos tenham a acesso a serviços públicos. Também, deverá cumprir suas obrigações de cidadão, porém seus direitos fundamentais não são sequestrados pela sua condição fática.

Para atender essa questão a concessionária na Baixada Santista elaborou Plano de Negócio Inclusivo - PNI para obter recursos junto ao FEHIDRO e promover a 
participação e controle social, adotou indicadores de universalização inclusiva e governança, instituiu mutirões junto ao judiciário e Ministério Público.

Nesse sentido, os mutirões de universalização inclusiva do saneamento poderão promover e autorizar a atuação das concessionárias nessas áreas, por meio dos órgãos técnicos da Secretaria de Recursos Hídricos definidos nas disposições transitórias da Lei 980/2015, em parceria com Secretaria da Justiça do Estado de São Paulo por meio dos mutirões de justiça dos estados e dos municípios ou por câmaras de mediação.

A elaboração do $\mathrm{PNI}$ atende a necessidade de um plano local considerando o estado de coisas da condição de exclusão social e das condições sanitárias e apresenta um quantitativo que considera: números, custos, volumes de água perdidos e ganhos das ações realizadas em termos físicos e financeiros.

A governança inclusiva promoverá a realização das ações previstas pelas partes para promoção da participação social. Garantirá o cumprimento das atualizações anuais de informações dos aglomerados para planejamento participativo pelos municípios, a continuidade de programas pela concessionária, de recursos pelos financiadores.

O Estado republicano tem por objetivo fundamental construir uma sociedade livre, justa e solidária, nesse sentido, não há direito superior ao fundamental para a cidadania inclusiva que promova isonomia e igualdade de oportunidades ao acesso. Esses são determinantes sociais da gestão dos serviços essenciais ao ser humano na provisão da Universalização Inclusiva, cujo processo democrático é o agente que apoia as garantias individuais e que será fortalecido pela governança inclusiva.

Para todos municípios da Bacia deve-se apresentar planos de superação e enfrentamento do problema com propostas de solução, conforme a Lei Estadual determina. A exemplo da Baixada Santista, o plano inclusivo elaborado servirá também para liberação de recursos fiscais e outros não onerosos, como orçamento da verba proveniente do PL 09/2015 do Senado REIS. 


\section{RESULTADOS DA AVALIAÇÃO DA ESTRATÉGIA EMPRESARIAL}

\subsection{CONSIDERAÇÕES GERAIS}

Conforme a revisão bibliográfica, ficou evidente que a inovação do modelo de negócio exige a revisão da estratégia empresarial e um plano de negócio, que contemple a governança e a gestão de maneira a construir um modelo específico para áreas de vulnerabilidade socioambiental. Deve permitir testar os temas organizacionais relevantes, nas dimensões dos movimentos e escolas da administração, considerando as controvérsias da universalização em áreas de vulnerabilidade social.

Destacam-se duas abordagens: o Modelo Negócio de Osterwalder (2001, 2005), e o Modelo de Congruência do Comportamento Organizacional para a identificação do sistema, seguido da especificação das variáveis essenciais ao mesmo, na perspectiva do diagnóstico, com base em componentes organizacionais isoladas, e enfatizando o processo da transformação de recursos organizacionais.

Essa etapa apresentou como resultado, o desenho do modelo e os pilares teóricos da teoria da administração aplicados ao negócio socioambiental.

O modelo de negócio do saneamento em áreas de vulnerabilidade deve ser capaz de demonstrar em seu mapa conceitual, qual a lógica de funcionamento para alcançar a estratégia empresarial de universalização inclusiva, considerando a geração de valor ao usuário/cidadão. Também deve permitir identificar como isso é obtido, e quais resultados financeiros, ambientais e sociais para os atores.

A inovação da estratégia e gestão são objetos desse capítulo, complementando os capítulos de plano de negócios para a cidade informal PNI, equacionamento financeiro e jurídico como inovações da tese.

\subsection{MODELO EMPRESARIAL DE GESTÃO}

A Regionalização por Bacias Hidrográficas foi o modelo adotado pela concessionária (Figura 29), como limites das Unidades de Negócio, cuja unidade de planejamento por bacia hidrográfica, atende as legislações de recursos hídricos. As Unidades de Negócio estão alocadas na Diretoria Metropolitana de Distribuição (contemplando sistemas produtores e distribuidores da Região Metropolitana de São Paulo) e 
Diretoria de Sistemas Regionais contemplando Região Metropolitana da Baixada Santista e demais municípios).

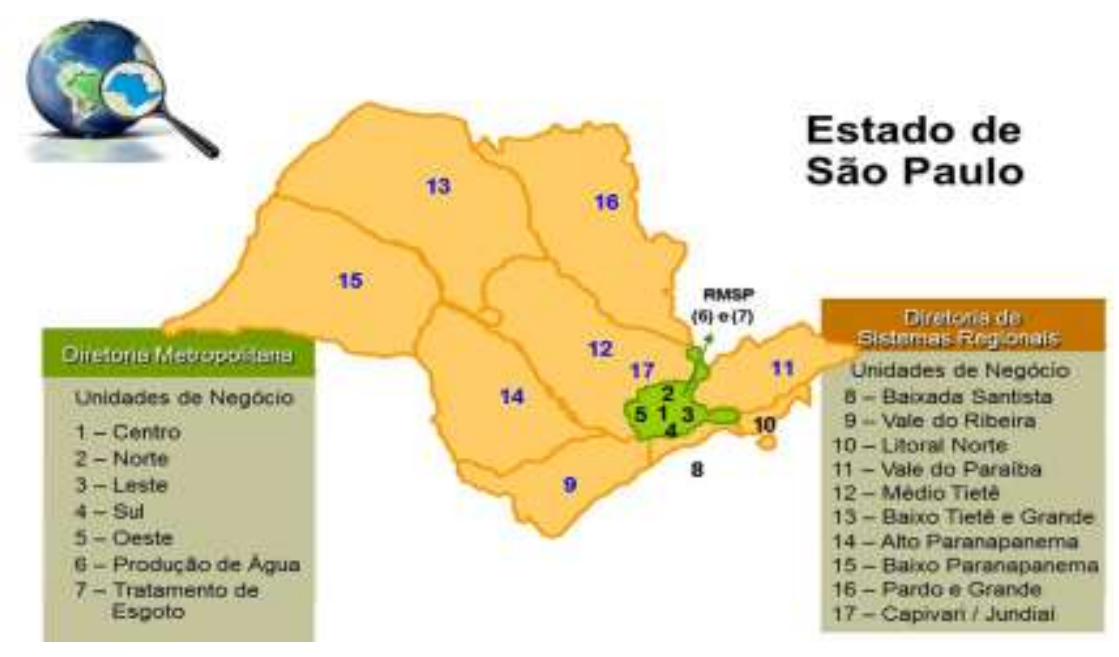

Fonte: SABESP(2015)

Figura 29 - Modelo de Gestão da Concessionária

O modelo de gestão apoia-se em regionalização por bacias hidrográficas, conforme legislação estadual de recursos hídricos e de saneamento, descentralização e desconcentração da organização da empresa, autonomia de gestão, relacionamento com os municípios com transparência participação social, controle social e canais privilegiados com a sociedade, para aferir os serviços prestados. As metas de universalização do atendimento são quantitativas e qualitativas para o provisão de SAAES com qualidade, visão a satisfação e manutenção dos atuais clientes em ambiente regulado. As metas contratuais dos novos contratos de programa e dos que estão em renovação são reguladas pela ARSESP nas regiões metropolitanas. $E$ a gestão econômico-financeira foca resultados empresariais, fontes de recursos, e criação de valor para o acionista. A construção do mapa estratégico tem cinco princípios na estrutura do BSC com temas estratégicos para atingir os objetivos financeiros, perspectivas de clientes, de processos internos e de aprendizado e crescimento.

Partindo de estratégias, objetivos e medidas inter-unidades, diversos autores afirmam que, um scorecard corporativo e sinérgico com adoção de outputs representa resultados de um processo, controle de recursos, custos, qualidade e 
produtividade, permitem monitoramento de desempenho, lucratividade, tendências e resultados de natureza da visão, estratégia e missão da organização, com desafio da adoção de até cinco indicadores-chave passíveis de implementação por meio do BSC. (Kaplan \& Norton, 1997; Hronec, 1994, Arveson, 1998, Schwarz, 2000, Olve, Roy \& Wetter (1999).

Os objetivos financeiros da empresa devem derivar de sua estratégia e devem atuar com o foco dirigido para os objetivos e indicadores das demais perspectivas do BSC, e identificam: crescimento, sustentabilidade e lucro do mapa estratégico para operacionalizar a gestão estratégica do modelo. (Kaplan \& Norton, 1997, 2000; Marinho, Mâsih \& Selig, 2000).

Os objetivos de clientes descreve os caminhos de geração de valor e os indicadores revelam as estratégias da organização em: participação no mercado; manutenção e novos clientes; satisfação com os serviços e lucratividade com indicadores de causa e efeito, proposta de valor no segmento objeto de análise cultivando core competence com um scorecard contemplando visão, estratégia, fatores críticos do sucesso e os indicadores críticos (Olve, Roy \& Wetter, 1999; Kaplan \& Norton, 1997; Hermanson, 1997).

A concessionária se caracteriza por um negócio socioambiental, pois apresenta um missão e visão, que tem por intencionalidade o impacto ambiental e a qualidade de vida. Dentre suas diretrizes estratégicas estão:

Sustentabilidade

Socioambiental

Fortalecer o compromisso com o meio ambiente e sociedade e ser reconhecida como importante agente do desenvolvimento sustentável, considerando as expectativas e necessidades da sociedade e das comunidades onde atua, contribuindo para o crescimento do negócio. Essa atuação se dá por meio de comportamento ético, transparente e exemplar, destacando: melhoria da qualidade de vida da população; atuação em conformidade com a legislação ambiental; otimização e preservação do meio ambiente e o uso racional dos recursos naturais; respeito incondicional aos Direitos Humanos, influenciando as partes interessadas; desenvolvimento de ações para promoção da responsabilidade socioambiental; atendimento as leis e normas aplicáveis; promoção de práticas inclusivas, visando à diminuição de desigualdades sociais e promoção da diversidade; e fomento a utilização de tecnologias ambientalmente corretas.

Fonte: SABESP (2014) 
Os objetivos empresariais são: prestar atendimento eficaz às necessidades dos clientes e municípios, tornar as decisões mais próximas das demandas e ações, atingir resultados de "excelência", e criar uma organização, simples, flexível e ágil. O objetivo estratégico PI07 - Fortalecer a gestão socioambiental, realizando o manejo adequado dos recursos hídricos, indica esse direcionamento. O diagnóstico mostrou que não havia indicadores ou metas para atendimento às comunidades de baixa renda e foram adotados na RMBS os indicadores IUI e IGI. O Mapa do BSC da concessionária consta da Figura 30.

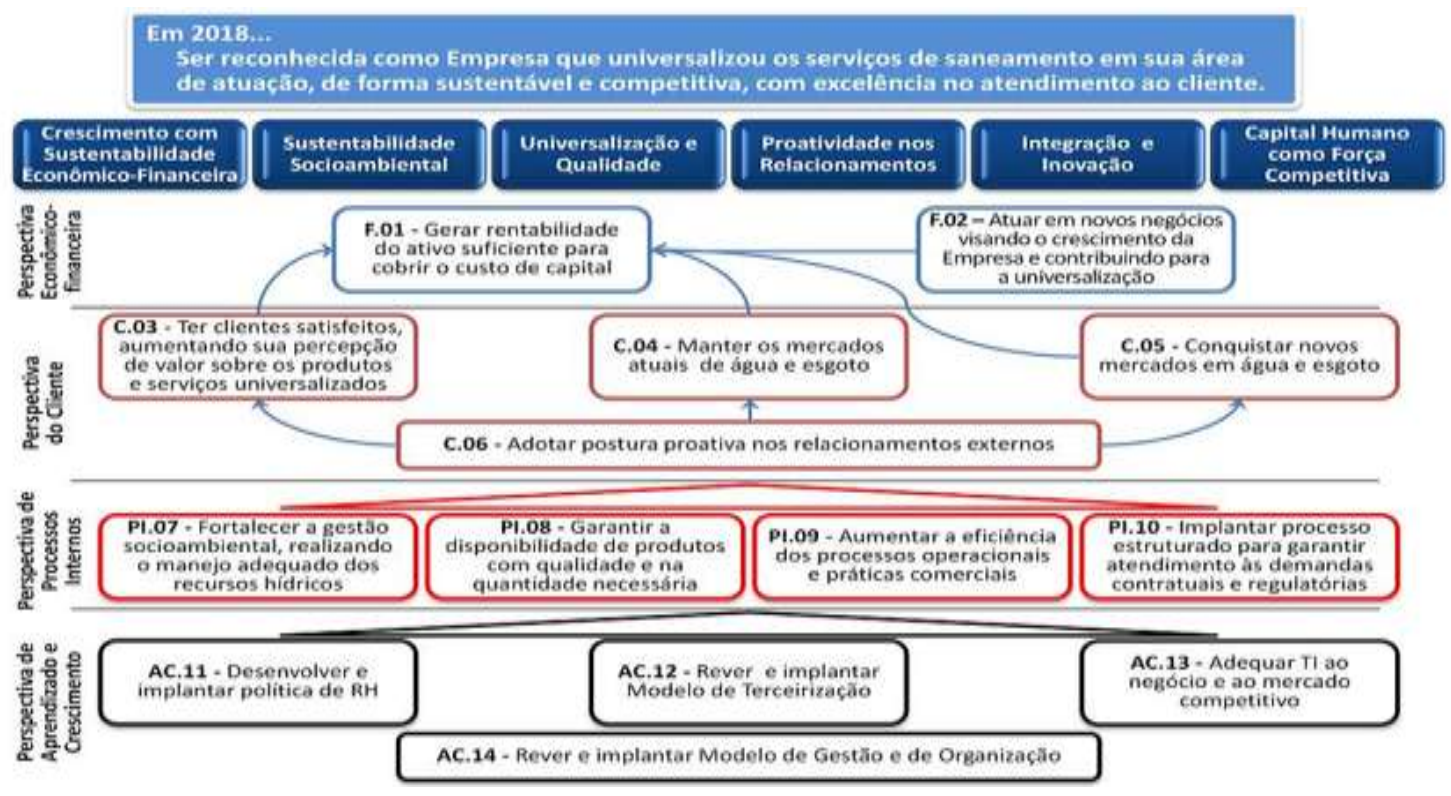

Fonte: SABESP(2015)

Figura 30 - Mapa Estratégico do BSC

O Planejamento Empresarial ocorre em workshops de planejamento estratégico, tático e operacional, de forma cíclica realimentando o processo de planejamento, considerando metas de governo, contratuais e objetivos do conselho de administração. O planejamento tático é conduzido em atendimento ao planejamento estratégico com metas e compromissos setoriais de curto, médio e longo prazo com planos de ação no planejamento operacional para atender os compromissos e metas assumidos de forma alinhada pela empresa (Figura 31). 


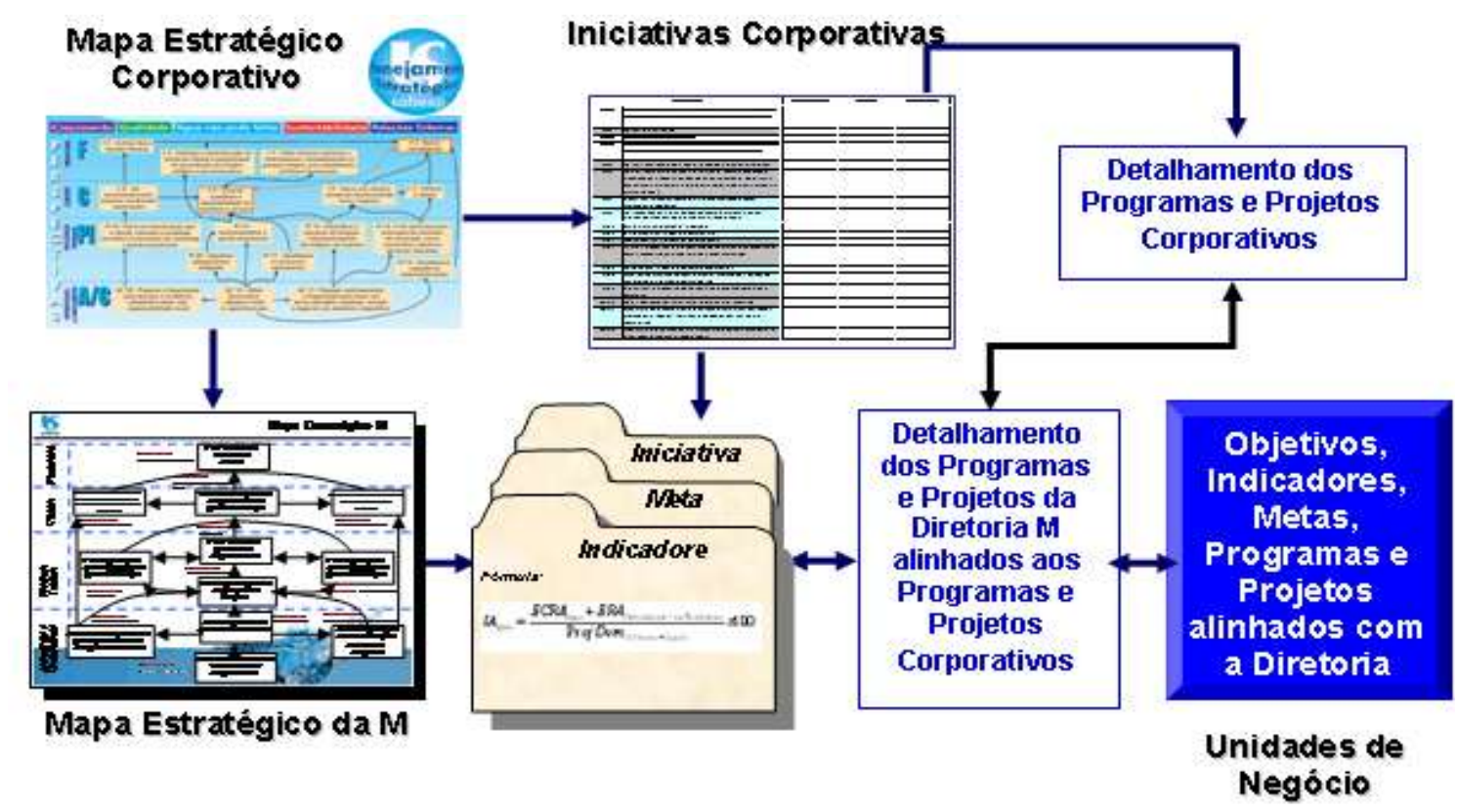

Fonte: Planejamento Estratégico SABESP (2014)

Figura 31 - Alinhamento estratégico do BSC

Identificou-se diretrizes de práticas inclusivas, como uma organização socioambiental, que opera com uma lógica financeira, distribui dividendos aos acionistas investidores, inclusive ao governo do estado, na atual condição de acionista majoritário e financiador de obras e programas de universalização subsidiados à baixa renda como o Seliga.

No entanto, diverge das práticas das organizações sociais, segundo a revisão bibliográfica, cujo lucro é reinvestido integralmente para aumentar o impacto na sociedade e meio ambiente e reforçar a missão de atingir a visão estabelecida.

Há um conselho de administração com representação do acionista majoritário e minoritário, que confere governança empresarial à empresa conforme regras das companhias abertas e melhores práticas. $O$ histórico de diversos programas de universalização dos serviços nas áreas de baixa renda e de ocupação irregulares, inseriu nos últimos anos mulheres - promotoras na cadeia produtiva e a metodologia de governança colaborativa mostraram uma característica de inclusão que trouxe retorno à cadeia de valor e à comunidade local na RMSP. A responsabilidade social corporativa é uma diretriz estratégica da organização composta de alguns programas financiados pelo acionista majoritário, como água é vida, programa 
mananciais e programas de voluntariado com a participação dos funcionários. A existência de uma agência reguladora promoveu a mudança de diversos processos como a criação de planos de contingências, revisão de práticas comerciais e técnicas para a eficiência e eficácia dos serviços em termos de tempos de atendimento telefônico, pedidos de ligação e reparo de vazamento e manutenção dos ativos.

A empresa atua com agentes comunitários em todas as unidades de negócio da Diretoria Matropolitana há dezoito anos e recentemente na Diretoria de Sistemas Regionais na Baixada Santista (funcionários operacionais localizados na base da pirâmide organizacional) que respondem às demandas das comunidades em todos as ocorrências técnicas e comerciais, realizam reuniões periódicas com as lideranças, recebem ligações telefônicas diretamente, funcionam como call center 24 horas por dia 7 dias por semana, fazem visitas às favelas diariamente para verificar a situação do atendimento e demandas necessárias, informam interrupções do abastecimento para realização de serviços, fazem mediação de conflitose apresentam uma alta eficiência na relação com as comunidades. Eles atuam exclusivamente nas áreas favelizadas, inclusive com programas de educação ambiental nas escolas e centros de convivência criando valor social e removendo barreiras de relações empresa-cidadão com dimensões intangíveis.

A estratégia empresarial e BSC (técnico) e (situacional) apresenta coerência de objetivo estratégico específico que é o PI07, que foi revisado em 2013 (Figura 32).

- Trabalhar os temas social e ambiental de forma integrada, mesmo que existam Superintendências especificas para cada um.

- Alinhar os temas ao negócio da SABESP. 


\begin{tabular}{|c|c|c|c|}
\hline \multirow[b]{2}{*}{$\sqrt{ }$} & \multicolumn{2}{|c|}{$\begin{array}{l}\text { P1-07 - Fortalecer a gestao } \\
\text { socioambiental realizando o manejo } \\
\text { adequado dos recursos hidricos }\end{array}$} & \multirow[b]{2}{*}{$\Downarrow$} \\
\hline & $\downarrow$ & $\downarrow$ & \\
\hline $\begin{array}{l}\text { Vertente Ambiental-T } \\
\text { - SGA-Sistema de geståo } \\
\text { ambiental / certificaçठes } \\
\text { - Regularizaça de outorgas } \\
\text { - Licenciamento ambiental } \\
\text { - Politica de Meio Ambiente } \\
\text { - Representaça institucional } \\
\text { - Gestao de emissōes } \\
\text { - Mudanças climaticas } \\
\text { - 3Rs } \\
\text { - Educação Ambiental } \\
\text { - SIGA }\end{array}$ & $\begin{array}{l}\text { Vertente } \\
\text { Socioambiental M/R } \\
\text { - Regularizacăo } \\
\text { fundiaria e } \\
\text { reurbanizacáo } \\
\text { - Se liga na rede } \\
\text { - Corrego Limpo } \\
\text { - Programa Mananciais } \\
\text { - Mangue/Bairros Cota } \\
\text { - Agente Comunitário } \\
\text { - Ecobarreiras }\end{array}$ & $\begin{array}{l}\text { Vertente dos Recursos } \\
\text { Hidricos M/R } \\
\text { - Gestào dos recursos } \\
\text { hidricos } \\
\text { - Qualidade da agua } \\
\text { - Quantidade de água }\end{array}$ & $\begin{array}{l}\text { Vertente da Acāo Social } \\
\text { - CR } \\
\text { - Politica/processo de } \\
\text { responsabilidade social } \\
\text { - Inclusdo social } \\
\text { - Reduça da desigualdade } \\
\text { social } \\
\text { - Valorizaça da diversidade } \\
\text { - Sistema de informaçøes de } \\
\text { responsabilidade social } \\
\text { - Programa de voluntariado } \\
\text { - Programas de aça social }\end{array}$ \\
\hline
\end{tabular}

Fonte: SABESP: 2015

Figura 32 - Alinhamento estratégico do BSC

\subsection{INOVAÇÃO DA ESTRATÉGIA EMPRESARIAL}

Em termos de estratégia empresarial e suas ferramentas de gestão para baixa renda há diferenças entre o atual BSC ou o Sustentability Balanced Score-Card - SBSC, conforme Diagnóstico do Mapa Estratégico do BSC para SBSC (Quadro 19). Identificou-se que há macro objetivo apenas na perspectiva do cliente, demandando outras perspectivas e alinhamento de ações.

Quadro 19 - Diagnóstico da Inovação do BSC

\begin{tabular}{|c|c|c|c|c|c|}
\hline Situação & $\begin{array}{l}\text { Perspectiva } \\
\text { Financeira }\end{array}$ & $\begin{array}{l}\text { Perspectiva } \\
\text { do Cliente }\end{array}$ & $\begin{array}{l}\text { Perspectiva } \\
\text { do } \\
\text { Processo }\end{array}$ & $\begin{array}{l}\text { Perspectiv } \\
\text { a } \\
\text { Aprendizad } \\
\text { o }\end{array}$ & $\begin{array}{l}\text { Perspectiva Non- } \\
\text { market }\end{array}$ \\
\hline \multirow[t]{3}{*}{ Atual } & $\begin{array}{l}\text { Crescimento da } \\
\text { Receita }\end{array}$ & Market share & $\begin{array}{l}\text { Inovação do } \\
\text { Processo }\end{array}$ & $\begin{array}{l}\text { Retenção } \\
\text { de } \\
\text { empregado } \\
\text { s }\end{array}$ & Liberdade de ação \\
\hline & $\begin{array}{l}\text { Crescimento de } \\
\text { Produtividade }\end{array}$ & $\begin{array}{l}\text { Novos } \\
\text { usuários }\end{array}$ & $\begin{array}{l}\text { Operação } \\
\text { dos } \\
\text { processos }\end{array}$ & $\begin{array}{l}\text { Produtivida } \\
\text { de } \\
\text { Empregado } \\
\mathrm{s}\end{array}$ & Legitimidade \\
\hline & $\begin{array}{l}\text { Utilização de } \\
\text { Ativos }\end{array}$ & $\begin{array}{l}\text { Retenção de } \\
\text { Usuários }\end{array}$ & Pós-venda & $\begin{array}{l}\text { Satisfação } \\
\text { empregado } \\
\text { s }\end{array}$ & Legalidade \\
\hline $\begin{array}{l}\text { Inovaçã } \\
0\end{array}$ & $\begin{array}{l}\text { Inovação } \\
\text { Regulatória, } \\
\text { implantação de } \\
\text { PNI, Revisão } \\
\text { Tarifária, e } \\
\text { estratégia de } \\
\text { Captação de } \\
\text { Recursos dos } \\
\text { Comitês de } \\
\text { Bacias }\end{array}$ & $\begin{array}{l}\text { Demanda } \\
\text { Governança } \\
\text { Inclusiva } \\
\text { para garantia } \\
\text { de } \\
\text { uniformidade } \\
\text { e } \\
\text { continuidade } \\
\text { de ações }\end{array}$ & $\begin{array}{l}\text { Necessidad } \\
\text { e de revisão } \\
\text { do } \\
\text { processo e } \\
\text { procedimen } \\
\text { tos }\end{array}$ & $\begin{array}{l}\text { Demanda } \\
\text { inovação } \\
\text { da política } \\
\text { de RH para } \\
\text { Agentes } \\
\text { Comunitári } \\
\text { os e } \\
\text { Capacitaçã } \\
0\end{array}$ & $\begin{array}{l}\text { Ações estruturantes } \\
\text { para potencializar o } \\
\text { empreendedorismo } \\
\text { local }\end{array}$ \\
\hline
\end{tabular}


O SBSC acrescenta ao BSC perspectiva de uma organização com objetivos além de sustentáveis já adotados, de objetivos inclusivos. Assim, geração, retenção e distribuição de valor para comunidade e ambiente implicam em ações socioambientais locais e corporativas que reconheçam essa estratégia empresarial. As inovação de ações socioambientais nas áreas funcionais demandam: estruturar e implantar política institucional de empreendedorismo sociotécnica, estruturar e implantar processo corporativo de responsabilidade sociotécnica, estruturar processo de inclusão, visando à diminuição de desigualdades sociais e a valorização da diversidade e desenvolver e implantar um sistema corporativo de informações de responsabilidade sociotécnica no foco do empreendedorismo e não filantropia. As ações socioambientais locais demandam: estruturar e implantar programa de universalização inclusiva, estruturar e implantar processo de governança inclusiva, desenvolver e implantar um sistema corporativo de gestão de informações dos programas de universalização inclusiva - plano de negócios inclusivo.

\subsection{CONCLUSÃO DA ESTRATÉGIA EMPRESARIAL}

As diferenças identificadas nas estratégias empresariais que afetam os resultados do negócio socioambiental encontram-se na variação de escala e objetivos. Elas devem se apoiar em: objetivos empresariais e programas contínuos diferentemente de iniciativas pontuais; percepção e enfrentamento dos obstáculos diferentemente da justificativa e negação; visão de longo prazo e persistência para maturação do processo diferentemente de imediatismo; inovação de serviços e produtos complementares com benefícios sociotécnicos diferentemente da massificação de procedimentos; implantações em grande escala diferentemente de pilotos; diretrizes de rentabilidade, valores da empresa, subsídios e créditos organizados em uma estratégia empresarial clara para retornos socioambientais; e estratégia de P\&D para atendiemento a populações vulneráveis com objetivos empresariais.

Como conclusão a inovação proposta para o saneamento deve-se apoiar na melhoria identificada no referencial teórico e benchmarking de práticas listadas para a condução do polo de construção do modelo de gestão e negócio. (Quadro 20) 
Quadro 20 - Resumo do Diagnóstico para Inovação da Estratégia Empresarial

Adotar na Estratégia empresarial clara de priorizações de ganhos econômico-socioambientais para as 5 perspectivas do BSC.

Incluir participação social no modelo de gestão e governança colaborativa;

Modificar a estrutura organizacional ou criar empresa social para evitar o desequilíbrio de forças orçamentárias com manutenção dos mecanismos de exclusão.

Atentar para as funções de atendimento às demandas dessas áreas, que se diluem nas diversas áreas funcionais sem uma tratativa especifica para os SBR.

Criar mecanismos de mensuração dos aglomerados, definição de metas, planejamento e medição de resultados com premiação específica e governança implantar o PNI;

Mensurar as externalidades como redução de doença e morte, redução do dano ambiental, valorização das áreas, aumento do nível de escolaridade. Aumentando o valor econômico e socioambiental;

Melhor mensurar o valor econômico de atender os SBRs como redução de volumes de perdas físicas;

Avaliar as controvérsias da atuação de uma concessionária do Estado com diversas vocações;

Observar a governança inclusiva, accontability e impacto social, considerando o efeito sobre o tecido social da comunidade e sua influência no bem-estar do cidadão;

Definir estrutura de Plano de Negócio e como ele se executa. Quais os impactos nessa comunidade se ela não for universalizada;

Medir os impactos sobre ativos, tarifas, balanço e perdas. Impacto operacional, financeiro e de investimentos na busca de maiores outcomes e incomes;

Ampliar a inclusão social nas atividades operacionais e de atendimento comercial;

Ampliar a estratégia de educação ambiental e comunicação dirigida;

Elaboração: a autora (2015) 


\section{AVALIAÇÃO DO MODELO DE GESTÃO PARA SBR}

\subsection{CONSIDERAÇÕES GERAIS}

No enfoque da administração e gestão, com a evolução do pensamento administrativo, o movimento da contingência possibilitou o amadurecimento do conceito de adaptação da organização ao ambiente. Burns e Stalker (apud Motta e Vasconcelos, 2005) realizaram estudo pioneiro em empresas inglesas, a partir do qual elaboraram dois tipos ideais de organização, cada qual adaptada a um tipo de setor ou meio ambiente: (1) a organização mecânicista - fortemente articulada e burocrática, caracterizada pela formalidade, existência de organograma detalhado e rígido, com pouca comunicação entre os diversos setores em nível horizontal, privilegiando-se o nível vertical e hierárquico com forte centralização de poder e (2) a organização orgânica - onde o poder de decisão é descentralizado e difuso, os papéis organizacionais não são explícitos, não se acentua as diferenças em nível hierárquico, autonomia controlada para os empregados, que se organizam em equipes multifuncionais, que interagem e se comunicam em qualquer nível. Morgan (2010), Maximiano (2008) e afrimam que a organização de modelo mecânico é mais frequente em um meio ambiente estável, o qual implica em pouca inovação tecnológica, demanda regular e previsível. Enquanto que para um ambiente turbulento, isto é, com uma alta taxa de inovação e um mercado caracterizado por forte concorrência, a organização de modelo orgânico seria a opção mais frequente. Posteriormente, Emery e Trist apresentam que cada tipo de meio ambiente sociotécnico e econômico seria um resultado da adoção pelas organizações de um tipo de estrutura adaptada às exigências e características do setor a qual está inserida - o encadeamento de causas e efeitos (Chiavenato, 2004; MOTTA \& VASCONCELOS, 2005).

Neste sentido Nadler e Tushman (1999) destacam as grandes transformações que o avanço tecnológico impôs às organizações, dentre as implicações, faz-se necessário encontrar novas e criativas formas de projeto e implementação de arquiteturas organizacionais que permitam maior celeridade e tempestividade das decisões sem, contudo, perca os benefícios existentes do planejamento e controles organizacionais tradicionais (competitividade e inovação caminhando simultaneamente e dicotomia organização formal vs. organização informal). 


\subsection{DIAGNÓSTICO DA GESTÃO PARA SBR}

O desenho do modelo de gestão para universalização dos serviços em áreas de vulnerabilidade social apoiou-se no mapa de controvérsias do polo epistemológico, gerando a chamada cartografia das controvérsias (Figura 33). Observou-se que a centralidade do modelo está nos gestores, os chamados change makers de Durana et al. (2010). O ponto de partida para atendimento das populações vulneráveis são os gestores - agentes comunitários empreendedores. Eles levam a organização e comunidade vulnerável a diversos tipos de parcerias com resultados múltiplos alcançáveis dentro de seus limites de atuação.

Pelo lado do regulador, o desenvolvimento de agentes reguladores sociais podem trazer grandes benefícios à universalização do saneamento, como agentes de mediação e fiscalização das responsabilidades definidas na política pública e contratos para o Poder concedente e concessionária, no tema da universalização. Sua atuação será de fomentar a execução da política pública cidadã (segundo estatuto da cidade) e da continuidade do planejamento de competência de seu contratante de quem recebeu a delegação para regulação dos serviços públicos de saneamento. 
Cartografia das Controvérsias da Universalização Inclusiva na Gestão do Saneamento

\begin{tabular}{|c|c|c|c|c|c|}
\hline $\begin{array}{l}\text { Natureza dus Grupos } \\
\text { (Parcerias Principais) } \\
\text { Municipio/Secretarias/Agê } \\
\text { ncia/ONG,s/Associação } \\
\text { de } \\
\text { Moradores/Promotoria } \\
\text { Pública/MP/Politicos/Segu } \\
\text { rança Pública/CETESB }\end{array}$ & $\begin{array}{c}\text { Natureza das } \\
\text { Açöes } \\
\text { (Atividades } \\
\text { Principais) } \\
\text { Coletar } \\
\text { Esgoto } \\
\text { Construir } \\
\text { Sistemas àgua } \\
\text { Abastecer }\end{array}$ & $\begin{array}{c}\text { Natur } \\
\text { eza } \\
\text { dos } \\
\text { Objet } \\
\text { os } \\
\text { Água } \\
\text { Legal e } \\
\text { Ilegal; } \\
\text { Esgotc } \\
\text { ilegal } 6 \\
\text { legal; } \\
\text { Prop } \\
\text { edade; }\end{array}$ & $\begin{array}{c}\text { Natureza das } \\
\text { Ciências } \\
\text { Sociais } \\
\text { (Recuperação } \\
\text { de Receita) } \\
\text { Tarifa Social, } \\
\text { Parcelamento } \\
\text { e acordos, } \\
\text { acessibilidade } \\
\text { à agencias }\end{array}$ & $\begin{array}{l}\text { Natureza das } \\
\text { Ciencias } \\
\text { Naturais } \\
\text { (Estrutura de } \\
\text { Custo) } \\
\text { Subsidios } \\
\text { Custos e } \\
\text { para Obras } \\
\text { (PAC) } \\
\text { Inclusão } \\
\text { moradores } \\
\text { na cadeia } \\
\text { produtiva }\end{array}$ & $\begin{array}{c}\text { Mecanismo } \\
\text { s de } \\
\text { Serviços de } \\
\text { Redes - } \\
\text { Eficácia } \\
\text { Social: } \\
\text { Mecanismo } \\
\text { s de } \\
\text { Exclusão } \\
\text { (Dupuy) } \\
\text { - Direito de } \\
\text { Propriedad } \\
\text { eXDireito } \\
\text { da àgua } \\
\text { Contagem } \\
\text { das } \\
\text { populaçöes } \\
\text { nas } \\
\text { Comunidad } \\
\text { es } \\
\text { tradicionais } \\
\text { Indicadores } \\
\text { Inclusivos } \\
\text { - }\end{array}$ \\
\hline
\end{tabular}

Figura 33 - Modelo de Gestão Inclusiva do Saneamento - Cartografia das Controvérsias da Gestão 
Partindo do Modelo de Gestão Inclusiva do Saneamento, figura 33, a construção da cartografia das controvérsias da universalização, identifica na complexidade da gestão dos serviços públicos na cidade informal o fluxo (seguindo as flechas vermelhas) que $\mathrm{o}$ actante (epicentro) da eficiência empresarial é 0 agente comunitário empreendedor (natureza dos grupos), que é o chamado foco transformador, segundo Latour, equaciona a controvérsia. Ele atua em atendimento à missão empresarial e com instrumentos (natureza das ciências sociais) como: Paritá, carta de instrumento precário, mobilização do MP, e poder concedente (natureza dos grupos) em duas dimensões: a superação dos mecanismos de exclusão de redes para a eficácia social e na autorização do atendimento ao direito fundamental ou regularização de propriedade (natureza dos objetos). Superada o impedimento legal atua nos contratos de serviços terceirizados (natureza das ciências naturais), inserindo os moradores na cadeia de serviços (natureza das ciências sociais), aplicando procedimentos comerciais (tarifa social, parcelamento e perdão de débitos) (apresentando proposta de valor) e técnicos com arranjos técnicos para atendimento em áreas autorizadas (natureza dos fatos), fomentando a participação social com identificação e capacitação de lideranças comunitárias (natureza dos grupos), utilizando portfólio para reuniões comunitárias (natureza dos agrupamentos) e educação ambiental, mobilizando finais de semana para atendimento com a agência móvel e mutirões, coordenando atendimento prioritário, e obtendo resultados nos indicadores de cobertura e atendimento e na eficiência técnica (ciências naturais e sociais).

Por fim, importante destacar a difícil missão do administrador na consecução e alinhamento dos objetivos da empresa, sua estrutura e seus funcionários. Kotler e Schlesinger (2008) destacam que não há nada mais difícil de conduzir, que gere mais dúvidas quanto ao sucesso e mais perigoso de se lidar, do que iniciar novos formas de ordenar uma organização.

\subsection{DIAGNÓSTICO DA ORGANIZAÇÃO NO ATENDIMENTO AOS SBR}

Mediante duas oficinas de pesquisa-ação com gestores foi realizado o diagnóstico da organização por meio das metodologias de Diagnóstico Nadler e da Matriz SWOT. 
. Para Nadler e Tushman $(1980 ; 1999)$ a função primordial do administrador é fazer com que a organização opere de forma eficiente, assim destacam que a dificuldade em se atender tal premissa considerando que compreender o comportamento de um único indivíduo já é tarefa difícil - estender a um grupo formado por diferentes indivíduos com diferentes relações torna o trabalho do administrador ainda mais complexo.

Pela análise Swot (Figura 34), identifica-se os pontos que demandam inovação e os confirmam como pilares da universalização: o agente comunitário empreendedor e com habilidades de fomentar lideranças.

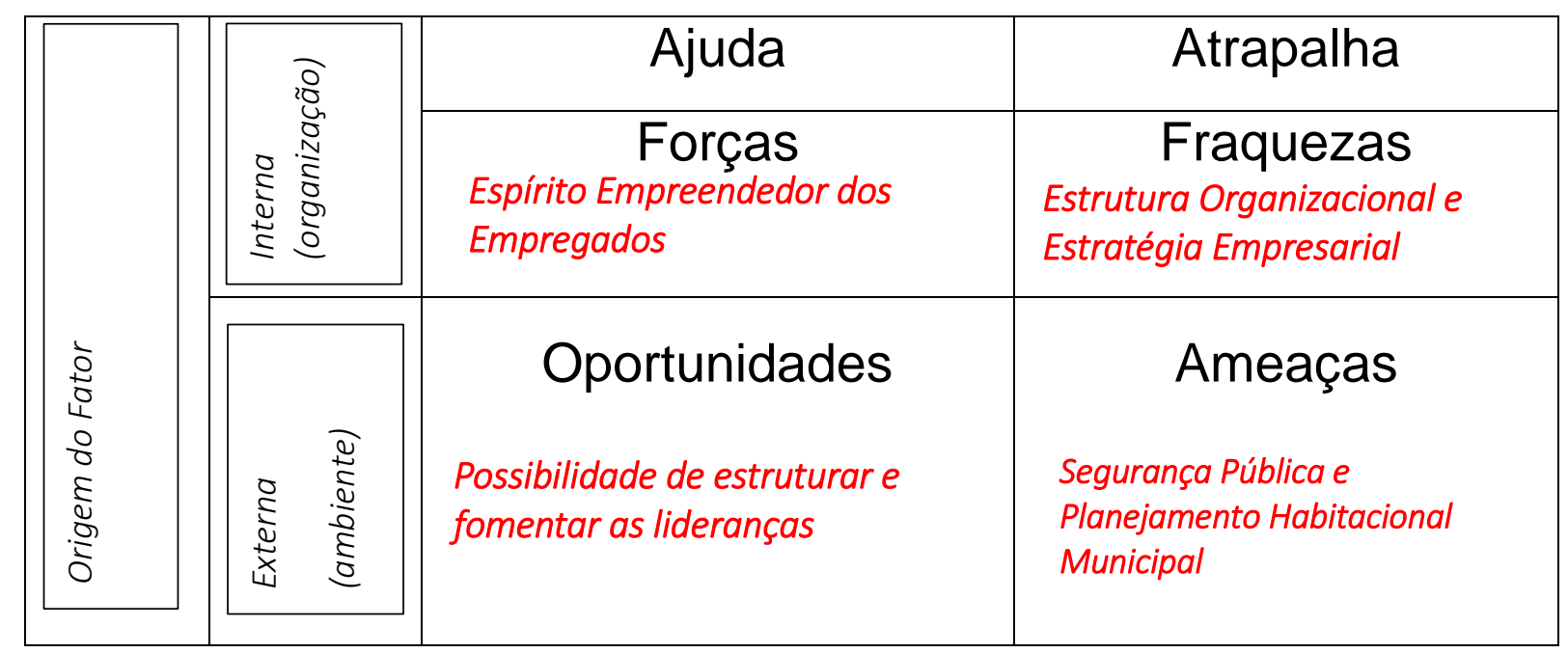

Elaboração: a autora (2014)

Figura 34 - Análise SWOT - Alcance do Objetivo da Universalização Inclusiva

Nadler e Tushman (1980) propuseram um modelo, denominado modelo de congruência do comportamento organizacional, que contemplava e reconhecia aspectos até então pouco ou nada discutidos das organizações, tais como: o ambiente (interno e externo), os recursos disponíveis (pessoas e componentes), a história da organização, a organização informal existente dentro da própria organização formal e, principalmente, a estratégia utilizada - atribuição essencialmente do administrador.

A teoria da contingência considera que a reação dos funcionários aos sistemas de controle depende do contexto de trabalho - o autor examina dois contextos de trabalho: a tarefa e a supervisão. 
Aplicou-se o diagrama para diagnóstico de Nadler (Figura 35) à área de estudo para obtenção do diagnóstico da organização em vermelho constam os pontos identificados nas oficinas de diagnóstico da organização. Em seguida foram detalhadas pelos participantes das oficinas as ações necessárias (Quadros 21 e 22)

\section{Nadler \& Trushman - Diagnóstico de uma Organização}

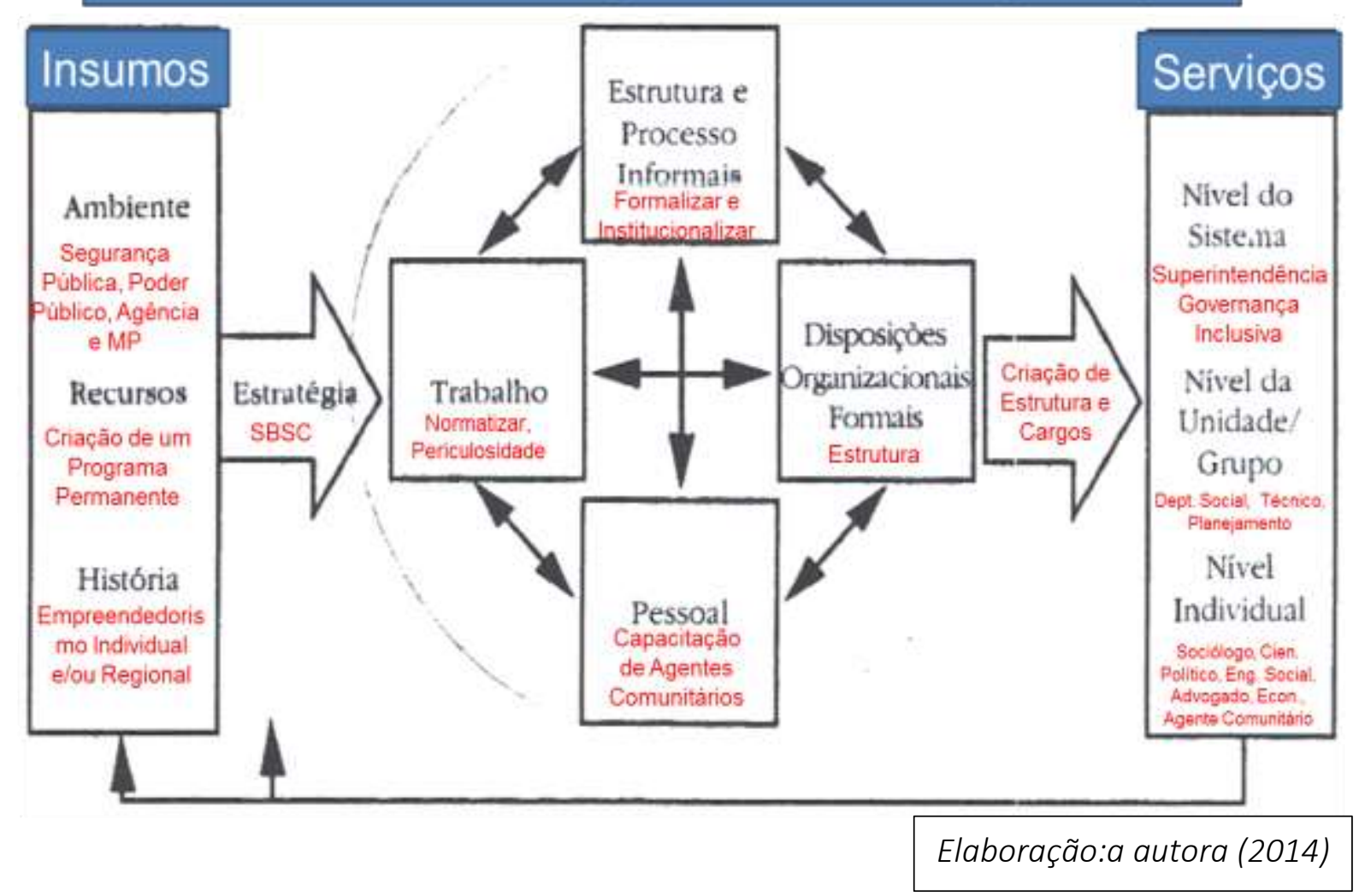

Figura 35 - Diagnóstico Resumido da Organização

Devido à abordagem de sistemas abertos, para a Teoria da Contingência é muito importante e apresenta maior detalhamento para o desenho organizacional aspecto bastante presente na obra de Nadler, que a Matriz Swot.

A adoção do Diagnóstico de Naddler, permitiu construir uma análise mais detalhada e completa do que a matriz SWOT. Quanto às dimensões de análise do diagnóstico da organização, duas oficinas foram necessárias e tempo de trabalho individual de duas equipes de estrutura das Ciências Naturais e outra das Ciências Sociais para realizar a análise do Quadro 21. 
Quadro 21 - Diagnóstico de Nadler pela Unidade de Estudo
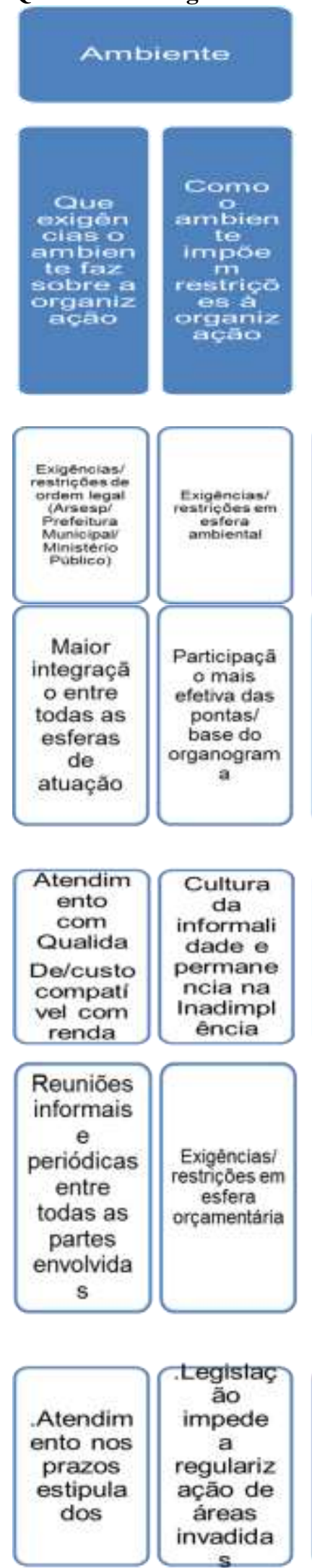
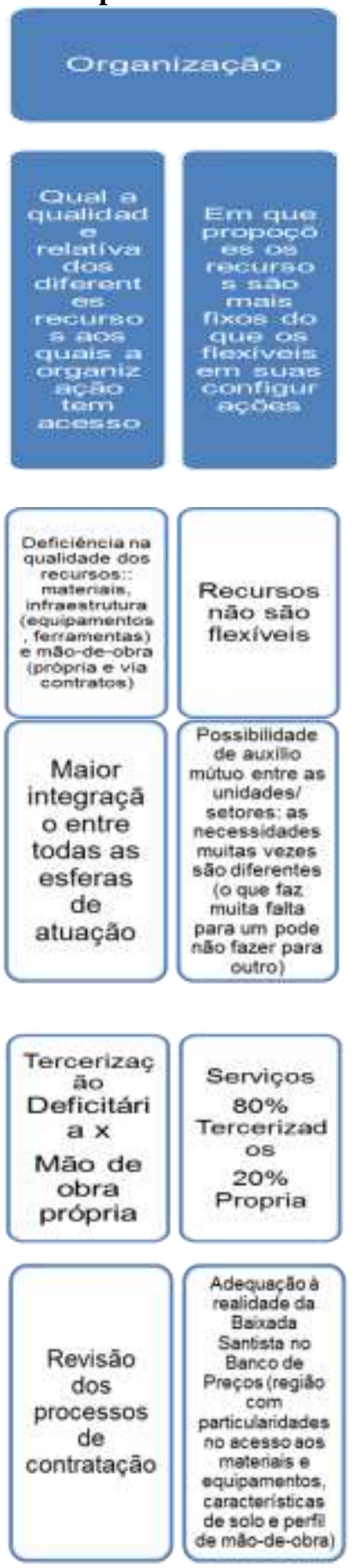
de mac-de-cbra)
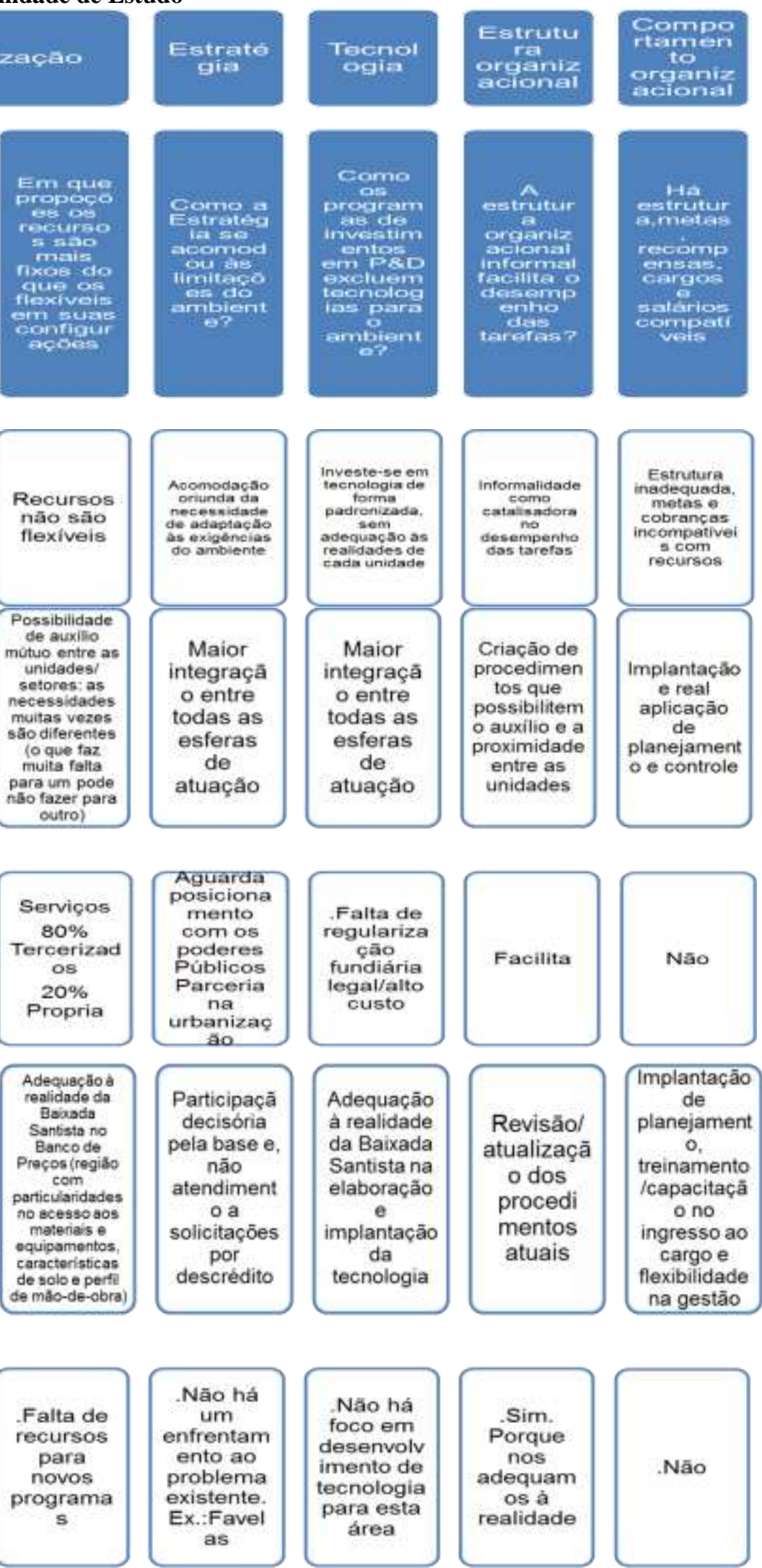
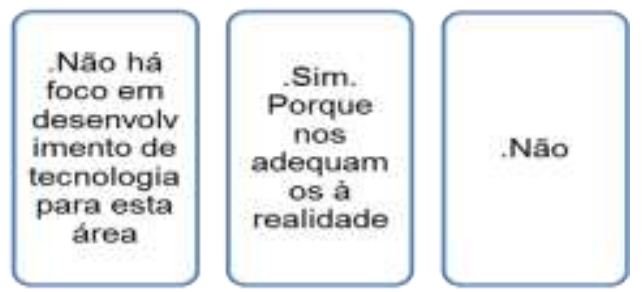

Elaboração: a autora (2015) 
O diagnóstico adotado para o modelo de gestão da organização para universalização em áreas de vulnerabilidade social revelou quanto ao Agente Comunitário que, para a inovação, há que se compreender que ela contempla e reconhece aspectos até então pouco ou nada discutidos das organizações, tais como: o ambiente (interno e externo), os recursos disponíveis (pessoas e componentes), a história da organização, a organização informal existente dentro da própria organização formal e, principalmente, a estratégia utilizada -atribuição essencialmente do administrador (Nadler e Tushman, 1980).

Quadro 22 - Diagnóstico de Nadler para Inovação da Organização pela Unidade de Estudo
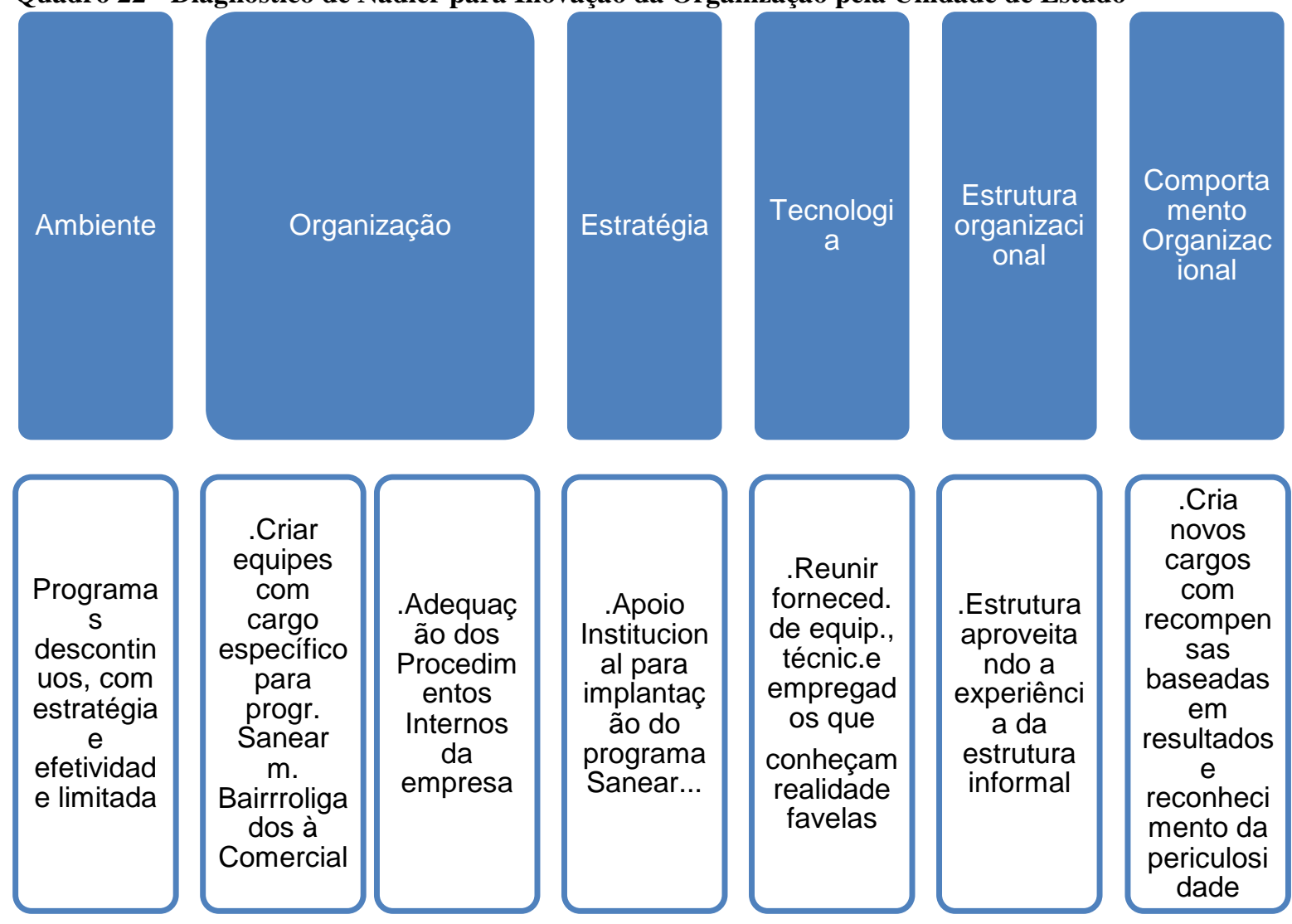

Elaboração: a autora (2015)

Nesse sentido a organização nas áreas de vulnerabilidade apresentou que o modelo diagnóstico organizacional, quanto à atuação do profissional agente comunitário, demandam algumas inovações (Figura 36). 


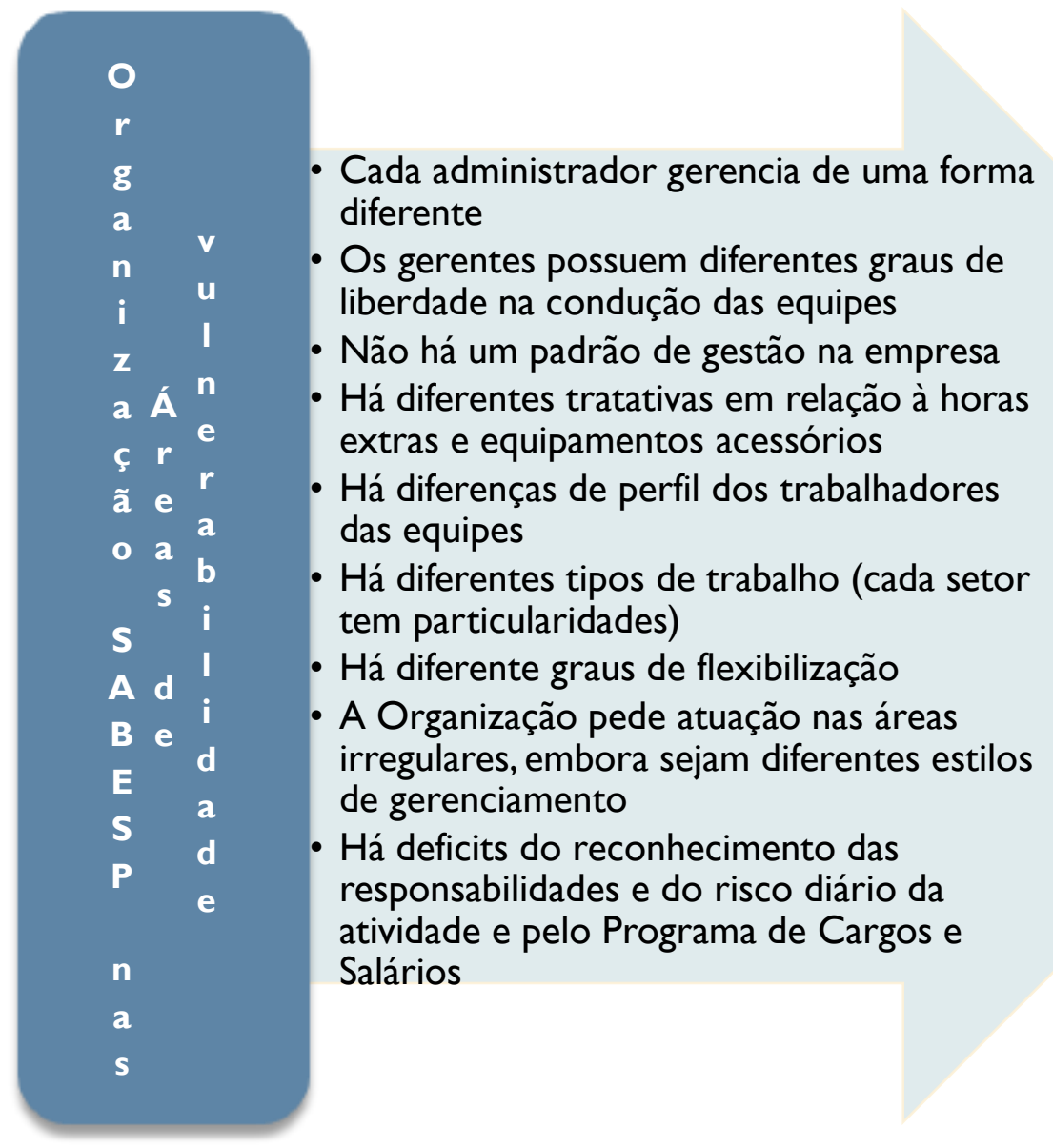

Elaboração: a autora(2015)

Figura 36 - Diagnóstico quanto atuação do Agente Comunitário

Como Implicações éticas, há que se enfrentar os diferentes desafios do ambiente externo impostos às Unidades como forma de evitar conflitos e riscos de segurança, tratar seus trabalhadores com conjuntos de "necessidades" distintas e, desenvolver padrões de relacionamento que permita considerar as peculiaridades das áreas vulneráveis na atividade do trabalhador de campo dentro das comunidades.

\subsection{PLANEJAMENTO PARTICIPATIVO}

O Planejamento Situacional e Plano de Negócio foram construídos de forma colaborativa com igual participação de todos os atores abaixo relacionados por meio de duas oficinas e 5 reuniões organizadas por tipo de atividade.

Carlos Matus, economista, ministro no Chile, identificou os fracassos experimentados pelo planejamento na América Latina com o fundamento básico do planejamento normativo - no qual quem planeja está fora da - ou sobre a - realidade planejada e não coexiste nesta realidade com outros atores que também planejam, o 
que conduziria a uma prática economicista e tecnocrática isolada do processo de governo e da razão política. Ao substituir este pressuposto por seu correspondente estratégico - o ator que planeja está dentro da realidade e ali coexiste com outros atores que também planejam. Matus formula o método de Planejamento Estratégico Situacional, aplicável aos casos de governos democráticos, nos quais existem diversos atores sociais, em situações de poder compartilhado (Matus,1978,1993).

\subsubsection{Planejamento Situacional - Conceiçãozinha, Marezinha e Prainha}

No planejamento situacional, colocadas as premissas teóricas, a pesquisadora participou como observadora e os documentos abaixo foram elaborados pelos técnicos da Diretoria de Sistemas Regionais usando como referência a documentação de boas práticas dos instrumentos de gestão da diretoria da RMSP e procedimento comercial.

Foram programadas e realizadas obras de assentamento de redes de água para substituição das antigas, que se tornaram insuficientes ao abastecimento das comunidades locais. A concessionária assumiu obras de implantação das redes de água, que tiveram as obras iniciadas pela prefeitura no âmbito do PAC, mas, por motivos diversos, não foram concluídas, causando transtornos e descrédito junto à população.

O fluxo apresentado na Figura 37 indica o planejamento e os processos contemplados num mecanismo de demanda adotados e os processos contemplando a participação e controle social. O processo foi validado, com ajustes, pelo superintendente da unidade de negócio. No processo comercial foram realizados levantamento do total de ligações existentes cadastradas, e dos débitos dos domicílios conectados, identificação de ligações inativas com e sem débito, ligações ou a substituição da rede executadas gratuitas; parcelamento de caixa abrigo do hidrômetro, negociação das ligações de água inativas com e sem débitos no processo de substituição das ligações, cadastramento em tarifa social, instalação de Unidade de Medição de Água (UMA) gratuitamente, negociação de débitos com redução de juros e multas, retroação em tarifa social. Foram designados dois revisores e um técnico comunitário para visitarem a comunidade duas vezes por semana para abordagem porta a porta e realização de um plantão na sede da associação comunitária por mês, aos sábados atendiemento. 


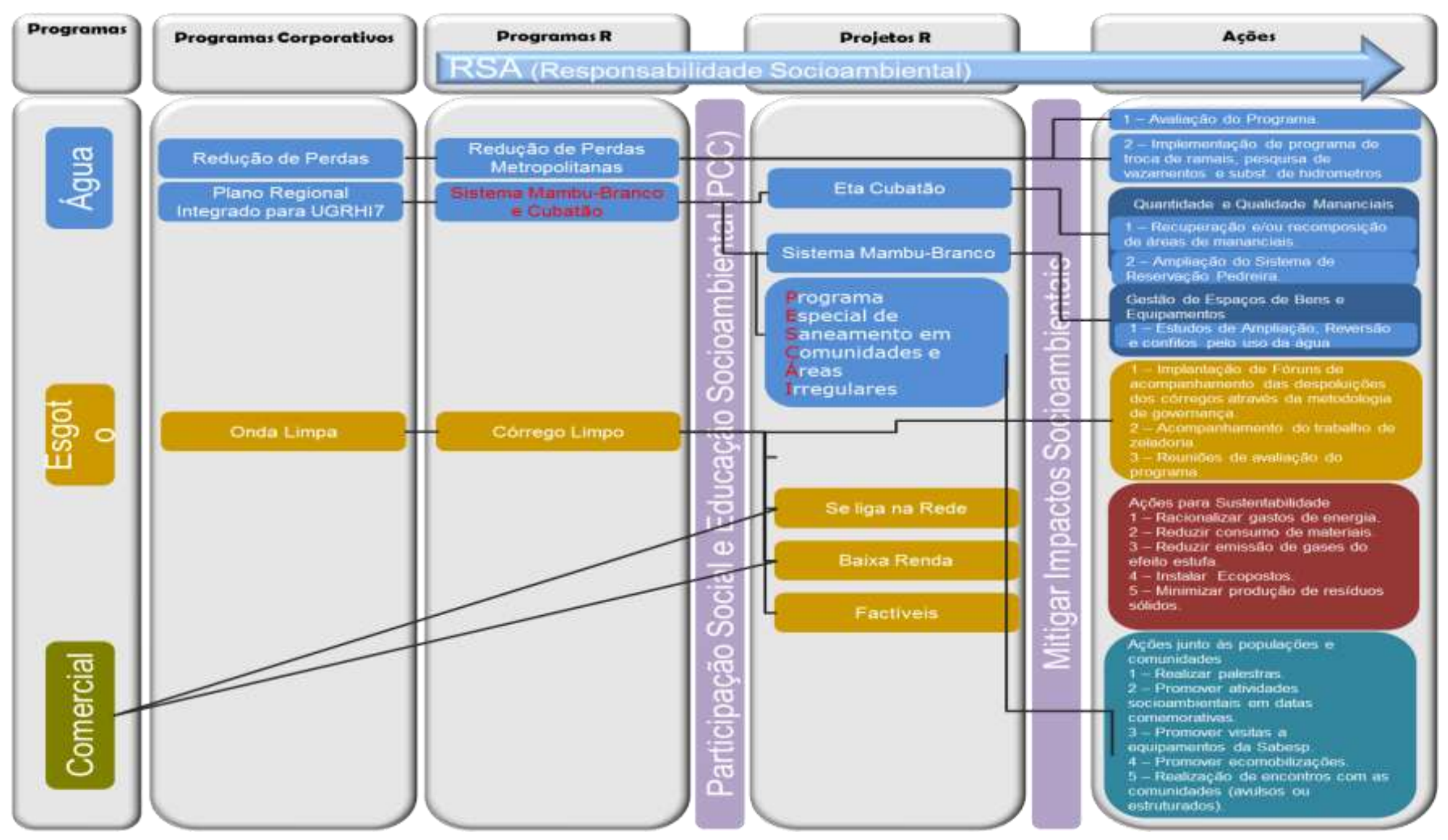

Elaboração: SABESP (2014)

Figura 37 - Planejamento Situacional da RMSP adaptado pela Diretoria de Sistemas Regionais para a RMBS 
No contexto social e de comunicação foram mobilizadas as lideranças comunitárias (associações) e os líderes de rua (moradores mais antigos), programadas reuniões com as lideranças e lideres antes do início das obras e abordagens de campo. Como material para comunicação foram adotados: duas faixas para colocar na comunidade em pontos estratégicos avisando que a concessionária estava atuando na área no assentamento e fazendo substituição de redes e ligações de água; panfletos para avisar a comunidade sobre as ações da concessionária:

Panfleto 1 - Aviso de obras

"A Concessionária está trabalhando nesta comunidade para melhorar o abastecimento, efetuar novas ligações de água, e negociar débitos. Um técnico da SABESP irá visitar sua casa para esclarecer dúvidas, fazer adesão de novas ligações e orientar quanto à negociação de débitos. No dia da vista o morador devia ter em mãos um documento de identidade e comprovante de residência (contrato de compra e venda, extrato bancário , carne de prestação, conta de luz e telefone)".

O panfleto 2 era deixado no imóvel caso o morador estivesse ausente no ato da visita:

"A SABESP esteve aqui para XXXXX, e pede que o morador entre em contato com o Sr. Agente Comunitário - fone $x x x x x$ ou se dirija ao plantão de atendimento na Rua XXXXX, Sede da Associação XXXX, no dia

A polo de comunicação programou com as lideranças as datas para realização de palestras sobre o uso racional da água, coincidindo com datas nas quais a comunidade já tinha eventos programados. Foi elaborado um calendário de eventos, com indicação dos responsáveis, data e endereço do local para cada atividade (Quadro 23).

Quadro 23 - Ações no Complexo Conceiçãozinha, Marezinha e Prainha

\begin{tabular}{|l|}
\hline Atividade de Comunicação Social \\
\hline Inicio das obras \\
\hline Colocação de faixas \\
\hline $\begin{array}{l}\text { Distribuição de panfletos informando a } \\
\text { visita da SABESP }\end{array}$ \\
\hline Abordagem porta a porta \\
\hline Plantão social na comunidade à tarde \\
\hline $\begin{array}{l}\text { Distribuição os panfletos-informando a } \\
\text { visita da SABESP }\end{array}$ \\
\hline Abordagem porta a porta \\
\hline Plantão social na comunidade à tarde \\
\hline
\end{tabular}


Como preparo para os eventos foram realizados levantamento dos débitos, ligações inativas com e sem débitos das comunidades listados por rua; relatório técnico social para montagem de dossiê; capacitação e preparo da equipe que atuou na comunidade. Com objetivo de fomentar atividades de geração de emprego e renda foram treinados alguns moradores pedreiros do bairro para instalar as caixas que abrigam os hidrômetros (unidades de medição - UMA) nos imóveis após Negociação com a liderança local.

\subsubsection{Planejamento Situacional - Santa Cruz dos Navegantes}

A comunidade possuía muitas ligações com débitos e inativas para re-supressão. No mapeamento dos líderes comunitários na área de palafitas identificou-se que as lideranças comunitárias cadastradas na comunidade tinham pouca inserção na área das palafitas. Foram realizadas: 1) vistas para identificar um morador que se destacava como líder para facilitar a inserção na comunidade, que é área de remoção, com grande concentração de palafitas e crime organizado; 2.) as mesmas ações do complexo; antecedidas de visitas aos moradores de Santa Cruz porta a porta após mapeamento de líderes levando informações sobre a concessionária e as obras que beneficiariam a comunidade; atualização cadastral; conclusão das obras de esgoto na comunidade; as ligações de esgotos factíveis foram vistoriadas dentro das ações do Ministério Público.

\subsubsection{Planejamento Situacional - Morrinhos 3 e 4}

Foi programada a mobilização de uma equipe para verificar o estado da rede em termos de vazamentos, pontos de contaminação e verificar a possibilidade de retirar os trechos onde a rede de água passa na galeria de água pluvial e situações de necessidade de remanejamento da rede água. Foram realizadas : regularização das áreas com assentamento precário; redução de Inativas; aumento do faturamento; redução de perdas físicas e aparentes; busca de ações para o esgotamento sanitário e tratamento de esgotos; melhoria na balneabilidade das praias.

Complementarmente, foram realizadas reuniões com a EMPLASA sobre o Plano de Ação da Macrometrópole - PAM para identificação da atuação do governo local no planejamento regional, os impeditivos do licenciamento ambiental em função das legislação e resoluções prévias a entrada da concessionária para implantação de redes e ligações. Foram realizadas reuniões com a Divisão Operacional de Guarujá 
da concessionária e Diretoria da Habitação da Prefeitura Municipal, líderes locais e da área de planejamento sociotécnico da diretoria da concessionária com a explanação dos objetivos de universalização dos aglomerados subnormais. A municipalidade informou que há um programa de reassentamento de unidades habitacionais em Santa Cruz dos Navegantes, onde 246 unidades habitacionais serão removidas da área de preservação ambiental. Havia previsão de contratação de projeto e construção de conjuntos habitacionais com licitação para em curso para licenciamento ambiental. Também foi realizada reunião com equipe da gerência de Cubatão nos mesmos moldes para atuação em Vila Esperança. O resumo das reuniões com providências e ações com as equipes da concessionária, poder concedente, lideranças comunitárias constam do Quadro 24.

Quadro 24 - Programação de ações pelos grupos em município exemplo

Reuniões com comunidade, concessionária, poder concedente e contratada levantamento qualitativo e providências

\begin{tabular}{|c|c|}
\hline $\begin{array}{c}\text { Natureza das } \\
\text { Ações e dos } \\
\text { Grupos MUNICÌPIO }\end{array}$ & $\mathrm{Na}$ \\
\hline & \multirow{3}{*}{$\begin{array}{l}\text { A proposta do evento foi incentivar a comunidade a aderir ao programa "Se liga } \\
\text { na Rede", pois segundo informações da Concessionária, o número de adesões } \\
\text { nesta comunidade está bem abaixo das expectativas. Para convidar os } \\
\text { moradores, foram fixas duas faixas na comunidade, a contratada disponibilizou } \\
\text { alguns profissionais para ajudar a distribuir panfletos de porta em porta e } \\
\text { realizar abordagem explicando o programa e falando sobre a importância da } \\
\text { adesão ao programa. Os técnicos da prefeitura que se comprometeram em } \\
\text { ajudar na convocação, infelizmente não tiveram a atuação esperada, } \\
\text { mostrando baixa capacidade de mobilização. }\end{array}$} \\
\hline $\begin{array}{l}\text { Comunidade Sá } \\
\text { Catarina, Sec. da } \\
\text { Habitação, } \\
\text { Concessionária }\end{array}$ & \\
\hline 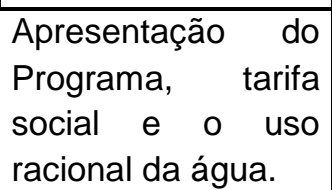 & \\
\hline $\begin{array}{l}\text { ções } \\
\text { rogram }\end{array}$ & $\begin{array}{l}\text { ero de ligações clandestinas, inadimplência, fraudes, consumo. } \\
\text { o deliberado sem um processo de conscientização pode ter } \\
\text { ivo e o não reconhecimento do benefício por parte da }\end{array}$ \\
\hline $\begin{array}{l}\text { ANTOS } \\
\text { omunida } \\
\text { oncessic } \\
\text { restador }\end{array}$ & \multirow{2}{*}{$\begin{array}{l}\text { Reunião programada com a comunidade, as Secretarias da Prefeitura de } \\
\text { Santos - SEMAM e SEHAB da PMS explanação dos Programas, com a } \\
\text { presença da equipe da Concessionária Informaram que a comunidade não } \\
\text { costuma se reunir e que é muito fragmentada, exceto pelas lideranças } \\
\text { informais. A única associação do bairro tem como Presidente, um Vereador } \\
\text { que é adversário político da atual gestão As demandas apresentadas pela } \\
\text { comunidade foram anotadas e encaminhadas. }\end{array}$} \\
\hline $\begin{array}{l}\text { Aprese } \\
\text { Pro }\end{array}$ & \\
\hline $\begin{array}{l}\text { TÃO } \\
\text { com as } \\
\text { s sociais } \\
\text { lor Social }\end{array}$ & $\begin{array}{l}\text { As assistentes sociais da prestadora e a pesquisadora entrevistaram } \\
\text { moradores da comunidade Vila Esperança na casa de apoio local da } \\
\text { contratada (COBRAPE) pela concessionária. As assistentes sociais } \\
\text { acompanharam as primeiras remoções para o conjunto habitacional Imigrante, }\end{array}$ \\
\hline
\end{tabular}




\begin{tabular}{|c|c|}
\hline $\begin{array}{l}\text { lomunidade } \\
\text { Vila Esperança } \\
\text { grupo focal de } \\
\text { lideranças } \\
\text { comunitárias r e } \\
\text { assistentes sociais } \\
\text { locais. }\end{array}$ & a atuação identificou-se lideranças e a \\
\hline 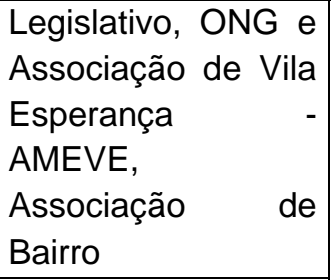 & \multirow{2}{*}{$\begin{array}{l}\text { As lideranças presentes falaram que a comunidade de Vila Esperança é de } \\
\text { fácil mobilização, reforçaram a necessidade de se fazer uma ampla campanha } \\
\text { educativa, e disse que a SABESP precisa ir até a comunidade se realmente } \\
\text { deseja negociar os débitos e convencer os moradores que possuem ligações } \\
\text { irregular, se regularizarem. A presença da empresa fisicamente é muito } \\
\text { importante. Os lideres presentes sugeriram a realização de eventos, que eles } \\
\text { chamaram de movimento da água. A programação previu a realização de } \\
\text { palestras de orientação, apresentação de vídeos, oficina de artesanato, } \\
\text { organizada junto com a comunidade, apresentação do grupo de capoeira e do } \\
\text { coral da ONG Cubatão de Bem Estar com o Mangue, além da presença da } \\
\text { agência móvel para facilitar a negociação de débitos de demais serviços } \\
\text { comerciais. }\end{array}$} \\
\hline $\begin{array}{l}\text { Conhecer } \\
\text { lideranças locais } \\
\text { estabelecer } \\
\text { parceria para } \\
\text { mobilização }\end{array}$ & \\
\hline $\begin{array}{l}\text { Reunião gestores } \\
\text { com área de } \\
\text { comunicação }\end{array}$ & \multirow{2}{*}{$\begin{array}{l}\text { Projeto Arte no Dique, uma ação social que a Concessionária apoia em Santos. } \\
\text { O Instituto Arte no Dique, organização não governamental, sem fins lucrativos, } \\
\text { desenvolve trabalho sociocultural com a população do Dique da Vila } \\
\text { O projeto tem como proposta a realização de ações, oficinas e cursos } \\
\text { profissionalizantes, regidas pelos princípios da inclusão social, pesquisa e } \\
\text { valorização da cultura local, aquisição de conhecimentos específicos do mundo } \\
\text { da arte e cultura. A SABESP para fomentar melhorias nas condições de } \\
\text { saneamento às comunidades da região apoiará o projeto. }\end{array}$} \\
\hline & \\
\hline $\begin{array}{l}\text { Reunião na } \\
\text { Comunidade Vila } \\
\text { Esperança }\end{array}$ & \multirow{2}{*}{$\begin{array}{l}\text { O evento contou com a presença de mais de } 100 \text { pessoas. No local havia } \\
\text { muitas crianças. Na ocasião o Sr. Zumbi, presidente da ONG Bem-Estar com o } \\
\text { Mangue distribuiu cestas básicas para famílias carentes, doadas por entidades } \\
\text { parceiras e brinquedos para as crianças. Aproveitando a ocasião e o momento } \\
\text { festivo, a SABESP foi apresentada como parceira para ouvir, orientar e agilizar } \\
\text { os encaminhamentos das demandas locais. Realizar ações de sensibilização e } \\
\text { educação ambiental. }\end{array}$} \\
\hline $\begin{array}{l}\text { oncessionária, } \\
\text { deranças locais e } \\
\text { munidade de Vila } \\
\text { sperança }\end{array}$ & \\
\hline
\end{tabular}

Elaboração: SABESP (2014)

A concessionária Identificou que a abordagem direta com a comunidade foi menos eficiente que a identificação de líderes locais que por meio deles se estabelece canais de mobilização e o planejamento depende de articulação com parceiros públicos, privados e sociedade civil para ser efetivo e produza resultados. A ausência de um procedimento dificulta o progresso das ações e resultados. 


\subsection{PROCEDIMENTOS ORGANIZACIONAIS E TEORIA ATOR-REDE}

Previamente a concessionara conceituou áreas de risco para um procedimento específico, como áreas ou locais que convivem com tráfico de drogas, moradores armados, ameaças físicas aos agentes de cobrança, domínio de grupos / facções criminosas, situações que podem colocar em risco a vida dos profissionais da SABESP e das contratadas de cobrança, para atividades não aceitas pela população local, tais como: cobrança administrativa, suspensão do abastecimento de água e cobrança judicial. estas áreas normalmente se assemelham aos locais de favelas, que se caracterizam por construções em madeira e/ou de alvenaria. $\mathrm{O}$ procedimento foi adaptado em uma oficina com a participação de gestores técnicos e comerciais, e agentes comunitários baseado em material pré-existente da Diretoria Metropolitana (benchmarking da unidade de negócio norte) ao contexto da Diretoria de Sistemas Regionais com ajustes de conteúdo apoiados na metodologia proveniente do mapa de controvérsias. Nesse sentido, a padronização dos trabalhos para as ações de universalização junto às áreas de vulnerabilidade social foi apoiada nas melhores práticas intra-organização.

\subsubsection{Objetivo}

Os objetivos estratégicos do BSC previamente identificados e aderentes ao contexto eram: contribuir para universalização do saneamento; contribuir para melhoria da imagem da empresa; contribuir para o maior efetividade do programa de perdas; contribuir com incremento de receita; contribuir com a despoluição dos corpos d'água; contribuir para a ampliação da visão empresarial de empreendedorismo socioambiental.

O programa de participação comunitária tem como objetivo identificar, analisar e atender as necessidades da comunidade, por meio procedimentos, reuniões, visitas e construção de parcerias entre entes que visem atender o planejamento e atuação em atendimento aos objetivos empresariais.

\subsubsection{Procedimento segundo a natureza das ações}

Como ações que caracterizam os arranjos sociotécnicos para a solução das controvérsias: visitação técnica/social, identificar necessidades das comunidades e 
buscar solução conjunta para o seu atendimento; realizar diagnósticos sociais, intermediando ações de planejamento e sua efetivação operacional; adequar cadastro - atualizar o cadastro de categoria residencial normal para social; propor a regularização de ligações de água, através de mutirão; estas visitas podem acontecer na ocorrência de chamado, na manifestação da empresa ou por solicitação externa.

As ações de mapeamento de áreas irregulares são: identificar áreas passíveis ou não de regularização; levantar número de domicílios; encaminhar áreas para cadastro no sistema; propor e acompanhar o processo de regularização do saneamento; monitorar o adensamento das áreas.

As ações de regularização das condições de saneamento são: pedir a elaboração de estudos e projeto de água e esgoto, levantar e identificar ligações inativas e débitos; identificar os imóveis que se enquadram em tarifa social; coletar documentos para realizar as novas ligações de água; propor a regularização das ligações de água, através de mutirão; acompanhar assentamentos de rede, ligações domiciliares, apuração de consumo; monitor as áreas pós-prolongamentos de rede; adequar cadastro- atualizar o cadastro de categoria residencial normal para social, fazer a setorização e instalação de medidores de vazão na comunidade; promover ações de educação Ambiental, acompanhar as áreas onde ocorreram regularizaçõesavaliação de inadimplência, reincidência de ligações irregulares; cadastro de tarifa social e indicadores de perdas. Deve-se promover encontros com todas as comunidades do município, com objetivo de aproximação para estabelecer e manter fortes elos de parceria entre a concessionária e população em áreas de vulnerabilidade socioambiental, promovendo levando-os à alta administração. Devese adotar questionários para avaliar a qualidade dos serviços, os mecanismos de inclusão, e o nível de satisfação dos usuários/cidadãos; identificar necessidades; informar sobre andamento de obras, programas, reservando tempo para perguntas e debates.

Deve-se promover reuniões com atores-rede e participar de reuniões com os Conselhos de Segurança - CONSEG, presidentes de associações de moradores de bairro, agentes municipais, concessionárias de outros serviços públicos, e agentes da saúde, a partir de necessidades específicas, solicitação externa da comunidade 
para esclarecimento de um serviço ou solicitação pendente. Devem participar dessas reuniões técnicos comunitários responsáveis pelas gerências e colaboradores das áreas funcionais envolvidas, quando necessário.

Deve-se promover reuniões de educação ambiental com objetivo de informar e esclarecer sobre cuidado ao meio ambiente, importância do tratamento de água e esgotos, prevenção de doenças de veiculação hídrica, uso racional da água, condições de inclusão na tarifa social, e adequação da água para consumo em regiões ainda não abastecidas pela rede oficial, entre outros. Devem ser programadas ou atendem solicitações da comunidade através de ofícios à superintendência da UN, departamento comercial ou coordenação comunitária. Nestas reuniões devem ser disponibilizados materiais didático: folhetos e filmes educativos.Deve-se garantir atendimento diferenciado de lideranças comunitárias, comissões de moradores, técnicos de governo e autoridades locais. E promover a integração entre associações de moradores, lideranças comunitárias, técnicos de governo e autoridades locais com a concessionária, buscando estabelecer um canal aberto de comunicação com a comunidade, conhecer suas necessidades, ouvir sugestões e opiniões sobre os serviços prestados. $O$ atendimento a clientes estratégicos deve ser prioridade e toda a unidade gerencial deve estar envolvida para resolver com agilidade os problemas e dúvidas apresentadas.eve-se promover Reuniões de Articulação com técnicos de governo e participar de reuniões para contribuir ou encaminhar demandas, exemplo: Programa Litoral Sustentável, Pré-sal, Programas de Aceleração do Crescimento - PAC e outros. Deve-se realizar mutirões para negociação de dívidas e possibilitar que usuários com dificuldades de pagamento possam negociar dívidas, aplicando deliberações de diretoria (DD) para usuários de baixa renda ou desempregados. Deve-se realizar recadastramento periódico por meio de visitas às áreas, com o objetivo de identificar a liderança comunitária e nome da comunidade, quantidade de moradias, pessoas e condição socioeconômica para atualização do banco de dados.

Deve-se promover encontros com caráter didático, com recursos audiovisuais, participativos e pré-agendados e procurar reunir todas as lideranças na área de atendimento da gerência. 


\subsubsection{Procedimento segundo a natureza dos fatos}

Deve-se prover dados para os sistemas de gestão dos indicadores como instrumentos de mensuração das atividades realizadas pelo Programa de Participação Comunitária para identificar os melhores parâmetros a fim de aferir os resultados das práticas. Adequar ações e para avaliação das mudanças comportamentais do cidadão atendido, apoiado em indicadores, identificando avanços e necessidades de mudança através de instrumentos de gestão, que auxiliaram no acompanhamento do alcance dos programas para as populações de baixa renda. Relação de dados e ações nos Quadros 25 e 26 define-se o procedimento segundo a natureza dos fatos, que se refere às definições da Figura 17 com a Cartografia das Controvérsias Sociotécnicas do Modelo de Gestão e das incertezas da universalização inclusiva na Tabela 5. Como atividades de suporte ao planejamento e gestão deve-se realizar diagnóstico através do levantamento dos dados obtidos nas fontes oficiais: sistema comercial de Informações; sistema de Informações Geográficas no Saneamento; base de dados da Fundação SEADE; Programa Saúde Familiar - PSO Indica Paulista de Vulnerabilidade social - IPVS; levantamento da situação do abastecimento de água, esgotamento sanitário e tratamento de esgoto para a comunidade em estudo; e dados do Sistema de planejamento da EMPLASA/AGEM

Quadro 25 - Natureza dos fatos - ligações

Número de domicílios subnormais

Número de ligações RGI em uma área após a ação social;

Número de ligações irregulares e/ou clandestinas transformadas em regulares;

Número de ligações inativas reativadas;

Índice de Universalização Inclusiva: dado pela cobertura da rede e pela ampliação da abrangência da mesma. (em vielas e favelas); 
№ de acordos para pagamento e/ou renegociação de dívida. (tem que haver um instrumento para acompanhar a evolução das negociações na área comercial);

Total anual e diminuição da inadimplência em uma área de trabalho social;

Adequação da tarifa as condições sociais dos clientes;

Aumento de volume da água faturado por $\mathrm{m}^{3}$;

Aumento de valores no faturamento;

Redução de perdas.

\subsubsection{Procedimento segundo a natureza das ciências sociais}

Os procedimentos que fundamentam os arranjos sociotécnico na relação sociedade e meio ambiente nos mecanismos de reconciliação das controvérsias para atingimento da universalização em áreas vulneráveis, em regime de eficiência técnica e eficácia social. como: redução de perdas em uma determinada área de atuação e melhora no índice de abastecimento local e regional; diminuição de consumo por ligação em uma área de atuação; quantificação da participação de beneficiários, em relação ao total de envolvidos, em ações realizadas em mutirão (demonstra envolvimento pessoal/compromisso); número de pessoas beneficiadas pelo incremento do número de ligações ou da cobertura de uma ampliação de rede; Número de pessoas participantes em eventos; Diminuição das desobstruções de rede e de coletores.

Os procedimentos de natureza social tem-se: identificação e cadastramento de lideranças comunitárias; número de lideranças que participam de eventos; número de atendimento de lideranças; número de pessoas participantes em eventos programados. número de visitas de técnicos às comunidades; número de ações desenvolvidas em cada programa socioambiental, e grau de satisfação da população em uma ação e/ou programa. A medição da efetividade prevista no plano situacional e PNI ocorre pelo procedimento para a governança inclusiva (Quadro 27 e 28). 
Quadro 27 - Natureza das ciências sociais - governança

Índice de Governança Inclusiva - garantia do cumprimento das funções do poder concedente, SABESP, Ministério Público e entidades governamentais, por meio de instrumentos institucionais com atribuições e competências claras e detalhadas de todos os atores para a universalização inclusiva dos serviços de saneamento:

Levantamento periódico e permanente das populações,

Planejamento participativo periódico,

Programa de universalização dessas áreas amplo e contínuo,

Recursos orçamentários empenhados,

Análise dos resultados positivos e negativos,

Realimentação do processo.

Quadro 28 - Natureza das ciências sociais - planejamento situacional

Analisar, identificar e definir ações clara para problemas;

Conhecer a situação social, política e econômica das realidades locais;

Considerar o impacto e força dos diferentes aspectos que se relacionam com os problemas levantados;

Definir território/área de atuação;

Definir metas de atendimento.

\subsubsection{Procedimento segundo a natureza das ciências naturais}

Os procedimentos que promovem as obras de engenharia estão apoiados inicialmente na elaboração e revisão anual do plano de negócios metropolitano dos SAAES das cidades formais da Baixada Santista tem por objetivo promover a universalização inclusiva, que é o processo realizado pela concessionária em parceria com os demais segmentos da sociedade e com a poder concedente para atender toda a população da cidade informal, por meio de ações integradas, para que a população residente em áreas irregulares tenha acesso ao saneamento básico. As consequências dessas ações se refletirão na diminuição da incidência de problemas de saúde e de impactos ambientais. 
Este plano documenta e apresenta informações que subsidiam o planejamento (Quadro 29), metas e indicadores para a universalização dos serviços públicos de saneamento básico em áreas favelizadas e assentamentos, podendo ser áreas regulares ou irregulares, que fazem parte da cidade informal do município de Guarujá. Compõem dentre outras, as informações:

Quadro 29 - Componentes do plano de negócio

Projeção de demanda por serviço (água e esgoto) para as comunidades;

Categorias de usuários das comunidades;

Quantidade de usuários: ligações e economias das comunidades;

Níveis de consumo: volumes consumidos, coletados, faturados para as comunidades;

Projeção da oferta: perdas, necessidade de produção, capacidade dos sistemas, dimensionamento dos sistemas de coleta e tratamento de esgoto;

Indicadores;

Planejamento de custos operacionais e receitas;

Plano de expansão da oferta: investimentos consistentes com a demanda projetada para as Comunidades;

Plano de desenvolvimento da empresa para as áreas de assentamentos precários e de exclusão social: eficiência produtiva, qualidade dos serviços, atendimento ao usuário, etc.

Elaboração: a autora (2015)

Outros procedimentos estão nas atividades de serviços técnicos.

As solicitações de serviço, revisões de contas e acertos cadastrais encaminhadas pelo técnico comunitário devem ser acatadas como prioridade pelo setor comercial ou operacional. $O$ quadro de funcionário e equipamentos devem ser dimensionamento para formação de uma equipe voltada para 0 atendimento das demandas.

É importante destacar que o conjunto de atividades descritas tem interface entre diversas áreas da empresa, fazendo as ligações que estabelecem interfaces intraorganização da figura da cartografia da universalização como: o setor comercial, operacional, financeiro. Com esta proposta e estrutura, procura-se atender as 
diretrizes estratégicas, que visam: desenvolver mecanismos que possibilitem diagnosticar e atender demandas de saneamento ambiental, com foco na área social, monitorando e avaliando resultados por meio de Indicadores de: satisfação dos clientes, saúde pública, ambiental e socioeconômicos; promover a participação e envolvimento do corpo gerencial, de modo que os aspectos sociais permeiem todas as ações desde o estudo de concepção até a pós-implantação dos sistemas; articular parcerias internas e externas para desenvolver ações que melhorem a qualidade de vida da população e promovam o saneamento ambiental; promover, conjuntamente, ações preventivas de saúde e meio ambiente que estimulem a conscientização da população; criar instrumentos que valorizem os produtos e serviços prestados pela concessionária; e incentivar o exercício da cidadania nas questões de saneamento ambiental. São eles: flexibilização das regras comerciais, competências e aplicabilidade, tratamento de débitos, elaboração de dossiês e aprovações, por situação ou por comunidade atendida, adequação do faturamento, carta de caráter precário ou acionamento do centro de cidadania.

\subsection{AVALIAÇÃO DA ESTRUTURA ORGANIZACIONAL}

A concessionária adota uma estrutura organizacional que considera a gestão ambiental, atuando como autoridade funcional por meio de superintendência alocada em diretoria técnica, com agentes ambientais nas unidades de negócio em atividades diversas junto a comitês de bacias e atuação sobre temas de recursos hídricos e meio ambiente. Também há um departamento social na superintendência de recursos humanos, responsável pelos programas filantrópicos da organização como: campanhas anuais do agasalho do governo do estado e muitas atividades de educação ambiental, demonstrando as melhores práticas integrando nas atividades de gestão tais enfoques. Conforme diversos autores (Llerena, 1996; Faucheux et al., 1997; Donaire, 1999; Garrod \& Chadwick, 1996) é necessário estrutura centralizada e específica para atender uma estratégia empresarial socioambiental das grandes organizações empreendedoras.

No entanto, o diagnóstico demonstra atuação descoordenada de atividades socioambientais para atuação em setores de baixa renda, cujos objetivos possam alcançar a universalização e governança inclusiva, conforme o apresentado no diagnóstico de Nadler e mapa da cartografia das controvérsias de Latour, resultado 
das oficinas com gestores. Nesse sentido, a estrutura proposta deve garantir prospecção e inovação para atender as estratégias empresariais que respondam com competitividade e inovação de processos os desafios das áreas de vulnerabilidade social das metrópoles (Godard, 1993; Porter \& Van Der Linde, 1995). Os autores asseguram, melhorias no desempenho ambiental e em outros critérios como os sociais, que afetam o negócio. A estrutura deve refletir o equacionamento das controvérsias conforme Quadro 30.

Quadro 30 - Estrutura organizacional proposta

Uma autoridade funcional de Superintendência para governança inclusiva com equipe multidisciplinar locada na Diretoria Técnica, formada por 4 departamentos:

Departamento econômico-financeiro com a atribuição de elaborar e consolidar os planos de negócio da cidade Informal das áreas metropolitanas e alavancar recursos não onerosos para investimentos e mecanismos de subsídios em contas específicas para cobertura dos custos de operação por arranjos inovadores.

Departamento técnico com a atribuição de contratar um programa contínuo, projetos e obras para as áreas favelizadas.

Departamento social com a atribuição de estabelecer um programa empreendedorismo em parceria com grande empresas de produtos e serviços para promover a universalização inclusiva por arranjos sociais.

Departamento jurídico com atribuição de alavancar os balcões de mediação em parceria com centros de cidadania da secretaria da justiça para superar os impedimentos aos serviços públicos essências de atender direitos fundamentais e desenvolvimento de concessões patrocinadas

Elaboração: a autora (2015)

O mapa de controvérsias da metodologia ANT construído nas oficinas (Quadro 31 e Figura 38), subsidia atribuições e competências que promovam o atendimento às áreas de vulnerabilidade socioambiental dos Quadros 30, 31 e 32.

Quadro 31 - Componentes da equipe

Uma equipe multidisciplinar locada na diretoria de operação, formada por dois analistas .

Uma equipe multidisciplinar locada na superintendência, formada por um gestor-, podendo ser uma analista com salário superior a de um encarregado ou supervisor e dois Técnicos em Gestão;

um ou dois Técnicos Comunitários por município. A quantidade pode variar de acordo com o número de ligações ou quantidade de população de baixa renda. 


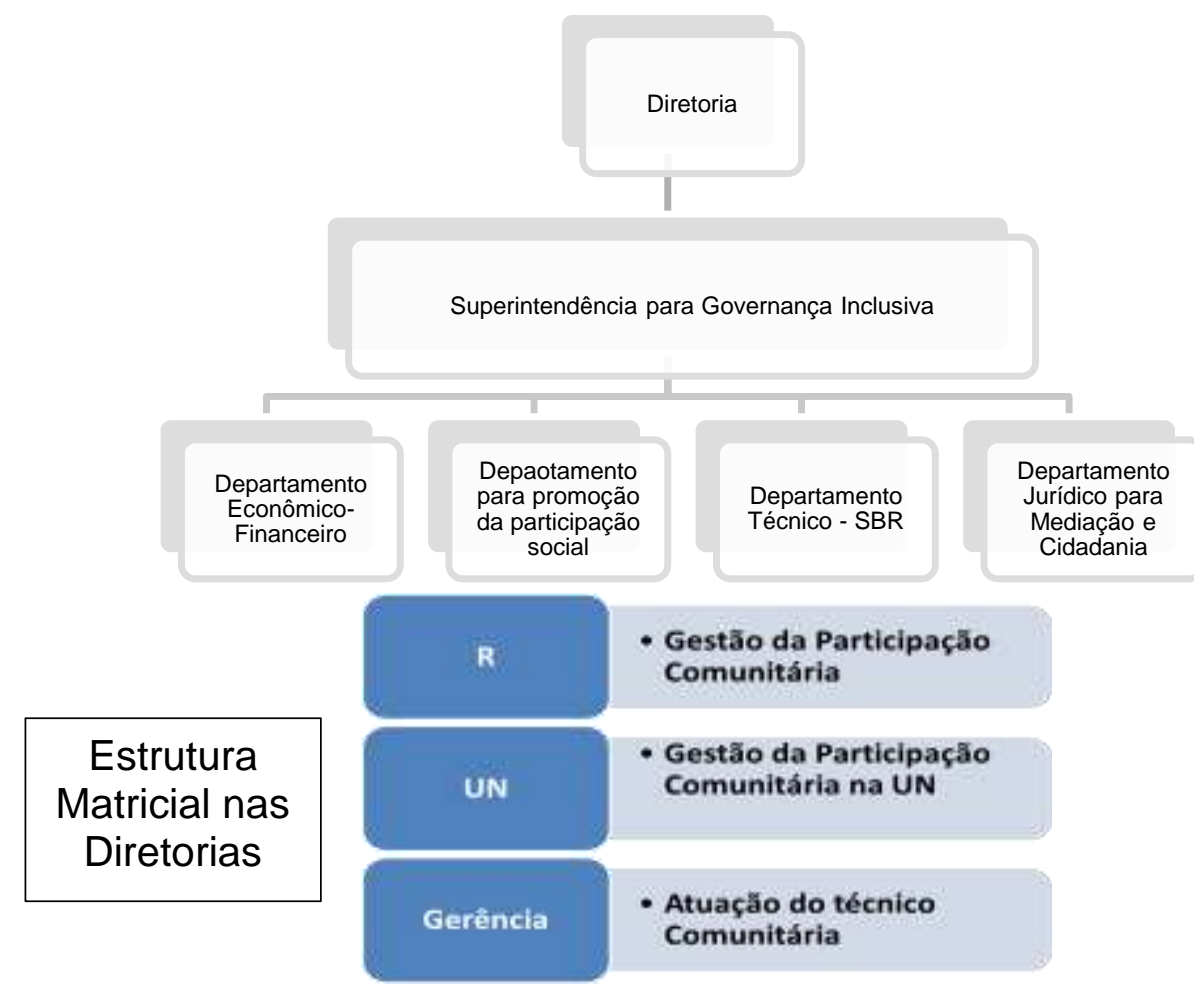

Elaboração: a autora (2015)

Figura 38 - Estrutura organizacional do equacionamento da controvérsia

\subsubsection{Atribuições e competências}

O Agente alocado na UN terá como atribuição: formular propostas e planejar as ações operacionais de participação comunitária no âmbito da sua área de atuação; assegurar a aplicação das diretrizes visando à uniformidade das ações nas UNs; manter interface com outras diretorias; e definir Indicadores, acompanhar e avaliar os resultados das ações.

Os profissionais alocados nas diretorias de operação, terão por atribuição: planejar as ações no âmbito da diretoria considerando as diretrizes estabelecidas no planejamento; formular projetos e propostas metodológicas em conjunto com gerencias dos municípios; acompanhar os trabalhos desenvolvidos nos municípios e sistematizar os relatórios das ações comunitárias da UN; identificar necessidades e planejar o treinamento dos técnicos da UN.

Os técnicos têm por atribuição desenvolver as atividades previstas em procedimento, de acordo com o planejamento das UNs, com as características do 
empreendedorismo social (Quadro 32). Na superintendência, a subordinação da estrutura proposta deve-se contemplar um departamento de planejamento inclusivo com o objetivo de viabilizar as informações, as metas definidas e os resultados a serem obtidos, bem como atender o leque de demandas da sociedade e propostas da diretoria e matricial à autoridade funcional, conforme com procedimentos metropolitanos da organização.

\section{Quadro 32 - Características Pessoais}

\begin{tabular}{|l|}
\hline Empreendedor \\
\hline Ser comprometido com a Universalização \\
\hline Ser comunicativo / habilidade para falar em público; \\
\hline Proativo; \\
\hline Visão sistêmica \\
\hline Visão político-social / sensibilidade para questões sociais; \\
\hline Habilidade para se relacionar em vários níveis; \\
\hline Articulador; \\
\hline Mediador com habilidade para lidar com situações de conflito; \\
\hline Facilidade de redação; \\
\hline Facilidade para exposição de ideias; \\
\hline Habilidade para elaboração de diagnósticos; \\
\hline Planejamento e organização; \\
\hline Flexibilidade de horário; \\
\hline Saber ouvir e compreender a demanda; \\
\hline
\end{tabular}

De preferência, os profissionais devem ocupar o cargo de técnico de gestão ou saneamento, uma vez que atualmente a estrutura de cargos e salários não permite alterações ou a criação de novos cargos. 
O Agente Comunitário foi definido como profissional de nível técnico, que deve atuar como interlocutor entre concessionária e comunidades com objetivo de promover a universalização do saneamento básico em áreas de vulnerabilidade socioambiental (Quadro 33), reduzindo as barreiras de entrada, por meio de um atendimento inovador, garantindo externalidades positivas sobre a vida e meio ambiente, garantindo a satisfação do usuário/cidadão, a eficiência técnica e a eficácia social por meio de atos de inclusão.

\section{Quadro 33 - Atribuições do agente comunitário}

Garantir o relacionamento da concessionária com a comunidade, atuando de forma local, conhecendo e recebendo suas demandas e mantendo um vínculo permanente de confiança.

Promover a mobilização social através de tecnologias sociotécnicas como a mediação de conflitos,

Facilitar a implantação e manutenção de redes de água e esgoto;

Disseminar a cultura de uso correto das redes de esgoto e a redução de prestação de serviços devido obstrução, refluxo e extravasamentos de esgotos

Contribuir para a inserção social através de regularização de abastecimento em núcleos de baixa renda e/ou projetos;

Sensibilizar a comunidade para o exercício da cidadania (diretos e deveres da SABESP e do cidadão).

Aprimorar o processo de articulação junto aos profissionais das prefeituras locais, entidades governamentais e não governamentais para buscar melhorias nas condições ambientais e de saúde da população local e regional;

Apoiar ações de saneamento desenvolvidas pelas unidades operacionais da UN Baixada Santista, através da sensibilização ambiental da população, para o incremento do aumento da cobertura de redes, regularização das condições de abastecimento de água; coleta e disposição final de esgotos e redução de perdas, nas áreas autorizadas pelas prefeituras e que não sejam objeto de ação do Ministério Público.

Dar suporte as ações de planejamento e operacionalidade disseminando a importância do uso racional da água, uso correto das redes coletoras, doenças causadas por veiculação hídrica, controle de perdas, desperdício de água e regularizações comerciais.

Elaboração: a autora (2015)

O traço fundamental que diferencia a atividade do técnico comunitário da atividade do técnico de gestão é a capacidade de mediação existente para controvérsias entre concessionária, poder público e comunidades, possibilitando a análise das singularidades locais e a construção participativa de micropolíticas que possam 
convergir para a universalização. Devem contribuir para a inserção social da população, promovendo o resgate da cidadania, a integração entre a racionalidade e os saberes para a universalização do saneamento em áreas de vulnerabilidade socioambiental.

O agente comunitário é promotor de um modelo singular, produzido mediante construção conjunta sanitarista-usuário. Ocorrerá por considerar o contexto, o modo de vida do usuário, as possibilidades de interagir, o que ampliará as possibilidades de atuação do sanitarista em atos de saneamento, evidenciando a relevância da universalização inclusiva. Deve avaliar a singularidade do usuário em termos de local, forma de vida, crenças e outros fatores que habitualmente não são considerados. Devem auxiliar as concessionárias a deslocarem a centralidade do saneamento da rede para o usuário, operando em planos em que o modelo organizativo da gestão considere todos os saberes que contribuam para a universalidade. Finalmente, deveram contribuir na tarefa de dar sentido a cada usuário daquilo que não é evidente (JULIANO ET. AL, 2012).

Considerando que os agentes comunitários exercem suas atividades rotineiras em áreas de risco, há mérito na inovação da política de recursos humanos. O adicional de periculosidade, previsto em norma regulamentadora do Ministério do Trabalho, é devido a profissionais que exerçam atividades de risco acentuado com exposição permanente de segurança pessoal ou patrimonial. Como exemplo, profissionais de escolas paulistas que estejam em regiões detectadas como vulneráveis pelo IPVS, desenvolvido pelo Seade (Fundação Estadual de Análise de Dados) recebem adicionais de periculosidade: $20 \%$ sobre o salário para os professores e $10 \%$ para servidores do quadro de apoio, como inspetores.

Até a presente data o cargo de Agente Comunitário não havia sido criado no Plano de Cargos e Salários da Concessionária. Os chamados "Agentes Comunitários" são técnicos de gestão.

\subsubsection{Recursos para equipe sociotécnica}

Para implementação da atendimento social do programa foi definido um Kit de trabalho com custos de aquisição: máquina fotográfica; veículo locado para 
utilização dos técnicos comunitários; telefone móvel; equipamentos de multimídia data show, tela de projeção, etc.; notebook com acesso a internet e aos sistemas comerciais da empresa; caixas de som e microfones; coletes apropriados para trabalho em campo; material de divulgação definidos no PNI.

\subsubsection{Diretrizes de atuação}

Por diretrizes foi determinado: criar instrumentos que valorizem os produtos e serviços prestados pela companhia; desenvolver mecanismos que possibilitem diagnosticar e atender demandas de saneamento socioambiental com foco nas áreas vulneráveis, monitorando e avaliando resultados por meio de indicadores de universalização inclusiva, governança e externalidades, incentivar o exercício da cidadania nas questões de saneamento ambiental, articular parcerias internas e externas para desenvolver ações que possam melhorar a qualidade de vida da população e promover o saneamento ambiental; promover ações de meio ambiente e saúde preventiva que estimulem a conscientização da população; desenvolver ações visando à elevação do nível socioeconômico, à qualidade de vida das famílias e a sustentabilidade dos empreendimentos por meio da inclusão na cadeia de valor; promover a participação e envolvimento do corpo gerencial, consolidando a estrutura da participação comunitária, de modo que os aspectos sociais permeiem todas as ações desde estudos de concepção a implantação de redes e serviços da UN.

\subsection{CONCLUSÃO DO MODELO DE GESTÃO PARA SBR}

Onde as incertezas entrelaçam-se, a eficiência da gestão e eficácia social e efetividade ambiental são determinadas na tomada de decisão, importante fator da gestão.

Assim, alguns dos argumentos apresentados por Morrison et al. (2006) a favor dessa integração incluem melhoria da coerência e eficiência das ações, diminuição da guerra entre os três pilares (social, ambiental e econômico), ajuda na identificação de soluções win-win, favorecimento de uma melhor identificação e documentação dos efeitos indiretos e sinérgicos que resultam de ligações entre impactos ecológico, social e econômico.

Controvérsias surgidas durante o processo de tomada de decisão são cada vez maiores e acentuam-se nos países em desenvolvimento econômico acelerado, 
confrontando os pilares da sustentabilidade com fatos e realidades.

Como os diferentes atores dos processos decisórios são requisitados a responder diante de riscos, danos, resiliência e adaptações de populações e ecossistemas?

Segundo Bruno Latour, o processo de tomada de decisão, num mundo de controvérsias, implica em escolhas e limitações éticas quanto à intervenção efetiva sobre sistemas e a vida dos cidadãos.

Para Dupuy, a lógica da decisão perpassa pelo custo aceitável. O que significa na prática que: a incerteza estabelecida permite adoção de medidas técnicas proporcionais, portanto há um dilema da engenharia ambiental - o custo aceitável. Ele está em um prato da balança, apoiada na teoria da decisão dos anos 50 , que não permite capturar a justa medida da incerteza confrontada a ser colocada no outro prato da balança pela engenharia ambiental. A incerteza estabelecida permite adoção de medidas técnicas proporcionais.

É fundamental deslocar o contexto da gestão urbana provenientes do uso e ocupação do solo para o contexto do risco, como a produção de vida ambientalmente insustentável, mecanismos de exclusão de rede na provisão de serviços públicos e consumo e danos ambientais caracterizam essas questões, conferindo risco às populações vulneráveis, mas também à gestão.

A falta de provisão de serviços de água e saneamento é o primeiro sinal de vulnerabilidade de uma população (Juliano, 2013), sendo que quanto mais pobres, mais correrão riscos, mais serão afetados por danos e menor será sua capacidade de se protegerem e se recuperarem de danos ocorridos.

A indefinição da estratégia e a gestão empresarial para atuação nas áreas de assentamentos precários confere riscos à organização de ordem ambiental (perdas físicas), econômicas (perdas comerciais) e social afetando a resiliência da organização, do meio ambiente e da sociedade.

Segundo Dupuy (2003), o risco é um monstro que merece um tratamento, cujo princípio da precaução é incapaz de conferir. Afirma ainda que o desaparecimento da resiliência do ecossistema é um alarme de que já é tarde demais, sendo que quando se está longe dos limites, permite-se transitar nos ecossistemas com total impunidade. Um estudo de viabilidade coloca num prato da balança custo e no outro prato "incertezas" (Figura 39).

Como um ponto cego da retina, na gestão socioambiental um axioma da lógica 
epistêmica, não pode contar com a sorte moral.

O desafio da estratégia é preencher o outro prato com pesos de equilíbrio.

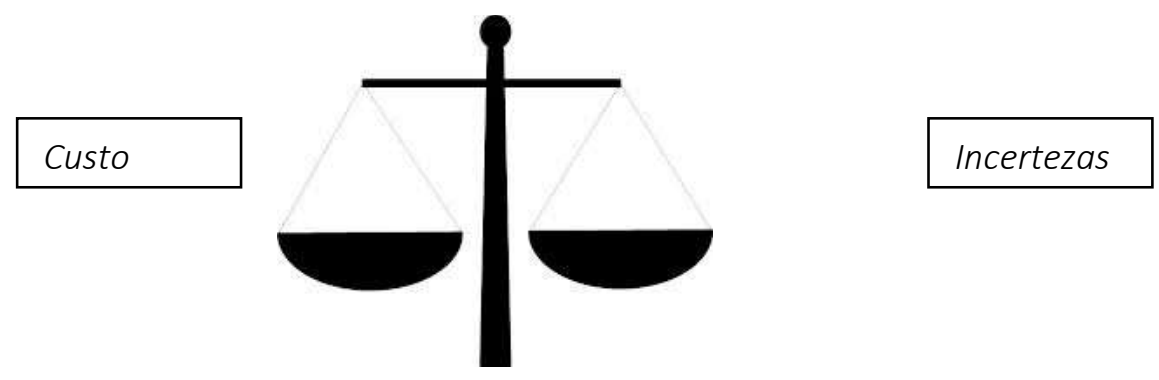

Figura 39 - Probabilidade Subjetiva de Savage (a autora)

Sobre esse paradigma o agente se posicionará sobre o custo razoável frente à incerteza do conhecimento que gravita sobre a irreversibilidade do dano. As probabilidades do risco não correspondem à regularidade da natureza, e a coerência da escolha feita pelo agente, se apoiará na incerteza do seu conhecimento. Assim, a probabilidade subjetiva de Leonard Savage incorre na coerência da escolha feita pelo agente. (Figura 40).

Identifica-se a Incerteza
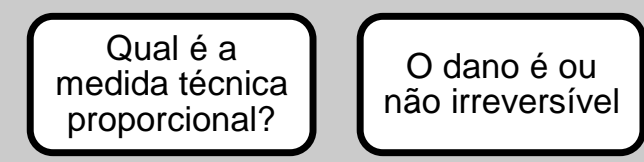

Salva-se a economia ou previni-se 0 dano?

Figura 40 - Probabilidade Subjetiva de Savage (a autora)

Sem descarte dos caminhos da decisão já percorridos, a defesa da racionalidade apoiada no modelo da teoria da decisão, certamente contribui para o estabelecimento de prioridades. Porém, a análise das controvérsias para a universalização do saneamento é um revelador das necessidades urgentes do ponto de vista da resiliência e adaptação.

As práticas convencionais não serão capazes de disciplinar o risco e o dano, pois estes representam fatos não controláveis.

Aceitar argumentos de risco presumido apoiado na gestão implica escolher certas intervenções efetivas sobre os paradigmas da decisão.

Nesse sentido, o modelo de gestão deverá prover estratégias para o agente de decisão compreender que o risco e a vulnerabilidade são suficientes justificativas à 
inovação do processo decisório e minimizar seus dilemas.

A inovação, que reconhece o modelo sociotécnico, deve estar na ordem do dia e auxiliar o desapego aos modelos conservadores de decisão, e promoção de espaço para os atuais paradigmas de sustentabilidade.

É fundamental aos processos decisórios o emprego de metodologias como as propostas nesse capítulo, que contemplem revisão de estratégia empresarial, diagnóstico organizacional, planejamento situacional, revisão de procedimentos e plano de negócio para uma gestão inclusiva. 


\section{MODELO DE NEGÓCIO INCLUSIVO DO SANEAMENTO - MIS 12.1. Considerações Preliminares}

$O$ atual modelo do saneamento não promoverá o atingimento dos objetivos e metas do Plano Nacional de Saneamento Básico no período planejado, nem dos Objetivos para o Desenvolvimento Sustentável de universalização dos SAAES para todos os cidadãos. Identifica-se como impeditiva a própria estrutura de negócio como um serviço público de capital intensivo, que deve atender um direito humano fundamental, num mercado de monopólio natural com deficiências do planejamento urbano frente ao uso e ocupação do solo. Neste modelo, como um serviço essencial de capital intensivo que ainda não foi universalizado, tem dificuldades, dentro de uma área de concessão, para prover o volume mínimo de subsistência há usuários de baixa renda, sem uma política social de subsídios. Em regime de monopólio, a participação privada não foi ampliada de maneira representativa, nem tão pouco alavancou-se o empreendedorismo socioambeintal.

O resultado das pesquisas realizadas com 175 especialistas do setor, vistorias em 2.500 domicílios e entrevistas a 68 líderes comunitários, representando 6.800 domicílios demonstraram os gaps do modelo do setor de saneamento comparativamente a outros setores da infraestrutura. Se, por um lado, os consumidores tem comportamento de adquirir telefonia celular e não se conectar a redes de esgoto, por outro, o arranjo institucional e a política pública foram provedores de mecanismos de incentivos para universalização da telefonia móvel e energia e não para o saneamento. Nesse sentido, explica-se o fato de que apenas $63,3 \%$ da população brasileira tenha esgotamento sanitário, enquanto 99,5\% tenham acesso a uma conexão de telefonia móvel (PNAD, 2013). A falta de capacidade de pagamento dos usuários e de investimentos do setor de telefonia na década de 90 não foi impeditiva ao atingimento da universalização e da conectividade entre cidadãos do século XXI, independentemente de sua condição social. Portanto, identifica-se diferenças estruturantes entre esses setores, além da própria vontade do usuário.

Esse tema eventualmente hibernaria por mais uma década, não fosse o aumento da concentração urbana e a crise hídrica em diversas áreas de concessão. Iniciou-se um debate entre Estado, academia e sociedade civil quanto ao planejamento, uso 
dos recursos hídricos e desempenho dos prestadores, no que tange a eficiência técnica frente a eventuais falhas na continuidade da prestação dos serviços urbanos de abastecimento e descontinuidade dos mesmos, modelos de gestão e de negócio. Também, surgiu um debate quanto a eficácia dos incentivos e punições financeiras à demanda para motivar um novo comportamento menos desperdiçador do usuário, que foi objeto de políticas tarifárias inovadoras no país.

Por um lado, o arranjo institucional que apoiou a inovação dos modelos de telefonia celular e energia para universalização dos serviços contou com um forte plano de privatização dos serviços de distribuição apoiado em fundos garantidores, subsídios à demanda, à oferta e criação de agências reguladoras nacionais de telefonia (ANATEL) e de energia (ANEEL), por outro lado, houve ausência de condições semelhantes para inovação do modelo de negócio do saneamento. O setor de saneamento, em todo o mundo, convive com o preconceito contra a entrada do capital privado, em especial nos serviços de abastecimento de água. Ainda assim, deve-se reconhecer que houve um esforço setorial no Braisl para um avanço do ingresso do recurso privado por concessões, PPP's e abertura de capital de algumas concessionárias.

Identificou-se, que o setor de saneamento tem sido remunerado pelo tradicional modelo de subsídios cruzados, rompido pela autonomia contratual municipal e pela evasão de grandes usuários para soluções autônomas. Nesse sentido, a ausência de um fundo para a demanda da prestação dos serviços a populações vulneráveis, e à oferta para investimentos estruturantes para atender essas demandas, acentuou 0 desequilíbrio dos contratos de concessões.

Programas nacionais de energia como o Luz para Todos ampliando a oferta e Bolsa Família, com cota de energia, equacionaram o subsídio à demanda, e o Inova Energia apoiou pesquisas e ações, que não foram propostas para o saneamento. Nessa questão, como monopólio estatal, o setor deu pouco incentivo ao empreendedorismo formal, ficando dependente das soluções tradicionais e da assistência social pelo Ministério do Desenvolvimento Social e Fundo Nacional da Saúde para áreas rurais, e iniciativas estaduais como COPANOR, e programas Seliga na rede.

A ausência de um fundo garantidor para incentivos ao aumento da participação de investidores privados, a frequente interferência política do poder concedente à que 
se subordina uma concessão em questões tarifárias, e as fragilidades institucionais dos reguladores do setor afastaram novos investidores. A justiça distributiva e redistributiva, base da focalização e universalização, foram entregues, na redação do Plansab, à boa performance tarifária do setor.

A pulverização dos reguladores em diferentes esferas de atuação promoveu conflitos e não trouxe contribuições à atração de novos investidores privados ao setor. Além desse fator, as dificuldades do poder concedente exercer sua competência de planejamento dos serviços de saneamento definidas no Marco Regulatório, e a falta de um ordenamento institucional regulatório e normativo aumentaram custos dos operadores e riscos para uma nova concessão.

Nesse sentido, a combinação empresarial de uma estratégia para um modelo de gestão e planejamento inclusivos, programas permanentes com recursos empenhados para arranjos sociotécnicos, e apoiados pela criação de fundos de subsídios à oferta e à demanda representarão, a exemplo de outros setores, avanços setoriais por meio da atração de novos investidores para ampliação de participação do capital privado e empreendedorismo socioambiental. Pode-se reduzir déficits da universalização do saneamento, com inovação dos mecanismos financiadores ao setor, que deve ocorrer para alavancar investimentos, e equacionar custos dos serviços.

Para Botton et. al (2013) os obstáculos à universalização do saneamento em países emergentes incluem falta de confiança nos arranjos sociotécnicos, falta de vontade política para equacionamento de subsídios e falta de know-how social das empresas. A análise foi feita para as concessões da SUEZ na Argentina e Haiti na década de 1990.

Segundo WHO (2014), é muito baixo o percentual de países com equacionamento de subsídios à baixa renda. Oitenta por cento têm financiamentos insuficientes; e em trinta e cinco a cinquenta por cento dos países, as tarifas não cobrem oitenta por cento dos custos dos serviços.

Países como Estados Unidos, Reino Unido, África, Índia, e Austrália adotaram a criação de fundos de impacto, cujos investidores aceitam um menor retorno sobre o capital em troca de um impacto social maior. Segundo a JPMorgan, é esperado um crescimento de dezenove por cento ao ano do mercado investidor de negócios de impactos sociais. Os escritórios familiares e individuais de alta renda representam o 
maior mercado potencial, que investiram oito bilhões de dólares em 2012, nove bilhões de dólares em 2013, e estão alocando dez por cento de suas carteiras em investimentos de impacto. Estes poderiam empenhar quinhentos bilhões de dólares no setor. Eles são chamados "Barões da água", e representam os investidores de impacto, que vão ajudar a tornar mais aceitável a entrada do capital privado no setor da água (Gasson, 2014).

Dentre modelos de negócios de serviços públicos recentes e efetivos, identificaramse alguns que merecem destaque no que tange conceito de negócio e não apenas de gestão.

\subsection{MODELOS DE NEGÓCIO INTERNACIONAIS COMPARÁVEIS}

Segundo Lambert (2006), o estudo de modelos de negócio ainda carece de aporte científico. No entanto, no que tange apoio ao empreendedorismo das organizações sociais para provisão de serviços públicos que a pesquisa monitorou na web nos últimos três anos, destacam-se alguns casos comparáveis.

O Relatório da International Energy Agency examina tipos de financiamentos para reduzir barreiras de entrada em regiões emergentes no mundo. Os modelos de negócios inovadores e mecanismos de financiamento para implantação de energia solar em regiões emergentes identificados foram: Pay-as-you-go, da Azuri Technologies do Reino Unido para aquisição de energia por cartão celular pré-pago; Parceria Publico Privada africana com a dinamarquesa Grundfos Lifelink para manutenção de bombas de água na África e Ásia; Banco Virtual Mosaico, na Califórnia, para financiamento de investimentos em energia renovável; Peer-to-peer, conhecido como crowdfunding, para cidadãos adquirirem casa própria no Reino Unido; Microgrid da Gham Power, no Nepal, que recebe recursos da holding e investidores locais e internacionais para investimentos em sistemas fotovoltaicos para população de baixa renda equacionar problemas de descontinuidade dos serviços pela concessionária de energia; e emissão de títulos públicos municipais para financiamento de sistema de leasing de longo prazo para geração de energia rural. A conclusão do documento é que a geração de modelos de negócios de sucesso não é uma tarefa fácil e rápida. A situação regulatória, econômica, social e 
cultural de uma região deve ser compreendida e tratada ao inovar modelos de negócios. Tradução livre (HONIG \& KARLSSON, 2004).

Modelos de Negócios conhecidos como "fazer mais com menos" demonstraram que a inovação empresarial e a liderança estratégica geraram crescimento e ruptura, onde os recursos financeiros eram insuficientes, a engenhosidade humana tornou-se o mais importante recurso. Na Índia, jugaad é uma palavra Hindi que significa uma correção inovadora ou solução improvisada com engenhosidade e desenvoltura. Soluções jugaad não são sofisticadas ou perfeitas, mas criam valor a um custo menor. Em outras palavras, é a essência da inovação frugal, flexível e inclusiva (CLEVELAND JEWISH NEWS, 2015).

Identificam-se iniciativas para gestão da demanda. A Silicom Valley, por meio do WaterSmart, é capaz de monitorar o consumo dos usuários armazenar no bigdata e fazer alertas sobre seu comportamento desperdiçador. Pesquisas realizadas por Peter Yolles identificou que apenas uma em cada dez pessoas estão motivadas em salvar o meio ambiente, mas oito em cada dez o vão fazer apenas para manter as aparências (MEDIUM, 2015).

No que tange políticas públicas criadas para o setor, destaca-se a norte-americana. Em 16 de janeiro de 2015, como consequência da crise hídrica nos Estados Unidos, a Casa Branca publicou medidas para ampliar investimentos em sistemas de abastecimento de água. Mais de seiscentos bilhões de dólares foram alocados para soluções inovadoras e alternativas de sistemas de água potável e saneamento nos próximos vinte anos com a criação de um novo Centro de Finanças de Água. Objetiva-se trabalhar com governos municipais e estaduais, prestadores de serviços públicos e privados com subsídios federais para atrair mais capital privado em projetos; promover PPP's para fornecimento de água, sistemas de esgoto e manutenção de córregos e rios limpos por meio da criação de títulos municipais bonds de infraestrutura pública; reunir investidores e patrocinadores para promover benchmarking; desenvolver estudos de caso e toolkits, maximizando os benefícios de mais de três bilhões de dólares em investimentos hídricos federais anuais; ajudar a atrair investimentos para pequenas comunidades que não dispõem de recursos para explorar alternativas de financiamento; fornecer treinamento financeiro e assistência técnica para pequenas comunidades e incentivar incubadoras para desenvolverem projetos de infraestrutura e finanças (WHITE HOUSE, 2015). 
Tais iniciativas demonstram a mobilização mundial na busca de equacionamentos para o setor de saneamento básico, devendo-se, entretanto, construir o referencial teórico seguido de um modelo, ambos aplicáveis ao contexto local de infraestrutura e cultura.

\subsection{REFERENCIAL TEÓRICO PARA O MODELO INCLUSIVO DO SANEAMENTO}

Nesse sentido, a inovação conceitual de modelo inclusivo do saneamento, foi construída por paráfrases, com a mesma lógica que há em modelos de negócio das grandes organizações sociais, acrescentando a dimensão ambiental, e a de serviços de rede, parafraseando diversos autores (ZOTT \& AMITT, 2008, CASADESUSMASANELL\&RICART, 2010; SHAFER AT AL. 2005):

O modelo de negócio de um SAAES deve criar, distribuir e capturar valor junto a cidadãos, meio ambiente e acionista no enfoque da organização e do relacionamento com seus steakholders, por meio da prestação de serviços essenciais de rede, que elevem a dignidade humana. Ele é insuficiente para atingimento da universalização, e dos objetivos setoriais, sendo dependente do Modelo Inclusivo de Saneamento (MIS).

Diversos acadêmicos concordam apenas em que Plano de Negócios, Estratégia e Modelo de Gestão são determinantes do modelo de negócio, sendo que o Plano é o norteador do modelo (DELMAR\&SHANE, 2003; HONIG \& KARLSON, 2004; ROSA, 2009; FRASER \& GREENE, 2010):

O Plano de Negócio Inclusivo - PNI é a declaração escrita, que apresenta o atual e futuro status da concessionária para a universalização inclusiva, explicitando metas do negócio inclusivo e etapas a serem atendidas para que os objetivos organizacionais sejam alcançados, dirimindo incertezas, minimizando riscos, ampliando a probabilidade de vida do negócio no longo prazo e equilíbrio da concessão. Deve conter projeções, metas, indicadores de universalização inclusiva, custos de investimento e operação, receitas previstas e desempenho da governança inclusiva ao longo do tempo. 
Parafraseando diversos autores quanto à estratégia empresarial das grandes organizações sociais (SEDDON \& LEWIS, 20003, PORTER, 2001; CASADEUS_MASANELL \& RICART, 2010; ZOTT \& AMITT, 2008, MAGRETTA, 2002, GADIESH \& GILBERT, 2001):

A estratégia empresarial de um SAAES deve fazer com que a concessionária seja mais bem sucedida que outra no atingimento de objetivos socioambientais do PNI, numa combinação singular de atos de gestão com arranjos sociotécnicos, preocupando-se com a escolha do modelo de negócio inclusivo, que atenda o mercado de vulneráveis, com alocação de recursos de capital, pessoas e tempo para a construção de uma vantagem competitiva sustentável e inclusiva, determinando limites de atuação.

Nesse sentido, os referenciais teóricos conceituais, o Modelo Inclusivo do Saneamento deve contribuir com equacionamento jurídico e econômico-financeiro (capítulos 8 e 9) para Universalização Inclusiva do saneamento. Conclui-se:

O Modelo Inclusivo do Saneamento deve estar apoiado em mecanismos institucionais garantidores do atendimento à dignidade humana, com segurança jurídica por meio de mecanismos solucionadores de conflitos por mediação. Deve garantir financiamento da oferta e subsídios à demanda, previstos no PNI. Deve promover a superação das controvérsias do modelo tradicional e promovam arranjos sociotécnicos em regime de eficiência técnica e eficácia social com inovação do modelo de negócio e do modelo de gestão. Sendo que, a governança inclusiva deve ser a ferramenta de monitoramento da efetividade da prestação dos serviços públicos a comunidades com alta vulnerabilidade social do MIS.

Nesse sentido, a gestão inovadora, para que a universalização inclusiva seja alcançada por arranjos sociotécnicos demandam uma nova governança - a que considera a superação de mecanismos de exclusão de rede. Ao inovar conceitos, indicadores inclusivos, procedimentos, ferramentas de planejamento e tomada de decisão, no plano de relacionamento com o cidadão-usuário, concessionária, poder concedente e agência foram necessários. Para mapeamento da natureza das incertezas, envidou-se esforços de pesquisa na compreensão do ambiente de relacionamento com as comunidades dentro da concessão, bem como dos aspectos 
político-legais, a fim de incorporar um olhar estratégico para as desigualdades não consideradas. Esses desafios para governança corporativa e regulamentar, a fim de considerar os direitos fundamentais do usuário, indicaram inovações do modelo de negócio quanto a mecanismos eficientes e eficazes para o desenvolvimento sustentável. Foi necessário inovar mecanismos que promovessem modelos mais cidadãos, menos alienados e mais inclusivos para universalização do saneamento em áreas de vulnerabilidade, considerando suas controvérsias, externalidades e interdisciplinaridade, bem como fortalecer a resiliência das comunidades em áreas vulneráveis, que sofrem fenômenos devidos à expansão urbana insustentável.

O MIS deve apoiar-se na constituição cidadã para promover a superação dos impeditivos legais provenientes do ordenamento jurídico do uso e ocupação do solo e do direito ambiental, que tradicionalmente tem sido tratado como superior ao direito humano fundamental; reduzir barreira de entrada financeira com mecanismos de subsídios à demanda; desenvolver estratégias inovadoras de subsídios de crédito por meio de fundos garantidores e de investimentos para atrair investidores de impacto social, parceiros privados e empreendedorismo; reduzir custos dos serviços com a inclusão dos cidadãos na cadeia de valor; garantir uma gestão estratégica sociotécnica; e promover o desenvolvimento do regulador e do poder concedente por meio de capacitação e implantação de normas e processos de mecanismos inclusivos. Por outro lado, deve ser capaz de reorganizar os serviços públicos, a fim de criar benefícios sociais em uma série de iniciativas para gerar e medir valor econômico, ambiental e social com inclusão dos cidadãos por meio de mediação.

A visão tradicional dos prestadores de serviços, quanto à universalização inclusiva, apresentou eficácia limitada à regularização fundiária; descontinuidade de programas de investimentos por ausência de um sistema institucional de subsídios; coordenação pulverizada por ausência de um programa empresarial de universalização inclusiva; estratégias conflitantes com modelo de geração de valor inclusivo; ação empresarial distanciada de objetivos socioambientais; modelo de gestão técnico-centrada; falha sistêmica com resultados ineficazes; incapacidade de capturar os ganhos dos impactos socioambientais alcançados e não valorização do empreendedorismo intraorganização, demonstrando a complexidade da conciliação de Modelo de Negócios com responsabilidade socioambiental inerente do setor. 
Os diferentes comandos estratégicos numa mesma organização dificultam e confundem os gestores, restando-lhes o voluntarismo empreendedor operacional, sem efetivos instrumentos no nível tático e estratégico da gestão para a universalização. Ainda que façam parte da estratégia de um departamento ou unidade de negócio, não necessariamente fazem da estratégia empresarial. Pode-se observar também no saneamento ações paliativas e compensatórias. Diversos autores estudados são defensores da criação de uma subsidiária, ou UN, que tenha a cobrança de resultados e que efetivamente tenha uma estratégia voltada para a visão social com resultados econômicos e ambientais.

Observou-se que as motivações empreendedoras individuais foram diferenciais à obtenção dos objetivos estabelecidos.

Conforme Fischer (2011), o conceito de empreendimento social, a autonomia jurídica, administrativa e gerencial, tem que gerar valor econômico e valor social.

Nesse sentido, o empreendedorismo socioambiental, a autonomia dos gestores e a estratégia empresarial, com seus instrumentos jurídicos e econômico-financeiros, têm que gerar valor ambiental e social, além de econômico. No caso da visão socioambiental, a criação de uma organização para Universalização Inclusiva pode promover programas permanentes de investimentos, subsídios para custos dos serviços e arranjos sociotécnicos, acelerando a universalização e manutenção de uma relação mais cidadã com os usuários vulneráveis.

Os resultados das pesquisas demonstraram que a universalização dos serviços de saneamento em áreas de vulnerabilidade socioambiental dependem da intersetorialidade e consideração efetiva da dignidade humana nas dimensões da sustentabilidade no setor.

O setor de saneamento não captura medições ou obtém ganhos dos impactos socioambientais da universalização. A criticidade está no fato das externalidades não serem intrínsecas ao negócio, porém dos setores de infraestrutura é o único que demanda um mínimo de serviços para a sobrevivência e dignidade humana, sendo, portanto, um serviço essencial à subsistência.

Os modelos adotados pelos casos apresentados, ainda que com deficiências, geram conforme Brugman\&Prahalad (2007), valor compartilhado, especialmente para Estado, empresa e sociedade mediante colaboração e alianças intersetoriais. O modelo colaborativo promoveu melhores resultados em relação ao assistencialismo, 
que não tem estratégia para emancipação, cidadania e inclusão na cadeia de valor do cidadão beneficiado.

No caso dos setores de populações vulneráveis, as diversas ações necessárias partiram da regularização fundiária e programas de urbanização, sustentada no direito constitucional de propriedade e da mobilização da comunidade, com diálogo entre atores-rede da concessionária e Ministério Público, Promotoria Pública para autorização à atuação em áreas irregulares.

A proposta de atos de mediação em favor da promoção da universalização inclusiva, ao serem adotados, ampliarão a prestação dos serviços públicos de saneamento em áreas vulneráveis. Demandaram-se esforços e entendimentos diversos sobre o tema incluindo a judicialização dos trabalhos para garantia da cidadania. Nesse sentido, o fundamento constitucional é suficiente ao entendimento que, nem o direito a propriedade, nem o ambiental, podem ser superiores ao direito humano.

Porter \& Kramer (2011) propõem uma estratégia de criação de valor social e econômico compartilhado ao definir serviços bons para a empresa e para o coletivo (Win-Win), como fundamental pensar no que é realmente bom para a sociedade, e que novos produtos e serviços devam ser gerados para inovação. A adoção deste modelo pela sociedade civil está fundamentada na recomendação do diálogo para a criação de um novo business, que envolva empresa e sociedade, com o modus operandi dessa organização de forma a ter uma reflexão do valor que gere com o que se faz, podendo-se ter um valor compartilhado do social e do econômico.

Assim, ultrapassadas as barreiras de entrada e organização da oferta, os desafios passaram por capacitar e envolver a própria comunidade na cadeia de valor de forma a garantir também a eficiência e eficácia da prestação dos serviços continuamente, pela gestão dos arranjos sociotécnicos, onde os indivíduos estarão conectados, entendidos como grupo humano, cidadãos corresponsáveis pelos ganhos da eficiência dos serviços e da gestão da demanda.

No saneamento, a inovação do Modelo de Negócio deve gerar valor inclusivo, considerando os resultados mediante as importantes dimensões econômicas e sociais, acrescentadas das dimensões ambientais e legais, sem as quais as externalidades positivas ficam ocultas e não valorizadas no modelo (Quadro 34). 
Kanter $(1999,2008)$ identificou uma modificação de estratégia ao inserir uma grande corporação como um ator fundamental, quando ainda não se adotava nas práticas de gestão a relação com Estado e sociedade civil como algo possível.

Assim, como resultado das oficinas, identificou-se que um Modelo de Negócio Inclusivo dos serviços públicos de saneamento, entendido como abastecimento de água e esgotamento sanitário, deve gerar benefícios sociais numa escala de iniciativas de geração de valor socioambiental e econômico com lições de inclusão. A universalização do saneamento deve transformar a condição de vida do usuário de áreas de vulnerabilidade frente à importância da relação do mesmo com água e esgoto e a saúde pública. Por meio de mudanças das práticas de gestão da organização e governança devem-se identificar controvérsias e mecanismos de exclusão, e definir estratégias para alcançar a universalização inclusiva, mensurando o impacto socioambiental gerado pelo negócio.

Nesse sentido, a adoção da universalização e governança inclusivas são as garantias à gestão do atendimento a populações excluídas pelo compartilhamento de atribuições dos diversos atores, que serão pressionados por mecanismos de participação social, controle social, e empoderamento da sociedade organizada.

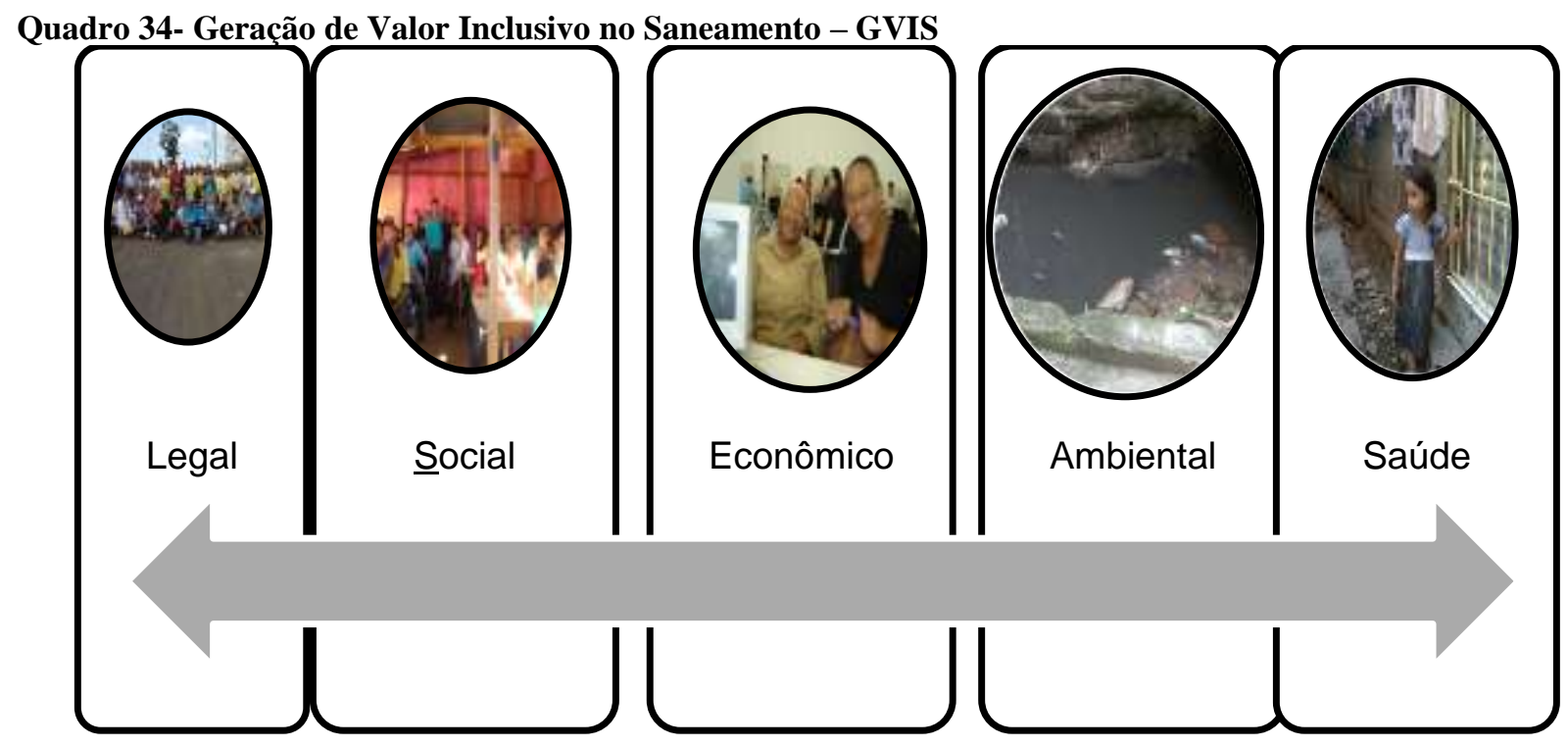

Elaboração: a autora (2015)

O desafio de revisão das práticas foi propor um modelo capaz de ter por objetivos (Quadro 35), o reconhecimento de externalidades ambientais e sociais; falhas de mercado; sustentabilidade socioambiental; situações que exacerbam as limitações 
no acesso à água e esgotamento sanitário, fomentando mitigações e ações de adequações e governança.
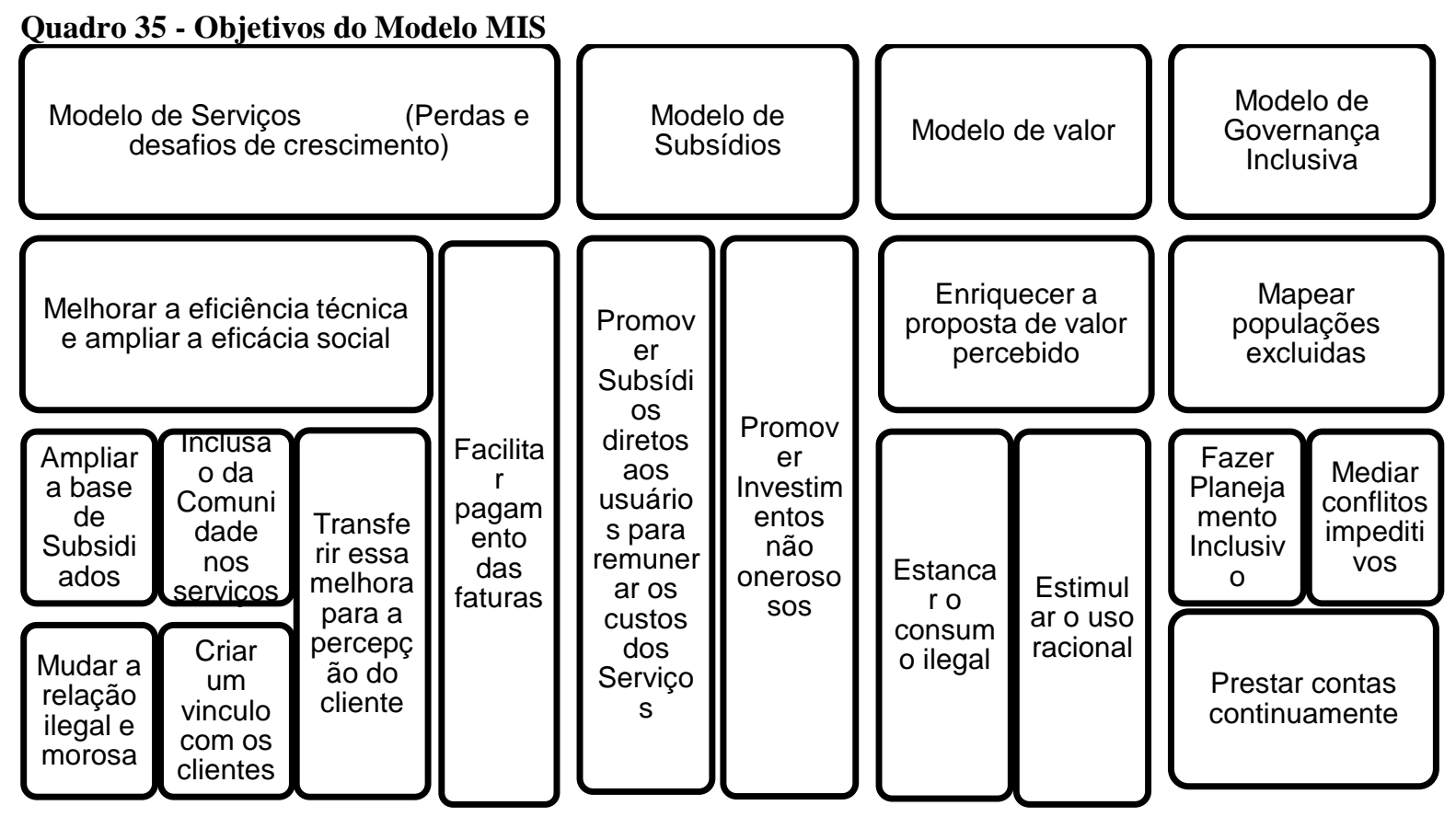

Elaboração: a autora

Considerando o deslocamento da centralidade do pensamento hegemônico da engenharia para a humanização do saneamento, observa-se que os modelos analisados são singulares, pois serão construídos por atores-rede conforme a natureza dos grupos, dos fatos, das ações, das Ciências Sociais e das Ciências Naturais, que compõem o ambiente objeto de intervenção, porém sempre há pilares para construção do Modelo de Negócio Inclusivo.

Nesse sentido, identificam-se 08 (oito) pilares do Modelo de Negócio para Universalização Inclusiva do Saneamento Básico (Figura 41): 


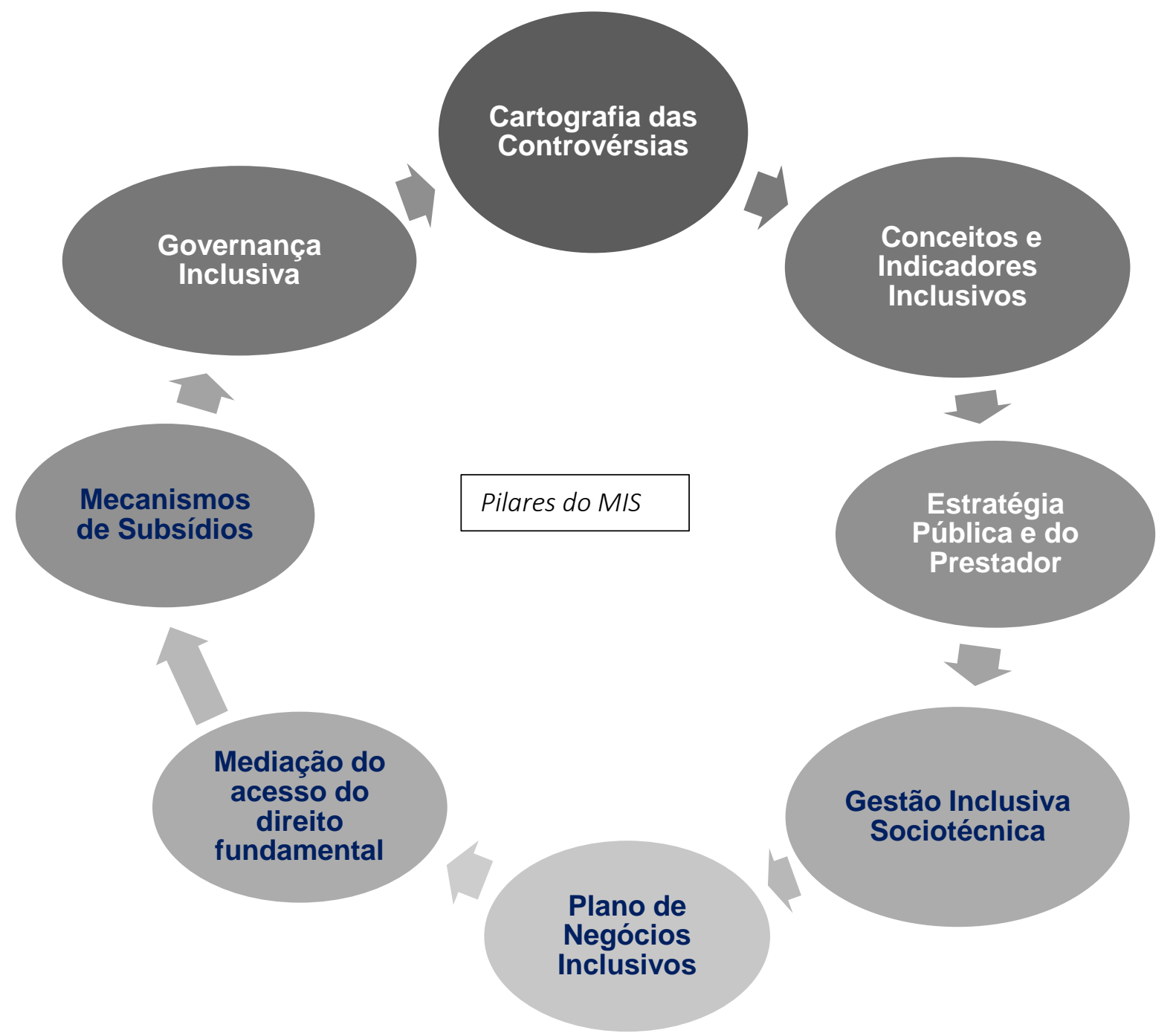

Elaboração: a autora (2015)

Figura 41- Pilares de Modelo Inclusivos do Saneamento (MIS)

Os pilares do MIS devem garantir a universalização dos serviços públicos essenciais a todos se apoiando em mapeamento da cartografia das controvérsias da universalização; adoção de bases conceituais e indicadores inclusivos; criação de estratégia clara que leve a organização a chegar à visão empresarial; adoção de um modelo de gestão sociotécnico, elaboração de um plano de negócios para atendimento das áreas de exclusão; eleição de câmaras de mediação para os conflitos do atendimento a áreas favelizadas; criação de um mecanismo de subsídios à baixa renda; instituição da governança inclusiva com instrumentos de participação, controle social e empoderamento. 
Deve-se, assim, efetivar a inserção de problemáticas da universalização inclusiva na tomada de decisão da organização, do poder público, dos agentes financeiros, do judiciário, dos reguladores e da sociedade civil.

Complementarmente, a gestão deve superar limitações do modelo organizativo por meio da governança inclusiva apoiada num sistema colegiado, cujo compartilhamento da gestão é constitutivo. As formulações desses grupos foram marcadas pela preocupação com a melhor representação possível de atores provenientes de diversos níveis e processos da organização, da sociedade civil, do poder público, de agentes financeiros e representantes que garantissem a representatividade da inter-setorialidade necessária. Visando, assim, constituir um espaço coletivo de contraste, disputa e composição das diferentes visões e interesses dos atores, na perspectiva de uma prática mais solidária, menos alienada, mais participativa e cuidadora dos cidadãos em situação de exclusão social.

Para alcançar e manter a universalização dos serviços de abastecimento de água e esgotamento sanitário deve-se promover a capacidade da concessionária ouvir as demandas do cidadão das áreas vulneráveis para a obtenção e manutenção da universalização. A governança inclusiva inovou a empresarial e a pública por meio da adoção da atuação articulada e integrada dos gestores do saneamento e setores correlatos ao desenvolvimento urbano e sociedade civil, combinando objetivos setoriais e empresariais do atendimento com o equacionamento dos problemas socioambientais, contribuindo no formato de tomada de decisão.

\subsection{CONSTRUÇÃO SINGULAR DO MODELO INCLUSIVO DO SANEAMENTO}

\subsubsection{Teste de Modelo Canvas}

Parte importante da inovação do modelo foi à revisão da estratégia empresarial mediante diagnóstico da organização de Nadler, Planejamento Estratégico Situacional de Matus, BSC e Plano de Negócio. Finalmente foi construído, sobre as bases participativas, um teste sobre o Modelo de Negócios Canvas desenvolvido por Osterwalder \& Pigneur,adotado pelas áreas sociais da concessionária para a construção do modelo de Negócio aplicando a teoria ator-rede de Latour para identificar as lacunas provenientes das controvérsias sociotécnicas não cobertas por 
Osterwalder, desenvolvendo os módulos de equacionamentos necessários à Complexidade do Modelo de Negócio do Saneamento, considerando serviços públicos essenciais e direito fundamental e o complexo mecanismo de exclusão de redes (Figura 42). A oficina para o preenchimento do Modelo Canvas identificou GAP's do modelo (Quadro 43).

Inicialmente, aplicaram-se para os parâmetros de Osterwalder as melhores práticas empresariais em áreas que obtiveram sucesso no atendimento, considerado como assentar redes de água e esgotamento sanitário, conectar os domicílios, aplicar práticas comerciais subsidiadas, e práticas sociais inclusivas. A identificação foi feita para parceiros, atividades, preposição de valores, benchmarking de clientes, segmento de clientes, canais, recursos chaves, receitas e custos.

Complexo

Mecanismo

Justificativo de

Exclusão de Rede
Mecanismo de Exclusão de Redes

Direito de Propriedade das

Comunidades Tradicionais

Eficácia Social

Funcionários,

Mecanismo de Exclusão

Elaboração: a autora (2015)

Figura 42 - Mecanismo de Exclusão de Redes de Saneamento no Brasil

No caso dos serviços de saneamento para áreas vulneráveis, o Modelo Canvas pode ser organizador de uma estratégia inicial de atuação intraorganização, porém apresenta duas dimensões que perdem efetividade para o modelo do saneamento:

1.) Canvas é estático semelhante a uma fotografia instantânea. Porém, a universalização nas áreas vulneráveis tem uma dinâmica mutante no eixo do tempo, partindo do acesso ilegal por ligações clandestinas, pois o ser humano não sobrevive sem água nas áreas urbanas, passando pela disponibilização de redes por tubulações na área de concessão promovendo a cobertura, seguida pela conectividade por meio das ligações domiciliares, promovendo o atendimento. Passa também pela qualidade dos produtos, medidos pelos padrões de potabilidade; pela qualidade dos serviços, representado pelas metodologias de medição da descontinuidade e falhas dos serviços que geram intermitência do abastecimento, chamados DEC/FEC, e, finalizando, pela atualidade dos ativos, na qual se garante a 
substituição das redes e equipamentos com finalidade de manter a universalização sem o sucateamento dos ativos. A ontologia dos serviços de redes publicas de abastecimento garante diferentes benchmarking regulatórios a serem referenciados quanto à eficiência técnica de uma concessionária (Quadro 7);

2.) Não está previsto no Modelo Canvas dimensão que permita inserir o complexo mecanismo de exclusão de redes que, por diversas razões, dependendo do setor, exclui cidadãos de serviços de redes públicas. No caso, a judicialização dos conflitos de propriedade e meio ambiente, sendo incapaz de acomodar o mecanismo de exclusão de redes em seu modelo.

A Figura 43 foi construída em oficina, contando com a participação de gestores e agentes sociais do setor, com objetivo preencher e testar as dimensões do Modelo de Negócios CANVAS (Osterwalder \&Pigneur,2010, 2011).

Constatou-se que o Modelo Canvas atendeu as dimensões propostas no que tange a gestão, porém não antevê o impedimento em atender as metas de universalização a vulneráveis, uma vez que não há onde explicitar incertezas e controvérsias, quanto à universalização inclusiva. Ou seja, os subcidadãos são excluídos naturalmente do modelo, por impeditivo superior a dimensão do modelo.

A complexidade da administração empresarial frente ao direito ambiental e ao direito de propriedade reforçaram o mecanismo de exclusão e a insuficiência do Modelo Canvas e o Plano de Negócios gerado por esse modelo para serviços públicos de rede em áreas de exclusão (Figura 42). Uma vez que há o impedimento de atuação em áreas irregulares e favelizadas, o modelo leva a aguardar decisão judicial ao setor, não sendo incluídas modelo de negócios, aquele que não supera na sua gestão as barreiras de entrada. Aguarda-se a regularização para posterior inclusão no modelo. A controvérsia não aparece no Modelo Canvas (Figura, 43) (SABESP, 2015), e será na Cartografia da Controvérsia da Universalização Inclusiva no Modelo de Negócio (Figura 44) e a inovação do modelo institucional contemplará o equacionamento da controvérsia (Figura 45). 
Figura 43 - Lacuna do Modelo de Negócios CANVAS em Serviços de Redes em áreas de Exclusão Social

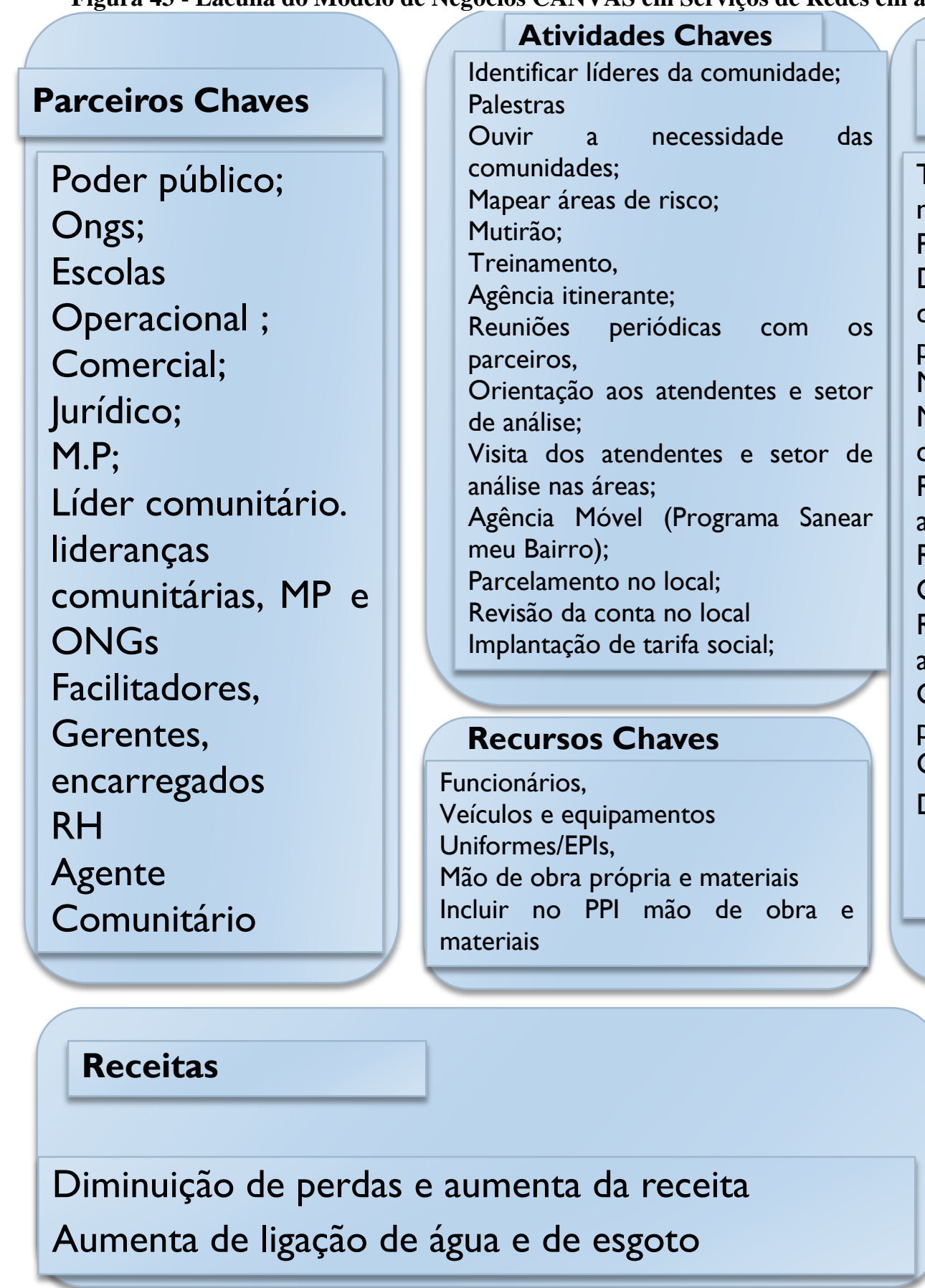

\section{Preposição de} Valores

Transformar líder em multiplicadores;

Palestras.

Diminuição da poluição dos mananciais, canais e praias,

Melhor atendimento;

Melhor imagem da

companhia;

Reconhecimento do

agente comunitário;

Redução de perdas;

Qualidade de vida;

Regularização

abastecimento de água

Qualidade de serviços

prestados.

Ganho de credibilidade,

Diminuição da burocracia

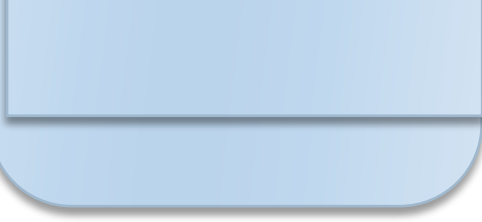

Relacionamento com clientes

Priorização e

individualização dos

clientes;

Tratativas

socioeconômico e

cultural;

Sociabilidade;

Integrar a empresa e

comunidade.

Agilidade na prestação

dos serviços;

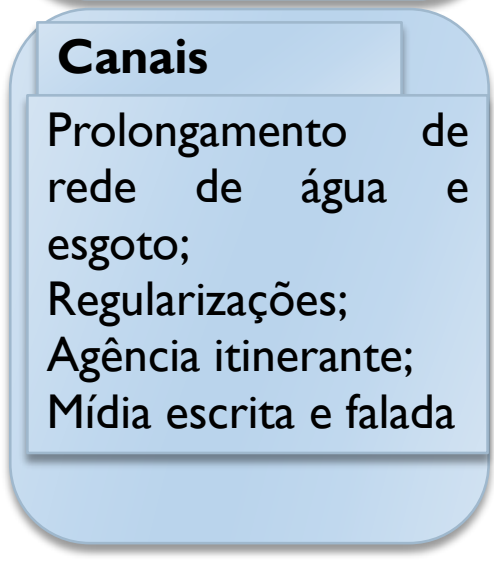

\section{Custos}

Necessário o levantamento das áreas a serem atendidas Pessoal, energia e material de tratamento e substituição Treinamento,

Sala Multi-mídia

Transporte e instrutor

\section{Segmento de} clientes

Cidadão de áreas regulares de baixa renda;

Cidadão excluído moradores de áreas irregulares

\section{GAP do Modelo Complexo Mecanismo Justificativo Exclusão de Rede}

Clandestinidade dos

domicílios

Direito de Propriedade e

Ambiental

Ausência de Subsídios

Estratégias excludentes

Parcialidade

Governança 


\subsubsection{Construção do Modelo Inclusivo do Saneamento (MIS)}

Duas principais abordagens alternativas ao modelo de negócio Canvas foram construídas. Aplicou-se sobre o Mapa da Cartografia das Controvérsias da Universalização dos serviços de saneamento em áreas vulneráveis construído (MAPA 2), apoiado nos resultados das oficinas de controvérsias, um diagrama que apresentou a Natureza das Incertezas, explicitando: quadro do fluxo das controvérsias da gestão inclusiva, discutido no capítulo do modelo de gestão figura 17, apoiado no agente comunitário empreendedor; e quadro do fluxo das controvérsias do modelo de negócio ator-rede. Assim, explica-se na Cartografia da Controvérsia da Universalização Inclusiva no Negócio do Saneamento (Figura 44) que a complexidade do Sistema para Inovação do Modelo de Negócio para Concessão do Saneamento da Cidade Informal tem como actante (epicentro) eficácia social, que somente foi alcançada por meio de articulação entre entes na construção de parcerias com objetivos inclusivos. Ainda que houvesse excelência nos mecanismos de gestão, somente mobilização para mediações pelo sistema legislativo e judiciário, bem como para novos arranjos para ampliação de fundos de incentivo à oferta, à demanda e garantidores, apoiados por uma estratégia empresarial de gestão inclusiva, promoverão equacionamentos eficazes e permanentes para promover e manter a universalização inclusiva. Ultrapassadas as barreiras legais e financeiras, o Modelo de Negócio será capaz de atrair investidores para os setores privados ou empreendedores. A estrutura empresarial inovadora na (Figura 38) pode ser alternativa e/ou provisória, até a criação de uma Organização de constituição independente como Fundação/Empresa ou outro arranjo, cuja arquitetura é parte do Modelo Inclusivo do Saneamento (Figura 44), para alcançar objetivos da Universalização Inclusiva. Uma organização socioambiental, cujas características definidas nos Pilares do Modelo Inclusivo, (Figura 41), para gerar, capturar e distribuir valor (Quadro 34), com objetivos (Quadro 35), cuja arquitetura é dada na Figura 45. Nesse sentido, o Modelo Inclusivo do Saneamento, contendo uma proposta de arranjos Institucionais, de gestão, econômico e jurídicos suficientes para atender o cidadão vulnerável. Esse arranjo forma o modelo e será garantido pela Governança Inclusiva com seu indicador e ferramentas de monitoramento dos objetivos e metas dos serviços alcançarem a Universalização Inclusiva. 
Cartografia da Controvérsia da Universalização Inclusiva no Modelo de Inclusivo do Saneamento - MIS

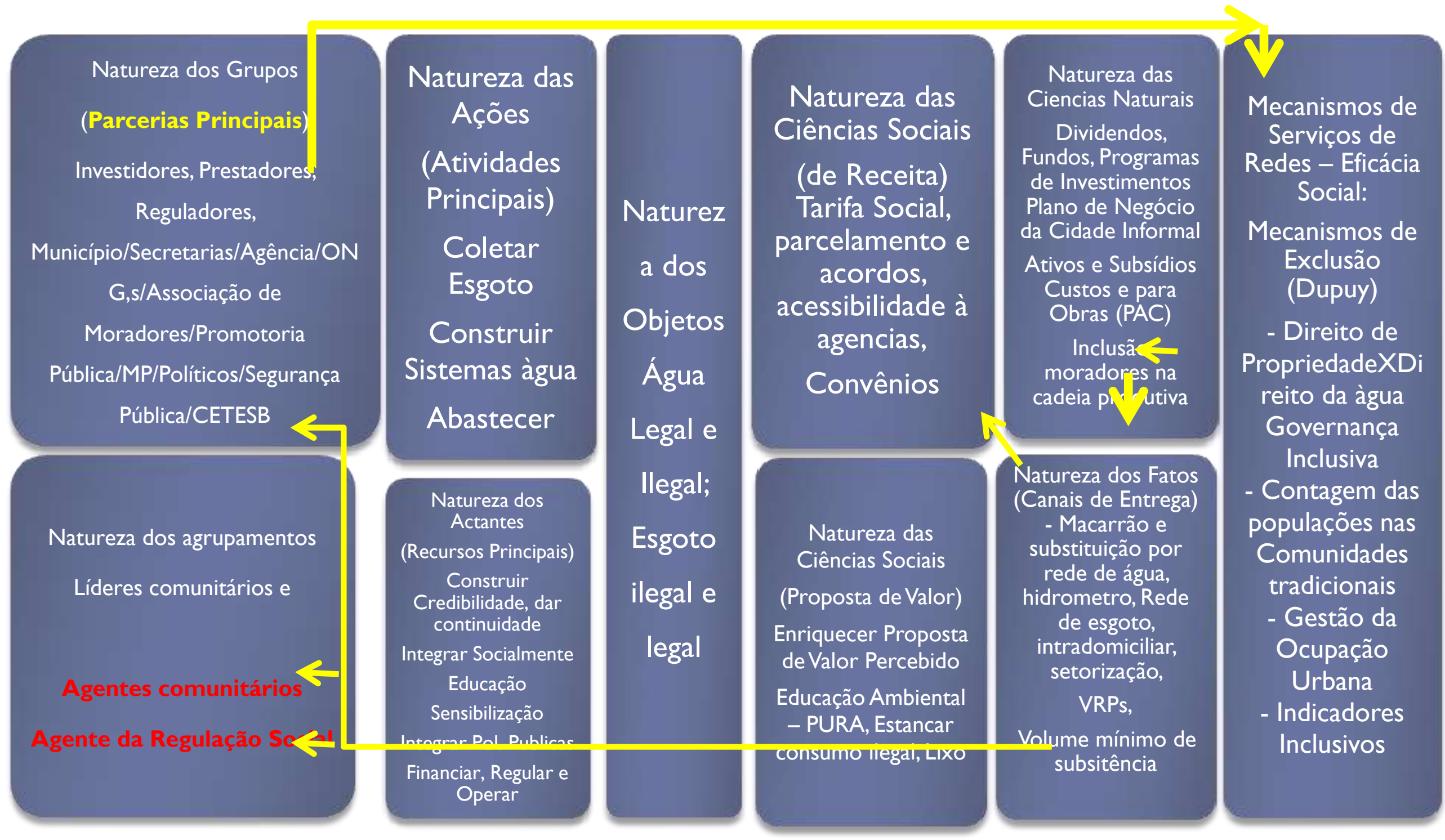

Figura 44 - Modelo de Negócios Inclusivos do Saneamento (MIS) 


\section{AGENCIA METROPOLITANA}

Reguladora e executora da Política Pública

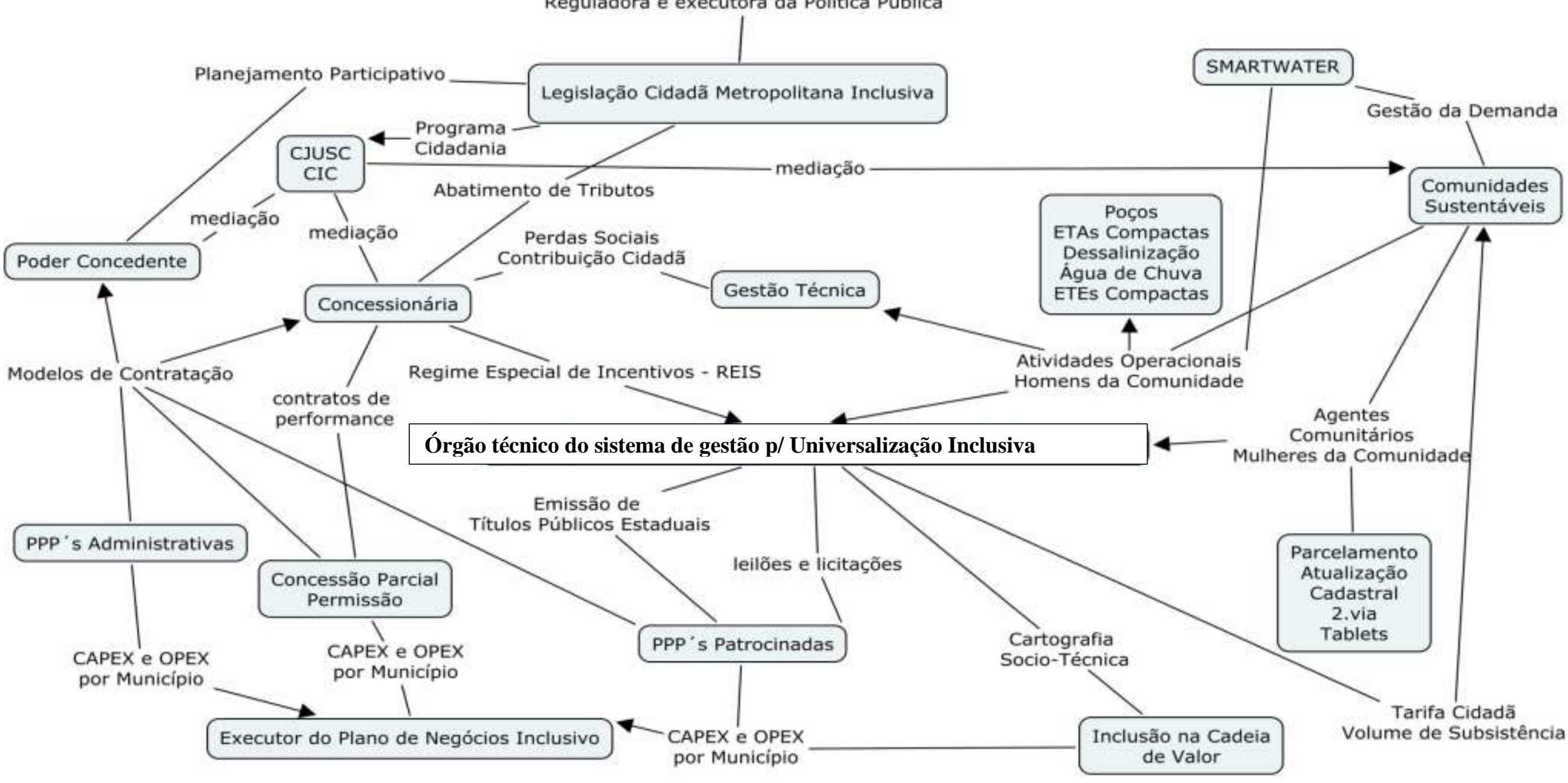

Figura 45 - Modelo Institucional para Universalização Inclusiva

Elaboração: a autora

(2015) 
Percebe-se que o financiamento para inversões inicias, e redução das barreiras de entrada favoreceram a infraestrutura de redes custosas, pagas por programas governamentais do Estado como o SELIGA e Mananciais. Esses programas locais e temporários eram parcialmente dependentes do orçamento da concessionária, portanto sofreram uma redução do ritmo em função da crise hídrica e das prioridades estabelecidas. Deve-se reconhecer que, num modelo nacional, diante da falta de subsídios ao setor, as demandas são razoáveis e o gestor precisa fazer escolhas frente aos dilemas.

Quanto à organização da demanda, o modelo MIS promoveu melhor interlocução entre cidadãos e concessionária, melhorou a relação com a concessionária, e a própria comunidade passou a organizar suas demandas. A contratação de mão de obra das comunidades pelas terceirizadas para trabalhar nos arranjos de ligação e rede, e contextos comerciais melhorou a condição social dos moradores, promoveu laços de confiança, garantiu acesso à área de operação pelos trabalhadores locais como provedores de insumos, e subcontratados de mão de obra terceirizada foram inseridos na cadeia de valor. Os trabalhos contínuos de educação ambiental e responsabilidade social em escolas, centros de atividades comunitárias, hortas promoveram mudança de hábitos de consumo e minimizaram vandalismos dos ativos de rede na comunidade. Todas essas ações promoveram mudanças na oferta com singularidades do negócio para cidadãos em áreas vulneráveis. Pesquisas (Gráfico 30) com os cidadãos demonstraram a mudança de postura da concessionária na Região da Baixada Santista em promover encontros comunitários para prestação de contas e ouvir as demandas que emergiam dos cidadãos. Identificaram-se como a cultura organizacional dificulta a inovação da gestão com objetivos de suportar as Unidades de Negócio em flexibilização de propostas de valor e jurídica em equacionamento a impeditivos legais à operação de áreas vulneráveis. No Modelo de Negócio (Figura 45) construído sobre o Mapa de controvérsias (Mapa 2) e Cartografia das Controvérsias do Modelo de Gestão e de Negócio na Teoria Ator-Rede (Figura 17 e 41), o ponto de partida será as parcerias, e o agente comunitário será empreendedor alavancador de atos de gestão e governança inclusiva. Superadas as questões institucionais, legais e financeiras, diversos modelos inclusivos serão possíveis de adoção, com arranjos como parcerias público-privadas patrocinadas, administrativas, concessões parciais, e permissões. 
Em resultado com atores estratégicos (Gráfico 31), do setor no estado de SP, foram identificados como drivers ou gatilhos para Inovação do modelo a escassez hídrica, a gestão da demanda, e as perdas. Ajustes quanto ao conceito de gestão e negócio foram ajustados para permitir a análise das contribuições (Tabelas 15 e 16).

Para Inovação do Modelo de Inclusivo demanda uma estrutura com estratégia específica para populações vulneráveis, por essa razão as grandes organizações tem adotado fundações para atingir objetivos sociais e negócios de impacto. Semelhantemente, sugere-se um órgão como uma fundação para a universalização inclusiva organizada por natureza dos grupos têm-se concessionária, regulador, poder público, agentes financeiros e cidadão como agentes do modelo de governança, uma vez que o setor tem dificuldades com recursos financeiros para a produção e a universalização por lacunas da política pública do saneamento, no que tange a focalização e distribuição de subsídios a usuários de baixa renda, dentre outros.

\subsection{CONCLUSÃO}

No trabalho de pesquisa foram desenvolvidos: a metodologia de mapeamento da cartografia social de controvérsias do saneamento, planejamento participativo e um PNI, fundamentados num modelo inovador de governança. Com o desenvolvimento de um sistema de projeção e análise possibilitou-se prever volume demandado, perdas, receitas, custos, investimentos no período até 2020, para o cálculo do subsídio necessário ao equilíbrio de um contrato regulado. Esses resultados compuseram o PNI, cujas projeções e definições de funções de referência permitiram ampliar a análise para todos os municípios da RMBS a partir das áreas piloto de com a previsão de: Inativas para um aglomerado, Volume disponibilizado, recuperação de volume perdido, índice de perdas, redução do mesmo.

Como resultado de intervenções sociotécnicas obteve-se uma redução entre 33,5 a $42,7 \%$ no índice de perdas sociais acompanhados no sistema corporativo, assumiuse $33,5 \%$ dados mais conservadores e um aumento de volume disponibilizado à rede de 40 a $57 \%$, assumiu-se $40 \%$ do volume entregue à área. Porém, a redução do índice de perdas total estimado para os municípios objeto do estudo pode chegar a 5,94\%, em função da ausência de setorização naqueles locais e perdas operacionais e sociais não estarem claramente identificadas. 
Como evidência objetiva, a metodologia para avaliação de resultados obtidos que compõem o estudo identificou que: na demanda, cada domicílio dos aglomerados subnormais que passou pela intervenção sociotécnica economizou $16 \mathrm{~m} 3 /$ domicílio subnormal/mês. A receita acessória proveniente da venda do volume não desperdiçado na demanda para domicílios com tarifa residencial normal foi de $R$ \$ 51,36/domicílio (calculado pelo produto entre volume vendido a outros usuários das áreas consolidadas e tarifa média do município). Esse paradigma mudou a interpretação de um estudo de viabilidade.

Porém, identificou-se que ainda há uma necessidade de subsídios de $R \$ 0,13 / \mathrm{m} 3$ em 2014 a $R \$ 1,79 / \mathrm{m} 3$ em 2020 à oferta para os investimentos necessários às intervenções. Identificou-se que o subsídio necessário à demanda para os custos dos serviços é de $R \$ 1,32 / m 3$ em 2014 a $R \$ 17,84 / m 3$ em 2020, em função do crescimento vegetativo dos aglomerados subnormais.

Nesse sentido foi adotado uma metodologia de fluxo de caixa descontado para análise da receita incremental, cujo resultado foi positivo em $\mathrm{R} \$ 10.141,98$, tornando a nova abordagem socioambiental diferencia para entendimento de que o negócio pode ser mais atrativo.

Como inovação que apresenta o tema da pesquisa, o Modelo inclusivo de Saneamento - MIS, deve Gerar Valor - a Universalização Inclusiva, Capturar Valor por meio da Governança Inclusiva, e Distribuir Valor - por meio da redução de volumes perdidos em áreas de vulnerabilidade social com consequente geração de receitas acessórias, e inclusão na cadeia de valor. Complementarmente, implica na redefinição da estratégia empresarial e reconhecimento dos ganhos efetivos da atuação sociotécnica, revisão de mecanismos de captação de recursos, e atração de novos investidores, incluindo a revisão da aplicação dos resultados financeiros na participação acionária e estabelecimento de uma gestão inclusiva com ferramentas de mediação. 


\section{CONCLUSÕES E RECOMENDAÇÕES DA TESE}

Considerou-se as controvérsias para a promoção da dignidade humana frente ao ordenamento jurídico, complexidade da gestão, o atual modelo e seus dispositivos, bem como as externalidades para contribuir à inovação necessária à universalização do saneamento em áreas vulneráveis da RMBS. Nesse sentido, os capítulos trouxeram:

O primeiro capítulo apresentou objetivos, procedimentos metodológicos, com definição da pergunta de pesquisa e delimitação do tema da tese;

O segundo capítulo apresentou inventário prévio, a problemática do atual modelo de negócios, o referenciado atual modelo e taxonomia de modelos num benchmarking comparáveis;

O terceiro capítulo, sob metodologia da Teoria-Ator-Rede, contém mapeamento da natureza dos grupos, das ações, dos objetos, das ciências naturais e das ciências sociais para a geração da cartografia das controvérsias da universalização em áreas vulneráveis;

O quarto capítulo, mediante a análise da política pública e das práticas do setor, propôs-se a inovação de conceitos e indicadores capazes de capturar as condições de exclusão do cidadão: Universalização Inclusiva, Governança Inclusiva e Vulnerabilidade Empresarial.

O quinto capítulo apresentou os resultados dos procedimentos de coleta de dados mediante questionários, entrevistas e oficinas com atores do setor de diferentes grupos, bem como usuários e sociedade civil organizada, e vistorias a domicílios;

No capítulo seis, a avaliação do capítulo cinco foi realizada apoiada no referencial teórico conceitual dos dados coletados por questionários e das entrevistas realizadas das práticas de gestão, lacunas da política pública, desafios do Poder Concedente na regularização e urbanização das áreas e do modelo atual.

O capítulo sete apresentou uma nova metodologia de elaboração de Planos de Negócios Inclusivos para áreas de aglomerados subnormais para todos os municípios, adotando os indicadores e conceitos inclusivos. identificam-se custos regionais de investimentos e operação de áreas vulneráveis para monetizar os recursos necessários para as metas definidas.

No oitavo capítulo estudou-se equacionamento econômico-financeiro para contexto que atenda o mecanismo de subsídio à baixa renda, as possibilidades, volumes de 
subsistência, impacto no orçamento familiar e referencial do setor.

O nono capítulo apresentou equacionamento jurídico baseado nos mecanismos de mediação, apoiado na constituição e princípio da dignidade humana, estatuto das cidades e função social da propriedade. A aplicação do direito humano fundamental é analisado como mecanismo de revisão do ordenamento jurídico quando se trata de serviços essenciais.

O décimo capítulo desenvolveu diagnóstico para inovação da estratégia empresarial e do Balance Score Card - BSC.

O décimo-primeiro capítulo desenvolveu o diagnóstico do modelo de gestão empresarial no sentido de alavancagem do modelo de negócio para universalização inclusiva, por meio da revisão de estratégia, estrutura organizacional, planejamento estratégico e situacional e procedimentos na teoria Ator-Rede.

O décimo segundo, consolidou os resultados da pesquisa, desenvolveu o referencial teórico conceitual para o Modelo Inclusivo do Saneamento (MIS), os pilares modelo, a geração de valor e os objetivos de um modelo de negócio socioambiental, testou o modelo adotado e Ator-rede. Finalizou com a arquitetura do MIS, o Modelo na Teoria Ator-rede.

A tese adotou metodologia qualitativa e recursos metodológicos multivariados de coleta de dados: pesquisa bibliográfica; pesquisa documental; pesquisa de dados êmicos; mapeamento de controvérsias; discussão de grupo (Bauer e Gaskell, 2002; Denzin, 1970a; Denzin, 1970b; Denzin, 2000; Kvale, 1996; Quivy e Van Campenhoudt, 2003; Latour, 2012; Triviños, 1995). A interpretação dos dados coletados foi realizada mediante emprego da triangulação múltipla (Adorno e Castro, 1994; Denzin, 2000; Minayo et al., 2005; Patton, 2002). A incorporação também de análise temática como procedimento interpretativo para aprofundamento de resultados obtidos foi realizada por meio da estratégia da triangulação (Bardin, 1995; Minayo, 2004). O horizonte de tempo considerado nas projeções do Plano de Negócios para a Cidade Informal (projeções adotadas para áreas de aglomerados subnormais) foi de 2014 a 2020. Para as projeções foi considerado como ano base 0 ano de 2013. As referências e projeções adotadas foram com nível de desagregação de dados de municipalidade para os municípios de Santos, Praia Grande, São Vicente, Cubatão, Guarujá, Bertioga localizados na Região Metropolitana da Baixada Santista. 
A sintetização dos resultados da pesquisa, cujo condutor foi o Polo Metodológico (Figura 1), contempla o comparativo das características do Modelo tradicional e do Modelo Inovador de características Inclusivas e Cidadãs para universalização do saneamento em áreas vulneráveis (Tabela 60).

Tabela 60 - Características do Novo Modelo de Negócio Inclusivo do Saneamento

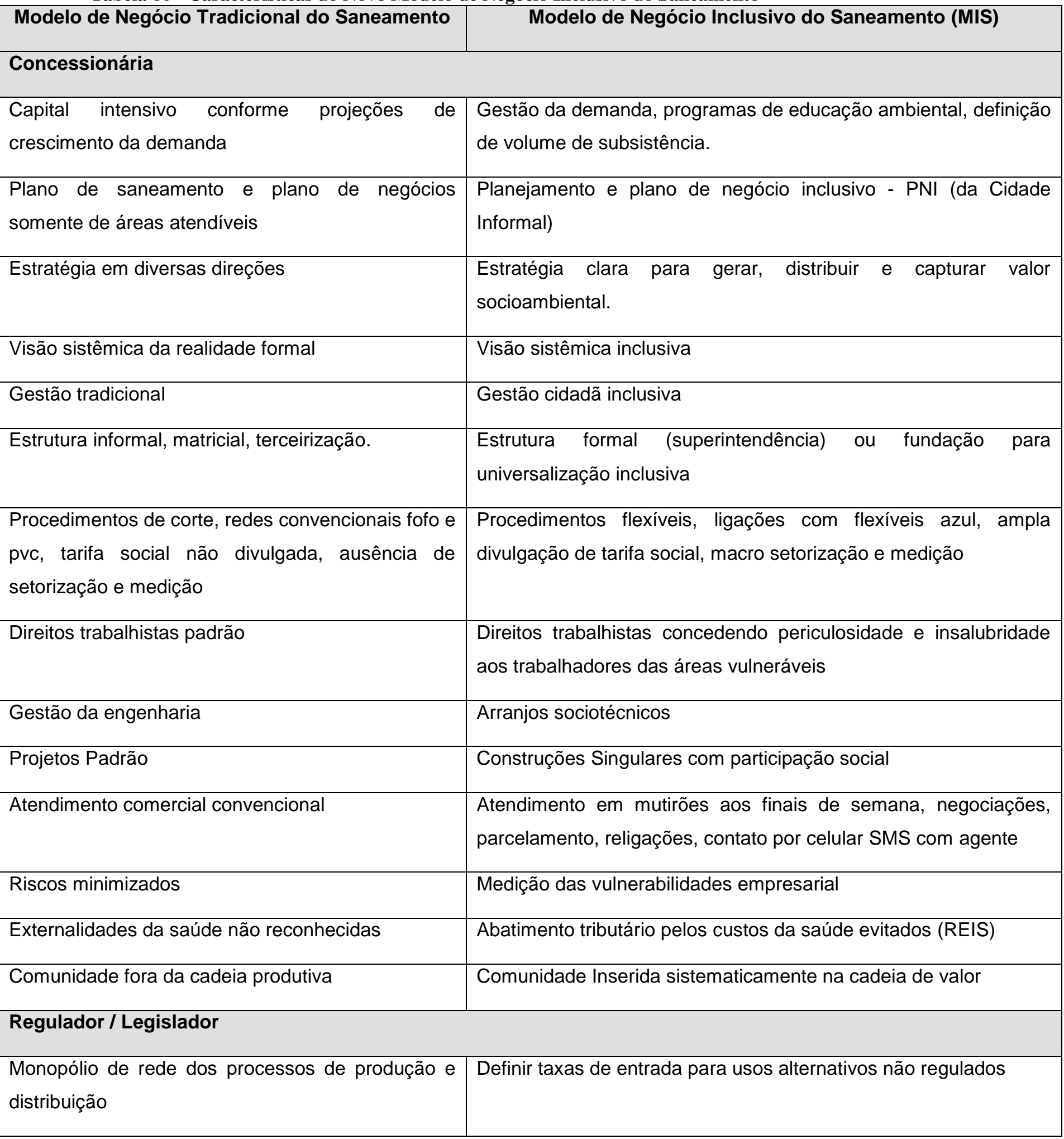


Contratos de programa de 30 anos

Contratos de gestão compartilhada, de performance (5 anos), contratos de programa de 40 a 50 anos, PPPs patrocinadas, PPP's administrativas, permissões, sub-concessões.

Eficiência técnica, sobre áreas regulares. Não regulados os serviços em áreas irregulares

DEC, FEC, custos de operação com inclusão dos moradores das comunidades, equilíbrio (regulação de toda área de concessão)

Acesso por redes públicas e serviços regulados

Incentivos a práticas de reuso, poços e soluções não regulamentadas, arranjos sociotécnicos, sistemas condominiais, empresários empreendedores

Tarifas médias remunerando BRR, custos dos serviços, WACC, subsídios e externalidades ou onerosidades e obras em andamento.

Novos parâmetros: impedir rateio da administração central para essas áreas, setorização de ativos doados, construídos em regime especial de incentivos; e construídos em mutirões; Impedimento da transferência dos ganhos sociais para outras camadas sociais

Externalidades ambientais não reconhecidas

Remuneração de APAs e APPs

Planejamento delegado à gestão da concessionária

Eficácia social sobre áreas atendíveis

Plano de negócios inclusivo, IGI, IUI da Cidade Informal

Fiscalização da base de beneficiados, tarifa social, condições de parcelamento, acessibilidade às agências

Custos eficientes globais

Plano $/ \mathrm{n}$. de habitantes $=\mathrm{R} \$ 39$ milhões $/ 400 \mathrm{mil}$ hab. $=$ $\mathrm{R} \$ 100 / \mathrm{hab} . / \mathrm{ano}$

Taxa de crescimento do município Taxa de crescimento dos aglomerados urbanos com ajustes pela concessionária

Investimento por taxas de mercado e recursos do acionista majoritário

Investimento com fundos que optam por menores taxas e maiores contribuições socioambientais e regime especial de incentivos

Preços Globais de equacionamentos e obras

Preços Locais com Inclusão na Cadeia Produtiva

Custos Globais de serviços

Custos do Setor Censitário /município

Segurança jurídica - aguarda acordos Ministério

Público e judiciário

Mediação apoiada no princípio da dignidade humana e Estatuto da Metrópole conduzida pelo Secretaria da Justiça

Subsídios Cruzados e Impostos do setor Subsídios à demanda pelo poder público, acionistas e por desoneração dos serviços,

Distribuição de dividendos

Reinvestimento dos dividendos

Produtos m3/s (fatura de água) e m3 demanda

Gestão da demanda: tecnologia smartwater

Perdas sociais misturadas com operacionais

Separação de perdas operacionais e contribuições voluntárias

Prestação de contas de acordo com o gestor

Governança Inclusiva e padronização de procedimentos 


\begin{tabular}{|c|c|}
\hline $\begin{array}{l}\text { Cadastramento por critérios de aplicabilidade da } \\
\text { concessionária }\end{array}$ & CADÚNICO e Volume de subsistência \\
\hline $\begin{array}{l}\text { Ausência de Indicadores e após regularização, } \\
\text { indicadores das áreas formais: índice de cobertura } \\
\text { e índice de atendimento }\end{array}$ & $\begin{array}{l}\text { Indicador de Universalização Inclusiva e Índice Governança } \\
\text { Inclusiva, Índices de Externalidade, Índice de Vulnerabilidade } \\
\text { Empresarial }\end{array}$ \\
\hline \multicolumn{2}{|l|}{ PODER PÚBLICO } \\
\hline Estado provedor, ou modelo de subsídios cruzados & Fundação, PPP's, títulos públicos municipais ou estaduais \\
\hline Poder concedente desarticulado & Poder concedente parceiro, decisor \\
\hline \multicolumn{2}{|l|}{ CIDADÃO } \\
\hline $\begin{array}{l}\text { Usuários excluídos dos processos de planejamento } \\
\text { e prestação de contas }\end{array}$ & Usuários incluídos pela governança inclusiva - cidadão \\
\hline \multicolumn{2}{|l|}{ INVESTIDORES E AGENTES FINANCEIROS } \\
\hline Concedentes de crédito & $\begin{array}{l}\text { Participativos e inovadores de soluções econômico financeira - } \\
\text { Fundos (socioambientais) }\end{array}$ \\
\hline \multicolumn{2}{|l|}{ JUDICIÁRIO E MINISTÉRIO P ÚBLICO - MP } \\
\hline $\begin{array}{l}\text { Atuação do Judiciário e MP processual, direito } \\
\text { objetivo }\end{array}$ & $\begin{array}{l}\text { Atuação do Judiciário como mediador com decisões pela } \\
\text { cidadania inclusivas - PL 517/2011 de mediação }\end{array}$ \\
\hline
\end{tabular}

Elaboração: a autora (2015)

Conforme as características estudadas, identificou-se que o modelo Inclusivo demanda: arcabouço institucional inovador, mecanismos financeiros mais coerentes a transpor as barreiras de entrada, suficientemente sensíveis às externalidades do setor, com um alicerce jurídico mais cidadão e menos liberal. Nesse modelo gestores empreendedores em todos os níveis da organização devem estar engajados e fortemente comprometidos com a inclusão cidadã. Acima de tudo, o poder público mais participante e ágil; os reguladores cônscios de que seu papel deverá ir além das normas do marco regulatório para alcançar propósitos republicanos e garantir a dignidade humana. Muitos modelos de negócio são possíveis, mas dependem do comprometimento de todas as partes e de uma governaça inclusiva e identificadora dos mecanismos de exclusão.

Como conclusão, entende-se que argumentos hegemônicos da gestão, num mundo de controvérsias, implicam em escolhas e limitações éticas do modelo de negócio quanto à intervenção efetiva sobre sistemas e a vida dos cidadãos individuais. Inclui a redefinição do espaço em que se exerce a provisão de água e saneamento em 
áreas de pobreza, a despeito do modo que os atores conectados, entendidos como coletivos e individuais, apresentem diferentes situações de legalidade dos domićlios. A inovação do modelo institucional parte do referencial conceitual, de indicadores testados e aplicados na metodologia do plano de negócios inclusivo. A barreira legal de atuação pode ser transposta por meio de mediação, por adoção de câmaras arbitrais de cidadania instituídas por lei, Secretaria de Justiça do Estado e apoiada pelo Conselho Nacional de Justiça e Ministério Público. O equacionamento financeiro depende de projeto de lei em tramitação no Senado.

Autores franceses nortearam os fundamentos da tese, desde o diagnóstico, construção de conceitos, e adoção de princípios de gestão e direito reconhecendo controvérsias dos mecanismos de exclusão de sistemas de infraestrutura de rede conforme Jean-Pierre-Dupuy, Gabriel Dupuy, Lagrange e Latour. Outros autores de melhores práticas e benchmarking fundamentaram o modelo, como as publicações do Banco Mundial de Durana e do Monitor Group sobre negócios inclusivos; Banco Interamericano de Desenvolvimento, IHE e Harvard subsidiaram a inovação de modelo de negócio em países pobres; Kaplan \& Norton subsidiou o planejamento empresarial; Marques e Berg a regulação; Mintzberg a estratégia e liderança, Brugmann e Prahalad o empreendedorismo, e Gibson, a governança e sustentabilidade.

Há que se considerar, que as construções de soluções para universalização inclusiva com participação social sendo de caráter público, privado, do terceiro setor ou conjunção de todos os atores sempre serão arranjos singulares, portanto merecem reconhecimento e aceitação considerando a condição de aplicabilidade mais eficaz.

A tese apresentada foi resultado de uma produção de oficinas de construção, deixando de ser de caráter estritamente técnico, trata-se de uma construção sociotécnica meritória. A ativação dos atores-rede da Teoria de Latour promoveu uma permanente oficina experimental na construção da inovação do modelo, sendo que a pesquisadora foi uma relatora, facilitadora, fundamentadora de referencias teóricos e melhores práticas. A resultante é uma construção de especialistas do setor em diversas esferas de atuação, pensando a inovação do saneamento para universalização, atendendo objetivos empresariais, mudando o pensamento hegemônico da gestão no tratamento da periferização dos centros urbanos, 
agravados pelas disparidades da gestão. Há que se reconhecer que se por um lado políticas e procedimentos perpetuam os mecanismos de exclusão, por outro, sanitaristas buscam meios e mecanismos para atender usuários em situação de exclusão social com serviços públicos de saneamento. Nesse sentido, a construção do modelo foi colaborativa, contando com o auxílio, mobilização, disponibilização de dados e materiais para consulta por todos os atores de diversas diretorias da concessionária, agência e municipalidades superando diferenças de toda ordem entre os mesmos.

Os resultados obtidos foram, em primeiro lugar, a inovação de conceitos e indicadores, para a criação de um $\mathrm{PNI}$, que levou a concessionária a atingir a universalização nas áreas de vulnerabilidade de estudo e melhorar a eficiência técnica e eficácia social. Em segundo lugar, a inovação do modelo de gestão por meio de um diagnóstico da organização e do entorno contemplando uma proposta de modelo de negócio inclusivo, promoveu mutirões com Ministério Publico para a superação dos impedimentos legais para a universalização - Mutirões da Cidadania. No contexto regulatório, o equacionamento econômico-financeiro tende a ser resolvido por uma tarifa única "de entrada na rede", ou seja, os usuários de maior renda e de menor custo de conexão subsidiam os de menor renda e de maior custo. O equacionamento é possível em duas alternativas, o regulador impor alguma regra de universalização, ou reequilibra a estrutura tarifária, pesando mais a carga intramunicipal, até que haja uma política nacional ou estadual de subsídios para o setor de saneamento básico.

Identificou-se que os usuários de baixa renda, sem a intervenção sociotécnica, consomem $28 \mathrm{~m} 3 / \mathrm{mês} /$ domicilio para o mesmo perfil social dos que consomem $12 \mathrm{~m} 3 / \mathrm{mês} /$ domicilio após intervenção. Em geral, os usuários passam a consomir menos, e tem um aumento de bem estar pelo uso da infraestrutura. Porém, observou-se que sem um subsídio, os usuários tendem a não ter recursos para arcar com a tarifa permanentemente, o que eleva o numero de inadimplência e de clandestinidade em $50 \%$ após três meses da regularização. Identificou-se também que o custo de assentamentos, manutenção e conexão a uma rede, no caso de favelas e municípios com população de baixa renda, é variável. Ele dependente do tipo de acesso e do próprio domicílio. Os custos em áreas urbanas com construções 
de palafitas no litoral tendem a ser bem menores do que os mesmos custos em casas de alvenaria nas áreas urbanas fora do litoral. No entanto, as dificuldades de acesso, condições de solo e níveis de criminalidade encarecem os arranjos sociotécnicos podendo tornar os custos muito semelhantes. Neste contexto, uma parte razoável dos usuários nas áreas de vulnerabilidade social provavelmente não se ligará à rede, se os valores cobrados forem calculados baseados em custos.

O alcance social da pesquisa atingiu 2515 domicílios subnormais nas comunidades do Guarujá de Prainha, Marezinha, e Santa Cruz dos Navegantes com uma população estimada de 10mil pessoas, além dos resultados prévios de Cubatão.

O modelo previu, para universalização dos assentamentos precários da Baixada Santista, cuja população atual estimada é de 117 mil domicílios, até 2020 um montante de $\mathrm{R} \$ 283$ milhões.

Destaca-se que, a alocação no projeto diariamente dentro da concessionária permitindo as pesquisas em período integral garantiu mobilização da gestão. Identifica-se que os colaboradores sanitaristas tem uma vocação transdisciplinar que os leva a romper barreiras hierárquicas em busca de soluções às populações vulneráveis. As dificuldades se concentraram na difícil tarefa de discutir um setor refém de uma política pública em amadurecimento, para diagnosticar e focalizar um possível equacionamento a ser proposto.

Visando garantir a atualidade das práticas, a pesquisadora monitorou de julho de 2011 até julho de 2015 alertas do google sobre publicações na web de modelos de negócio de saneamento, modelos de negócios socioambientais, enterpreunership e grandes organizações sociais nos idiomas português e inglês.

A contribuição da tese é um modelo institucional apoiado no modelo de negócio e gestão, PNI, conceitos e indicadores para a medição da vulnerabilidade de uma concessão, contemplando a inclusão de usuários em áreas irregulares, assentamentos precários, e uma governança que considere os mecanismos de exclusão de redes provenientes do sistema jurídico e da leniência do poder público. A tese fornece metodologia para a garantia do planejamento para o atendimento de populações em áreas irregulares com controle social. A fundamentação jurídica construida permite a argumentação para autorização judicial a fim de prestar 
serviços públicos a essas populações. Também apresenta procedimentos para se operar áreas de assentamentos precários, pois, a universalização inclusiva implica na prestação de serviços públicos a todo cidadão, ainda que morador de domicílios em aglomerados subnormais e áreas irregulares. O saneamento é serviço público essencial atendendo a um direito humano, que atenderá populações excluídas. Demanda investimentos em infraestrutura que frequentemente são financiados a juros de mercado ou recursos próprios da concessionária, com parcela razoável dos custos irrecuperáveis, considerando a capacidade de pagamento dessa população, por essa razão, a política de bem-estar social é pilar do modelo de negócio inclusivo, sendo de competência e responsabilidades do Estado.

Nesse sentido, pelo modelo regulatório de eficiência econômica, a remuneração deve ocorrer por tarifas sociais, e quando a renda dos usuários for insuficiente para equilíbrio da concessão, indicam as melhores práticas, que devem ser subsidiadas pelo Estado, visando remunerar adequadamente a própria infraestrutura (pagamento pela construção e operação e reposição da rede); o uso da rede; o investimento e o custo de oportunidade do capital para atração de novos investidores e operadores no setor.

\subsection{RECOMENDAÇÕES E CONSIDERAÇÕES FINAIS}

A exemplo das melhores práticas das grandes empresas relatadas na revisão bibliográfica, com a criação de órgão/fundação com objetivos sociais e ambientais, com chamados negócios de impacto socioambiental, para ampliação da escala, sugere-se a criação de uma subsidiária num modelo de fundação para universalização inclusiva. Os subsídios concedidos no projeto de lei do regime especial na desoneração do setor e dividendos da concessionária matriz devem permitir um programa permanente para universalização inclusiva. Esse modelo demanda dois equacionamentos: o da alocação, do responsável pela universalização - "órgão técnico do sistema de gestão" nos termos da Lei 980/2015 a Fundação; o de financiamento e compensação via transferência direta de recursos, ou subsídios necessários ao custo dos serviços, que podem ocorrer por dividendos da concessionária como no mecanismo do SELIGA; ou por outros arranjos e diversas parcerias com um fundo garantidor para ampliar a participação 
privada nesse modelo e promover a entrada do empreendedorismo nas áreas vulneráveis e recursos do FEHIDRO.

A grande questão que resta neste contexto é como uma nova organização mudará o paradigma sobre a universalização. De maneira mais ampla, outras questões surgem quanto ao modelo mais adequado a ser adotado: uma empresa, fundação ou PPP's, contratos de performance e PPPs patrocinadas com títulos públicos. Questões que implicam na forma de prestação de serviço e de financiamento que pode alterar as condições de competição e melhorar o bem-estar social são pertinentes e deve-se prever compartilhamento de riscos em parcerias, prevendo o eventual descumprimento do contrato em caso de PPPs. No caso da Sabesp, foi adotado pela Diretoria da RMSP contratos de performance apoiados nos conceitos desta tese de volume acessório e receita excedente no estudo de viabilidade por aglomerado objetivando atratatividade de terceiros contratados, bem como remuneração dos mesmos. A unidade de Negócio Sul é a percursora do modelo.

Sob o ponto de vista regulatório, os modelos adotados podem gerar diferentes resultados quanto ao nível de bem-estar social e a política distributiva de renda ou redistribuição de riquezas entre agentes econômicos. Em termos de alocação, podese, restringir a entrada, impondo a universalização inclusiva exclusivamente à concessionária estabelecida ou remeter à uma nova organização proposta. Em um modelo como este, há que se escolher se ao prestador dos serviços será imposta a obrigação de universalizar aglomerados subnormais ou universalizar sem discriminar usuários.

Para estabeler a regulação em modelo de prestadores diferentes, em regime de PPP, demanda uma escolha e sopesar os dilemas. No caso da não permissão de discriminação, se o regulador fixar uma taxa de entrada muito alta, a tendência é que apenas a concessionária prestará o serviço, sendo necessário, neste caso equacionar a necessidade do subsídio cruzado. Se ao contrário, a taxa for muito baixa, a nova concessionária poderá servir os consumidores de baixo custo, que são os mais lucrativos, retornando o mecanismo de exclusão de redes ao iniciar pelos usuários mais lucrativos em áreas mais consolidadas. Assim, o nível de taxa a ser estabelecido definirá se os novos entrantes atenderão os objetivos da política pública e do plano de negócios inclusivo em regime de eficiência produtiva, uma vez 
que a taxa de entrada eleva os custos da concessão, e deverá ser remunerada por subsidio.

Pode-se estabelecer uma regra do tipo play or pay que obriga a concessionária estabelecida a prover a universalização com seus dividendos e dá a opção à outra concessionária por PPPs ou empresa que queira entrar no mercado seguir a regra de universalização inclusiva (play) para os mercados menos lucrativos. Deve-se destacar que uma nova concessionária somente entrará no mercado menos lucrativo se ela for muito competitiva, se o prêmio for muito elevado, ou se o nível de impacto social for considerado pelo investidor, e os resultados dependerão da estratégia empresarial definida. Este modelo é mais eficiente tecnicamente e produz maior eficácia social.

Há ainda, a possibilidade de realização de leilão de concessões administrativas, em que o concessionário vencedor será aquele que se comprometer a estabelecer a menor tarifa, dada a obrigação de universalização inclusiva ou para servir apenas os usuários de baixa renda. No segundo caso, é necessário subsidiar tal atividade por meio de transferência governamental ou taxar o mercado com um fundo garantidor.

Modelos mais simples como os contratos de performance também são de implantação mais rápida, porém deve-se considerar o risco de não conseguir atingir os objetivos finais,se o prestador iniciar por áreas mais rentáveis e fáceis de intervenção, deixando áreas mais complexas para o final abandaonando o contrato ao final.

O regulador deverá impedir a desconexão entre o mercado lucrativo e não-lucrativo, podendo interferir inclusive nos sinais tarifários e da eficiência técnica.

A escolha de um Modelo de Negócio Inclusivo do Saneamento não é trivial, uma vez que é um monopólio, que afeta a sobrevivência de populações vulneráveis, de forma que prevalece no setor um temor quanto à participação privada e seus objetivos empresariais.

Há também que se considerar externalidades ambientais nas Bacias hidrográficas e a crise hídrica, que demandam mais recursos para o setor, remunerados exclusivamente por tarifas. Nesse sentido as demandas são muitas e os gestores 
públicos devem fazer escolhas razoáveis. Há uma disciplina de mercado. Olhar para a sustentabilidade financeira, considerando o direito humano e serviços públicos essenciais a vulneráveis deve ser uma responsabilidade compartilhada entre a concessionária, poder público e a comunidade. A sociedade civil tem o papel de assegurar que o sistema responda melhorar a governança, mas não é um substituto pra ele.

Deve-se empenhar esforços em identificar a quantidade de recursos direcionados ao bem-estar social promovido pelo saneamento a um cidadão, que deverá ser identificado e qualificado em situação de vulnerabilidade social. Na criação de um selo para água (como existe para energia e gás) cujos usuários pagariam tarifa equalizada por uma política social. A concessionária deve ser eficiente tecnicamente, eficaz e ter efetividade as ações para cumprimento das metas trabalhando por tarifas módicas. Nesse contexto, os usuários em situação de vulnerabilidade teriam uma parte de seu uso da água paga pelo subsídio governamental como um "Água para todos" ou "Água Paga". Assim, atender aos vulneráveis demanda mais do que fazer o que é legal, significa reconhecer que há um mínimo necessário à promoção da dignidade humana, preconizados em fundamentos e princípios de justiça, equidade e solidariedade e política pública de focalização e distributiva, que assim os considere. Também definir os limites e atribuições de cada ente no bem-estar social.

$\mathrm{Na}$ gestão empresarial, recomenda-se definir estratégia empreendedora com visão inclusiva socioambiental, com valores da cidadania e inclusão. Demanda a construção participativa de um $\mathrm{PNI}$, assumir riscos que os gestores empreendedores da base da organização têm assumido diariamente, por causa do caráter de suas ações, Porque estar com os cidadãos vulneráveis diariamente, olhar suas necessidades, faz com que o gestor nunca mais consiga tomar decisões alienado dessa realidade fática. $O$ fenômeno social que ocorre nas relações humanas entre cidadãos e trabalhadores sanitaristas extrapola em muito a racionalidade e as normas de exclusão. Passa por saberes, nos quais se observa construções singulares, cuidadoras, alinhadas com a realidade de vida dos vulneráveis. Gestores e Agentes Sociais se alienaram da indiferença para arriscarem-se pessoalmente em 
julgamentos pelo atendimento aos excluídos - os chamados subcidadãos, sendo urgente a implantação, ainda que em etapas de uma solução para a questão.

Nesse sentido, urge o judiciário e executivo assumirem sua parcela na execução da política pública do bem-estar-social, as concessionárias adotarem um posicionamento estratégico, com um plano de negócios e gestão inclusivos, que defina os limites do equilíbrio econômico-financeiro de uma concessão, e aos reguladores executarem a política pública, garantindo que os prestadores operem em regime de eficiência e eficácia da prestação dos serviços para efetividade de ações inclusivas e empresariais.

A aplicação na concessionária, como resultado da tese, levou a redefinição de estratégia, ampliação da escala com Plano de Negócio Inclusivo na Baixada Santista e RMSP iniciando pela Unidade de Negócio Oeste, para planejamento de universalização, encaminhamento desses resultados para obtenção de recursos não honerosos em Comitês de Bacias e adoção da avaliação dos custos das áreas não atendíveis nos contratos de programa, visando o equilíbrio da concessão. Quanto ao modelo de negócio, adotou os conceitos inovadores da tese de receita acessória e volume excedente e contração de terceiros em contratos de performance para universalização de aglomerados subnormais iniciando pela Unidade de Negócio Sul da RMSP. Também definiu a criação do mutirão da cidadania com o Ministério Público.

Para Núcleo de Pesquisa em Sustentabilidade (NUPs) do Centro de Recursos Hídricos e Sustentabilidade da Escola de Engenharia de São Carlos da Universidade de São Paulo e no IHE-Unesco, o tema alinha com os objetivos do grupo trazendo contribuições às pesquisas de indicadores de sustentabilidade, bem como para o Instituto Superior Técnico da Universidade de Lisboa, e Companhia de Saneamento Básico do Estado de São Paulo - SABESP. Como resultado da pesquisa, elaborouse uma proposta de projeto do NUPs/EESC/USP à FAPESP objetivando ampliação das pesquisas e implantação da mesma metodologia no Comitê de Bacias do Piraciacaba Capivari e Jundiai - PCJ. 


\section{REFERÊNCIAS BIBLIOGRÁFICAS TESE}

ABREU, A. B. Novas reflexões sobre a evolução da Teoria Administrativa: os quatro momentos cruciais no desenvolvimento da teoria organizacional. Revista de Administração Pública, Outubro/Dezembro, vol. 16, n.ำ 4, 1982.

ASSOCIAÇÃO BRASILEIRA DE NORMAS TÉCNICAS, ABNT. Activities relating to drinking water and wastewater services - Guidelines for the management of drinking water Utilities and for the assessment of drinking water services. INTERNATIONAL ISO STANDARD 24512. First edition 2007-12-01. BRASIL. 2012.

ADGER WN. Vulnerability. Global Environmental Change 16 p. 268-281. 2006.

ADMIRAAL, R. J.; VAN HELDEN, G. J. Benchmarking in the Dutch Waste-Water treatment sector. Public Money \& Management, v. 3, p. 113-118. 2003.

ADORNO, R. C. F.; CASTRO, A. L. O exercício da sensibilidade: pesquisa qualitativa e a saúde como qualidade. Saúde e Sociedade, v. 3, n. 2, p. 172-85, 1994.

ALEGRE, H., HIRNER W., BAPTISTA J.M., PARENA, R., Indicadores de desempenho para serviços de abastecimento de água, 2014. IWA, Performance indicators of water supply services. IWA International Water Association Publishing, 2000.

ALIER, Joan. Pobreza e meio ambiente: uma crítica ao Informe Brundtland. In: . Da economia ecológica ao ecologismo popular. Blumenau: Editora da FURB, 1998.

. Ecologismo dos Pobres: conflitos ambientais e linguagens de valoração. 2009.

ALMANSI F, HARDOY A, PANDIELLA G, SCHUSTERMAN R, URQUIZA G, GUTIERREZ E. Everyday Water Struggles in Buenos Aires WaterAid and Tearfund: London (2003).

ANDREAZZI,M.A.R., BARCELLOS C.,HACON S. Velhos indicadores para novos problemas: A relação entre saneamento e saúde. Rev Panam Salud Publica/Pan Am J Public Health 22(3), 2007. 
ANSOFF, H.Igor; DECLERCK, Roger P.; HAYES, Robert L. (Org.). Do planejamento estratégico à administração estratégica. São Paulo: Atlas, 1990.

ANTHONY, J., MCMICHAEL, A.J. The urban environment and health in a world of increasing globalization: issues for developing countries. Bulletin of the World Health Organization, 2000, 78 (9): 1117-1126.

ARAUJO, J.M.; GÜNTHER, W.M.R. Health risk in contaminated area: social theoretical contributions. Saúde e Sociedade, 2009, vol.18, n. 2, ISSN 0104-1290. ARSESP. AGÊNCIA REGULADORA DE SANEAMENTO E ENERGIA DO ESTADO DE SÃO PAULO. Processo n.05/2012. Disponível em: http://www.sabesp.com.br/sabesp/filesmng.nsf/B7CA544FCE64C55383257B2C007B B4B3/\$File/parecer68 2012 revisao encargo legal.pdf. Acessado em 03/10/2013.

. Contribuição SABESP à consulta pública 01/2012. Metodologia detalhada para 0 processo de revisão tarifária da SABESP. Primeiro ciclo tarifário. São Paulo: SABESP. Disponível em: <http://www.arsesp.sp.gov.br/ConsultasPublicasBiblioteca/Contribuicao_SABESP.pd f>. Acesso em: 13 jun. 2013.

1ำ revisão tarifaria da SABESP. Diretrizes metodológicas. São Paulo: ARSESP. Disponível em: $<$ http://www.arsesp.sp.gov.br/BancoDadosAudienciasPublicasArquivos/Apresentacao Ar sesp.pdf>. Acesso em: 13 jun. 2013.

Deliberação ARSESP $\mathbf{n}^{\circ}$ 253, de 09 de agosto de 2011, Comunica as tarifas e demais condições que vigorarão para a SABESP a partir de 11 de setembro de 2011.

PLANO DE NEGÓcIO. Nota Técnica Final (NTF) $N^{\circ}$ RTS/01/2012 para o Processo de Revisão Tarifária do Segundo Ciclo Tarifário da SABESP. 2012

DELIBERAÇÃO ARSESP № 156, de 30-07-2010. Agência Reguladora de Saneamento e Energia do Esatdo de São Paulo. http://www.arsesp.sp.gov.br/downloads/secoes/saneamento/consulta/022010/DELIB ERA\%C3\%87\%C3\%830\%20ARSESP\%20N\%20156\%2030 07 2010.pdf. 
ASIA W. Willing to pay but unwilling to charge: do" willingness to pay" studies make a difference Field Note, DFID (1999).

BARBETTA, P. A., Estatística aplicada às Ciências Sociais, Florianópolis: Ed. da UFSC, 1999.

BARBOSA, C. Pro-poor incentives for water and sanitation services provision: A case study of Water Utilities in the State of Sao Paulo, Brazil. The partial fulfilment of requirements for the Master of Science degree at the UNESCO-IHE Institute for Water Education, Delft, the Netherlands. 2010.

BARDIN, L. Análise de conteúdo. Lisboa: Edições 70, 1995.

BARROSO, A DIGNIDADE DA PESSOA HUMANA NO DIREITO CONSTITUCIONAL CONTEMPORÂNEO: NATUREZA JURÍDICA, CONTEÚDOS MÍNIMOS E CRITÉRIOS DE APLICAÇÃO. Disponível em: legislador.http://www.luisrobertobarroso.com.br/wp-

content/uploads/2010/12/Dignidade_texto-base_11dez2010.pdf. Acessado em: $11 / 06 / 2015$.

BATEMAN, Thomas S.; SNELL, Scott A. Administração: construindo vantagem competitiva. São Paulo: Atlas, 1998.

BAUER, M. W. ; GASKELL, G. (Eds.). Pesquisa qualitativa com texto, imagem e som: um manual prático. 3. ed. Petróplis Vozes, 2002.

BHATT, G. D. Knowledge management in organizations: examining the interaction between technologies, techniques, and people. Journal of Knowledge Management, v. 5, n. 1, p. 68-75. doi: 10.1108/13673270110384419, 2001.

BERG, S. V. (2007) Conflict resolution: benchmarking water utility performance. Public Administration and Development, v. 27, p. 1-11.

BERG, S. V.; MARQUES, R. Quantitative studies of water and sanitation utilities: a benchmarking literature survey. Water Policy, v. 13, n. 5, p. 591-606. 2011.

BERGER,P.L.;BERGER,B. O que é uma Instituição Social? In: https://docs.google.com/viewer?a=v\&q=cache:SiW2TNErpdlJ:cappf.org.br/tikidownload_wiki_attachment.php\%3Fattld\%3D188+\&hl=pt- 
BR\&gl=br\&pid=bl\&srcid=ADGEESjixrds82bR72-

irehq0txdypPeaHZHOk6qVBOU8dtvn-

XvluAQhBNZmN9mCi5E94c7e0e_rhGivdbG1S3ai8N5nYVHNfQ8JTUa4ItRA3S3MTp

AEdvkz85sFgwbZgrB3Ui5uqzP\&sig=AHIEtbRfeBclWykY2FAKOC8JzHuPXJbHJA.

Acessodo em 02/08/2012.

BERGERON, B. Essentials of Knowledge ManagementStudies in health technology and informatics. v. 160, p.1-208. New Jersey: John Wiley \& Sons, Inc. Retrieved from http://www.ncbi.nlm.nih.gov/pubmed/20841910, 2003.

BID - Banco Interamericano de Desenvolvimento. Iniciativa de Água Potável e Saneamento. Documento do Banco Interamericano de Desenvolvimento, 2007.

BOBBIO, N. A era dos direitos. Rio de Janeiro. Campus, 1992.

BORZAGA, C \& GALERA, G. Social Enterprise: an international overview of its concepts evolution and legal implementation, 2n.EMES International Conference on Social Enterprise. Social Enterprise Journal, 5 (3): 210-228.2009

BOSE, R. Knowledge management metrics. Industrial Management \& Data Systems, v. 104, n. 6, p. 457-468. doi: 10.1108/02635570410543771, 2004.

BOSSEL, $H$. Indicators for sustainable development: theory, methods, applications: a report to Balaton Group. International Institute for Sustainable Development. Winnipeg, Manitoba, Canada, IISD, 124p. 1999.

BOTTON, S; Braïlowsky, A; Matthieussent, S. THE REAL OBSTACLES TO UNIVERSAL ACCESS TO THE WATER SERVICE IN DEVELOPING COUNTRIES, Disponível em: http://wedc.lboro.ac.uk/resources/books/PPP and the Poor Real Obstacles to Universal Access to Drinking Water - Complete.pdf. Acessado em 20/04/2015. 2005.

BRASIL. Constituição da República Federativa do Brasil de 1988 Atualizada, 2010.

Decreto de regulamentação do Código das Águas. DECRETO № 24.643, DE 10 DE JULHO DE 1934. DEPARTAMENTO NACIONAL DE ÁGUAS E ENERGIA ELÉTRICA - DNAEE. Breve Histórico. 1934. 
Decreto Federal n. 82.587, de 6 de novembro de 1978. Regulamenta a Lei ํo 6.528, de 11 de maio de 1978, que dispõe sobre as tarifas dos serviços públicos de saneamento e dá outras providências. 1978A.

Lei federal n. 6.528. Dispõe sobre as tarifas dos serviços públicos de saneamento básico, e dá outras providências. 11 de maio de 1978B.

Lei Federal no 11.445, Estabelece diretrizes nacionais para 0 saneamento básico. 05 de janeiro de 2007.

Proposta de Plano Nacional de Saneamento Básico - Plansab. Site oficial do Ministério das Cidades 25/06/2012 18:35, Brasília, Disponível emhttp://www.cidades.gov.br/images/stories/ArquivosSNSA/PlanSaB/VP Plansab13 042011.pdf. 2012

SUS: histórias da Reforma Sanitária e do Processo Participativo / Ministério da Saúde, Secretaria de Gestão Estratégica e Participativa. - Brasília: Ministério da Saúde, 2006. 300 p. - (Série I. História da Saúde no Brasil). 2006

, Regularização Fundiária, LEI № 11.977, DE 07 DE JULHO DE 2009.

Política Judiciária Nacional de Atendimento Adequado dos Conflitos de Interesse no âmbito do Poder Judiciário. Resolução 125. CONSELHO NACIONAL DA JUSTIÇA -Disponível em: www.cnj.jus.br/atosadministrativos/atos-da-presidencia/323-resolucoes/12243-resolucao-no-125-de-29de-novembro-2010 acessado em 23/02/2015 às 11:51. 2015

SUPREMO TRIBUNAL FEDERAL. ADI 1842 - AÇÃO DIRETA DE INCONSTITUCIONALIDADE. Disponível em: < http://www.stf.jus.br/portal/processo/verProcessoAndamento.asp?incidente $=1714588$ >. Acesso em: 12 out. 2013.

O Estatuto da Metrópole - LEI № 13.089, DE 12 DE JANEIRO DE 2015, (BRASIL, 2015).

- Plano Nacional de Saneamento Básico PLANSAB. Ministério das Cidades. 2010. 
Diagnóstico domanejo de resíduos sólidos urbanos. Ministério das Cidades. Secretaria Nacional de Saneamento Ambiental. Sistema Nacional de Informações sobre Sanemaneto. (2009b) - 2009. Brasília,DF: MC. Disponível em: <http://www.snis.gov.br/PaginaCarrega.php?EWRErterterTERTer=91> Acesso em: 03 out. 2013.

Indicadores e Dados Básicos - Brasil - 2009. Rede Interagencial de Informações para a Saúde. 2009. Ministério da Saúde. Brasília, DF: MS. Disponível em: <http://tabnet.datasus.gov.br/cgi/idb2009/matriz.htm>. Acesso em: 03 out. 2013.

Cadastro Unico. MDS - Ministério do Desenvolvimento Social.

Disponível em: http://www.mds.gov.br/bolsafamilia/cadastrounico/sistemas/sistemadecadastrounico. Acesso em 26 de março de 2012.

BRESSER-PEREIRA, L. C. e SPINK, P. (orgs.). Reforma do Estado e Administração Pública Gerencial. São Paulo, ed. Fundação Getúlio Vargas. 1998.

BROCKLEHURST C, EVANS B Serving poor consumers in South Asian cities: private sector participation in water and sanitation. overview paper, Water and Sanitation Program South Asia, January. 2001.

BROCKLEHURST C, JAN J. B Innovative Contracts, Sound Relationships: Urban Water Sector Reform in Senegal. WATER SUPPLY AND SANITATION SECTOR BOARD DISCUSSION PAPER SERIES. Paper n. 1. The World Bank, Washington, DC. January. 2004.

BOVAIRD, T.; LÖFFLER, E. (2002) Moving from excellence models of local service delivery to benchmarking 'good local governance'. International Review of Administrative Sciences, v. 68, p. 9-24.

BOWERMAN, M.; FRANCIS, G.; BALL, A.; FRY, J. (2002) The evolution of benchmarking in UK local authorities. Benchmarking: an International Journal, v. 9, n. 5 , p. $429-449$. 
BRUGMANN, Jeb; PRAHALAD, C.K. Co-Creating Business's: New Social Compact. Harvard Business Review. p. 80-90. Feb 2007.

BRUYNE, P. et al. Dinâmica da pesquisa em Ciências Sociais; os polos da prática metodológica. 5. Ed. Rio de Janeiro, 1991.

BURRELL \& MORGAN, Social Paradigms and Organizational Analysis. London. 1979.

CALDERÓN, YCG. Indicadores para Benchmarking na prestação dos serviços de água e esgoto em áreas com populações vulneráveis da Baixada Santista. São Carlos, 2014. [Dissertação de Mestrado apresentada ao Programa de Pós Graduação em Ciências da Engenharia Ambiental, da EESC-USP).

BUSH, R.A.B., FOLGER, J.P., La promessa de mediacion: como afrontar el conflicto através del fortalecimento próprio y el reconocimiento de los otros. Buenos Aires: Granica. 1996.

CAFFÉ ALVES, A. Regiões Metropolitanas, Aglomerações Urbanas e Microrregiões: Novas Dimensões Constitucionais da Organização do Estado Brasileiro. Parecer elaborado para a SABESP. 2010.

CALIJURI, M. L.; SANTIAGO, A. F; CAMARGO, R. A.; MOREIRA NETO, R. F. (2009) Estudo de indicadores de saúde ambiental e de saneamento em cidade do Norte do Brasil. Engenharia Sanitária e Ambiental, Rio de Janeiro, v. 14, n. 1, p. 19-28.

CANOTILHO, J. J. Gomes. Direito Constitucional. 6. ed. Coimbra: Livraria Almedina, 1993, p. 493

Dignidade da pessoa humana e Direitos fundamentais na Constituição Federal de 1988. Porto Alegre: Livraria do Advogado, 2001.

Coimbra: Almedina, 2006

Direito Constitucional e teoria da constituição.

CAPONI,S. A saúde como abertura ao risco. In: CZERESNIA, D.; FREITAS, C. M. 
de (orgs.). Promoção da Saúde: conceitos, reflexões, tendências. Rio de Janeiro: Editora Fiocruz, 176 p. (55-77), 2003.

CARDOSO, F. B. F.; OLIVEIRA, F. R.; NASCIMENTO, F. S.; VARELLA NETO, P. L.; FLORES, P. M. (2008) Poços tubulares construídos no Brasil. In: Congresso Brasileiro de Águas Subterrâneas, 15. Natal: ABAS. CD-ROM. 9 p.

CASADESUS-MASANELL, R.; RICART, J. Competing through business models. papers.ssrn.com. Navarra. Retrieved from http://papers.ssrn.com/sol3/papers.cfm?abstract_id=1115201, 2007.

CASADESUS-MASANELL, R.; RICART, J. E. From Strategy to Business Models and onto Tactics. Long Range Planning, v. 43, n. 2-3, p. 195-215. Elsevier Ltd. doi: 10.1016/j.lrp.2010.01.004, 2010.

CASTRO, J. E.; HELLER, L. Water and Sanitation Services: public policy and management. Earthscan, UK and USA, 2009.

CAVE,M, (2009). Independent Review of Competition and Innovation in Water Markets: Final report, www.defra.gov.uk/environment/water/industry/cavereview London, 2009.

CERQUEIRA, MONIQUE BORBA E PUPOB, LÍGIA RIVERO.Condições e modos de vida em duas favelas da baixada santista e suas interfaces com o acesso aos serviços de saúde. 2009

CHIAVENATO, I. Teoria geral da administração, volume 2. Rio de Janeiro: Campus, 1999.

CHIAVENATO, Idalberto. Administração - teoria, processo e prática. 3.ed. São Paulo: Makron Books, 2000. 416 p.

CHIAVENATO, I. Introdução à teoria geral da administração: uma visão abrangente da moderna administgração das organizações. Edição Compactada. São Paulo: Elsevier Editora Ltda, 2004.

CHRISTENSEN, Clayton. OVERDORF, Michael. Meeting the challenge of disruptive change. Harvard Business Review, mar-april, 2000.

CIDADES, Secretaria Nacional de Saneamento Ambiental. 2008.

CIRCUITO MATO GROSSO. CAB Cuiabá inviabiliza 12 mil unidades habitacionais na capital. Disponível em: 
http://circuitomt.com.br/editorias/cidades/67622-cab-cuiaba-inviabiliza-12-milunidades-habitacionais-na-capital-.html. 2015. Acessado em 25/05/2015/10:00.

CLEVELAND JEWISH NESWS, The frugal business model: how to do more with less.

Disponível em: http://www.clevelandjewishnews.com/special sections/career path/article d58d7602 -a17e-11e4-9bcc-1f3df84de3c3.html. Acessado em: 07022015 18:23

COPASA. Relatório Anual e de Sustentabilidade. 2013. Disponível em http://www.copasa.com.br/media2/RelatorioAnual/Relatorio Anual Copasa 2013 P ortugues.pdf

COPASA. Formulário de Referência - 2013 - COMPANHIA DE SANEAMENTO DE MINAS GERAIS. 2013. Disponível em http://www.mzweb.com.br/copasa/web/default download.asp?NArquivo=Copasa FR 2013.

COUDOUEL et al. Poverty Measurement and Analysis. PRSP Sourcebook, World Bank, Washington D.C. 2002

CRESPO, A.P. A. e GUROVITZ, Elaine. A pobreza como um fenômeno multidimensional. RAE-eletrônica, Volume 1, Número 2, jul-dez/2002.

CRISTIA, A. C. (2006). El benchmarking como herramienta de evaluación. ACIMED, v. 14, n. 4. Disponível em: <http://bvs.sld.cu/revistas/aci/vol14_4_06/aci15406.htm>. Acesso em 03 out. 2013.

CROSS P, MOREL. A Pro-poor strategies for urban water supply and sanitation services delivery in Africa. Water science and technology: a journal of the International Association on Water Pollution Research 51: 51, 2005.

CROSSAN, Mary M.; APAYDIN, Marina. A multi-dimensional framework of organizational innovation: a systematic review of the literature. Journal of Management Studies, Sept 2010, 47:6.

CZERESNIA, D., FREITAS, C. M. Promoção da Saúde. Capítulo: O Conceito de Vulnerabilidade e as Práticas de Saúde: novas perspectivas e desafios. Ayres, José Ricardo de Carvalho Mesquita \& cols. 2003. 
DANI, F. A.; OLIVEIRA, A. B. de.; BARROS, D. S. O desenvolvimento sustentável como ótimo de Pareto na relação entre os princípios constitucionais ambientais e os princípios constitucionais econômicos. Rev. Direito Econ.

Socioambiental, Curitiba, v. 1, n. 2, p. 303-331, 2010. Disponível em:

http://www2.pucpr.br/reol/index.php/DIREITOECONOMICO?dd1=5043\&dd99=pdf. Acesso em 20 de Maio de 2012.

DAVIS, M. Planeta favela. Biotempo: São Paulo, 2006.

DAWBOR, L. Informação para a cidadania e o desenvolvimento sustentável. Disponível em ; <ppbr.com/ld/artigos/03hazelindicadores.pdf> 16:31hs 12/10/2011

DELMAR, F.; SHANE, S. Does business planning facilitate the development of new ventures?. Strategic Management Journal, v. 24, n. 12, p. 1165-1185. doi: 10.1002/smj.349, 2003.

DENZIN, N. K. Sociological methods: a sourcebook. Chicago: Aldine; 1970a.

DENZIN, N. K. The research act: a theoretical introduction to sociological methods. Chicago: Aldine; 1970b.

DIÁRIO DE CUIABÁ. Parecer enviado ao MPE pode complicar a CAB. 2015. Disponível em:

http://www.diariodecuiaba.com.br/detalhe.php?cod=472058. Acessado em 25/05/2015 10:10

DORSCH, J. J.; YASIN, M. M. (1998) A framework for benchmarking in the public sector: Literature review and directions for future research. International Journal of Public Sector Management, v. 11, n. 2/3, p. 91-115.

DENZIN, N. K. The practice and politics of interpretation. In: DENZIN, N. K.;

LINCOLN, Y. S. (eds.). Handbook of qualitative research. 2. ed. Thousand Oaks, California: Sage; 2000. p. 897-922.

DIAS L.C. Geografia e qualidade de vida: Pensando as redes técnicas, Palestra do XV SEMAGEO - Semana de Geografia da Universidade Federal de Santa Catarina - UFSC. GEOSUL,NO 17, ADo IX. (1994).

DONAHUE , JOHN D . 2004 . On Collaborative Governance. Working paper, John F. Kennedy School of Government, Center for Business and Government . 
DUPUY, G., OFFNER J.M. Réseau: bilans et perspectives. Flux n 62 Octobre Décembre pp 38-46. 2005.

DUPUY, JEAN-PIERRE Principe de precaution et catastrophisme éclairé - Les Cahiers du M.U.R.S. - \#42 - 2. Semestre 2003 - Remetre la science en culture. 2003

DUPUY, G. Villes, Systèmes et Réseaux - Le Rôle Historique des Techniques Urbaines, Les Annales de La Recherche Urbaine, n. 23-24, p. 231-241, 1984.

. L'Urbanisme des réseaux : théories et méthodes. In: Flux $n^{\circ} 9, \quad$ 1992. $\quad$ pp. 60-61.doi : $10.3406 /$ flux.1992.1648. http://www.persee.fr/web/revues/home/prescript/article/flux 1154$\underline{2721} 1992$ num 891648.

La respuesta del urbanismo clásico. In: El urbanismo de lãs redes. Teorias y métodos. Paris: Armand Colin Editeur, 1992. Barcelona: Oikos-tau, 1998. p. 71-119. (1998).

DURANA V., FRANCO N., GUTIERREZ R., LOBO I.D., TRUJILLO D. (2010), Serviços Públicos, Interesses Privados e Benefícios Sociais, in Negócios Inclusivos, Iniciativas de Mercado com los pobres de Ibero-America. Un proyecto de investigación colectiva de la Social Enterprise Knowledge Network. Oficina de Relaciones Externas del BID. 2010.

EMPLASA. Estudo da Morfologia e Hierarquia Funcional da Rede Urbana Paulista e Regionalização do Estado de São Paulo. 2010. Disponível em: http://www.emplasa.sp.gov.br/emplasa/ProjetosEstudos/Relatorios/Novosrelatorios 8-8/Rede REG relatorio\%207volume III.pdf.

O fenômeno da mobilidade pendular na Macrometrópole do Estado de São Paulo: uma visão a partir das quatro Regiões Metropolitanas Oficiais. Equipe responsável pelo NEPO/UNICAMP. 2013. Disponível em http://www.emplasa.sp.gov.br/emplasa/RELATORIO-PENDULARIDADE-UNICAMP06-02-2013.pdf.

ESCODA, M. S. Q. (2005) Avaliação de efetividade de ações de saneamento: análise 
de gestão. Ciência \& Saúde Coletiva, Rio de Janeiro, v. 10, n. 2, p. 493-497.

ESCRIVÃO FILHO, E. E. A natureza do trabalho do executivo. (Tese de Doutorado). Florianópolis: Eng. de Produção, UFSC. 1995. http://www.eps.ufsc.br/teses/escrivao/capit_1/edmcap1.htm\#1.2.1.

ESCRIVÃO FILHO, E; MENDES, J, V. O trabalho do administrador: uma visão geral e crítica. São Paulo: Saraiva. 2010.

ESCRIVÃO FILHO, E.; PERUSSI FILHO, S. (Org.).Teorias de Administração: introdução ao estudo do trabalho do administrador. São Paulo: Saraiva, 2010.

EWALD, F. A Concept of Social Law. In G. Teubner (ed.) Dilemas of Law in the Welfare State 40. Pag 40-75. Berlin. 1986.

FISHER, R., WILLIAM U., BRUCE P. Como chegar ao sim: Negociação de acordos sem concessões. 1981. Editora: Penguin Group, 1994.

FAUCHEUX, S.; HAAKE, J.; NICOLAÏ, I. Implications de la mondialisation économique sur la relation environnement-entreprises. Rapport de Recherche: C3ED/DGAD/SRAE n 95285, 1997.

FISCHER, R. Empreendedorismo social: apontamentos para um debate, Políticas Sociais: ideias e práticas, Moderna, São Paulo, 2011

FIORILLO, C. A. P. Curso de direito ambiental brasileiro. São Paulo: Saraiva, 2005.

FÖRSTER, Michael F. Measurement of Low Incomes and Poverty in a Perspective of International Comparisons. OCDE - Organização para a Cooperação e Desenvolvimento Econômico. Labour Market and Social Policy Occasional Paper No.14. Paris. 1994

FOUCAULT, M. Microfísica do poder. Rio de Janeiro: Graal, 1979.

. Naissance de La biopolitique. Gallimard: Paris, 2004,

O estado NeOliberal e a polittica neoliberal num espírito de luta ideológica partidária, 2011. 
FRASER, H. M. The practice of breakthrough strategies by design. Journal of Business Strategy, v. 28, n. 4, p. 66-74. doi: 10.1108/02756660710760962, 2007. G1, Rocinha e Vidigal marcharam em paz até o Leblon por saneamento e saúde, Disponível em http://g1.globo.com/rio-de-janeiro/noticia/2013/06/rocinha-evidigal-marcharam-em-paz-ate-o-leblon-por-saneamento-e-saude.html. Acessado em 26/06/2013;

G1, Assembleia em Itu discute medidas para enfrentar épocas de seca, Disponível em: http://g1.globo.com/sao-paulo/sorocabajundiai/noticia/2014/12/assembleia-em-itu-discute-medidas-para-enfrentar-epocasde-seca.html, Acessado em 07/12/2014.

. Juíza manda CAB Cuiabá provar que tem cumprido contrato de
concessão. Disponível em: http://g1.globo.com/mato-grosso/noticia/2015/05/juiza-manda-cab-cuiaba-provarque-tem-cumprido-contrato-de-concessao.html. 2015. Acessado em 25/05/2015/11:00.

GADIESH, O.; GILBERT, J. L. Transforming corner-office into frontline action. Harvard Business Review, v. may, p. 112-119, 2001.

GALIANI S, ROZADA M, SCHARGRODSKY E. Water Expansion in Shantytowns: Health and Savings. 2006.

GALVÃO JUNIOR, A. C. Regulação da Qualidade e Controle Social. In:

Regulação: indicadores para a prestação de serviços de água e esgoto. [S.I.]:

Fortaleza Expressão Gráfica e Editora Ltda., 2006. p. 161-178.

GARCIA MANJON, J. V. (2010) A Proposal of Indicators and Policy Framework for Innovation Benchmark in Europe. Journal of Technology Management \& Innovation, Santiago, v. 5, n. 2, p. 13-23.

GARROD, B.; CHADWICK, P. Environmental management and business stratety: towards a new strategic paradigm. Futures, v. 28, n. 1, p. 37-50, 1996.

GASSON C. Three reasons we're running out of water. 2014. Disponível em: https://agenda.weforum.org/2014/11/three-reasons-were-running-out-of-water/. Acessado em: 12/11/2014 08:01 hs.

GHAZIANI, A.; VENTRESCA, M. J. Keywords and Cultural Change: Frame Analysis of Business Model Public Talk, 1975-2000. Sociological Forum, v. 20, n. 4, p. 523-559. doi: 10.1007/s11206-005-9057-0, 2005. 
GIBSON, R. B. Specification of sustainability-based environmental assessment decision criteria and implications for determining "significance" in environmental assessment. Canadian Environmental Assessment Agency Research and Development Programme. Canada, 2001.

. Sustainability assessment: basic components of a practical approach. Impact Assessment and Project Appraisal, v. 24, n. 3, 2006.

. Beyond the pillars: Sustainability assessment as a framework for effective integration of social, economic and ecological considerations in significant decision-marking. Journal of Environmental Assessment Policy and Management. Waterloo. Vol. 8, No. 3 pp. 259-280. September 2006a

Sustainability-based assessment criteria and associated frameworks for evaluations and decisions: theory, practice and implications for the Mackenzie Gas Project Review. A report prepared for the Joint Review Panel for the Mackenzie Gas Project. Canada. January 2006b. Disponível em http://www.reviewboard.ca/upload/project_document/EA0809-

001_Gibson\%20Report_1218741818.pdf. Acesso em 18 jun 2012.

GLEICK, Peter H. e IWRA. M. Basic water requirements for human activities:

meeting basic needs. In: Water International, 21 (1996) 83-92. IWRA, EUA, 1996. GODARD, $O$. Stratégies industrielles et conventions d'environnement: de l'univers stabilisés aux univers controversés. In: INSEE. Environnement et économie. Paris. (Coll. INSEE - Méthode, n. 39-40), 1993.

GORDON, David. Indicators of Poverty \& Hunger. Apresentação no Expert Group Meeting on Youth Development Indicators. United Nations Headquarters, New York. 12-14 dezembro de 2005.

GUILAM, M.C.R. O conceito de Risco - Sua utilização pela Epidemiologia, Engenharia e Ciências Sociais. Disponível em: http://www.ensp.fiocruz.br/projetos/esterisco/

GUIMARÃES, E. F.; TEMÓtEO, T. G.; MALHEIROS, T. F. (2013) Benchmarking aplicado às Revisões Tarifárias de Saneamento, Revista DAE, n. 192, p. 34-47. 2013.

GUIMARÃES, E. F. \& MALHEIROS, T.F. Indicadores de Benchmarking do setor de saneamento aplicado a Revisões Tarifárias do Saneamento. Revista DAE. In: VIII 
Congresso Brasileiro de Regulação. 2013.

GUIMARÃES, E.F., COUTINHO,S, MALHEIROS,T.F, PHILIPPI JUNIOR, A. Os Indicadores do Saneamento medem a universalização em áreas de vulnerabilidade social? Engenharia Sanitária e Ambiental. , v.19, p.165 - 171, 2014.

GUIMARÃES, E.F., MALHEIROS,T.F.; MARQUES,R.C., Universalização inclusiva e governança inclusiva: Novos conceitos e indicadores de saneamento básico para áreas de vulnerabilidade social. IV Workshop Interdisciplinario de Investigación e Indicadores de Sustentabilid. Concepcion Chile. 422-433. 2015.

GUIMARÃES, E.F. ; ROGERS, A. P. . 'O Brasil está no Caminho certo'. Revista Brasileira de Saneamento e Meio Ambiente, Rio de Janeiro, p. 36 - 39, 03 ago. 2014. GÜNTHER, W. M. R. Áreas contaminadas no contexto da gestão urbana. São Paulo em Perspectiva, v. 20, n. 2, p. 105-117, abr./jun. 2006. Disponível em< http://www.seade.gov.br/produtos/spp/v20n02/v20n02 08.pdf>.

HABERMAS, J., The Theory of Communicative Action. London: Blackwell, v. 1, 1986.

HELLER, L.; NASCIMENTO, N. O.; PAIVA, J. E. M. SANEAMENTO. IN: MINAS GERAIS DO SÉCULO XXI. BELO HORIZONTE: ROMA, V. 3, 2002.

HOGAN, DANIEL J. AND MARANDOLA JR., EDUARDO. Toward an interdisciplinary conceptualisation of vulnerability. Population, Space and Place 11, 455-471. (2005).

Bringing a population-

environment perspective to hazards research. Popul Environ. In press 2012.

HONIG, B.; KARLSSON, T. Institutional forces and the written business plan. Journal of Management, v. 30, n. 1, p. 29-48. doi: 10.1016/j.jm.2002.11.002, 2004.

HUNTINGTON, S. P. Political order in changing societies. New Haven: Yale University Press, 1968.

IBGC Instituto Brasileiro de Governança Corporativa, Código das Melhores

Práticas de Governança Corporativa (2004). 
IKAWA, D. Universalismo, Relativismo e Direitos Humanos. In: Direito Internacional dos Direitos Humanos: Estudos em Homenagem à Prof. Flávia Piovesan. Juruá Editora. 2004.

IMPERIAL, M. T. Using Collaboration as a Governance Strategy: Lessons From Six Watershed Management Programs. Administration \& Society 2005; 37; 281.

INSTITUTO BRASILEIRO DE GEOGRAFIA E ESTATíSTICA. Ministério do Planejamento, Orçamento e Gestão. Pesquisa Nacional de Saneamento Básico. Coordenação de População e Indicadores Sociais. 2008. Disponível em http://www.ibge.gov.br/home/estatistica/populacao/condicaodevida/pnsb2008/PNSB 2008.pdf.

O Atlas de

Saneamento. Instituto Brasileiro de Geografia e Estatística - IBGE. Rio de Janeiro. RJ. 2011.

. (2011) Censo

demográfico 2010. Aglomerados subnormais. Primeiros Resultados. Rio de Janeiro: $\quad$ IBGE. 259 p. Disponível em: < http://www.ibge.gov.br/home/estatistica/populacao/censo2010/aglomerados_subnor mais/agsn2010.pdf >. Acesso em: 13 jun. 2013.

Pobreza e Desigualdade 2003. Release. Disponível em: http://www.ibge.gov.br/home/presidencia/noticias/noticia_visualiza.php?id_noticia=12 93\&id_pagina=1. Acesso em 22 de março de 2012.

Sistema SIDRA. Geração de tabelas. Disponível em: http://www.sidra.ibge.gov.br/bda/pesquisas/pof/default.asp Acesso em 22 de março de 2012b.

POF - Pesquisa de Orçamento Familiar. (2012a) do IBGE - Instituto Brasileiro de Geografia e Estatística. Disponível em http://www.ibge.gov.br/home/estatistica/populacao/condicaodevida/pof/2008_2009/d efault.shtm Acesso em 22 de março de 2012a. 
Instituto de Pesquisa Econômica Aplicada. IPEA. Cidades em Movimento: Desafios e Políticas Públicas. http://noticias.terra.com.br/brasil/cidades/ipea-n-demoradores-de-favelas-cresce-mais-de-50-embrasilia,55b3e12eba4a2410VgnCLD2000000ec6eb0aRCRD.html. 2013.

. Política, planejamento e governo. Brasília: IPEA,1993. 2 v. - Instituto de Pesquisa Econômica Aplicada (2012). Metodologia na determinação das linhas de pobreza e indigência (por insuficiência no consumo de calorias por dia). Disponível em: www.ipeadata.gov.br. Acesso em 23 de março de 2012.

IRAR - Instituto Regulador de Águas e Resíduos. Guia de Avaliação de Desempenho das entidades Gestoras de Serviços de Águas e Resíduos. 2005. JULIANO,E.F. - Desregulamentação no Saneamento, Custos no Sistema Único de Saúde e a utilização de taxas de entrada como mecanismo de regulação econômica, Trabalho Técnico aprovado para o Anais do 25 Congresso Brasileiro de Engenharia Sanitária e Ambiental, ABES - Associação Brasileira de Engenharia Sanitária e Ambiental, 2011.

JULIANO, E. F. G.A. E TUROLLA F. A. - Diagnóstico da utilização crescente das fontes alternativas de abastecimento - o papel do estado, do regulador e das concessionárias, frente aos riscos de saúde dos consumidores, e a ausência de políticas públicas integradas, In $<$ http://www.abesdn.org.br/eventos/abes/25cbes/PO.pdf $>$.2009. Pernambuco. Brasil. Resumos Anais do 25ํㅡㄹ Congresso Brasileiro de Engenharia Sanitária e Ambiental, ABES Associação Brasileira de Engenharia Sanitária e Ambiental, 107-212.

JULIANO, E. F. G.A., COUTINHO, S. M. V., PROTA, M. G., MALHEIROS T.F., Inter-relações Ambiente e Saúde no Uso de Poços Oficiais para Consumo Humano em Áreas de Contaminação dos Recursos Hídricos Subterrâneos. Environment and Health Interrelations in the use of official wells for human consumption in Areas of Contamination of Groundwater Resources. Número Especial: "Saúde Desenvolvimento e Sustentabilidade: Desafios da Rio +20". Revista Saúde em Debate (Revista do Centro Brasileiro de Estudos de Saúde) ISS: 01031104 v.36. Junho 2012. Ministério da Saúde. FIOCRUZ. Fundação Osvaldo Cruz. Pag $85-97$. 
JULIANO,E.F.G.,FEUERWEKER,L.,COUTINHO,S.;MALHEIROS,T.F.Racionalidade e Saberes na Produção de Modelos Organizativos para a Universalização do Saneamento em Áreas Urbanas do Brasil, Ciência \& Saúde Coletiva, 17(11):3037-3046, 2012b.

JUSBRASIL, Arsae recebe denúncias sobre serviços da Copasa e Copanor. Disponível em: http://al-mg.jusbrasil.com.br/noticias/2667345/arsae-recebedenuncias-sobre-servicos-prestados-pela-copasa-e-copanor. Acessado em 03/10/2013.

KALANTARI, B., HERBERT A. S., on making decisions: enduring insights and bounded rationality. Journal of Management History, v. 16, n. 4, p. 509-520, 2010. KAPLAN RS, NORTON DP. The balanced scorecard - measures that drive performance. Harvard Bus Rev. 1992; 70 (1): 70-9.

Putting the balanced scorecard to work. Harvard

Bus Rev. 1993; 71 (5): 134-9.

. Using the balanced scorecard as a strategic management system. Harvard Bus Rev. 1996a; 74 (1): 75-86.

. The balanced scorecard: translating strategy into action. Boston: Harvard Business School Press; 1996b.

. Having trouble with your strategy? Then map it. Harvard Bus Rev. 2000; 78 (5): 167-76.

.The strategy focused-organization: how balanced scorecard companies thrive in the new business environment. Boston: Harvard Business School Press; 2001.

Strategy maps: converting intangible assets into tangible outcomes. Boston: Harvard Business School Press; 2004. . The office of strategy management. Harvard

Bus Rev. 2005; 83 (10): 72-81. 
Alignment: using the balanced scorecard to create corporate synergies. Boston: Harvard Business School Press; 2006.

. The execution premium: linking strategy to operations for competitive advan3age. Boston: Harvard Business Press; 2008.

KANTER, R. From spare change to real change: the social sector as beta site for business innovation. Harvard Business Review, v. 77, n. 3, mai./jun. 1999.

KANTER, R. Transforming Giants: What kind of company makes it its business to make the world a better place?, Harvard Business Review, Janeiro, 2008

KATZ, D. \& KAHN, R. L. Psicologia social das organizações. 2a. ed. São Paulo: Atlas, 1987.

KAY, J.J. et al. An ecosystem approach for sustainability: addressing the challenge of complexity. Futures. 31, 721-742. 1999.

KLEIN, N., This Changes Everything - Capitalism X Climate. 2014.

KEEN, P.; QURESHI, S. Organizational Transformation through Business Models: A Framework for Business Model Design. In: IEEE (Eds.); 39th Hawaii International Conference on System Sciences. Anais.. . v. 00, p.1-10. Hawaai, 2006. KHANNA, N. Measuring environmental quality: an index of pollution. Ecological Economics, v. 35, n. 2, p. 191-202, nov. 2000.

KLEIN, L. Joan Woodward Memorial Lecture: Applied social science: is it just common sense? Human Relation. Vol. 59 (8), 2006. p. 1155-1172.

KLANG, D. J. H.; WALLNÖFER, M.; HACKLIN, F. The Anatomy of the Business Model: A Syntactical Review and Research Agenda. Summer Conference 2010 Opening Up Innovation. Anais.. . p.1-31. London: Imperial College London Business School, 2010.

KOONTZ, $\mathrm{H}$. The Management jungle theory revisited. Academy of Management Review. Vol. 5, n.․․ 2, 1980. p. 175-187.

KOTTER, J. P.; SCHLESINGER, L. A. Choosing strategies for change. Harvard Business Review. v. 8, 2008. p. 451-459. 
KRIKTEK, P.B., La negociacion em una mesa desparelha. Buenos Aires: Granica.1998

KVALE, S. The plurality of interpretations. In: InterViews: an introduction to qualitative research interviewing. Thousand Oaks, California: Sage; 1996. p. 221-8.

LAGRANGE,E.;The Thoughts of René-Jean Dupuy: Methodology or Poetry of International Law? The European Journal of International Law. Vol. 22 no. 2 @ EJIL 2011; all rights reserved.

LATOUR, B. (1993). We never have been modern. London: Harvest Wheatsheaf, Hemel Hempstead.

(2012). Reagregando o Social - Uma Introdução à Teoria AtorRede. Salvador:Edufba; Bauru, São Paulo:Edusc, 2012.

LLERENA, D. Internalisation de l'environnement et apprentissages dans les organisations. Thèse (Doctorat) - Facultés de Sciences Économiques et de Gestion de Strasbourg, Université Louis Pasteur. Strasbourg, France, 1996.

LUTHANS, F. Introduction to management: a contingency approach. New York, McGraw-Hill, 1976. p. 28-55.

MAGRETTA, J. Why business models matter. Harvard business review, p. 3-8.

Retrieved from

http://www.thetawer.com/wiki/images/8/8c/Why_Business_Models_Matter.pdf, 2002. MALACRIDA M.J.C., YAMAMOTO M.M., Corporte Governance: Information Disclousure Level and its Relation with the Stock Price Volatility on IBVESPA, R. Cont. Fin. Edição Comemorativa, p. 65-79, setembro de 2006. In: $<$ www.scielo.br/pdf/rcf/v17nspe/v17nspe06.

MALHEIROS, T. F.; PHILIPPI JR, A.; COUTINHO, S. M. V. (2006) Interfaces dos serviços de água e esgoto. p. 91-122. In: Regulação: indicadores para a prestação de serviços de água e esgoto. 2 ed. Alceu de Castro Galvão Júnior, Alexandre de Caetano da Silva, Editores. Fortaleza Expressão Gráfica e Editora Ltda. 204 p. 
MARANDOLA JR. AND HOGAN, DANIEL J. As dimensões da vulnerabilidade. São Paulo em Perspectiva 28, 1, 33-43 (2006).

MARQUES, R.C.; A regulação dos serviços de abastecimento de água e de saneamento de águas residuais - Uma perspectiva Internacional. Editora Entidade Reguladora de Serviços de Água e Resíduos (ERSAR) Centro de Sistemas Urbanos e Regionais (CESUR). Europress. Lisboa. Portugal. 2011.

MARQUES, R.; SIMÕES, R.; PIRES, J. Best practices in worldwide water regulation. Em publicação na Water Science and Technology, ISSN: 1606-9749. In press. 2010

MARQUES, R.; SIMÕES, R.; PIRES, J. The international experiences in use of benchmarking in the regulation of water utilities. Vol. 20, no. 1, pp. 125-132, Polish Journal of Environmental Studies, ISSN: 1230-1485, 2011

MARQUES, RUI. C (2005). A regulação dos Serviços Públicos. ED. SíLABO: LISBOA. 1.ED., 2005, 402P.

MARTINS G.A., THEÓPHILO C.R. Metodologia da Investigação Científica para Ciências Sociais Aplicadas. 2.ed.São Paulo.Atlas, 2009.

MATUS, C. Estrategia y Plan. 2. ed.Siglo XXI, México, 1978.

Fundamentos da planificação situacional. In: RIVERA, F. J. U. (Org.) Planejamento e Programação em Saúde: um enfoque estratégico. 2.ed. São Paulo: Cortez, 1992.

. Política, Planejamento e Governo. Ipea, Brasília, 1993.

MAXIMIANO, Antonio Cesar Amaru. Teoria geral da administração. 2.ed. São Paulo: Atlas, 2000.

MAXIMIANO, A. C. A. Teoria Geral da Administração. São Paulo: Atlas, 2008.

MCMICHAEL A. J., ENVIRONMENTAL AND SOCIAL INFLUENCES ON EMERGING INFECTIOUS DISEASES: PAST, PRESENT AND FUTURE. 2004.

MEDIUM. Every Flush You Take - Silicon Valley is watching your water habits. That's probably a good thing. DISPONÍVEL EM: 


\section{HTTPS://MEDIUM.COM/BACKCHANNEL/CONSERVING-WATER-WITH-}

SOFTWARE-AND-SHAME-3A846C01B811.ACESSADO EM: 20/01/2015 20:00HS.

MELO, H. P. \& BANDEIRA, L. A pobreza e as políticas de gênero no Brasil. CEPAL - COMISSÃO ECONÔMICA PARA A AMÉRICA LATINA E O CARIBE. SERIE MUJER Y DESARROLLO № $66-79$ PP. SANTIAGO DE CHILE. JUNHO DE 2005.

MEYER, J. W.; ROWAN , B. Institutionalized Organizations: Formal Structure as Myth and Ceremony. American Journal of Sociology, Vol. 83, No. 2 (Sep., 1977), pp. 340-363.

MIAGUSKO, E. Movimentos de Moradia e Sem Tetos em São Paulo: Experiências no contexto do desmanche. São Paulo: Alameda. 2012.

MIGLIATO, A. L. T.; PERUSSI FILHO, S. Administrar é comunicar e obter cooperação: a visão de Chester Barnard. In: MILHORATTI, A.M.; BEKERMAN, S.; MARQUES, J.B.; PEDROSA, C.V. Abordagem Sociotécnica para redução das perdas de água num sistema de distribuição em área de habitação subnormal do município de Santos - caso de Vila Gilda. Anais do 25․ Encontro Técnico AESABESP.2014.

MINISTÉRIO DAS CIDADES. Estudo sobre as deficiências de acesso e a probabilidade de cumprimento das metas de desenvolvimento do milênio nos serviços de saneamento básico no Brasil. São Paulo: MCid, 2008.

MINTZBERG, H.; AHLSTRAND, B.; LAMPEL, J. Safari de estratégia: um roteiro pela selva do planejamento estratégico. Porto Alegre: Bookmann, 2000, 2010.

MINTZBERG, $H$. The rise and fall of strategic planning. New York: Free Press; 1994.

Tracking strategies: towards a general theory. Oxford: Oxford University Press; 2007.

MINTZBERG H, LAMPEL B, QUINN JB, GHOSHAL S. The strategy process: concepts, context, cases. 4th. ed. Upper Saddle River: Prentice Hall; 2002. MINTZBERG H, WATERS JA. Of strategies, deliberate and emergent. Strat Manag J. 1985; 6 (3): 257-72. 
MITCHELL, G. Problems and fundamentals of sustainable development indicators. Sustainable Development, v. 4, n. 1, p. 1-11, 1996.

MONITOR GROUP, Emerging Markets, Emerging Models, Relatório da Monitor Group, 2009.

MONTANA, P. J.; CHARNOV, Bruce H. Administração. São Paulo: Saraiva, 1998.

MOORE, C..W. O processo de mediação - estratégias práticas para resolução de conflitos. Porto Alegre: Artmed. 1998.

MORGAN, Gareth. Imagens da organização. São Paulo: Atlas, 1996.

MORIN, E. (2010), Ciência com consciência, Bertrand, Rio de Janeiro, pp.344.

MORRISON-SAUNDERS, A.,THERIVEL, R. Sustainability integration and assessment. Journal of Environmental Assessment Policy and Management. Vol. 8, No. 3 (September 2006) pp. 281-298. September 2006.

MOSER, C. O. N. (1998) The asset vulnerability framework: reassessing urban poverty reduction strategies. World Development 26, 1, 1-19.

MOTTA, F. C. P.; VASCONCELOS, I. F. G. Teoria geral da administração. São Paulo: Pioneira Thomson Learning, 2005.

NADLER, D. A.; GERSTEIN, M. S.; SHAW, R. B.; e associados. Arquitetura organizacional: a chave para a mudança empresarial. Rio de Janeiro: Campus, 1994.

NADLER, D. A.; TUSHMAN, M. L. A model for diagnosing organizational behavior. Organizational Dynamics, 1980. p. 35-51.

NADLER, D. A.; TUSHMAN, M. L. The organization of the future: strategic and core competencies for the 21st century. Organizational Dynamics. Vol. 28, 1999. p. $45-60$.

NDLOVU, H.N. (2011). Working Paper. Developing and Testing Indicators for ProPoor Water and Sanitation Benchmarking: Case Studies in Bulawayo and Pietermaritzburg MSc Thesis WM.11.07. UNESCO-IHE -INSTITUTE FOR WATER EDUCATION. 
NYBAKK, Erlend; JENSSEN, Jan Inge. Innovation strategy, working climate and financial performance in tradicional manufacturing firms: an empirical analysis. International Journal of Innovation Management. Vol. 16, no. 2, April, 2012.

OCDE, Organização para a Cooperação e o Desenvolvimento Econômico, Peer Review - Relatório Final sobre Governança Regulatória no Brasil: Uma Visão Geral, 2008.

Handbook on Constructing Composite Indicators. Methodology and user guide. OECD Publications, Paris. 2008a.

Guidelines on Corporate Governance of State-Owned Enterprises. 2013.

Growing Unequal?: Income Distribution and Poverty in OECD Countries. OECD, Paris. 2008b

OLIVEIRA, ELY FRANCINA TANNURI DE E GRÁCIO, MARIA CLÁUDIA CABRINI, Análise a respeito do tamanho de amostras aleatórias simples: uma aplicação na área de Ciência da Informação, DataGramaZero - Revista de Ciência da Informação - vol.6 n.3 jun/05.

OROGANIZAÇÃO MUNDIAL DA SAÚDE - OMS. Guias para a qualidade da água potável Terceira Edição / Volume 1 Recomendações Organização Mundial da Saúde. Genebra 2004, baseado em Howard Bartram (2003).

ONU - Organização das Nações Unidas. Substantive issues arising in the implementation of the international covenant on economic, social and cultural rights. General Comment No. 15 (2002), The right to water (arts. 11 and 12 of the International Covenant on Economic, Social and Cultural Rights) http://www.unhchr.ch/tbs/doc.nsf/0/a5458d1d1bbd713fc1256cc400389e94/\$FILE/G0 340229.pdf. Página visitada em 24/10/2010.

Relatório dos Objetivos do

Milênio 
http://www.un.org/millenniumgoals/pdf/MDG\%20Report\%202010\%20En\%20r15\%20low\%20res\%2020100615\%20-.pdf Página visitada em 05/08/2010.

Comentário Geral N. 15. Comite da ONU sobre Direitos Económicos, Sociais e Culturais (CESCR). http://www.unhchr.ch/tbs/doc.nsf/0/a5458d1d1bbd713fc1256cc400389e94/\$FILE/G0 340229.pdf . Pagina visitada 20/10/2012.

, Human Development Report 2006 -

Beyond Scarcity, Powerty and Global Water Crisis (N.Y., Palgrave Macmillan,2006).

. Comitê de Direitos Econômicos, Sociais e

Culturais. (2002) Direitos à Água. Observação Geral no 15. Geneva: ONU.

. Questiones sustantivas que se plantean

en la aplicación del pacto internacional de derechos económicos, sociales y culturales. El derecho al agua (artículos 11 y 12 del Pacto Internacional de Derechos Económicos, Sociales y Culturales). Observación general no 15. 2002.

0 direito humano à água. Disponível em: http://www.un.org/spanish/waterforlifedecade/human right to water.shtml. Acesso em: 26 de março de 2012.

OSTERWALDER, A.; LAGHA, S.; PIGNEUR, Y. An ontology for developing ebusiness models. International Conference on Decision Making and Decision Support in the Internet Age. Anais.. Retrieved from http://citeseerx.ist.psu.edu/viewdoc/download?doi=10.1.1.24.404\&amp;rep=rep1\&amp;ty pe=pdf, 2002.

OSTERWALDER, A.; PIGNEUR, Y. An ontology for e-business models. Value Creation from E-Business Models. p.1-26. Wendy Currie, 2003.

OSTERWALDER, A.; PIGNEUR, Y. Modeling value propositions in e-Business. Proceedings of the 5th international conference on Electronic commerce - ICEC '03, p. 429-436. New York, New York, USA: ACM Press. doi: 10.1145/948005.948061, 2003b.

OSTERWALDER, A. The Business Model Ontology - A proposition in a design science approachBusiness, 2004. 
OSTERWALDER, A.; PIGNEUR, Y.; TUCCI, C. L. Clarifying Business Models: Origins, Present and Future of the Concept. Communications of the Association for Information Systems. Anais.. . v. 16, p.1-29, 2005.

OSTERWALDER A. Business model generation: a handbook for visionaries, game changers and challengers. Hoboken: John Wiley \& Sons, 2010.

OSTERWALDER, A.; PIGNEUR, Y. Business Model Generation (John Wiley \& sons, Eds.). p.278 p. New Jersey - USA, 2010.

OSTERWALDER A. Business model generation: a handbook for visionaries, game changers and challengers. Hoboken: John Wiley \& Sons, 2010.

OSTERWALDER, ALEXANDER E PIGNEUR, YVES. Business Model Generation, Inovação em Modelos de Negócios. Rio de Janeiro, RJ : Alta Books, 2011.

PATELI, A. G.; GIAGLIS, G. M. A research framework for analysing eBusiness models. European Journal of Information Systems, v. 13, n. 4, p. 302-314. doi: 10.1057/palgrave.ejis.3000513, 2004.

PARITÁ SABESP, Projeto de ações, regularização, e transformação de áreas irregulares. Documento de circulação restrita. 2011.

PAVITT, Keith. R\&D, patenting and innovative activities. A statistical exploration. Research Policy. Vol. 11, p. 33-51, 1982.

PERUSSI FILHO, S. (Org.). Teorias de Administração: introdução ao estudo do trabalho do administrador. São Paulo: Saraiva, 2010.

PIOVESAN, Flávia. Direitos Humanos e o Direito Constitucional Internacional. 4. ed. São Paulo: Max Limonad, 2000.

PMSP - Prefeitura Municipal de São Paulo, Plano Municipal de Saneamento Básico de São Paulo. Volume I. Texto. 2009. Disponível em: http://www.prefeitura.sp.gov.br/cidade/secretarias/upload/habitacao/arquivos/PMSB Volume I.pdf. Acessado em: 17/08/2015.

PNUD - Programa das Nações Unidas para o Desenvolvimento. (2006a). What is poverty? Concepts and measures. 2006a. 
do Desenvolvimento Humano 2006. A água para lá da escassez: poder, pobreza e a crise mundial da água. NY: PNUD. 2006b. Atlas de

desenvolvimento humano. Disponível em: http://www.pnud.org.br/atlas/. Acesso em 22 de março de 2012.

PORTER, M. Strategy and the Internet. Harvard business review, v. 79, n. 3, p. 6278, 164. Retrieved from http://www.ncbi.nlm.nih.gov/pubmed/11246925, 2001.

PORTER, M.; KRAMER, M. Creating Shared Value. Harvard Business Review. Jan-Feb 2011.

PORTER, M. E.; VAN DER LINDE, C. Toward a new conception of the environment-competition relationship. Journal of Economic Perspectives, v. 8, n. 4, p. 97-118, 1995.

PRABHU, R., COLFER, C. J. P., DUDLEY, R. G. Guidelines for developing, testing and selecting criteria and indicators for sustainable forest management. Toolbox Series, n. 1. Indonesia: CIFOR, 1999.

PRAHALAD, C.K. A riqueza na base da pirâmide: como erradicar a pobreza com o lucro. Wharton School Publishing, 2008.

PRESTER, Jasna; BOZAC, Marli Gonan. Are innovative organizational concepts enough for fostering innovation? International Journal of Innovation Management. Vol. 16. nr. 1, February, 2012.

PRIMEIRO, G. Ações Integradas de Urbanização de Assentamentos Precários. Ministério das Cidades. 2010.Disponível em: http://issuu.com/gabrielprimeiro/docs/snh003. Acessado em: 01/05/2015.

QUIVY, R.; VAN CAMPENHOUDT, L. Manual de investigação em ciências sociais. 3. ed. Lisboa: Gradiva, 2003. p. 226-32.

RASERA, D. Indicadores de universalização dos serviços de abastecimento de água e esgotamento sanitário em áreas com populações em vulnerabilidade socioambiental: Estudo de caso no município de Cubatão/SP. São Carlos, 2014. [Dissertação de Mestrado apresentada ao Programa de Pós Graduação em Ciências da Engenharia Ambiental, da EESC-USP). 
REFICCO, E. 2010. Negocios Inclusivos y Responsabilidad Social: un Matrimonio Complejo. Debates IESA, XV (3).

REFICCO, E. Políticas Sociais - ideias e práticas. Empreendedorismo Social e Desenvolvimento Sustentável. As empresas na sociedade: os limites das boas intenções. 2011. Editora Moderna. Disponível em: http://www.centroruthcardoso.org.br/anx\%5CPoliticas Sociais Final.pdf. Acessado em 03/10/2013.

REED, M. S. (2008) Stakeholder participation for environmental management: A literature review. BiologicalConservationn. 141, p. 2417-2431

RIBAS, R.P. Vulnerabilidade à pobreza no Brasil: medindo risco e condicionalidade a partir da função de consumo das famílias. Pesquisa e planejamento econômico. V. 37. N.2. Ago, 2007.

RIVERA, J. R. (2004) Benchmarking. Instrumentos de la gestión de procesos de negocio. [S.I.: s.n.]. Disponível em: <http://www.slideshare.net/iorifoar/benchmarkinginstrumentos-de-la-gestion-de-procesos-de-negocio>. Acesso em: 16 jun. 2013.

ROSA, C. A. Como elaborar um plano de negócio. v. 1, p.1-122. Brasília: Sebrae. Retrieved from www.sebrae.com.br, 2009.

RAMANASWAMI, S. N. Marketing controls and dysfunctional employee behaviors: A test of traditional and contingency theory postulates. Journal of Marketing. Vol. 60, 1996. p. 105-120.

SABATINI, F. Residential segregation pattern changes in Chile's main cities: scale shifts and increasing malignancy. International Seminar on Segregationand the City, Cambridge, Lincoln Institute of Land Policy. 2001.

SABESP Estudo de Tarifas para Uso Racional da Água - documento de acesso restrito. Estudo de Consultoria do Consórcio INECON-GERENTEC. São Paulo. 2004, 2005.

Projeto Piloto: Estratégias de Organização e Articulação com a Comunidade do Programa Córrego Limpo. Relatório de Circulação Restrita Síntese/CEBRAP -; 2011 
Estudos para a Revisão Tarifária do Estado de São Paulo documento de acesso restrito. Estudo de Consultoria SIGLASUL S/A. São Paulo, 2012a.

Relatório de Sustentabilidade, São Paulo, 2012b.

Site www.sabesp.com.br, acessado em 03/10/2013.

. Governador vistoria obras de esgoto do Programa Se Liga na Rede. http://site.sabesp.com.br/site/imprensa/noticias-detalhe. aspx? secaold=65\&id=5037 21/02/2013 16:50.

. Governo lança programa que vai custear ligação de esgoto. http://www.saopaulo.sp.gov.br/spnoticias/lenoticia.php?id=216244 - 21/02/2013 16:58.

. SABESP aplica o programa "Se Liga na Rede" em moradias de baixa renda. Disponivel em: http://ocultural.com/blog/2012/07/26/sabesp-aplica-oprograma-se-liga-na-rede-em-moradias-de-baixa-renda/. Acessado em: 21/02/2013 17:00.

SAMPAIO, E. V. S. B.; Sampaio, Y.; Vital, T.; Araújo, S. B.; Sampaio, G. R. (2003). Desertificação no Brasil: conceitos, núcleos e tecnologias de recuperação e convivência. Recife: Editora Universitária da UFPE.

SÃO PAULO. Governo sanciona lei que cria o programa Se Liga na Rede. http://www.saopaulo.sp.gov.br/spnoticias/lenoticia.php?id=217279 - dia 21/02/2013 $16: 47$.

- Lei Estadual n. 13.798/09 Política Estadual de Mudanças Climáticas do Estado de São Paulo - PEMC. 2009.

. DECRETO № 58.280, DE 8 DE AGOSTO DE 2012. Substitui os anexos que especifica do Decreto no 58.208, de 12 de julho de 2012, que regulamenta o Programa Pró-Conexão. 2012. Disponível em: www.legislacao.sp.gov.br/legislacao/dg280202.nsf/.../14.687.doc. Acessado em 17/08/2015. 
. Lei Estadual n.980/2015 que Dispõe sobre a Área de Proteção

e Recuperação dos Mananciais do Alto Tietê e Cabeceiras - APRM-ATC. 2015.

SÃO PAULO. TRIBUNAL DE JUSTIÇA DE SÃO PAULO. Guia Prático de Funcionamento do SEJUSC. Disponível em: www.tjsp.jusbrasil.com.br/noticias/100614320/tjsp-lanca-versao-eletronica-do-guia-praticode-funcionamento-do-cejusc acessado em 23/02/2015 às 11:51

SARLET, I. W. O Estado Social de Direito, a proibição do retrocesso e a garantia fundamental da prosperidade. Revista Eletronica sobre a Reforma do Estado (RERE), Salvador, Instituto Brasileiro de Direito Público, no 9, mar/abr/maio, 2007. Disponível em: <http://www.direitodoestado.com/revista/RERE-9-MAR\%C7O2007-INGO\%20SARLET.pdf>. Acesso em: 10/1/2015.

Proibição de retrocesso, dignidade da pessoa humana e direitos sociais: manifestação de um constitucionalismo dirigente possível. Revista Eletronica sobre a Reforma do Estado (RERE), Salvador, Instituto Brasileiro de Direito Público, ํo 15, set/out/nov, 2008. Disponível em: <http://www.direitodoestado.com/revista/RERE-15-SETEMBRO-2008INGO\%20SARLET.pdf>. Acesso em: $10 / 1 / 2015$.

A eficácia do direito fundamental à segurança jurídica: dignidade da pessoa humana, direitos fundamentais e proibição do retrocesso social no direito constitucional brasileiro. Revista Eletronica sobre a Reforma do Estado (RERE), Salvador, Instituto Brasileiro de Direito Público, № 21, mar/abr/maio, 2010. Disponível em: <http://www.direitodoestado.com/revista/RERE21-MAR-2010-INGO-SARLET.pdf>. Acesso em: 10/1/2015.

SANTOS, R. F. (2004) Planejamento ambiental: teoria e prática. São Paulo: Oficina de textos.

SANTOS, David Ferreira Lopes; BASSO, Leonardo Fernando Cruz; KIMURA, Herbert. A estrutura da capacidade de inovar das empresas brasileiras: uma proposta de construto. Revista de Administração e Inovação, v.9, n. 3, p. 103-128, jul-set 2012. 
SARLET, I.W. O Estado Social de Direito, a proibição do retrocesso e a garantia fundamental da prosperidade. Revista Eletronica sobre a Reforma do Estado (RERE), Salvador, Instituto Brasileiro de Direito Público, № 9, mar/abr/maio, 2007. Disponível em: <http://www.direitodoestado.com/revista/RERE-9-MAR\%C7O-2007INGO\%20SARLET.pdf>. Acesso em: 10/1/2015.

\section{Proibição de retrocesso, dignidade da pessoa}

humana e direitos sociais: manifestação de um constitucionalismo dirigente possível. Revista Eletronica sobre a Reforma do Estado (RERE), Salvador, Instituto Brasileiro de Direito Público, ํo 15, set/out/nov, 2008. Disponível em: <http://www.direitodoestado.com/revista/RERE-15-SETEMBRO-2008-

INGO\%20SARLET.pdf>. Acesso em: 10 /1/2015.

A eficácia do direito fundamental à segurança jurídica: dignidade da pessoa humana, direitos fundamentais e proibição do retrocesso social no direito constitucional brasileiro. Revista Eletronica sobre a Reforma do Estado (RERE), Salvador, Instituto Brasileiro de Direito Público, no 21, mar/abr/maio, 2010. Disponível em: <http://www.direitodoestado.com/revista/RERE21-MAR-2010-INGO-SARLET.pdf>. Acesso em: 10/1/2015.

SEADE - Fundação Sistema Estadual de Análise de Dados. (2012a). Disponível em: http://www.seade.gov.br/ Acesso em 23 de março de 2012.

Pesquisa de

Condição de Vida (PCV). Disponível em:

http://www.seade.gov.br/produtos/pcv/index.php. Acesso em 23 de março de 2012b.

Índice

Paulista de Responsabilidade Social (IPRS). Disponível em:

http://www.seade.gov.br/projetos/iprs/. Acesso em 23 de março de 2012c. Índice

Paulista de Vulnerabilidade Social (IPVS). Disponível em:

http://www.al.sp.gov.br/web/ipvs/index_ipvs.htm. Acesso em 23 de março de 2012d. SEDDON, P.; LEWIS, G. Strategy and Business Models: What's the Difference ?. Pacific Asia Conference on Information Systems. Anais.. Adelaide, 2003. 
SCHUMPETER, Joseph A. Teoria do desenvolvimento econômico. São Paulo: Abril Cultural,1982.

SEGOV. Caderno de Indicadores / Escritório de Prioridades Estratégicas. Belo Horizonte, Minas Gerais. Escritório de Prioridades Estratégicas. 2012. 251p.: il.

SEN, Amartya K. (1999). Desenvolvimento como Liberdade. São Paulo: Companhia das Letras, 1999. . (1999). Sobre Ética e Economia. São Paulo: Companhia das Letras, 1999.

SHIELDS, D.; SOLAR, S.; MARTIN, W. The role of values and objectives in communicating indicators of sustainability. Ecological Indicator, v. 2, n. 1-2, p. 149-160, nov. 2002.

SILASUL. Estudo de Tarifas para a Primeira Revisão Tarifária da SABESP. Produto B.7 - Recomendações e proposta de estrutura tarifária para Sabesp. Documento de circulação restrita. 2012a.

SILASUL. Estudo de Tarifas para a Primeira Revisão Tarifária da SABESP. Produto B.4 - Proposta de Subsídios Tarifários para SABESP. Documento de circulação restrita. 2012b.

SILVA, C. F., (2008). Trabalho informal e redes de subcontratação:dinâmicas urbanas da indústria de confecção em São Paulo. Mestrado em sociologia, FFLCH-USP, São Paulo, 2008.

SILVA, R.T. Público e privado na oferta de infraestrutura urbana no Brasil. In: Anuário Gedim 2002 (Cidades, serviços e cidadania). Programa Interdisciplinar Globalização Econômica e Direitos no Mercosul (Gedim), Unesco/MOST. Rio de Janeiro: Lúmen Júris, 2002. p. 53-112.

A regulação e o controle público da infraestrutura e dos serviços urbanos no Brasil. In: DEÁK, C.; SCHIFFER, S.R. (Org.). O processo de urbanização no Brasil. São Paulo: Edusp, 2004. p. 261-312.

. Pesquisa em saneamento - elementos para uma tecnologia socialmente inclusiva. Artigo apresentado na $3^{\text {a }}$ Conferência Nacional de Ciência Tecnologia e Inovação, Brasília, 16 a 18 de novembro de 2005. 
SILVA, A.H.L. (2006) Mensuração da Produtividade Relativa para o Setor de Distribuição de Energia Elétrica Nacional inserida no Cálculo do Fator $\mathbf{X}$. Dissertação (Mestrado). Departamento de Economia, Universidade de Brasília, Brasília, DF.

SLOMSKI, V. Controladoria e Governança no Setor Público. São Paulo, 2005.

SNSA - Secretaria Nacional de Saneamento Ambiental. Sistema Nacional de Informações sobre saneamento: diagnóstico dos serviços de água e esgotos 2008. Brasília: MCIDADES. SNSA, 408 p. 2010.

SOARES, S.I.O., A mediação de conflitos na gestão de recursos hídricos no Brasil. São Paulo, 2008, 172 p. Dissertação de mestrado PROCAM/USP, Orientador: Jacobo, P. R., 2008.

SOBRAL, A \& FREITAS, C.M. Modelo de Organização de Indicadores para Operacionalização dos Determinantes Socioambientais da Saúde. Saúde Soc. São Paulo, v.19, n.1, p.35-47, 2010.

SUARES, M. Mediacion, conduccion de disputas, comunicaccion e técnicas. Buenos Aires: Paidós, 2005.

SOARES, S.R.A. BERNANRDES, R.S.,NETTO, O.M.C. Relações entre saneamento, saúde pública e meio ambiente: elementos para formulação de um modelo de planejamento em saneamento. Cad. Saúde Pública, Rio de Janeiro, 18(6):1713-1724, nov-dez, 2002.

SOSNA, M.; TREVINYO-RODRÍGUEZ, R. N.; VELAMURI, S. R. Business Model Innovation through Trial-and-Error LearningThe Naturhouse Case. Long Range Planning, v. 43, n. 2-3, p. 383-407. doi: 10.1016/j.Irp.2010.02.003, 2010.

SPENDOLINI MJ. (1994) Benchmarking. Bogotá: Norma S.A. p. 11.

STONER, James A. Administração. Rio de Janeiro: Prentice-Hall, 1985.

STONER, James A. F.; FREEMAN, R. Edward. Administração. 9.ed. Rio de Janeiro: Prentice Hall do Brasil, 1992. 
TARR, J. and Dupuy G. The rise of the networked city in Europe and North America. Temple University Press, Philadelphia. 1988

TEMÓTEO, T. et al. Indicadores para serviços de abastecimento de água e esgotamento sanitário voltados às populações vulneráveis. Revista Brasileira de Ciências Ambientais, São Paulo, v. 17, p. 65-76, 2010.

TRATABRASIL. Benefícios Econômicos da Expansão do Saneamento Brasileiro. 2010. Disponível em: http://www.tratabrasil.org.br/novo site/cms/files/trata fgv.pdf. Acessado em 01/12/2014.

TORGERSEN, P. E.; CRAIG, R. J. A reexamination of Barnard's theory of organization. Engineering Management International, v. 1, p. 125-130, 1982.

TRIVIÑOS, A. N. S. Pesquisa qualitativa. In: Introdução à pesquisa em ciências sociais. São Paulo: Atlas; 1995. p. 116-73.

VELTZ, Pierre. La polarización: hechos, imaagenes, teorias. In: Mundialización, ciudades y territorios. Barcelona: Ariel, 1992 p.53-80.

TEECE, D. J. Business Models, Business Strategy and Innovation. Long Range Planning, v. 43, n. 2-3, p. 172-194. Elsevier Ltd. doi: 10.1016/j.Irp.2009.07.003, 2010. TORRES, H. G. Segregação Residencial e Políticas Públicas: São Paulo na década de 1990. Revista Brasileira de Ciências Sociais. V. 19 n. 54, 2004.

TRATABRASIL. Benefícios Econômicos da Expansão do Saneamento Brasileiro. 2010. Disponível em: http://www.tratabrasil.org.br/novo site/cms/files/trata fgv.pdf. Acessado em 01/12/2014.

TRIVIÑOS, A. N. S. Pesquisa qualitativa. In: Introdução à pesquisa em ciências sociais. São Paulo: Atlas; 1995. p. 116-73.

VAN DE VEN, A., H.; ANGLE, H L.; POOLE, M S. Research on the management innovation. The Minnesota Studies. New York: Oxford University Press, 2000. 
VENTURINI, T., LATOUR, B. The Social Fabric: Digital Traces and Qualiquantitative Methods InProceedings of Future En Seine 2009. Cap Digital. 2010.

VENTURINI, T., Building on Faults - How to Represent Controversies with Digital Methods. Public Understanding of Science, Forthcoming. 2012.

VIDAL, D.F.Z. (2006) Benchmarking como herramienta de evaluación y diagnóstico de sistemas de innovación. In: I Congresso lberoamericano de Ciência, Tecnología, Sociedad e Innovatión CTS +1, Mesa 11.

VILHENA JUNIOR, E. M. Direitos Fundamentais da Sociedade. Revista Jurídica da Escola Superior do Ministério Público de São Paulo. v.1. p. 71-95. 2012.

WHITE HOUSE, FACT SHEET: Increasing Investment in U.S. Roads, Ports and Drinking Water Systems Through Innovative Financing. Disponível em: http://www.whitehouse.gov/the-press-office/2015/01/16/fact-sheet-increasinginvestment-us-roads-ports-and-drinking-water-syste.Acessado em: January 16, 2015 22hs.

[WHO] - World Health Organization (1986) - Letter OTTAWA. First International Conference on Health Promotion. Ottawa, novembro de 1986.

World Health Organization and UNICEF - Joint Monitoring Programme for water Supply and Sanitation. Progress on sanitation and drinking-water - 2013 update. France: WHO. 2013.

- World Health Organization (2014) - Investing in water an sanitation: increasing acces, reduces inequalities.

- World Health Organization (2015) - Water for Women.

WERNECK, Paulo de Lacerda. Teoria Geral da Administração. 2. ed. - Rio de Janeiro : [s.n.], 2005. 51 p. Reprográfico.

WORLD BANK. Governance and Development. Washington, D.C., 1992.

World Development Indicators, World Bank, Washington. ISBN 978-

0-8213-7829-8. 2009.

World Development Report 2010: Development and Climate Change, World Bank, 300 pages. ISBN:0-8213-7987-9. 2009

Collection Title: World Development Indicators Date Stored: 2003/03/04 Document Date: 1998/03/31 Document Type: World Development Indicators ISBN: ISBN 0-8213-4124-3. 1998. 
WORLD BANK. Glossary. Disponível em:

http://www.worldbank.org/depweb/english/beyond/global/glossary.html. Acesso em 22 de março de 2012.

WREN, D. A. The evolution of management thought. 2rd. ed. New York: John Wiley \& Sons, 1979 p. 462.

. Ideias de administração: o pensamento moderno. São Paulo:

Editora Ática, 2007.

ZOTT, C.; AMIT, R. The fit between product market strategy and business model:

implications for firm performance. Strategic Management Journal, v. 26, n. August 2007, p. 1-26. doi: 10.1002/smj.642, 2008.

ZOTT, C.; AMIT, R. Business Model Design: An Activity System Perspective.

Long Range Planning, v. 43, n. 2-3, p. 216-226. Elsevier Ltd. doi:

10.1016/j.lrp.2009.07.004, 2009.

ZOTT, C.; AMIT, R.; MASSA, L. The Business Model: Theoretical Roots, Recent

Developments, and Future Research. Business. Madrid - Espanha, 2010. 


\begin{tabular}{|c|c|c|c|c|c|c|c|c|c|c|c|c|c|c|c|c|c|}
\hline \multirow{2}{*}{ Atividades Doutorado Ester Feche } & \multicolumn{12}{|c|}{2012} & \multicolumn{2}{|l|}{2013} & \multicolumn{3}{|c|}{2014} \\
\hline & jan & fev & mar & $\mathrm{abr}$ & mai & jun & jul & ago & set & out & nov & dez & jan/mar/abr/ago & set/dez & $\mathrm{jan} / \mathrm{abr}$ & $\begin{array}{c}\text { Mai/Ag } \\
0\end{array}$ & Set/dez \\
\hline \multicolumn{18}{|l|}{ Inscrição da Qualificação } \\
\hline \multicolumn{18}{|l|}{ Qualificação } \\
\hline \multicolumn{18}{|c|}{ Pesquisa Documental das Práticas Sabesp para Universalização } \\
\hline \multicolumn{18}{|c|}{ Workshops Estratégicos de Planejamento e Mobilização das Unidades SABESP } \\
\hline \multicolumn{18}{|c|}{$\begin{array}{l}\text { Levantamento e Construção do Dicionário dos Marcos Teóricos e Conceituais da } \\
\text { Universalização em àreas vulneráveis }\end{array}$} \\
\hline \multicolumn{18}{|l|}{ Estudo de Caso } \\
\hline \multicolumn{18}{|c|}{ Planejamento de Questionários e Aprovação pelo Comitê de Ética da USP } \\
\hline \multicolumn{18}{|l|}{ Aplicação de Questionários } \\
\hline \multicolumn{18}{|c|}{ Resultado dos questionários/tratamento, análise e interpretação dos dados } \\
\hline \multicolumn{18}{|l|}{ Construção e Revisão do Modelo } \\
\hline \multicolumn{18}{|c|}{ Avaliação Quantitativas e Qualitativas, Formatação e Edição } \\
\hline \multicolumn{18}{|l|}{ Doutorado Sanduiche } \\
\hline \multicolumn{18}{|c|}{ Artigo Técnico Publicação Nacional Indexada } \\
\hline \multicolumn{18}{|c|}{ Artigo Técnico Publicação Internacional Indexada } \\
\hline \multicolumn{18}{|l|}{ Redação da tese } \\
\hline \multicolumn{18}{|c|}{ Consolidação dos dados, conclusões e recomendações } \\
\hline \multicolumn{18}{|l|}{ Pré-banca } \\
\hline \multicolumn{18}{|c|}{ Análise das recomendações da pré-banca } \\
\hline Defesa & & & & & & & & & & & & & & & & & \\
\hline
\end{tabular}


MAPA 1 - Mapa da Controvérsia da Universalização do Saneamento em Áreas de Vulnerabilidade segundo Grupos e Ações

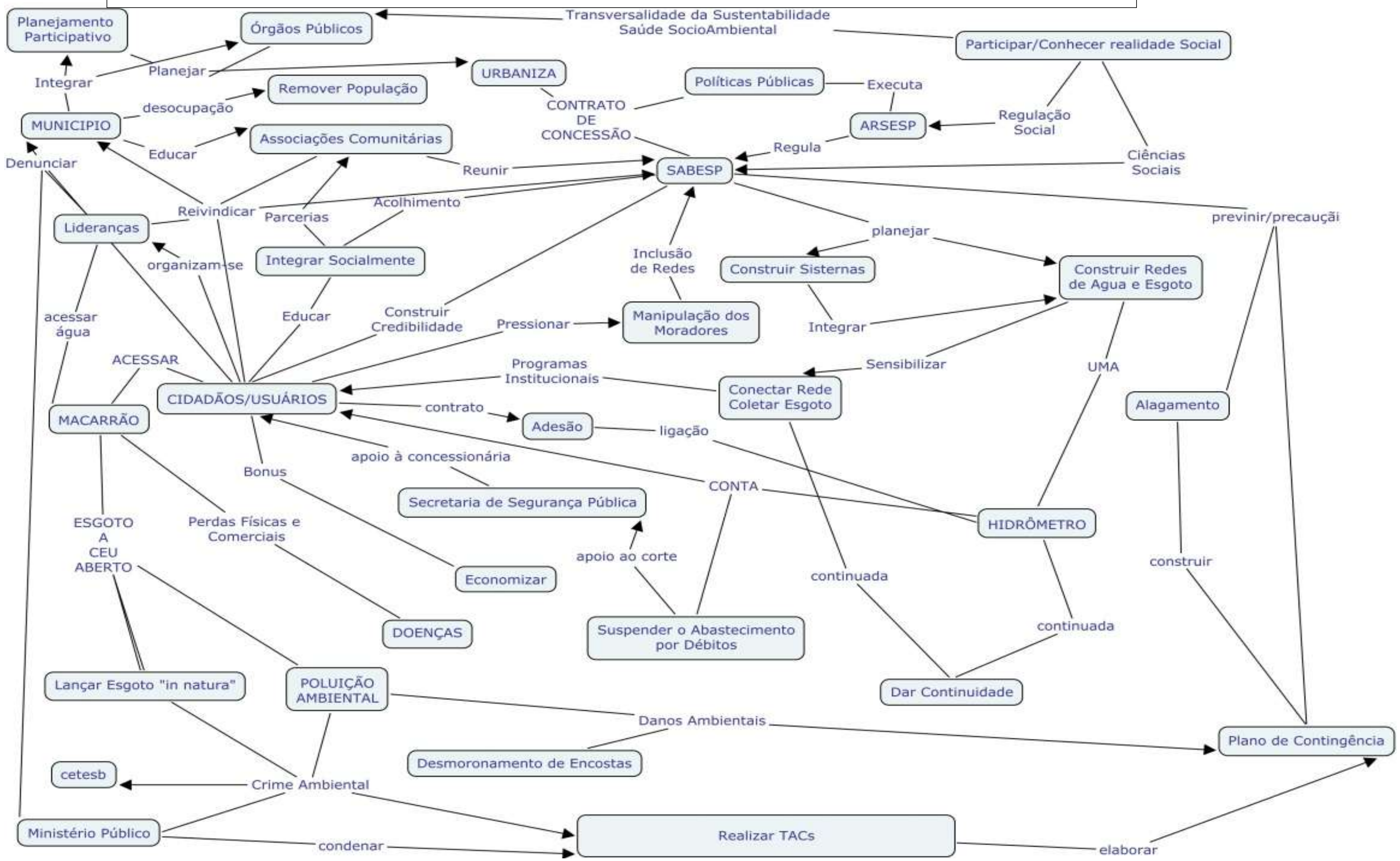

Mapa 1 - Mapa da Controvérsia pela Natureza dos Grupos e Ações 


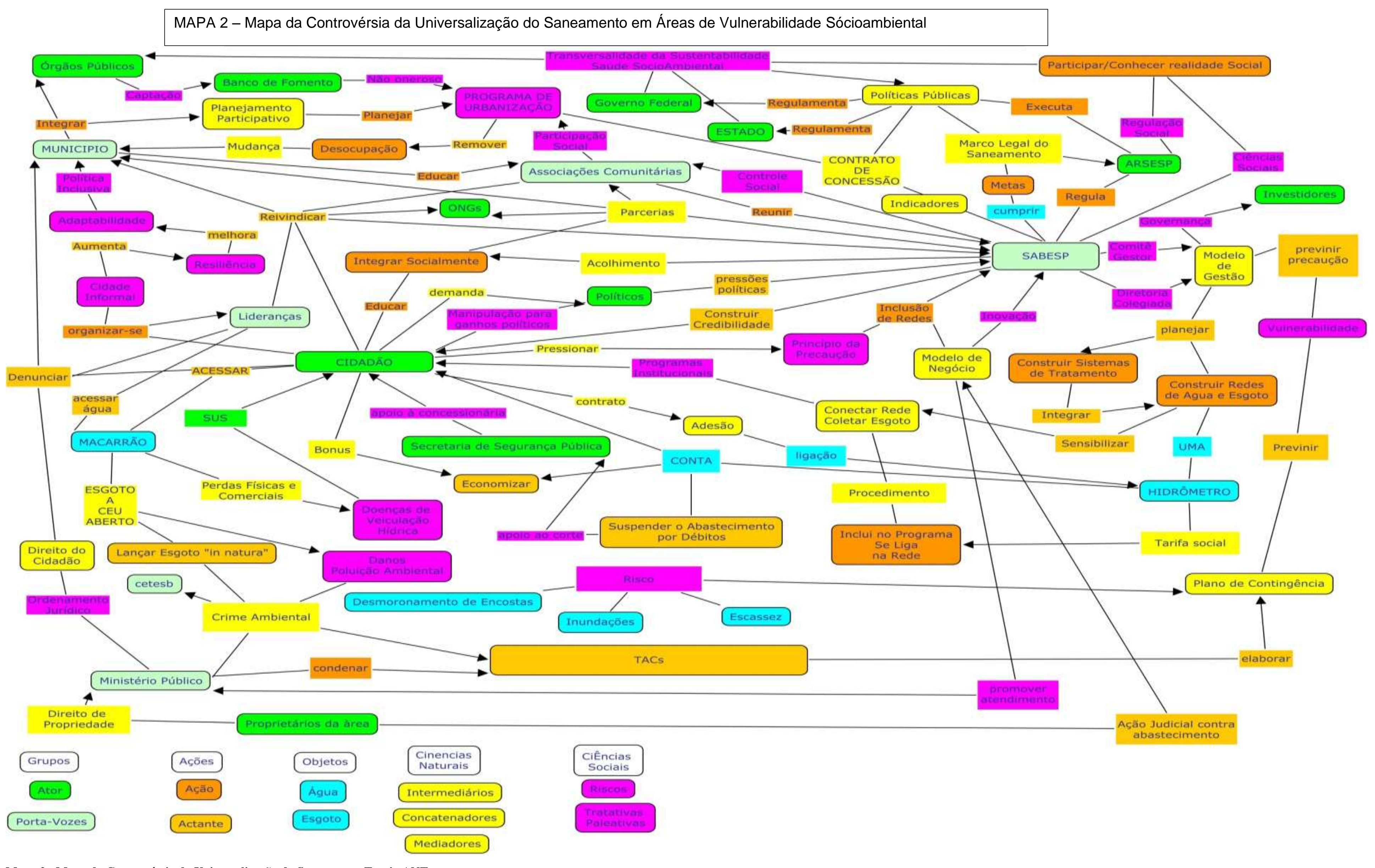

Mapa 2 - Mapa da Controvérsia da Universalização do Saneamento Teoria ANT 
Mapa 3 - Mapeamento de Áreas Vulneráveis e Irregulares na RMSP

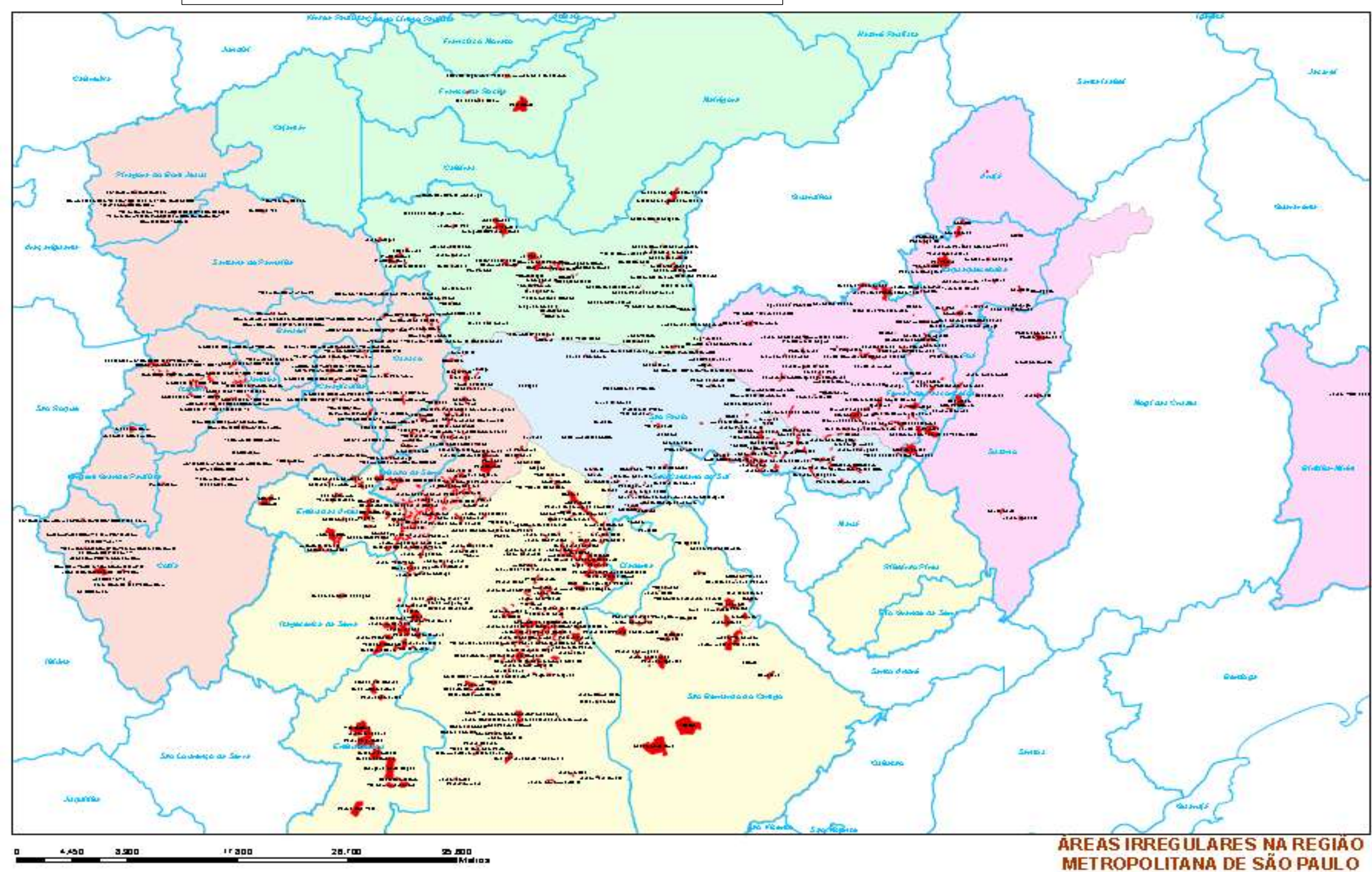

Mapa 3 - Mapeamento de Áreas Vulneráveis e Irregulares na RMSP 


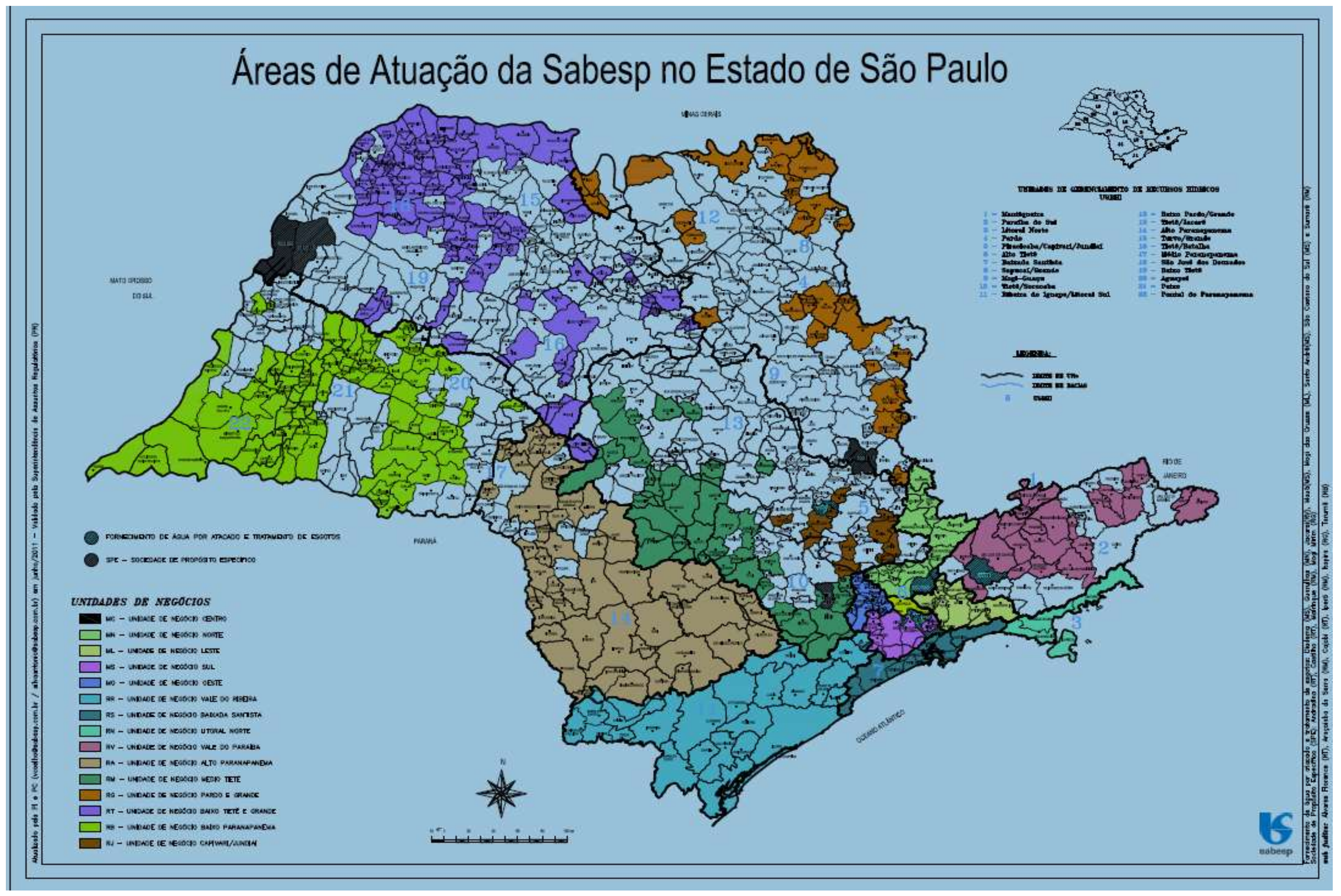

Mapa 4 - municípios do Estado de São Paulo 


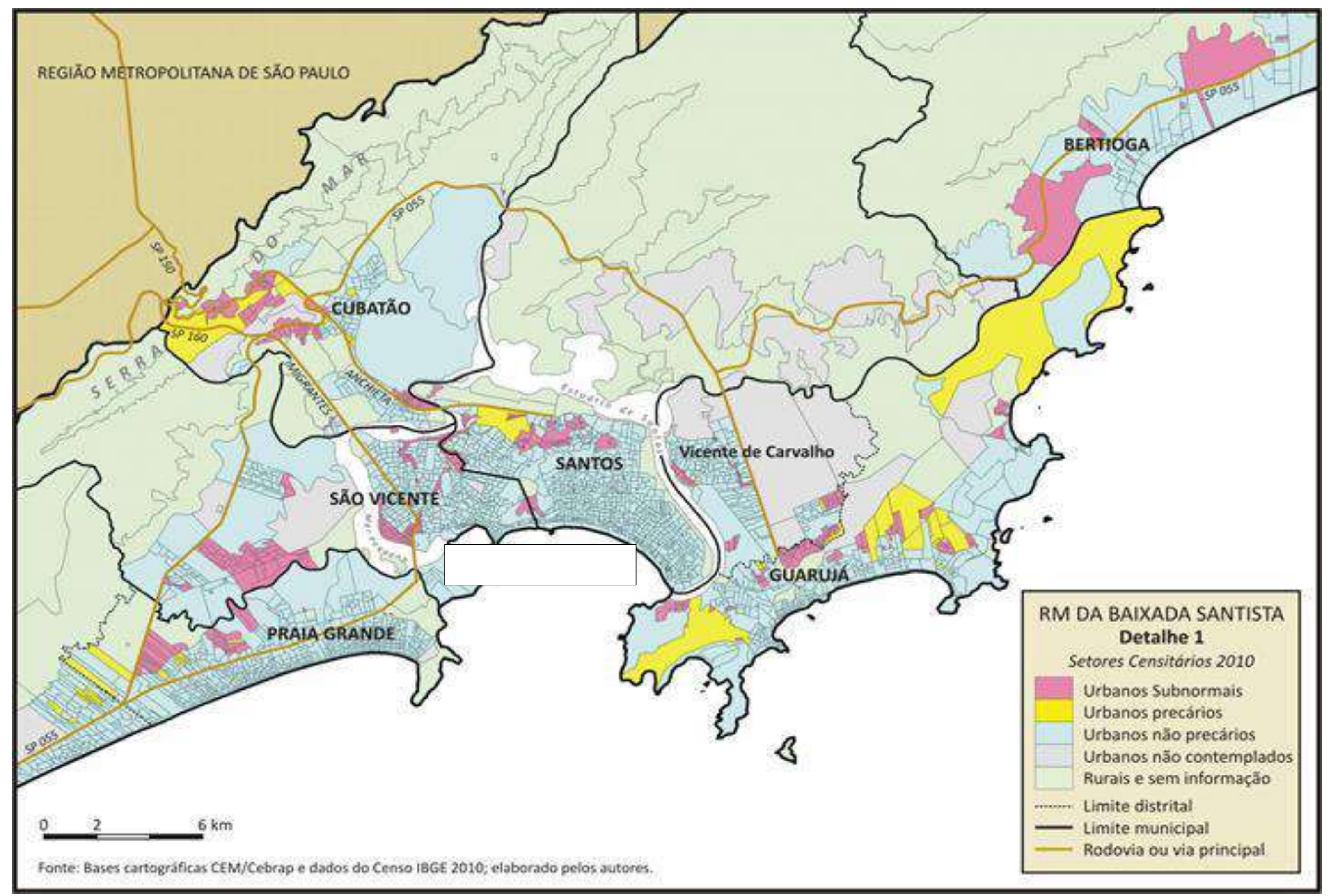

Mapa 5 - Distribuição urbana da RMBS 


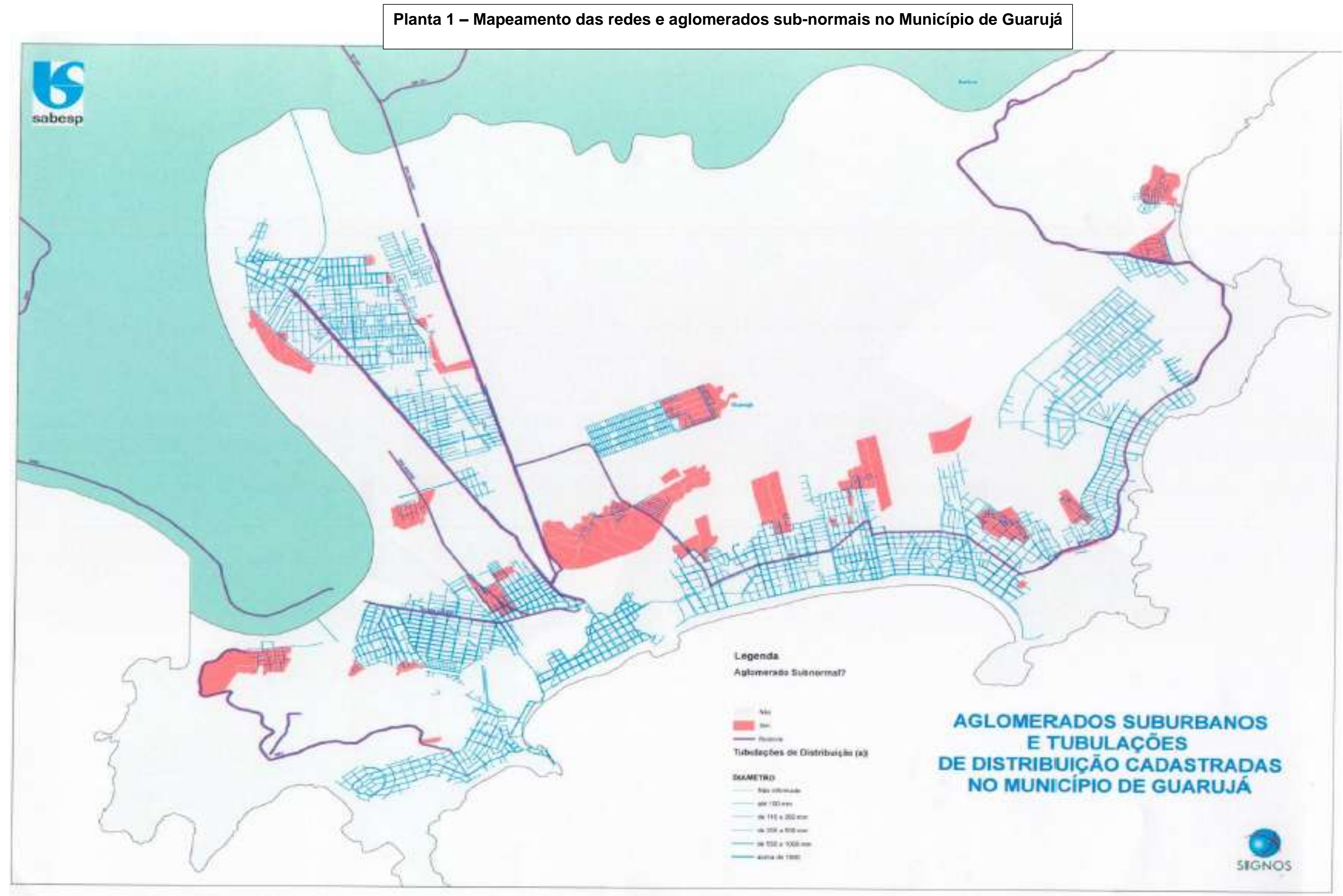


Tabela 61 - Tabela de Vistorias dos Domicílios nos Pilotos Prainha e Marezinha

\begin{tabular}{|c|c|c|c|c|c|c|}
\hline PRAINHA & TOTAL DE VISTORIAS & LIGAÇÕES CLANDESTINAS & COM VAZAMENTO & NÃO LOCALIZADOS & ATIVAS & INATIVAS \\
\hline C1 & 132 & 2 & 2 & 0 & 128 & 6 \\
\hline $\mathbf{C 2}$ & 125 & 1 & 0 & 0 & 111 & 14 \\
\hline C3 & 131 & 3 & 2 & 0 & 112 & 19 \\
\hline C4 & 125 & 2 & 7 & 0 & 114 & 11 \\
\hline C5 & 134 & 5 & 3 & 0 & 118 & 16 \\
\hline C6 & 117 & 9 & 0 & 6 & 79 & 38 \\
\hline $\mathbf{C 7}$ & 125 & 1 & 0 & 5 & 88 & 37 \\
\hline C8 & 143 & 4 & 2 & 0 & 112 & 31 \\
\hline $\mathrm{Cg}$ & 123 & 0 & 0 & 7 & 88 & 35 \\
\hline C10 & 104 & 0 & 1 & 24 & 99 & 5 \\
\hline C11 & 122 & 6 & 0 & 6 & 95 & 27 \\
\hline TOTAL & 1381 & 33 & 17 & 48 & 1144 & 239 \\
\hline MAREZINHA & TOTAL DE VISTORIAS & LIGAÇÕES CLANDESTINAS & COM VAZAMENTO & NÃO LOCALIZADOS & ATIVAS & INATIVAS \\
\hline C1 & 35 & 12 & 0 & 4 & 16 & 19 \\
\hline $\mathrm{C} 2$ & 43 & 1 & 0 & 3 & 38 & 5 \\
\hline C3 & 52 & 2 & 2 & 2 & 36 & 16 \\
\hline $\mathrm{C} 4$ & 50 & 4 & 0 & 5 & 29 & 21 \\
\hline C5 & 52 & 0 & 0 & 0 & 40 & 12 \\
\hline C6 & 54 & 4 & 0 & 2 & 37 & 17 \\
\hline $\mathrm{C} 7$ & 88 & 36 & 0 & 0 & 31 & 57 \\
\hline C8 & 54 & 19 & 1 & 0 & 25 & 29 \\
\hline $\mathrm{C} 9$ & 52 & 2 & 0 & 0 & 44 & 8 \\
\hline C10 & 64 & 6 & 0 & 0 & 43 & 21 \\
\hline TOTAL & 544 & 86 & 3 & 16 & 339 & 205 \\
\hline
\end{tabular}

Elaboração autora dados trabalhados da SABESP (2015) 
Tabela 62 - Tabela de Vistorias dos Domicílios nos Pilotos Santa Cruz dos Navegantes

\begin{tabular}{|c|c|c|c|c|c|c|}
\hline $\begin{array}{c}\text { STA CRUZ } \\
\text { dos } \\
\text { Navegantes }\end{array}$ & TOTAL DE VISTORIAS & LIGAÇÕES CLANDESTINAS & COM VAZAMENTO & NÃO LOCALIZADOS & ATIVAS & INATIVAS \\
\hline C1 & 39 & 1 & 0 & 6 & 28 & 11 \\
\hline $\mathrm{C2}$ & 35 & 0 & 0 & 10 & 32 & 3 \\
\hline C3 & 40 & 3 & 0 & 7 & 29 & 11 \\
\hline C4 & 52 & 12 & 0 & 7 & 33 & 19 \\
\hline C5 & 44 & 0 & 0 & 1 & 32 & 12 \\
\hline C6 & 47 & 4 & 0 & 2 & 37 & 10 \\
\hline C7 & 42 & 0 & 0 & 3 & 30 & 12 \\
\hline C8 & 44 & 2 & 0 & 3 & 40 & 4 \\
\hline C9 & 41 & 1 & 0 & 5 & 37 & 4 \\
\hline $\mathrm{C} 10$ & 39 & 5 & 0 & 11 & 31 & 8 \\
\hline C11 & 36 & 0 & 0 & 9 & 26 & 10 \\
\hline C12 & 3 & 0 & 0 & 42 & 3 & 0 \\
\hline C13 & 22 & 0 & 0 & 23 & 12 & 10 \\
\hline C14 & 43 & 4 & 0 & 2 & 36 & 7 \\
\hline C15 & 40 & 2 & 0 & 6 & 38 & 2 \\
\hline C16 & 23 & 0 & 0 & 1 & 22 & 1 \\
\hline TOTAL & 590 & 34 & 0 & 138 & 466 & 124 \\
\hline
\end{tabular}

Elaboração autora dados trabalhados da SABESP (2015) 


\section{ANEXO1 - AGENDA DE ENTREVISTAS, OFICINAS, OBSERVAÇÃO PARTICIPANTE}

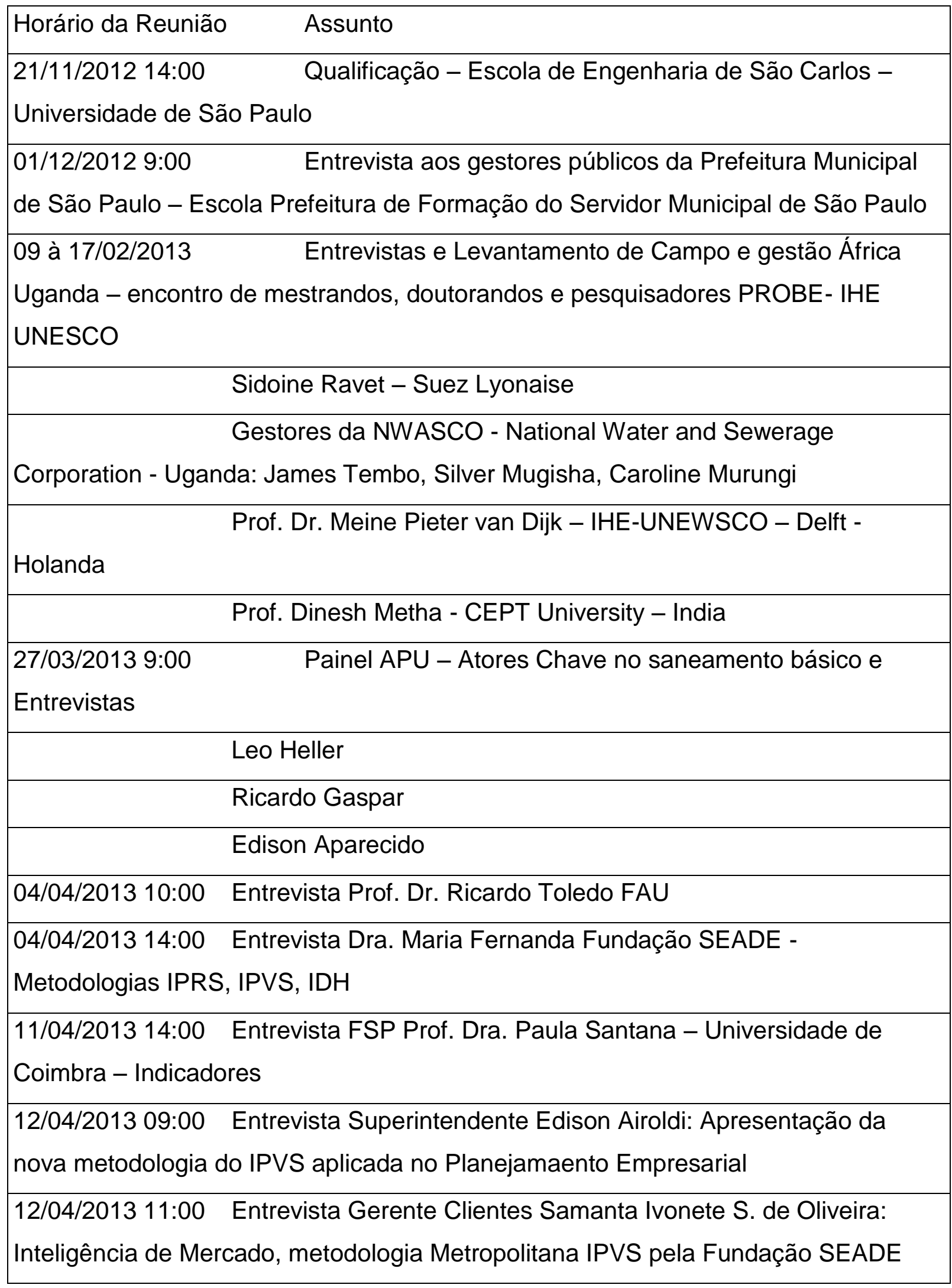


12/04/2013 13:00 Entrevista Gerente Tarifas Danilo Bermudes Perrella:

metodologia aplicada nas tarifas sociais

24/04/2013 14:00 Entrevista Engenheiro consultoria Celso Setape (em Ponte

Pequena) - Base de Remuneração Regulatória

29/04/2013 09:30 Reunião/Entrevista gerente SABESP e ARSESP Contabilidde e

Plano de Contas Regulatório

02/05/2013 14:30 Rui Cunha Marques Reunião entrevista USP

09/05/2013 09:00 Reunião Arsesp - Contabilidade Regulatória

10/05/2013 08:00 Oficina I - Práticas de Gestão nas áreas de vulnerabilidade da

RMSP e RMBS ABES USP - Aplicação de Questionários à 15 Agentes

Comunitários e Entrevistas

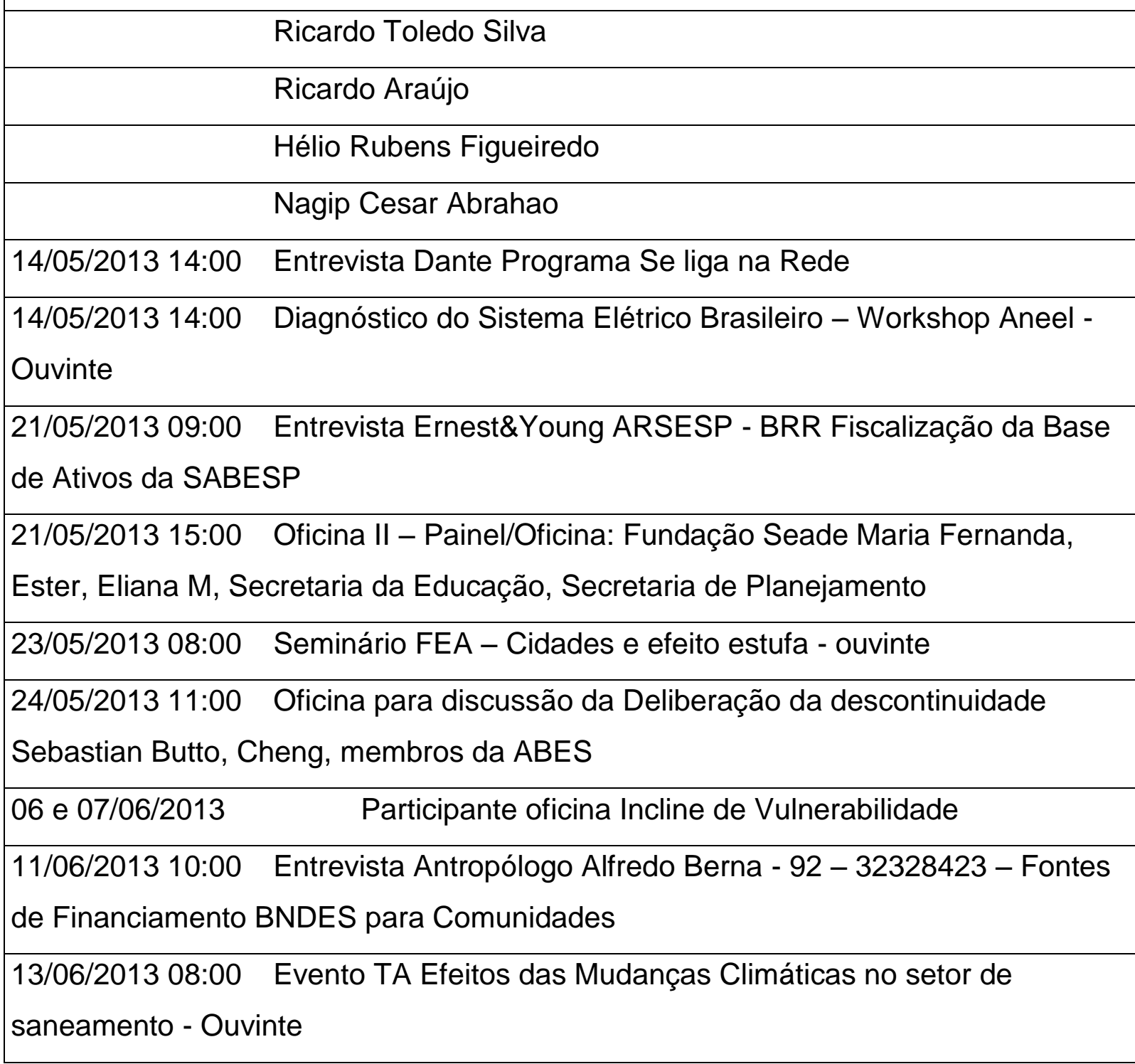




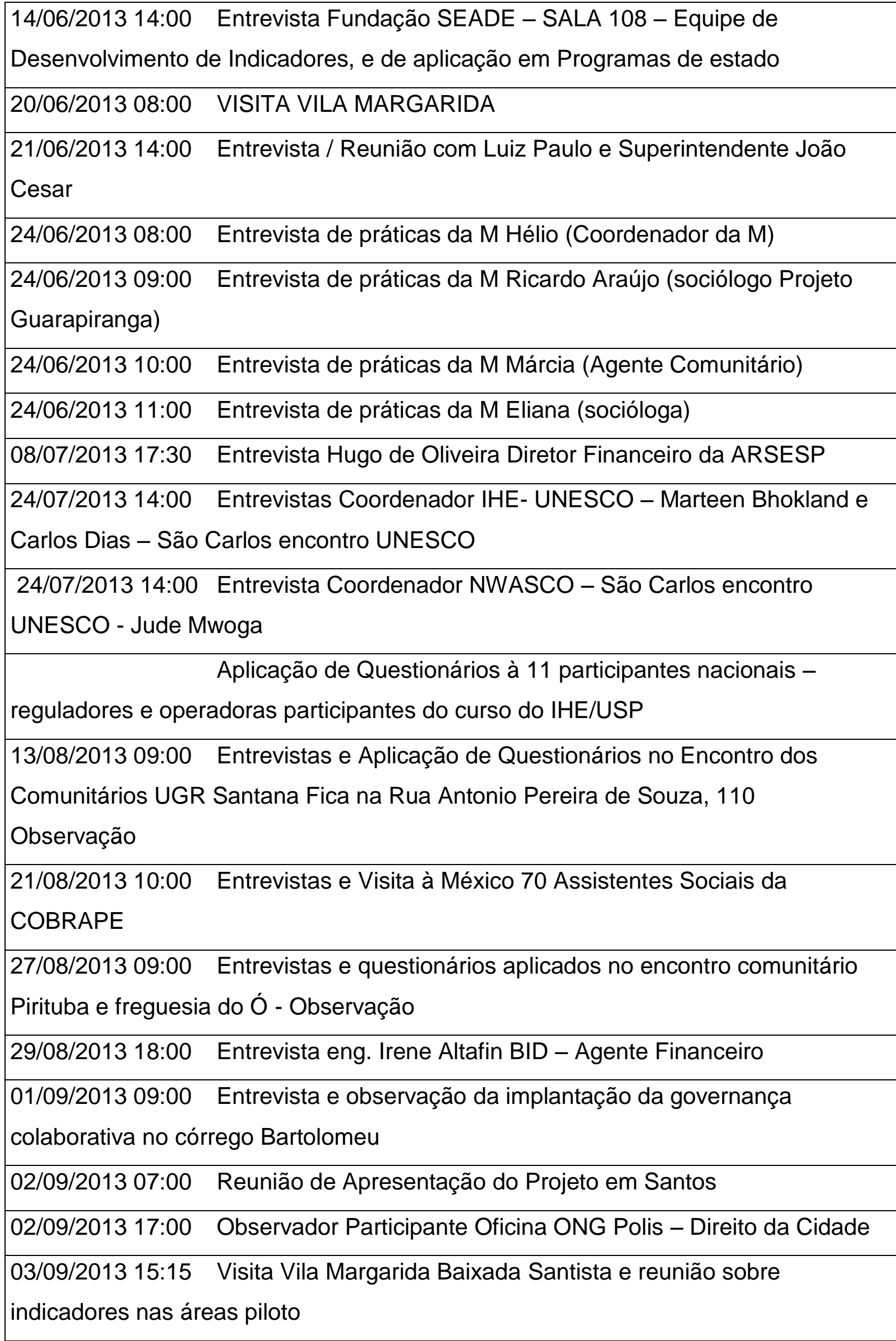




\begin{tabular}{|c|c|}
\hline \multirow{7}{*}{\begin{tabular}{|l|}
$04 / 09 / 201315: 15$ \\
$09 / 09 / 201314: 00$ \\
\end{tabular}} & Entrevistas e Levantamento de Campo Comunidade México70 \\
\hline & Entrevista e Visita USP - Prefeitura São Vicente \\
\hline & Marco Antonio Vilela \\
\hline & Thais \\
\hline & Macajé \\
\hline & Francisco \\
\hline & Marlene \\
\hline 10/09/2013 09:00 & Entrevistas e Reunião Emplasa \\
\hline 11/09/2013 09:00 & Entrevistas e Visita USP - Prefeitura São Vicente \\
\hline 16 à 19/09/2013 & Coordenação de Painel de Reguladores no Congresso \\
\hline \multirow{2}{*}{\multicolumn{2}{|c|}{$\begin{array}{l}\text { Anual da ABES - Tema Universalização e desafios Regulatórios - objetivo: } \\
\text { Diagnóstico }\end{array}$}} \\
\hline & \\
\hline \multicolumn{2}{|r|}{ Raymundo Figueiras - NE } \\
\hline \multicolumn{2}{|r|}{ José Luiz Oliveira - SP } \\
\hline \multicolumn{2}{|r|}{ Vinicios Benevides - DF } \\
\hline \multicolumn{2}{|r|}{ Alceu Galvão - CE } \\
\hline \multicolumn{2}{|r|}{ Rodrigo Polisp - ARSAE } \\
\hline \multicolumn{2}{|r|}{ Eduardo Cunha - GO } \\
\hline \multicolumn{2}{|r|}{ Zevi Kahan - Gas } \\
\hline \multicolumn{2}{|r|}{ Manoel Negrisol - Energia } \\
\hline \multicolumn{2}{|r|}{ Jadir Proença - Proreg } \\
\hline \multicolumn{2}{|r|}{ Rui Cunha Marques - ITL } \\
\hline \multicolumn{2}{|r|}{ Paulina Beato - FMI } \\
\hline 16 à 19/09/2013 & Organização do Painel das Empresas Concessionárias - \\
\hline \multicolumn{2}{|c|}{ Tema Universalização e desafios Regulatórios - objetivo: Diagnóstico - entrevistas } \\
\hline \multicolumn{2}{|r|}{ Ricardo Campos - MG } \\
\hline \multicolumn{2}{|r|}{ João Papa - SP } \\
\hline \multicolumn{2}{|r|}{ CAESB } \\
\hline \multicolumn{2}{|r|}{ SANEAGO } \\
\hline & CAGE \\
\hline
\end{tabular}




\begin{tabular}{|c|c|}
\hline & CORSAN \\
\hline & SANEPAR \\
\hline & José Sardinha - EPAL \\
\hline $\begin{array}{l}16 \text { à } 19 / 09 / 2013 \\
\text { questionários }\end{array}$ & Entrevistas a atores chave e aplicação de 147 \\
\hline $\begin{array}{l}\text { 21/09/2013 09:30 } \\
\text { - UGR São Mateus }\end{array}$ & Entrevista aos Gestores da UN Leste Rua Nelson de Oliveira 50 \\
\hline $\begin{array}{l}\text { 23/09/2013 07:00 } \\
\text { São Vicente }\end{array}$ & Observador - Audiência Pública do Contrato de Programa de \\
\hline $\begin{array}{l}\text { 26/09/2013 07:00 } \\
\text { Guimarães 24/09/2 }\end{array}$ & $\begin{array}{l}\text { Reunião Entrevista Prefeitura de Cubatão Aceito Ester F. } \\
01314: 23\end{array}$ \\
\hline $\begin{array}{l}\text { 01/10/2013 19:00 } \\
\text { Palácio do Govern }\end{array}$ & $\begin{array}{l}\text { Entrevista ao Ganhador do Prêmio Fundação Bunge" 19:30hs } \\
\text { o }\end{array}$ \\
\hline $\begin{array}{l}02 \text { e 03/10/2013 } \\
\text { Viegas, Dr. Hugo d }\end{array}$ & $\begin{array}{l}\text { Entrevistas Prof. Dr. Alaor Caffé Alves, Dr. Pedretti, Dr. } \\
\text { e Oliveira e Dr. Pedretti sobre a Adi RMs e competências }\end{array}$ \\
\hline 04/10/2013 9:00 & Levantamento e Pesquisa de Campo Guarujá \\
\hline $\begin{array}{l}\text { 04/10/2013 14:00 } \\
\text { Margarida }\end{array}$ & Aplicação de Questionários à 12 gestores da Vila \\
\hline $\begin{array}{l}\text { 05/10/2013 } \\
\text { Andrade - ONG AI }\end{array}$ & $\begin{array}{l}\text { Visita de Campo e entrevistas à Comunidade Pedra da Lua V. } \\
\text { MIS }\end{array}$ \\
\hline $\begin{array}{l}\text { 07/10/2013 14:00 } \\
\text { México } 70\end{array}$ & Observador das Práticas sociais de Campo na Comunidade \\
\hline $08 / 10 / 2013$ & Observador Painel PPPs e entrevistas \\
\hline & Alceu Bittencour - ABES - SP e Cobrape \\
\hline & Valdir Folgosi \\
\hline & Paulo Simão \\
\hline & Ives Besse \\
\hline & Lucas Gianella \\
\hline & Paulo Massato - SABESP \\
\hline 09/10/2013 & Observador Painel e entrevistas - Estela Goldstein - ONG \\
\hline
\end{tabular}


21/10/2013 07:00 Observador das Práticas Sociais Visita à Vila dos Pescadores

Baixada Santista

23/10/2013 13:30 Ouvinte do Plano de Saneamento para a Macrometropole

Paulista

25/10/2013 10:00 Ouvinte e entrevista FABHAT - Rua Boa Vista, 84 - $6^{\circ}$ andar -

Centro - São Paulo - SP

27/10/2013 09:00 Observador, entrevistas e questionário no Encontro

comunidades Jardim Guapira MN - CEU JAÇANA Rua Antônio

28/10/2013 07:00 Reunião de levantamento com a Prefeitura de Guarujá com eng. Zenivaldo e Visita para identificar lideranças

30/10/2013 Visita à Comunidade Baixada Santista

04/11/2013 09:00 Reunião com ONG da Comunidade Vila Andrade - Ester Lobo Entrevistas sobre a atuação da ONG e práticas da SABESP

12/11/2013 09:00 Ouvinte na Reunião GT-PAM Aceito Ester F. Guimarães

$11 / 11 / 201316: 24$

13/11/2013 09:00 Entrevista Paulina Beato consultora do FMI

26/11/2013 09:00 Reunião Lino - MO - AMIS (ONG) - Observador Participante

29/11/2013 09:00 Organização de Painel sobre a titularidade dos serviços públicos nas Região Metropolitana STF Prof. Alaor Caffe - CRQ - São Paulo Observador 13/12/2013 09:00 Reunião/Entrevista à Catarina Albuquerque economista da ONU - FSP/USP

28/01/2014 14:00 Observador Participante Planejamento Integrado do estado na RMBS GT-PAM - Auditório 'A' do mezanino do Edifício Cidade I, Rua Boa Vista, 170 14/03/2014 07:00 Oficina III - Controvérsias Sociotécnicas Metodologia ANT Baixada Santista - Santos

18/03/2014 14:30 Observador Participante Oficina de indicadores - GO - Av. Brig. Faria Lima, 2081 - 3‥ Andar

19/03/2014 18:00 Observador Participante Reunião com Representante do Brasil na ONU Prof. Marcovitch - SDSN Amazônia -WTC: Av. Nações Unidas, 12.559 21/03/2014 14:30 Entrevista Consultor Sebastian sobre o Instituto Ascende 


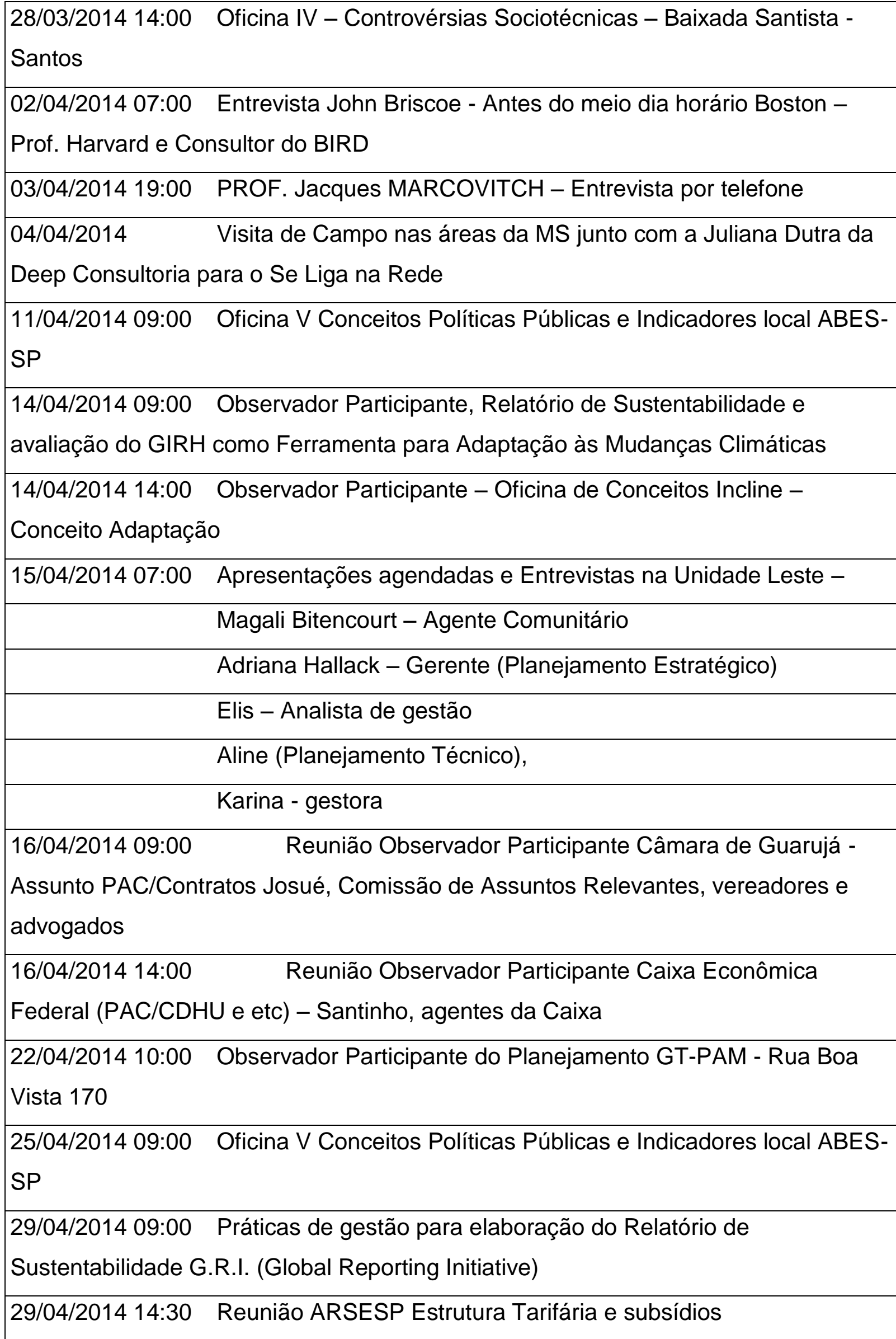


09/05/2014 07:00 Oficina VI - Conceitos: Práticas Jurídicas - Dr. Wagner, Magali

Bittencourt - Paritá, Sociais e Comerciais - Sociologa Eliane - FSP/USP

15/05/2014 07:00 MS - Bench Comunitário RS e MS

21/05/2014 09:00 Entrevista sobre sistema de Mapeamento SIG Nagip César

Abrahão - PR - Sala da PR

23/05/2014 07:00 Oficina VII - Conceitos: Arranjos Técnicos e Controvérsias Socio

Técnicas FSP/USP

28/05/2014 09:00 Planejamento da Macrometrópole da Baixada - AGEM

Observador Participante

28/05/2014 16:00 Observador Participante Reunião Procedimento para

Flexibilização de Débitos RS - Sergio/Eliana/Nilda/Fátima

30/05/2014 09:00 Oficina VIII - Planejamento Situacional de Matus - Baixada

Santista organizada em sub-grupos: técnico, planejamento, comercial

04/06/2014 09:00 Espaço Vida - Premiação de Melhores Práticas - Entrevistas

05/06/2014 09:00 Oficina XI - Planejamento Situacional - RS

10/06/2014 09:00 Observador Participante Participante Comitê Fehidro

10/06/2014 09:30 Observador Participante - Oficina de Discussão de Material para análise - PIS ABES

13/06/2014 09:00 Oficina X - Diagnóstico da Organização - Análise SWOT e Diagnóstico de Nadler - RMBS

17/06/2014 14:00 Reunião de apresentação dos trabalhos em curso com

Prof.Tadeu e Representantes da Diretoria de Sistemas Regionais

26/06/2014 09:00 Oficina XI de Planejamento da Cidade Informal da Baixada

Apresentação dos déficits, metodologia proposta

27/06/2014 14:00 Apresentação da etapa do Projeto junto à ARSESP e SABESP _ USP - Auditório ARSESP

01/08/2014 Observador Painel PPP’s Encontro Técnico AE-SABESP e posterior Entrevista

Arisnandes Antonio da Silva - PPP - São Lourenço 


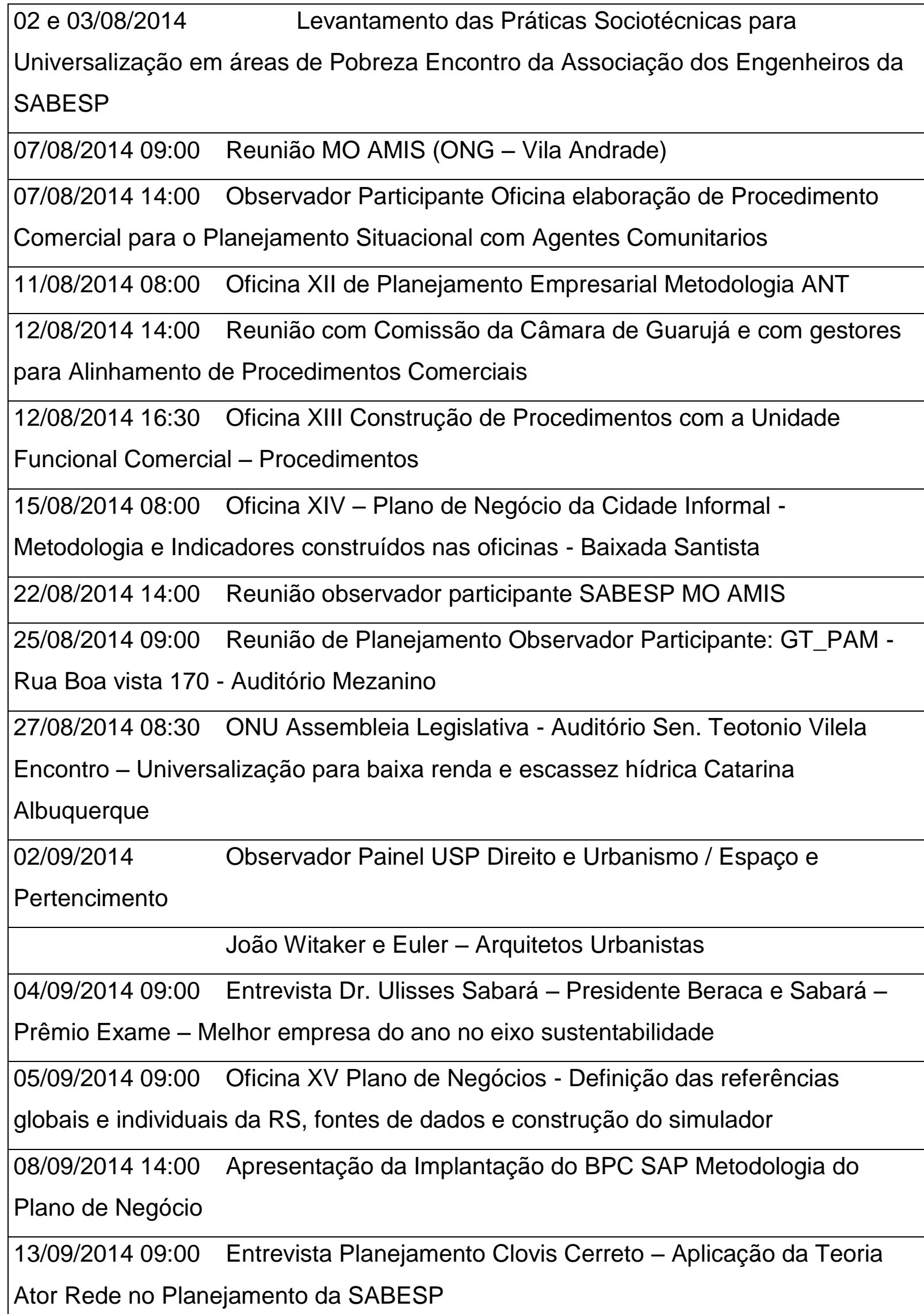


15/09/2014 09:00 Oficina XVI do Plano de Negócios Geração com primeiros números dos gestores consistentes e discussão dos gestores - Baixada Santista

17/09/2014 9:00 Entrevista Celso Gerente Cubatão

17/09/2014 14:00 Observador Participante Oficina de Procedimento Comercial X Sanear meu bairro

20/09/2014 9:00hs Observador Participante - Mutirão Comunidade Vila Andrade SABESP/AMIS/Escola da Comunidade Morro da Lua e Phulman 26/09/2014 9:00hs Observador Defesa do Mestrado da Denise Rasera (Academia e resultados empresariais)

29/09/2014 9:00hs Reunião Agente comunitário da MO - Aglinésio - Providências Técnicas paras as demandas da ONG e Comunidade 30/09/2014 9:00hs Observador Participante - Reunião Comunidades da Zona Norte - Rua José Soriano de Souza, 297 - Crise hídrica nas comunidades

2/10/2014 16:30 Observação Participante Mecanismos de Inclusão e
Geração de Renda na MN Rua Antônio Pereira de Souza, 110 Formatura Tecnicos da MN

03/10/2014 09:00 Oficina de Plano de Negócio XVII - Simulador dos Planos de Negócios dos municípios Apresentação do Proceidmento Comercial desenvolvido e re-definição de fontes de dados, consistências

11/10/2014 09:00 Oficina de Plano de Negócio XVIII - Simulador para elaboração dos Planos dos municípios pelos gerentes

24/10/2014 09:00 Observador Participante Apresentação Emplasa PAM 2040 Rua Boa Vista, 170 - Bloco I - 15ํandar 26/09/2014 9:00hs Observador Defesa do Mestrado da Carolina Yani (Academia, Fundação Seade e resultados empresariais)

06 à 08/11/2014 09:30 PGE-USP Democracia e Direitos Fundamentais Levantamento das correlações possíveis no Direito Aplicado à Universalização Ouvinte Jean Pierre Burge, Fernanda Menezes Dias, Patricia Werner, Carlos Mourão, Roger Stifilman 
11/11/2014 08:00 Levantamento e Entrevista das Empresas com Balanço das Ações do Fórum Clima - 2014 Gabriel Azevedo - Odebrecht e Caio Pereira - CPFL 12/11/2014 08:30 Levantamento e Entrevista Banco Financiadores de projetos com impactos sócio-ambientais BID- Marcelo José Lomba Valença,

12/11/2014 08:30 Levantamento e Entrevista Financiadores de projetos com impactos sócio-ambientais Roberto Damas - Head de Risco socioambiental do Itaú BBA

13/11/2014 15:00 Entrevista Coordenador do Departamento de Engenharia Elétrica da Poli - USP - Sidney Colombo Martini 25/11/2014 9:00 Oficina Observador Participante - ABES sistema condominial

26/11/2014 14:00 Reunião entrevista com UN Norte

26/11/2014 14:00 Reunião de levantamento na área referência das melhores práticas da SABESP - MN

09/12/2014 Encontros Comunitários Norte 9, 15, 16, 17 e 19

15/12/2014 Encontros Comunitários Norte 9, 15, 16, 17 e 19

16/12/2014 Encontros Comunitários Norte 9, 15, 16, 17 e 19

17/12/2014 Encontros Comunitários Norte 9, 15, 16, 17 e 19

19/12/2014 Encontros Comunitários Norte 9, 15, 16, 17 e 19

09/06/2015 Apresentação dos resultados da plano de negócios regulatório à SABESP

Apresentação ao Coordenador de Saneamento da Secretaria de Recursos Hídricos Apresentação a alta administração da concessionária de serviços

Apresentação ao Comitê de Bacias da Baixada Santista Apresentação a Agencia 


\section{ANEXO 2 - QUESTIONÁRIOS}

\section{QUESTIONÁRIO 1 - ATORES-REDE}

Quais personagens identifica-se atuantes nos arranjos para universalização dessas áreas?

_)concessionária/ (_)poder concedente/ ( )MP/ (_)investidores/ (__)agentes fianceiros/ _ONG's/ (_)comunidade e mutirões/ (_)fundações/ (_)organizações religiosas/ )movimentos sociais/ ( )regulador/ ( )outros por Responsabil.Social

O poder público tem instrumentos articulados de gestão dessas áreas? ( )sim （ )não

Qual as DUAS principais Motivações das Concessionárias (ordene)? ( ) metas contratuais e regulação ( ) missão empresarial ( ) perdas ( ) meio ambiente ( ) financeira

Qual as DUAS principais motivação dos Reguladores ( ) metas contratuais ( ) deliberações ) bem estar social ( )eficiência dos serviços

Requer uma inovação do planejamento? ( ) sim ( )não

Da prestação dos serviços? ( ) sim ( )não

Qual a Motivação dos Usuários para usarem os serviços?

saúde ( ) social ( ) valorização imobiliária ( ) meio ambiente

A estrutura tarifária tem robustez para financiar tarifas sociais? ( ) sim （ )não

O poder público deve subsidiar os custos dos serviços para baixa renda? ( )sim （ ) não

Essas áreas tem margens financeiras? ( ) sim ( ) não

Acarreta novos custos de produção e distribuição? ( ) sim ( ) não

Acarreta novos custos de serviços e tecnologia? ( ) sim ( ) não

Os clientes tem capacidade de pagamento? ( ) sim ( ) não

Como fazer redução de custos dos serviços para a população de baixa renda? (_)contratos terceirizados mais baratos e com novas modelagens ( )inclusão da comunidade nos serviços )pessoal próprio ( ) serviços locais

Como fazer redução de Custos de ativos? ( )financiamentos não onerosos ( )soluções técnicas alternativas ( )soluções participativas

Deve-se ter taxas de remuneração diferenciadas? ( )sim ( )não

Demanda inovação regulatória? ( ) sim ( )não

Qual a contribuição que você ou a empresa onde trabalha daria num processo de universalização? ( ) estudo ( ) projeto ( ) workshop ( ) mutirão ( ) capacitação ( ) gestão ( ) financiamento ( )regulação.

O usuário de baixa renda já tem consciência ambiental, quanto à: ( ) uso racional da água ( ) conexão do esgoto

( ) lançamento de lixo em córregos 


\section{QUESTIONÁRIO 2 - LÍDERES COMUNITÁRIOS}

NOME DO LÍDER:

COMUNIDADE/BAIRRO:

EMAIL / TELEFONE:

Mora em área irregular ou de risco? ( ) sim ( ) não

É a SABESP que fornece água ( ) sim ( ) não

Recebe conta de água? ( ) sim ( ) não

As vezes usa caminhão pipa ou bica? ( ) sim ( ) não

Com que frequência? ( ) mais que 1 vez por semana ( ) menos que 1 vez por semana

O caminhão é ( ) Particular ( ) SABESP

Onde mora tem esgoto a céu aberto? ( ) sim ( ) não

Sua casa já tem ligação de esgoto? ( ) sim ( ) não

Quando chove há enchentes? ( ) sim ( ) não

Tem caixa dágua ( ) sim ( ) não

Qual tamanho da sua casa? m2

Como lava a roupa? Você tem tanquinho? ( ) sim ( ) não

Usa a água depois? ( ) sim ( ) não

Como você lava a louça? ( ) bacia ( ) direto na torneira

Usa a água do banho para outras coisas? ( ) sim ( ) não

Quando chove, guarda a água da chuva? ( ) sim ( ) não

Sabe ver se tem vazamento? ( ) sim ( ) não

Há muita gente que não paga a conta na comunidade? ( ) sim ( ) não

Há vazamento nas ruas da comunidade? ( ) sim ( ) não

Quando vê um vazamento liga para avisar? ( ) sim （ ) não. Quem? ( ) 195 ( ) técnico comunitário

Tem o nome na conta? ( ) sim ( ) não

Sabe quando vai faltar água? ( ) sim ( ) não Quem te avisa? 
Sabe quando tem reunião comunitária com a SABESP? ( ) sim ( ) não

Gosta dos Agentes comunitários da SABESP? ( )sim ( )não.

Por quê?

Qual o nome do técnico comunitário?

telefone:

Se fez reclamações/pedidos a SABESP no último ano, fez na agência ( ), telefone ( ) ou reunião comunitária ( ) ou telefone do técnico comunitário ( )

Estudou até que série? ( ) ou se está estudando, em que série está de que curso?

Possui carteira assinada? ( ) sim ( ) não ( ) Desempregado

Quanto você ganha por mês? ( ) abaixo de 3 SM ( ) acima de 3 SM ( ) Desempregado

Quanto gasta de conta de luz por mês? R\$

Você que paga as contas da sua casa? ( ) sim ( ) não.

Se não for você, qual o sexo de quem paga as contas da casa? ( ) F ( ) M

Quantas pessoas moram na sua casa?

Quantos até 12 anos?

Quantos com mais de 55 anos?

Alguém da sua casa teve doenças como: ( ) diarreia ( ) hepatite ( ) leptospirose

É visitado pelos agentes do SUS? ( ) sim （ ) não

Está cadastrado na tarifa social? ( ) sim （ ) não

Sabe como se cadastrar? ( ) $\operatorname{sim} \quad$ ( ) não

Quantos Celulares sua família tem?

Quanto gasta por mês de celular?

O que acha do preço da água da SABESP? ( ) baixo ( ) alto

E se comparar com telefone celular? ( ) baixo ( ) alto

Tem conta atrasada? ( ) sim ( ) não

E se precisar negociar atraso é fácil? ( ) sim ( ) não

Consegue pagar a conta em muitos lugares? ( ) sim ( ) não

Tem Bolsa Família? ( ) sim ( ) não

O técnico comunitário levanta as necessidades da comunidade? Comunica as decisões da SABESP? Promove mudanças? ( ) sim ( ) não 


\section{QUESTIONÁRIO 3 - INTRA-ORGANIZAÇÃO}

Planejamento inclui áreas irregulares? Quais ferramentas para medir e mapear? Quais indicadores?

E os planos de saneamento? E os de Investimento? E os de Negócio?

Precisa de financiamentos não onerosos $\mathrm{p} /$ as metas? Como a companhia obtem esse recurso?

Se não está no Plano de Investimento, como ficaria o resultado dos EVEFs se incluísse essas áreas?

Como você ve o mecanismo de subsidio e como acha que deveria ser?

O que acha do Bolsa família e do modelo do setor de energia?

Quais seriam os problemas para implantar um subsidio dessse tipo?

Há reunião de planejamento que considere demandas da comunidade?

Estão no BSC estratégico? E no Tático? E no operacional?

Há reunião de prestação de contas com a comunidade? Com que frequência?

Há sistemática de informar previamente as intermitências às comunidades?

Como é a governança?

Uma regularização é demorada? Quanto tempo em geral?

Onde é feito o projeto de regularização de áreas?

Quem conduz esses programas? Qual o cargo? Qual o sexo?

quais leis apoiam essas ações de regularização?

Como é feita a mobilização da comunidade? Quem? Cargo? Que sexo?

Há pesquisas tecnológicas em curso para atender essas áreas?

Como é a Gestão de Perdas Físicas e Não Físicas?

Conte o arranjo que deu certo? (empresa/governo/sociedade) tem dados e publicações?

O que deu errado? Tem dados e publicações?

O gestor faz diferença?

Pode indicar alguém para entrevistar?

Qual a estrutura organizacional?

Para o sup e diretor: Vc fala em média com que frequência com o comunitário? 
Para o comunitário: Vc falal em média com que frequência com o sup ou diretor?

Quem faz a interlocução com sub-prefeito, representantes da secretaria, órgãos públicos? Que nível está?

Quem faz a interlocução com a sociedade civil? Em que nível da organização está? O que poderia melhorar? Como?

Como é a estrutura organizacional desse pedaço do organograma? Deveria mudar? Como?

Há inclusão de moradores da comunidade nas serviços? Quais serviços? Como são

remunerados? Há sucesso?

Se não há sucesso explique o que está errado?

O Regulador contribui?

O Regulador deve atuar de que forma?

Deseja falar mais alguma coisa?

\section{QUESTIONÁRIO 4 - INFLUENCIADORES E DECISORES NA CRISE HÍDRICA}

Pedimos um momento de sua atenção para responder às questões abaixo:

Ordene os itens referentes para atuação no setor de saneamento por ordem de importância segundo sua visão:

( ) Estratégia de Conservação dos Recursos Hídricos e biodiversidade

( ) Gestão de Perdas

( ) Gestão da Contaminação por lançamentos

( ) Gestão do uso e ocupação do solo

( ) Programa de Uso Racional da Água

Na sua opinião, o que seria a inovação no modelo de gestão do setor de saneamento atualmente em áreas de vulnerabilidade socioambiental?

Na sua opinião, qual seria a inovação do modelo de negócio do setor de saneamento atualmente em áreas de vulnerabilidade socioambiental? 


\section{ANEXO 3 - SIMULADOR PLANO DE NEGÓCIO INCLUSIVO - PNI da RMBS}
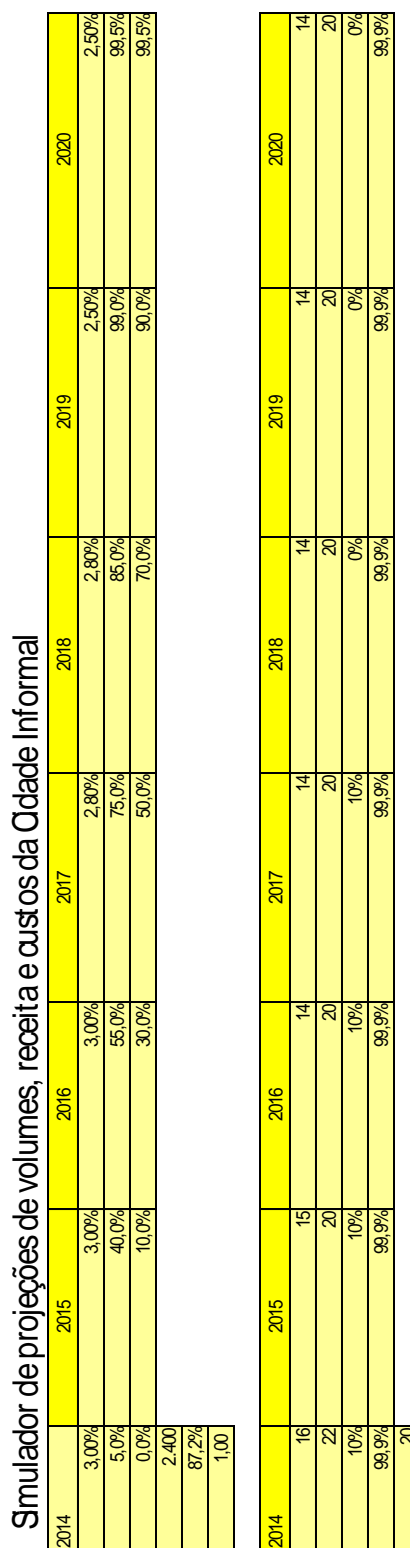

ฉั

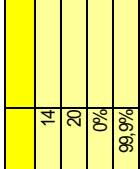

ฉ్

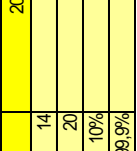

ํํำ

ํㅗำ

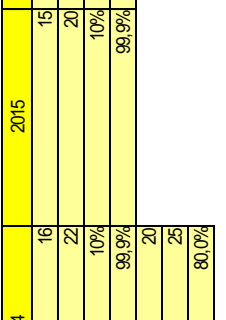

ปั

Bertioga

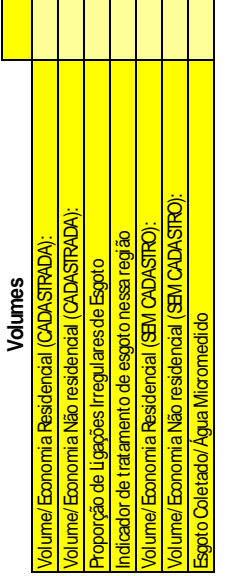

ปั่

ลี้

ฉ్

울

สิิ

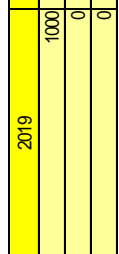

으응

동

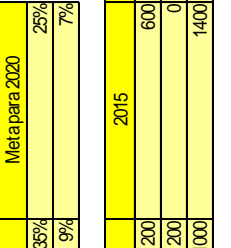

잉잉

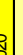

สิุ

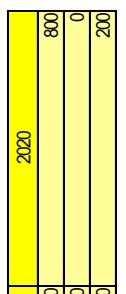

ำ
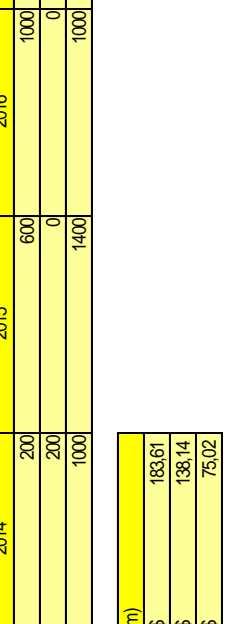

है⿴囗十心
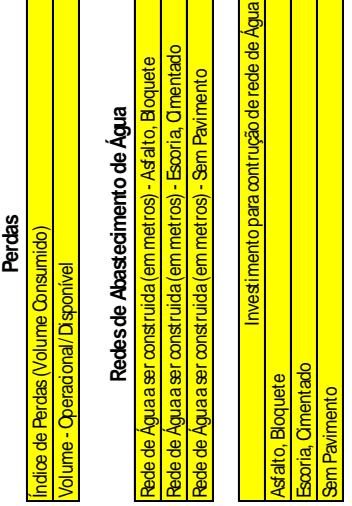

흔

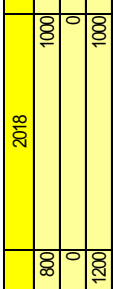

ิㅡำ
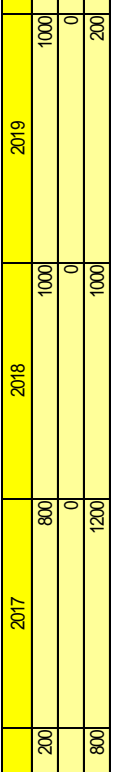

ลั

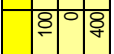

党
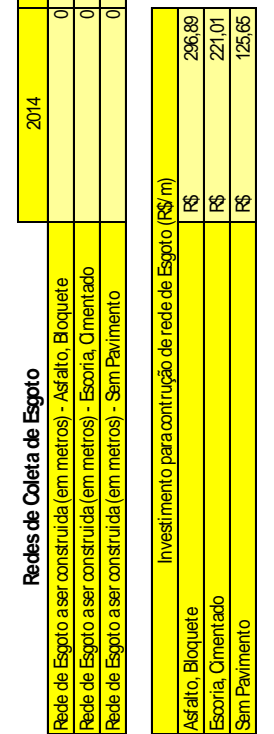

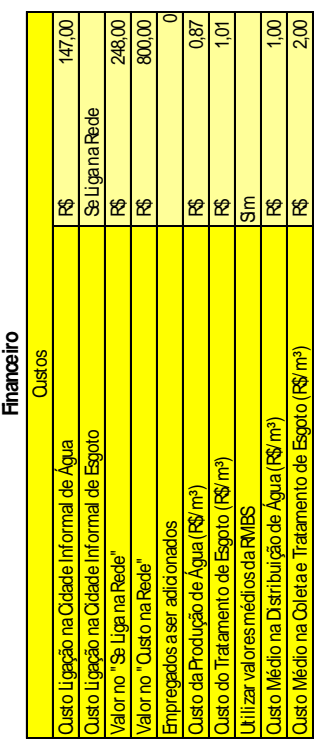

\begin{tabular}{|l|l|}
\hline &
\end{tabular}

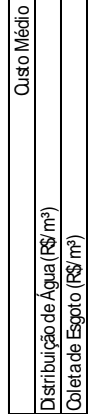

cdxliii 


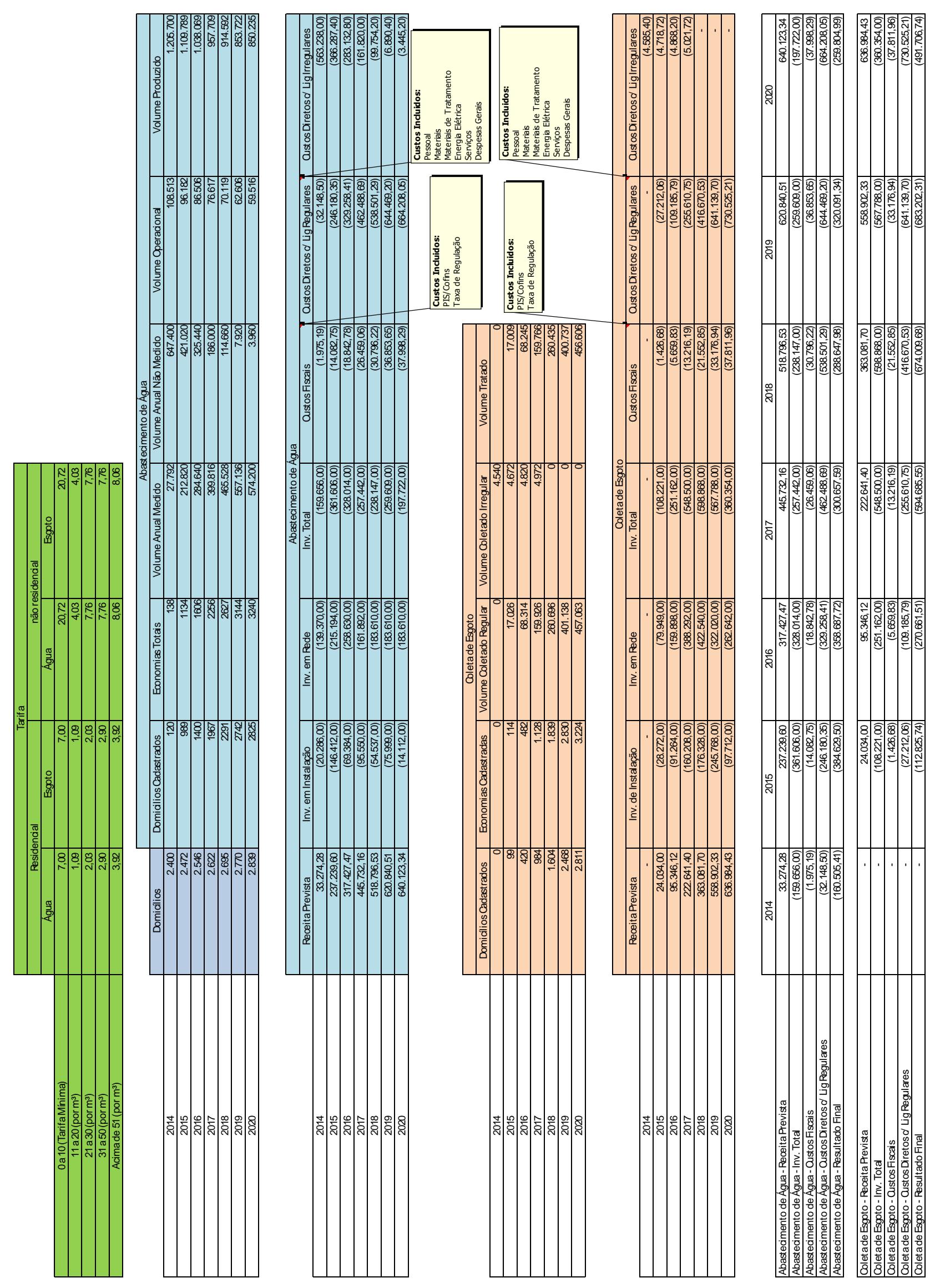




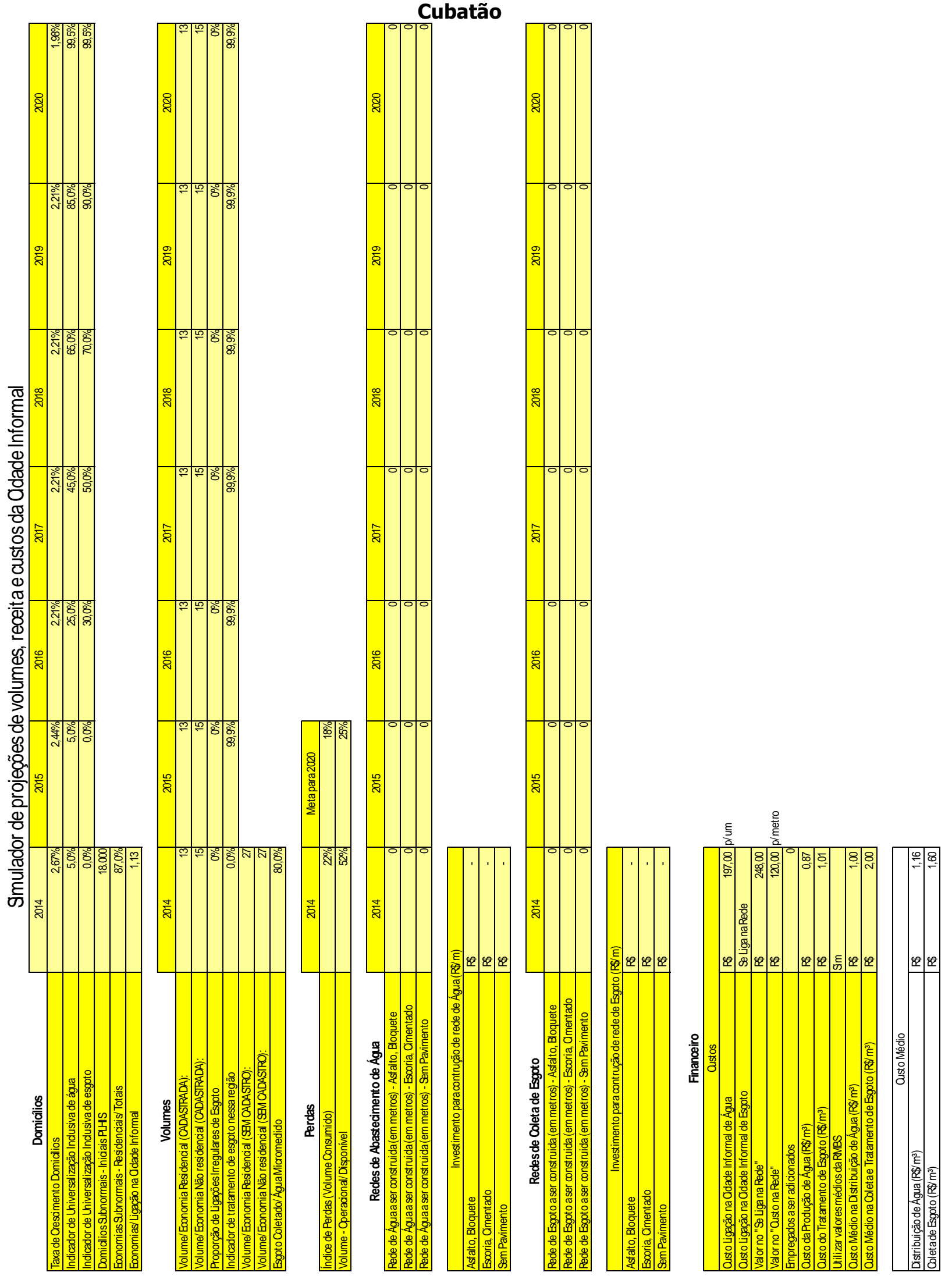

cdxlv 


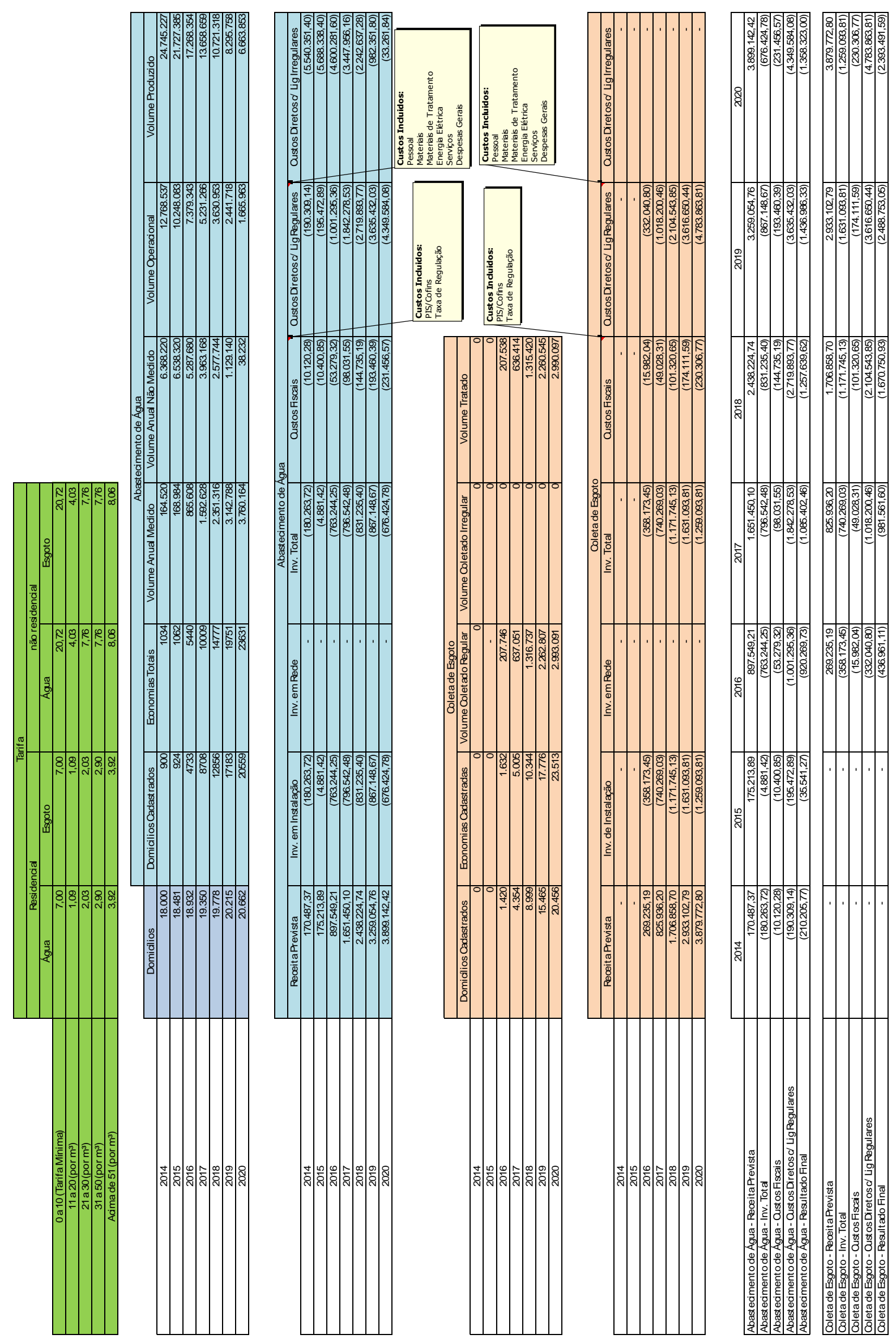

cdxlvi 


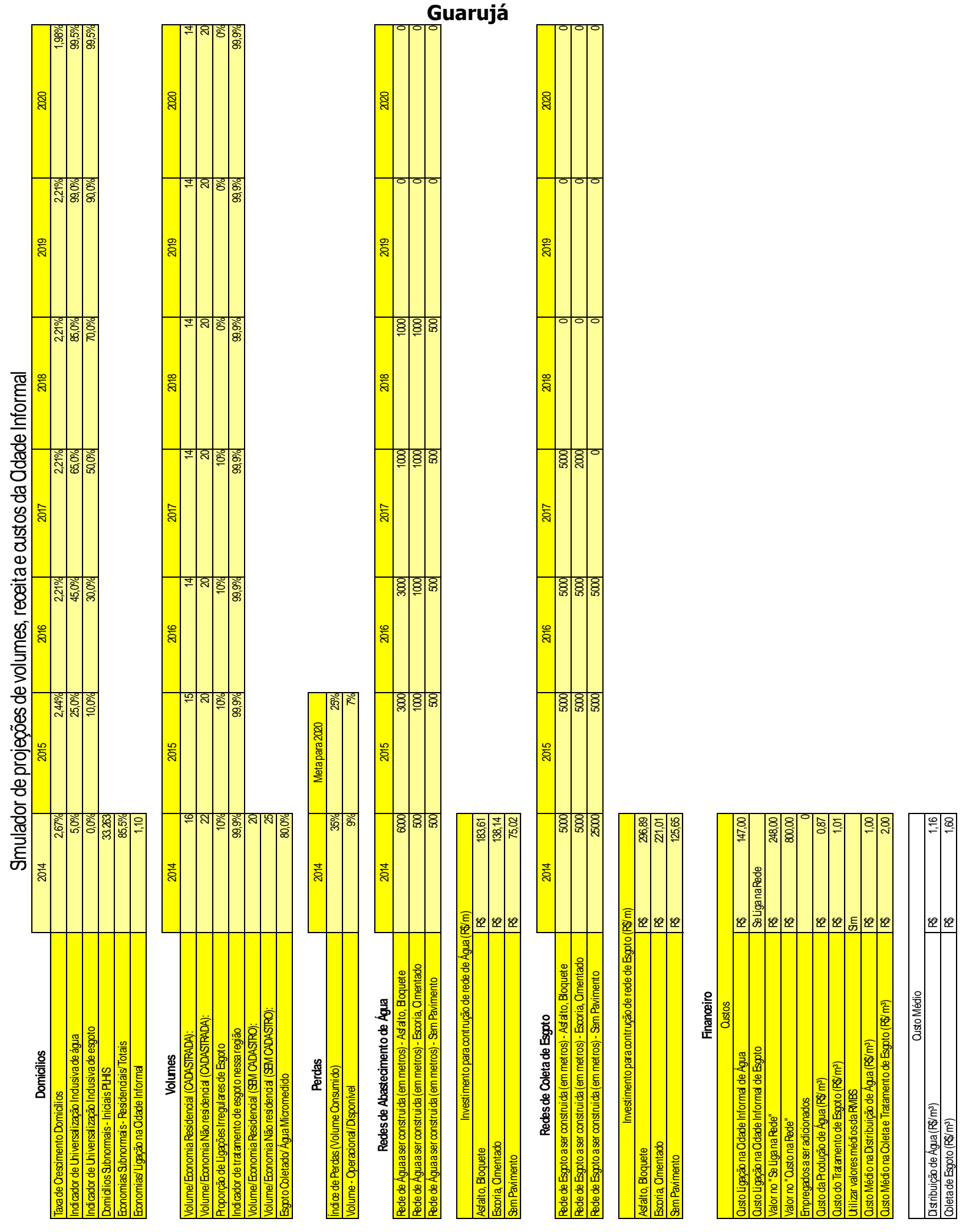




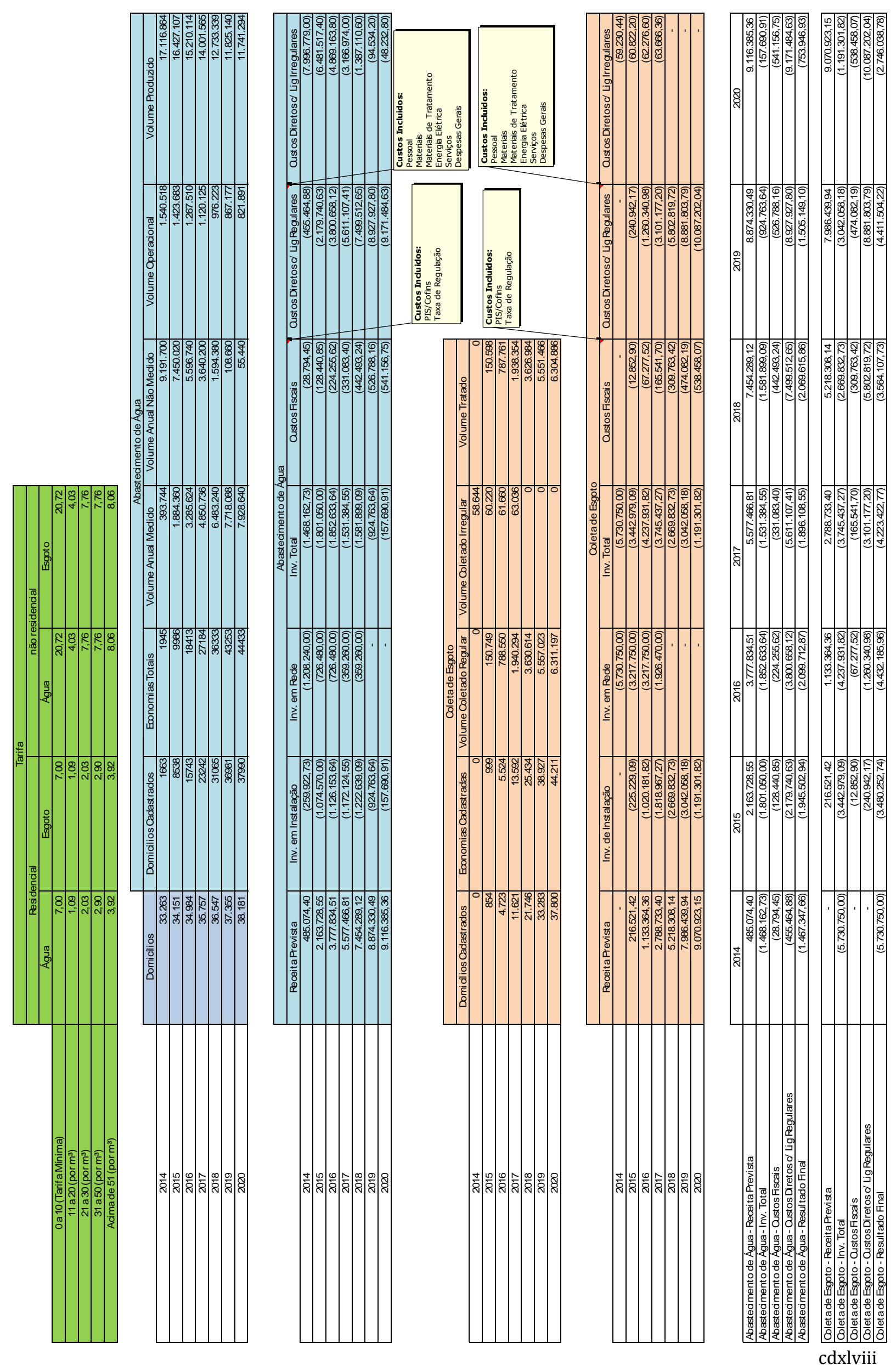




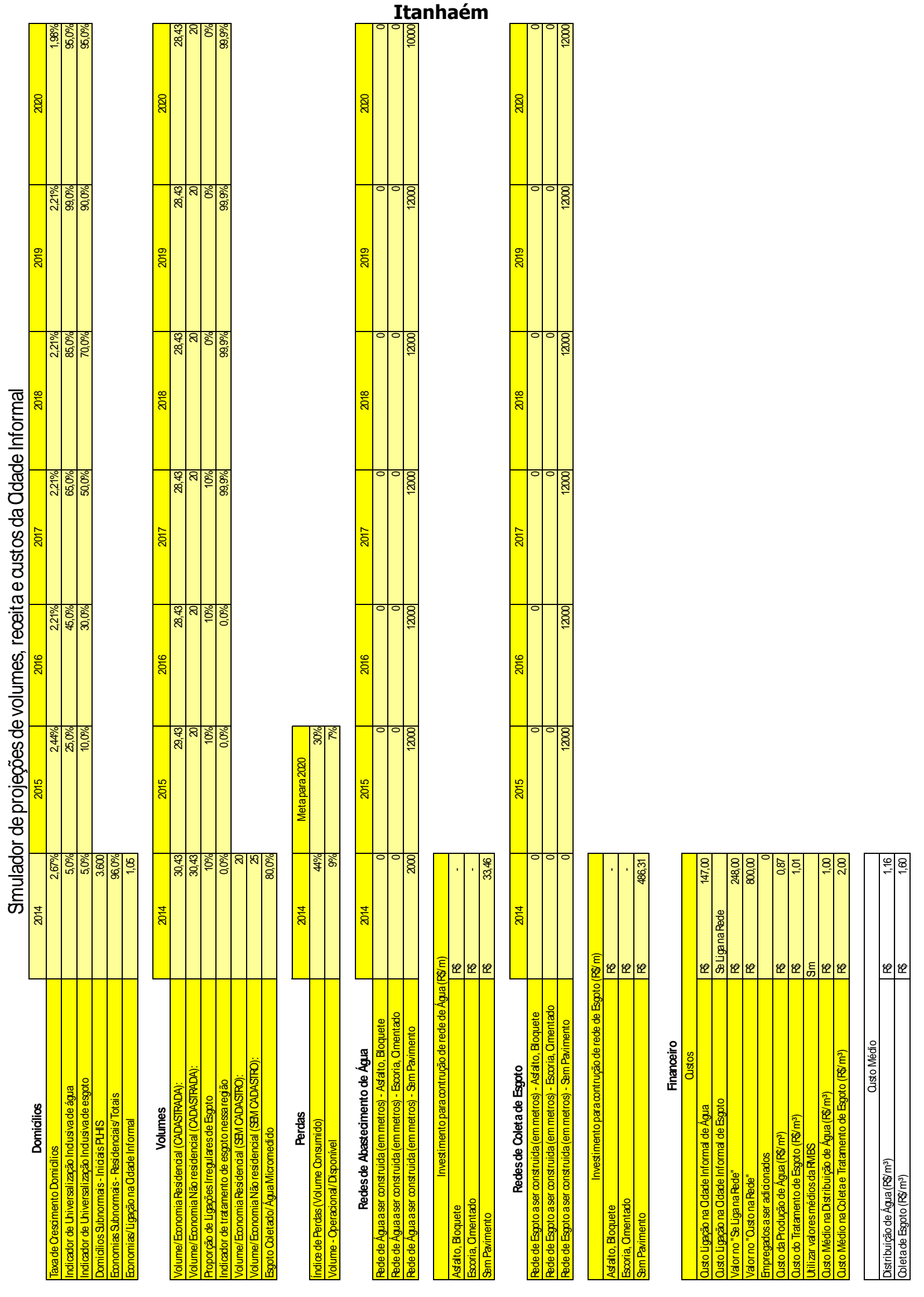

cdxlix 


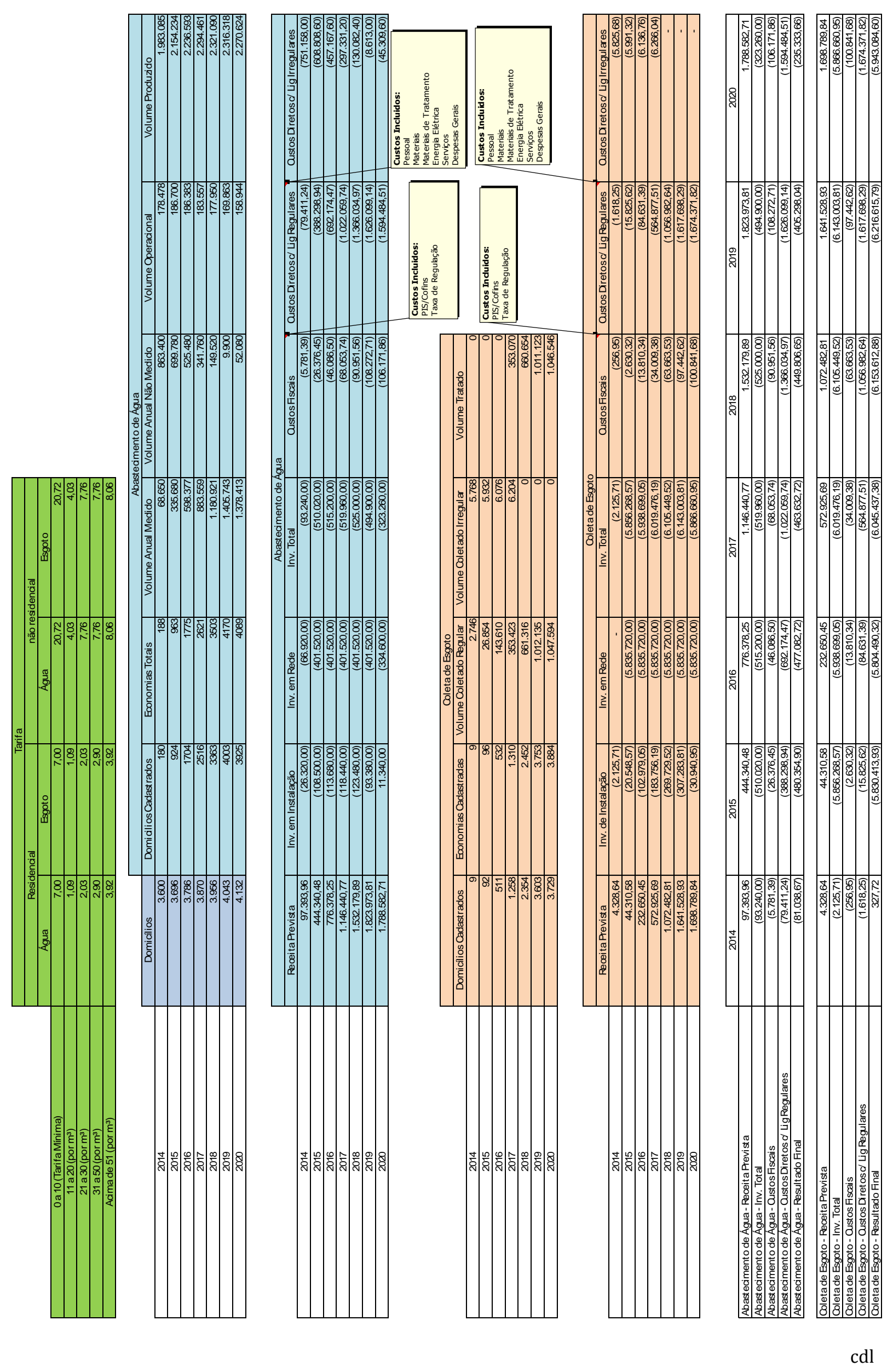



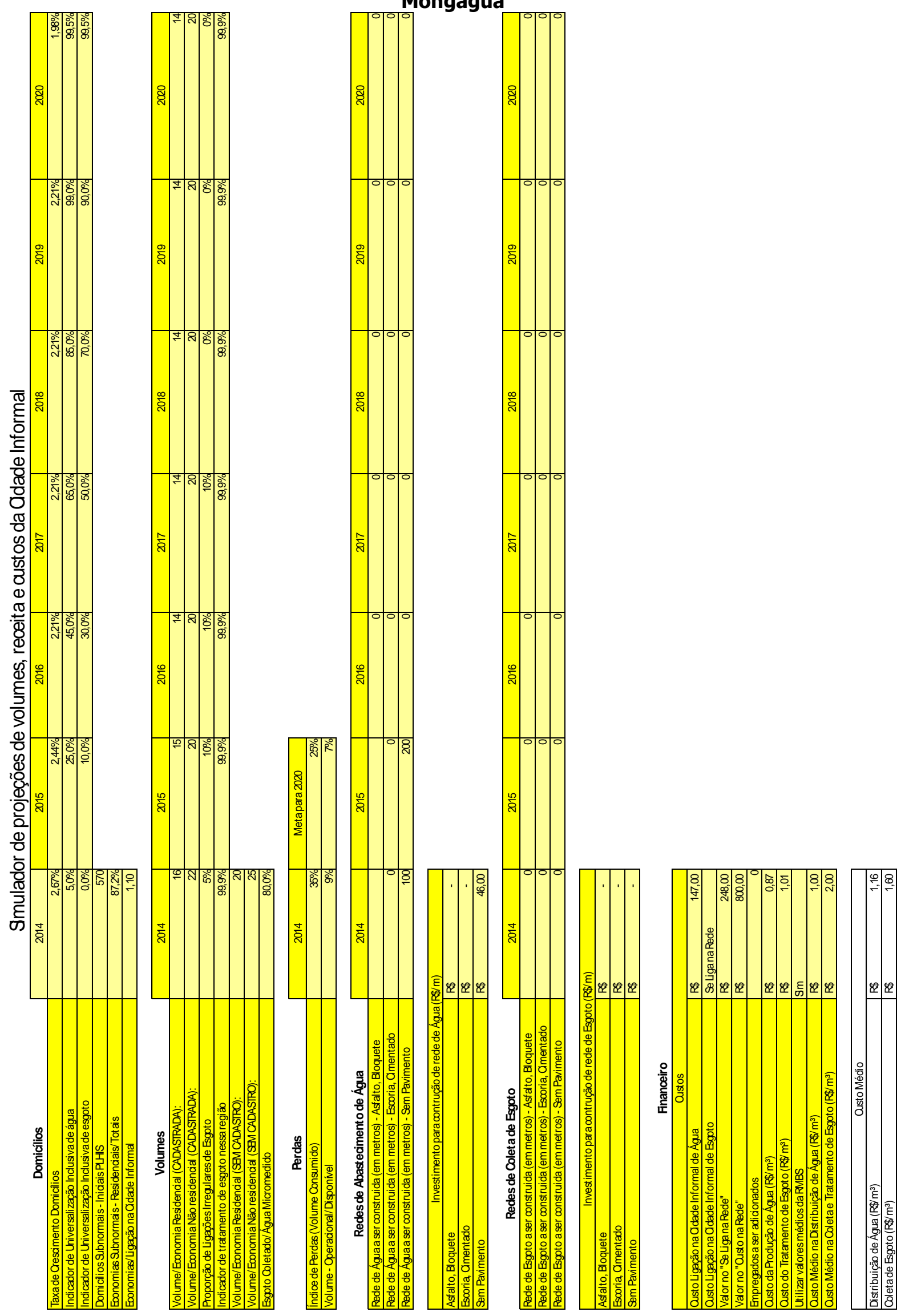

cdli 


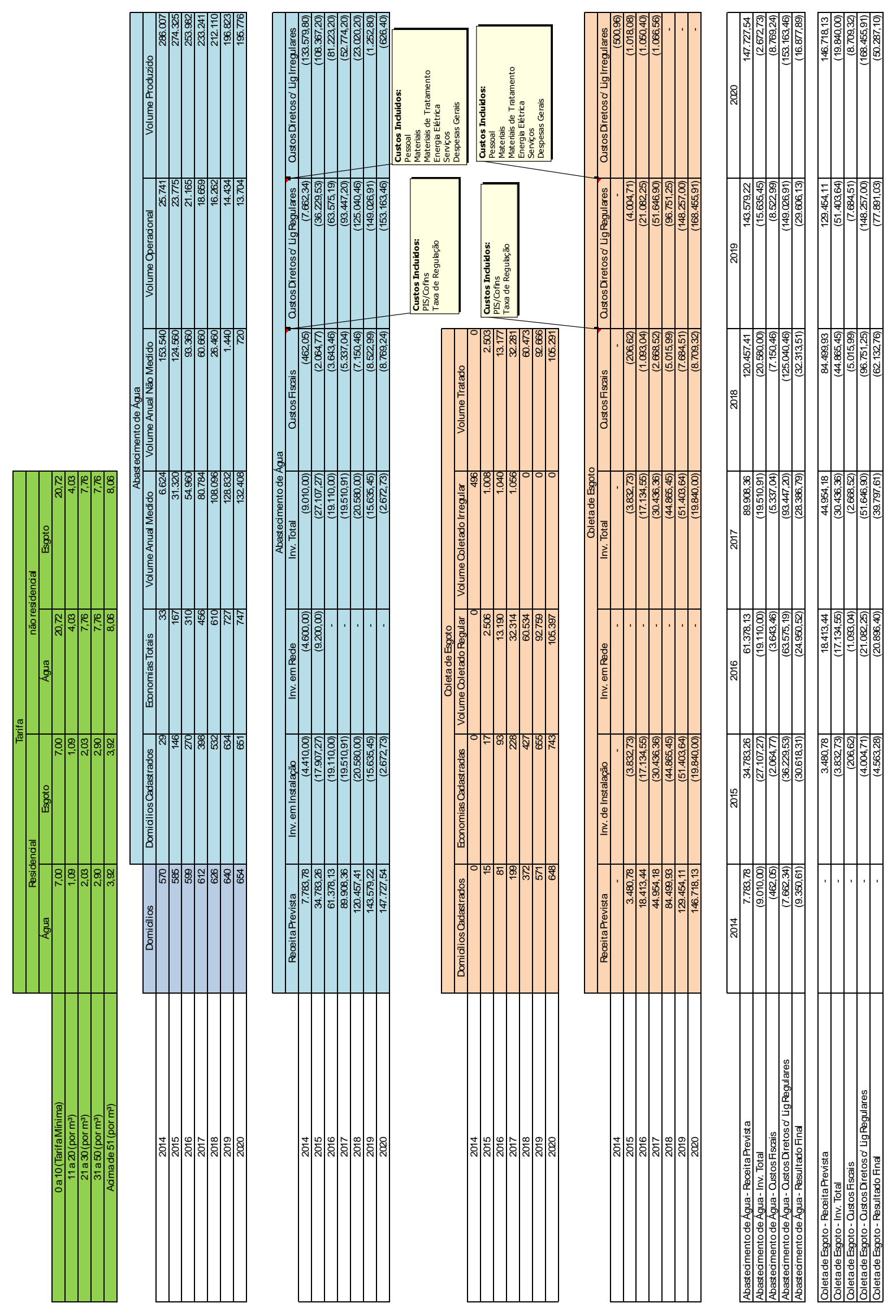




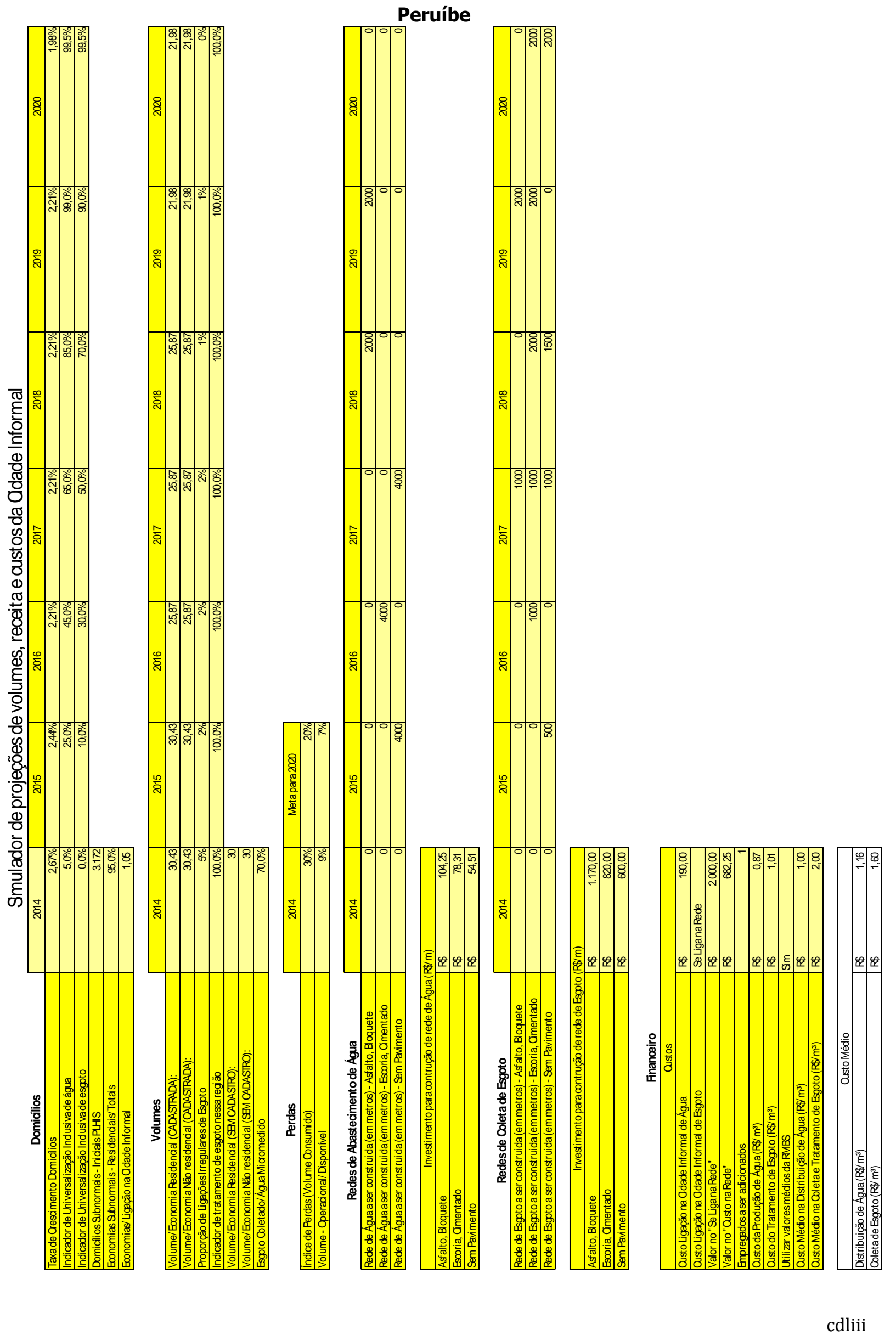




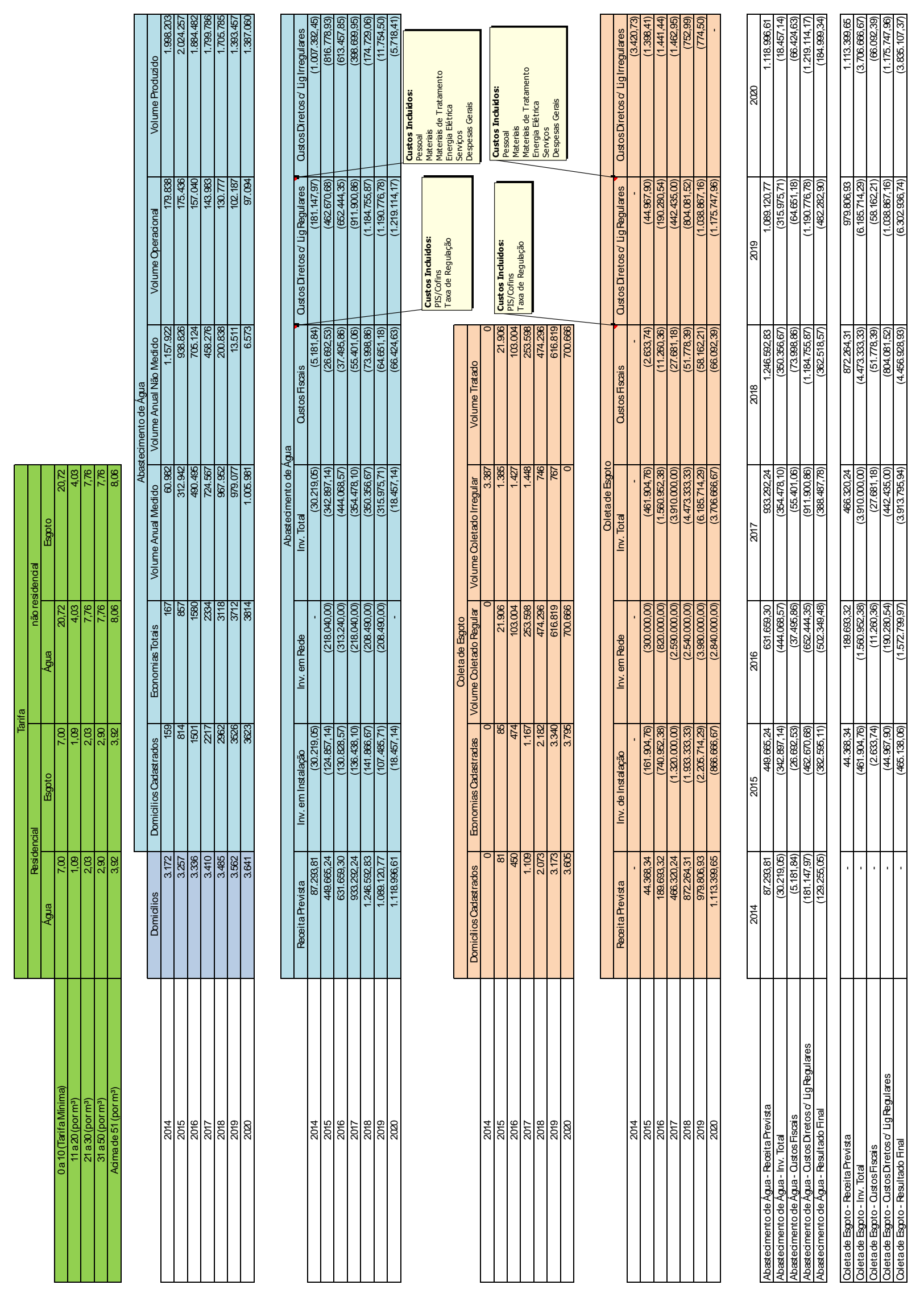




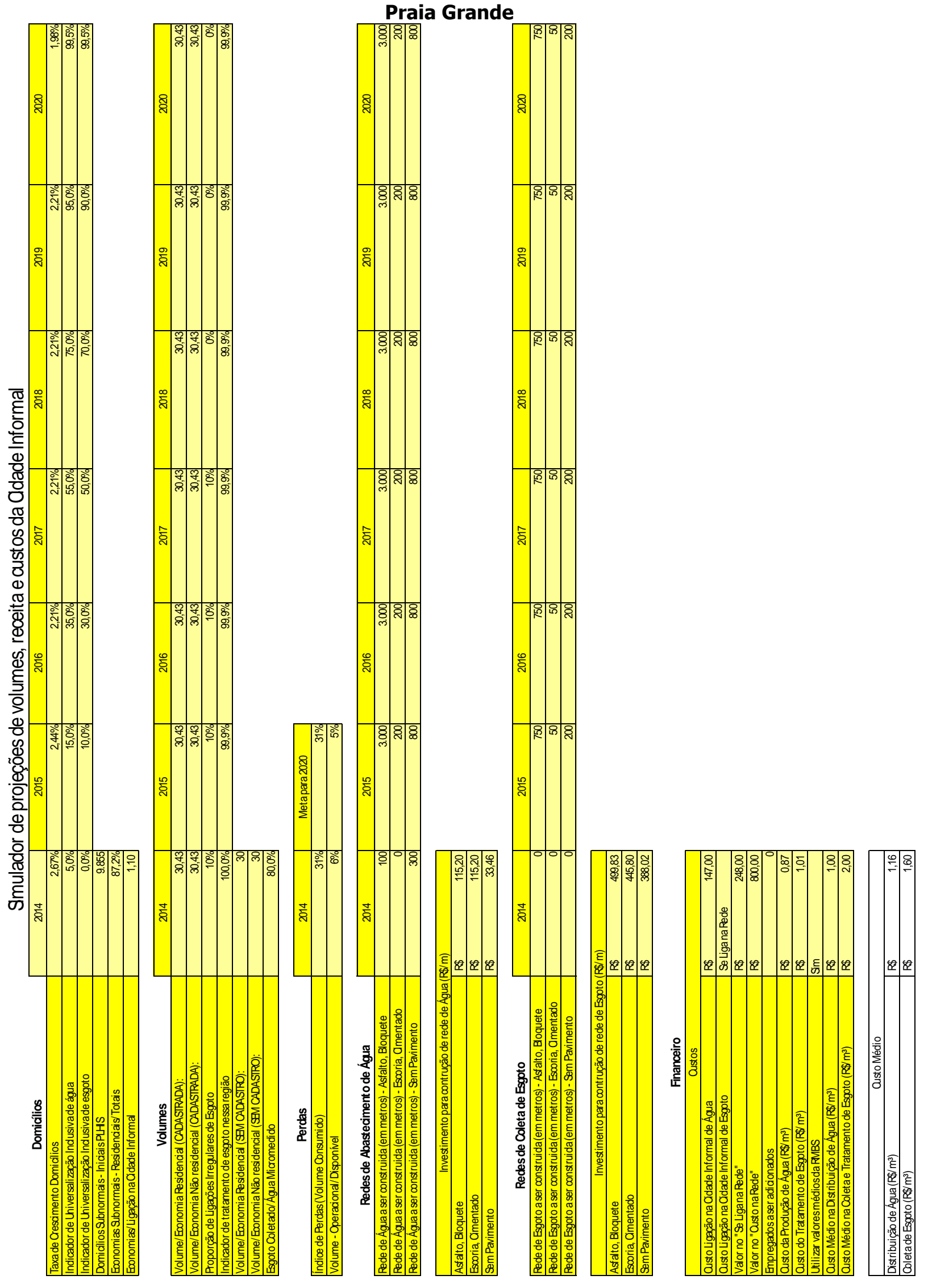



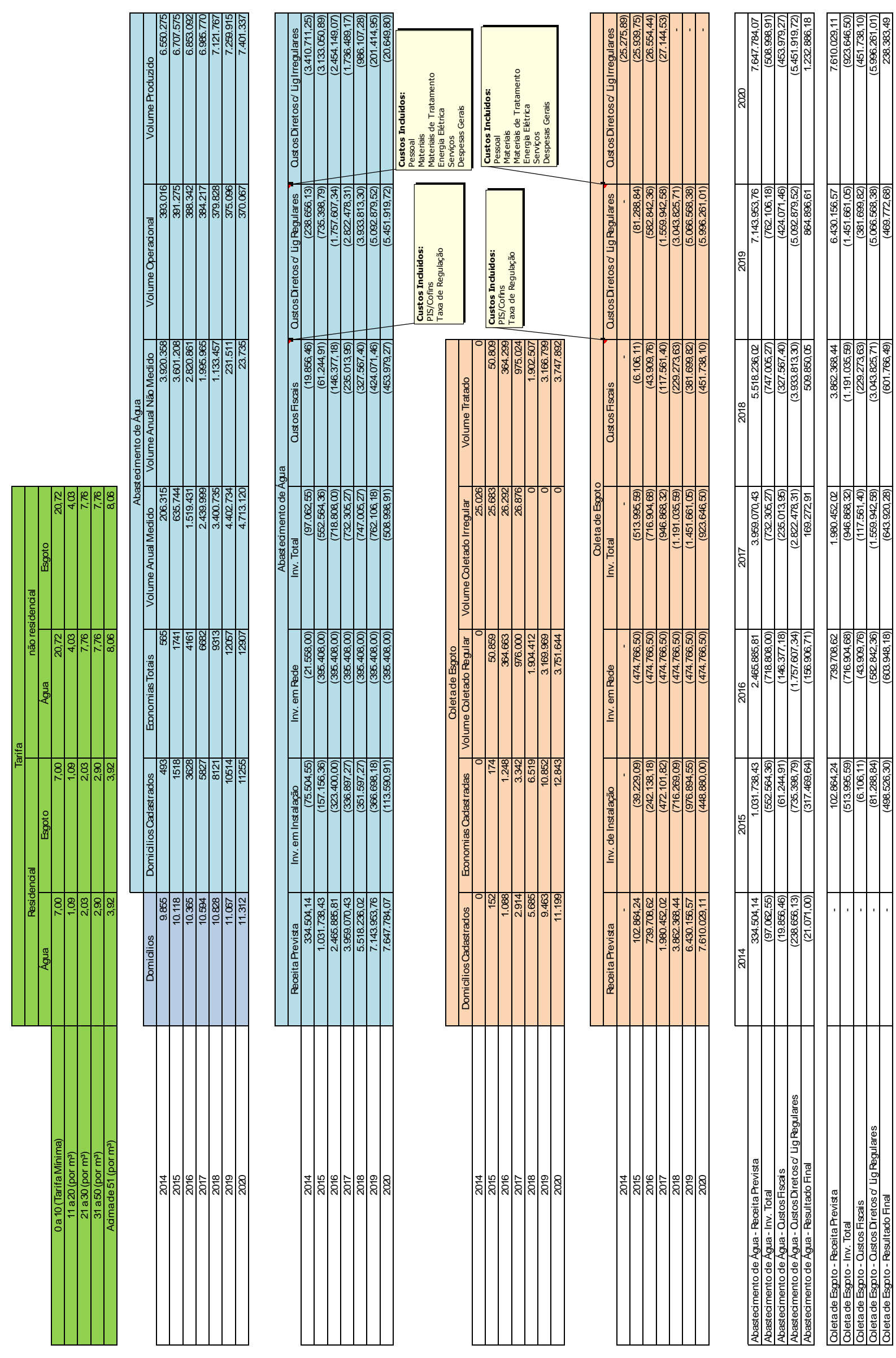

文

|

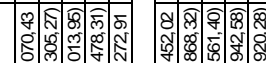
政

ลิ้

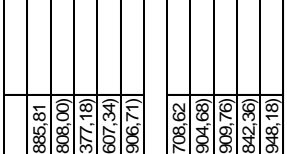

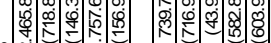
ลั้

ते $=-6$

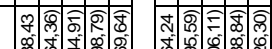

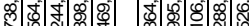

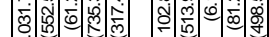
เั็ิ

(1)

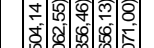

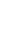

ปั
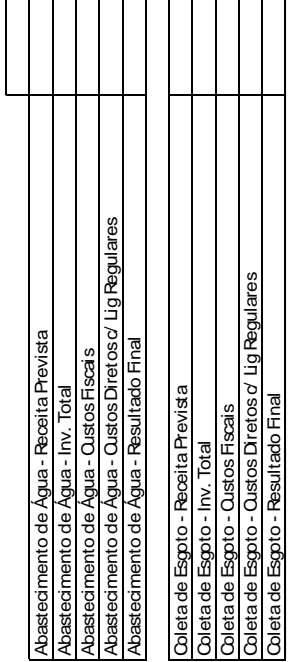

cdlvi 


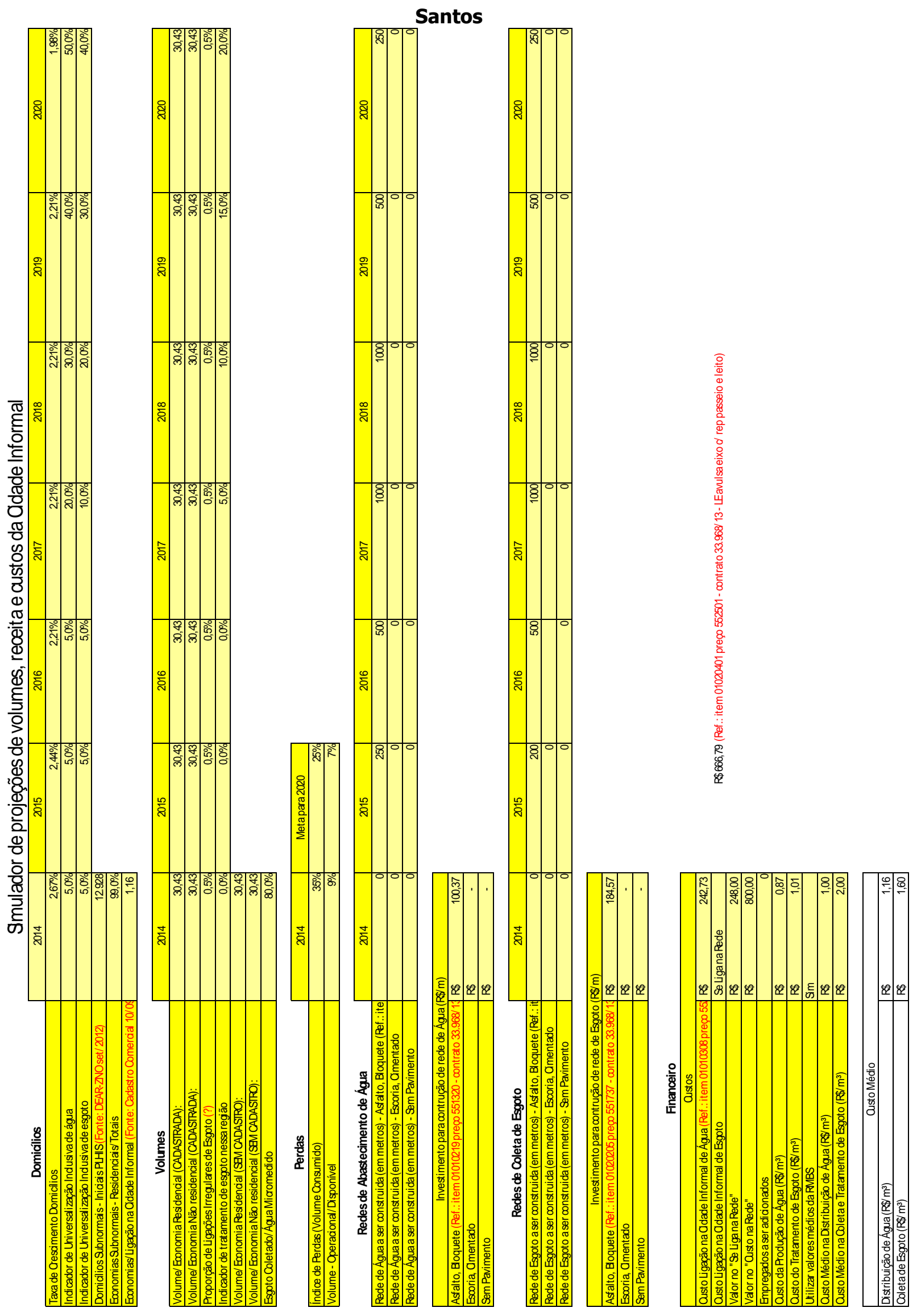

cdlvii 


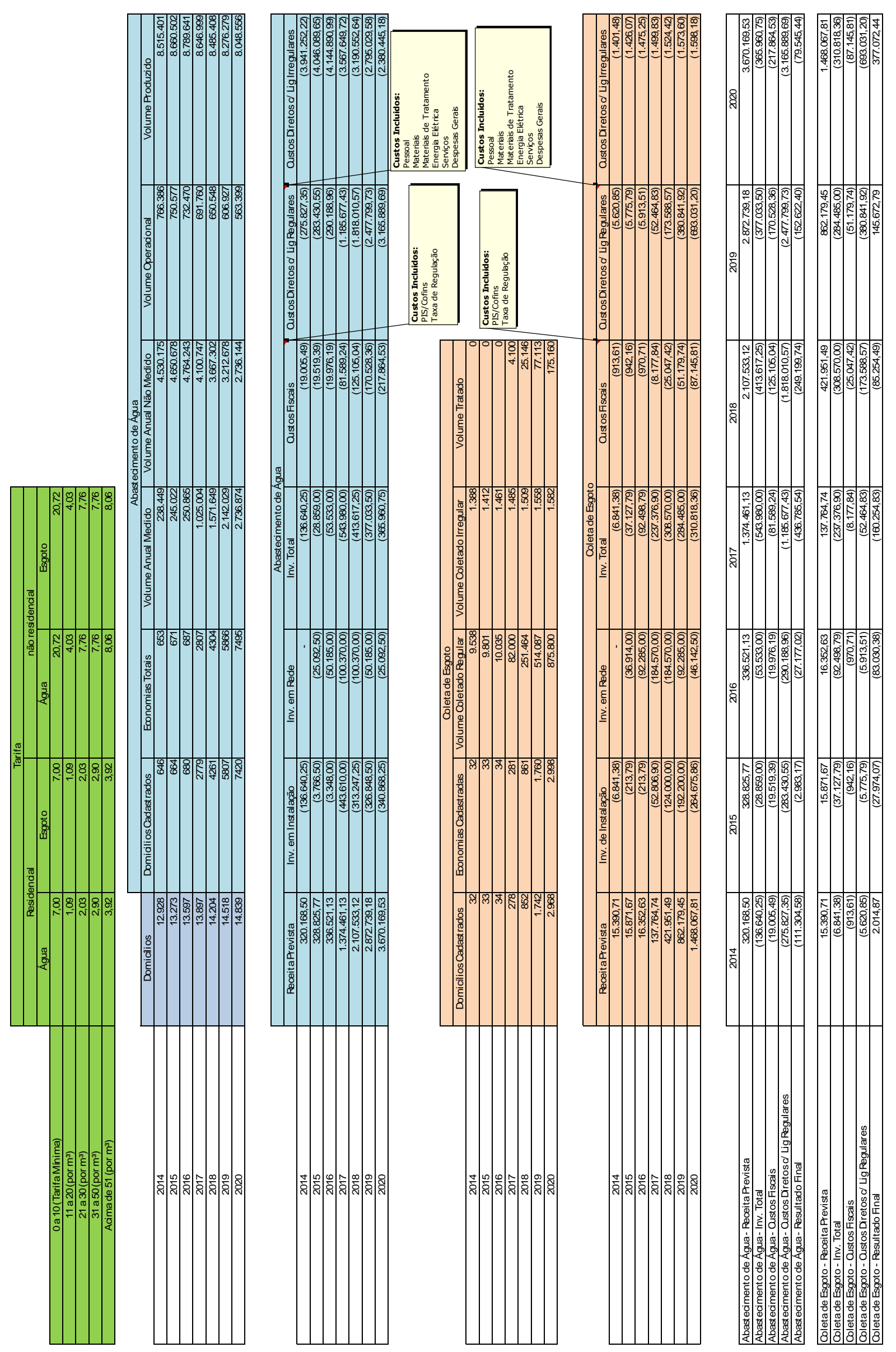

cdlviii 


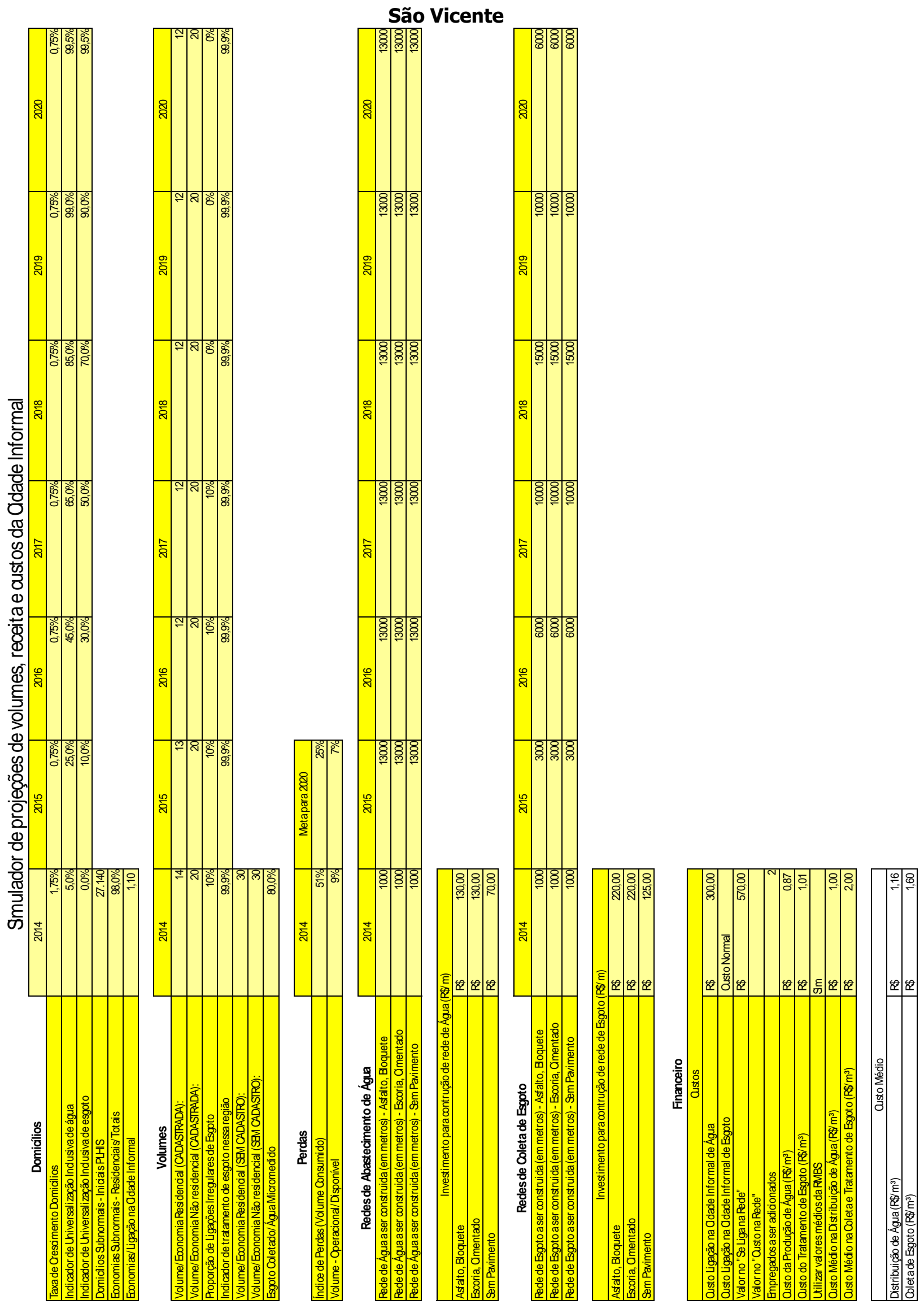

cdlix 

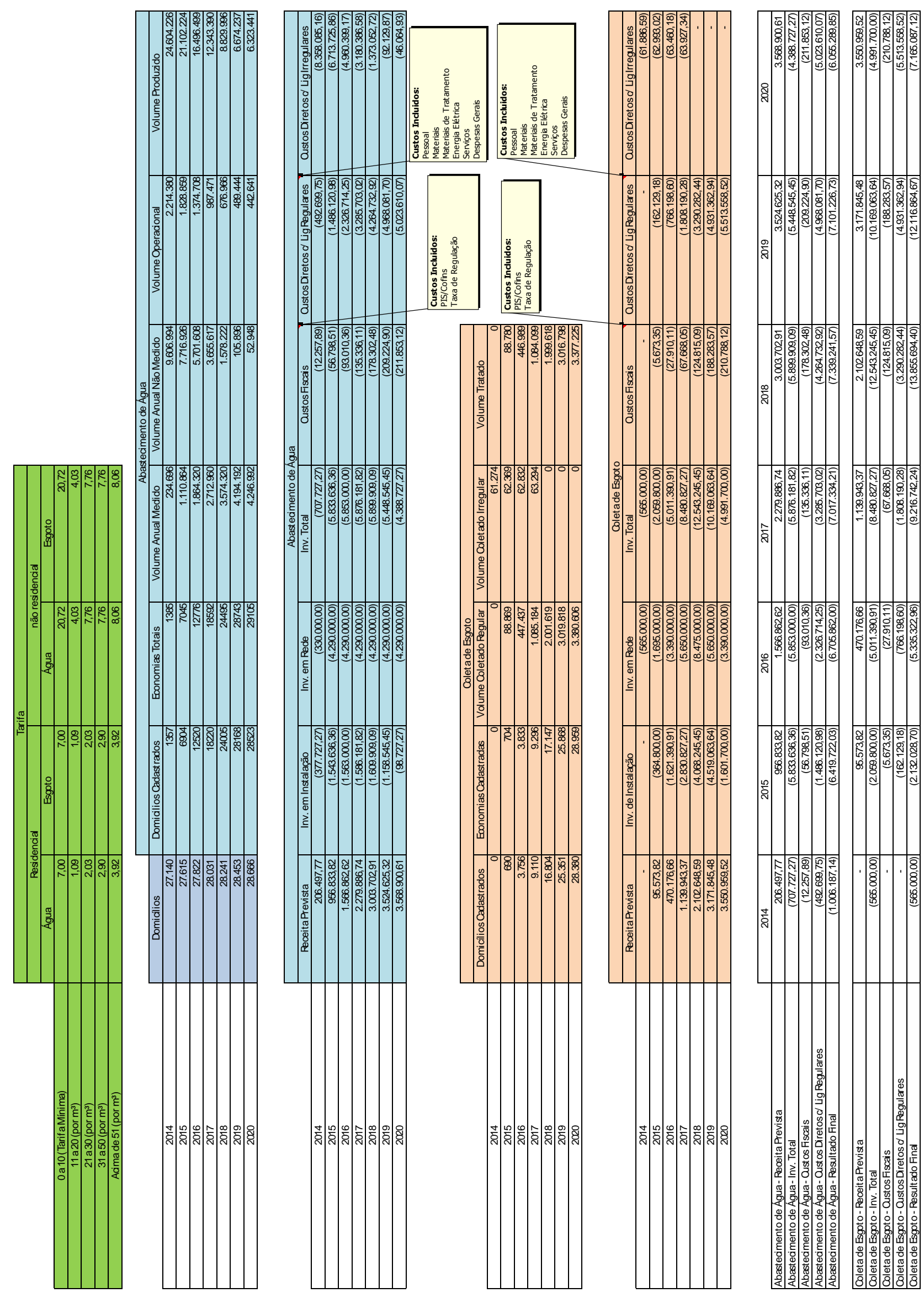

กิ่

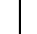

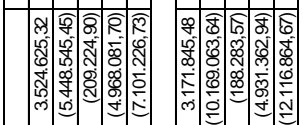

ํํ

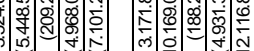

(

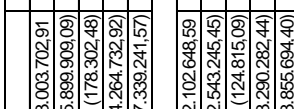
㐫

=

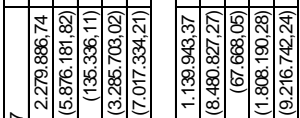
ลิำ

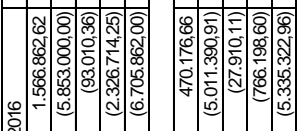

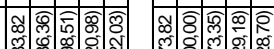
정

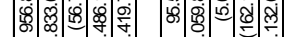
สี

$=0$

वे $=$ ज

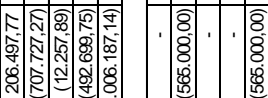

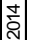

다의
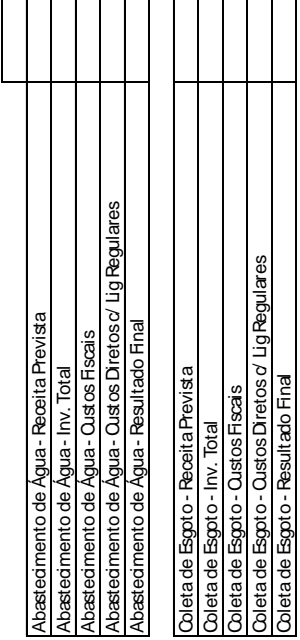

cdlx 
Consolidação do Plano de Negócio Inclusivo - PNI

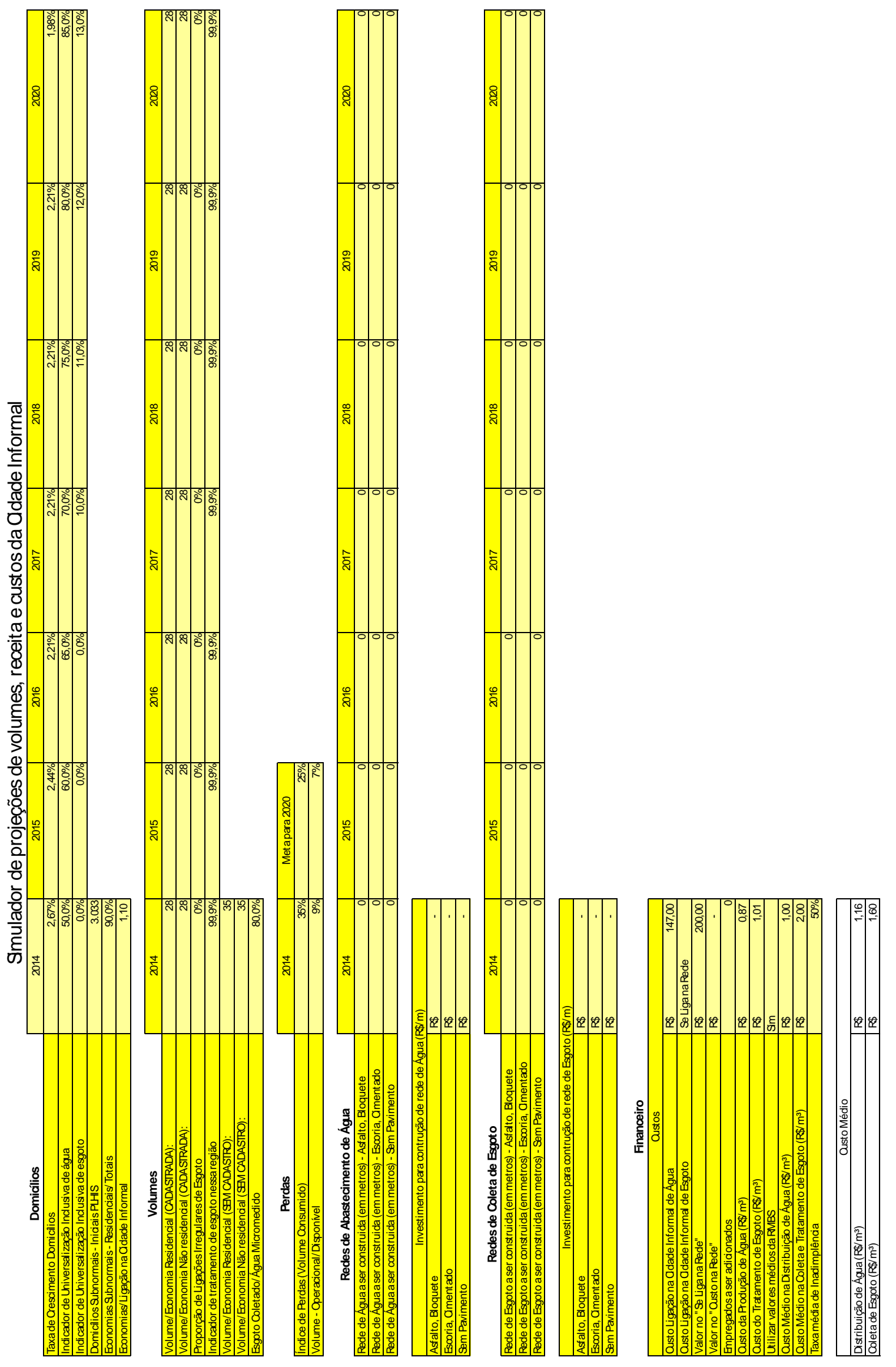

cdlxi 


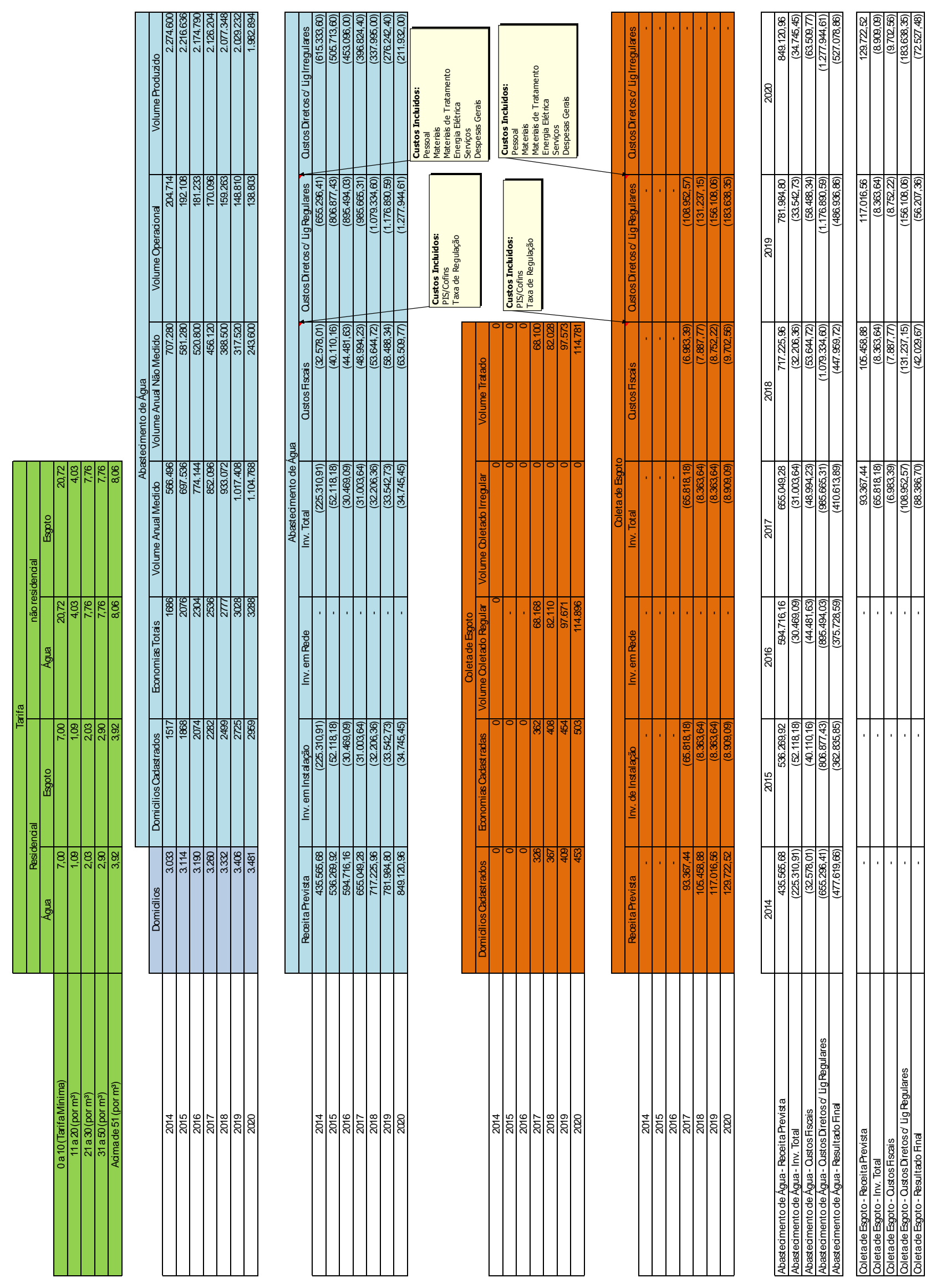

cdlxii 


\section{Resultados Financeiros do Plano de Negócios Inclusivos da RMBS}

\begin{tabular}{|c|c|c|c|c|}
\hline Resultados Financiros & 2014 & 2015 & 2016 & 2017 \\
\hline Abastecimento de Água- Recita Prevista & $1.382 .919,06$ & $4.620 .927,81$ & $8.596 .425,73$ & $13.855 .324,39$ \\
\hline Abastecimento de Água-Inv. Total & $(2.881 .981,57)$ & $(9.462 .621,55)$ & $(10.547 .611,46)$ & $(10.631 .785,13)$ \\
\hline Abastecimento de Água- Oustos Fiscais & $(103.435,05)$ & $(345.621,01)$ & $(642.967,27)$ & $(1.036 .305,13)$ \\
\hline Abastecimento de Água- Orstos Diretos $d$ Lig Pegulares & $(1.953 .327,29)$ & $(6.013 .543,35)$ & $(10.913 .916,45)$ & $(17.237 .141,19)$ \\
\hline Abastedimento de Água-Pesultado Final & $(3.555 .824,85)$ & $(11.200 .858,09)$ & $(13.508 .069,45)$ & $(15.049 .907,06)$ \\
\hline Coleta de Esgoto - Peœita Prevista & $15.650,27$ & $434.146,71$ & $2.511 .857,76$ & $6.491 .802,58$ \\
\hline Coletade Esgoto - Inv. Total & $(6.304 .717,09)$ & $(12.484 .129,53)$ & $(18.184 .847,63)$ & $(24.659 .191,34)$ \\
\hline Coletade Esgoto - Orstos Fiscais & $(1.170,56)$ & $(32.471,88)$ & $(187.873,70)$ & $(485.552,57)$ \\
\hline Coleta de Esgoto - Oistos Diretosd Lig Regulares & $(7.239,10)$ & $(582.146,26)$ & $(3.352 .516,22)$ & $(8.854 .545,52)$ \\
\hline Coletade Esgoto - Pesultado Final & $(6.297 .476,48)$ & $(12.664 .600,97)$ & $\begin{array}{ll}(19.213 .379,80) \\
\end{array}$ & $(27.507 .486,85)$ \\
\hline ReœitaPrevista & $1.398 .569,33$ & $5.055 .074,52$ & $11.108 .283,48$ & $20.347 .126,97$ \\
\hline Inv. Total & $(9.186 .698,66)$ & $(21.946 .751,08)$ & $(28.732 .459,09)$ & $(35.290 .976,47)$ \\
\hline Oistos Fiscais & $(104.605,60)$ & $(378.092,89)$ & $(830.840,97)$ & $(1.521 .857,70)$ \\
\hline Oustos Diretos d Lig Pegulares & $(1.960 .566,40)$ & $(6.595 .689,61)$ & (14.266.432,67) & $\begin{array}{l}(26.091 .686,71) \\
\end{array}$ \\
\hline Kt Agente Comunitário & $(551.340,00)$ & - & - & - \\
\hline Pesultado Final & $(10.404 .641,33)$ & $(23.865 .459,06)$ & $(32.721 .449,25)$ & $(42.557 .393,92)$ \\
\hline
\end{tabular}

\begin{tabular}{|c|c|c|c|c|}
\hline Resultados Finanœiros & 2018 & 2019 & 2020 & Total \\
\hline Abastecimento de Água- Peceita Prevista & $19.000 .009,98$ & $23.295 .410,97$ & $25.077 .628,74$ & $95.828 .646,68$ \\
\hline Abastecimento de Agua- Inv. Total & $(10.607 .749,77)$ & $(9.465 .717,60)$ & $(6.639 .914,49)$ & $(60.237 .381,57)$ \\
\hline Abastedimento de Agua - Oustos Fiscais & $(1.421 .100,46)$ & $(1.742 .373,78)$ & $(1.875 .674,26)$ & $(7.167 .476,96)$ \\
\hline Abastecimento de Água- Oustos Diretos d Lig Regulares & $(23.450 .295,81)$ & $(28.712 .492,82)$ & $(30.793 .458,38)$ & $(119.074 .175,28)$ \\
\hline Abastecimento de Água- Pesultado Fnal & $(16.479 .136,06)$ & $(16.625 .173,23)$ & $(14.231 .418,39)$ & $(90.650 .387,14)$ \\
\hline Coleta de Esgoto - Receita Prevista & 12463860.42 & 1959794964 & 23.155273 .37 & 6467054073 \\
\hline Coleta de Esgoto - Inv. Total & $\frac{12.40 .06 .004,42}{(29.9)}$ & $(29.526 .271,42)$ & $(18.630 .082,11)$ & $(138.896 .184,152)$ \\
\hline Coleta de Esgoto - Oistos Fiscais & $\frac{1932.230,97)}{(93)}$ & $\frac{1.02 .265 .823,19)}{(1.46)}$ & $(1.731 .892,23)$ & $(4.837 .015,10)$ \\
\hline Coleta de Esgoto - Oustos Diretos $d$ Lig Pegulares & $(16.789 .546,24)$ & $(26.323 .189,62)$ & $(30.823 .017,48)$ & $(86.732 .200,45)$ \\
\hline Coletade Esgoto - Resultado Final & $(34.364 .862,00)$ & $(37.717 .334,60)$ & $(28.029 .718,45)$ & $(165.794 .859,14)$ \\
\hline Reœita Prevista & $31.463870,40$ & $42893,360,61$ & 4823290210 & 16049918741 \\
\hline \begin{tabular}{|l|l} 
Inv. Total \\
\end{tabular} & $\begin{aligned} 0.1403 .00,404 \\
(39.714 .694,97)\end{aligned}$ & $\begin{array}{ll}4.095 .000,01 \\
(38.991 .989,02)\end{array}$ & $\begin{array}{ll}40.202 .092<, 10 \\
(25.269 .996,60)\end{array}$ & $\begin{array}{ll}10.499 .10,4,41 \\
(199.133 .565,89)\end{array}$ \\
\hline Qistos Fiscais & $(2.353 .331,43)$ & $(3.208 .196,97)$ & $(3.607 .566,49)$ & $(12.004 .492,06)$ \\
\hline Oustos Diretos d Lig Pegulares & $(40.239 .842,06)$ & $(55.035 .682,44)$ & $(61.616 .475,86)$ & $(205.806 .375,74)$ \\
\hline Kt Agente Comunitário & & & & $(551.340,00)$ \\
\hline \begin{tabular}{|l} 
Pesultado Fnal \\
\end{tabular} & $(50.843 .998,06)$ & $(54.342 .507,82)$ & $(42.261 .136,85)$ & $(256.996 .586,28)$ \\
\hline
\end{tabular}

Kit Agente Comunitário

\begin{tabular}{|c|c|c|c|c|c|c|c|c|c|c|c|c|}
\hline MUNId́'PIO & Note Book & $\begin{array}{c}\text { Projetor } \\
\text { Multimídia }\end{array}$ & $\begin{array}{l}\text { Tela de } \\
\text { Projeção }\end{array}$ & $\begin{array}{c}\text { Caixa de som + } \\
2 \text { microfones }\end{array}$ & Celular & $\begin{array}{l}\text { Câmera } \\
\text { Digital }\end{array}$ & Veículo & Coletes & Bonés & $\begin{array}{c}\text { Material } \\
\text { Divulgação (Faixas } \\
\text { e Banners) }\end{array}$ & $\begin{array}{c}\text { Encontro } \\
\text { Comunitário }\end{array}$ & TOTALR\$ \\
\hline BERाIOGA & 0,00 &, 00 & 0,00 & 0,00 & $R \$ 100,00$ & $R \$ 900,00$ & $20.400,00$ & 90,00 & $R \$ 30,00$ & 000,00 & $R \$ 5.000,00$ & $\mathrm{R} \$ 61.220,00$ \\
\hline CUBATÃO & $R \$ 6.000,00$ & $R \$ 3.000,00$ & $R \$ 500,00$ & $R \$ 1.200,00$ & $R \$ 100,00$ & $R \$ 900,00$ & $\mathrm{R} \$ 20.400,00$ & $R \$ 90,00$ & $R \$ 30,00$ & $R \$ 24.000,00$ & $\mathrm{R} \$ 5.000,00$ & $\mathrm{R} \$ 61.220,00$ \\
\hline GUARUJA & $R \$ 6.000,00$ & $R \$ 3.000,00$ & $R \$ 500,00$ & $\mathrm{R} \$ 1.200,00$ & $R \$ 100,00$ & $R \$ 900,00$ & $R \$ 20.400,00$ & $R \$ 90,00$ & $\mathrm{R} \$ 30,00$ & $R \$ 24.000,00$ & $R \$ 5.000,00$ & $\mathrm{R} \$ 61.220,00$ \\
\hline ITANHAEM & $R \$ 6.000,00$ & $R \$ 3.000,00$ & $P \$ 500,00$ & $R \$ 1.200,00$ & $R \$ 100,00$ & $R \$ 900,00$ & $R \$ 20.400,00$ & $R \$ 180,00$ & $R \$ 60,00$ & $R \$ 24.000,00$ & $R \$ 5.000,00$ & $\mathrm{R} \$ 61.340,00$ \\
\hline MONGAGUA & $R \$ 6.000,00$ & $\mathrm{R} \$ 3.000,00$ & $R \$ 500,00$ & $\mathrm{R} \$ 1.200,00$ & $R \$ 100,00$ & $R \$ 900,00$ & $\mathrm{R} \$ 20.400,00$ & $R \$ 90,00$ & $R \$ 30,00$ & $R \$ 24.000,00$ & $R \$ 5.000,00$ & $\mathrm{R} \$ 61.220,00$ \\
\hline PERUIBE & $\mathrm{R} \$ 6.000,00$ & $\mathrm{R} \$ 3.000,00$ & $R \$ 500,00$ & $R \$ 1.200,00$ & $R \$ 100,00$ & $R \$ 900,00$ & $R \$ 20.400,00$ & $R \$ 90,00$ & $R \$ 30,00$ & $\mathrm{R} \$ 24.000,00$ & $\mathrm{R} \$ 5.000,00$ & $\mathrm{R} \$ 61.220,00$ \\
\hline PRAIA GRANDE & $R \$ 6.000,00$ & $\mathrm{R} \$ 3.000,00$ & $R \$ 500,00$ & $\mathrm{R} \$ 1.200,00$ & $R \$ 100,00$ & $R \$ 900,00$ & $R \$ 20.400,00$ & $R \$ 180,00$ & $\mathrm{R} \$ 60,00$ & $\mathrm{R} \$ 24.000,00$ & $\mathrm{R} \$ 5.000,00$ & $\mathrm{R} \$ 61.340,00$ \\
\hline SANTOS & $R \$ 6.000,00$ & $R \$ 3.000,00$ & $R \$ 500,00$ & $R \$ 1.200,00$ & $R \$ 100,00$ & $R \$ 900,00$ & $R \$ 20.400,00$ & $R \$ 90,00$ & $R \$ 30,00$ & $R \$ 24.000,00$ & $R \$ 5.000,00$ & $R \$ 61.220,00$ \\
\hline SÃOVICENTE & 00 & 00 & 00 & 00 & $R \$$ & 00 & 00 & 00 &, 00 & 0,00 &, 00 & 0,00 \\
\hline TOTALRS & $R \$ 54.000,00$ & $R \$ 27.000,00$ & $\mathrm{R} \$ 4.500,00$ & $R \$ 10.800,00$ & $R \$ 900,00$ & $\mathrm{R} \$ 8.100,00$ & $R \$ 183.600,00$ & $\mathrm{R} \$ 1.080,00$ & $\$ 360,00$ & $R \$ 216.000,00$ & $\mathrm{R}^{2} \$ 45.000,00$ & $\mathrm{R} \$ 551.340,00$ \\
\hline
\end{tabular}

\begin{tabular}{|c|c|}
\hline \multirow{2}{*}{$\begin{array}{l}1 \text { Bote Book } \\
1 \text { Projetor Multimídia } \\
1 \text { Tela de Projeção } \\
1 \text { Caixa de som } \\
2 \text { Microfones }\end{array}$} & Material Divulgação(Faixase Banners) \\
\hline & $\begin{array}{c}\mathrm{R} \$ 2.000,00 \text { por mês por município } \\
\text { (cadafaixa e cada Banner +ou- } \\
\mathrm{R} \$ 150,00) \text { + folhetos e formulários } \\
\text { etc...) }\end{array}$ \\
\hline \multicolumn{2}{|l|}{1 Celular } \\
\hline 1 Câmera Digital & Colete \\
\hline $\begin{array}{l}1 \text { Veículo } \\
2 \text { Coletes }\end{array}$ & $\begin{array}{l}\text { Valor Unitário }=\mathrm{R} \$ 45,00 \\
2 \text { para cadafuncionário }\end{array}$ \\
\hline \multicolumn{2}{|l|}{2 Bonés } \\
\hline & Celular \\
\hline & $\begin{array}{c}\text { Oaparelho é gratis, atarifaé: } \\
\text { Exec=R\$55,85, Gern=R\$39,37, } \\
\text { Oper=R\$39,37. A média de valor de } \\
\text { uma conta de um operacial da RSé } \\
\text { R\$100,00 }\end{array}$ \\
\hline
\end{tabular}

\begin{tabular}{|c|}
\hline Encontro Comunitário \\
\hline $\begin{array}{c}\text { Se hover } 1 \text { por ano (aluguel de onibus } \\
\text { paralevar os participantes, lanche, } \\
\text { material paradivulgação etc...) }\end{array}$ \\
\hline Bonés \\
\hline $\begin{array}{l}\text { Valor Unitário }=\mathrm{R} \$ 15,00 \\
2 \text { para cadafuncionário }\end{array}$ \\
\hline Veículo \\
\hline $\begin{array}{c}\text { Doblô Fiat / Aluguel = Valor mensal } \\
\text { R } \$ 1.700,00 \text { cada }\end{array}$ \\
\hline \begin{tabular}{|c|} 
Valores de Note Book, Projetor \\
Multimídia, Câmera Digital e Veículo \\
refrente a ultima compra na RS Tela \\
de Projeção, Caixade Som, \\
microfone, oletes, bonés, orçamento \\
por email. \\
\end{tabular} \\
\hline
\end{tabular}




\section{Fórmulas}

Memória do Simulador de projeções de volumes, receita e custos do Plano de Negócio Inclusivo - PNI da RMBS

Os valores apresentados no projeto são os resultados de um simulador feito para cada município. Nesse simulador dever inserido as informações divididas em 5 grupos: Domicílios, Volumes, Perdas, Redes (Água e Esgoto) e Informações Financeiras.

Para se fazer o Cálculo das projeções levou-se em conta algumas premissas:

- A água consumida na área informa é retirada irregularmente da SABESP;

- O objetivo para o abastecimento de água é efetuar o cadastramento comercial, porque essas economias já possuem ligação física;

- O objetivo da coleta de esgoto é efetuar a ligação física, comercial e intra-domiciliar;

- A meta de universalização a principio seria para o ano de 2020, mas os municípios ajustaram de acordo com a sua capacidade de planejamento considerando as atuais condições empresariais.

\section{Formulas utilizadas:}

$$
\begin{aligned}
& \text { Receita }=\text { Qtd.Domicílios } \text { Atendidos }_{\text {Dolume }} \times \text { Faturado }_{\text {VTarif }} a_{\text {social }} \\
& + \text { Qtd.Econ. ñ. Resid } x \text { Volume }_{\text {Faturado }} \times \text { Tarif }_{\text {social }}
\end{aligned}
$$

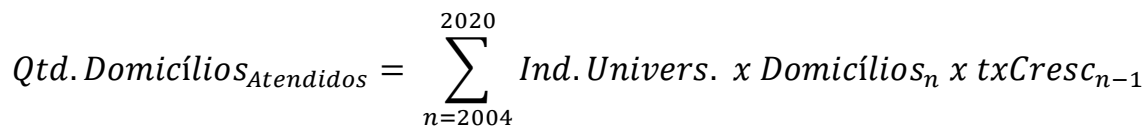

$$
\begin{aligned}
& \text { Qtd.Econ. ñ. Resid. }=\sum_{n=2004}^{2020} \text { Domicílios }_{n} x\left(\frac{\text { Qtd.Econ.tot }}{\text { Qtd.Econ.resid }}-1\right) \\
& \text { Custo }=\text { Vol }_{\text {prod }} \times \text { Custo }_{\text {produção }}+\text { Vol }_{\text {Coletado }} \times \text { Custo }_{\text {tratamento }}
\end{aligned}
$$

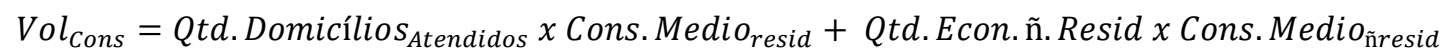

$$
\begin{aligned}
& V o l_{\text {prod }}=\operatorname{Vol}_{\text {Cons }}+V_{\text {ol }} l_{\text {perdas }}+V_{o l} l_{\text {oper }} \\
& V o l_{\text {Cons }}=\text { Vol }_{\text {prod }}-\text { Vol }_{\text {perdas }}-\text { Vol }_{\text {oper }} \\
& \frac{\text { Vol }_{\text {cons }}}{\text { Vol }_{\text {prod }}}=1-\frac{\text { Vol }_{\text {perdas }}}{\text { Vol }_{\text {prod }}}-\frac{\text { Vol }_{\text {oper }}}{\text { Vol }_{\text {prod }}} \\
& \frac{V_{o l} l_{\text {cons }}}{\text { Vol }_{\text {prod }}}=1-\text { Índice } e_{\text {perdas }}-\text { Índice } \text { oper }
\end{aligned}
$$

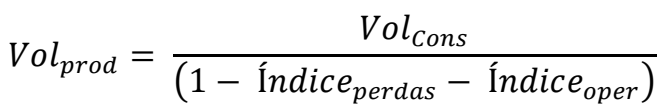




\section{Dados de referência para populações e domisílios:}

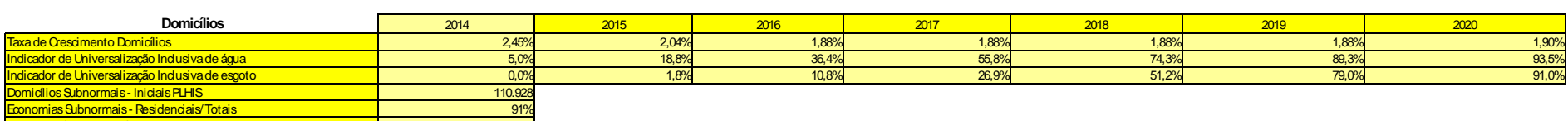

Informações vindas do município

\begin{tabular}{|c|c|c|c|c|}
\hline Informação & Célula & Unidade & Explicação & Fonte \\
\hline $\begin{array}{l}\text { Taxa de Crescimento } \\
\text { Domicílios }\end{array}$ & B3:h3 & Percentagem & Taxa de Crescimento Domicílios por ano & Seade \\
\hline $\begin{array}{l}\text { Indicador de Universalização } \\
\text { Inclusiva de água }\end{array}$ & B4:h4 & Percentagem & $\begin{array}{l}\text { Meta para Índice de Cobertura com } \\
\text { Abastecimento de Água na região. }\end{array}$ & $\begin{array}{l}\text { A } \\
\text { gerência } \\
\text { de cada } \\
\text { município } \\
\text { definiu }\end{array}$ \\
\hline $\begin{array}{l}\text { Indicador de Universalização } \\
\text { Inclusiva de esgoto }\end{array}$ & B5:h5 & Percentagem & $\begin{array}{l}\text { Meta para Índice de Cobertura com Coleta } \\
\text { de Esgotos na região. }\end{array}$ & $\begin{array}{l}\text { A } \\
\text { gerência } \\
\text { de cada } \\
\text { município } \\
\text { definiu }\end{array}$ \\
\hline $\begin{array}{l}\text { Domicílios Subnormais - } \\
\text { Iniciais PLHIS }\end{array}$ & B6 & Domicílios & $\begin{array}{l}\text { Quantidades Domicílios Subnormais de uma } \\
\text { cidade ou região onde será feito o estudo. }\end{array}$ & PLHIS \\
\hline $\begin{array}{l}\text { Economias Subnormais - } \\
\text { Residenciais/Totais }\end{array}$ & B7 & Percentagem & $\begin{array}{l}\text { É proporção de Economias Residenciais } \\
\text { para o de Economias Totais. Esse valor } \\
\text { deverá ser entre } 0 \% \text { e } 100 \% \text {. }\end{array}$ & \begin{tabular}{|l} 
A \\
gerência \\
de cada \\
município \\
definiu \\
(valor \\
inicial \\
$90 \%$ ) \\
\end{tabular} \\
\hline $\begin{array}{l}\text { Economias/Ligação na } \\
\text { Cidade Informal }\end{array}$ & B8 & Unidades & $\begin{array}{l}\text { É proporção entre Ligações Totais para } \\
\text { Economias Totais. Esse valor tem que ser } \\
\text { superior a um. }\end{array}$ & \begin{tabular}{|l} 
A \\
gerência \\
de cada \\
município \\
definiu \\
(valor \\
inicial \\
1,1 ) \\
\end{tabular} \\
\hline
\end{tabular}

Informações no Consolidado

\begin{tabular}{|c|c|}
\hline Informação & Cálculo efetuado \\
\hline $\begin{array}{l}\text { Taxa de Crescimento } \\
\text { Domicílios }\end{array}$ & $\frac{\sum \text { Domicilios Projetados }_{\text {ano } n}}{\sum \text { Domicilios Projetados }_{\text {ano } n-1}}-1$ \\
\hline $\begin{array}{l}\text { Indicador de Universalização } \\
\text { Inclusiva de água }\end{array}$ & $\frac{\sum \text { Dom. Ate.Água }}{\text { ano } n}$ \\
\hline $\begin{array}{l}\text { Indicador de Universalização } \\
\text { Inclusiva de esgoto }\end{array}$ & $\frac{\sum \text { Dom. Ate. Esgoto ano n }}{\text { DDom. Projetados }}$ \\
\hline $\begin{array}{l}\text { Domicílios Subnormais - } \\
\text { Iniciais PLHIS }\end{array}$ & $\sum$ Domicilios Projetados $_{\text {ano } 0}$ \\
\hline $\begin{array}{l}\text { Economias Subnormais - } \\
\text { Residenciais/Totais }\end{array}$ & 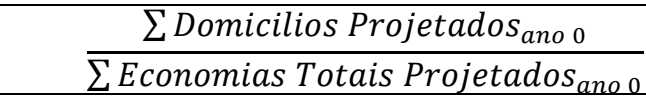 \\
\hline $\begin{array}{l}\text { Economias/Ligação na Cidade } \\
\text { Informal }\end{array}$ & $\frac{\text { Economias Totais Projetados ano } 0}{\sum_{\text {Ligaçoses Totais Projetados }}}$ \\
\hline
\end{tabular}




\section{Cálculo de Volumes e Perdas}

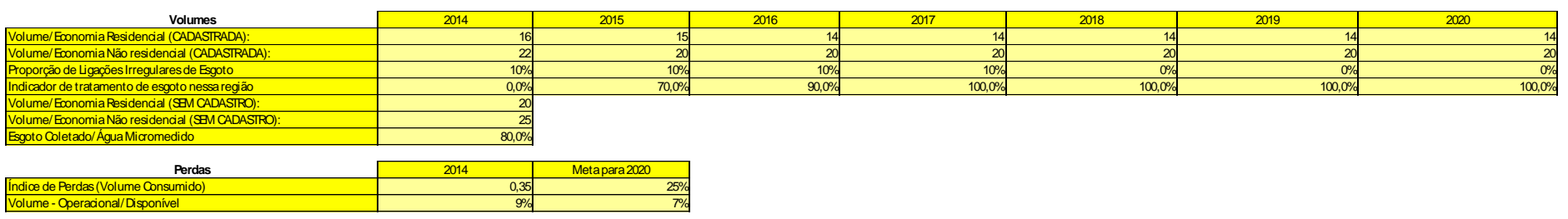

Informações vindas do município

\begin{tabular}{|c|c|c|c|c|}
\hline Informação & Célula & Unidade & Explicação & Fonte \\
\hline $\begin{array}{l}\text { Volume/Economia } \\
\text { Residencial (Cadastrada): }\end{array}$ & B11:H11 & $\mathrm{m}^{3} /$ mês & $\begin{array}{l}\text { É o consumo médio mês por economia } \\
\text { residencial quando ela está cadastrada }\end{array}$ & \begin{tabular}{|l|} 
A \\
gerência \\
de cada \\
município \\
definiu
\end{tabular} \\
\hline $\begin{array}{l}\text { Volume/Economia Não } \\
\text { residencial (Cadastrada): }\end{array}$ & B12:H12 & $\mathrm{m}^{3} / \mathrm{mês}$ & $\begin{array}{l}\text { É o consumo médio mês por economia } \\
\text { residencial quando ela está cadastrada }\end{array}$ & \begin{tabular}{|l|} 
A \\
gerência \\
de cada \\
município \\
definiu \\
\end{tabular} \\
\hline $\begin{array}{l}\text { Proporção de Ligações } \\
\text { Irregulares de Esgoto }\end{array}$ & B13:H13 & Percentagem & Proporção de Ligações Irregulares de Esgoto & \begin{tabular}{|l|} 
A \\
gerência \\
de cada \\
município \\
definiu \\
(inicial \\
$10 \%$ ) \\
\end{tabular} \\
\hline $\begin{array}{l}\text { Indicador de tratamento } \\
\text { de esgoto }\end{array}$ & B14:H14 & Percentagem & $\begin{array}{l}\text { Meta para Índice de Tratamento de Esgoto } \\
\text { em relação ao esgoto coletado da região. }\end{array}$ & SNIS \\
\hline $\begin{array}{l}\text { Volume/Economia } \\
\text { Residencial (SEM } \\
\text { CADASTRO): }\end{array}$ & B15 & $\mathrm{m}^{3} / \mathrm{mês}$ & $\begin{array}{l}\text { É o consumo médio mês por domicilio } \\
\text { quando ela não está cadastrada. }\end{array}$ & \begin{tabular}{|l|} 
A \\
gerência \\
de cada \\
município \\
definiu \\
\end{tabular} \\
\hline $\begin{array}{l}\text { Volume/Economia Não } \\
\text { residencial (SEM } \\
\text { CADASTRO): }\end{array}$ & B16 & $\mathrm{m}^{3} / \mathrm{mês}$ & $\begin{array}{l}\text { É o consumo médio mês por economia não } \\
\text { residencial quando ela não está cadastrada. }\end{array}$ & $\begin{array}{l}\text { A } \\
\text { gerência } \\
\text { de cada } \\
\text { município } \\
\text { definiu }\end{array}$ \\
\hline $\begin{array}{l}\text { Esgoto Coletado/Água } \\
\text { Micromedido }\end{array}$ & B17 & Percentagem & $\begin{array}{l}\text { É proporção entre cada } \mathrm{m}^{3} \text { de água } \\
\text { fornecido para cada } \mathrm{m}^{3} \text { de esgoto coletado. }\end{array}$ & $\begin{array}{l}\text { Contrato } \\
\text { de São } \\
\text { Paulo } \\
(80 \%) \\
\end{array}$ \\
\hline \multirow{2}{*}{$\begin{array}{l}\text { Índice de Perdas (Volume } \\
\text { Consumido) }\end{array}$} & B20 & Percentagem & $\begin{array}{l}\text { Índice de Perdas utilizando o volume de } \\
\text { micromedido no ano de } 2014 \text {. }\end{array}$ & $\begin{array}{l}\text { A } \\
\text { gerência } \\
\text { de cada } \\
\text { município } \\
\text { definiu } \\
\end{array}$ \\
\hline & $\mathrm{C} 20$ & Percentagem & $\begin{array}{l}\text { Meta para Índice de Perdas utilizando o } \\
\text { volume de micromedido no ano de } 2020 \text {. }\end{array}$ & $\begin{array}{l}\text { A } \\
\text { gerência } \\
\text { de cada } \\
\text { município } \\
\end{array}$ \\
\hline
\end{tabular}




\begin{tabular}{|l|l|l|l|l|}
\hline & & & & definiu \\
\hline & B21 & Percentagem & $\begin{array}{l}\text { Volume Operacional dividido pelo volume } \\
\text { produzido no ano de 2014 }\end{array}$ & $\begin{array}{l}\text { A } \\
\text { gerência } \\
\text { de cada } \\
\text { município } \\
\text { definiu }\end{array}$ \\
\cline { 2 - 4 } & C21 & Percentagem & $\begin{array}{l}\text { Meta para Volume Operacional dividido pelo } \\
\text { volume produzido no ano de 2020 }\end{array}$ & $\begin{array}{l}\text { gerência } \\
\text { de cada } \\
\text { município } \\
\text { definiu }\end{array}$ \\
\hline
\end{tabular}

Informações no Consolidado

\begin{tabular}{|c|c|}
\hline Informação & Cálculo efetuado \\
\hline $\begin{array}{l}\text { Volume/Economia } \\
\text { Residencial (Cadastrada): }\end{array}$ & $\frac{\sum E \text { Econ_resid } \times \text { Vol }_{\text {Cons }}}{\sum E \text { Econ_resid }}$ \\
\hline $\begin{array}{l}\text { Volume/Economia Não } \\
\text { residencial (Cadastrada): }\end{array}$ & $\frac{\sum E c o n \_\tilde{n} \_r e s i d \times V o l_{\text {Cons }}}{\sum E \text { con_ñ }}$ \\
\hline $\begin{array}{l}\text { Proporção de Ligações } \\
\text { Irregulares de Esgoto }\end{array}$ & $\frac{\sum \text { Ligações Irregulares de esgoto }}{\sum \text { Domicílios }+ \text { Eco_ñ_resid }}$ \\
\hline $\begin{array}{l}\text { Indicador de tratamento } \\
\text { de esgoto }\end{array}$ & $\frac{\sum \text { EconTotai }_{\text {Esgoto }} \times \text { Ind.Trat. Municipal }^{\text {That }}}{\sum \text { EconTotais }_{\text {Esgoto }}}$ \\
\hline $\begin{array}{l}\text { Volume/Economia } \\
\text { Residencial (SEM } \\
\text { CADASTRO): }\end{array}$ & $\frac{\sum \text { Dom_sem_cadastro } \times V_{\text {Vol }} \text { cons }}{\sum \text { Dom_sem_cadastro }}$ \\
\hline $\begin{array}{l}\text { Volume/Economia Não } \\
\text { residencial (SEM } \\
\text { CADASTRO): }\end{array}$ & $\frac{\sum E c o n \_s e m_{-} \text {cadastro } \times V_{\text {Vol }} \text { Cons }}{\sum E \text { Econ_sem_cadastro }}$ \\
\hline $\begin{array}{l}\text { Esgoto Coletado/Água } \\
\text { Micromedido }\end{array}$ & $\frac{\sum \text { Esgoto Coletado }}{\sum \text { Vol Água Micromedido }}$ \\
\hline $\begin{array}{l}\text { Índice de Perdas (Volume } \\
\text { Consumido) }\end{array}$ & $\frac{\sum \operatorname{Vol}_{\text {prod }}-\text { Vol }_{\text {cons }}-\text { Vol }_{\text {oper }}}{\sum V_{\text {ol }}}$ \\
\hline $\begin{array}{l}\text { Volume - } \\
\text { Operacional/Disponível }\end{array}$ & $\frac{\sum V o l_{\text {oper }}}{\sum V o l_{\text {prod }}}$ \\
\hline
\end{tabular}




\section{Cálculo de extensão de redes, material e tipo de solo}

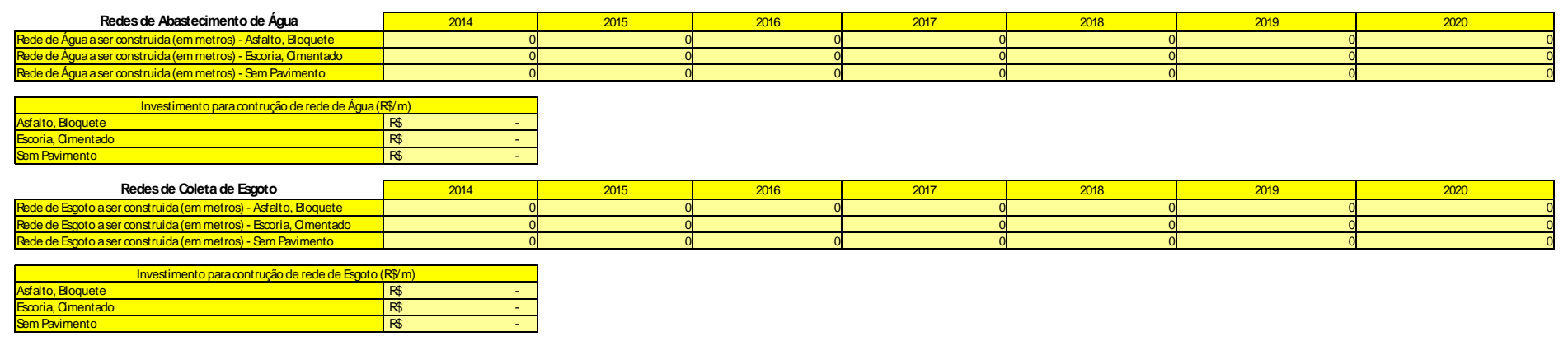

Informações vindas do município

\begin{tabular}{|c|c|c|c|c|}
\hline Informação & Célula & Unidade & Explicação & Fontes \\
\hline $\begin{array}{l}\text { Rede de Água a ser } \\
\text { construída (em metros) - } \\
\text { Asfalto, Bloquete }\end{array}$ & B24:H24 & metros & Rede construída no ano & \begin{tabular}{|l|} 
A \\
gerência \\
de cada \\
município \\
definiu \\
\end{tabular} \\
\hline $\begin{array}{l}\text { Rede de Água a ser } \\
\text { construída (em metros) - } \\
\text { Escoria, Cimentado }\end{array}$ & B25:H25 & metros & Rede construída no ano & $\begin{array}{l}\text { A } \\
\text { gerência } \\
\text { de cada } \\
\text { município } \\
\text { definiu }\end{array}$ \\
\hline $\begin{array}{l}\text { Rede de Água a ser } \\
\text { construída (em metros) - } \\
\text { Sem Pavimento }\end{array}$ & B26:H26 & metros & Rede construída no ano & $\begin{array}{l}\text { A } \\
\text { gerência } \\
\text { de cada } \\
\text { município } \\
\text { definiu } \\
\end{array}$ \\
\hline Custo do cada tipo & B30:B32 & Reais & & \\
\hline $\begin{array}{l}\text { Rede de Esgoto a ser } \\
\text { construida (em metros) - } \\
\text { Asfalto, Bloquete }\end{array}$ & B24:H24 & metros & Rede construída no ano & $\begin{array}{l}\text { A } \\
\text { gerência } \\
\text { de cada } \\
\text { município } \\
\text { definiu }\end{array}$ \\
\hline $\begin{array}{l}\text { Rede de Esgoto a ser } \\
\text { construida (em metros) - } \\
\text { Escoria, Cimentado }\end{array}$ & B25:H25 & metros & Rede construída no ano & $\begin{array}{l}\text { A } \\
\text { gerência } \\
\text { de cada } \\
\text { município } \\
\text { definiu }\end{array}$ \\
\hline $\begin{array}{l}\text { Rede de Esgoto a ser } \\
\text { construida (em metros) - } \\
\text { Sem Pavimento }\end{array}$ & B26:H26 & metros & Rede construída no ano & \begin{tabular}{|l|} 
A \\
gerência \\
de cada \\
município \\
definiu \\
\end{tabular} \\
\hline Custo do cada tipo & B30:B32 & Reais & & \\
\hline
\end{tabular}

Informações no Consolidado 


\begin{tabular}{|c|c|}
\hline $\begin{array}{l}\text { Rede de Água a ser } \\
\text { construída (em metros) - } \\
\text { Asfalto, Bloquete }\end{array}$ & $\sum R e d e_{-}$Água $a_{\text {Asfalto }}$ \\
\hline $\begin{array}{l}\text { Rede de Água a ser } \\
\text { construída (em metros) - } \\
\text { Escoria, Cimentado }\end{array}$ & $\sum$ Rede_Água ${ }_{E s c o r i a}$ \\
\hline $\begin{array}{l}\text { Rede de Água a ser } \\
\text { construída (em metros) - } \\
\text { Sem Pavimento }\end{array}$ & $\sum$ Rede_Água $a_{\text {Sem Pavimento }}$ \\
\hline Custo do cada tipo & $\frac{\text { Investimento em Rede de Água }}{\sum \text { Rede_Água }}$ \\
\hline $\begin{array}{l}\text { Rede de Esgoto a ser } \\
\text { construida (em metros) - } \\
\text { Asfalto, Bloquete }\end{array}$ & $\sum$ Rede_Esgoto $_{\text {Asfalto }}$ \\
\hline $\begin{array}{l}\text { Rede de Esgoto a ser } \\
\text { construida (em metros) - } \\
\text { Escoria, Cimentado }\end{array}$ & $\sum$ Rede_Esgoto $_{\text {Escoria }}$ \\
\hline $\begin{array}{l}\text { Rede de Esgoto a ser } \\
\text { construida (em metros) - } \\
\text { Sem Pavimento }\end{array}$ & $\sum$ Rede_Esgoto $_{\text {Sem Pavimento }}$ \\
\hline Custo do cada tipo & $\frac{\text { Investimento em Rede de Esgoto }}{\sum \text { Rede_Esgoto }}$ \\
\hline
\end{tabular}

cdlxix 


\section{Calculo Financeiro (custos de referência)}

\begin{tabular}{|c|c|c|}
\hline \multicolumn{3}{|c|}{ Financeiro } \\
\hline \multicolumn{3}{|l|}{ Qustos } \\
\hline Qusto Ligação na Oidade Informal de Água & $R \$$ & 197,50 \\
\hline Qusto Ligação na đdade Informal de Esgoto & Se & \\
\hline Valor no "Se Liga na Rede" & $\mathrm{R} \$$ & 478,44 \\
\hline Empregados a ser adicionados & & 3 \\
\hline Qusto da Produção de Água $\left(\mathrm{R} \$ / \mathrm{m}^{3}\right)$ & $R \$$ & 0,87 \\
\hline Qisto do Tratamento de Esgoto $\left(\mathrm{R} \$ / \mathrm{m}^{3}\right)$ & $\mathrm{R} \$$ & 1,01 \\
\hline Utilizar val ores médios da RMBS & $9 m$ & \\
\hline Qusto Médio na Distribuição de Água $\left(\mathrm{R} \$ / \mathrm{m}^{3}\right)$ & $\mathrm{R} \$$ & 1,00 \\
\hline Qusto Médio na Coleta e Tratamento de Esgoto $\left(\mathrm{R} \$ \mathrm{~m}^{3}\right)$ & $\mathrm{R} \$$ & 2,00 \\
\hline Kt Agente Comunitário & $\mathrm{R} \$$ & $551.340,00$ \\
\hline \multicolumn{3}{|c|}{ Ousto Médio } \\
\hline Distribuição de Água $\left(\mathrm{R} \$ \mathrm{~m}^{3}\right)$ & $\mathrm{R} \$$ & 1,16 \\
\hline Coleta de Esgoto $\left(\mathrm{R} \$ / \mathrm{m}^{3}\right)$ & $\mathrm{R} \$$ & 1,60 \\
\hline
\end{tabular}

Informações vindas do município

\begin{tabular}{|c|c|c|c|c|}
\hline Informação & Célula & Unidade & Explicação & Fonte \\
\hline $\begin{array}{l}\text { Custo Ligação na Cidade } \\
\text { Informal de Água }\end{array}$ & B49 & Reais & $\begin{array}{c}\text { É custo para instalação de uma nova ligação } \\
\text { de água. }\end{array}$ & $\begin{array}{l}\text { A gerência } \\
\text { de cada } \\
\text { município } \\
\text { definiu }\end{array}$ \\
\hline $\begin{array}{l}\text { Custo Ligação na Cidade } \\
\text { Informal de Esgoto }\end{array}$ & B50 & Reais & $\begin{array}{c}\text { É custo para instalação de uma nova ligação } \\
\text { de esgoto. }\end{array}$ & $\begin{array}{l}\text { A gerência } \\
\text { de cada } \\
\text { município } \\
\text { definiu }\end{array}$ \\
\hline $\begin{array}{r}\text { Custo da } \\
\text { Água }\end{array}$ & B51 & Reais & $\begin{array}{l}\text { É o custo para a produção de um } \mathrm{m}^{3} \text { de } \\
\text { Água. }\end{array}$ & $\begin{array}{l}\text { A } \\
\text { controladoria } \\
\text { da RS } \\
\text { informou }\end{array}$ \\
\hline $\begin{array}{l}\text { Custo da Produção de } \\
\text { Tratamento de Esgotos } \\
\left(\mathrm{R} \$ / \mathrm{m}^{3}\right)\end{array}$ & B52 & s & $\begin{array}{l}\text { É o custo para a produção de um } \mathrm{m}^{3} \text { de } \\
\text { Água. }\end{array}$ & $\begin{array}{l}\text { A } \\
\text { controladoria } \\
\text { da RS } \\
\text { informou }\end{array}$ \\
\hline $\begin{array}{l}\text { Utilizar valores médios da } \\
\text { RMBS }\end{array}$ & B53 & $\begin{array}{l}\text { Sim ou } \\
\text { Não }\end{array}$ & $\begin{array}{l}\text { O usuário deverá escolher entre utilizar os } \\
\text { valores médios da RMBS, ou utilizar o valor } \\
\text { digitado pelo usuário. }\end{array}$ & $\begin{array}{l}\text { A gerência } \\
\text { de cada } \\
\text { município } \\
\text { definiu }\end{array}$ \\
\hline $\begin{array}{l}\text { Custo por Distribuição de } \\
\text { Áqua }\left(\mathrm{R} \$ / \mathrm{m}^{3}\right)\end{array}$ & B54 & ais & produção e d & $\begin{array}{l}\text { Informação } \\
\text { do FCC560 }\end{array}$ \\
\hline $\begin{array}{l}\text { Custo na Coleta de Esgoto } \\
\left(\mathrm{R} \$ / \mathrm{m}^{3}\right)\end{array}$ & B55 & Reais & Custo na Coleta e Tratamento de Esgoto & $\begin{array}{l}\text { Informação } \\
\text { do FCC560 }\end{array}$ \\
\hline
\end{tabular}

Informações no Consolidado

\begin{tabular}{|c|c|}
\hline Informação & Cálculo efetuado \\
\hline $\begin{array}{c}\text { Custo Ligação na Cidade } \\
\text { Informal de Água }\end{array}$ & $\frac{\text { Investimento em Ligação de Água }}{\sum \text { Ligação_Água }}$ \\
\hline $\begin{array}{c}\text { Custo Ligação na Cidade } \\
\text { Informal de Esgoto }\end{array}$ & $\frac{\text { Investimento em Ligação de Esgoto }}{\sum \text { Ligação_Esgoto }}$ \\
\hline $\begin{array}{c}\text { Custo da Produção de } \\
\text { Água (R\$/m³) }\end{array}$ & $\begin{array}{c}\text { "não há cálculo porque o valor é igual para } \\
\text { todos municípios da RS" }\end{array}$ \\
\hline $\begin{array}{c}\text { Custo da Produção de } \\
\text { Tratamento de Esgotos }\end{array}$ & $\begin{array}{c}\text { "não há cálculo porque o valor é igual para } \\
\text { todos municípios da RS" }\end{array}$ \\
\hline
\end{tabular}




\begin{tabular}{|c|l|}
\hline$\left(\mathrm{R} \$ / \mathrm{m}^{3}\right)$ & \\
\hline $\begin{array}{c}\text { Custo por Distribuição de } \\
\text { Água }\left(\mathrm{R} \$ / \mathrm{m}^{3}\right)\end{array}$ & $\begin{array}{l}\text { "não há cálculo porque o valor é igual para } \\
\text { todos municípios da RS" }\end{array}$ \\
\hline $\begin{array}{c}\text { Custo na Coleta de Esgoto } \\
\left(\mathrm{R} \$ / \mathrm{m}^{3}\right)\end{array}$ & $\begin{array}{l}\text { "não há cálculo porque o valor é igual para } \\
\text { todos municípios da } \mathrm{RS}^{3}\end{array}$ \\
\hline
\end{tabular}

cdlxxi 
Estudo do Piloto - Vila dos pescadores

Simulação Prevista

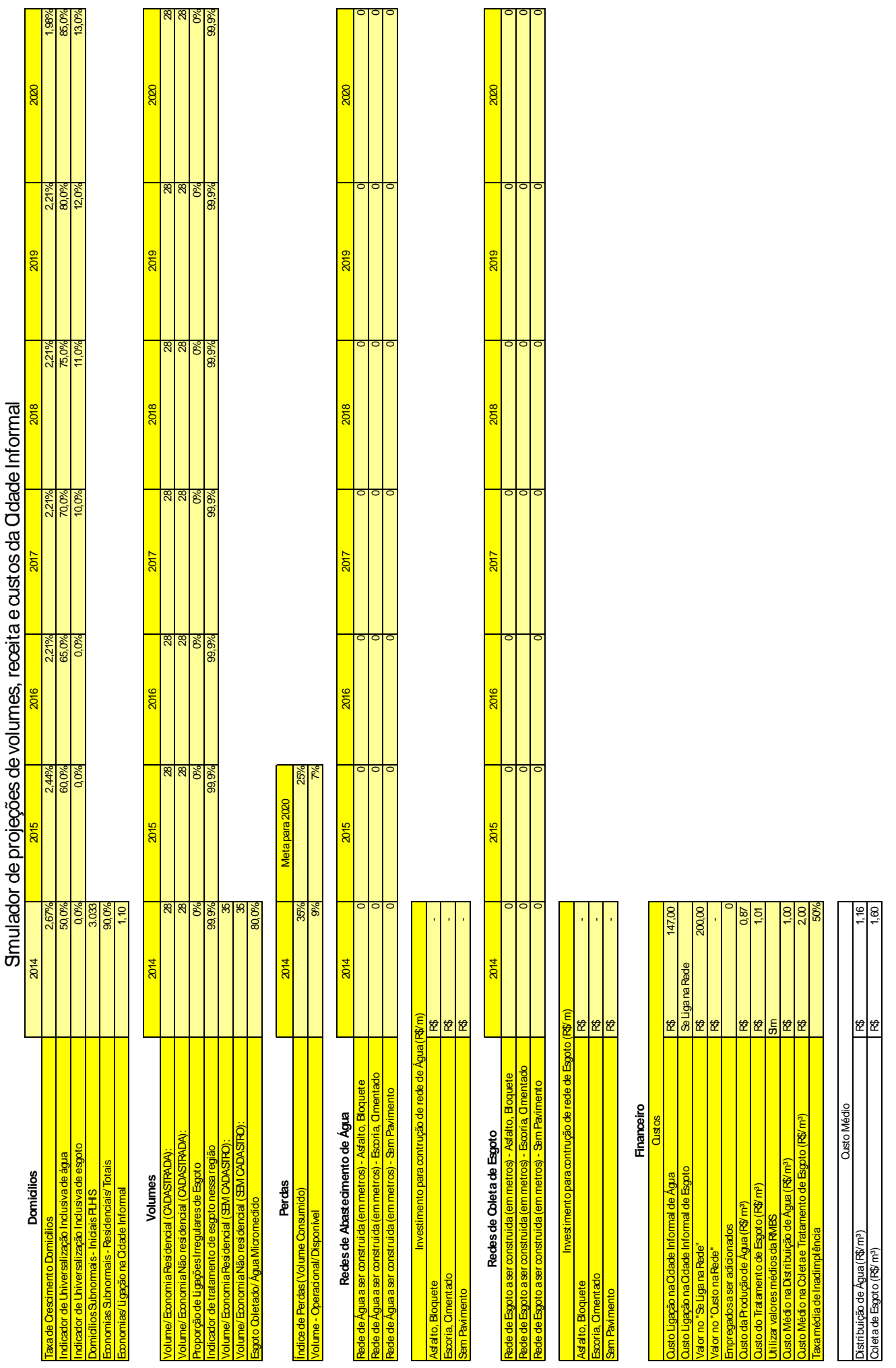

cdlxxii 


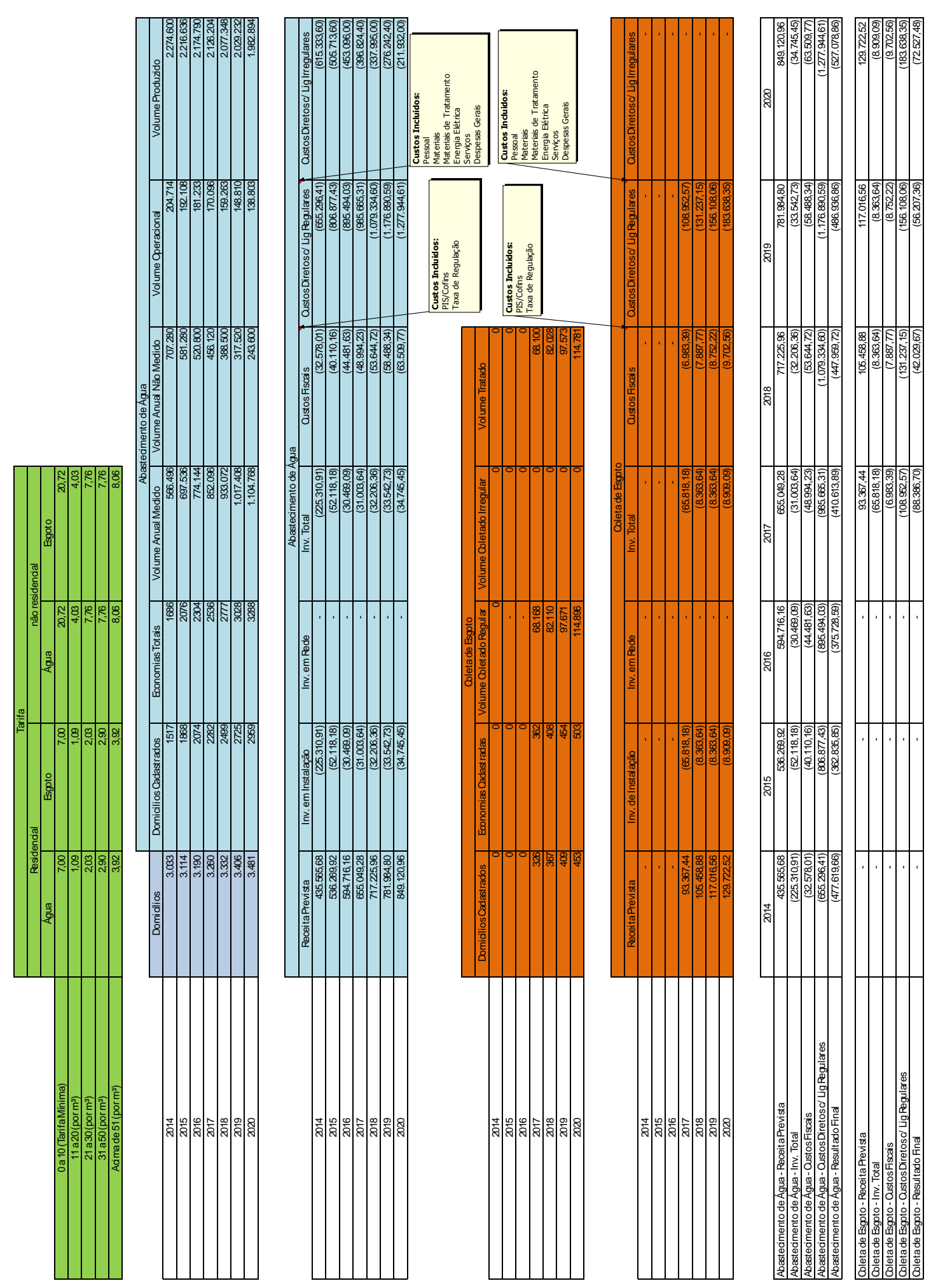

cdlxxiii 
Anexo - Projeções Globais para o Plano de Negócios 2014-2020

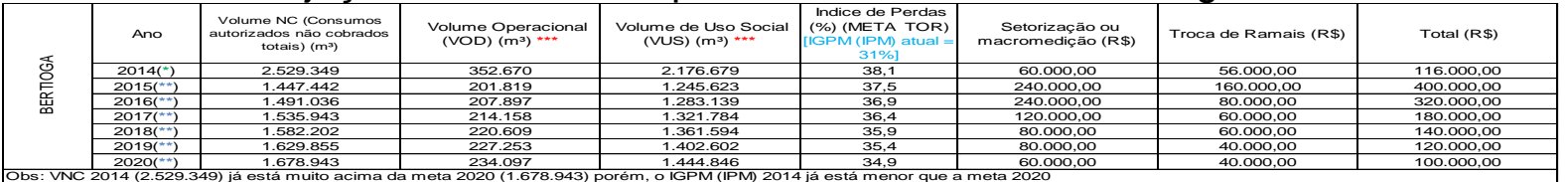

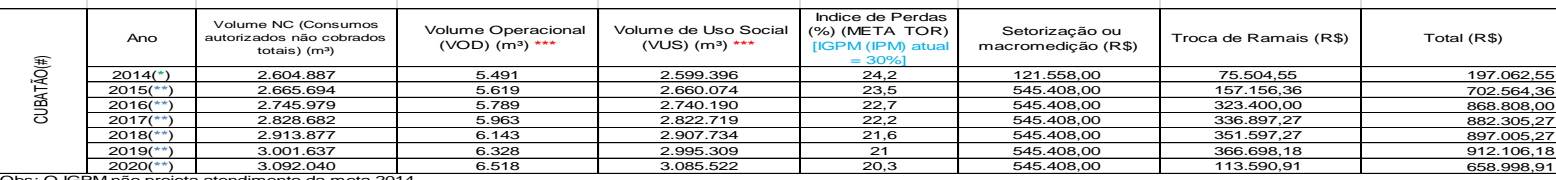

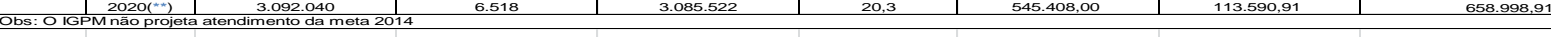

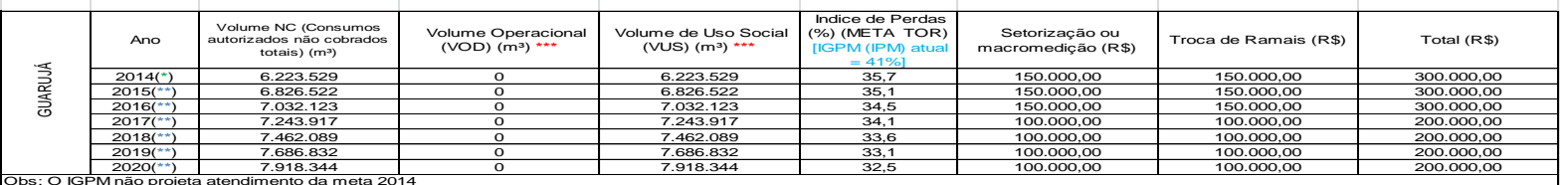

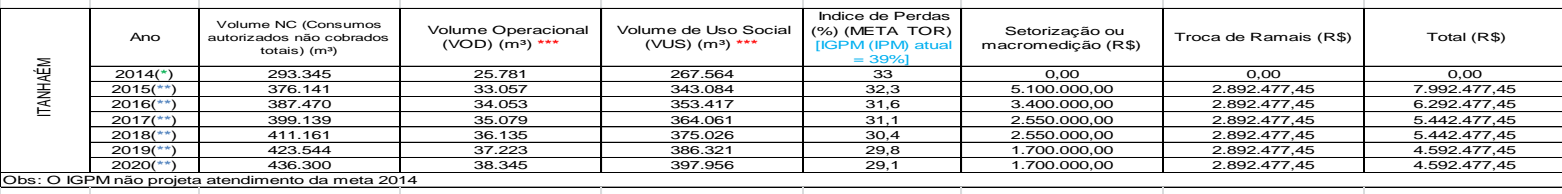

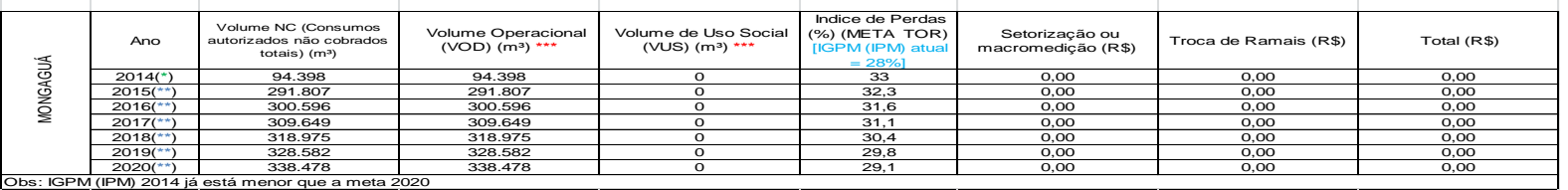

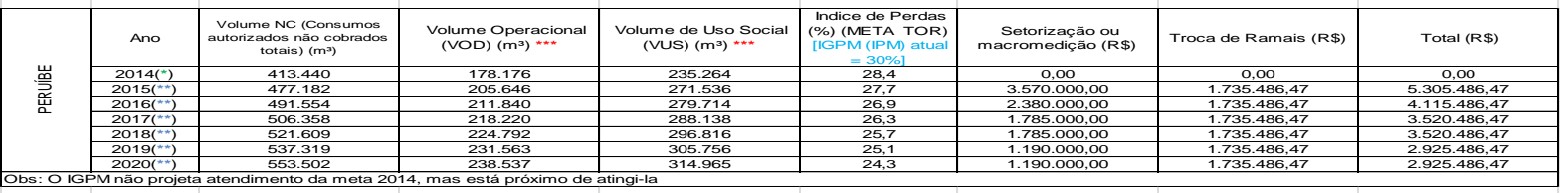

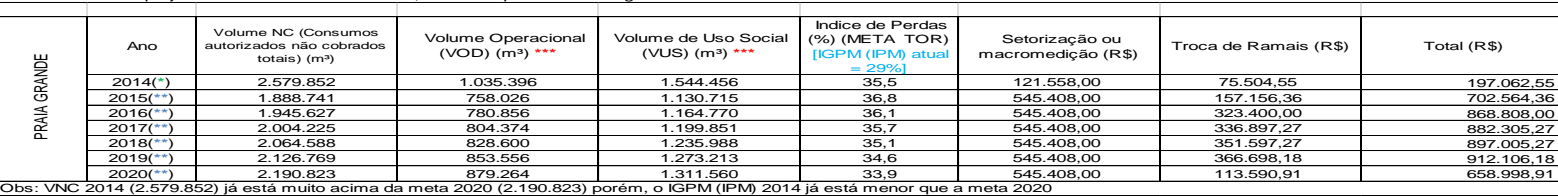

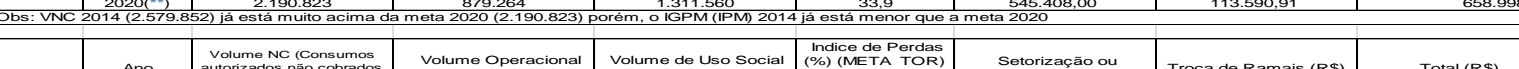

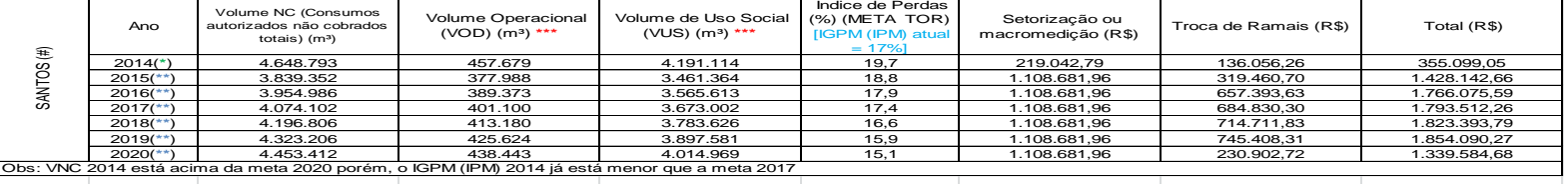

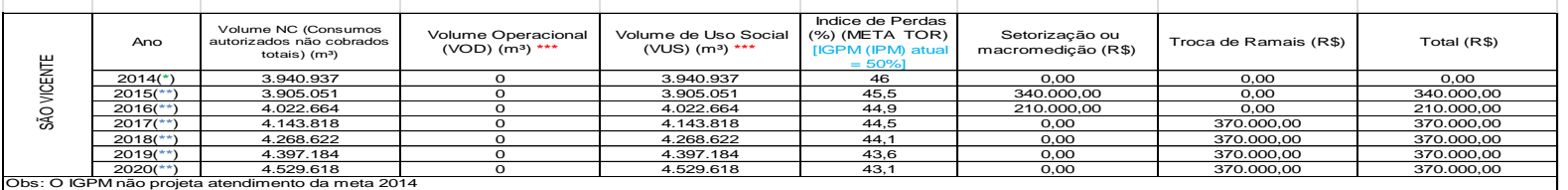

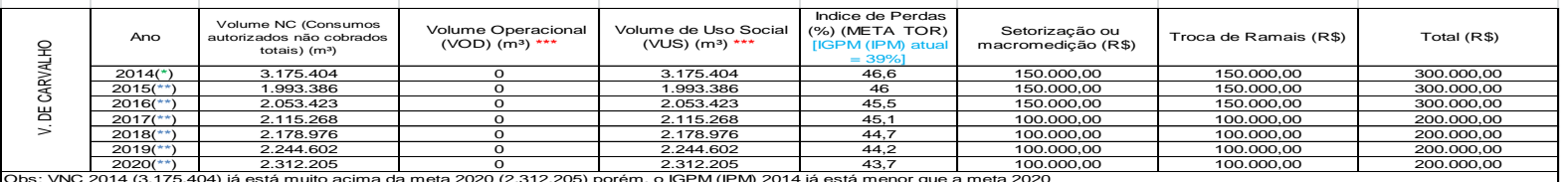

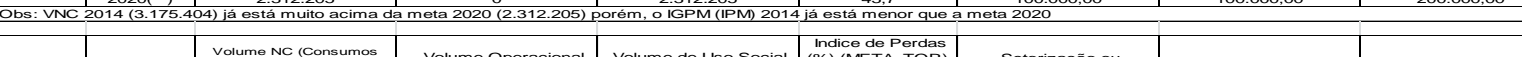

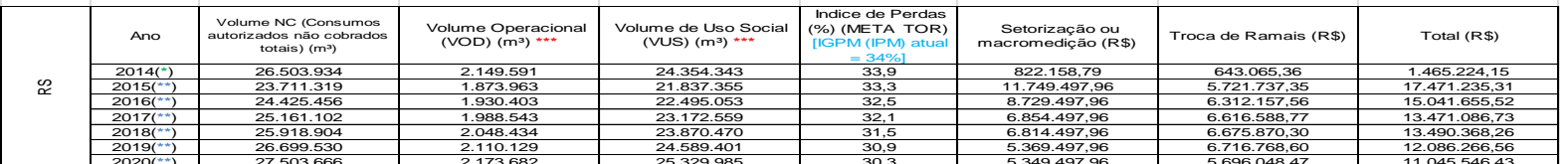

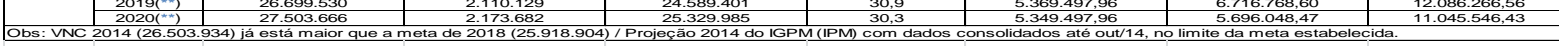

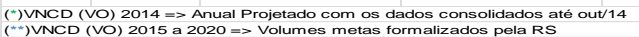

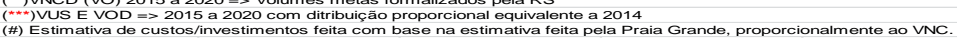




\section{ANEXO DE FOTOS E LEVANTAMENTOS DA SABESP}

Fraudes e desperdício em Morro do Engenho - Guarujá
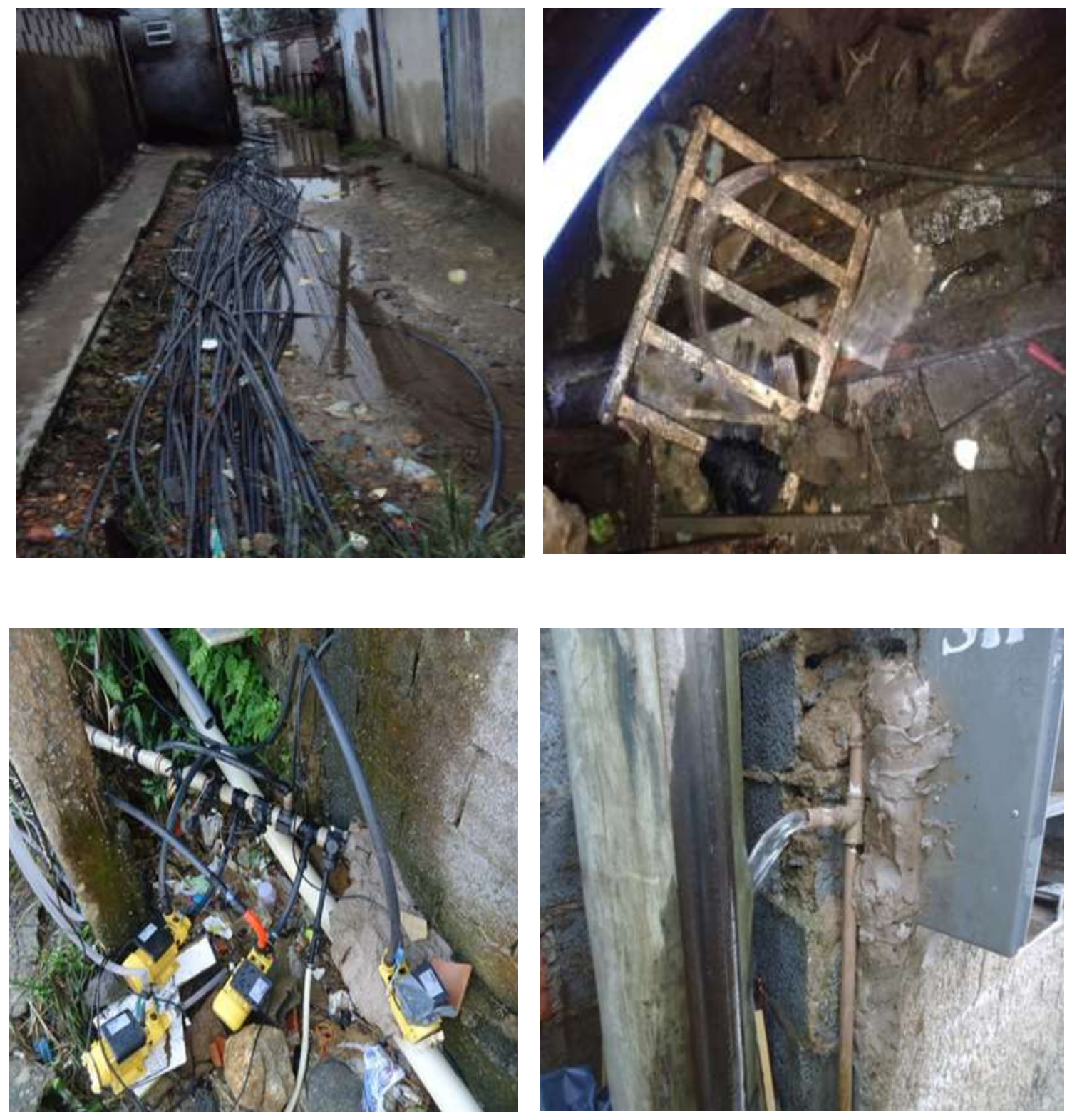

Elaboração: Sabesp(2013, 2014) 


\section{Localização das Comunidades de Guarujá:}
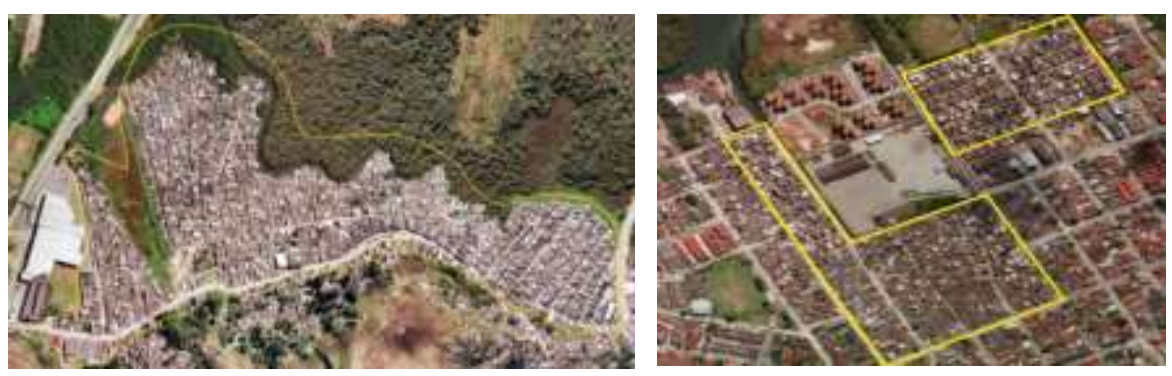

Cachoeira, Vila da Noite e Santa Clara

Jardim Primavera e Mangue Seco

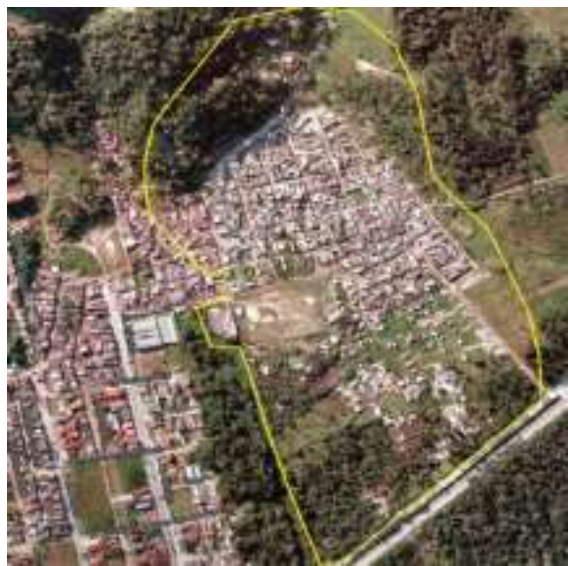

Canta Galo

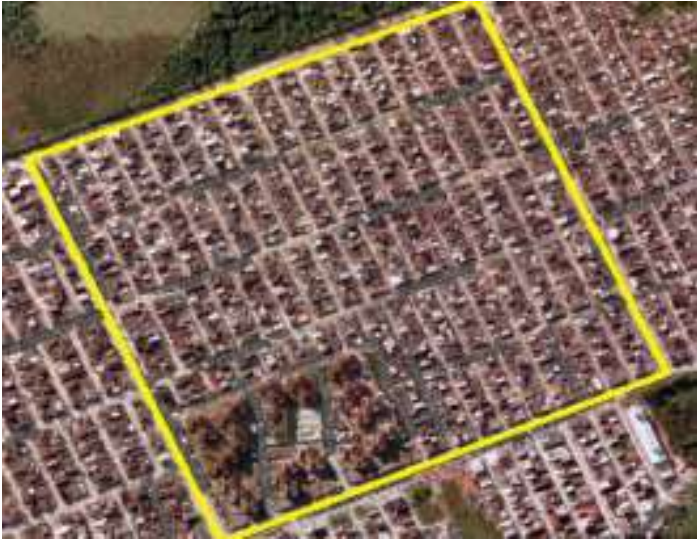

Morrinhos 3

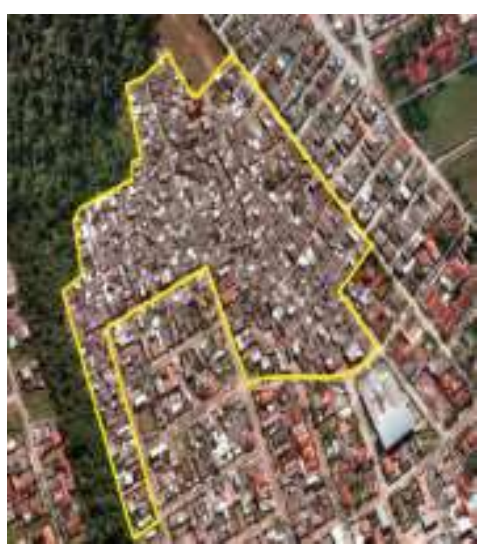

Mar e Céu e Maré Mansa

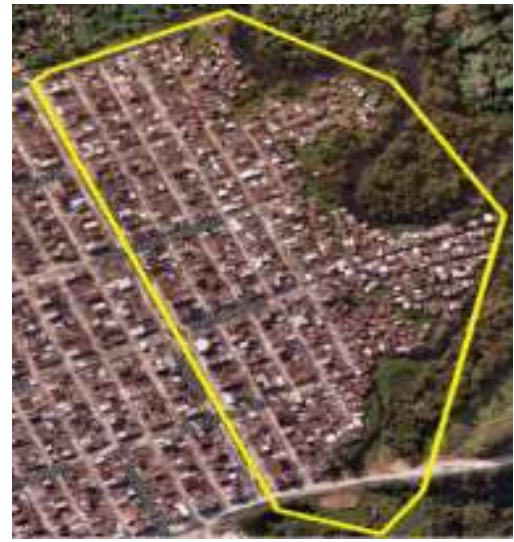

Morrinhos 4

Fonte: IBGE - Aglomerados Urbanos (2010) 


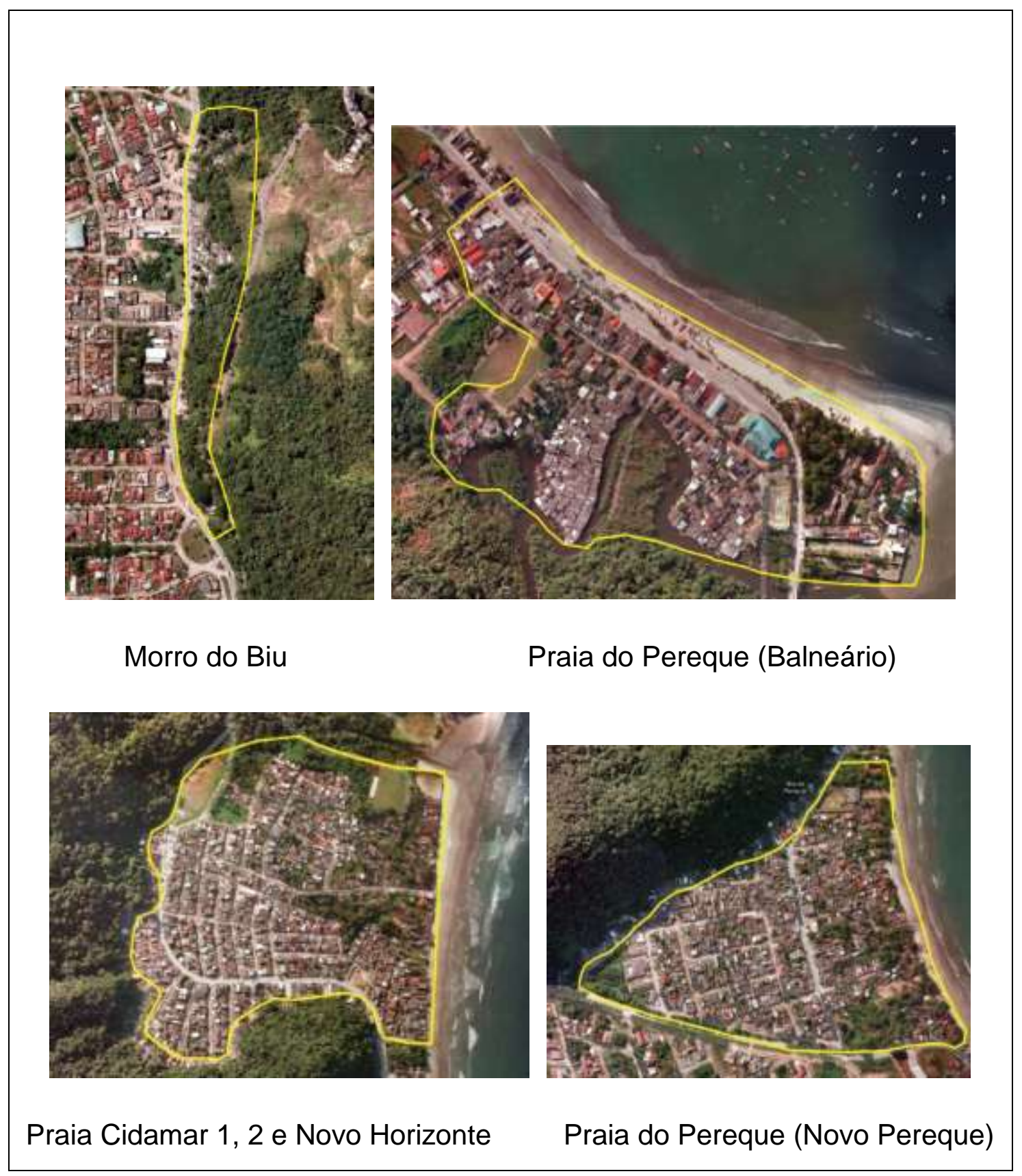

Fonte: IBGE - Aglomerados Urbanos (2010) 


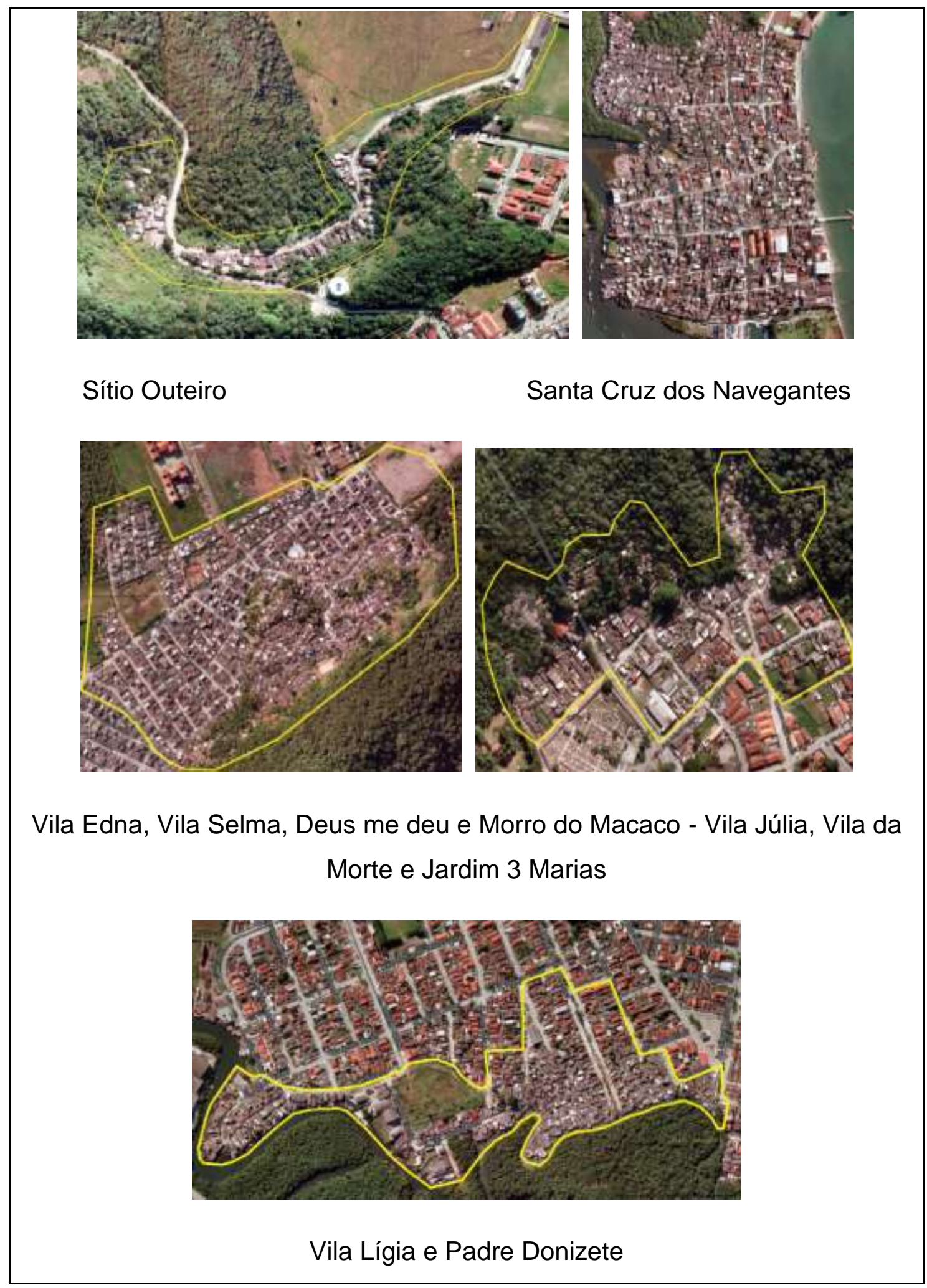

Fonte: IBGE - Aglomerados Urbanos (2010) 

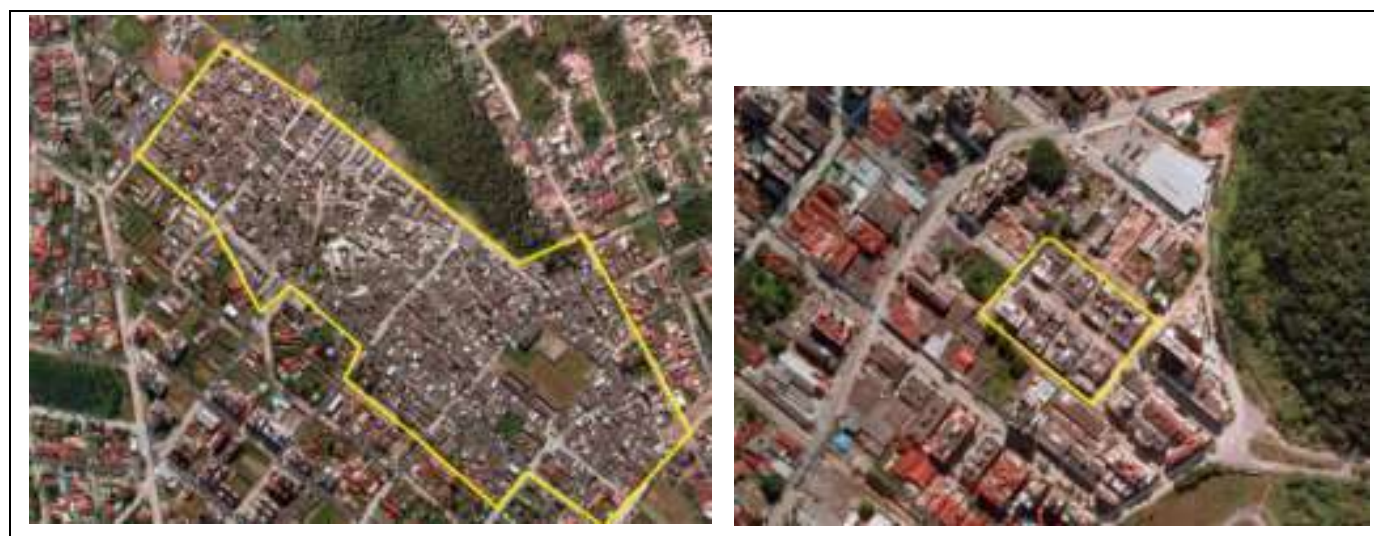

Vila Rã, Sossego e Areião

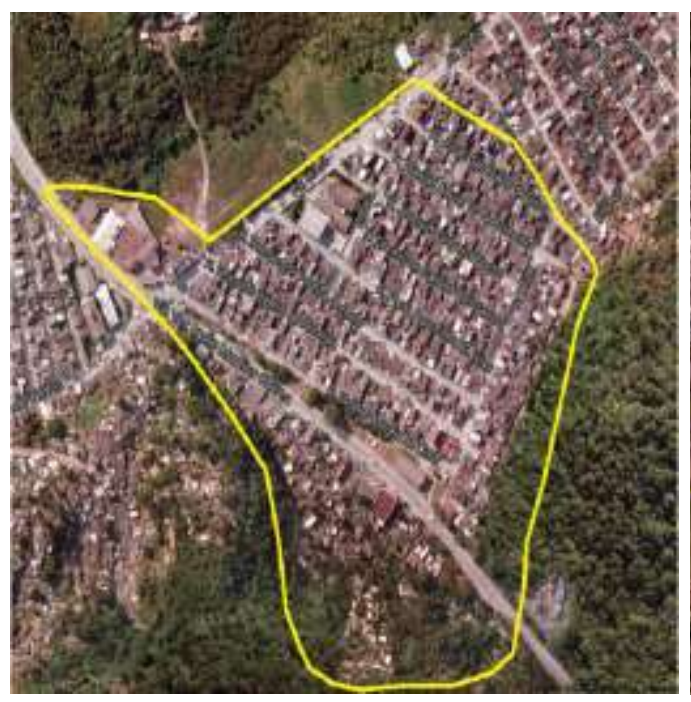

Vila Zilda e Jardim das Flores

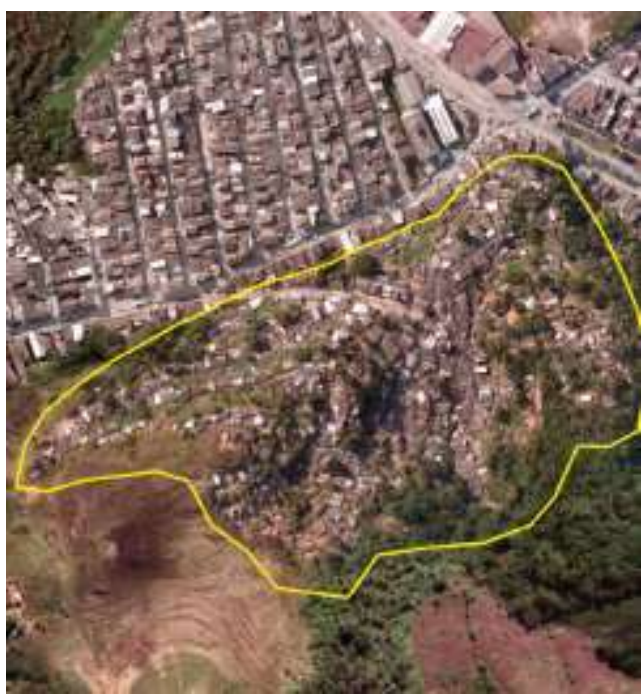

Morro do Engenho

Fonte: IBGE - Aglomerados Urbanos (2010)

cdlxxix 
Comunidades de Vicente de Carvalho:

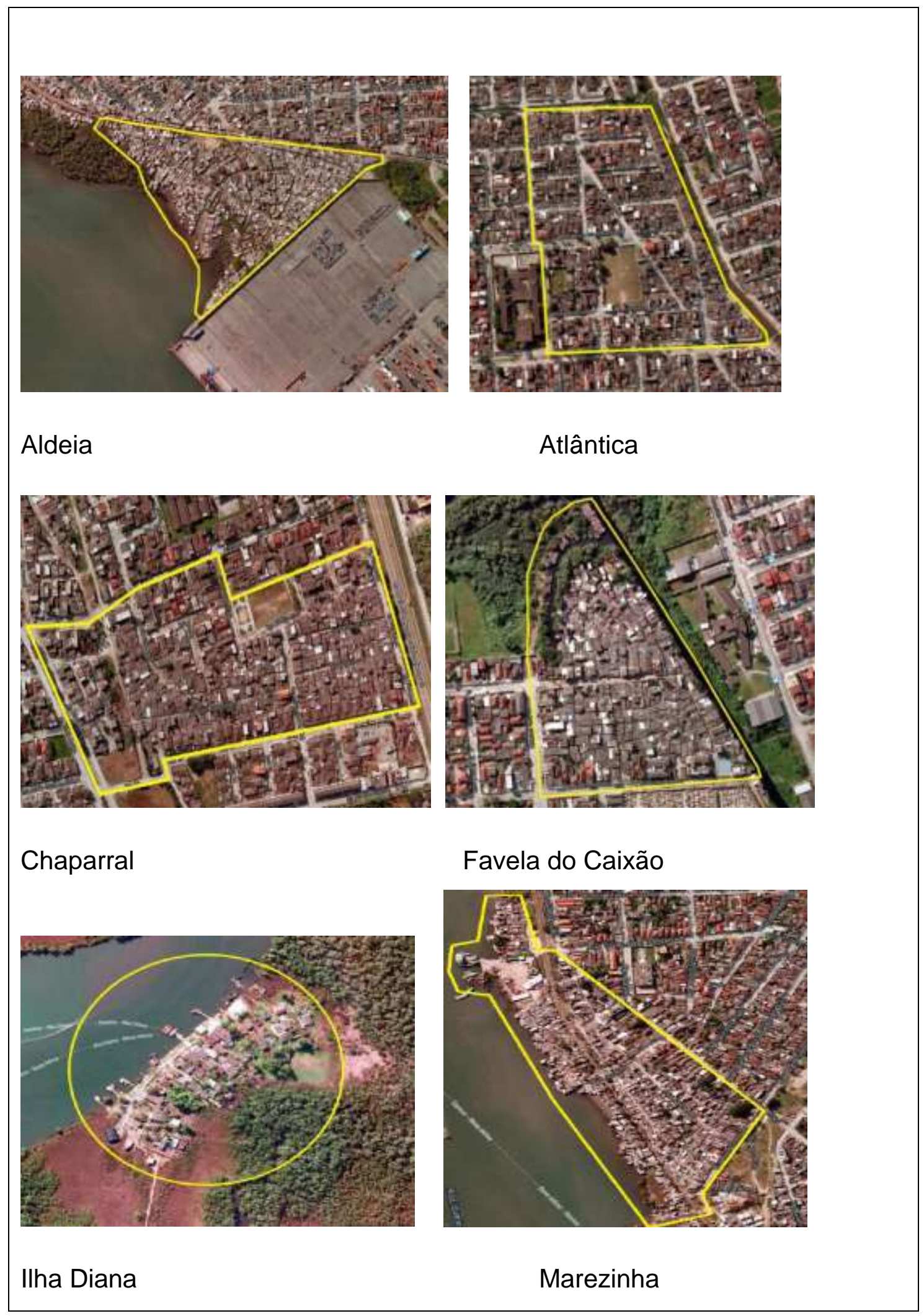




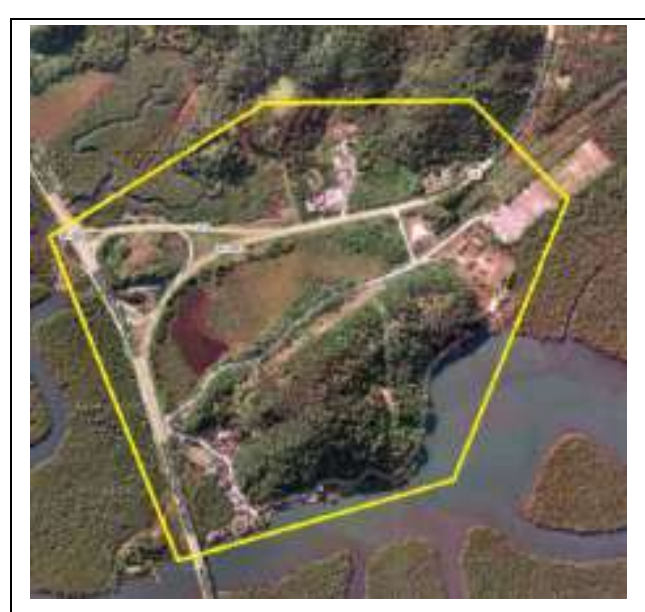

Monte Cabrão

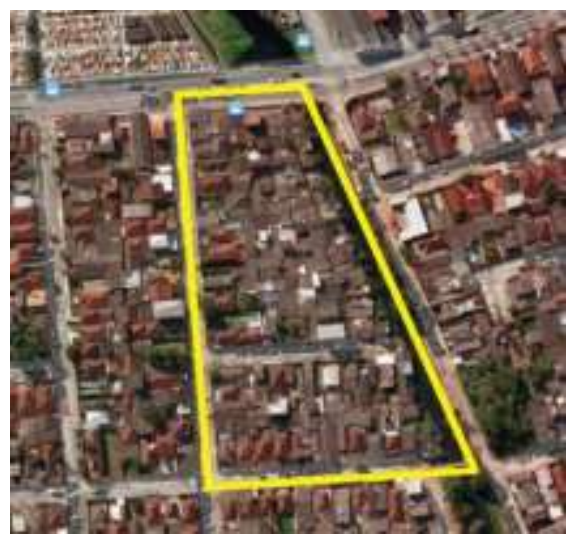

Santa Madalena

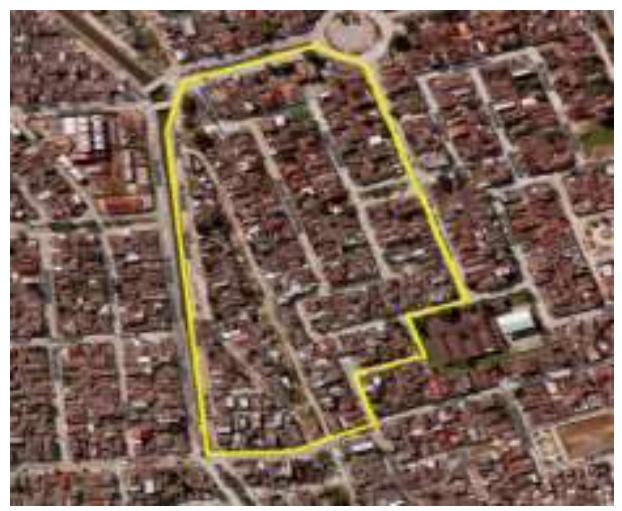

Transmissão Acaraú

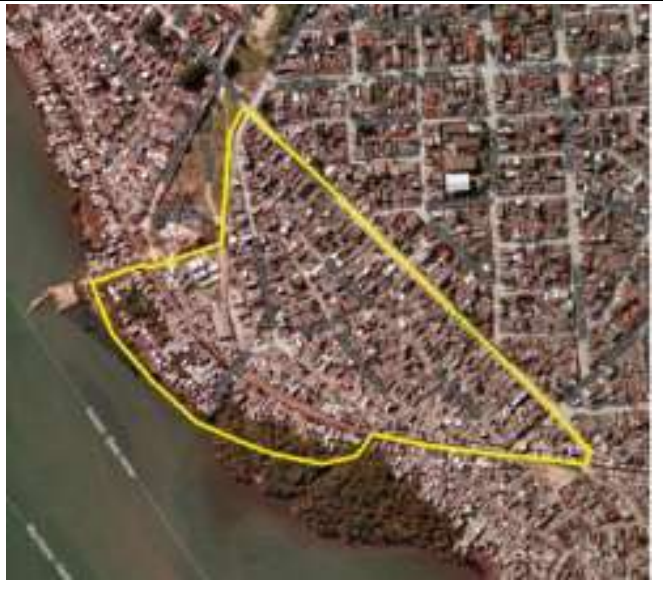

Prainha

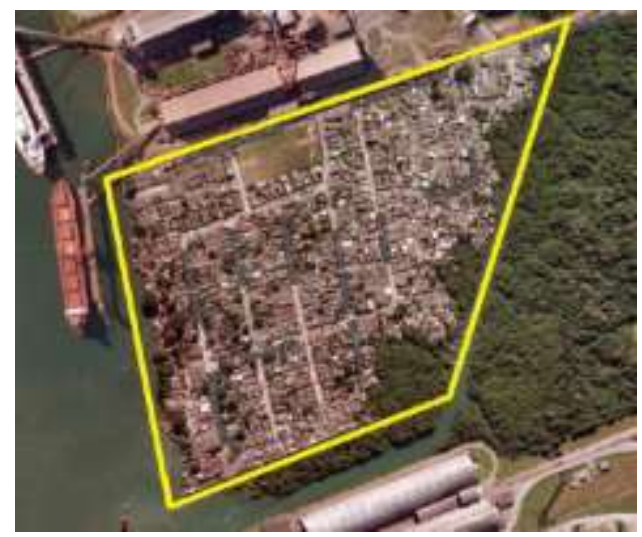

Sítio Conceiçãozinha

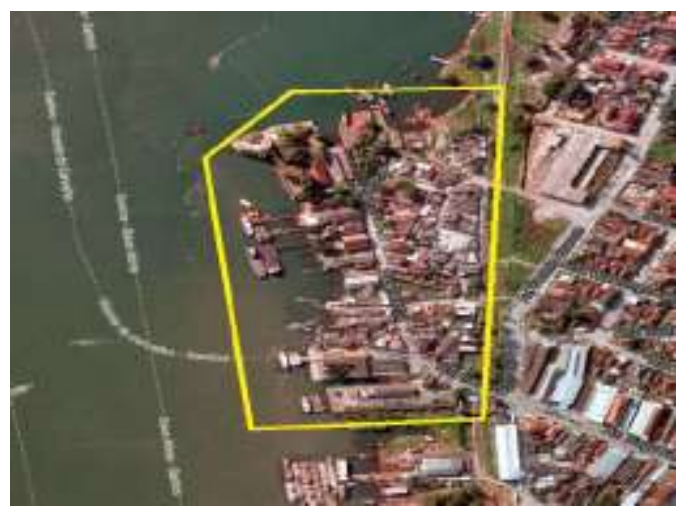

Travessia Imigração 


\section{Obras civis $^{38}$}

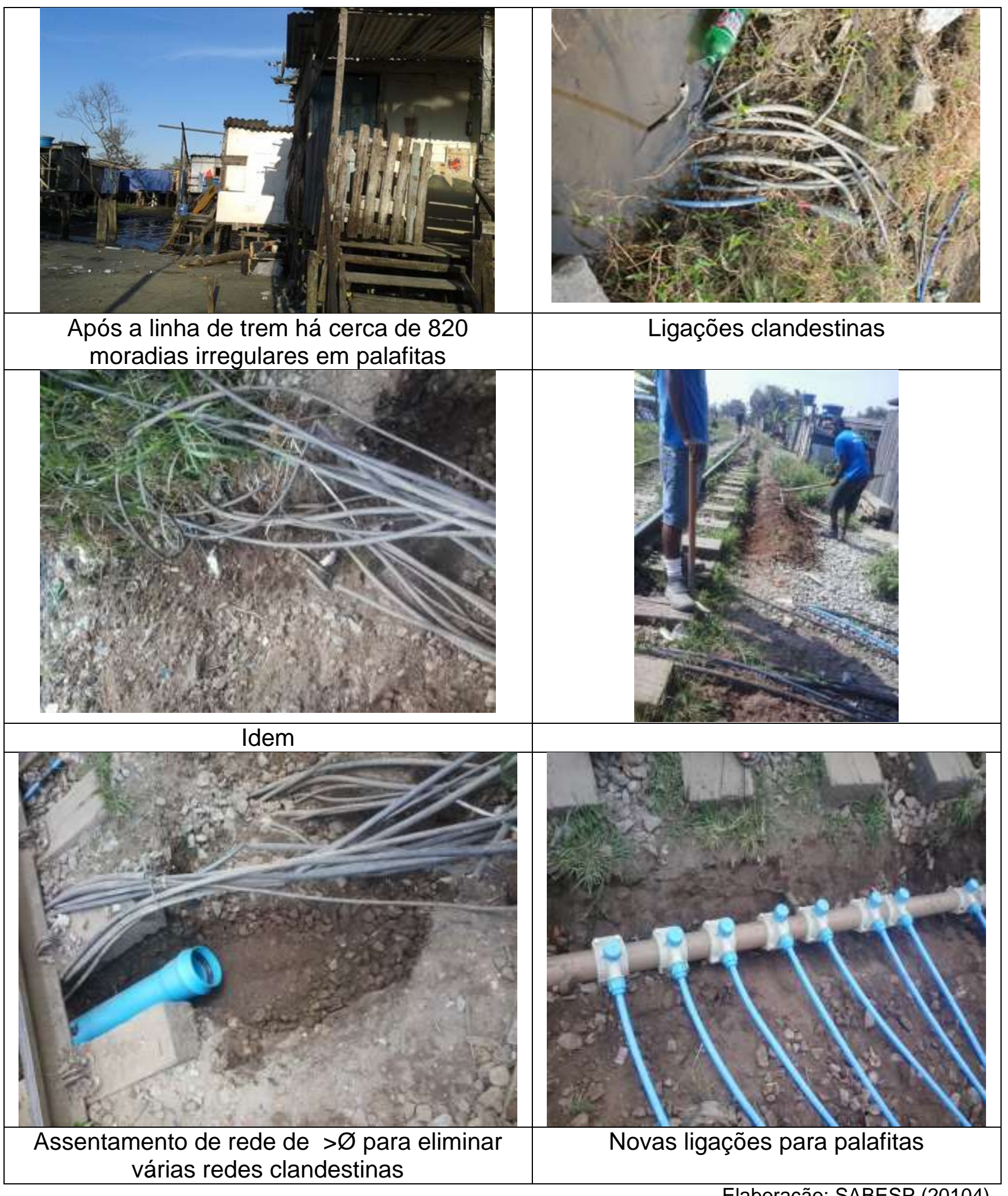

Elaboração: SABESP (20104)

\footnotetext{
${ }^{38}$ Fotos da Companhia de Saneamento
} 


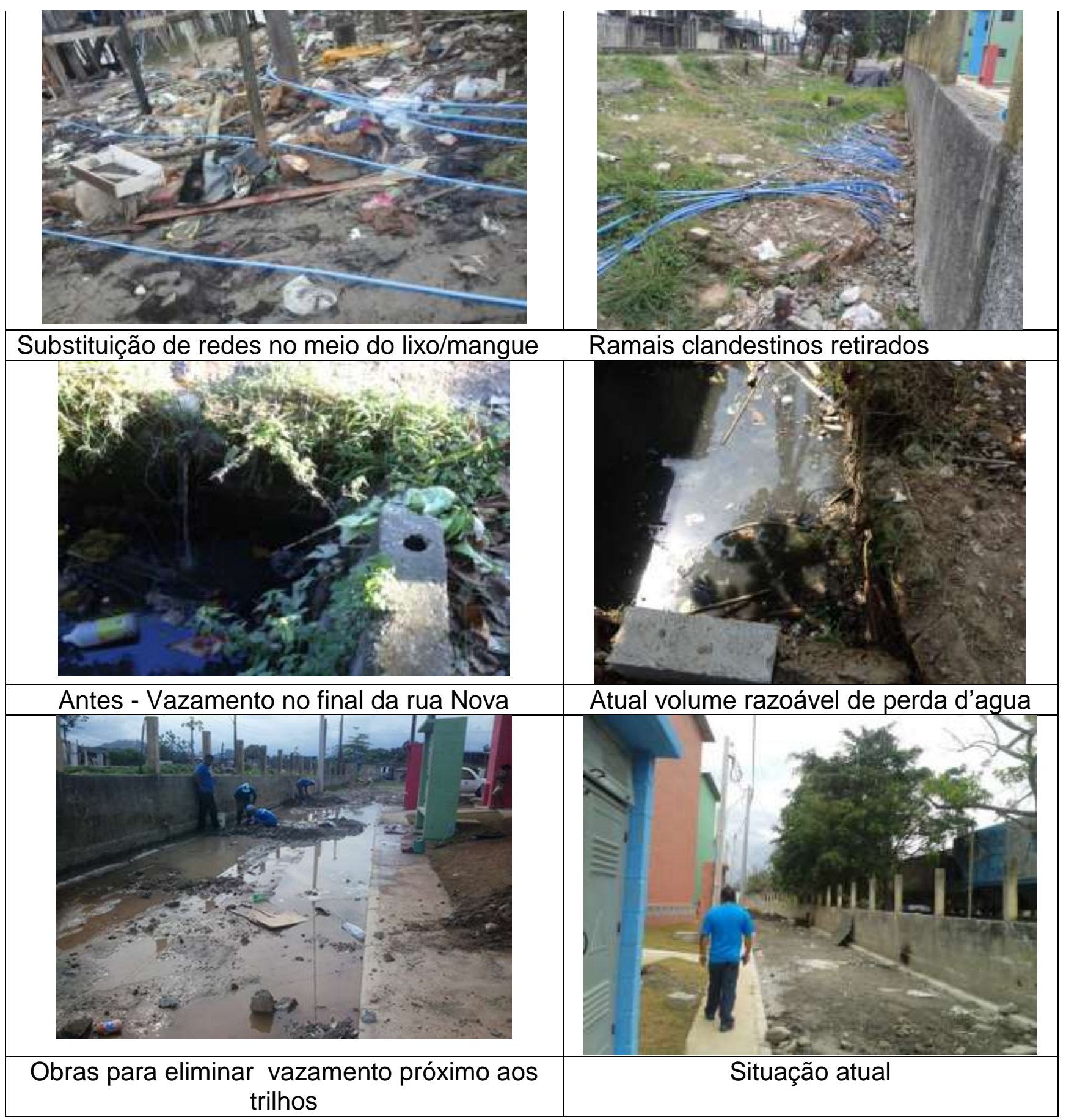

cdlxxxiii 


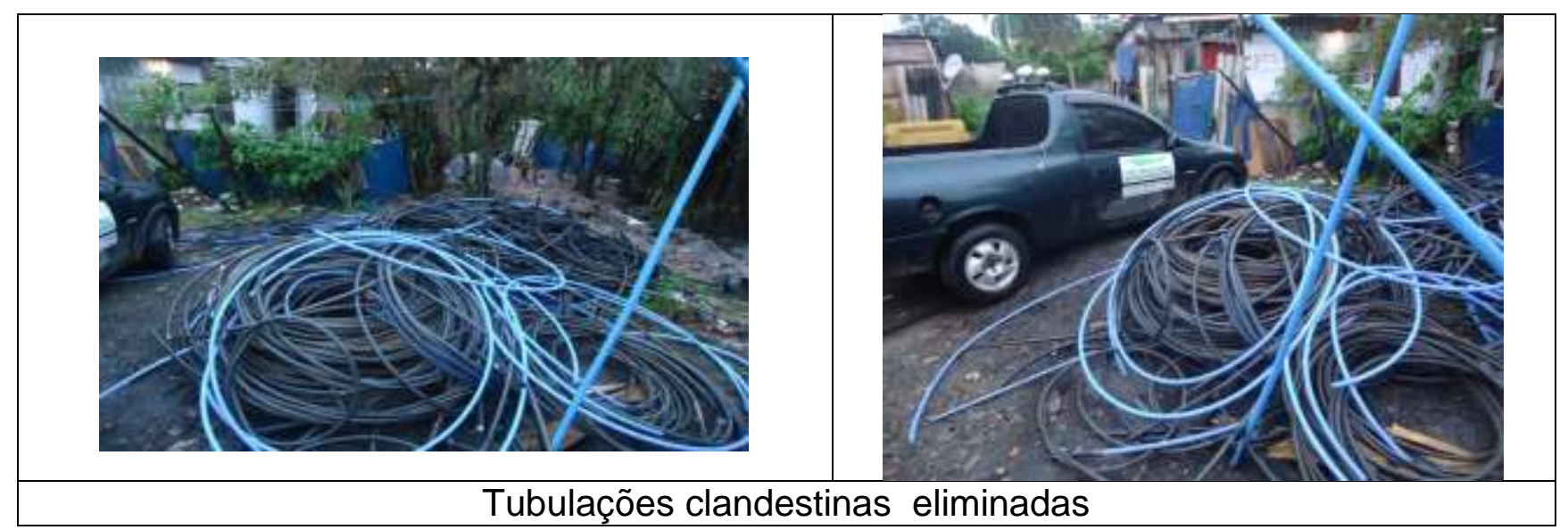

Fotos 22: Comunidade Santa Cruz dos Navegantes

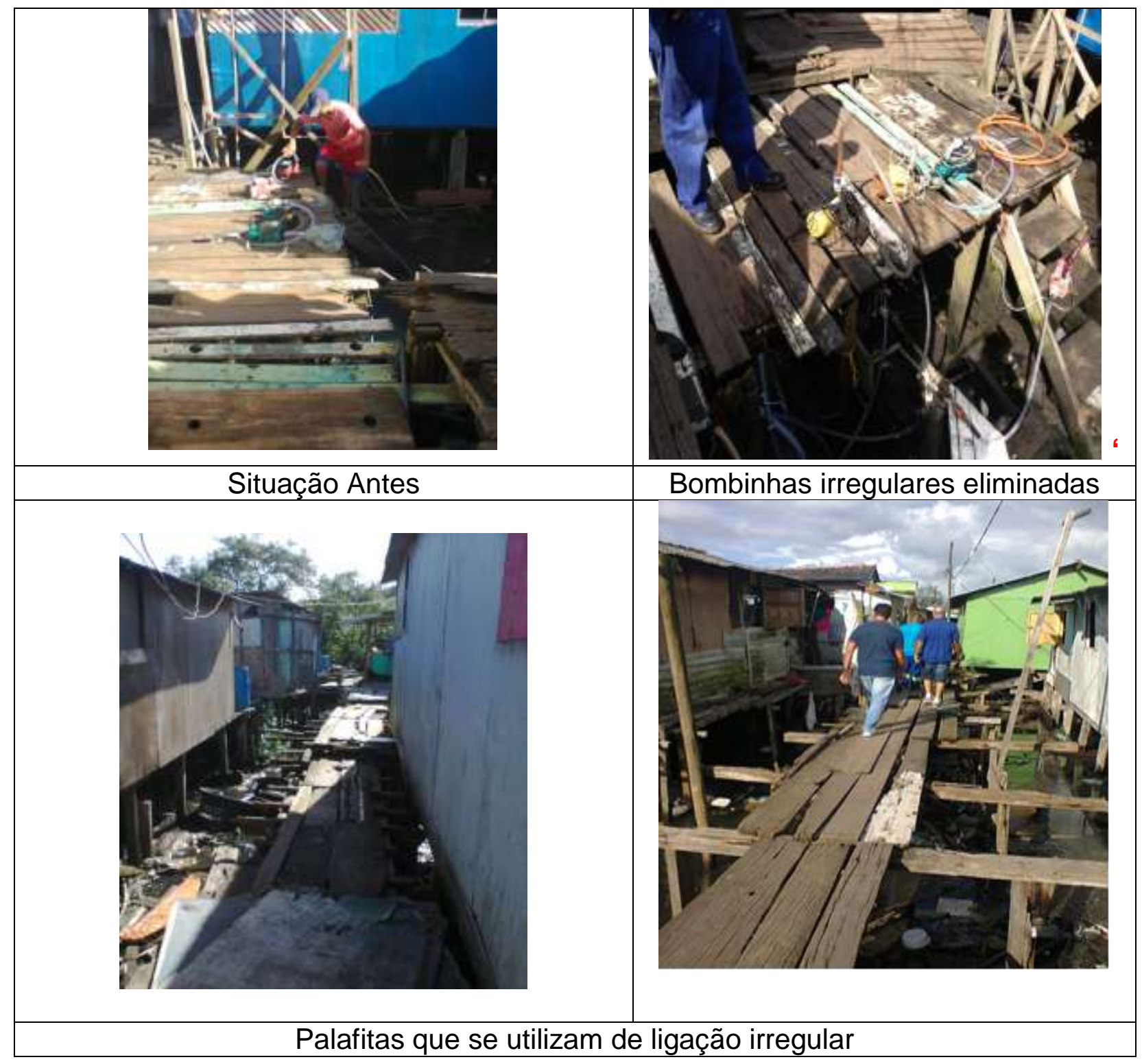



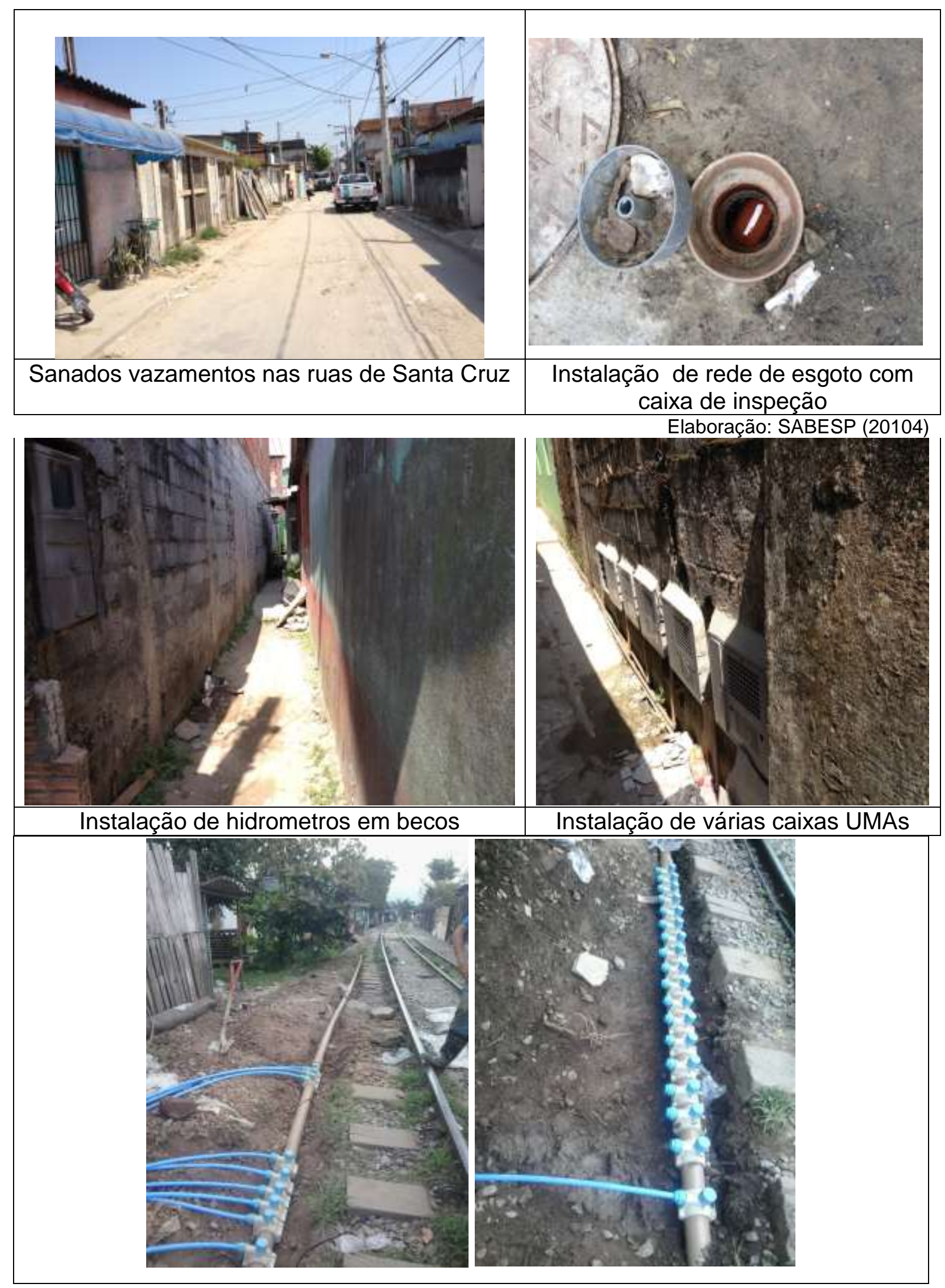


\section{PRODUÇÃO ACADÊMICA DURANTE O DOUTORADO}

Este capítulo apresenta os capítulos da tese já publicados e/ou aprovados para publicação em formato de livro, artigos, anais de congressos, e matérias produzidas durante o curso de doutorado, com dois prêmios. Todos os capítulos da tese estão publicados ou aprovados para tal. São eles:

A. JULIANO, E.F.G.A. ; COUTINHO,S ; MALHEIROS,T.F ; PROTA, M. G. . Interrelações Ambiente e Saúde no Uso de Poços Oficiais para Consumo Humano em Áreas de Contaminação dos Recursos Hídricos Subterrâneos. Saude em Debate, v. 36, p. 85-97, 2012.

B. JULIANO, E.F.G.A. ; FEUERWEKER,L ; COUTINHO,S ; MALHEIROS,T.F . Racionalidade e saberes para a universalização do saneamento em áreas de vulnerabilidade social. Ciência e Saúde Coletiva (Impresso), v. 17, p. 3037-3046, 2012. Citações:2

C. GUIMARÃES, E.F. ; MALHEIROS,T.F . Benchmarking aplicado às Revisões Tarifárias do Saneamento. Revista DAE, v. 192, p. 34, 2013.

D. GUIMARÃES, E.F. ; MALHEIROS, T. . Metodologia da base de remuneração regulatória da primeira revisão tarifária do Estado de São Paulo. In: VIII Congresso Brasileiro de Regulação, 2013, Fortaleza Ceará. VIII Congresso Brasileiro de Regulação, 2013.

E. GUIMARÃES, E.F. ; MALHEIROS, T. . INDICADORES DE BENCHMARKING DO SETOR DE SANEAMENTO APLICADOS A REVISÕES TARIFÁRIAS. In: VIII Congresso Brasileiro de Regulação, 2013, Forataleza. VIII Congresso Brasileiro de Regulação, 2013.

F. GUIMARÃES, E.F. . Metodologia da Base de Remuneração Regulatória da Primeira Revisão Tarifária da Sabesp. In: XVI SEMEAD - SEMINÁRIOS EM ADMINISTRAÇÃO, 2013, SÃO PAULO. XVI SEMEAD - SEMINÁRIOS EM ADMINISTRAÇÃO. Sâo Paulo: FEA/USP, 2013.

G. Prêmio SISCA (Sustainability Innovation Student Challenge Award), DOW Química do Brasil. - 2013.

H. GUIMARÃES, E.F. ; COUTINHO,S ; MALHEIROS,T.F ; PHILIPPI JUNIOR, A. Os Indicadores de Saneamento medem a universalização em áreas de vulnerabilidade social? Engenharia Sanitária e Ambiental, v. 19, p. 165-171, 2014.

I. GUIMARÃES, E.F. . Diagnóstico da Regulação do saneamento no Brasil. Bio (Rio de Janeiro), v. 69, p. 52-53, 2014.

J. Livros publicados/organizados ou edições

MARCOVITCH, J. ; GUIMARÃES, E.F. ; SASSAKI, A. H. ; SLOVIC, A. D. ; DIAS, B. G. ; GONCALVES, C. ; SOARES, C. S. ; IMORI, D. ; FERREIRA, G. T. C. ; MARTINHO, H. M. ; BATAGLIN, J. C. ; FERRAZ, J. ; GUIMARAES, J. G. A. ; ESTEVES, K. ; MACEDO, L. S. V. ; GUIMARAES, L. F. ; FREITAS, L. P. ; PINSKY, V. . Fundo Amazônia: cooperação internacional e gestão brasileira (Portuguese 
Edition). 1/1. ed. Amazon Whispernet: Amazon Digital Services, Inc., 2014. v. 1. 331 pagesp .

K. Textos em jornais de notícias/revistas

GUIMARÃES, E.F. ; ROGERS, A. P. . 'O Brasil está no Caminho certo'. Revista Brasileira de Saneamento e Meio Ambiente, Rio de Janeiro, p. 36 - 39, 03 ago. 2014.

L. Trabalhos completos publicados em anais de congressos

GUIMARÃES, E.F. ; SILVA, R. T. ; MALHEIROS,T.F . Controvérsias da Universalização do Saneamento em Áreas de Vulnerabiliade no Brasil. In: Congresso de Geografia da Saúde dos Países de Língua Portuguesa GeoSaúde 2014, 2014, Coimbra - Portugal. A GEOGRAFIA DA SAÚDE NO CRUZAMENTO DOS SABERES. Coimbra - Portugal: Universidade de Coimbra, 2014. v. 1. p. 15-15.

M. GUIMARÃES, E.F. ; MALHEIROS, T. ; MARQUES, R. C. . Managing the Universal Access to Water and Sanitation Services in Brazil. In: IWA World Water Congress \& Exhibition 2014, 2014, Lisboa. IWA World Water Congress \& Exhibition 2014 Poster. Lisboa: IWA World Water Congress \& Exhibition 2014, 2014. v. 1.

N. Premio SemeAd - Melhor Artigo da Àrea Administração Pública, FEA USP - SemeAd $-2014$.

O. Capítulos de livros aprovados:

1. Capítulo do Livro Gestão do Saneamento - organização Prf. Dr. Arlindo Philippi Junior - USP - Capítulo - Gestão para universalização dos serviços de saneamento em áreas de vulnerabilidade social. Aprovado em 2014

2. Capítulo do Livro Planejamento, organizado pelo Prof. Dr. Arlindo Philippi Junior - USP - Capítulo - Metodologia para o planejamento participativo dos serviços de saneamento em aglomerados subnormal. Aprovado em julho de 2015

1. Capítulo do livro Investigación e Indicadores de Sustentabilid Universidade de Concepcion do Chile. UNIVERSALIZAÇÃO E GOVERNANÇA INCLUSIVA: Novos Conceitos e Indicadores de Saneamento Básico para Áreas de Vulnerabilidade. Aprovado em março de 2015.

P. Inclusive Governance: New concept of water and sanitation services in social vulnerability áreas - Utility Policies - Lisbon - Portugal. 2015 